Cadernos do Programa de Pós-Graduação

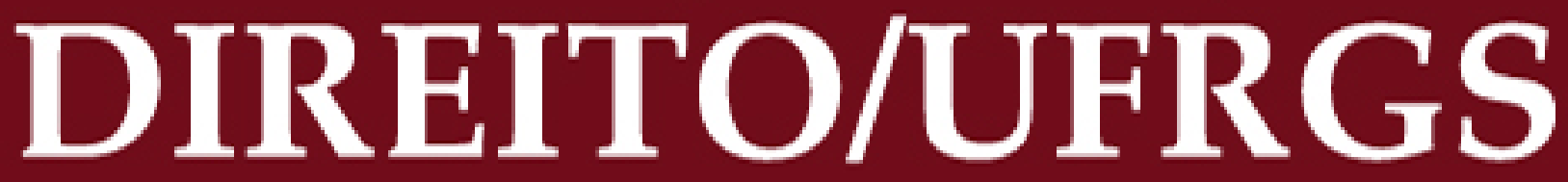

volume 8 | n.2 | 2013 | seer.ufrgs.br/ppgdir

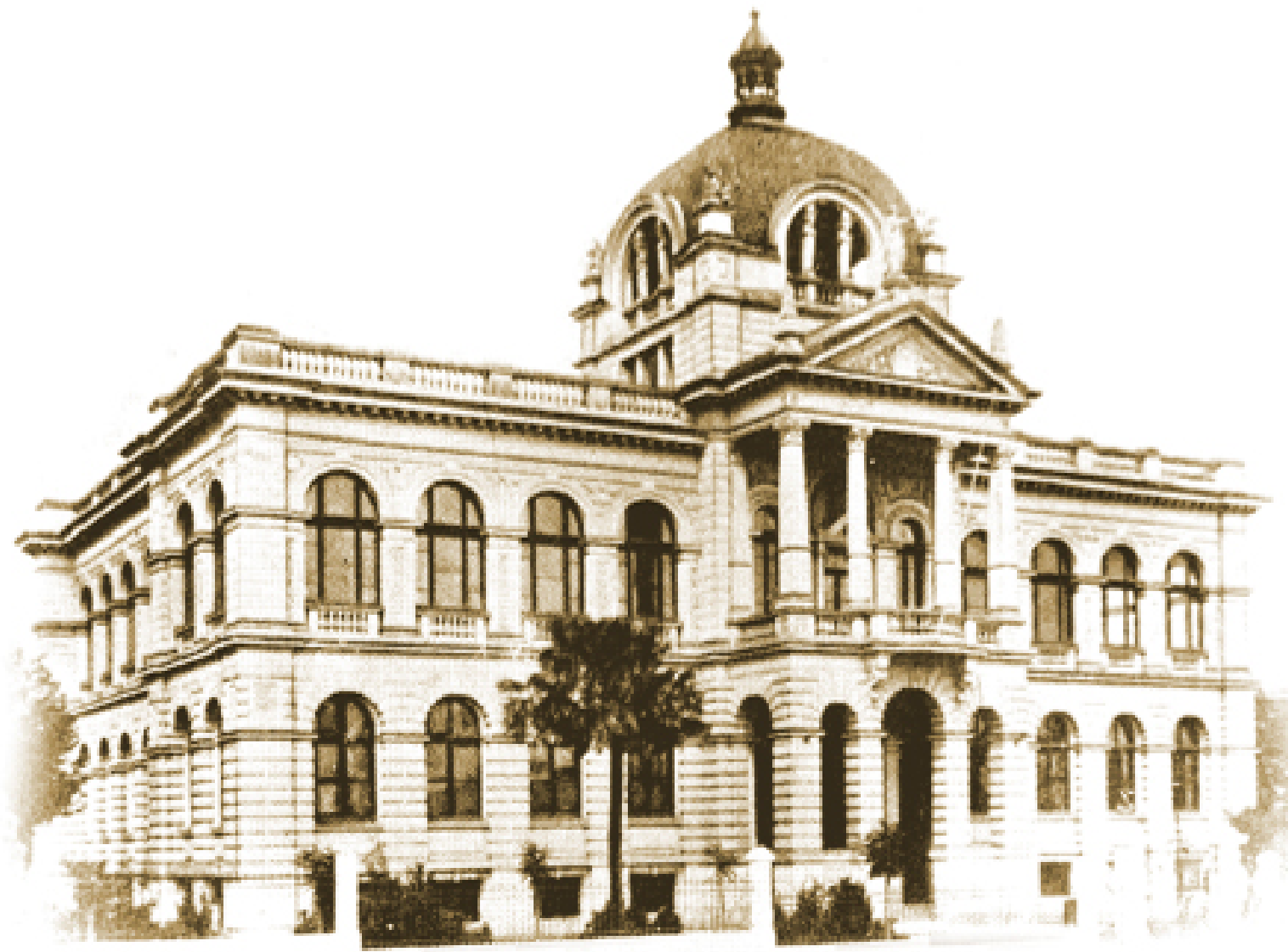


ISSN 1678-5029

E-ISSN 2317-8558

\section{Cadernos do Programa de Pós-Graduação em Direito/UFRGS}

\section{Volume VIII | Número 2 | Ano 2013}

seer.ufrgs.br/ppgdir 


\section{Universidade Federal do Rio Grande do Sul}

Reitor: Carlos Alexandre Netto Vice-Reitor: Rui Vicente Oppermann

\section{Faculdade de Direito}

Diretor: Danilo Knijnik

Vice-Diretor: Carlos Klein Zanini

\section{Programa de Pós-Graduação} eM Direito

\section{Coordenador:}

José Alcebíades de Oliveira Júnior

\section{Coordenadora Substituta:}

Claudia Lima Marques

Professores Permanentes: Alfredo de Jesus Dal Molin Flores Augusto Jaeger Junior Carlos Klein Zanini Cesar Viterbo Matos Santolim Cezar Saldanha Souza Junior Claudia Lima Marques Daniel Francisco Mitidiero Danilo Knijnik Fabio Costa Morosini Humberto Bergmann Ávila José Alcebíades de Oliveira Júnior Leandro Amaral D. de Dorneles Luciane Cardoso Barzotto Luís Afonso Heck Luis Fernando Barzotto Luiz Felipe Silveira Difini Martha Lucía Olivar Jimenez Véra Maria Jacob de Fradera Wladimir Barreto Lisboa

Professores Colaboradores: Carlos Silveira Noronha Rafael Da Cás Maffini Tupinambá Pinto de Azevedo

\section{Cadernos do Programa de Pós-Graduação em Direito}

\section{Editor-Chefe:}

José Alcebíades de Oliveira Júnior

\section{Responsável Acadêmico:} Wagner Silveira Feloniuk
Secretária Executiva:

Rosmari de Azevedo

Colaborador Executivo:

Anderson de Lima Kovalsky

\section{Conselho Editorial:}

Alvaro Sanchez Bravo (Facultad de Derecho de la Universidad de Sevilla, España)

Antonio Carlos Wolkmer (Universidade Federal de Santa Catarina, Brasil)

Felipe Chiarello de Souza Pinto (Universidade Presbiteriana Mackenzie, Brasil) Fredie Souza Didier Junior (Universidade Federal da Bahia, Brasil)

Gisele Guimarães Cittadino (Pontifícia Universidade Católica do Rio de Janeiro, Brasil)

Luiz Guilherme Marinoni (Universidade Federal do Paraná, Brasil)

Samyra Haydêe Dal Farra Naspolini Sanches (Universidade Nove de Julho, Brasil) Sérgio Cruz Arenhart (Universidade Federal do Paraná, Brasil) Vladmir Oliveira Silveira (Pontifícia Universidade Católica de São Paulo, Brasil)

Editores-Executivos:

Wagner Silveira Feloniuk

Gustavo Castagna Machado

Anatércia Rovani

Lucas Gerhardt Gavronski

Avaliadores:

Adriana Silva Maillart (UNINOVE)

André Gomes de Sousa Alves (UFPB)

André Pires Gontijo (UniCEUB)

Andressa Guimarães Torquato Fernandes

(UFRN)

Basile Georges Campos Christopoulos (USP)

Carlos Magno Spricigo Venerio (UFF)

Cecilia Caballero Lois (UFRJ)

Cristiano Becker Isaia (UFSM)

Daniel Lena Marchiori Neto (UCPEL)

Diego Romero (UNISC)

Eduardo Kochenborger Scarparo (UFRGS)

Erivaldo Moreira Barbosa (UFPB)

Eugênia Cristina Nilsen Ribeiro Barza (UFPE)

Eugênio Battesini (UFRGS)

Guilherme Recena Costa (USP)

Gustavo César Machado Cabral (Estácio FIC)

Gustavo Silveira Siqueira (UERJ)

Igor Danilevicz (UFRGS) 
Isadora Vier Machado (CEUMAR)

João Paulo Forster (UFRGS)

Joséli Fiorin Gomes (UFRGS)

Laila Maia Galvão (UnB)

Leandro do Amaral Dorneles de Dorneles

(UFRGS)

Leonardo Rocha Souza (UFRGS)

Luana Renostro Heinen (UFSC)

Luciane Cardoso Barzotto (UFRGS)

Lúcio Antônio Machado Almeida (UFRGS)

Luiz Felipe Silveira Difini (UFRGS)

Marcelo Schenk Duque (UFRGS)

Marcos Roberto de Lima Aguirre (UFRGS)

Maria Goretti Dal Bosco (UFMG)
Marta Marques Ávila (UFRGS)

Nataly Evelin Konno Rocholl (FGV)

Pablo Castro Miozzo (UFRGS)

Pablo Rodrigo Alflen da Silva (UFRGS)

Pedro Parini Marques de Lima (UFPB)

Pedro Ricardo e Serpa (FGV)

Raquel Lima Scalcon (UFRGS)

Ricardo Antônio Lucas Camargo (UFRGS)

Roberta Camineiro Baggio (UFRGS)

Romulo Ponticelli Giorgi Júnior (UFRGS)

Tupinambá Pinto de Azevedo (UFRGS)

Vera Lúcia da Silva (UFSC)

Vivian Caroline Koerbel Dombrowski (UnB)

\section{Cadernos do Programa de Pós-Graduação em Direito}

A revista Cadernos do Programa de Pós-Graduação em Direito é a publicação do Programa de Pós-Graduação em Direito da Faculdade de Direito da Universidade Federal do Rio Grande do Sul.

O Programa de Pós-Graduação em Direito da UFRGS, compreendendo o Doutorado e o Mestrado, apresenta como peculiaridade o transpasse, em suas quatro áreas de concentração (Direito Privado, Direito Público, Teoria do Direito e Direito Internacional), de uma mesma ideia nuclear, sintetizada na expressão "Fundamentos da Experiência Jurídica". Em torno dessa ideia se agrupam as três linhas de pesquisa agora propostas, a saber: Fundamentos Dogmáticos da Experiência Jurídica; Fundamentos Teórico-Filosóficos da Experiência Jurídica; e Fundamentos da Integração Jurídica.

A opção por essa linha transversal - expressa na ideia de "Fundamentos da Experiência Jurídica", a ligar as várias áreas do conhecimento jurídico e projetos institucionais e individuais de pesquisa - encontra justificativa nos planos histórico e metodológico.

Núcleo de Criação, Editoração, ReVisão e Web da Gráfica da UFRGS

Acompanhamento Editorial:

Oberti do Amaral Ruschel

Capa: Débora Lima

Projeto Gráfico: Glauber Winck Machado, Natasha Moreira

Diagramação: Glauber Winck Machado

Revisão: Ana Santos, Cecília Fischer Dias, Felipe Raskin Cardon, Pamela Bielefeld

\section{Programa de Pós-Graduação} em Direito

Faculdade de Direito - UFRGS - Av. João

Pessoa, 80 - $2^{\circ}$ andar

Porto Alegre - RS - 90040-000

Fones: (51) 3308-3306 - 3308-3280 / Fax: (51)

3316-3987

E-mail:ppgd@ufrgs.br

Site: www.ufrgs.br/ppgd

Site da revista: www.seer.ufrgs.br/ppgdir

C122 Cadernos do Programa de Pós-Graduação em Direito - PPGDir/

UFRGS - vol. 8 n. 2 (2013). Porto Alegre: PPGDir/UFRGS, 2003-

Semestral

ISSN 1678-5029, E-ISSN 2317-8558

1. Direito - Periódicos I. Universidade Federal do Rio Grande do Sul

CIP - Brasil. Dados Internacionais de Catalogação na Publicação. (Jaqueline Trombin - Bibliotecária responsável CRB10/979) 


\section{Sumário}

El Gobierno y la Administración Local en España: sobre las Alteraciones de los Términos Municipales Jaime Rodríguez-Arana Muñoz

As Finanças Portuguesas nos Séculos XVII e XVIII António Manuel Hespanha

A Sociedade de Risco e a Repercussão das Capacidades Individuais do Sujeito para a Culpa Não Imputável

Selma Pereira de Santana

Medidas Provisórias, Constituições Estaduais e Federação Álvaro Bettanin Carrasco

Imposto sobre Serviços e Planos ou Convênios Funerários: Análise Crítica do Subitem 25.03 da Lista Anexa à Lei Complementar no 116/03

Martha Toribio Leão

Créditos Não Tributários Estaduais, Prazo de Prescrição e Procedimento diante da Ausência de Lei Específica Juliano Heinen

O Realismo Jurídico como Meio de Garantia da Justiça Ambiental

Manuela Braga Fernandes

A Autopoiese no Direito e o Funcionalismo Sistêmico de Günther Jakobs na Aplicação da Lei Penal 
O Conceito de Eficácia como Fundamento do Sistema Penal Ana Gabriela Souza Ferreira

Os Efeitos da Unificação do Regime das Obrigações pelo Código Civil de 2002: Estudo do Contrato de Comodato na Relação de Distribuição de Derivados de Petróleo Luciano Zordan Piva

Parâmetros Racionais de Aferição do Real Conteúdo das Hipóteses que Ensejam o Julgamento Monocrático do Art. 557 do Código de Processo Civil Brasileiro à Luz do Princípio da Colegialidade

Ludmilla Camacho Duarte Vidal

O Desenvolvimento dos Direitos da Personalidade, sua Aplicação às Relações de Trabalho e o Exercício da Autonomia Privada

Fábio Siebeneichler de Andrade

Andressa da Cunha Gudde

Pluralismo Jurídico: o Palimpsesto Político e Jurídico em Moçambique e Direito de Pasárgada no Brasil Custódio Vique Jossia Júnior

A Interpretação do Duty to Mitigate the Loss na Convenção das Nações Unidas sobre Contratos de Compra e Venda Internacional de Mercadorias e a sua Recepção pelo Direito Civil Brasileiro

Fernanda Sirotsky Scaletscky

Notícias 


\section{Prefácio}

A revista Cadernos do Programa de Pós-Graduação em Direito da UFRGS apresenta, com satisfação, sua segunda edição de 2013, consolidando o seu novo formato online e já vislumbrando novos desafios (novo projeto gráfico da revista impressa que em breve disponibilizaremos), de vez que muito humildemente temos recebido retornos positivos do acerto e da seriedade do nosso trabalho.

A novidade principal dessa edição diz respeito ao incremento de seções, que associam trabalhos científicos, notícias, teses etc., mas que, sobretudo, reúnem artigos da lavra de professores internacionais convidados. Aliás, o espírito da UFRGS, considerada uma das melhores universidades do país nas últimas avaliações, não poderia ser diferente, e por isso não perderemos o trem da história que conduz a internacionalização, sem deixar de considerar em alta conta as produções brasileiras.

Gostaríamos de ressaltar também nesta apresentação que, a partir de agora e das reais condições de qualidade que estamos adquirindo, passaremos a pleitear um significativo crescimento junto ao Qualis CAPES, buscando oferecer ainda mais significado e importância científica àqueles que conosco ajudam a construir a pós-graduação brasileira.

Por dever de reconhecimento e em função do grande esforço que temos dispendido em prol da qualidade, pedimos licença aos nossos leitores para agradecer a algumas pessoas que nos ajudaram: primeiramente, ao nosso corpo de avaliadores com os quais temos travado contato por todo o Brasil e que sem dúvida compõem um dos pilares de sustentação da revista. Muito obrigado a todos! Por outro lado, nessa edição se faz necessário também um especial agradecimento aos servidores dessa universidade, pois são diversas as contribuições 
que temos recebido dos órgãos administrativos e assessores. Também à Gráfica da UFRGS, por ter elaborado o novo projeto de revista impressa, que logo reforçará a repercussão dos artigos virtuais e acarretará um relevante aumento de impacto de cada publicação. Às servidoras da Biblioteca da Faculdade de Direito e da Secretaria da Faculdade que dispensaram vários esforços na obtenção das revistas antigas, colaborando com o projeto de digitalização dos números anteriores, e que estamos levando a cabo. Um último agradecimento à Imprensa da UFRGS, que tem se mostrado imensamente disponível para a extração de fotos do patrimônio histórico que é a nossa Faculdade de Direito, e que estaremos disponibilizando futuramente.

Enfim, só nos resta insistir no agradecimento a todos, desejando não só boas leituras, mas um ótimo 2014, ainda mais vibrante do que este ano que tanto nos recompensou.

Porto Alegre, 30 de dezembro de 2013.

Prof. Dr. José Alcebíades de Oliveira Junior

Coordenador PPGDir - UFRGS

Editor-Chefe

Profa. Dra. Claudia Lima Marques

Coordenadora Substituta do PPGDir - UFRGS

Doutorando Gustavo Castagna Machado

Doutorando Wagner Silveira Feloniuk

Mestranda Anatércia Rovani

Mestrando Lucas Gerhardt Gavronski

Editores Colaboradores 


\section{El Gobierno y la Administración Local en España: sobre las Alteraciones de los Términos Municipales \\ O Governo e a Administração Local na Espanha: sobre as Alterações dos Limites Municipais \\ Local Government and Administration in Spain: on Changes on Municipal Boundaries}

Jaime Rodríguez-Arana Muñoz*

Resumen: La cuestión de los espacios territoriales locales y sus Gobiernos y Administraciones es un asunto de discusión permanente y, hoy en día, de gran actualidad. El debate académico y político, por ejemplo, acerca del tamaño de los municipios es permanente [...]. Ciertamente, desde el Estado se han transferido a las Comunidades Autónomas numerosas competencias. Sin embargo, todavía esta pendiente de realización, el congruente traspaso de competencias de las Comunidades Autónomas a los Entes locales desde la lógica de la subsidiariedad, desde la lógica de que las personas reciban los mejores servicios que puedan mejorar, valga la redundancia, sus condiciones de vida y así poder ser más libres personal y solidariamente.

Palabras clave: Gobierno. Administración Local. España. Municípios. Autonomia. Subsidiariedad.

Resumo: A questão dos espaços territoriais locais e seus governos e administrações é um assunto de discussão permanente e, hoje em dia, de grande atualidade. $\mathrm{O}$ debate acadêmico e político, por exemplo,

\footnotetext{
* Catedrático de Direito Administrativo da Universidade da Coruña e Presidente do Foro Iberoamericano de Derecho Administrativo.
} 
El Gobierno y la Administración Local en España...

acerca do tamanho dos municípios é permanente [...]. Certamente, o Estado tem transferido às comunidades autônomas numerosas competências. Contudo, está pendente de realização a transferência harmônica de competências das comunidades autônomas aos entes locais a partir da lógica da subsidiariedade, a partir da lógica de que as pessoas recebam os melhores serviços para que possam melhorar, vale a redundância, suas condições de vida e assim possam ser mais livres pessoal e solidariamente.

Palavras-chave: Governo. Administração Local. Espanha. Municípios. Autonomia. Subsidiariedade.

Abstract: The issue of local territorial spaces and their governments and administrations is a subject of ongoing discussion and, today, of great current relevance. The academic and political debate, for example, about the size of municipalities is permanent [...]. Certainly, the state has transferred to the autonomous communities numerous powers. However, it is pending a consistent transfer of powers from autonomous communities to local bodies based on the logic

8 of subsidiarity, on the logic that people receive the best services in order that they can improve, it is worth the redundancy, their living conditions and therefore be freer personal and solidarily.

Keywords: Government. Local Administration. Spain. Municipalities. Autonomy. Subsidiarity.

\section{Introducción}

La cuestión de los espacios territoriales locales y sus Gobiernos y Administraciones es, desde luego, un asunto de discusión permanente y, hoy en día, de gran actualidad. El debate académico y político, por ejemplo, acerca del tamaño de los municipios es permanente. En la propia Historia de España, sin ir más lejos, este polémico tema lo encontramos, desde la Constitución de Cádiz en 1812 hasta nuestros días sea cuál sea la forma de gobierno, sea cuál sea el partido político en el poder. 
Es lógico que así sea por que siendo como es la Administración y el Gobierno local la estructura política y administrativa primaria, la primera con la que se topa la persona, ésta ha de tener una organización y unos medios adecuados para cumplir sus tareas de mejora de las condiciones de vida de los vecinos. Sin embargo, al menos en España, tras la Constitución de 1978, los Entes locales han sido las Administraciones y Gobiernos territoriales más olvidados por el sistema político, probablemente, como se ha dicho y escrito hasta la saciedad, porque había que cuidar y alimentar adecuadamente a las Comunidades Autónomas, de emergencia y creación constitucional. Hasta tal punto esto es así que en la agenda política surgió no hace mucho una expresión para llamar la atención acerca de la relevancia de estas instituciones públicas y su sistemática preterición en la acción pública de los últimos tiempos: el pacto local, también denominado, según los casos y las circunstancias, la segunda descentralización.

Ciertamente, desde el Estado se han transferido a las Comunidades Autónomas numerosas competencias. Sin embargo, todavía esta pendiente de realización, el congruente traspaso de competencias de las Comunidades Autónomas a los Entes locales desde la lógica de la subsidiariedad, desde la lógica de que las personas reciban los mejores servicios que puedan mejorar, valga la redundancia, sus condiciones de vida y así poder ser más libres personal y solidariamente. Esta segunda descentralización esta pendiente, aunque es verdad que en algunas Comunidades Autónomas se han adoptado algunas medidas en esta dirección, sin que el proceso, ni mucho menos, haya alcanzado un volumen de transferencias razonable.

El análisis de la realidad político-administrativa local entre nosotros, debe hacerse desde la perspectiva del derecho, por supuesto, pero también, como desarrollaré en el siguiente parágrafo, desde la óptica de la ciencia política. Por una razón 
El Gobierno y la Administración Local en España...

poderosa, los Entes locales son estructuras de servicio objetivo al interés general, por supuesto, pero por su carácter representativo de la ciudadanía y la forma de elección de sus regidores, tienen un obvio carácter político que no se puede perder de vista. Es decir, no son exclusivamente Entes públicos dotados de autonomía administrativa o de mera gestión, tienen autonomía política, por mucho que algunas doctrinas intenten supeditar la naturaleza de la autonomía al hecho de disponer de una Asamblea legislativa, a la capacidad de autoformación del máximo rango.

Los postulados del pensamiento abierto, plural, dinámico y complementario, tan importantes en las ciencias sociales, han de facilitar un acercamiento de tal naturaleza a la realidad local, una realidad que constituye el primer espacio de encuentro para la persona con el interés público. Un concepto, éste de interés público, que tiene una dimensión compuesta y que pude ser gestionado y gobernado desde cada Ente público de acuerdo con su imbricación en la esfera de competencias y atribuciones propias. Por eso, para estar en mejores condiciones de comprender el alcance y operatividad de los Entes locales, sería menester disponer de un estudio en el que se clarificara el ámbito de competencias de cada Ente territorial, tanto desde la perspectiva constitucional y autonómica, como desde una consideración del interés público local y las competencias que en un estado compuesto como el español debieran corresponder a los Entes locales, sean Ayuntamientos, Diputaciones, Consejos o cabildos insulares.

Con alguna frecuencia los estudios jurídico-administrativos y políticos sobre las estructuras políticas y administrativas se olvidan de un elemento central: del ciudadano, en este caso del vecino. Tal preterición constituye todavía una herencia del modelo de Estado burocrático que todavía habita en las mentes de no pocos gestores y académicos, más preocupados 
de análisis y estudios endogámicos que se agotan y se cierran sobre sí mismos. En cambio, cuando el centro de la cuestión pasa del la estructura a la persona, de la institución al ciudadano, entonces las reflexiones y las propuestas, de uno $\mathrm{u}$ otro signos alcanza parámetros de racionalidad que permiten comprender mejor el objeto de estudio y dar a cada actor el valor que realmente tiene.

El marco constitucional y estatutario va a estar necesariamente presente en nuestro análisis. Porque es una premisa metodológica y sustancial de cualquier investigación sobre los Entes locales en España y porque para un jurista son sus principales armas para la tarea. En este sentido, también vamos a trabajar en el contexto de la ya "vieja" ley de bases de 1985 así como, para el caso gallego, en el ámbito de la legislación propia en la materia.

Las experiencias comparadas acerca de cómo han resuelto y resuelven la cuestión local proporcionan, desde luego, aportaciones muy importantes en orden a pensar posibles soluciones para nosotros. También existen legislaciones autonómicas en España, por ejemplo la catalana, que ofrecen planteamientos y desarrollos de interés. Especial interés ofrecen los casos de las reformas realizadas en los países del Norte de Europa y especialmente en Alemania, dónde se ha conseguido reducir el número de los Entes locales a partir de estrategias públicas bien interesantes que conviene conocer, no sólo para aprender, sino para comprender mejor el sentido del éxito en las reformas administrativas, algo desde luego ignoto para muchos especialistas y estudiosos de la Administración pública en general. Como regla, deberíamos entrar que todas las cuestiones que afecten de manera relevante a los espacios locales cuenten con el concurso y participación de los vecinos, no sólo de sus representantes o gobernantes. Algo, ciertamente, olvidado en un momento en que relevantes y trascendentales políticas 
El Gobierno y la Administración Local en España...

públicas que afectan a cuestiones vitales para la existencia de los hombres se adoptan sin contar con la opinión de la población. Al menos, en el ámbito local, la participación vecinal debiera ser una pieza maestra de cualquier solución que se adopte. De lo contrario seguiremos en planteamientos burocráticos en los que una serie de iluminados o elegidos por la tecnoestructura tengan la última palabra y decidan cuestiones que en cualquier democracia seria y madura se consultan con el pueblo en su conjunto.

En el caso español, la realidad local es la que es que todos conocemos. Despoblación, y consiguiente inframunicipalismo en los espacios rurales y superpoblación en los espacios urbanos, escasa natalidad, fórmulas organizativas bien rígidas, también para las grandes ciudades a pesar de las previsiones de la nueva Ley de modernización del gobierno local de 2003, bien reciente. La planta de los Entes locales, heredada de la tradición francesa, se aplica por igual a todos los Entes locales, ahora con algunas especialidades para los grandes Ayuntamientos. La estructura de gobierno y administración local deja mucho que desear y es menester diseñarla en función de la realidad y de las necesidades colectivas de los vecinos.

En España, la existencia de una panoplia de Entes públicos con competencias en el territorio: Estado, Comunidades Autónomas, Provincias, Islas, Municipios, Comarcas... plantea también, aprovechando la crisis económica en que estamos sumergidos, soluciones a una presión administrativa que elevan irracionalmente el gasto público, lo que lleva inevitablemente a una competencia entre Administraciones a veces propia de una novela surrealista. Es conveniente, desde nuestro punto de vista, una reforma institucional, reforma, insisto, que sólo será posible si previamente se diseña un mapa competencial realista y objetivo. A partir de él, el montaje institucional es más sencillo y coherente. 
Los Entes locales en España, como señaló una temprana sentencia del Tribunal Constitucional sobre el tema, de 1981, son Entes públicos con una naturaleza bifronte o híbrida. En efecto, en lo que atiende a las bases o a la ordenación general de su régimen jurídico es el Estado quien tiene la competencia. Ahora bien, si se trata de la ordenación de asuntos sectoriales entonces es la Comunidad Autónoma quien dispone normativamente de estas materias. La ley de bases de 1985 está superada tal y como reconoce unánimemente la doctrina. Es momento, también, para elaborar una Ley de bases que permita una mayor flexibilidad a los Entes locales, al modo anglosajón o centroeuropeo, para diseñar esquemas de gobierno y gestión más cordes con las necesidades colectivas de los vecinos.

Mientras que en Europa, el porcentaje de gasto público que administran los Entes locales es del orden del $24 \%$, en nuestro país es del $16 \%$. Otro dato para la reflexión: las Corporaciones locales españolas tienen un gasto sobre el producto interior bruto del $6 \%$ mientras que el conjunto de la Euro-zona se encuentra en el $10.1 \%$.

En Galicia, los datos son los que son: 315 municipios, dos más que hace veinte años; más de 3.000 Parroquias, y la mitad de los núcleos de población de todo el Reino: 32.000. Del total de Ayuntamientos, 200, más de la mitad cuentan con apenas 2.000 o 3.000 habitantes. Tenemos un Ayuntamiento de menos de 500 habitantes y 16 con menos de 1.000 En estas condiciones, no es difícil colegir que las arcas locales, sobre todo en una época de aguda crisis como la que sufrimos, no estén muy boyantes. Más bien, el gran problema del mundo local en España, y especialmente en Galicia, es que numerosos municipios, por su tamaño y capacidad de gestión, serán inviables sino se buscan soluciones que permitan superar estos problemas.

En el ámbito de Galicia, como en otras Comunidades, especialmente en Valencia, cuyo anteproyecto de ley del 
El Gobierno y la Administración Local en España...

régimen local apuesta por los fenómenos de asociacionismo y las fusiones locales fomentándolos claramente, se ha abierto un debate acerca de cómo resolver este gran tema. Un debate en el que deben participar los políticos, los empresarios, los sindicatos, los usuarios, la universidad, los colegios profesionales y todas aquellas instituciones y corporaciones relacionadas con el ámbito local. Estas líneas se escriben desde la invitación de la Xunta de Galicia a pensar en libertad acerca de cuáles pueden ser algunas líneas que puedan desembocar en soluciones reales que permitan que los Entes locales sigan prestando servicios para la mejora de las condiciones de vida de los vecinos. Este es la clave, tener bien presente que las fórmulas que se puedan arbitrar no pueden dejar de espaldas a los vecinos, por muy bien diseñadas que estén o por muy bien que puedan encajar en el Ordenamiento Jurídico. Si no se tiene claro que los dueños de los intereses públicos locales son los vecinos, si

14 no se es consciente de que los vecinos son los propietarios de las instituciones públicas locales, si los políticos no asumen que son delegados o representantes de los vecinos a quienes deben dar cuenta de sus decisiones permanentemente, entonces estaremos perdiendo una oportunidad magnífica para poner las bases de la solución del problema.

Estamos en el siglo XXI y así como no tiene sentido alguno, por ejemplo, seguir explicando en la Universidad las instituciones y categorías del Derecho Administrativos por los manuales de autores franceses tan relevantes como Cormenain o Laferriere, que editaron sus lecciones en la primera mitad del siglo XIX, así tampoco es lógico que la planta organizativa de los Entes locales siga teniendo una impronta pensada para otros tiempos, con otro modelo de Estado y en un ambiente político y social distinto. Por tanto, reconociendo como se reconoce la importancia del Derecho Francés en el nacimiento del moderno Derecho Administrativo, es lo cierto que a día de 
hoy, la centralidad de los derechos de los vecinos y sus razonables expectativas de mejores servicios han de presidir las soluciones a adoptar. Soluciones que demanda el tránsito del Estado burocrático al Estado social y democrático de Derecho y que deben alumbrar nuevas piezas normativas y nuevas posibilidades organizativas. Ahora, sin embargo, tenemos que operar con lo que hay, de ahí que lo más razonable y sensato sea tener en cuenta los medios disponibles y buscar la mejor solución posible.

\section{Una Aproximación Multidisciplinar a la Realidad Local}

Las cuestiones que afectan a la realidad política y administrativa, especialmente las que se refieren al estudio de las Administraciones y Gobiernos locales han de afrontarse desde una perspectiva abierta, plural, complementaria. Todos los enfoques que tienen relación, directa o indirecta, con los espacios territoriales locales han de ser convocados a su estudio. Si así no se hace, si se invoca una pretendida orientación como única para el estudio, entonces aviados estamos. Tanto si se decide que el enfoque politológico como el jurídico, el histórico, el económico o el psicológico han de tener pretensión de pensamiento único, entonces el estudios será parcial y, además, probablemente será un análisis sesgado, insuficiente. Esto ha acontecido en muchas ocasiones, no me importa confesarlo, con la pretendida soberanía científica del Derecho Administrativo en relación con la Administración Pública. Sin embargo, tan perverso es la dictadura en esta materia del Derecho Administrativo como, por ejemplo, la dominación de la ciencia política.

Los Entes locales, como reza la Carta Europea de la Autonomía Local, son uno de los principales fundamentos de la democracia. No sólo porque son el primer espacio público, y 
El Gobierno y la Administración Local en España...

por ende político, con el que se encuentran las personas, sino porque en las democracias los Entes locales tienen un obvio carácter representativo que no se puede obviar. Como dice la exposición de motivos de la ya vetusta ley de bases del régimen local de 1985, constituyen uno de los principales fundamentos del régimen democrático. Como ha señalado el profesor Meilán Gil, son la expresión de la convivencia social más próxima dentro del Estado (2009, p. 22). No los crea la Constitución precisamente porque a lo largo de los siglos, sin que sean necesariamente la encarnación de una institución tan antigua como el mismo ser humano, el espacio local ha sido, es y seguirá siendo, el primer ámbito de acercamiento de las personas a la dimensión pública. Es decir, la persona penetra en el espacio de la deliberación pública ordinariamente en el municipio. En este sentido, siempre se ha entendido que el tamaño de los municipios y su población son elementos muy importantes 16 en orden a facilitar la participación vecinal. En municipios de varios millones de personas, el grado real de participación es más bien bajo, creciendo en consecuencia la desafección y la distancia de los habitantes en relación con los asuntos públicos, y tantas veces con los propios representantes locales.

En la Constitución española de 1978, como es bien sabido, están reconocidos en el Título VIII como elementos integrantes del Estado y dotados de autonomía, para la gestión de sus intereses, al igual que las Comunidades Autónomas. Es verdad que las Comunidades Autónomas según el artículo 2 de la Constitución disponen de capacidad legislativa, la mayor expresión de la autonomía. Que, además, la utilización del término Administración local sea el elegido por el constituyente para el capítulo II del Título VIII de la Constitución no ayuda de demasiado. Ahora bien, como ha señalado Meilán Gil, el carácter representativo de los municipios, expresado claramente en el artículo 140 de la Constitución no deja lugar a dudas (2009, p. 24), 
como también abona la tesis de la naturaleza política, también administrativa, de los Entes locales, que la nota de la representatividad, de la elección, no figura, dice Meilán Gil, en el artículo 103 de la Constitución, que es el referido por antonomasia a la Administración pública. Se trata de gobiernos y administraciones locales, o por mejor decir, gobiernos locales, pues la denominación gobierno incluye en sí misma, la existencia de una Administración que actúa bajo la dirección del gobierno para el servicio objetivo del interés general.

En el Reino Unido, como sabemos, los llamados poderes locales están en la entraña misma de la democracia y son, desde luego, una de sus pilares más destacados. Junto a la institución democrática, la vitalidad de los poderes locales es fundamental, junto al Parlamento, para una vida democrática real. Como recuerda Meilán Gil, hay un dicho bien claro en la literatura sobre los poderes locales británicos que demuestra claramente este aserto central: si el self-government se marchita, las raíces de la democracia se secan (2009, p. 24).

En realidad, la explicación de conformar a los Entes locales desde la perspectiva administrativa exclusivamente, como Administración local, hunde sus raíces en la ideología burguesa que conformó el quehacer público en la España del siglo XIX y que tanto influyó, aunque parezca sorprendente, en la perspectiva centralista, unilateral y anclada en el Estado de la misma concepción del Derecho Administrativo y de todas sus categorías e instituciones. Hoy, sin embargo, como ha ratificado el Tribunal Constitucional ya en su sentencia de 2 de febrero de 1981 son corporaciones locales de naturaleza representativo, y su gobierno y administración tienen el carácter de autónomas para la gestión de sus respectivos intereses, lo que exige que se dote a cada Ente local de todas las competencias propias y exclusivas que sean necesarias para satisfacer el interés respectivo. 
La autonomía local existe porque hay un determinado círculo de intereses públicos imbrincados sustancialmente con la dimensión local. El problema es que si bien la Constitución quiso establecer las materias de competencia de las Comunidades Autónomas y del Estado, en el caso de los Entes locales guardó silencio. Un silencio que demuestra de alguna manera que los constituyentes se concentraron especialmente en las Comunidades Autónomas y dejaron a los Entes locales bajo la disponibilidad normativa del Estado y de las propias Autonomías. Desde el principio el Tribunal Constitucional reconoció, desde esta perspectiva, la naturaleza bifronte de los Entes locales. Por una parte, es el Estado quien puede ordenar jurídicamente los asuntos centrales y medulares de la vida local. Y, por otra, son las Comunidades Autónomas, a través de sus correspondientes Parlamentos, las competentes para la ordenación sectorial de los Entes locales.

La Constitución reconoce que existen intereses locales, reconocimiento que debe ser garantizado. La técnica elegida, ahora un poco pasada de moda, fue la de la garantía institucional, de tradición germana. De esta manera, la actuación normativa del Estado y de las Comunidades Autónomas sobre los Entes locales, deben respetar la garantía institucional de la autonomía local, que se centra en los elementos esenciales o núcleo primario del autogobierno. La garantía institucional acogida tempranamente por la doctrina del Tribunal Constitucional por ejemplo, en la sentencia de 28 de julio de 1981, cuando afirma el alto Tribunal que la garantía institucional no garantiza un contenido concreto o un ámbito competencial determinado y fijado de una vez por todas, sino preservación de una institución en términos recognoscibles que para la imagen que de la misma tiene la conciencia social en cada tiempo y lugar.

En el caso del espacio local, hay gobierno, porque hay elecciones, y hay administración porque se toman decisiones 
políticas que precisan de implementación, como ahora se dice, administrativa, porque hace falta tarea de "servicio objetivo al interés general". Y, por supuesto, el enfoque económico y presupuestario es capital porque las políticas públicas locales han de estar soportadas en un presupuesto que tiene ingresos, procedentes de varias fuentes, $\mathrm{y}$ tiene gastos para atender el personal y las obras y servicios de interés vecinal. Es más, si las haciendas locales no están saneadas, la autonomía local será una quimera y no se podrán prestar adecuadamente servicios a los vecinos.

También desde la realidad social se observa un fenómeno preocupante desde el punto de vista de la capacidad de gestión y de la suficiencia financiera de los Ayuntamientos. Me refiero a que en muchas ocasiones los Entes locales asumen competencias que no son propias, que se llaman impropias, que terminan por descuadrar los presupuestos a pesar de que se trata realmente de tareas que si no las realizan los Entes locales se quedan sin hacer. Esta realidad ha de tenerse presente en un futuro catálogo de competencias locales.

Años atrás, en 1999, el gobierno británico, entonces liderado por Blair, publicó un libro blanco sobre la reforma administrativa bajo el mandato del ministro Cunningham, que llevaba como rótulo: la Administración pública una tarea para la mejora de las condiciones de vida de los ciudadanos. Pues bien, para que las Administraciones y Gobiernos locales puedan contribuir decisivamente a la mejora de las condiciones de vida de los vecinos es obvio que han de poder organizarse, en el marco de unas bases generales amplias, de la forma que entiendan más eficaces y eficientes. Este es un punto muy relevante porque imponer un modelo organizativo único para todos los casos, sea cual es el tamaño y la dimensión del Ente local, resulta algo anacrónico en los tiempos en que vivimos en los que, insisto, el modelo de Estado burocrático ha sido 
El Gobierno y la Administración Local en España...

abandonado por un modelo de Estado humano, a escala humana, con estructuras e instituciones territoriales, entre ellas las locales, dedicadas a contribuir a la mejora de las condiciones de vida de los vecinos.

De la ciencia política, nos interesan sobremanera las consideraciones sobre la definición, ejecución, y evaluación de políticas públicas locales y, sobre todo, las políticas de participación vecinal, de forma y manera que la opinión de los vecinos tenga el peso que debe tener, por ejemplo, en los procesos de fusión municipal. Las explicaciones sobre la forma de prestar los servicios locales de manera más eficaz y eficiente, las cuestiones sobre las tripas de la gestión local o sobre el manejo y conducción de determinados intereses públicos locales también competen a la ciencia política y de la administración y son relevantes para el análisis de la situación de los Entes locales en España y en Galicia.

Los aspectos financieros son básicos. Las políticas públicas locales, consecuencia de las competencias de que disponen los Entes locales según el esquema de atribuciones dibujado en el bloque de constitucionalidad, sólo serán posibles si los Gobiernos y Administraciones locales tienen fondos para afrontar tales responsabilidades. Y hoy, tras más de treinta años de andadura constitucional, es lo cierto que la suficiencia financiera de estos Entes de los que tanto se espera y en lo que tanto se confía, no es más que una quimera. Por eso, la financiación local es una cuestión indisolublemente unida al un nuevo esquema organizativo en el mundo local puesto que sin fondos no hay autonomía posible, no hay autonomía real. La autonomía en estos casos, bien lo saben los alcaldes y concejales, no es más que pura retórica.

Como es bien sabido, la historia ofrece siempre perspectivas iluminadoras de la realidad porque ayuda sobremanera a comprender las causas y el sentido que tienen en el presente 
las instituciones objeto de estudio o análisis. En el campo de los Entes locales, no es ningún secreto afirmar que en efecto el mapa local española es manifestación del espíritu ilustrado que presidió las Cortes de Cádiz de 1812. En virtud de la lógica racionalista del momento y del protagonismo de la institución estatal como paladín y solución de todos los males y transmisor de todos los bienes, la benemérita Constitución de Cádiz de 1812 dispone que se constituya en cada pueblo de al menos mil habitantes un Ayuntamiento. Más adelante, por mor de un Real Decreto de 1835 los Ayuntamientos verán ampliado su territorio con la incorporación de parroquias vecinas hasta alcanzar la nada desdeñable cifra de 11.271 municipios, muy superior a la actual, lo que quiere decir que en algún momento se procedió a racionalizar un mapa de estructuras locales demasiado elevado. Las leyes de 1856, 1870 y 1877 vincularon la dimensión territorial del Ayuntamiento con la capacidad para gestionar y administrar las competencias atribuidas, estableciéndose como parámetros básicos para que un Ayuntamiento viniera al mundo: contar con no menos de 2.000 habitantes residentes y capacidad para atender los gastos municipales con los recursos autorizados por las leyes de entonces. Recordemos que hoy hay en España, y también en Galicia, reino donde los haya de inframunicipalismo, hay Concellos de menos de 2.000 habitantes.

Es bien conocida la óptica profundamente racionalizadora desde la que se elaboraron las bases para la Ley Orgánica Municipal de 1906, entre las que se exigía una población no menor de 2000 habitantes para ser considerado Ayuntamiento. Los municipios que no contaran con esta población habrían de ser incorporados a los más próximos prohibiéndose la constitución de nuevos Entes locales con una oblación menor a la referida. El tamaño, pues, de los Entes locales, estuvo muy presente en los legisladores y gobiernos del siglo XIX y del XX 
El Gobierno y la Administración Local en España...

hasta el punto de propiciarse, a principios del siglo XX operaciones de incorporación para disponer de Entes locales con capacidad suficiente para prestar los servicios a la medida de los vecinos. Esta es la cuestión: Entes locales con medios suficientes para gestionar las competencias en un marco de mejora de las condiciones de vida de los habitantes. Incluso durante la etapa política anterior a la actual, los Gobernadores civiles podían, bajo los auspicios de la todopoderosa dirección general de Administración local, proceder a operaciones de fusión o incorporación para que los Entes locales tuvieran el tamaño y los medios adecuados para atender razonablemente a los vecinos. En 1966, una modificación parcial de la Ley de Régimen local constituyó un Fondo Nacional de la Hacienda Municipal con el propósito de, entre otros, de estimular económicamente las agrupaciones municipales a efectos del sostenimiento económico del servicio o una ulterior racionalización de la orga22 nización territorial. Ya por entonces se tomó conciencia, desde el centralismo imperante, de la necesidad de proceder a una reforma de la organización territorial de base local. Otra norma destacable en este proceso racionalizador es el Real Decreto 3.046/1977 por el que se estableció la agrupación forzosa de los municipios de menos de 5000 habitantes para el sostenimiento de la secretaría municipal y en su caso de personal común cuando la población no alcanzaba los 2.000 habitantes, algo que a día de hoy se produce, al menos que yo sepa en el ámbito de las secretarías, gracias al apoyo técnico que ofrece para estos supuestos la Diputación provincial.

Con el advenimiento del régimen constitucional, las competencias para la alteración, según el artículo 148.1.2ํㅡ CE, corresponde a la Comunidad Autónoma, que tiene las facultades para diseñar una estructuración del mundo local que, coherente con las bases estatales, puede realmente racionalizar y modernizar unos Entes públicos territoriales hoy en muchos 
casos sin medios, sin personal, sin capacidad real de incidir positivamente en la vida de los vecinos. La ley de bases del régimen local de 1985 atribuyó al Estado la posibilidad de adoptar medidas de fomento para las fusiones municipales. Veamos el resultado brevemente en los últimos cincuenta años más o menos.

Se calcula que entre 1960 y 1980, con estas medidas racionalizadoras, desaparecieron 1.263 municipios, mientras que se constituyeron, con los nuevos criterios, 103: 13 por segregación 90 por fusión. Por tanto, precedentes en España los hay. En los países del Norte de Europa, especialmente en Alemania, en la década de los sesenta del siglo pasado, se pusieron en marcha una serie de medidas orientadas a racionalizar el mapa local que dieron bastante resultado con un relativo coste para los políticos y reformadores.

Hoy contamos con 8.112 Ayuntamientos. En 1981 había 8.022, luego hemos crecido. En Galicia, de 313 en 1990, ahora tenemos 315. Este es el drama, que sabemos que hay que racionalizar pero caemos presos de la irracionalidad política, tantas veces a causa de tolerar y permitir que sean los políticos locales los dueños y señores de un mundo en el que los vecinos deberían participar más activamente y desde las instancias autonómica y nacional, proceder a lanzar más mensajes racionalizadores. En efecto, entre 981 y 1991 desparecieron 12 Ayuntamientos y se crearon 67: 2 por fusión y 65 por segregación. Entre 1991 y 2001 todavía seguimos creciendo, aunque a un ritmo menor: se crearon 10 municipios, llegándose, repito a 2008 con 8.112 municipios, más de los que había en 1981. Es verdad que hoy hay menos que en 1812, pero también es verdad que hoy las cosas son distintas y que hoy las potencialidades de los Entes locales no tienen comparación alguna con las posibilidades de entonces de los más de 11.000 Ayuntamientos. 
El Gobierno y la Administración Local en España...

Desde el punto de vista de la fenomenología actual, hay que tener presente que la tendencia que se aprecia en todo el mundo acerca del asentamiento de las poblaciones refleja un claro predominio de las Áreas metropolitanas. En general, la corriente circula en dirección a los fenómenos de integración, de asociación, siendo capaz más escasos los procesos de segregación o aislamiento. Desde el campo de la Hacienda pública, los fenómenos de colaboración suelen denominarse: fusión, asociación y aglomeración. La profesora Cadaval Sampedro ha estudiado esta cuestión desde la perspectiva de la Hacienda pública (2001, p. 8). Por lo que se refiere a la fusión, reunir sobre un mismo territorio administrativo, financiero y político a varios Entes locales que asumen diversas funciones en un área determinada, hay argumentos de diversa naturaleza. Cadaval Sampedro (2001, p. 8) entiende que la fusión permite una mayor eficacia en la provisión de bienes y servicios 24 públicos, economías de escala, incremento en la calidad de las prestaciones, reducción de los costes así como una mejor internalización de los efectos desbordamiento. Por otra parte, la fusión facilita que los el nuevo Ente local tenga una mayor posición institucional para negociar de forma efectiva con otras instancias de gobierno superior al aumentar la autonomía perceptible y mejorar el sistema de perecuación financiera. Otra ventaja que señala Cadaval Sampedro (2001, p. 8) se refiere a que la fusión municipal permite desarrollar capacidades relacionadas con el capital humano y los medios financieros que no serían posibles anteriormente, posibilitando la puesta en valor de las potencialidades del territorio a través, por ejemplo, de la creación de polígonos industriales, recalificación de usos del suelo, canalización de suministros o mejora de las comunicaciones.

Sin embargo, no todo son ventajas en estos casos de fusiones de municipios desde la óptica de la Hacienda pública. 
La profesora Cadaval Sampedro señala también algunos problemas que debemos registrar: la fusión no resuelve todos los problemas de inadaptación del territorio: algunos se mitigarían pero otros subsistirían. Es decir, podría ocurrir que se interiorizaran todos los efectos externos, se aprovechasen las economías de escala y se redujesen los costes de congestión, sin asegurar que esto sea así para todos los bienes públicos locales. La situación es más complicada en las denominadas fusiones mayores, donde es prácticamente imposible encajar los territorios funcional, institucional y relacional para todas y cada una de las funciones del sector público local (CADAVAL SAMPEDRO, 2001, p. 9). Además, cuanto mayor es el Ente público, normalmente mayores son los problemas burocráticos aumentando la ineficacia. Según parece, la fusión con el tiempo distancia a los vecinos de los problemas reales generando una cierta dejadez a la hora del ejercicio del derecho democrático del voto. Como apunta la profesora Cadaval Sampedro (2001, p. 9), la desaparición de un número de municipios elegidos de manera democrática hace susceptible el incremento de la distancia entre los ciudadanos y sus representantes. Las fusiones encuentran resistencia, fundamentalmente, en las circunscripciones más pequeñas, al considerar que todo el poder se centrará en la ciudad mayor, la que impondrá sus preferencias sobre todos los demás, privándoles de participar en las decisiones que les atañen.

\section{Panorama General y Particular}

En el ámbito de la Unión Europea se considera que el umbral mínimo para un municipio viable, aquel que puede operar en un marco de suficiencia financiera, política y técnica, se cifra en 5.000 habitantes. Pues bien, Galicia, como ha señalado un interesante Informe del Círculo de Empresarios de 
El Gobierno y la Administración Local en España...

Galicia, tiene un registro difícil de superar: el 63.2\% de nuestros Ayuntamientos, 199, tenían en 2008 una población inferior a los 5.000 habitantes (2009, p. 11). Tenemos un Ayuntamiento de menos de 500 habitantes y 16 con menos de 1000. Es decir, la mayoría de nuestros Ayuntamientos, según estos registros de la Unión Europea tienen dificultades para prestar servicios con la calidad, eficacia y eficiencia exigibles en un moderno Estado social y democrático de Derecho. Porque no se trata, simplemente, de prestar servicios como sea. Se trata de adecuar las estructuras políticas y administrativas a las necesidades colectivas de los habitantes. Si así no fuera, estaríamos instalados en un grave problema porque entonces las instituciones y las entidades públicas serían fines en sí mismos, normalmente al servicio de unos dirigentes para quienes lo realmente determinante no es tanto atender cada mejor al pueblo, a los vecinos, sino mantenerse como sea en el poder.

26 Por si fuera poco, tenemos unas 3.000 parroquias y cerca de 32.000 núcleos de población. La despoblación de las zonas rurales y su concentración en las áreas urbanas también caracteriza el panorama gallego. El proceso de modernización operado en la segunda mitad del siglo pasado también dejó su huella en nuestra Comunidad Autónoma, de manera que la creciente urbanización producida en esos años facilitó, como señala el informe del Círculo de Empresarios de Galicia, un acceso generalizado a bienes y servicios avanzado, especialmente en materia de salud, educación y comunicación. En opinión del Círculo de Empresarios de Galicia,

[...] el ingreso de España en la UE acentuó la urgencia de una ordenación del territorio que atienda a esa nueva realidad urbana. Porque solo desde una articulación eficiente de los diferentes núcleos de población en torno a grandes polos urbanos-metropolitanos tendrá acceso toda la población a los servicios del Estado de bienestar y a actividades y empleos con futuro (CÍRCULO DE EMPRESARIOS DE GALICIA, 2009, p. 12). 
En este marco, los pequeños Ayuntamientos se han ido quedando aislados mientras crece la mayoría de edad de los vecinos y son mayores los problemas para el acceso a las nuevas tecnologías y a las nuevas oportunidades (2009, p. 11).

Es fácil de comprender que los Ayuntamientos con menor población tienen más dificultades ordinariamente para prestar los servicios que los habitados por cientos de miles de personas. Tal y como señala el informe que comentamos, la razón es bien sencilla: los Ayuntamientos con menor población tendrían que asumir proporcionalmente y por habitante mayor gasto que los Ayuntamientos más grandes para prestar los servicios mínimos que establece la ley de bases del régimen local de 1985.

Una buena ocasión para afrontar un proceso gradual de asociacionismo e integración de Entes locales lo ofrece la aguda crisis económica y financiera que también afecta, es obvio, a los Entes locales. Primero porque el problema de la financiación local lleva demasiado pendiente por atender preferentemente a las Haciendas de las Comunidades Autónomas. Y segundo porque la situación de crisis económica y financiera actual facilita enormemente las cosas. La necesidad de optimizar los recursos, de racionalizar los gastos, es a día de día una urgencia obvia entre nosotros. Reflexiones y comentarios como el de que hay que gastar menos, que hay que gastar mejor con menos, se suceden en este tiempo entre los responsables de las arcas públicas de la dimensión territorial que sean. Como señala el Círculo de Empresarios de Galicia en su informe,

[...] aplicar economías de escala derivadas de de la reducciónagrupación-optimización de las Administraciones locales, y del incremento de eficacia y de eficiencia, y conjugar todo ello con la adecuación de los servicios a las necesidades reales de los ciudadanos, pueden ser algunas de las medidas que nos permitan alcanzar la inevitable austeridad en el gasto público sin que esto afecte a los servicios que 
El Gobierno y la Administración Local en España...

recibe la población; más bien, al contrario, al menos en lo que se refiere a esos pequeños municipios que, hoy por hoy, tienen enormes dificultades para prestar esos servicios con la calidad exigible (CENTRO DE EMPRESARIOS DE GALICIA, 2009, p. 12).

Varias cuestiones me llaman poderosamente la atención del informe del Círculo de Empresarios de Galicia: la necesidad de pensar cómo prestar mejor los servicios en las áreas metropolitanas, la adecuación de los servicios a las necesidades reales de los vecinos y, sobre todo, la caracterización del gasto público de austero. Veamos. Es verdad que en las zonas de creciente urbanización han ido surgiendo, junto a las grandes ciudades, áreas urbanas que aunque no integradas formalmente en ellas, constituyen una mera prolongación. Estos ciento de miles de habitantes no pueden estar discriminados en los servicios a recibir solamente por fijar su residencia en uno $u$ otro municipio. Más grave es, desde luego, la cuestión de la naturaleza y necesidad de los servicios y actividades que realizan los Entes locales. Por una razón bien sencilla: no siempre se tiene en cuenta la opinión de los vecinos a la hora de establecer un determinado servicio o realizar una concreta actividad porque tales políticas obedecen a necesidades de personal de los propios concejales o de las personas que les han votado esperando a cambio, como si estuviéramos en el tradicional sistema del botín, sr colocados a costa del presupuesto público. Por lo que se refiere que el gasto público sea austero en todo momento y circunstancia, no sólo en época de crisis, es algo asumido en la doctrina científica. La Constitución en su artículo 31, ya lo hemos dicho, señala que la programación del gasto público ha de realizarse con arreglo a parámetros de economía y eficiencia.

Es bien sabido, y no por ello conviene olvidarlo, que en Galicia los Ayuntamientos se formaron a partir de las parroquias, compuestas de aldeas y lugares, en torno a una cabeza municipal. Galicia contaba en 1836 con 347 Ayuntamientos, más 
o menos lo que tenemos en la actualidad. Sin embargo, al contrario de lo que ocurrió en otras partes de España, la identidad propia de la persona no era tanto con el Ayuntamiento como con la parroquia, con la aldea, algo que está todavía vigente entre nosotros y que explica la fuerte vinculación, sobre todo con la aldea, que se encuentra en tantos y tantos gallegos. De ahí que el propio Estatuto de Autonomía, aunque dejando la cuestión abierta, reconociera nada menos que personalidad jurídica a la parroquia.

En 1918, como recuerda el informe del Círculo de los Empresarios de Galicia, descendió considerablemente el número de municipios. Pasamos de 347 en 1836 a 322 en 1918, ninguno con menos de 1.000 habitantes. En este período de tiempo disminuyó el número de municipios considerablemente. ¿Qué ocurrió entonces?. Pues que se acometieron procesos de fusión municipal, algo que ya tienen precedentes entre nosotros y que, como veremos al analizar brevemente algunas experiencias comparadas, ha caracterizado los procesos de reorganización municipal en Alemania y en los países del Norte de Europa en la década de los sesenta y setenta del siglo pasado. Tal y como recuerda el informe del Círculo de Empresario, las últimas fusiones se produjeron en 1962, cuando Enfesta se incorporó a Santiago de Compostela; en 1963, cuándo Vilameá y Vilaodriz se convirtieron en A Pontenova, en la provincia de Lugo; en 1967 Acevedo pasó a Celanova (Ourense). Sin embargo, desde la promulgación del Estatuto de Autonomía, las cosas han tomado derroteros bien distintos: de 314 Ayuntamientos en esa fecha hemos pasado a día de hoy, tras las segregaciones de Cariño de Ortigueira en 1988, Burela de Cervo en 1994y A Illa de Vilanova de Arousa en 1997, a 315. Esta es la realidad.

Así las cosas, la cuestión del tamaño y población de los Ayuntamientos en Galicia es un asunto presente en los discursos de todos los partidos políticos en la actualidad, sobre 
El Gobierno y la Administración Local en España...

todo después que la actual Xunta de Galicia haya manifestado su voluntad política de proceder a un proceso de fusiones y concentraciones municipales y, en general, de asociacionismo y colaboración intermunicipal. En realidad, el asunto del tamaño no es lo prioritario: lo central es si con la dimensión que tienen permite o no atender a los vecinos como exige un Estado social y democrático de Derecho. Este es el punto capital: si los poderes públicos locales mejoran o no cada día las condiciones de vida de los vecinos.

Cómo es sabido, durante la presidencia de Fraga Iribarne se puso un marcha un proceso de comarcalización orientado a hacer de las comarcas espacios de planificación y desarrollo económico y social, sin constituir como Entes locales estas demarcaciones territoriales. Sin embargo, tras relevantes estudios de la realidad comarcal gallega desde diferentes puntos de vista, el gobierno bipartito no participó de esta estrategia y, al cabo del tiempo, abandonó esta política de desarrollo territorial que sirvió para conocer mejor las necesidades colectivas de las comarcas. Hoy, en la ley de Administración local de Galicia de 1995 se establece como población mínima para la constitución de un nuevo Ayuntamiento 5.000 habitantes, señalando que el procedimiento para llevar a cabo fusiones municipales puede ser iniciado de oficio por la consellería competente o a instancias de los municipios afectados o de las propias diputaciones provinciales, disponiéndose que en caso de iniciarse de oficio con oposición de alguno o algunos municipios, que tal reorganización territorial sea aprobada por el Parlamento de Galicia.

La dispersión de la población gallega es un problema relevante. La dispersión implica un mayor coste para la creación de infraestructuras y para la prestación de los servicios. Por otra parte, el envejecimiento de la población, especialmente en 
los pequeños municipios a causa de la dispersión poblacional, es otro grave problema pues la previsión es poco halagueña.

La dispersión, sin embargo, no es privativa de Galicia. En efecto, la despoblación, el éxodo rural, el envejecimiento demográfico y la desaparición de municipios por quedarse sin habitantes es una realidad en algunas partes de España. Sin ir más lejos, la provincia de Huesca ha perdido 29 pueblos en 10 años: desde el 2000 a nuestros días la provincia de Huesca, por despoblación, ha perdido 31 municipios en la zona pirinaica especialmente. En términos generales, en España han desparecido 900 pueblos en los últimos quince años, sobre todo en Asturias y en Galicia. Por provincias, el caso de Lugo es particularmente significativo porque una de cada 4 poblaciones deshabitadas en los últimos 15 años era lucense. En nuestra Comunidad Autónoma, 75 municipios han perdido la mitad de su censo en los últimos 40 años. En efecto, 75 Ayuntamientos gallegos han perdido desde 1970 más de la mitad de su población, con las dramáticas consecuencias que de ello se deriva. Aquí, en Galicia, el éxodo rural se produjo más tarde que en otras zonas de España y, unido al problema de la baja natalidad, configura un nuevo reparto poblacional del que han salido beneficiadas indiscutiblemente las ciudades y sus áreas de influencia llevándose la peor parte los municipios rurales, especialmente los de las provincias interiores de Lugo y Ourense.

Más adelante comentaremos algunas experiencias europeas, especialmente la de Alemania para reorganizar el mapa territorial. En este punto interesa, sin embargo, llamar la atención acerca de que es posible emprender políticas dirigidas a paliar las negativas consecuencias de esta situación en Galicia. En Europa, en la década de los sesenta y setenta del siglo pasado se emprendieron, con éxito, procesos de reorganización 
El Gobierno y la Administración Local en España...

territorial. Es verdad que en algunos casos fue el poder político el que tomó directamente las riendas del proceso, en ocasiones sin contar con los propios vecinos, más preocupados de mantener a capa y espada unas identidades que los sumirían en la pobreza y la marginalidad.

Las Haciendas locales, es bien sabido, están en una situación dramática. De hecho no contamos con un modelo de financiación local razonable puesto que primero se ha atendido a resolver, no siempre con rigor y eficacia, la financiación de las Comunidades Autónomas. Por lo que se refiere al ámbito de la Comunidad Autónoma de Galicia, la viabilidad y solvencia de determinadas Entidades locales, Diputaciones y Ayuntamientos, es cuestionada. En efecto, el Consello de Contas de Galicia en su último informe publicado llama la atención de que los Entes locales gallegos disponen de los ingresos por habitante más bajos de España, alcanzando el $65.93 \%$ de la media de los 32 Ayuntamientos españoles. Como refleja el informe del Círculo de Empresarios de Galicia, Galicia está a la cola de España en lo que a ingresos tributarios locales se refiere, ascendiendo al $68 \%$ de la media del conjunto nacional. La media de este concepto está en 345,08 euros por habitante. Mientras que las ciudades gallegas de más de 50.000 están en 502,12 euros per cápita, los Ayuntamientos de menos de 5.000 habitantes están en 195,26 euros (2009, p. 21).

Al tratar del pacto local, de la segunda descentralización, sigue siendo una reclamación permanente de las asociaciones de Entes locales el derecho de estas Corporaciones a recibir las transferencias necesarias para atender las competencias que les son propias. A este problema de insuficiencia financiera ordinaria se suma la cuestión relativa a competencias que se prestan a iniciativa de las Comunidades Autónomas en virtud de determinadas subvenciones que, cuando desaparece la subvención, es francamente difícil explicar a los vecinos que 
a partir de entonces se quedarán sin tales o cuales actividades o servicios prestados por mor de dichas competencias.

En sede de Haciendas locales siempre conviene recordar el principio de suficiencia financiera de los Entes locales establecido nada menos que en el artículo 142 de la Constitución. Suficiencia que parte de los ingresos tributarios locales y de la participación en los ingresos del Estado y de las Comunidades Autónomas. En esta materia, hay que recordar que los baremos establecidos para esta participación acusan, dice el informe del Círculo de Empresarios de Galicia, la enorme fragmentación municipal, que repercute en el sobredimensionamiento del gasto público, restando eficacia y eficiencia a la gestión municipal. Se priman criterios como la población, el esfuerzo fiscal y el inverso de la carga tributaria. Sobre todo se valora la población, de manera que siempre los Entes locales más poblados son los que reciben más fondos por esta vía. Es más, el 75 $\%$ del reparto de los ingresos del Estado se realiza en función de la población de derecho municipal, a la que se aplican tres coeficientes multiplicadores: 1 , para los municipios de menos de 5.000 habitantes, 1,7 en el caso de Ayuntamientos con una población comprendida entre los 5001 y los 20.000, 1.3 para poblaciones de 20.001 a 50.000. Los pequeños municipios están claramente penalizados por este concepto. El 25\% restante de reparto de estos ingresos se valora, por partes iguales, en función del esfuerzo fiscal y el inverso de la carga tributaria (CÍRCULO DE EMPRESARIOS DE GALICIA, 2009, p. 22-23).

El artículo 142 de la Constitución también habla de la participación en los ingresos de las Comunidades Autónomas. Sin embargo, esta previsión constitucional está prácticamente inédita y sin desarrollar sistemáticamente. Claro que hay fondos autonómicos para atender a necesidades de financiación local, pero lo que plantea la Constitución es que se articule un sistema para que tal precepto se pueda cumplir. 
El Gobierno y la Administración Local en España...

En este contexto, el 63,2\% de los municipios gallegos, que son los que tienen menos de 5.000 habitantes, se calcula que para 2025 ascienda al 65,7\%. De esta forma, estos Entes locales, vía participación en los ingresos del Estado recibirán un 40 $\%$ menos de lo que reciben por habitante los municipios que superan los 50.000 habitantes, un $30 \%$ menos de los de 20.001 a 50.000 , y un $17 \%$ menos que los comprendidos entre 5.001 y 10.000 vecinos (CÍRCULO DE EMPRESARIOS DE GALICIA, 2009, p. 23).

El nivel de gasto público de los Entes locales oscila entre el 13 y el $16 \%$ según cuál sea la estadística que se maneje. En todo caso, estamos muy lejos de $56 \%$ de los daneses, del $27 \%$ de los italianos o del $18 \%$ de los franceses. La cuestión local en España es bien compleja: prestan un gran número de servicios y realizan actividades vinculadas a los intereses públicos con gran intensidad. Sin embargo, tienen un peso en

34 el gasto público general que claramente no es acorde con las competencias ejercidas.

En este contexto, es razonable que, en Galicia u otras partes de España, Castilla-León o Valencia entre otras, se planteen políticas de fusión municipal en el marco de procesos de asociacionismo e integración municipal. Los números cantan y la necesidad de prestar servicios a los vecinos, no de cualquier manera, sino de forma que contribuyan a mejorar sus condiciones de vida, aconsejan tomar decisiones en esta dirección. Por se entiende bien que el propio Círculo de Empresarios de Galicia acabe de reclamar que se pongan en marcha fusiones de pequeños Entes locales y que se regulen las áreas metropolitanas.

En efecto, los procesos de asociacionismo voluntario vía mancomunidades y consorcios intentan resolver el problema. En Galicia en 2006 existían 24 mancomunidades de municipios y 27 consorcios locales. La percepción de estas fórmulas de 
colaboración es positiva. El problema es que tales instituciones, que bien podrían generar economías de escala, normalmente no la producen porque no se elimina los órganos que con anterioridad se encargaban de prestar los servicios que ahora se prestan vía mancomunidad o vía concierto. Las comarcas no se han constituido como Entes locales y ahora la comarcalización está en dique seco. Las áreas metropolitanas tampoco se llegaron a conformar normativamente.

El gran problema es que de seguir las cosas como hasta ahora empezarán a desaparecer municipios por falta de población y los más pequeños que sobrevivan, que en Galicia tienden a crecer van a tener infinitos problemas de financiación, sobre todo en lo que concierne a los servicios más básicos para los vecinos. La razón invita, pues a reorganizar municipios para prestar mejor los servicios. El principal problema es que muchos se aferran, a veces por interés de los políticos, a su identidad propia y al temor a desaparecer. El informe Roca, que aconsejó la fusión de los municipios catalanes de menos de 250 habitantes, tuvo una reacción visceral de los pequeños municipios. No hay que olvidarlo. No sólo fue el detonante de la posición de los pequeños municipios el miedo a la desaparición. La pérdida de representatividad política, como recuerda el informe del Círculo de Empresarios de Galicia, también explica la reacción de los pequeños municipios: el $70 \%$ de los concejales españoles pertenecen a municipios de menos de 5.000 habitantes.

\section{Alteraciones Territoriales: Fusiones e Incorporaciones}

En España el Ordenamiento jurídico distingue diversas fórmulas para propiciar horizontes o espacios de asociacionismo municipal: fusiones, incorporaciones, mancomunidades, comarcas, consorcios o áreas metropolitanas entre otros. Es claro que 
El Gobierno y la Administración Local en España...

los fenómenos de segregación, de división de municipios no interesan porque agravarían más el problema de los pequeños municipios. Otra cosa sería si la realidad fuera de municipios demasiado grandes, como pasa por ejemplo en Iberoamérica, y para fomentar la participación vecinal fuera menester dividir algunos grandes municipios. En este caso operamos sobre la realidad española, singularmente sobre la gallega que es la que es y todos conocemos bien.

En el Texto refundido de disposiciones vigentes en materia de régimen local se establece en el artículo 3, 1 igual que el artículo 2 del Reglamento de población, que las alteraciones de los términos municipales pueden producirse por fusión, por incorporación o por segregación de parte de un municipio para agregarlo a otro limítrofe, y por segregación de parte del territorio de uno o varios municipios para formar otro independiente.

Es bien sabido que de acuerdo con lo dispuesto en la legislación del Estado en la materia, las alteraciones de los términos municipales no pueden no pueden generar enclaves nuevos. Además, la alteración de los términos municipales tampoco puede modificar los límites provinciales tal y como dispone el artículo 3.2 del Texto refundido. El artículo 13.2 de la ley de bases del régimen local dispone una serie de requisitos sustanciales para que puedan operarse procesos de alteración de los términos municipales. En los casos de segregación es necesario que se trate de núcleos territorialmente diferenciados, que los municipios resultantes tengan los recursos suficientes para prestar los servicios mínimos, y que ello no implique un empeoramiento de la calidad de los servicios prestados. En los casos de fusión o incorporación, como veremos, las cosas discurren por otros derroteros exigiéndose, como es lógico, que el municipio resultante de la operación esté en mejores condiciones de prestar los servicios a los vecinos. 
La ley de bases del régimen local, consciente del problema general de España en la materia, dispuso acertadamente que el Estado pueda adoptar medidas de fomento para la fusión de municipios con la idea de salir al paso de la problemática de tantos pequeños municipios con dificultades reales para prestar adecuadamente los servicios mínimos a los vecinos.

Las alteraciones territoriales plantean un importante problema desde la consideración de su lesión, o no, del principio de la autonomía local. La profesora Escuín Palop ha estudiado esta cuestión en su proyección histórica (2003, p. 1269). Veamos brevemente su interesante argumentación. El municipio según la ilustración francesa, entendido como una comunidad de vecinos regida por sus representantes y cuya esfera de actuación se circunscribe a la satisfacción de los asuntos locales trae consigo dos relevantes consideraciones: extensión de la institución municipal a todas las comunidades de vecinos desde una perspectiva de igualdad formal, y uniformidad de su régimen jurídico. Consecuencias que salen al paso de lo acontecido en la Edad Media, dónde los municipios disponían de toda una serie de privilegios y singularidades frente al poder del monarca. El Estado liberal trata de suprimir todos estos privilegios a base de diseñar un régimen igual para todos los municipios, sometiendo los Entes locales sin excepción al poder central a base de un régimen jurídico unitario e igual para todos. El advenimiento de los Borbones en España, con Felipe $\mathrm{V}$ a la cabeza, supone un intento de generalización del municipio castellano, aunque, como es bien sabido, ya desde entonces Navarra, Gupúzcoa y Vizcaya conservaron sus instituciones tradicionales de virreinato, corregidor regio y diputación.

Más adelante, como señala Escuín Palop, esta versión homogeneizadora y uniforme del régimen local es sustituida por la doctrina de la perspectiva iusnaturalista del municipio 
El Gobierno y la Administración Local en España...

enraizada en la interpretación idealista del autogobierno local anglosajón que entre nosotros defendieron nada menos que Oliván u Ortiz de Zúñiga. Desde este punto de vista, el municipio era anterior al Estado y está compuesto por un conjunto de competencias indisolublemente vinculadas y emanadas de las necesidades colectivas de naturaleza local. Esta concepción del municipio, estático e inmovilista, implica un profundo respeto al municipio y a su dimensión territorial de manera que las posibilidades de reorganización territorial de los municipios desde el poder central tendrán escasas opciones de prosperar (ESCUÍN PALOP, 2003, p. 1270-1271).

En cambio, desde la posición ilustrada, municipios como prolongación del poder central, municipios como apéndices del poder central para llegar al último rincón de la nación, las alteraciones territoriales fueron posibles puesto que su régimen jurídico era de libre disposición para el legislador. 38 Ya sabemos que nuestra Constitución parte de este punto de vista al disponer que en su artículo 140 que la garantía de la autonomía local, una autonomía que se ha entendido, sobre todo en los primeros momentos, protegida por la técnica alemana de la garantía institucional, que aplicada a la autonomía local, parece referirse a la misma entraña del autogobierno y de la naturaleza representativa del mismo municipio, sin que se refiera al territorio porque lo relevante es que a través del carácter representativo, cauce inmediato de de participación ciudadana en los asuntos públicos, como dice el artículo 1.1 de la ley de bases de 1985, se presten los servicios públicos necesarios para la satisfacción de los intereses y necesidades de la Entidad local portadora de autonomía. En efecto, los fenómenos de alteración territorial del término municipal no se oponen a la autonomía local, aún incluso en contra de la voluntad de las propias Corporaciones (ESCUÍN PALOP, 2003, p. 1271). Este argumento demuestra hasta qué punto los Entes locales son 
partes integrantes del Estado y hasta qué punto el criterio del mejor servicio a los vecinos, razonablemente argumentado en cada caso, pueden permitir procesos de fusión amparados por la legislación del Estado que se completa en el ámbito de cada Comunidad Autónoma con la legislación propia.

En la doctrina se ha discutido acerca de si las alteraciones territoriales pueden ser impuestas por el legislador general o particular. Unos (Parejo o Embid Irujo) entienden que para la garantía institucional el territorio es de libre disposición por el legislador. Otros, entre los que se encuentra Castells Arteche, entienden que cuando la población afectada se opone a la alteración entonces no procede la alteración de los términos municipales basándose en la doctrina del Tribunal Constitucional acerca de la supresión de la provincia (sentencia de 28 de julio de 1981). Es, desde luego, un tema complejo porque si afirmamos que los Entes locales son esencialmente gobiernos representativos, elegidos por los vecinos, éstos han de tener un peso fundamental en decisiones sobre alteraciones de los términos municipales. El legislador general o particular no debe ser insensible a esta realidad debiendo proceder a la fusión de municipios cuando efectivamente, de manera objetivada, se demuestre que los vecinos van a estar mejor atendidos desde la perspectiva de los servicios prestados después que con anterioridad a la fusión.

La profesora Escuín Palop esgrime tres argumentos para justificar las denominadas fusiones forzosas. Primero, la Constitución supedita a la aprobación de una ley orgánica la alteración de los términos provinciales (artículo 141) y facilita que las Comunidades Autónomas asuman competencias para alterar los términos municipales, sin someter la modificación territorial a ningún procedimiento legislativo especial, lo que lleva a pensar que el respeto que la Constitución muestra por la alteración de los términos provinciales no es mayor para los 
El Gobierno y la Administración Local en España...

municipios que para las provincias. Segundo, la Constitución no exige ni para la modificación de los límites provinciales ni para los municipales el beneplácito de la población afectada y la sentencia del Tribunal Constitucional de 28 de julio de 1981 consideró constitucional la alteración forzosa de alguna provincia cuando se realice de acuerdo con el procedimiento establecido. Y, tercero, en el caso del municipio, la doctrina del Tribunal Constitucional permite la alteración de los términos municipales, de forma voluntaria o forzosa, siempre que se tramite por el procedimiento legalmente establecido y se resuelva por el órgano competente (ESCUÍN PALOP, 2003, p. 1272). En cualquier caso, el concurso de la población afectada debiera ser tenido en cuenta por la autoridad autonómica que inicia de oficio el procedimiento de fusión por obvias razones. En mi opinión, no es suficiente que la institución local manifieste su voluntad en el procedimiento de alteración a favor o en contra. En el

40 Derecho Comparado Europeo es verdad que algunos procesos de fusión municipal, como refieren Cassese para Italia o Latour para Bélgica, se han operado desde una visión complementaria de la garantía de la autonomía local con significación misma de la alteración territorial del término municipal.

Una cuestión relevante en esta cuestión se refiere a la proyección de las alteraciones territoriales de los municipios sobre la organización local y sobre la propia población municipal. El tema de la organización, del mayor o menor número de concejales, parece que depende más bien de la población que de las alteraciones de los términos municipales. Sin embargo, a poco que se estudie con cierto detenimiento se comprenderá que sin espacio físico la población no puede asentarse y que la despoblación total de un municipio no determina por sí sola la desaparición del mismo, ya que en este caso se requiere una decisión administrativa expresa. La legislación básica no establece el número mínimo de habitantes necesario para constituir 
un municipio probablemente por entender que el legislador central debe respetar las diferentes formas de asentamiento de la población, que en muchos casos son características de una identidad propia forjada en el tiempo y que expresa una manera de ser y de entender la vida loca, remitiendo esta cuestión a la legislación propia de las Comunidades Autónomas en materia local. Como es sabido, la ley de organización y atribuciones de los Ayuntamientos de 1840 y la Ley de Ayuntamientos de 1845 representan la preocupación por suprimir municipios demasiado pequeños y por condicionar los nuevos municipios a un mínimo poblacional. La ley de 1870 concretó dicha exigencia en 2.000 habitantes manteniéndose a partir de entonces dicha exigencia (ESCUÍN PALOP, 2003, p. 1273).

Es interesante en este punto comentar previamente la doctrina del Consejo de Estado acerca del municipio, el municipio con escasa población y escasos recursos económicos. En este sentido, el propio Consejo Estado ha puesto muchas dificultades las alteraciones municipales que den como resultado municipios de esta denominación, que es consecuencia, dice por ejemplo el dictamen de 19 de diciembre de 1991, de una reflexión histórica iniciada con la ley de 1870 vigente hasta el Estatuto de Calvo Sotelo, en el que ya se estableció una población mínima de 2.000 habitantes.

En este sentido, la sentencia del Tribunal Supremo de 9 de mayo de 1997 utiliza esta denominación y señala que en estos casos la legislación de 1985, para evitar estas situaciones de minifundismo municipal, "adopta un criterio de prevención [...] dirigiendo precisamente frente a municipios tan exiguos una orientación hacia la fusión. Y todo ello para poder cumplimentar la satisfacción del interés general, que corresponde a la población que se asienta en una determinada demarcación territorial". 
El Gobierno y la Administración Local en España...

El problema, como señala Escuín Palop, se encuentra en la ausencia de criterios generales que ponderen la relación óptima entre las dimensiones del término municipal y el nivel poblacional, lo que trae consigo no pocos problemas para mantener en todo el territorio un principio básico de igualdad o un mínimo común denominador en la satisfacción de las necesidades públicas locales. Aunque la cuestión quede a la legislación de las Comunidades Autónomas, el legislador general debió haber asumido algún criterio que evitara una situación de desamparo de los vecinos de tantos pueblos y villas condenados a unas pésimas condiciones de vida a causa del minifundismo municipal (ESCUÍN PALOP, 2003, p. 1275) y hoy, de la aguda crisis económica y financiera que padecemos.

La cuestión de la participación vecinal en los procesos de alteración municipal es un asunto bien polémico. Pareciera, 42 y así lo entiende la Carta Europea de la Autonomía Local, que en estos casos de alteraciones municipales el referéndum vecinal debiera ser determinante. Sin embargo, la legislación española no ha querido dejar estos procedimientos en manos de los vecinos. Es menester, señala el dictamen del Consejo de Estado de 8 de septiembre de 1994 la concurrencia de otros requisitos que sirvan de fundamento, entre los que la suficiencia económica ocupa, es lógico, un lugar central.

En efecto, la suficiencia económica se nos presenta como el criterio capital para proceder o no a estas operaciones. La suficiencia económica local permite a los municipios prestar los servicios y ejercer las competencias que las leyes atribuyan a los Entes locales. En los casos de minifundismo local, las fusiones precisamente se plantean para que las competencias se ejerzan en mejores condiciones y los servicios se presten con arreglo a estándares de calidad. Aunque no es el único requisito para estas operaciones de alteraciones municipales, 
probablemente es el más importante porque si no hay viabilidad económica para el nuevo municipio, entonces su constitución será imposible. Otras causas de la alteración municipal atienden al interés público y al orden urbanístico.

En efecto, si las condiciones de vida de los vecinos no van a mejorar, entonces la alteración poco sentido tendrá. Esta es, me parece, la principal razón de interés público que ha de justificar la alteración. Evidentemente, la mejora de las condiciones vitales está muy relacionada con la suficiencia económica, pero no son causas idénticas. Pueden citarse, si atendemos a algunos pronunciamientos del Consejo de Estado, como razones de interés público que pueden aconsejar la alteración municipal, entre otros, el establecimiento de nuevas dotaciones públicas (dictamen de 4 de agosto de 1971), la mejora del desarrollo social (dictamen de 5 de marzo de 1964) o la prestación de los servicios públicos indispensables (dictamen de 25 de mayo de 1972). Es decir, se trata de mejorar la gestión pública local a través de nuevos servicios públicos o de interés general. En todo caso, la expresión mejoras de interés general hemos de vincularla a la existencia de nuevas posibilidades reales de que objetivamente mejoren las condiciones de vida de los vecinos, bien sea porque tendrán nuevos servicios públicos o porque los existentes se van a prestar en mejores condiciones.

Como señala Escuín Palop (2003, p. 1282), es fundamental que esas mejoras sean objetivas, permanentes y concretas. Las mejoras deben poder fundamentarse en sólidos criterios, con memorias económicas que lo demuestren y, obviamente, si estos datos se pueden suministrar y son viables, lo serán porque estaremos planteando mejoras concretas y específicas. En este punto, hay que tener en cuenta que aunque la voluntad de los vecinos no es determinante, probablemente para evitar situaciones de irracionalidad, es lo cierto que la existencia de 
El Gobierno y la Administración Local en España...

una mayoría amplia de vecinos puede considerarse también como una razón más, bien poderosa, para proceder a la alteración municipal de que se trate.

Otro criterio ha de considerar en las alteraciones municipales es el de la confusión de los núcleos urbanos. El concepto de núcleo urbano, como señala Escuín Palop, comprende las edificaciones, los servicios y las dotaciones públicas propias del suelo urbano tales como espacios destinados a viales, parques, jardines públicos, zonas deportivas, de recreo, de expansión o, entre otros, centros culturales o docentes. Por tanto, la confusión de núcleos urbanos no se reduce sólo a la continuidad de edificaciones, también se proyecta a la unidad del medio urbano en su conjunto (ESCUÍN PALOP, 2003, p. 1279).

Los supuestos de confusión de los núcleos urbanos es más evidente en el marco del fenómeno metropolitano, dónde 44 parece más razonable desde el punto de vista de la mejor administración de las competencias sobre el territorio que se realicen desde un solo municipio que desde varios. En estos casos, la fusión municipal o la incorporación, total o parcial puede ser, según los casos, una buena solución precisamente para evitar, como señala Escuín Palop, una acumulación de competencias para atender las mismas necesidades (2003, p. 1280).

El criterio de las ventajas económicas de la alteración municipal debe conectarse con el de suficiencia financiera. Mal se podrá justificar un expediente de fusión, por ejemplo, si se pone en peligro la suficiencia financiera local. Suficiencia financiera que debe estar garantizada para que pueda operar la causa de las ventajas económicas. En este punto, el tamaño de los municipios, por ser muy grandes o por ser muy pequeños, tiene mucho que ver con la viabilidad y rentabilidad económica. En concreto, para el caso que nos ocupa, parece fuera de toda duda que las ventajas de las fusiones municipales son evidentes si tenemos en cuenta las condiciones económicas en que se 
desenvuelve el minifundismo local gallego. Si los servicios se van a prestar mejor y a un menor precio, no debiera haber problemas a las fusiones. Se evitan duplicidades competenciales en relación con las mismas materias para una población que tiene las mismas necesidades sociales y públicas.

Así, por ejemplo, sería menester proceder a alteraciones municipales en los casos, citados por Escuín Palop (2003, p. 1284), de dificultades económicas que supongan la incapacidad del municipio para ejercer sus competencias en todo el término municipal (dictamen del Consejo de Estado de 25 de mayo de 1972), de imposibilidad de dos o más municipios de sobrevivir por separado (dictamen del Consejo de Estado de 27 de abril de 1961), de pérdida obvia de población, de ausencia de recursos económicos para atender los servicios obligatorios (dictamen del Consejo de Estado de 28 de noviembre de 1968) $\mathrm{y}$, en, general, de insolvencia municipal acreditada por lo exiguo de los presupuestos, el reducido inventario patrimonial y el agotamiento de las fuentes de imposición permitidas por la ley (sentencia del Tribunal Supremo de 1 de abril de 1976).

Las alteraciones municipales, por tanto, tienen que venir exigidas por razones de interés público en concreto, han de traer consigo mejoras económicas que repercutan en la calidad de vecinos de los vecinos, éstos han de poder pronunciarse y la institución local resultante ha de estar en objetivas mejores condiciones de ejercer las competencias que el Ordenamiento le atribuye así como prestar mejor los servicios públicos o de interés general. Por eso, como entendió el Consejo de Estado en su dictamen de 28 de noviembre de 1968, si resulta que los Entes locales no han puesto todos los medios a su alcance para aumentar los ingresos locales y la población se opone a la alteración, es más que razonable que tal operación no proceda. Igualmente, el propio Consejo de Estado, por dictamen de 9 de abril de 1959, se mostró en contra de la alteración municipal por 
El Gobierno y la Administración Local en España...

entender que los municipios afectados disponían de medios más que suficientes para financiar la gestión local y por constar la voluntad en contra de los vecinos. En el mismo sentido, también recoge Escuín Palop (2003, p. 1284) el caso de la simple disminución de los gastos de personal o administración que se derivaría de una fusión o incorporación que contara con la negativa de los vecinos pues, como señala el Consejo de Estado en dictamen de 29 de enero de 1970, existen otros medios para alcanzar dicho fin.

Hoy, en una época de crisis económica y financiera aguda, los procesos de fusión municipal serán imparables pues no se observa en el horizonte de qué otra manera van a poder garantizar su suficiencia financiera tantos pequeños municipios con el fin de ejercer las competencias que el legislador le atribuye y de prestar adecuadamente los servicios de su responsabilidad.

El Estado se ha reservado en estos procesos de alteración municipal, algunas competencias. Por ejemplo, en el artículo 13.1 de la ley de bases de régimen local de 1985. En efecto, el Estado debe tener conocimiento de las solicitudes de alteración municipal al tiempo de que se pida el informe al Consejo de Estado u órgano equivalente de la Comunidad Autónoma. La razón de esta información reside, como indica Escuín Palop (2003, p. 1289), en que con estos datos el Estado, cuando la alteración lo requiera, podrá adecuar los servicios de competencia estatal a la nueva dimensión municipal y, cuando proceda, detectar algunas irregularidades en que hayan podido incurrir las Comunidades Autónomas y así poder instar la actuación de los Tribunales de Justicia. Por lo demás, el régimen de la creación, supresión y demás alteraciones municipales es de competencia autonómica.

El número 2 del artículo 13 establece los criterios sobre los que deberán autorizarse nuevos municipios: a partir de núcleos de población territorialmente diferenciados, siempre 
que los municipios resultantes cuenten con recursos suficientes para el cumplimiento de las competencias municipales, y que no supongan disminución de la calidad de los servicios que se venían prestando. Entiendo que estos criterios son de general observancia por las Comunidades Autónomas a la hora de regular el régimen de las alteraciones municipales en su propio territorio.

En el párrafo tercero del artículo 13 se atribuye al Estado la competencia básica de establecer medidas, atendiendo a criterios geográficos, sociales, económicos y culturales, tendentes a la fusión de municipios con el fin de mejorar la capacidad de gestión de los asuntos públicos locales. Obviamente, esta competencia de fomento hay que entenderla en el marco de las competencias de la Comunidad Autónoma en la materia. La función de fomento debe circunscribirse a la materia económica a partir de la competencia básica del Estado de ordenación de la actividad económica general. Las medidas de fomento de las fusiones municipales desde el punto de vista geográfico habrán de fundarse en razones de interés general, al igual que la apelación a razones culturales, en este caso de más difícil justificación.

El régimen de las alteraciones de los términos municipales corresponde a las Comunidades Autónomas, en unos casos a través del propio Estatuto y en otras, la mayoría, a través de la legislación propia en materia de régimen local. En estos casos, las Comunidades Autónomas pueden iniciar, tramitar y resolver los procedimientos de alteración precisando en el territorio propio los criterios que establece el párrafo segundo del artículo 13 de la ley de bases, en especial los de dimensión territorial y de población para las alteraciones que se produzcan.

La normativa general sobre alteración de términos municipales está en el Texto Refundido de Disposiciones Legales Vigentes en Materia de Régimen Local de 18 de abril de 1986 y en el Reglamento de Población y Demarcación Territorial de 
El Gobierno y la Administración Local en España...

las Entidades Locales. En ambos textos normativos se prevén los casos de incorporación de uno o más municipios a otro u otros limítrofes, la fusión de dos o más municipios limítrofes, la segregación de parte del territorio de uno o varios municipios para constituir otro independiente, y la segregación de parte del territorio de un municipio para agregarlo a otro limítrofe.

En este trabajo nos interesan los dos primeros supuestos, el de incorporación y el de fusión. En caso de incorporación de uno o varios municipios a otro u otros limítrofes, según el Texto Refundido, tal alteración procederá cuando concurran notorios motivos de necesidad o conveniencia económica o administrativa, que el Tribunal Supremo en sentencia de 10 de junio de 1999 considera concepto jurídico indeterminado y, por ello, susceptible de ser aplicado por la Administración

[...] mediante una razonada concreción de los supuestos de hecho [...] siendo mucho más exigente con el requisito de la motivación del acto administrativo, debiendo quedar clara la finalidad perseguida, que pueda potencialmente lograrse mediante los mecanismos puestos en movimiento, sin necesidad de acudir a otros menos favorables [...]. La idea de conveniencia no debe ser aislada de un contexto general y referirla solo al municipio que va a experimentar el aumento de superficie, pues en ese caso lo normal es que siempre se produzca para él. La conveniencia, por eso, ha de ser para el interés común y no responder exclusivamente a un criterio de expansión, cuando las finalidades que se persiguen pueden ser satisfechas en el propio territorio del municipio que pretende la anexión.

La alusión a la necesidad da idea de la gravedad en la que debe producirse la incorporación, mientras que el criterio de conveniencia económica o administrativa ha de interpretarse de acuerdo con la doctrina citada del Tribunal Supremo, que pone de manifiesto es esfuerzo de argumentación y racionalidad que es exigible a la hora de aducir dichas razones de conveniencia, 
nunca de arbitrariedad, que es precisamente, como gustaba decir a Locke, es la ausencia de la misma racionalidad. El Reglamento agrega a la necesidad económica o administrativa, "cuando lo imponga la mejora de la capacidad de gestión de los asuntos públicos", un nuevo concepto jurídico indeterminado que implica un notable esfuerzo de argumentación y de concreción por parte de la Administración.

Por lo que se refiere a la fusión, la alteración que más nos interesa y la que probablemente tenga más probabilidades de éxito en Galicia, las normas estatales reclaman como condiciones para su aplicación, las siguientes: falta de recursos para atender, separadamente, los servicios mínimos exigidos por la ley, confusión de núcleos urbanos, y notorios motivos de necesidad o conveniencia económica o administrativa. En realidad la primera y segunda condición podrían ser redundantes si es que no entiende el primer requisitos, la falta de recursos, a aspectos técnicos o de personal, tal y como señala Escuín Palop (2003, p. 1304). Como en este supuesto de fusión se da lugar a un nuevo municipio, de acuerdo con el artículo 13.2 de la ley de bases, es menester que se realice cuando afecte a núcleos de población territorialmente diferenciados, se garantice la suficiencia económica del nuevo municipio para atender las nuevas competencias y no suponga disminución en la calidad de los servicios prestados por los municipios originarios.

Veamos a continuación, muy sucintamente, el tratamiento que de las fusiones de municipios encontramos en el Derecho Autonómico.

En Andalucía, la ley de 7 de julio de 1993 dispone que la fusión municipal podrá acordarse cuando se de alguna de estas condiciones: falta de recursos para prestar por sí o asociados los servicios mínimos impuestos por la ley, confusión entre los núcleos urbanos, y cuando existan condiciones de orden geográfico, económico, demográfico, administrativo o 
El Gobierno y la Administración Local en España...

cualquier otra que pudiera hacerla necesaria o conveniente. La amplitud de la redacción de las causas o motivos reclama la necesidad de concretar muy bien, de argumentar a fondo las razones que aconsejen la fusión, evitando el ejercicio indiscriminado y general de las argumentaciones, pues, de lo contrario, las fusiones se producirían en atención a razones de conveniencia en ocasiones poco confesables. La incorporación de municipios podrá acordarse, dice la ley andaluza, cuando se produzca alguna de las circunstancias siguientes: insuficiencia de medios para atender los servicios obligatorios exigidos por la ley, descenso acusado y progresivo de la población, merma sustancial de su territorio por razones de obras públicas y confusión de núcleos urbanos.

En Aragón, la ley de 9 de abril de 1999 regula las alteraciones municipales. En términos generales, el legislador aragonés ha establecido tres finalidades para cualquier proceso de alteración municipal. Primera, disponer de una base territorial que mejore la capacidad económica y de gestión de los servicios públicos esenciales y obligatorios. Segunda, favorecer el autogobierno y la participación en relación con la población y sus condiciones de asentamiento sobre el territorio. Y, tercera, adaptar los términos municipales a la realidad física, social y cultural de los núcleos de población, de forma que las colectividades con conciencia de tal y con unos específicos valores históricos y tradicionales que puedan tener una representatividad. Llama la atención positivamente la importancia que el legislador aragonés otorga al autogobierno y a la participación. La incorporación o fusión de municipios procede en los siguientes supuestos: cuando como consecuencia del desarrollo urbano estemos ante municipios con núcleos de población unidos, cuando separadamente carezcan de los recursos necesarios para la prestación de los servicios mínimos obligatorios, cuando carezca de una base demográfica que posibilite el funcionamiento 
efectivo de una organización municipal o sea injustificable el mantenimiento, por una población reducida, del disfrute en el aprovechamiento de bienes y servicios de titularidad pública y, finalmente, cuando exista falta de presentación de candidaturas en las elecciones municipales o ausencia de funcionamiento de régimen de concejo abierto, y cuando existan otros motivos de interés general debidamente fundados. Igualmente, la creación de nuevos municipios sólo puede realizarse a partir de núcleos de población territorialmente diferenciados que cuenten con recursos suficientes para el desempeño de las competencias municipales y estén dotados de una base demográfica estable.

La ley de 7 de noviembre de 1986 del Principado de Asturias prevé entre las modalidades de alteración de los términos municipales, la fusión y la incorporación. Entre las causas generales determinantes de la alteración deben estar el consentimiento de las corporaciones afectadas y la concurrencia de uno de estos motivos: posibilidad de mejora en la prestación de los servicios públicos, especialmente los de carácter obligatorio; necesidad de unificar las dependencias administrativas de núcleos urbanos pertenecientes distintos concejos en los que se haya producido o se vaya a producir su confusión como consecuencia de su expansión urbanística; insuficiencia de medios económicos, materiales o personales, para atender separadamente la prestación de los servicios obligatorios exigidos por la ley, $\mathrm{y}$, notorios motivos de necesidad o conveniencia económica o administrativa que así lo aconsejen atendidas las circunstancias de orden geográfico, demográfico, social o cultural que concurran. Además, el legislador asturiano prevé cuatro razones en cuya virtud puede prescindirse del consentimiento vecinal: cuando la necesidad de unificar las dependencias administrativas se presente como perentoria, cuando la insuficiencia de recursos para tender los servicios obligatorios tenga una notoriedad acusada, imposibilidad de 
El Gobierno y la Administración Local en España...

mantener una organización administrativa independiente por la despoblación del concejo, y cuando la mayoría de los residentes vecinos en una zona territorialmente delimitada inste directamente al órgano autonómico competente para incorporarse a otro término municipal. La lista de conceptos jurídicos indeterminados que jalonan el régimen de las alteraciones de términos, obliga a los Gobiernos y Administraciones autonómicas a trabajar en orden a perfilar, materializar, puntualizar y concretar, lo que exige memoria justificativas bien argumentadas a partir de datos y elementos objetivos.

En Castilla-La mancha, la ley de 14 de marzo de 1991 regula las alteraciones de términos municipales. En estos casos, la fusión o incorporación procede cuando existe confusión de los núcleos de población que sean capitalidad de los respectivos municipios, cuando hay falta de los recursos económicos necesarios para preservar los servicios mínimos previstos en 52 la legislación del Estado, cuando hay ausencia de población u organización municipal (cuando no existan listas electorales que concurran al proceso electoral local o cuando dimitieran los miembros electos y no fuera posible la designación de una comisión gestora), cuando concurran motivos de interés general apreciados por la Administración autonómica o cuando medie solicitud de las dos terceras partes de los vecinos del municipio a incorporar, siempre que acrediten los motivos que aleguen para la alteración. De nuevo, pues, nos topamos con fórmulas muy generales que habrán de ser gravemente motivadas para evitar que la arbitrariedad campee en toda esta materia.

En la ley de Castilla y León de 4 de junio de 1998 se establecen las causas de la creación de un municipio por fusión: cuando separadamente carezcan de capacidad o recursos suficientes para atender los servicios mínimos exigidos por la ley, cuando sus núcleos de población se confundan como consecuencia del desarrollo urbanístico, y cuando existan 
notorios motivos demográficos, económicos, administrativos o de cualquier otro carácter que pudieran hacerla necesaria o conveniente.

En Cataluña hay que estar a la ley de 19 de noviembre de 1998 que modificó el Reglamento de sobre Demarcación Territorial y Población de 24 de mayo de 1988, en la que se establecen los presupuestos o condiciones generales que han de presidir estas alteraciones de los términos municipales. En este sentido, estas operaciones territoriales deben fomentar la conciencia de colectividad y el deseo de representación de los intereses propios, así como la capacidad para gestionar los servicios públicos que el municipio tiene encomendado, la existencia de valores históricos y tradicionales y al suficiencia económica. En este marco, la fusión se produce cuando exista dificultad para gestionar los servicios obligatorios por la insuficiencia de medios económicos, materiales y personales, cuando los núcleos de población formen un continuo urbano (cuando resulte que entre los suelos clasificados de urbanos y urbanizables no hay solución de continuidad) o cuando consideraciones de orden geográfico, demográfico, económico o administrativo lo hacen necesario o aconsejable. La ley de 1998 encomienda al gobierno autonómico que impulse medidas de fomento para la fusión o agregación voluntaria de municipios cuando consideraciones de orden geográfico, demográfico, económico o administrativo lo aconsejen.

Por Decreto Legislativo de 28 de abril de 2003 se aprobó en Cataluña el Texto Refundido de la Ley municipal y de régimen local de Cataluña, en la que encontramos algunos preceptos relevantes. Por ejemplo, el artículo 20 en materia de fomento de fusiones, y el 21 relativo al fomento de mancomunidades. En materia de fusiones, el legislador dispone que el Gobierno adoptará medidas de fomento a las fusiones o agregaciones voluntarias de municipios cuando consideraciones de orden 
El Gobierno y la Administración Local en España...

geográfico, demográfico, económico o administrativo así lo aconsejen. Las medidas de fomento pueden consistir, entre otras, en ayudas económicas y técnicas para estas iniciativas, previsiones especiales en los criterios de distribución del Fondo de cooperación local de Cataluña, criterios prioritarios o especiales en la asignación de subvenciones finalistas, o previsiones especiales para la realización de inversiones a cargo de la Administración de la Generalidad.

Por lo que se refiere al fomento de las mancomunidades, el artículo 21 del Texto Refundido dispone que el Gobierno impulsará la constitución de mancomunidades cuando la mejor garantía en la prestación de servicios públicos de competencia municipal y la eficacia necesaria en la prestación lo hagan conveniente. En concreto, estas medidas pueden consistir en ayudas económicas y técnicas para estas iniciativas, previsiones especiales en los criterios de distribución del Fondo de cooperación local de Cataluña y en la asignación de subvenciones finalistas, y cualquier otra que conduzca a la mejor garantía en la prestación de los servicios públicos municipales y a la eficacia necesaria en su prestación.

Si aún así, si las medidas de fomento para impulsar fusiones y mancomunidades no fueran suficientes para garantizar un nivel homogéneo en la prestación de los servicios públicos municipales, entonces el Gobierno puede iniciar un proceso de reforma de la organización municipal en los ámbitos territoriales de Cataluña que así lo requieran.

Por lo que se refiere a Galicia, la ley de Administración local de 22 de julio de 1997 regula esta materia. En concreto, la Comisión Gallega de Delimitación Territorial es el órgano de estudio, informe y propuesta en relación con las cuestiones concernientes a la determinación, revisión y modificación de los límites territoriales de los Entes locales de nuestra Comunidad Autónoma. Por lo que hace a la fusión municipal, es necesario, 
según la ley, que concurra alguno de los cuatro requisitos siguientes. Primero: que se confundan los núcleos de población que sean capitalidad de los respectivos municipios. Segundo, que separadamente carezcan los municipios de los medios necesarios para mantener los servicios mínimos. Tercero, que aparezcan notorios motivos de necesidad o conveniencia económica, administrativa o consideraciones de orden geográfico o demográfico. Cuarto, que del proceso de fusión se deriven significativas ventajas para ambos municipios y así sea apreciado por ellos. La ley diseña también el procedimiento de alteración de los términos municipales, en el que debe intervenir el Consello Consultivo. El procedimiento puede iniciarse de oficio por la consellería competente o a instancia de cualquiera de los municipios interesados o de la diputación provincial.

En la ley de 22 de septiembre de 1993 de La Rioja se establecen los objetivos que habrán de perseguir las alteraciones territoriales. A saber: mejorar los servicios de competencia municipal e incrementar la capacidad de gestión de las Entidades locales afectadas. En relación con la fusión municipal, la ley autonómica citada determina los motivos que pueden dar lugar a un nuevo municipio por fusión: confusión de las capitalidades de ambos municipios, insuficiencia de los recursos para prestar los servicios mínimos exigidos por la ley, ausencia de población o de organización municipal y, finalmente, cuando lo soliciten las dos terceras partes de los vecinos de los municipios afectados.

En Madrid, la Ley de 11 de marzo de 2003, de Administración local, señala que las alteraciones de los términos municipales se orientarán al establecimiento de una adecuada dimensión territorial de los municipios o a mejorar su capacidad económica y de gestión de los asuntos públicos locales. En relación con las fusiones e incorporaciones, la ley dispone que estas operaciones podrán llevarse a cabo siempre que concurra alguna de las siguientes circunstancias. Primera, que los municipios 
El Gobierno y la Administración Local en España...

afectados carezcan de recursos suficientes para prestar los servicios mínimos impuestos por la legislación básica estatal. Segunda, cuando se confundan sus núcleos de población. Tercera, cuando desparezcan o disminuya notablemente alguno de los elementos constitutivos del municipio. Cuarta, cuando sea preciso para mejorar la capacidad de gestión de los asuntos públicos locales, existan necesidades o conveniencia económica o administrativa o razones geográficas o demográficas.

Finalmente, en Navarra, la competencia de alteración municipal es de la Comunidad Autónoma tal y como lo previene el artículo 46 del Estatuto, de la LORAFNA. Ahora, con la Ley foral de 2 de julio de 1990, se regula en concreto el régimen de las alteraciones de términos municipales que han de perseguir, según esta ley, mejorar la prestación de los servicios de competencia municipal, incrementar la capacidad de gestión de los Entes locales afectados, adaptar los términos municipales a 56 las realidades físicas, demográficas, urbanísticas y culturales, y facilitar la participación ciudadana en los asuntos locales. En materia de fusión e incorporación, el legislador navarro entiende que pueden practicarse en los siguientes supuestos: cuando carezcan separadamente de medios económicos suficientes para atender a los servicios mínimos exigidos en la ley, cuando se confundan sus núcleos urbanos como consecuencia del desarrollo urbanístico y cuando concurran motivos notorios de necesidad o conveniencia económica o administrativa.

En fin, la concreción y precisión que hacen las Comunidades Autónomas del artículo 13 de la ley de bases en orden a las fusiones e incorporaciones municipales subrayan la viabilidad económico-financiera, la garantía de la suficiencia financiera, la existencia de confusión de núcleos de población, la inexistencia de organización o población, la mejora de la prestación de los servicios obligatorios, la mejora de la capacidad de gestión pública local, fomentar la participación ciudadana en los asuntos 
locales o adaptar los términos municipales a las realidades físicas, demográficas, tradicionales, urbanísticas y culturales.

\section{Experiencias de Fusiones Municipales}

Las distintas fusiones municipales acontecidas en el pasado, como ya hemos indicado, fueron ocasionadas en su gran mayoría por la incapacidad de los municipios de prestar los servicios de su competencia debido a las dificultades financieras existentes. Hoy, en una situación de aguda crisis económica y financiera, la posibilidad de las fusiones constituye una realidad que debe plantearse si es que se pretende que los Entes locales sean un instrumento adecuado para la mejora de las condiciones de vida de los vecinos y la mejor gestión y administración de los asuntos locales.

Como es sabido, en la segunda mitad del siglo pasado se inició un proceso de fusiones municipales que redujo drásticamente el número de Entes locales, más a instancia del poder político de turno que a la propia voluntad de los vecinos. Se demuestra una vez más que a pesar de que la población es elemento capital de la institución municipal no siempre, por obvias razones, está en condiciones de iniciar procesos que pueden afectar a sentimientos, emociones y otras consideraciones subjetivas relativas al sentido de las instituciones y a su historia. En realidad, la conformación en esos años del Estado de bienestar trajo consigo la necesidad de articular nuevos servicios públicos que, con gracoste económico, impusieron una nueva adaptación de la realidad local a las nuevas exigencias públicas y sociales. Según el Consejo de Europa, entre 1950 y 1992, la mayor parte de los países redujeron notablemente el número de municipios. Bulgaria el $88 \%$, pasando de 2.178 a 255; Suecia el $87 \%$, pasando de 2.281 a 286; Dinamarca el $80 \%$, pasando de 1.387 a 285; Bélgica el 78\%, pasando de 2.669 a 589; 
El Gobierno y la Administración Local en España...

Reino Unido el 76\%, pasando de 2.028 a 484; Alemania el 67\%, pasando de 24.272 a 8.077; Chequia el 44\%, pasando de 11.051 a 6.196; Austria el 42\%, pasando de 3.999 a 2.301; Noruega el 41\%, pasando de 744 a 439; y Holanda, el 36\%, pasando de 1.015 a 647.

Sin embargo, en España y Francia, dónde el inframunicipalismo es más fuerte, la reducción de municipios apenas alcanzó un $12 \%$ y un 5\% respectivamente para el período de 1950 a 1992. En Italia y Portugal, por el contrario, en lugar de reducir municipios, los aumentaron: en Italia se pasó de 7.781 a 8.100 y en Portugal, de 303 a 305 municipios.

En Alemania, de las más de 24.000 comunas que tenían en 1960, el 70\% con una población inferior a los 1.000 habitantes, pasaron a ser, tras la reunificación, 8.400, con un tamaño siete veces mayor. En Bélgica, la tendencia a la reorganización local se produce con mayor intensidad en la década de los 70 del siglo pasado cuando sus Entes locales se redujeron en una cuarta parte. El caso del Reino Unido también es significativo pues la reducción operada es notable. La metodología empleada en Gran Bretaña es bien ilustrativa de la importancia de que estos procesos de reorganización local se aborden a partir de estudios serios y minuciosos con presencia de todos los sectores implicados: sociólogos, economistas, juristas, geógrafos... y, sobre todo, teniendo presente la naturaleza de los servicios y prestaciones que habrían de realizar los Entes locales. Como es sabido, tras diez años de trabajos, la Local Government Act de 26 de octubre de 1972 aprobó el nuevo mapa local británico. Dinamarca es ciertamente uno de los países que ha efectuado más fusiones municipales reduciendo a una quinta parte su número de Entes locales. La integración de Entes locales se produjo también en Suiza, pasando de 3.203 municipios en 1.850 a los 2.880 actuales. Sin embargo, en el área mediterránea, las fusiones no han tenido mucho éxito. El caso de España y 
Francia así lo atestigua. Y dentro de España, en Galicia hemos pasado de 303 municipios a 305 en la última década.

Desde luego, si se pretende implementar una política de fusiones municipales es menester premiar a quienes asuman esta operación de alteración de los términos municipales. Así, por ejemplo, la ley de promoción para la fusión de municipios distritales de Perú, de 20 de mayo de 2007, dispone toda una serie de incentivos para las fusiones: desde subvenciones de un fondo público hasta la asesoría directa de la presidencia de la República para la formación del personal y para la preparación del plan de desarrollo concertado pasando por la prioridad para la asignación de recursos de cooperación técnica por el consejo de ministros y para el financiamiento de adquisición de maquinaria y equipos a través del programa de equipamiento básico municipal. Si no existen estímulos a la fusión con los que transmitir a la población que es rentable unirse, tales alteraciones de los términos municipales son imposibles, especialmente por razones políticas fáciles de colegir, que no de justificar.

En Taiwan, la consideración de municipio especial ofrece mayor autonomía en materia tributaria y en lo que se refiere a la propia Administración pública. Por eso algunas ciudades y distritos han solicitado ante el ministerio del interior la pertinente fusión con el fin de convertirse en locomotoras del desarrollo local.

En Asturias, por ejemplo, el catedrático de economía de la Universidad de Oviedo Carlos Monasterio es partidario de las fusiones municipales en su región porque el mapa local actual es deudor de situaciones económicas y demográficas de hace doscientos años, mientras que hoy en día hay concejos con muy poca población, sin apenas actividad económica. Es más, con la actual división territorial y su reducida capacidad de gestión no se puede ofrecer una red de servicios potente. 
El Gobierno y la Administración Local en España...

Además, la población es un elemento muy importante para la captación de fondos, sobre todo europeos. Según este profesor, la fusión de municipios beneficiará a los ciudadanos porque dispondrán de mejores servicios, aunque reconoce que el tema de las alteraciones de los términos municipales es un tema espinoso por que donde hay tres o cuatro alcaldes pasaría a haber uno. Desde luego, sin un mínimo consenso vecinal estas operaciones están llamadas al fracaso pues el 70 \% de los concejales españoles lo son de pueblos de menos de 5.000 habitantes. Por su parte, el catedrático de geografía de la misma Universidad, tras reconocer que el mapa municipal asturiano le parece inamovible desde el punto de vista político, reconoce que desde una óptica económica muchos concejos deberían de fusionarse para mejorar las prestaciones a los vecinos ya que las prestaciones de los pequeños municipios son muy limitadas.

En 1990, el Comité de las Regiones, tal y como recuerda el informe del Círculo de Empresarios de Galicia en su página 18, señalaba en un dictamen al referirse a España que es responsabilidad primaria de las Comunidades Autónomas la política de fomentar fusiones o agrupaciones de municipios, aunque hasta el momento lo que se aprecia es un estímulo tímido a la constitución de mancomunidades voluntarias para la prestación de determinados servicios. En realidad, si las mancomunidades voluntarias funcionan, es más probable que una política de fusiones municipales pueda producirse sin graves problemas puesto que puede decirse que la consecuencia lógica de una inteligente política de asociacionismo voluntario de municipios es su fusión.

Una pregunta que debemos formularnos a la luz de la experiencia comparada es la relativa a si es recomendable o no establecer un número mínimo de habitantes por municipio de manera que se asegure la viabilidad económica. Por ejemplo, el 
propio Consejo de Europa propuso algunas ratios para algunos países: de 5.000 a 6.000 en Dinamarca, 5.000 en Noruega, de 6.000 a 7.000 en Países Bajos, 8.000 en Suecia. En ningún caso se contemplan municipios de menos de 5.000 en habitantes. En España, de 8.112 municipios, el 84 \% (6.082) tienen menos de 5.000 habitantes con una población que apenas llega al 15\% del total nacional. En Galicia, estos municipios de menos de 5.000 habitantes, que son 199 de 305, suponen el $63.2 \%$ del total de municipios y el 17 \% de la población de Galicia.

\section{La Cuestión Competencial: el Tema Pendiente}

La cuestión competencial en España es uno de los temas más importantes para el desarrollo territorial. Mientras sigamos en un cierto entorno de ambigüedad y abstracción en cuya virtud se producen solapamientos y duplicidades entre diversas Administraciones territoriales, será difícil avanzar en esta materia. Por eso, no sería descabellado iniciar un estudio multidisciplinar acerca de cuáles deberían ser las competencias propias de las diferentes Administraciones territoriales con el fin, más adelante, de proceder a las reformas normativas que fuera menester. En concreto, la situación de las competencias en materia local es especialmente grave y mientras no se soluciones las cuestiones que atienden a las alteraciones de los términos municipales estarán siempre en el candelero pero sin poderse aplicar.

Como es sabido, nuestro ordenamiento jurídico contiene principios aplicables al régimen jurídico de los Entes locales que contienen rasgos comunes con el principio de subsidariedad. Así, en el artículo 137 de la Constitución, aparece la idea de un Estado descentralizado, que reserva a cada instancia territorial un ámbito judicial delimitado por el respectivo interés público propio. El artículo 140 de la Carta magna incide en la misma 
El Gobierno y la Administración Local en España...

idea asignando el Gobierno y la Administración municipal a los Ayuntamientos. En el artículo 2 de la ley de bases encontramos la doctrina de la necesaria organización de los poderes públicos a partir del principio de proximidad al ciudadano, cuando dispone que se deberá atribuir competencias a los Entes locales "en atención a las características de la actividad pública de que se trate y a la capacidad de gestión del Ente local, de conformidad con los principios de descentralización y de máxima proximidad de la gestión administrativa a los ciudadanos". Por su parte, el artículo 28 de la citada ley de bases, donde se regulan las actividades complementarias de los municipios, concibe determinadas materias como áreas en donde siempre cabe un desarrollo más detallado en el ámbito local.

Otro caso de aplicación clara de la subsidiariedad como reserva de un espacio competencial a la instancia inferior, pese a la aparición de Entes superiores, lo encontramos en el 62 artículo 43.4 de la ley de bases cuando impide que la creación de comarcas pueda suponer la pérdida de las competencias municipales para prestar los servicios esenciales señalados en el artículo 26 o la privación de toda intervención en cada una de las materias enumeradas en el art. 25.2, también de la ley de bases.

Asimismo es de gran interés, al tratar del principio de subsidariedad y su relación con las Entidades Locales, hacer referencia a la Carta Europea de la Autonomía Local. En efecto, elaborada en el marco del Consejo de Europa, y ratificada por nuestro país el 20 de enero de 1988, su trascendencia es innegable puesto que se trata de un texto normativo incorporado a nuestro Derecho interno y por tanto, plenamente invocable ante los Tribunales de Justicia españoles. Esta invocabilidad es, precisamente, una de las características que le otorga mayor actualidad y justifica que le dediquemos nuestra atención. 
Entre los principios que la Carta Europea de la Autonomía Local consagra, destacan la suficiencia de recursos, la autonomía para el gasto y el ingreso, el derecho a ser oído cuando se dicten medidas y criterios de redistribución de los recursos, la preferencia de subvenciones y el libre acceso al mercado para concretar operaciones de crédito destinadas a gastos de inversión. Criterios todos ellos que deberían aconsejar la realización de un estudio integral acerca de las competencias de los Entes públicos en España de acuerdo con los respectivos intereses públicos territoriales.

La Carta nos plantea que las Entidades Locales ordenan y gestionan los asuntos públicos en beneficio de sus habitantes y, que sus órganos de gobierno son directamente representativos de dichos ciudadanos. Ello viene a suponer, en definitiva, la asunción de competencias propias sobre la parte importante de los asuntos públicos y la financiación suficiente para ejercitarlas. En la carta se parte directamente de dos principios: uno, que ya ha sido mencionado anteriormente, el de subsidariedad y otro, el de proximidad, la cercanía a los ciudadanos como criterio de atribución competencial. Así se expresa en el punto primero del apartado tercero del artículo cuarto de la Carta, al establecer que: "el ejercicio de las responsabilidades públicas debe, de modo general, incumbir preferentemente a las autoridades más cercanas a los ciudadanos".

Al mismo tiempo, el mismo apartado tercero en su punto segundo exige que: "La atribución de una responsabilidad a otra autoridad debe tener en cuenta la amplitud o la naturaleza de la tarea o las necesidades de eficacia o economía".

En relación con este punto hemos de agregar otros tres elementos normativos. De una parte, la potestad reglamentaria se realiza según el artículo 3 de la Carta "en el marco de la Ley". De otra, la libertad de los Entes Locales para ejercer su iniciativa en toda materia que no esté excluida de su competencia o 
El Gobierno y la Administración Local en España...

atribuida a otra autoridad. Finalmente, se establece una reserva reglamentaria en materia de organización local.

La Carta afirma el principio de autogobierno, al establecer el ya citado artículo 3 que la gestión de los asuntos públicos la realizará el Ente local bajo su propia responsabilidad. Este principio de autogobierno es, sin duda, un instrumento interpretativo fundamental con relación al régimen de las competencias de los Entes locales.

Hay otro aspecto de la Carta Europea que no podemos dejar de mencionar por la conexión que se está produciendo últimamente entre el principio de subsidiariedad y el problema del déficit democrático de las Instituciones de la Unión Europea. Me refiero a la conexión de la autonomía local con el principio democrático. En efecto, el Preámbulo de la carta señala a los entes locales como un ámbito privilegiado de la participación de los ciudadanos en la gestión de los asuntos públicos como cuna de la democracia: "La defensa y el fortalecimiento de la autonomía local en los diferentes países de Europa representan una contribución esencial en la construcción de una Europa basada en los principios de democracia y descentralización". Por eso, en orden a las decisiones que se puedan adoptar en materia de alteraciones territoriales, especialmente en el caso de las fusiones, es menester valorar el grado de adhesión de los vecinos a estas políticas puesto que la iniciativa administrativa, si se dicta al margen de la voluntad del pueblo, estaría llamada al fracaso.

Esta reflexión parte esencialmente del principio democrático, desde la perspectiva de posibilitar que los ciudadanos se sientan representados con la máxima intensidad posible en las decisiones que les afectan. De aquí la preferencia por la autoridad representativa más próxima, que sólo debe quedar desplazada cuando los efectos benéficos de una autoridad superior compense la pérdida de integración democrática. En 
este sentido, la propia Carta recoge, como no podía ser de otra forma, el principio de subsidariedad al contemplar la proximidad a los ciudadanos como criterio de atribución competencial, estableciendo que el ejercicio de las competencias públicas debe de modo general incumbir preferentemente a las autoridades más cercanas a los ciudadanos. Se trata, así, de acercar la Administración al ciudadano. Algo que aquí, en España, se ha dado en llamar la Administración común, ordinaria, general, sincronizada o única.

La Administración común exige necesariamente que sean los Entes Locales los que presten un mayor número de servicios y dispongan de una correlativa carga administrativa. La doctrina de la Administración común supone, pues, un claro reforzamiento del Ente titular de competencias en su propia demarcación territorial, lo cual debe propiciar un mayor protagonismo de Ayuntamientos, Cabildos, Consejos y Diputaciones en el ejercicio de las competencias sobre su propio territorio.

La Administración común no es incompatible con la función que la Constitución asigna a las Corporaciones Locales. Muy al contrario, ya que el proceso de redistribución de competencias no se completaría si no se produjese un proceso paralelo de desconcentración de competencias de la Administración Autonómica hacia las Administraciones Locales, en todos aquellos servicios en que su prestación por estos entes redundara en un mejor servicio al ciudadano, que es en definitiva la pieza clave del sistema en función del cual debe reorientarse todo el aparato administrativo.

Siendo ello así, al haberse producido en España un proceso de distribución territorial del poder con el desarrollo del fenómeno autonómico, resulta necesario que se reconozca, en esta estructuración del reparto del poder político establecido por la Constitución, un lógico protagonismo de las Entidades Locales. Sin embargo, durante mucho tiempo se ha prestado 
El Gobierno y la Administración Local en España...

una atención más que prioritaria a la descentralización de competencias del Estado hacia las Comunidades Autónomas, con un cierto olvido de las Entidades Locales.

Es cierto, como es bien sabido, que la Constitución no ha establecido un listado de materias sobre las que los Entes Locales ejerzan sus competencias. Pero también es posible - y deseable - que se ponga en marcha, una vez que el contenido propio de las autonomías este bien definido, una auténtica descentralización hacia los Entes Locales, habida cuenta que es habitualmente el legislador sectorial autonómico quien tiene la última palabra sobre la funcionalidad competencial de los Entes Locales.

La realidad competencial de los Entes locales es criticable por la existencia de un cierto descontrol en la realización de actuaciones, atendiéndose a auténticas "modas". Así a comienzos de los años 90 del siglo pasado, fue frecuente la eclosión de patronatos y empresas municipales, mediante la utilización de distintas tipologías societarias, ordinariamente sin estudios serios económicos, de gestión y financieros que los sustentasen, para poder desarrollar, en un marco de huida del Derecho Administrativo, las actividades que se pretendían, lo que ha provocado que gran número de ellas sean prácticamente inoperativas.

También podemos recordar la tendencia de las Corporaciones Locales de asumir cada vez mayor nivel competencial en aras a la actividad positiva de generación de empleo, fomento de la economía, y desarrollo socio-económico de la población, lo que supone un salto cualitativo respecto a una visión tradicional y arcaica de los entes locales como embalses estancados de competencias no productivas. Sin duda, el desarrollo competencial de los Entes locales debe pasar por el fenómeno del asociacionismo, otorgando un papel importante a las áreas metropolitanas y las mancomunidades de municipios como vías 
en transición a fenómenos de fusión o incorporación de municipios, sin olvidarnos del papel de la provincia como instancia garantizadora de los servicios en los pequeños municipios y como posible opción organizativa para la ejecución de determinadas políticas propias de base autonómica en su territorio.

En este sentido, conviene recordar que desde el propio Parlamento se ha instado a la redefinición del marco competencial a partir del principio de subsidariedad. Desde esta perspectiva, el significado del denominado pacto local es, pues, la respuesta a la insuficiencia de los instrumentos jurídicos para definir positivamente y hacer eficaz el contenido competencial concreto que la autonomía local reclama para la gestión de los intereses propios.

A este respecto, la situación actual de las competencias de los Entes Locales ha motivado que por diversos sectores se haya apuntado una progresiva pérdida del papel que deben desempeñar las Corporaciones Locales en el conjunto del Estado autonómico, con la consiguiente disminución de su poder de iniciativa y de respuesta, cuya causa puede encontrarse en una cierta cultura política imperante en las instituciones territoriales superiores, Comunidades Autónomas y Administración del Estado, que no se han conducido con el dinamismo necesario para dar satisfacción al autogobierno de los intereses locales.

Respecto a la posición de los poderes locales, uno de los mayores problemas es la complejidad administrativa y otro la estructura competencial. El proceso de descentralización observado a nivel internacional - con la posible excepción actual del Reino Unido - ha supuesto la aparición o el reconocimiento de Gobiernos y Administraciones regionales. Este proceso positivo de descentralización y, por tanto de acercamiento de los poderes públicos al territorio y al ciudadano, supone problemas de competencias y funciones. El desarrollo regional pone en marcha a menudo mecanismos de centralización 
El Gobierno y la Administración Local en España...

interna, con asunción de competencias locales y reducción, por tanto, del espacio del gobierno local. Pero la situación también es aquí diferente, por cuanto en algunos países las regiones o niveles de administración similares son considerados parte de la administración local (Francia, Reino Unido).

Los procesos de descentralización observados en la mayoría de los países, que convierten esta descentralización en una característica de nuestro tiempo, conllevan también problemas comunes de solapamiento de competencias, de duplicación a veces de los servicios y, lo que es más importante, de lagunas en la resolución de ciertos problemas.

La complejidad de las sociedades actuales hace lógica una relativa complejidad y una pluralidad de Administraciones públicas que operan en el territorio. Lo importante es saber convertir esta complejidad en un sistema eficaz de resolución de los problemas de los ciudadanos. Un reto del futuro inmediato será el de tratar mecanismos de cooperación que, mediante técnicas de negociación y contrato, permita una mayor eficacia y eficiencia pública, a la vez que garanticen el principio de responsabilidad. La complejidad no ha de impedir identificar claramente las administraciones responsables en cada caso, garantizando la seguridad jurídica y la transparencia frente a los ciudadanos.

La actuación de los poderes locales es incuestionable en su ámbito territorial, pero en dicha área intervienen también otras administraciones, bien directamente o bien de forma indirecta a través de decisiones normativas que afectan a los municipios. En el primer caso, la intervención directa, parece obvio reclamar la mejora de los mecanismos de coordinación operativa, que son todavía muy deficitarios. La Administración del Estado y las Administraciones regionales intervienen a menudo sobre el territorio sin la necesaria implicación del municipio. 
En el ámbito del Consejo de Europa, como ya se ha destacado, la Carta Europea de la Autonomía Local consagra el concepto de autonomía local, afirma el principio democrático que rige sus destinos, y reconoce la aplicación de la subsidariedad o proximidad así como la autonomía y suficiencia financiera así como la protección legal de su autonomía.

Refiriéndonos al caso español, se ha planteado en los últimos años una revisión general de las competencias de las Entidades locales, incardinado en este proceso de fortalecimiento de poder local que encuentra su base en la Carta Europea de la Autonomía Local. Pues bien, dicho proceso, como ya he señalado, podría girar en torno a los siguientes principios.

Primero, la Administración del Estado y las Comunidades Autónomas únicamente deberán asumir aquellas competencias que no sea posible residenciar en la Administración Local. Segundo, debe permitirse a los Entes Locales la elaboración de políticas propias mediante el reconocimiento de potestad normativa. En este sentido debiera implantarse una interpretación flexible del principio constitucional de reserva de Ley aplicado a la Administración Local. Tercero, la atribución de competencias no debe limitarse a funciones meramente ejecutivas. Además, debe potenciarse la descentralización de funciones en perjuicio de la delegación y, en cualquier caso, deberán evitarse las restricciones que minoren la efectividad de la autonomía local. Cuarto, en aquellas Comunidades Autónomas donde no existan deberán constituirse Comisiones Autonómicas de Régimen Local, como mecanismo que permita a las Entidades Locales participar en los procesos de planificación y ordenación de los asuntos que les afecten.

Esta potenciación de los Entes locales va ligada a la idea de subsidariedad, ya que la mayor proximidad de los municipios a los intereses ciudadanos tendría que proyectarse en una descentralización de funciones y competencias en favor de las 
El Gobierno y la Administración Local en España...

Entidades Locales, extrayendo en su plenitud las posibilidades de delegación de competencias estatales o autonómicas en su favor y abordando, si ello fuera preciso, las reformas legales necesarias para alcanzar ese objetivo.

Para alcanzar estos fines se planteó la necesidad de suscribir un Pacto, de carácter político y territorial, que permitiese abordar de un modo lógico, claro y de forma conjunta el futuro, las competencias y la posición de las Entidades Locales y que debería basarse en una serie de principios, entre los que pueden citarse: la autonomía en la gestión de los intereses propios, la subsidariedad, la descentralización y el acercamiento de la gestión, la eficacia en el desempeño de la función, la eliminación de duplicidades y la cooperación y coordinación ejecutivas.

Bajo la rúbrica del Pacto Local se encuentra, realmente, un complejo proceso de redistribución territorial del poder, que afecta al conjunto de los Gobiernos públicos y de las Administraciones territoriales, complementario de la construcción del denominado Estado autonómico. Un proceso de redistribución territorial que se guía por el principio de subsidariedad o, si se prefiere denominarlo así - dado el grafismo del término - por el de proximidad, entendiendo como la atribución preferente de las responsabilidades públicas a las autoridades más cercanas a los ciudadanos, debiendo atenderse solamente a la amplitud o a la naturaleza de la tarea, así como a las necesidades de eficacia o economía, para apartarse de tal criterio atribuyendolas a una autoridad de nivel territorial superior, como certeramente destaca la Carta Europea de la Autonomía Local.

Obviamente, el gran beneficiario de este segundo proceso descentralizador en la historia de la democracia española surgida de la transición política y de la Constitución de 1978 debe ser el poder local, que hasta ahora se había limitado a contemplar 
el surgimiento y la consolidación de ese novedoso y decisivo nivel de poder territorial constituido por las Comunidades Autónomas (que él mismo había contribuido a crear de forma también decisiva mediante el ejercicio de la iniciativa que a las Entidades locales confiere el título VIII de la Constitución), sin beneficiarse de forma significativa del proceso descentralizador que el Estado autonómico ha comportado. El objetivo es dotar a las corporaciones locales del marco legal de los medios y las competencias que les permitan ejercer un papel que es fundamental al servicio de la sociedad en su conjunto. Para ello, las Entidades locales han de tener un papel clave el modelo de desarrollo territorial y han de ser capaces de explotar las potencialidades de las reformas legislativas recientemente aprobadas por el Parlamento.

Esta reforma encuentra su justificación en la previsión de un proceso de descentralización de funciones desde el Estado y, en su caso, desde las Comunidades Autónomas hacia las Entidades Locales obliga a mejorar previamente la capacidad de respuesta y efectividad de las instituciones locales, para asegurar el correcto desempeño de las nuevas competencias que se le confían.

En el ámbito autonómico, debe destacarse no sólo la necesidad de una mayor transferencia de competencias y de recursos financieros a las Entidades locales, sino también la del cumplimiento del principio del carácter predominantemente no finalista de las transferencias y subvenciones de otras Administraciones públicas, exigido por el artículo 9.7 de la Carta Europea de la Autonomía Local, que si bien es respetado escrupulosamente por el Estado, no puede decirse lo mismo de todas las Comunidades Autónomas. La generalización de fondos municipales no finalistas en todas las Comunidades Autónomas, constituidos esencialmente por un porcentaje suficiente de sus ingresos impositivos, deviene una verdadera 
El Gobierno y la Administración Local en España...

exigencia del Pacto Local, dando también cumplimiento a la exigencia contenida en el artículo 142 de nuestra Constitución.

En fin, pensamos que un estudio multidisciplinar sobre las competencias de los Entes territoriales en España supondría aclarar una cuestión bien polémica y, sobre todo, facilitar a la población una mejor gestión pública, de más calidad y con menor coste.

\section{Reflexión Final}

Los Gobiernos y las Administraciones locales tienen sentido en la medida en que son capaces de atender razonablemente los asuntos públicos locales. Cuanto mejor gobiernen y administren el espacio público local al servicio de la mejora de las condiciones de vida de los vecinos, más sentido y justifica72 ción tendrán. Si, por el contrario, se convierten en instituciones que poco o nada aportan a la calidad de vida de los ciudadanos, entonces habría que poner en marcha algún proceso de reforma que los convierta en lo que deben ser.

Las Administraciones y los Gobiernos locales se justifican en la medida en que se conviertan en instituciones al servicio objetivo de los intereses generales de dimensión local. Prestan servicios y ejercen competencias en función de las personas de su territorio. Están para los vecinos porque ciertamente son de los vecinos en cuanto que personas con necesidades colectivas.

En el marco del denominado derecho a la buena administración de los asuntos públicos, recogido ya en el artículo 41 de la Carta Europea de los Derechos Fundamentales, la existencia de Entes locales con medios suficientes para satisfacer este nuevo derecho fundamental de las personas resulta elemental. Tal derecho fundamental quedaría reducido a la nada si en los pequeños Ayuntamientos, por problemas económicos o 
de personal, no se pudiera contribuir al bienestar y mejora de las personas que allí conviven.

La experiencia británica de una Royal Commission en la que aportaron sus puntos de vista todos los colectivos profesionales afectados por la cuestión local permitió, durante más de diez años, buscar acuerdos y preparar una reforma que gozó del beneplácito general y que redujo sustancialmente el número de municipios con objeto de que los servicios locales se prestaran en mejores condiciones para la mejora, valga la redundancia, de las condiciones de vida de los vecinos.

La realidad es la que es. Hoy está presidida por una aguda crisis económica y financiera que afecta soberanamente al sector público, y especialmente a los Entes públicos más débiles, a los peor financiados, que son los municipios, y dentro de ellos, obviamente, los más pequeños. Por eso, la reforma local es urgente y cuanto antes comience las consecuencias serán menos dañinas para los vecinos.

Los planteamientos inmovilistas, como de costumbre, nos condenan a seguir empeorando el nivel de prestación de los servicios obligatorios y a descuidar la gestión pública de los asuntos públicos locales. Los vecinos, en tal contexto, se distancian de los electos y de las posibilidades de la participación. Es menester reformar la realidad aprovechando la legislación vigente, que ofrece distintas fórmulas para salir del atolladero. También se pueden implementar las innovaciones normativas que sean necesarias, todo ello al servicio de contar con instituciones locales que realmente puedan cumplir su función constitucional.

En este contexto, buena cosa sería proceder a un estudio en profundidad del mapa competencial de los distintos Entes territoriales. A día de hoy todavía existen muchas duplicidades y superposiciones que podrían eliminarse si dispusiéramos de mayor claridad competencial. Si tras un estudio sereno 
El Gobierno y la Administración Local en España...

y riguroso se llegara a la conclusión de que fuera necesario modificar la Constitución para delimitar con mayor precisión las competencias del Estado, de las Comunidades Autónomas y de los Entes locales, adelante. Si, por el contrario, se concluyera que es mejor confiar estas cuestiones a los procesos de deliberación pública de manera que sea el consenso y la colaboración entre Gobiernos Administraciones públicas el que presida la solución a estos temas, adelante.

En este orden de cuestiones, también merecería la pena pensar en la idoneidad de las diputaciones provinciales para erigirse, no sólo en instancias públicas en las que la Xunta, como dispone el Estatuto, pueda delegar o confiar la ejecución de sus acuerdos de naturaleza provincial, sino en las Administraciones periféricas provinciales del propio Gobierno de la Comunidad Autónoma.

La realidad es la que es. En Galicia todos sabemos cuáles son nuestros problemas en esta materia y cuáles los caminos para iniciar su solución. Desde luego con tantos municipios de menos de 5.000 habitantes es muy difícil gestionar y administrar los espacios públicos locales razonablemente, coherentemente y al servicio de las necesidades colectivas de los vecinos. Por eso, también aquí, en nuestra Comunidad Autónoma, el Gobierno de la Xunta plantea distintas fórmulas presididas por el asociacionismo y las fusiones para luchar contra las enormes dificultades que a día de hoy presentan no pocos municipios gallegos de menos de 5.000 habitantes que no se sabe cómo pueden pagar los gastos corrientes, las nóminas y, lo que es más grave, cómo prestar los servicios municipales obligatorios. Para ello, a imagen y semejanza de lo que se plantea en otras Comunidades Autónomas, se tendrá que acudir a medidas de fomento que faciliten fusiones, mancomunidades o consorcios, en cada caso lo que sea más razonable. En este sentido, se pretende que la Comisión Galega de Delimitación 
Territorial, prevista en la ley gallega de Administración local de 1997, pueda revisar el mapa de planta municipal y así poder realizar estudios y propuestas de fomento para la fusión o la asociación municipal, vía mancomunidades o consorcios, y establecer ayudas económicas y técnicas, fijación de criterios prioritarios o especiales en la asignación de subvenciones finalistas y en la creación de un Fondo especial ad hoc para facilitar estas operaciones de unión municipal.

En la Comunidad Valenciana está previsto que la nueva ley de régimen local contemple la posibilidad de que los pequeños municipios se asocien para afrontar determinados gastos en materia de personal. Se prevén también mancomunidades de interés preferente, un camino para que los municipios que opten por esta fórmula de asociacionismo municipal dispongan de especiales programas de fomento.

En Cataluña, como hemos señalado en el epígrafe anterior, si las medidas de impulso y fomento de las fusiones y las mancomunidades fracasarán, el Gobierno podrá poner en marcha una reorganización territorial que modifique el mapa local. Primero, pues, es menester fomentar las fusiones y el asociacionismo municipal con efectivas medidas de fomento como las que aquí hemos expuesto. Y, después, entonces, habrá que analizar lo que ha acontecido y por qué.

Si fuera posible propiciar fórmulas de integración local sin que desaparezca ningún municipio de manera que se fortalezcan los presupuestos y se puedan prestar en mejores condiciones los servicios municipales obligatorios, entonces se produciría la cuadratura del círculo. Algo que, por el momento no parece posible. Sí que es posible seguir trabajando en el fomento de mancomunidades voluntarias que presten objetivamente mejor los servicios a los vecinos y en consorcios que garanticen igualmente mejores capacidades y técnicas que redunden en la calidad de vida de los vecinos. Crear ahora 
El Gobierno y la Administración Local en España...

nuevos Entes locales superpuestos a los ya existentes es, desde luego, en este momento, irracional. En mi opinión, lo razonable, es trabajar desde las estructuras reales y buscar las mejores soluciones posibles. En todo caso, el asociacionismo voluntario no es mal camino hacia fusiones que hagan posible de verdad una mejor prestación de los servicios públicos municipales a los vecinos.

\section{Referencias}

BARREIRO RIVAS, X.L. Hacia una nueva estructura municipal. In: RODRIGUEZ GONZÁLEZ, R. Reformar la Administración Territorial. A Coruña: Netbiblo, 2009. p. 3-19.

CADAVAL SAMPEDRO, M. Las aglomeraciones urbanas desde la perspectiva de la Hacienda Pública. Documento n. 19/04. Madrid: Instituto de Estudios Fiscales, 2001.

76 CÍRCULODE EMPRESARIOS DE GALICIA. Un nuevo mapa municipal para Galicia. Cuadernos para el debate n. 16. Vigo: Club Financiero de Vigo, 2009.

ESCUIN PALOP, C. La alteración de los términos municipales. In: MUÑOZ MACHADO, S. (Director). Tratado de Derecho Municipal. Madrid: Civitas, 2003.

LÓPEZ ARRIBAS, C. La reorganización territorial: hacia unos Ayuntamientos eficientes y viables: la fusión selectiva de municípios. In: RODRÍGUEZ GONZÁLEZ, R. Reformar la Administración Territorial. A Coruña: Netbiblo, 2009. p. 185-199.

MEILÁN GIL, J. L. Municipio y estructuras políticas. In: RODRIGUEZ GONZÁLEZ, R. Reformar la Administración Territorial. A Coruña: Netbiblo, 2009. p. 21-39.

OLIVEIRA, A. C. O marco administrativo local em Portugal. In: RODRÍGUEZ GONZÁLEZ, R. Reformar la Administración Territorial. A Coruña: Netbiblo, 2009. p. 43-65.

ORDUÑA PRADA, E. El municipio como marco relacional. In: RODRIGUEZ GONZÁLEZ, R. Reformar la Administración Territorial. A Coruña: Netbiblo, 2009. p. 99-125. 
RODRIGUEZ GONZÁLEZ, R. (Director). Reformar la Administración Territorial. A Coruña: Netbiblo, 2009.

. Ayuntamiento de Deza: estructura organizativa de una utopia. In: Reformar la Administración Territorial. A Coruña: Netbiblo, 2009. p. 203-227. . Territorio y gobierno local en España: un planteamiento de reestructuración por fusión como realidad necesaria. Madrid: Civitas, 2005.

SOSA WAGNER, F. Creación, fusión y supresión de municípios. In: RODRÍGUEZ GONZÁLEZ, R. Reformar la Administración Territorial. A Coruña: Netbiblo, 2009. p. 69-95. . Manual de Derecho Local. Pamplona: Aranzadi, 2001.

VARELA ALVAREZ, E. El nuevo minicipalismo gallego. ¿Administraciones versus gobiernos locales? In: RODRÍGUEZ GONZÁLEZ, R. Reformar la Administración Territorial. A Coruña: Netbiblo, 2009. p. 169-181. 


\title{
As Finanças Portuguesas nos Séculos XVII e XVIII
}

\author{
The Portuguese Finances \\ during the 17th and 18th Centuries
}

António Manuel Hespanha*

Resumo: Depois de traçar um panorama dos princípios normativos específicos do cálculo financeiro da época moderna na Europa, o artigo descreve resumidamente a estrutura básica das rendas da coroa portuguesa, desde os finais do séc. XVI até ao início do séc. XVIII. Um conjunto de gráficos resume o estado das finanças portuguesas deste período, quer na Europa, quer no ultramar, desde os finais do séc. XVI até ao início do séc. XIX.

Palavras-chave: Finanças Públicas. Coroa. Estado Moderno. Cálculo Financeiro.

Abstract: After drawing an overview of the specific normative principles which guide financial calculus in the European early modern age, the article sums up the basic structure of the revenue of the Portuguese crown during the 17th and 18th centuries. A set of graphics gives an insight into the Portuguese finances, either in the realm or overseas, from the late 16th to the early 19th century.

Keywords: Public Finances. Crown. Modern State. Financial Calculus.

$\overline{\text { * Universidade NOVA }}$ de Lisboa (UNL) - Portugal. 


\section{Introdução: \\ a Estrutura Financeira das Monarquias Corporativas}

Nos seus Advertimentos dos meios mais efficases e convenientes que há, para o desempenho do patrimonio real e restauração do bem público destes Reynos de Portugal sem oppressão do povo e com commua utilidade de todos ${ }^{1}$, Baltasar de Faria Severim inicia o seu discurso com algumas considerações não isentas de ironia sobre o estado da reflexão sobre as matérias da fazenda e finanças neste início do século XVII. Escreve ele: «Todos os que até agora escreverão do governo político (a que os modernos chamão Razão de Estado) tratarão esta matéria tão largamente, e nos deixarão escrito tão doutos e excellentes tratados, que em parte parecerá a alguem pouco necessário este nosso trabalho. Porém, se se considerar com attenção as regras que derão, e as questões que ventilarão facilmente se achará que somente nos

80 insinuarão huas theoricas tão especulativas e espirituaes, que vem a ser de mui pouco momento, e utilidade para a Republica, pela difficuldade que tem de se porem em pratica. Porque ordinariamente fasem hua descripção das grandes virtudes e partes que hade ter o Principe o Governador: como hade ser justo, temente a Deus, mizericordioso, liberal, afavel, prudente, e valeroso; dizem muitas cousas da fidelidade, scientia, prudencia, e experiência dos Conselheiros, mostram, quão prudente, animoso, acautelado, e experimentado hade ser o Capitão; tratão mui diffusamente o muito que convem que o Rey tenha muitas rendas, grandes riquezas e thesouros, e dizem outras muitas cousas, que servem somente de pintar hum perfeito Príncipe, e hua perfeita Republica [...] E finalmente são tão especulativos, que não consideram mais que a bondade dos fins, sem darem regras de como se hão de achar os meios para estes fins se alcançarem [...] escrevem dos grandes thesouros

1 1607, Arq. Nacional da Torre do Tombo, manuscrito «Livraria», 1821. 
e rendas que o Principe ha de ter, e não dão remedios para se aiuntar este dinheiro, e para as rendas de presente se desempenharem» (p. 1-3).

Este texto descreve muito justamente a situação. Na verdade, o tema da riqueza do rei era abordado pela literatura tradicional sobre o governo, desde os espelhos dos príncipes até aos capítulos das obras de teologia moral dedicados aos específicos deveres e virtudes dos reis ${ }^{2}$. Como diz Baltasar Severim, nem os novos «políticos» (como Maquiavel ou Botero) ou «económicos» (como Castiglione ou Della Casa) inovam muito sobre o tema. Os segundos, porque, referindo-se explicitamente ao governo da casa, não cuidam dos problemas e meios específicos da Fazenda da república. Os primeiros, por sua vez, por duas ordens de razões.

Primeiro, porque, na esteira de Maquiavel e, afinal, dos grandes moralistas da Antiguidade, se deixam conduzir, na discussão dos problemas da Fazenda dos príncipes, pela polémica, aberta pelo florentino (Il principe, cap. XVI), acerca da avareza ou da liberalidade como virtudes reais, com o que se reduzem a um discurso político-moralista sobre a eficácia de cada uma destas qualidades como estratégias de governo e dispensam qualquer reflexão de natureza técnica sobre o modo de engrandecer, conservar e gerir o património da coroa ${ }^{3}$.

2 V., para nos restringirmos a peninsulares de grande voga na época, Martin de Azpilcueta Navarro, Manual de confessores, \& Penitentes..., Coimbra, 1549, cap. 25, p. 413 («De alguas perguntas particulares [...] quanto aos senhores»), Juan de Azor, Institutionum moralium, Roma, 1600-1611, pars. II (= tom. II), lib. XI, «De regum origino, officiis et potestate», maxime, c. VII («De regum vitiis et peccatis»); António Escobar de Mendoza, S.J. Liber theologiae moralis, Lugduni, 1659, tr. II, ex. III, p. 302 et seq. Para um teólogo moral italiano de grande divulgação na Península Ibérica, Tomás de Vio Caietanus, Peccatorum summula [...] novissime recognita [...], Duaci, 1613, p. 721.

3 Giovanni Botero (Della ragion di Stato e della grandezza e magnificenza delle città, 1589, maxime, livro VII; utilizei uma versão castelhana mais próxima da época que nos interessa, Razón de Estado con tres libros de la grandeza de las ciudades, Burgos, 
Depois, porque, na perspectiva tradicional, a riqueza do rei não era um bem superior ou sequer separável da riqueza do Reino, entendida como o somatório da riqueza dos súbditos; de onde, a riqueza do Reino fosse medida, segundo esta corrente do pensamento financeiro, pelo bem-estar e, logo, pela abundância da população (Magalhães, 1959, vol. 9, p. 157). Daqui decorria que as regras de ouro da gestão financeira fossem as mesmas que presidiam a toda a atividade de governo: as da justiça, ou seja, de que qualquer intromissão do rei no património dos vassalos deveria ser excepcional e que só seria legítima precedendo justa causa, igualdade e justiça materiais e processo devido (que poderia incluir o consentimento do Reino). Especificando mais, daqui resultava que o rei devia cobrir as despesas da coroa com as rendas do património próprio do rei, mas, não sendo isto possível (e tinha-se a consciência de que o era cada vez menos num período de desvalorização monetária 82 como fora o século XVI e de crescentes gastos da coroa), usar de uma tributação justa.

A questão da justiça (distributiva, isto é, relativa ao equilíbrio entre carga fiscal e recursos dos contribuintes, e comutativa, isto é, equilíbrio relativo dos contribuintes) estava, assim, no centro da reflexão financeira e encaminhava-a, portanto, para duas direções. Por um lado, para a questão de como aumentar a riqueza do Reino, de modo a poder, sem desproporção e comoção, aumentar a carga fiscal. É o problema do aumento da riqueza, ao qual se ligam sucessivamente, na teoria seiscentista e setecentista, os do aumento da população, da acumulação de metais preciosos, da criação de indústrias, do equilíbrio favorável do comércio externo, do favor da agricultura. Por outro lado, para a questão dos meios mais justos e menos

1603); no entanto, marca uma ruptura - ou não fosse ele um pensador de ruptura, embora controlada -, ao desenvolver numa prototeoria financeira a sua máxima de que convém ao príncipe ter um grande tesouro (livro VII, p. 90 et seq.). 
opressivos de transformar a riqueza do Reino em riqueza do rei. É a questão da política fiscal, que normalmente se reduz a questões de ética fiscal, como veremos.

Em contrapartida, é mais difícil que surjam, neste contexto, questões de oportunidade ou de mera técnica financeira.

As primeiras são mesmo suspeitas de imoralidade ou de indecência, de tal modo o plano em que se colocam é diferente daquele considerado adequado. Por exemplo, a questão, levantada por Maquiavel, da vantagem de um príncipe ser miserável (ou avaro) contrariava - independentemente da oportunidade dos resultados financeiros - tudo o que se cria estabelecido quanto à deontologia do ofício de reinar, porque desde a Antiguidade se definiam a liberalidade e a magnificência como qualidades reais por natureza. Do mesmo modo, discorrer sobre se seria conveniente ao príncipe, por razões de oportunidade política, empenhar o seu patrimônio - de modo a conseguir que a multidão dos seus credores (de juros, de tenças, de ordenados) ficasse naturalmente solidária com o destino do monarca e da sua fazenda - era aberrante, de tal modo a solução afirmativa contrariava tanto os fundamentos naturais da obediência dos vassalos como as ideias fundamentais de liberdade (G. Botero, Ragion di Stato..., cit., p. 40 v.o, 92) e de reputação do príncipe, para não falar já do fato de se promover um meio tão pecaminoso como a usura ${ }^{4}$.

Quanto às questões meramente técnicas, existiam idênticas reservas. Nos finais do século XVI, põe-se, por exemplo, a questão de saber se seria «em serviço e proll» da Fazenda real «aver nella livro de caixa e correr por esta ordem ou pella

${ }^{4}$ Num curioso texto de 1609 , escrito como apêndice à antes referida obra de seu tio (Resposta que se dá a hua ojecção que alguns oppoem contra a doutrina deste livro, dizendo ser boa Razão de estado estar empenhado o património real em Hespanha, Arq. Nacional da Torre do Tombo, Manuscritos da Livraria, nº 1821, p. 82-91), Manuel Severim de Faria discute esta última questão. 
antigua feita no ano de 1591» (Arq. Nac. da Torre do Tombo, manuscrito «Livraria», cod. 2257, p. 205-207). Um dos pareceres é no sentido negativo, com o fundamento em que tais técnicas contabilísticas seriam ajustadas aos comerciantes, mas, em contrapartida, impróprias de reis. Embora com outros pontos de vista, Duarte Gomes Solis dá conta desta mesma distância entre a contabilidade real e a contabilidade dos comerciantes ${ }^{5}$. E, de fato, é só no século XVIII que métodos rigorosos, já há muito em uso na contabilidade dos privados - como a contabilidade por partidas dobradas -, começam a ser usados na contabilidade da coroa ${ }^{6}$. Mas, sobretudo, estas questões técnico-organizativas, como métodos de previsão de receitas e despesas, sistemas de administração das rendas, sistemas de contabilidade e de organização burocrática, não suscitam a atenção dos teóricos ou dos cultores da «alta política». Mesmo já nos meados do século XVIII, um político tão atento aos mecanismos quotidianos de governo como D. Luís da Cunha não dedica às finanças senão umas notas fugidias e menos ainda à sua organização técnica (Instruções Inéditas de [...] a Marco António de Azevedo Coutinho, 1738, ed. de Pedro de Azevedo e

5 «O primeiro e principal ponto do mercador é o livro de caixa, que na Casa da Índia havia de haver [...]", Duarte Gomes Solis, Alegación en favor de la Compañia de la India Oriental, 1628, p. 42 (ed. util., Lisboa, 1955, cuidada por Moses Bensabat Amzalak).

${ }^{6}$ A escrituração por partidas dobradas é instituída com a criação do tesoureiro-mor do Reino (carta de lei de 22 de dezembro de 1761, tít. XII). Em França fora introduzido na contabilidade da coroa em 1716. Em Castela, a existência de um «livro de caixa e razão», o método do «dever e haver», que teria correspondido à escrituração por partidas dobradas, data de 1592 [cf. Esteban Hernández Esteve, Estabelecimento de la partida doble en las cuentas centrales de la real hacienda de Castilla (1592). I. Pedro Luís de Torregosa, primer contador del libro de caja, Madrid, Banco de Espanha, 1986]. Se for assim, a citada e contemporânea discussão, entre nós, a respeito da existência de um «livro de caixa e correr» pode ser interpretada com o mesmo sentido. Mas a ênfase da Lei de 1761 indicia que, realmente, a escrituração anterior não correspondia à usada nos círculos mercantis do século XVIII sob a designação «partidas dobradas». 
António Baião, Coimbra, Imprensa da Universidade, 1929, p. 191 et seq.), confessando mesmo que ignora «a quanto montam as rendas não casuais da coroa» (Testamento Politico ou Carta Escrita ao Senhor Rei D. José I, antes do Seu Governo, Lisboa, 1820, 23)7.

A exceção mais brilhante é o já citado texto de Baltasar de Faria Severim, injustamente esquecido ${ }^{8}$.

Onde esta discussão existe é em textos de muito menores ambições teóricas, da pena de arbitristas ou, sobretudo no período filipino, nos memoriais enviados ao rei sobre o estado das finanças do Reino (v. infra). E, muito mais tarde, quando - também no domínio das finanças - as considerações de oportunidade sobrelevam as de justiça, na literatura reformista dos finais do século XVIII.

\section{Constrangimentos do Cálculo Financeiro}

Mas não era isto que impedia que os diagnósticos sobre as dificuldades da Fazenda fossem quase todos coincidentes e, de um ponto de vista estritamente financeiro, bastante exatos.

\footnotetext{
7 Ignorância clássica desde o século XVII (v. Advertencias sobre a Confusão Que Ha na Renda e Despesa da Fazenda Real de Portugal e como Se Poderia Atalhar, Bib. Nac. Lisboa, cod. 917, 115 v.-18 v., 1624; Advertencias Importantes Que Se Mandarão ao Conde Duque sobre o Reyno de Portugal, Bib. Nac. Lisboa, cód. 2632, p. 119-122, 1628, e Solis, 1622, p. 131, 1628, p. 118 et seq.). Raras são, de resto, as relações das rendas da coroa que não contenham erros de cálculo, explicados, talvez, pela dualidade entre unidades monetárias com curso efetivo (como os cruzados) e unidades meramente de conta (como os contos de réis).

8 Até por ser a fonte (quase sempre copiada ipsis verbis) de muito do que aparece atribuído ao seu sobrinho Manuel Severim, no «seu» conhecido discurso «Dos meios com que Portugal pode crescer em grande número de gente [...]» (cf., sobre ele, José Calvet de Magalhães, "História do pensamento económico em Portugal", Boletim de Ciências Económicas (Faculdade de Direito de Coimbra), vol. IX (1959), p. 144 et seq.).
} 
O que impedia que esta perspicácia do diagnóstico se transformasse numa eficácia da terapêutica era o fato de o cálculo financeiro estar subordinado a uma série de constrangimentos relacionados com a deontologia do governo. «Constrangimentos morais e religiosos», que excluíam todas as medidas financeiras que atentassem contra a deontologia do governo ou contra a liberdade da Igreja. «Constrangimentos intelectuais», correspondentes à evidência de certos modelos de gestão do património, como o modelo da «casa», que se impunha desde Xenofonte e Aristóteles à administração pública e privada europeia. "Constrangimentos políticos», que sobrepunham, por exemplo, a reputação ou a política dinástica do príncipe à sua solvabilidade. A que se acrescentavam, naturalmente, «constrangimentos técnicos e institucionais».

Os constrangimentos «morais e religiosos» da política financeira incidiam sobretudo sobre dois aspectos: a licitude 86 dos tributos (que incluía o aspecto particular da licitude da tributação da Igreja) e a licitude das operações creditícias.

A primeira questão ainda envolvia dois momentos distintos. Um, o da licitude in abstracto, por assim dizer, do tributo, face à ordem ético-jurídica comum. Outro, o da sua licitude no plano de uma ordem jurídica concreta, $v$. g., a portuguesa, com as limitações específicas que ela contivesse ao poder tributário do rei.

No primeiro plano - o da moral e do direito comum -, a doutrina tinha como guia dois princípios. $\mathrm{O}$ do caráter odioso de novos tributos e o de que, de qualquer modo, estes (como os antigos) tinham que ser legítimos.

O primeiro princípio estava, de resto, consagrado no $\S \mathrm{V}$ da bula In Coena Domini (Bula da Ceia, de Gregório IX, publicada anualmente na Quinta-Feira Santa), em que se excomungavam os senhores que, nas suas terras, impusessem novas portagens ou gabelas (isto é, impostos sobre as vendas) ou as 
aumentassem sem especial permissão da Santa Sé, a não ser nos casos permitidos pelo direito 9 . É certo que este cânone distingue as portagens ou gabelas - que incidem sobre as mercadorias que transitam (importadas ou exportadas) - das talhas, ou fintas, que constituem contribuições pro rata impostas pelos magistrados a quem compete curar do bem da república e destinadas a subvencionar os gastos comuns, estas últimas podendo ser licitamente criadas. Em todo caso, esta proibição de novos tributos (embora o cânone só falasse de certo tipo de tributos) permaneceu como um tópico de invocação corrente, pronunciando-se os autores pela presunção da sua injustiça, o que importava consequências bem concretas - ninguém seria obrigado a pagá-los, podendo ainda defraudar o fisco sem perigo da sua consciência (Baptista Fragoso, Regimen Reipublicae christianae..., cit., vol. II, livro I, disp. 3 et seq., ad. § V, n.o. 114).

De qualquer modo, novos ou antigos, senhoriais ou régios, os tributos tinham que ser legítimos, sob pena de excomunhão para quem os impusesse e de recusa justificada de pagamento pelos tributados. De facto, a ilicitude dos tributos podia decorrer de quatro circunstâncias, que a teologia moral escolástica tinha arrumado de forma característica, segundo o modelo expositivo das quatro causas aristotélicas. Assim, os tributos (novos) podiam ser ilícitos e levar à excomunhão: I) ex causa efficiente, ou seja, por falta de poder tributário de quem os criou; II) ex causa finale, por não terem em vista o bem comum; III) ex causa materiale, se incidissem sobre bens de sustento - mas não já sobre as mercadorias objeto de comércio (Baptista Fragoso, Regimen Reipublicae christianae..., cit., vol. II, livro I, disp. 3 et seq.,

9 Embora, na interpretação dos juristas mais modernos (a partir, pelo menos, do século XIV), este cânone não se aplicasse aos senhores ou repúblicas que não reconhecessem superior (cf. Baptista Fragoso, Regimen Reipublicae christianae, Colonia Allobrogum, 1652, vol. II, livro I, disp. 3 et seq., ad. § V, ns. 114 e 115, citando fontes doutrinais ainda medievais, como Baldo e Bartolomeu de Saliceto). 
ad. $\S$ V, n. 119 , citando a opinião comum); IV) ex causa formale, se não fossem iguais ou proporcionados, sobrecarregando mais os pobres do que os ricos.

Para além disto, os tributos tinham que ser lícitos em face do ordenamento jurídico concreto, o que levantava, desde logo, o problema da obrigatoriedade ou não do consentimento dos povos. Em Portugal, a opinião geralmente recebida até ao início do século XVIII era a da necessidade do consentimento do Reino, reunido em cortes $^{10}$.

Caso particular, neste capítulo da licitude dos tributos, era o da tributação da Igreja. Na verdade, o $\S 18$ da Bula da Ceia feria de excomunhão todos os que impusessem, sem licença expressa do papa, quaisquer coletas, décimas, talhas, contribuições ou outros ónus sobre os eclesiásticos, instituições da Igreja, benefícios eclesiásticos ou bens patrimoniais adquiridos de qualquer modo pela Igreja (Baptista Fragoso, Regimen Reipublicae christianae..., cit., parte 2, liv. I, disp. 3, p. 220), embora se admitisse que, quando se tratasse de ónus exigidos pela utilidade pública, os clérigos estivessem obrigados a eles, podendo ser coagidos pelo juízo secular ou eclesiástico (ibid., n.. 311). No direito nacional, a discussão girava em torno de três textos das ordenações: Ordenações Filipinas, II, 1, 19, que estabelecia a sujeição dos clérigos ao foro comum (e, implicitamente, aos respectivos tributos) no caso de questões levantadas pela aplicação dos tributos das alfândegas, sisas, dízimas, portagens e aduanas, «nos casos em que, conforme nossas Ordenações, e direito os deverem»; um outro era o das Ordenações Filipinas, II, 11, 1, em que expressamente se

\footnotetext{
${ }^{10}$ É esta, ponto por ponto, a doutrina defendida por Pantaleão Rodrigues Pacheco no seu Tractatus de justa exactione tributi (c. 1640) (Bib. Nac. Lisboa,cód. 395-414), publ. por Moses Bensabat Amzalak, Frei Pantaleão Rodrigues Pacheco e o Seu «Tratado da Justa Exacção do Tributo», Lisboa, Ed. Império, 1957 (onde se publica uma versão traduzida; para os passos citados, cf. p. 17-19).
} 
isentavam os clérigos de dízima (do pescado, das sentenças, das alfândegas), portagem e, em parte, da sisa; o último era o das Ordenações Filipinas, II, 33, 8, que estabelecia a sujeição de princípio dos clérigos em relação às jugadas. Tudo combinado, e atenta a magna discussão exegética e doutrinal que estes textos levantavam (António Manuel Hespanha, As vésperas..., cit., vol. I, p. 439 et seq.), o balanço era muito favorável aos eclesiásticos, que, como diz Baptista Fragoso, podiam, sem receio de sisa, portagens ou aduanas, vender os seus bens móveis e imóveis, bem como as rendas dos seus benefícios (Baptista Fragoso, Regimen Reipublicae christianae..., cit., I, parte 1, liv. II, disp. 4, ns. 311 et seq.).

A Igreja portuguesa conseguiu manter quase intacto este regime de isenção - que se tinha fortalecido nos últimos anos da dinastia de Avis - até aos finais do século XVIII, em contraste com o que se passava, por exemplo, em Castela, onde a Igreja contribuía desde o início da época moderna com uma parte das suas rendas para os gastos do Reino. Na verdade, os eclesiásticos (salvo os clérigos comerciantes) sempre estiveram isentos de sisa (António Manuel Hespanha, As vésperas do Leviathan. Instituições e poder político - Portugal, séc. XVII, ed. autor, $1986^{11}$, p. 167, p. 440) e, quanto às décimas, só vieram a ser a elas sujeitos pelo regimento de 1672. Mas por pouco tempo, pois logo em 1777 foram de novo isentos, apenas voltando a pagá-las a partir de 1796. Dada a amplitude do estado eclesiástico, a importância das suas rendas e o fato de os clérigos pretenderem, embora sem grande sucesso (pelo menos doutrinário), que as suas isenções abrangessem os seus caseiros ou colonos (Ordenações Filipinas, II, 25, e Alvaro Valasco, Decisionum..., vol. II, dec. 131), já se avalia como era central, do ponto de vista financeiro, esta questão da «liberdade da Igreja».

${ }^{11}$ Ver: $<$ https://drive.google.com/?usp=chrome_app\#folders/0BxG11aEdnDQ2Zlh1 aVdidXBiVDQ>. Ed. impressa, não integral: Coimbra: Almedina, 1994. 
Claro que a Igreja acabava por contribuir, indiretamente, para os gastos da coroa. Por um lado, por meio das rendas das capelas e igrejas do Padroado Real (António Manuel Hespanha, As vésperas..., cit., vol. I, p. 451, e Jorge de Cabedo, De patronatu ecclesiarum regiae coronae, ed. cons. Antuerpiae, 1734). Por outro, pelas rendas dos mestrados das ordens militares, incorporados na coroa nos meados do século XVI (1550-1552) (António Manuel Hespanha, As vésperas..., cit., vol. I, p. 455). Apesar de os rendimentos das comendas terem um valor importante, $\mathrm{o}$ fato de a maior parte delas andar concedida fazia com que o rendimento dos mestrados fosse insignificante no cômputo das rendas da coroa.

A Bula da Cruzada - produto das esmolas dadas pelos fiéis a troco de indulgências e outras graças (para vivos ou para defuntos) e aplicada à luta contra os infiéis - constituía uma concessão pontifícia aos reis de Portugal, tornada regular a partir de 1591 (Bula Decens esse videtur, de Gregório XIV, data em que se cria, para administrar o seu rendimento, o Tribunal da Bula da Cruzada; novo regimento em 10.5.1634, J. J. Andrade e Silva, Col. Chron...). As esmolas para este fim eram suscitadas por uma pregação adequada. Mas, tendo que concorrer com outras esmolas e pressupondo um controlo sobre os montantes arrecadados que a coroa não podia exercer, a bula teve sempre um rendimento relativamente pouco importante.

Um outro meio, este eventual, de punção das rendas eclesiásticas eram os pedidos de subsídios, a que se recorreu frequentemente no período filipino, incitando a sua aceitação pela ameaça de aplicar rigorosamente o preceito das Ordenações que proibia a Igreja de adquirir bens de raiz (Ordenações Filipinas, II, 18; sobre a qual v. Sampaio, 1793, parte 3, p. 64 et seq.). As somas obtidas foram-no, porém, sempre dificilmente, de pequena monta e, em geral, tardiamente pagas. E, mesmo quando o braço do clero, nas cortes do período brigantino, concordou em 
contribuir para o esforço da guerra, não faltaram cabidos que se dessolidarizaram dos seus representantes em cortes, negando-se ao serviço. Para além de que a literatura pró-eclesiástica difundia continuamente a ideia de que as empresas pagas com dinheiro da Igreja terminavam sempre de forma catastrófica, invocando uma série de exemplos em apoio ${ }^{12}$. Finalmente, um derradeiro meio: o recurso a breves pontifícios que autorizassem a tributação da Igreja. Foi o expediente usado, nomeadamente, para a imposição dos reais sobre a carne e o vinho, nos meados do século XVII. A obtenção dos breves, em que os não privilegiados insistiam fortemente para não terem que arcar, só eles, com o peso do tributo, era frequentemente menos difícil do que a sua pacífica aceitação pelos eclesiásticos, que chegaram a recorrer de sentenças do tribunal do coleitor pontifício no sentido de os obrigar ao pagamento dos reais.

A isenção tributária da Igreja representava, assim, um desses condicionantes - a um tempo ético, religioso e jurídico-político - do cálculo financeiro do Antigo Regime. Condicionante cujo alcance não pode ser minimizado, pois a importância dos rendimentos eclesiásticos era enorme (cf. supra) ${ }^{13}$. Daí que os povos, em cortes, e a literatura reformista (D. Luís da Cunha, Melo Freire, J. A. B. Chichorro) sempre tenham insistido na necessidade da igualdade da tributação (ainda aqui, recorrendo a um tópico da teologia moral) e alertado para o crescente poder econômico (maxime fundiário) da Igreja.

\footnotetext{
12 «Deve o príncipe fazer os possíveis para não impor tributos nos religiosos e eclesiásticos, porque não são felizes em suas consequências», escreve, já nos meados do século XVIII, Damião António de Lemos Faria e Castro, Política Moral e Civil..., Lisboa, 1749, p. 164.

${ }^{13}$ V. indicação das rendas eclesiásticas em L. A. Rebelo da Silva, História de Portugal nos sécs. XVII e XVIII, Lisboa 1860-1871, vol. V, p. 308-320, e Bib. Nac. Lisboa, cód. 7641, p. 63 v. - 69 v.. ; c. 1630, somariam cerca de 90 contos (quase tanto como os almoxarifados do Reino).
} 
O problema da tributação da nobreza era também um problema ético, dizendo respeito à deontologia do bom governo. Um governo que mantivesse a ordem social justa e as distinções estatutárias pelas quais ela se revelava. É justamente neste plano que a questão é posta por Damião de Faria e Castro, quando reflete que «a nobreza, se se vê tributaria, exaspera-se; porque sem distinção dos plebeos, se lhe igualaão os privilégios, que merece a virtude, e herdou o sangue. A soberba das nossas Hespanhas não sofre estas igualdades [...]» (Politica Moral..., Lisboa, 1749, p. 164). O autor recorda, decerto, a eficácia classificativa que, em Castela, tinha a distinção entre pecheros e hidalgos. Em todo caso, a distinção entre nobres e não nobres nunca foi muito aparente ao nível da tributação real, que, na generalidade dos casos, era geral para os estados seculares. Em matéria de alfândegas, de sisas ou de décimas não existiam privilégios para os nobres. A distinção apenas era relevante no plano dos ónus foraleiros, nomeadamente jugadas, quartos ou oitavos; mas estes impostos locais, pela sua diminuta importância para as finanças da coroa e por estarem de há muito fixados nos forais, não entravam nos cálculos financeiros da coroa.

Duvidosos, do ponto de vista moral, eram ainda outros expedientes financeiros. Um deles, a venda de ofícios. Alguns aproximavam-na da simonia, sobretudo se os ofícios incluíam jurisdição, para além de ponderarem os prejuízos que adviriam aos povos, sobre quem os compradores repercutiriam o preço pago, e à própria justiça distributiva, pela preferência que assim se daria aos mais solventes sobre os mais meritórios. Mas Gaspar Severim, v. g., defende-a também longamente, debatendo as objeções morais e apontando as suas vantagens político-económicas (Advertencias dos Meios..., 1607) ${ }^{14}$. Seja como

\footnotetext{
${ }^{14}$ No caso de ofício cujos réditos fossem emolumentares (v. g., notários), a operação era absolutamente gratuita para a coroa, pois eram os clientes e não esta quem tinha que pagar a renda correspondente ao preço da venda.
} 
for, uma das contínuas censuras feitas aos reis de Espanha foi o fato de os terem vendido ${ }^{15}$.

Mas o meio de legitimidade mais duvidosa eram os juros. Não apenas pelas razões de política financeira largamente expostas por Gaspar de Severim (Advertencias..., 1607, na esteira de G. Botero, Ragion di Stato..., p. 92), mas sobretudo porque consistiam em operações usurárias, proibidas pelo direito divino (Exod., 22, vers. 25; Deut., 23, vers. 19-20; Proverb., 28, vers. 8; Ezeq., 18, vers. 8-9; Levit., 26, vers. 35/37; Lucas, 19, vers. 23; Math., 25 , vers. 27$)^{16}$ e que consistiam no fato de alguém se comprometer a pagar ao credor algo mais além do principal («usura est quidquid sorti principali accedit ex pacto», Covarrubias).

De fato, era doutrina pacífica que o príncipe católico estava obrigado a eliminar os costumes dos súbditos que induzissem em pecado mortal (Baptista Fragoso, Regimen Reipublicae christianae, Colonia Allobrogum, 1652, p. 1, livro § IV). É certo que se estabelecia uma importante limitação casuística à regra - a de que tais costumes deviam ser permitidos quando se não pudessem extirpar sem escândalo ou perigo de toda a república, ou em vista de evitar males maiores (ibid., p. 46, n.o 173). Este princípio aplicava-se à usura. Tal como se permitiam os prostíbulos ou o divórcio, para evitar o mal maior da devassidão generalizada, o príncipe poderia permitir também a usura (maxime a infiéis, pois neste caso o pecado de usura era consumido pelo mais fundamental da infidelidade) (ibid., n.o 175). Para além disto, o direito tinha encontrado formas de justificar

\footnotetext{
${ }^{15}$ Resta saber I) o que há de rigor nesta acusação e II) se a prática foi introduzida pelos reis da casa de Áustria (cf. António Manuel Hespanha, As vésperas..., cit., vol. 1, p. 719 et seq.).

${ }^{16}$ Também pela lei da Igreja, cap. quia in omnibus, de usur, e q. 4, cap. quia dicam, cap. plerique, q. 4; também pelo direito civil, Auth., De Eccles., \& I, e pelo direito natural, Aristóteles, Politic., l, cap. 7. No direito português, a usura é proibida pelas Ordenações Filipinas, 11, vols. 9 e IV, p. 67; cf. Cardoso, Liber utilissimus...; s.v. «Usura»; há uma enorme literatura teológico-jurídica sobre o tema.
} 
a percepção pelo credor de um «crescimento» das quantias mutuadas. A principal era o recurso aos conceitos de lucrum cessans ou damnum emergens. Na verdade, se aplicado, por exemplo, à compra de terras ou de um rebanho, o capital reproduzia-se "naturalmente", sob a forma de frutos ou de crias. Quem emprestasse dinheiro abdicava deste rendimento suplementar, deixando de lucrar ou aceitando o dano decorrente da renúncia à liquidez. Ou, seguindo outra via argumentativa, dizia-se que o dinheiro presente sempre se presumia valer mais do que o dinheiro futuro, com o que se legitimava uma operação usual nesta época como era a compra por menor preço de um crédito (Amaro Luís de Lima, Commentaria ad Ordinationes... Ulyssipone, Francisco Luiz Ameno, 1761, ad IV, 67, n.o 54). Finalmente, justificava-se o juro como uma liberalidade, correspondente à liberalidade do credor e integrada numa economia de trocas beneficiais típica da sociedade do Antigo Regime ${ }^{17}$.

Por outro lado, existiam formas arquiconhecidas de disfarçar a usura. As mais conhecidas eram os censos e os contratos de câmbio. Os censos podiam tomar a forma de censo consignativo [pedido de uma soma em dinheiro, consignando ao mutuante (comprador da renda) os rendimentos de certa terra] ou de censo reservativo (em que o mutuante cedia uma propriedade, reservando-se o direito de receber uma renda). Os censos podiam ser (e, se encobriam contratos usurários, eram-no normalmente) a retro, podendo o devedor («censista», ou «censuário», vendedor da renda ou tomador da propriedade) desfazer livremente o contrato, restituindo a quantia mutuada ou a propriedade recebida.

\footnotetext{
${ }^{17}$ Cf., sobre o tema, Bartolomé Clavero, Antidora. Antropologia catolica de la economia moderna, Milão: Giuffrè, 1991. Isto é particularmente verdade nos juros reais, em que as quantias a pagar pela coroa surgem frequentemente equiparadas a mercês ou tenças de natureza beneficial, remunerando serviços prestados pelo vassalo mutuante (cf. José da Costa Gomes, Colecção de Leis da Dívida Pública Portuguesa, Lisboa: Imprensa Nacional, 1883, p. 46).
} 
No contrato de câmbio, por sua vez, tratava-se de pôr à disposição de um credor de um dos contratantes, numa praça diferente (distincto loco) ou em moeda diferente (distincta moneta), uma certa soma. A licitude do contrato decorria do fato de se considerar o juro (neste caso o excesso da soma dada em um lugar sobre a soma recebida em outro) como a remuneração das despesas feitas pelo cambista com a manutenção da rede de correspondentes noutras praças ${ }^{18}$.

No caso de no contrato de câmbio não se verificar nenhuma das duas condições que o legitimavam (diversidade de lugares ou diversidade de moeda), mas apenas um deferimento no tempo («câmbios secos», titulados por «letras da terra»), o contrato era considerado usurário e, logo, proibido (Amaro L. de Lima, Commentaria..., cit., loc. cit., n.o 31; Manuel Mendes de Castro, Practica lusitana, $1696^{19}$, 1. - parte, livro III, cap. 22, n. 28 , na sequência de uma constituição de Pio $V)^{20}$.

Mas existiam outras formas de encobrir a usura. Uma era a venda pelo credor (mutuário) ao devedor (mutuante) de géneros por um preço superior ao justo, diferindo o pagamento para certo tempo futuro (António Cardoso do Amaral, Liber utilissimus..., $1610^{21}$, s.v. «Usura», n.. 9). Outra, a venda a retro, em que o comprador da coisa (credor) podia ficar com os frutos dela (juros) durante o período em que a venda se mantivesse (Ordenações Filipinas, IV, 67, 2). Outra, ainda, estruturalmente semelhante, a venda de ofícios, em que a coroa recebia, por uma vez, do comprador um capital, pagando-lhe periodicamente uma renda, o salário; o único traço distintivo era o de

\footnotetext{
${ }^{18}$ Sobre este contrato, v. Ordenações Filipinas, IV, 67, 5.

${ }^{19}$ Cf. <http://purl.pt/index/livro/aut/PT/43227.html>.

${ }^{20}$ A permissão legal das letras «de terra» apenas surge com o alvará de 16 de janeiro de 1793.

${ }^{21}$ Cf. <http://purl.pt/13997>.
} 
que, sendo os ofícios patrimonializados, a coroa nunca podia remir a dívida (tal como, até certo ponto, acontecia com a dívida consolidada).

Perante a generalizada realidade da usura, a doutrina jurídica não cessa de alargar o espaço da sua licitude. Não apenas a desta usura, praticada profissionalmente pelos banqueiros, tolerada um pouco como o amor mercenário, quando praticado pelas profissionais do ofício. Mas também de qualquer forma de mútuo oneroso, mesmo praticado por particulares. Assim, desde os finais do século XVI que se legitima, perante a prática jurídica portuguesa, o contrato dito «à razão de juro», mesmo entre pessoas que não exercem o comércio $^{22}$; assim, no Reino, consideram-se válidos os contratos de mútuo em que se recebe anualmente entre $4 \%$ e 6,25\% de juro como lucro cessante ou dano emergente (Amaro L. Lima, op. cit., loc. cit., n. - 56). Deste modo, o recurso à venda de juros, desde 96 que não ultrapassassem 6,25\%, tomava-se um meio legítimo para a coroa, na perspectiva moral. A ponto de esta apenas se preocupar com as outras espécies de mútuo oneroso (aberta ou encapotadamente realizado) quando estas competissem com ela no mercado de capitais. É assim que um diploma de 13 de dezembro de 1615 (Febo, Decisiones..., II, decreto 211) indiretamente legitima todas as formas de mútuo oneroso encobertas com censos, desde que não ultrapassassem a taxa de 20 o milhar, no caso de censos perpétuos, de 12 o milhar, no caso de duas vidas, e de 10 o milhar, no caso de censos em uma vida, justificando-se a decisão com a concorrência que os censos usurários faziam aos juros reais, «por estar taão cahido o trato, e commercio, e cobrança de minhas rendas do Reyno de Portugal sendo a principal causa disso os muitos interesses

${ }^{22}$ Cf. Melchior Febo, Decisiones Senatus Regni Lusitaniae..., 1678, vol. II, dec. 205, n. I et seq., que refere ter sido julgado, em 1588, na Casa da Suplicação, ser justo o contrário «à razão de juro» de $61 / 4 \%$; cf. ainda o aresto n.․ 70 . 
e reditus, que os que se achão com dinheiro, conseguem, e tem por meios cambios, e compras de juros, e censos, a que se applicão por grangearia segura, e de mais valor $»^{23}$.

Abertamente admitidos desde o início da idade moderna, eram, em contrapartida, os montes de piedade e os bancos. Os montes de piedade - permitidos por Leão $X$ no Concílio de Latrão, em $1515^{24}$ - eram fundos de dinheiro ou de cereais constituídos para ajudar os pobres, evitando as usuras (Baptista Fragoso, Regimen Reipublicae christianae, Colonia Allobrogum, 1652, loc. cit., n.o 26), lícitos sob a condição de que: I) só se emprestasse aos pobres por uma certa soma e por certo período, contra entrega de penhor; II) o mutuário pagasse algo para as despesas da gestão do monte; III) no caso de não pagamento, se vendesse o penhor, restituindo ao mutuário o sobrante. $\mathrm{O}$ que o monte recebia do mutuário era, portanto, justificado pelas despesas de gestão e de crescimento do fundo caritativo (ibid., n. 29). Maiores problemas levantavam os montes de piedade «mistos» - algo de intermédio entre os anteriores e os bancos -, em que os participantes contribuíam para o monte sob condição de receberem anualmente um juro («quid per centum ab eodem monte salva sorte»). Mas também estes foram expressamente aprovados por Júlio III, sob a condição de a retribuição do capital se situar entre $4 \%$ e 6,25\%, segundo o costume da região, em razão do lucro cessante ou do dano emergente, pois os depositantes «poderiam com esse dinheiro comprar prédios, ou censos ou depositá-lo junto de mercadores» (Baptista Fragoso, Regimen Reipublicae christianae..., parte 1, livro VII, disp. 20, p. 833-835).

${ }^{23}$ Cf. também os alvarás de 12 de outubro de 1643 e de 23 de maio de 1698. Mais tarde, o alvará de 17 de janeiro de 1757 e a lei de 6 de agosto do mesmo ano fixaram o juro livremente permitido em 5\%, por influência da encíclica Vix pervenit, de Bento XIV.

${ }^{24}$ Acerca dos montes de piedade, v. Baptista Fragoso, Regimen Reipublicae christianae..., cit., lib. 7, disp. 20, \& I, p. 833. 
Quanto aos bancos, considera-se, logo no início do século XVII, que não é usurário colocar neles dinheiro, pois o lucro remunerava o risco e o fato de se ter o dinheiro parado (António Cardoso do Amaral, Liber utilissimus..., s.v. «Usura», n.o 15). E, assim, defendia-se que a usura não era passível de pena quando fosse feita pública e abertamente pelos profissionais da banca e finança (Amaro L. Lima, op. cit., loc. cit., n. 48 ).

Em resumo, mais pela teoria dos impostos do que pela teoria da usura (o que explica, juntamente com as dificuldades políticas mais efetivas quanto à tributação do que quanto ao empenhamento das suas rendas, o maior crescimento da dívida pública do que o da carga fiscal), a coroa encontrava limitações doutrinais (que não apenas técnicas ou políticas) no momento de aumentar as suas receitas. Mas estas não constituíam os únicos constrangimentos «externos» do cálculo financeiro.

Um outro tipo destes constrangimentos de um cálculo financeiro «puro» era constituído pela influência sobre a gestão financeira dos modelos, não já de natureza ético-religiosa, mas de administração da «Casa». Como diz António da Natividade («Operis ratio», Stromata oeconomica [...] sive de regimine domus, Olysipone, 1653), «Nem as coisas públicas nem as privadas podem ser bem geridas, nem sequer geridas, sem a oeconomia». A «oeconomia», concebida como «arte ou ciência pela qual a ordem das coisas domésticas é disposta de forma sábia» (ibid., p. 1, cap. 1, 1, n. - 1), é, portanto, concebida como o fundamento da política, porque a mesma casa é o fundamento da república (ibid.). E daí que, por natureza, os dirigentes se devam primeiro treinar no governo doméstico, antes de se iniciarem no governo da república (ibid., p. 1, cap. 2). O tema é, enfim, conhecido (v. Daniela Frigo, "Disciplina rei famillariae". A "oeconomia", como modelo administrativo de "Ancien Régime"», em Penélope, n. 6 , 1991, p. 47-62). Assim, não admira que a imagem da gestão do património doméstico se perfile sempre como um horizonte 
da gestão do património real. Desde logo, no que toca à prudência administrativa, tal como o pai de família deve manter sempre de reserva uma quantia côngrua para ocorrer a qualquer necessidade, o rei deve cuidar de que uma parte das rendas da coroa fique sempre livre para as despesas da administração.

Mas, em contrapartida, o rei, tal como o chefe de família, tem obrigações civis que o forçam a atos de beneficência ou de liberalidade. É por meio deles que, por um lado, constrói as redes de amizade de que depende a preservação da casa e que, por outro, projeta para o exterior uma imagem favorável que, também ela, garante o seu prestígio, com a tradução material que este necessariamente tem [nomeadamente no momento de casar os filhos, de obter crédito, de ser nomeado para certos lugares (v. g., tesoureiro) que supunham uma certa riqueza económica]. Por outras palavras, o futuro da «casa» vivia da capacidade do pai para gerir a «amizade» e a «reputação». O mesmo se passava com o rei, ainda em mais alto grau. A liberalidade era, para ele, um dever central, do mesmo modo que a avareza era o seu principal defeito ${ }^{25}$. Mas o dever régio de liberalidade era ainda multiplicado pelo seu dever de «magnificência», pois desde Aristóteles que vinha a ensinar-se que a liberalidade dos grandes devia ser uma liberalidade magnífica, uma liberalidade em que a medida justa era a desmedida. Por isso, Damião de Lemos Faria e Castro duvida de que os príncipes devam usar da parcimónia que aos outros se aconselha, "porque como sempre têm muito, devem dar sempre à proporção do que têm. $\mathrm{O}$ seu thesouro se augmenta quando o erario se esgota. Cada vassalo rico he hum thesouro do Rey» (Politica Moral e Civil..., cit., vol. I, p. 300).

\footnotetext{
${ }^{25}$ V. António Manuel Hespanha, «Les autres raisons de la politique. L'économie de la grâce», em J.-F. Schaub (ed.), Recherches sur l'histoire de l'État dans le monde ibérique (15e.-20e. siècles), Paris: Presses de l’École Normale Supérieure, 1993, p. 67-86.
} 
Tudo isto não representa apenas um mero tópico deontológico, mas insere-se numa estratégia política explícita, sintetizada em afirmações como «as mercês são cadêas que se não rompem» (ibid., p. 302), «a liberalidade faz ao príncipe duas vezes rey, porque tanto domina nas vontades como nas pessoas» (ibid.), ou «a força que vence não reina nos corações; a generosidade que obriga, domina nas vontades» (ibid., p. 304) ${ }^{26}$.

As consequências destes pontos de vista em matéria financeira tomam-se imediatamente evidentes. E, de fato, aquilo que costuma ser descrito como o problema do desequilíbrio estrutural das finanças modernas não era tanto que as coroas, em virtude do seu poder (e dos seus projetos de poder), estivessem a assumir novas e onerosas funções, mas, antes, que elas, em virtude da sua debilidade, tinham que complementar a pouca força de que dispunham com os meios «doces» de captação do favor dos súbditos por meio da liberalidade ou da demonstração magnificente. A «oeconomia» (a deontologia do governo da casa) e a «política» (a deontologia do governo da república) irrompem assim no cálculo financeiro, introduzindo-lhe componentes que hoje nos parecem espúrios e irracionais. A multiplicação das mercês (sob forma estrita, sob a forma de padrões de juro ou sob a forma de empregos) e a política «de reputação», apoiada na exibição do luxo ou na condução de guerras «de ostentação política», são, decerto, os factores mais constantes do empenhamento das rendas reais; mas elas são também os eixos de uma nacionalidade político-financeira específica e não, como por vezes se pretende, o produto de derrapagens devidas ao egoísmo dos grupos privilegiados, à corrupção do sistema ou à frivolidade dos monarcas.

${ }^{26}$ Cf., sobre o tema, António Manuel Hespanha, «Les autres raisons de la politique. L'économie de la grâce», cit. 
É certo que, em épocas de crise aberta, o tópico da prudente gestão do património familiar emerge de entre os outros e leva a melhor sobre o tópico da liberalidade e da reputação. A prodigalidade é, então, censurada como um pecado do rei, pois daí nasceria que «Os impostos e tributos fossem mais elevados do que o adequado (quam par sit), as dívidas se contraíssem em maior número do que seria justo e os povos fossem gravados com ónus pesadíssimos» [Juan de Azor, Institutionum moralium, Roma, 1600-1611, parte II, livro II («De regum origine, officio et potestate»), cap. 7 («De regum vitiis et peccatis»), p. 1106]. Mas, como era igualmente um pecado ofender os direitos dos particulares (ius suum cuique tollere) e como - ainda que se não admitisse um direito (ou, pelo menos, uma expectativa fundada) ao benefício - os benefícios já concedidos se enraizavam no património dos beneficiários, esta gestão parcimoniosa nunca podia implicar um corte nas tenças concedidas, uma violação dos contratos de juro (como seria a sua denúncia, distrate ou redução unilateral) ou uma privação injustificada dos ofícios.

O problema da «reforma dos assentamentos», que ocupa os círculos políticos logo a partir dos inícios do século XVII, não representava outra coisa senão encontrar um sistema de compatibilizar este dever de extrema liberalidade com a dura experiência da insuficiência dos meios para levá-la a cabo, hierarquizando os pagamentos dos assentamentos (entre os quais, tenças) incidindo sobre rendas já esgotadas. Assim, muitos assentamentos viam a sua satisfação longamente adiada (ou convertida em títulos de dívida consolidada); mas, embora cumprindo mal, o rei não se via limitado nessa virtude tão sua da liberalidade, nem, mais prosaicamente, se via confrontado com os graves problemas políticos (e mesmo jurídicos ${ }^{27}$ ) que decorriam do refrear desta sua prática dadivosa.

${ }^{27}$ Já que os juristas consideravam como quasi debitem a obrigação de remunerar serviços (v. Hespanha, 1990). 
A todos estes constrangimentos somavam-se outros de ordem institucional, que dificultavam o diagnóstico preciso das situações.

Num texto datado de janeiro de 1624 («Advertencias sobre a confusão que lia na receita e despesa da fazenda real de Portugal, e como se poderá atalhar», Bib. Nacional de Lisboa, cód. 917, p. 115 v. - -118 v. $\left.{ }^{-}\right)$, Manuel Severim de Faria relaciona, até certo ponto, as dificuldades financeiras com o modo «confuso» como estava organizada a administração financeira e a contabilidade. $\mathrm{O}$ sistema de arrendamentos por períodos desiguais e não coincidentes nos seus termos impossibilitava a estimativa rigorosa das receitas, pois não haveria nenhum ano em que não se iniciasse ou terminasse um arrendamento. O sistema de consignações das receitas a certas despesas, que tomava disponíveis apenas os saldos, agravava ainda a situação, pois nunca se sabia se certa receita daria, em certo ano, para cobrir a despesa a que estava consignada (Bib. Nacional de Lisboa, cód. 917, p. 115 v.o), e, por outro lado, pulverizava o saldo global em pequenos saldos, arrecadados pelo miúdo e em tempos diversos, dificilmente se podendo lançar mão deles para as despesas, que, essas, eram em grandes quantias e em tempos certos (Bib. Nacional de Lisboa, cód. 917, p. 116). A isto se acrescia a falta de centralização na decisão das despesas, nomeadamente das tenças, mercês e alvitres, distribuídas sem controlo pelos vários conselhos (ibid.) ${ }^{28}$, bem como a impossibilidade, pela dispersão dos seus assentamentos, de se saber ao certo a quanto montavam. Mas mesmo despesas mais centralizadas, como os custos das armadas, seriam dificilmente computáveis (p. 116 v.o.). Também o fato de diferentes organismos darem ordens de pagamento aos diferentes tesoureiros

${ }^{28}$ Cf. também, já para os finais do século XVIII, José de Abreu Bacellar Chichorro, "Memória económica..." (a memória de Chichorro é de 1795), final. 
impedia que se determinasse o saldo livre de encargos, o que ainda era agravado pelo fato de, normalmente, estes encargos (fossem eles juros, tenças ou ordenados) estarem «situados» em certa receita que, assim, lhes ficava parcialmente consignada («Advertencias sobre a confusão...», Bib. Nacional de Lisboa, cód. 917, p. 117).

O núcleo das propostas de Manuel Severim é, afinal, a criação de uma tesouraria-geral (entregue a um assentista, que, ao mesmo tempo, adiantava as receitas), por onde passasse toda receita e despesa e onde pudessem ser conferidas, anualmente, todas as verbas recebidas e gastas (Bib. Nacional de Lisboa, cód. 917, p. 118 v. - ), bem como a criação de uma espécie de serviço da dívida, concentrando em certas rendas todas as consignações particulares e deixando totalmente livres para as despesas da coroa as outras rendas (Bib. Nacional de Lisboa, cód. 917, p. 117).

Foi, no entanto, preciso esperar quase 150 anos para que estas reformas tivessem lugar, com a criação de um tesoureiro-geral e único, por onde passassem todos os movimentos financeiros. Isto acontece em 1761 (carta de lei de 22 de dezembro, Colecção de Legislação Extravagante. Leis e Alvarás²9, IV, 364 et seq.), com a grande forma pombalina da organização contabilística e financeira. No preâmbulo desta importante lei - que cria os cargos de tesoureiro-mor do Reino e de inspector-geral do Tesouro e que instaura a escrituração por partidas dobradas $^{30}$ - pondera-se, de fato (na sequência da opinião expressa por Manuel Severim de Faria), o modo como se arruinavam

\footnotetext{
${ }^{29}$ Ed. on-line: $<$ http://www.iuslusitaniae.fcsh.unl.pt/verobra.php?id_obra=67>.

${ }^{30}$ Outra lei do mesmo dia estabelece uma jurisdição especial para as causas da Fazenda, cometida privativamente ao Conselho da Fazenda (Colleç̧ão de Legislação Extravagante, Leis e Alvarás. IV, p. 398 et seq.)
} 
as monarquias ${ }^{31}$, pela «divisão e dilaceração das suas rendas, separadas em muitos e muitos ramos, e em muitas e muito diversas repartições [...] evaporando-lhes toda a força, por mais quantiosas que fossem» (preâmbulo, loc. cit., p. 365).

Esta longa espera não tem, porém, a ver apenas com motivos de ordem técnica. É que a dispersão orçamental não era senão um dos sinais da dispersão política típica da monarquia corporativa. Outro deles, ainda no domínio financeiro, era a dispersão quanto ao conhecimento jurisdicional das questões relativas a matérias financeiras, que, depois de diversas flutua-

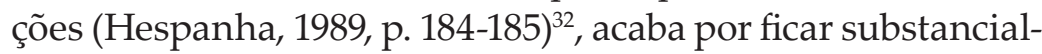
mente nas mãos da jurisdição comum da Casa da Suplicação, sujeita, assim, ao processo ordinário, com todas as garantias que este dava aos particulares ${ }^{33}$, enquanto a instauração do princípio da unidade orçamental e contabilística ${ }^{34}$ manifesta um novo sentido da unidade do Poder, a proto-história do Estado, que se deve datar, justamente, desta segunda metade do século XVIII.

${ }^{31}$ E, mais do que isso, as repúblicas, já que da saúde do Erário Régio decorria a saúde das fazendas dos vassalos, pelo que o «Erário, chamando-se Régio, he na realidade público e commum» (preâmbulo, loc. cit., p. 365).

${ }^{32}$ Cf. António Manuel Hespanha, As vésperas do Leviathan..., Coimbra: Almedina, 211, 236.

${ }^{33} \mathrm{E}$ a isto que se refere o preâmbulo da primeira carta de lei de 22 de dezembro de 1761, quando fala da «sujeição, em que a arrecadação das mesmas rendas se achava aos meios ordinários dos processos e delongas dos pleitos». A segunda lei da mesma data põe termo a este estado de coisas, concentrando no Conselho da Fazenda toda a jurisdição financeira voluntária e contenciosa (cf. tít. 1).

${ }^{34}$ Que se reforça, ainda, pela união do Erário Régio (ou Tesouro Real) com o Conselho da Fazenda, pelo alvará de 17 de dezembro de 1790 (António Delgado da Silva, Collecção..., vol. resp., p. 629; v. <http://www.iuslusitaniae.fcsh.unl.pt/verobra. php?id_obra $=63>$ ). 
Segundo Manuel Severim de Faria ${ }^{35}$, «as Rendas Reaes deste Reyno, se podem reduzir a cinco generos ou especies, que são Proprios, Tributos, Estancos, condenações e o que se recebe das Igrejas» (fonte cit., p. 140).

Os próprios da coroa são constituídos pelas rendas dos bens do património real que não são bens da coroa. Ou seja, os reguengos. São ainda reais as ilhas e margens do Tejo, periodicamente cobertas pelas cheias - as lezírias e pauis -, que se arrendavam ou se cultivavam por conta da Fazenda real. A mais disto, as jugadas, que impendem sobre certas terras, em que os lavradores devem pagar um tanto (ordinariamente, a meação do trigo ou do milho e o oitavo do vinho ou do linho) por cada junta de bois; embora a maior parte estivesse na mão dos donatários, algumas sobravam para a coroa, nomeadamente em Sintra.

Estas rendas são recolhidas nos respectivos almoxarifados dos próprios ou, como também se lhes chama, nos almoxarifados «de pão» (almoxarifados de Salvaterra, Malveira, Alcoelha, Benavente, Azambuja, Ota, Muge, Asseca, Trava, Algés, Oeiras, Alcochete; ou «das jugadas» de Santarém e de Sintra).

Próprios da coroa são ainda as coutadas (como as de Almeirim e Salvaterra), bosques de caça coutados pela coroa. Ou as defesas, «herdades grandes, que tinhão arvoredo silvestre, e pastagens para todo o genero de gado» (fonte cit., p. 140 v. $)^{-}$, de que quase só se conservavam os pinhais de Leiria e Almada, utilizados para a fábrica das naus. Ou ainda os relegos, proibições de venda dos frutos de certas terras durante certas épocas do ano, ou monopólios de estalagens ou de fornos. O rei tinha ainda casas e prédios rústicos aforados, de que recebia foros e laudémios, e os tabeliães pagavam-lhe as

35 «Carta do chantre de Évora de 6 de Dezembro de 1630, com hua relação das rendas reais de Portugal», Bib. Nac. Lisboa, cód. 917, p. 137 et seq. 
pensões (de 800 réis) pelo privilégio de exercer a sua profissão, embora estas estivessem quase sempre na mão dos donatários (fonte cit., p. 141).

Como se verá, a importância destas rendas era muito pequena, sobretudo porque a sua maior parte andava, na época a que nos reportamos, alheada da coroa e ainda porque parte delas se consumia na administração e «fábrica» dos mesmos rendimentos e o resto, cobrado em géneros, mais dificilmente transportáveis, se esvaía quase de todo.

Embora Severim de Faria as não refira neste contexto, existem ainda outras rendas da coroa conceitualmente próximas, como as provenientes de rendas de direitos reais, dos enumerados nas Ordenações (Ordenações Filipinas, II, 26), como, v. g., os direitos de foral das terras reais, as rendas das minas (v. g., de estanho ou, mais tarde, os quintos do ouro e diamantes do Brasil), o rendimento de certas instalações «industriais» da coroa, como os fornos (de biscoito) do Vale de Zebro ${ }^{36}{ }^{37}$. E, para além destas, as rendas das capelas e igrejas do padroado da coroa (António Manuel Hespanha, As vésperas..., cit., vol. I, p. 177) e as receitas da Bula da Cruzada, concedida pelos pontífices a partir de 1591 e afetada à defesa e conservação dos lugares de África ${ }^{38}$.

\footnotetext{
${ }^{36}$ V., sobre estas rendas, António Manuel Hespanha, As vésperas do Leviathan, Coimbra: Almedina, 1994, p. 167.

${ }^{37}$ A estas rendas dos próprios da coroa haveria de juntar as dos próprios das ordens militares, a partir da sua integração da administração régia, nos meados do século XVI. Nelas, à parte rendas fundiárias e fiscais (jugadas, direitos de foral, de que fossem donatárias), existiam as rendas das comendas vagas, que algumas fontes computam em valores elevados, dependendo, naturalmente, este montante do maior ou menor número de comendas que estivessem por doar.

${ }^{38}$ António Manuel Hespanha, As vésperas..., cit., vol. I, p. 109, e José de Abreu Bacellar Chichorro, "Memória económica...", p. 88.
} 


\section{Tributos}

No capítulo dos tributos, o segundo capítulo das receitas, segundo Manuel Severim de Faria, incluem-se vários, uns que já vinham de trás, outros aparecidos neste período de que nos ocupamos. Enumeremos os principais.

As portagens, «direito real, [que] se paga em cada lugar das cargas que os de fora do povo trazem para vender nelle ou [...] quando se tirão cargas delle para se venderem fora» e que se pagavam na proporção das cargas, consoante o porte das bestas e dos taipais, ou do valor das mercadorias (p. 141) ${ }^{39}$.

As «sisas» consistiam na décima parte do que se comprava ou se vendia (salvo ouro, prata e pão cozido ${ }^{40}$ ), correndo metade por cada uma das partes. Delas estavam isentos os eclesiásticos e os comendadores da Ordem de Cristo ${ }^{41}$.

A partir dos meados do século XVI, as sisas tornam-se numa renda fixa, que se manterá ao nível dos 200 contos durante cerca de 150 anos $^{42}$. Isto porque, a pedido dos povos (nas cortes de 1525), o rei se dispõe a fixar, por contrato (de

\footnotetext{
${ }^{39}$ No final do Antigo Regime, as portagens são severamente criticadas (cf. José de Abreu Bacellar Chichorro, "Memória económica...", p. 379 et seq.).

${ }^{40}$ Mais tarde foram introduzidas outras isenções. V. José de Abreu Bacellar Chichorro, "Memória económica...", p. 80, n. a).

${ }^{41}$ Carta régia de 1 de agosto de 1498 e 25 de janeiro de 1504 (cf. Ordenações Filipinas, II, 11). O alvará de 24 de outubro de 1796 abole todas as isenções de sisa, nomeadamente de eclesiásticos e cavaleiros de ordens (António Delgado da Silva, Colleç̧ão..., p. 303). Sobre as sisas, cf., com maior desenvolvimento, António Manuel Hespanha, As vésperas..., cit., vol. I, p. 68 et seq. e 169 et seq., com bibliografia suplementar. O regimento (ou Artigos...) das sisas é o de 27 de setembro de 1476, confirmado em 16 de janeiro de 1674. Existem várias edições desde o século XVI (cf. José Anastácio de Figueiredo, Synopsis Chronologica de Legislação Portuguesa, Lisboa, 1790, vol. I, p. 109-235 et seq.).

${ }^{42}$ Se se manifestou alguma tendência, pelo menos até aos meados do século XVIII, foi para a queda, mesmo a preços correntes, do valor das sisas, pois frequentemente se concederam quebras nos cabeções, nomeadamente a terras de fronteira.
} 
«encabeçamento»), uma soma certa a pagar por cada terra a troco da cobrança direta das sisas, ficando a repartição deste «cabeção» a cargo dos órgãos dos concelhos. Para efeito de cobrança interna (ou de arrendamento), os concelhos dividiam as sisas por «ramos», de acordo com o tipo de produtos sobre que incidiam, de modo que cada «ramo» não excedesse uma certa quantia ${ }^{43}$.

Se o encabeçamento das sisas teve vantagens para o rei, «acertando» - tal como os restantes «arrendamentos» de rendas, de que este não se distinguia estruturalmente - os montantes da contribuição (aliás incertos e de difícil cobrança), não interessava menos aos concelhos, que, assim, evitavam a entrada indiscreta dos oficiais régios e, sobretudo, realizavam uma importante renda própria, da qual fundamentalmente viveram até aos finais do Antigo Regime. E tendo-se desatualizado o cabeção, por via da subida dos preços das mercadorias, as câmaras recebiam do lançamento efetivo da sisa uma soma muito superior àquela que tinham que entregar ao rei (os «sobejos» das sisas); frequentemente, apenas com a renda das sisas «das correntes» e dos «bens de raiz» conseguiam atingir o «cabeção». Em contrapartida, para a coroa, o encabeçamento revelou-se fatal, logo num futuro próximo, pela mesma razão. Em 1630, já a sua desvalorização era avaliada em cerca de um terço do que deviam valer a preços constantes (Manuel Severim de Faria, Bib. Nac. Lisboa, cód. 917, p. 148).

No Reino, as sisas eram cobradas pelos almoxarifados do Reino: Viana, Ponte de Lima, Guimarães, Porto, Vila Real,

\footnotetext{
${ }^{43}$ Normalmente os ramos eram três: $\mathrm{O}$ «das correntes» (isto é, das mercadorias forâneas vendidas no concelho, já que as restantes estavam incluídas no cabeção), o das "propriedades e bens de raiz» (sobre a venda de imóveis) e o "cabeção", compreendendo o resto das sisas e consignado ao pagamento do encabeçamento régio. Em Lisboa, Évora e Santarém, cobrava-se, além da sisa geral, uma outra - a «imposição [dos vinhos]» -, pela qual estes concelhos remiam o dever de aposentadoria (cf. Hespanha, 1986, vol. I, p. 172).
} 
Miranda, Moncorvo, Pinhel, Lamego, Viseu, Guarda, Castelo Branco, Aveiro, Coimbra, Leiria, Tomar, Abrantes, Alenquer, Sintra, termo de Lisboa, Santarém, Portalegre, Estremoz, Évora, Elvas, Beja, Campo de Ourique e Algarve. Aqui se cobravam, para além das sisas, outras rendas reais, como os relegos e o subsídio para a obra pia. Nestas receitas estavam assentes sobretudo salários, tenças e juros. Em Lisboa, as sisas não estavam encabeçadas, sendo cobradas pelas Casas de Lisboa (ou Sete Casas): Casa das Frutas, Casa das Carnes, Casa (ou Paço) da Madeira, Casa dos Vinhos, Casa do Pescado, Três Casas (Casa de A Ver-o-Peso, da Marçaria e das Herdades e Escravos) e Casa da Portagem, cada uma delas especializada na cobrança da sisa de certos produtos (ou de certo «ramo») $)^{44} 4$.

As «terças dos concelhos» (ou terças dos povos) consistiam na terça parte das rendas das câmaras, concedida ao rei para a fortificação dos lugares.

Consistiam as «dízimas "nova" e "velha" do pescado", cada uma, em 10\% do valor do peixe pescado (andavam doadas aos duques de Bragança; cf. Manuel Severim de Faria, Bib. Nac. Lisboa, cód. 917, p. 143 v.ọ). Além disso, existia o imposto das almadravas, pago pelas companhas («almadravas») de pesca do atum e da sardinha de Setúbal e do Algarve (aqui, 16, desde a de Beliche até à de Faro), consistindo em cerca de $40 \%$ a $60 \%$ do valor do atum, sardinha e peixe miúdo. Ambos os impostos tinham sido criados para o sustento de uma armada de costa, destinada a proteger a pesca e o comércio (António Manuel Hespanha, As vésperas..., cit., vol. I, p. 175).

\footnotetext{
${ }^{44}$ Indicação da competência de cada uma (que, entretanto, foi variando com o tempo) em António Manuel Hespanha, As vésperas..., cit., vol. I, p. 173.

${ }^{45}$ Nos finais do século XVIII, o pensamento de inspiração fisiocrática critica duramente as sisas, pela arbitrariedade e desigualdade com que eram cobradas, mas sobretudo pelos entraves que causavam ao comércio (cf. José de Abreu Bacellar Chichorro, "Memória económica...", loc. cit.).
} 
$\mathrm{O}$ «consulado» fora oferecido no reinado de Filipe I pelos mercadores (em 6 de julho de 1591) para a organização de uma armada de costa de proteção contra os piratas e inimigos.

As «alfândegas» foram instituídas para a cobrança da décima das mercadorias que passassem por portos de mar. $\mathrm{O}$ mais comum era o pagamento de direitos de entrada: «A instituição destas alfândegas foi para nellas se arrecadar o direito da dizima, que se devia das mercadorias que entravam pelos portos de mar.» (Francisco Carneiro, «Relação de todas as rendas deste Reyno de Portugal», 1593, ed. de Francisco Mendes da Luz, Bol. Bib. Un. Coimbra, 19, 1949, p. 43.) Mas, pelo menos nalgumas alfândegas, também se pagavam direitos de saída, de antiga tradição (cf. lei de 26 de dezembro de 1253), quando se sacassem «dos lugares destas alfândegas quaisquer mercadorias por estrangeiros» ou quando os exportadores nacionais não se comprometessem a importar idêntica quantidade de géneros no prazo de um ano (ibid., p. 48 et seq.). A importância relativa das rendas alfandegárias no conjunto da tributação era muito grande. Esse fato foi objeto de juízos desencontrados. Enquanto, por exemplo, D. Luís da Cunha critica que o Reino viva à custa do exterior, relacionando a falta de operosidade da gente do Reino com a insuficiência do látego fiscal, o pensamento mercantilista propõe-se usar as alfândegas como factor de proteção das indústrias do Reino. Uns e outros estão, no entanto, unidos pela mesma concepção do papel das alfândegas. Elas deviam deixar de ser «humas casas, sem outro fim, que o de se receberem nellas os Direitos Reaes» (Chichorro, 1943, p. 77), para serem também consideradas nos seus aspectos económicos, como «barometros politicos e chaves do comercio e da industria» (ibid.), por elas se conhecendo «a importação, e exportação do Estado; o augmento d'agricultura, comercio e artes; quaes são os ramos, que necessitão de favor, quaes aquelles que se devem suspender; quaes os generos que 
devem ser livres, quaes sobrecarregados, e quaes merecem ser prohibidos» (ibid.). Foi esta uma das ideias inspiradoras da reforma pautal de 1782 (decreto de 14 de fevereiro), que, no entanto, provocou um enorme clamor público ${ }^{46}$.

Os «portos secos» (por oposição a «portos molhados», ou «de mar») eram as alfândegas terrestres dos lugares que confinavam com Castela, onde se pagava a dízima das mercadorias entradas ou saídas (Manuel Severim, Bib. Nac. Lisboa, cód. 917, p. 143). Foram estabelecidos na segunda metade do século XVI: 1559, do lado espanhol; 1590, do lado português. Andavam normalmente arrendados, cobrando ainda os rendeiros o produto das penas por contrabando ou descaminho.

$\mathrm{O}$ «tributo do sal» decorria do direito real sobre o mar litoral e suas margens (litora maris), os salgados, ou salinas. No tempo de D. Sebastião, ter-se-ia pensado num imposto efetivo sobre as salinas; mas, sendo considerado injusto por uma junta de teólogos, teria sido levantado por D. Henrique (carta da Câmara de Lisboa de 18 de outubro de 1631, Eduardo Freire de Oliveira, Elementos para a História do Município de Lisboa, Vols. I a X, Lisboa, Typographia Universal, 1885 et seq., vol. III, p. 451 et seq.). Em 1601 (provimento de 1 de abril), finalmente, criou-se um direito sobre o sal exportado por $\operatorname{mar}^{47}$, de 220 réis por moio, medida que afetava grandemente o comércio tradicional do sal com o Norte da Europa, que, no entanto, se deve ter continuado a fazer por contrabando, quer direto, quer através destas regiões da coroa de Castela.

\footnotetext{
${ }^{46}$ Do ponto de vista institucional e, nomeadamente, jurisdicional, as alfândegas sofrem profundas remodelações a partir da criação, primeiro, dos superintendentes-gerais do contrabando e, depois, dos superintendentes-gerais das alfândegas (cf. supra).

${ }^{47}$ Excetuava-se expressamente o sal vendido por terra para Castela e, mesmo por mar, para a Galiza, Astúrias e Biscaia.
} 
Em 1630, para evitar novos reais-d'água, a Câmara de Lisboa aventa a criação de um estanco sobre o sal, ideia que o rei apanha imediatamente, prometendo tratar disso, oportunamente, «por outra via» (carta régia de 24 de setembro de 1630, Eduardo Freire de Oliveira, Elementos..., vol. III, p. 374). Em 1631 (alvará de 18 de abril), cria-se, de fato, um estanco do sal, com o fundamento de que, sendo o sal um mineral, pertencia às regalia (Ordenações Filipinas, II, 26, e «papel» de Jerónimo de Ataíde, em Eduardo Freire de Oliveira, Elementos..., vol. III, p. 493). O rei comprava um terço da produção, vendendo-o em estanco, devendo as câmaras arrematar o sal necessário ao consumo dos povos (para os usos industriais, como a salga, o preço seria inferior). A exportação estava livre de estanco, mas pagava o consulado, o antigo imposto e um novo imposto de 18 reais de Castela (isto é, 700 réis; cf. alvará de 4 de agosto de 1631, Eduardo Freire de Oliveira, Elementos..., vol. III, p. 444-445). Em 1638 (regimento de 13 de julho) é regulada a sua cobrança e em 1641 (alvará de 22 de fevereiro) os vários direitos (consulado, «velho», «novo») são reduzidos a um só de 500 réis, por moio ${ }^{48}$. Além disto, o sal pagava sisa, dízima e consulado, como qualquer outra mercadoria. A sua renda está avaliada, para 1632, em «200 000 cruzados e mais» (ou seja, tanto como os almoxarifados) (Eduardo Freire de Oliveira, Elementos..., vol. III, p. 508).

Os «reais-d'água», pagos sobre a carne e o vinho, foram originariamente impostos camarários. Em Lisboa, os reais já existiam em 1609, sob forma de um na carne e dois no vinho, encarando-se então a criação de mais, sobre a renda dos quais se pudessem vender juros para a prevista visita real (Eduardo Freire de Oliveira, Elementos..., vol. II, p. 293). Em 1635, a coroa decide a extensão dos reais a todo o Reino (decreto de 6 de

${ }^{48}$ Novo regimento do tributo sobre a exportação (1 000 réis por moio) em 23 de dezembro de 1761 e novamente (1400 réis por moio) em 18 de outubro de 1806. 
março e Eduardo Freire de Oliveira, Elementos..., vol. IV, p. 106; cf. também decreto de 12 de julho de 1635, J. J. Andrade e Silva, Colecção..., breve papal, Eduardo Freire de Oliveira, Elementos..., vol. III, p. 304, n.; cf. regimento de 31 de outubro de 1636), para desempenho das tenças, de acordo com um plano de 1632, de criação de uma «renda fixa». Os reais passam então a ter uma nova natureza: são, por um lado, um imposto geral e, por outro, um imposto régio. Em 1641, como aconteceu com quase todos os impostos anteriores, depois da euforia dos primeiros tempos da Restauração, os reais são confirmados (regimento de 12 de setembro de 1641, J. J. Andrade e Silva, Colecção..., p. 103) para as despesas da guerra, sendo a sua administração superintendida pelos oficiais da administração da décima, como acontecerá também no seguinte regimento, de 23 de janeiro de 1643 (J. J. Andrade e Silva, Colecção..., p. 182). Com o fim da guerra, os reais são suspensos; mas logo em 1669 (carta régia de 18 de julho de 1669, J. J. Andrade e Silva, Colecção..., p. 171) se mandam continuar, para a fortificação das fronteiras. Nos finais do século XVIII seguia-se pagando, por todo o Reino, um real na carne e outro no vinho e, em Lisboa, os cinco e sete reais ${ }^{49}$ (p. 82). Salientava-se, então, o caráter regressivo do imposto, pois o consumo dos géneros sobre que incidia era maior na gente de menores posses, nomeadamente na entrega a trabalhos pesados, que «não saberá subsistir sem carne de porco, de vaca, ou de carneiro, e sem vinho; género este de que o maior consumo nacional se passa entre semelhante gente» (ibid., p. 82 et seq.); além dos seus efeitos negativos sobre o consumo (e, logo, sobre a produção da carne e do vinho) (ibid., p. 83).

\footnotetext{
${ }^{49}$ José de Abreu Bacellar Chichorro, "Memória económica política da Província da Extremadura, traçada sobre as instrucções regias de 17.I.1973", em Economia e finanças: anais do Instituto Superior de Ciências Económicas e Financeiras. Lisboa, Vol. 1. 1943, p. 73 et seq.
} 
O imposto régio das «meias-anatas» foi introduzido em Portugal em 1631 (carta de lei de 22 de junho e 31 de junho), contemporaneamente à sua introdução em outros territórios da monarquia católica. A inspiração pode ter provindo das meias-anatas eclesiásticas, pagas pelo titular de um benefício no momento do seu provimento e que, entre nós, eram pagas pelos comendadores das ordens militares, pelo menos desde os finais do século XVI. Seja como for, as meias-anatas reais incidiam sobre os rendimentos efetivos dos ofícios e outras mercês (títulos, comendas, tenças etc.). Para os ofícios, elas consistiam no pagamento, altura do provimento, de metade do rendimento anual do cargo. Para os rendimentos não certos, pagar-se-ia segundo a sua avaliação, que poderia incidir, inclusivamente, sobre benefícios imateriais, como a «honra» do cargo ou função concedidos (António Manuel Hespanha, As vésperas..., cit., vol. I, p. 55 et seq.). O imposto deu lugar a uma enorme reação, que era tanto mais de temer quanto provinha de grupos politicamente muito poderosos - oficiais, grupos palatinos ${ }^{50}$. Apesar disso, parece ter sido ainda cobrado, existindo quatro regimentos sobre anatas no período filipino (12 de

\footnotetext{
${ }^{50}$ Para testemunhos dessa reação, v. António Manuel Hespanha, As vésperas..., cit., vol. I, p. 56, n. 52, a que há que acrescentar, para além de muita documentação existente em Simancas, o cód. Ajuda 51-11-15, p. 98 et seq. Merece ser citada a referência de Francisco Velho (Bib. Nac. Lisboa, cód. 2632, p. 286): «De proximo pôs V. Magde sem consentimento dos tres Estados dos Reinos o tributo das meas annatas [que] a respeito dos filhamentos da Caza Real que segundo o regimento dela, e foros dos Reynos, cap. 13, se hão-de continuar, [dos] officios da justiça, fazenda e guerra, e nos quais segundo as leis do estillo dos Reynos e ordens em razão dellas dadas succedem os filhos e netos; e das graças mixtas, ou puras em ordem ao governo politico necessarias, e que a este fim estão por leis concedidas por meyo dos Ministros, e Tribunais pellas mesmas leys para isso dispostos; dos quais procede directamente o beneficio das ditas graças e não do nosso Príncipe que de justiças as hade conceder, e as não pode negar, [pelo que] He menos justificado. No que Vossa Magde, tanto pellas leys da justiça quanto pellas da piedade, o deve mandar limitar, e também por ser de calidade que dentro em três anos esgotara os Reynos de todo o dinheiro e os deixara sem sustância alguma, e aos Vassallos em estado que não possam nelle viver».
} 
outubro de 1631; 22 de fevereiro de 1632; 18 de agosto de 1638; 23 de novembro de 1639). Depois da Restauração, o imposto foi provisoriamente mantido (carta régia de 14 de dezembro de 1640, J. J. Andrade e Silva, Colecção...), tendo sido finalmente suspenso, a pedido das cortes, pela carta de lei de 27 de fevereiro de 1641. No entanto, como aconteceu noutros casos, é restabelecido, por três anos, com o nome de «novos direitos» (alvará de 24 de janeiro de 1643, ibid., 187), justificando-se pela insuficiência das décimas. Basicamente, o sistema é o mesmo, apenas se dividindo o pagamento em duas prestações (n.․ 1). Em todo caso, surgem agora expressamente tributados (por taxa fixa) certos ofícios, que hoje seriam considerados "profissões liberais», mas cujo exercício dependia então de carta régia (médicos, 6 cruzados; cirurgiões e boticários, 4 cruzados; advogados da Casa da Suplicação, 20 cruzados; outros advogados, 6 cruzados; procuradores do número e solicitadores do número da Casa da Suplicação, 2 cruzados) (regulamento cit.).

A Guerra da Restauração obriga à criação de novos impostos. As «décimas» tiveram como fonte inspiradora os dízimos a Deus, pagos à Igreja, tanto enquanto fonte de legitimação pois se considerava que para com o senhor natural se tinham obrigações semelhantes às que se tinham para com o Senhor sobrenatural - como enquanto base de cálculo.

Entretanto, hesitou-se muito sobre os meios a usar. A primeira ideia foi a da extensão dos reais; depois, a Câmara do Porto sugeriu uma capitação do tipo da taille francesa (alvará de 16 de junho de 1641, J. J. Andrade e Silva, 80). Finalmente, o regulamento de 5 de setembro de 1641 (ibid., 100) instituiu uma décima de todas as rendas de bens de raiz, juros, ordenados, tenças, outras rendas ou honra de ofícios, do trato e meneio, vintena da renda das casas em que morem os trabalhadores ou mesteres, não sendo miseráveis, segunda décima das chancelarias e da Casa dos Cincos (n. 1). O lançamento 
era feito por juntas paroquiais de cinco pessoas - em Lisboa, fidalgo, letrado, cidadão ou nobre, dois do povo; no Reino, um vereador, um nobre ou cidadão, um fidalgo (se o houver) e um do povo, escolhidos em Câmara (n. III; cf. outro alvará da mesma data, J. J. Andrade e Silva, Colecção..., 101) -, que chamariam os fregueses dos róis, se informariam das suas rendas e as assentariam, dando recurso para a junta dos Três Estados $^{51}$. Com o Regimento de 1654, verificam-se grandes progressos no processo de determinação do valor das rendas, pois, abandonando-se os métodos de lotação, finta ou arbitramento antes usados, procura-se agora, em certos casos, obter o valor efetivo das rendas (II, 17 a 19; III, p. 14 et seq.).

As décimas são suspensas em 1668, levantando-se de novo em 1704 (carta de lei de 26 de maio) e durando até 1715 (carta de lei de 25 de novembro), no fim da Guerra da Sucessão, sendo substituídas, nos ínterins, pelo tributo dos 4,5\%. Repostas em vigor em 1762, em substituição dos 4,5\%, por motivo da guerra, a chamada «guerra fantástica» com a Espanha, de 1762-1763, conhecem então um novo regimento (alvará de 26 de setembro de 1762, em Collecção das Leis, Decretos e Alvarás, Que Comprehende o Feliz Reinado del Rey Fidelíssimo D. Jozé o I, Lisboa, 1770, vol. II, p. 98; cf. instr. 18 de outubro de 1762, ibid., vol. II, p. 110-115). Fundamentalmente, o regimento apenas sistematiza e aperfeiçoa o sistema anterior, reforçando, além disso, a infraestrutura administrativa do imposto pela instituição de novos superintendentes da décima. Para além de que se

\footnotetext{
${ }^{51}$ O Regimento de 7 de junho de 1642 (J. J. Andrade e Silva, p. 143) não inova grandemente, o mesmo acontecendo com os de 19 de janeiro de 1643 (impresso por António Álvares em Lisboa, 1643) e de 28 de março de 1646 [J. J. Andrade e Silva, p. 472 (resumo, transcr. de Manuel Borges Carneiro, Resoluções Chronologicas, II, p. 559)]. Novidades traz, porém, sobretudo nas técnicas de avaliação do rendimento coletável, o regimento (definitivo, pelo menos até ao pombalino) de 9 de maio de 1654 (J. J. Andrade e Silva, p. 302).
} 
abole, finalmente, qualquer privilégio, nomeadamente o dos eclesiásticos. Mas esta pretensão de generalidade foi, a breve trecho, prejudicada pelo alvará de 6 de agosto de 1777, que isenta de novo os eclesiásticos, os hospitais, as misericórdias e os conventos, medida que o pensamento reformista criticou duramente (José de Abreu Bacellar Chichorro, "Memória económica", p. 72 et seq.) e que acaba por ser revogada em 1796 (decreto de 24 de outubro).

A dupla décima (ou «quinto»), paga pelos «donatários» da coroa, justificava-se pela ideia de que, não perdendo os bens da coroa essa natureza pela sua doação, lógico era que às suas rendas se recorresse mais intensamente aquando dos apertos da Fazenda. Esta ideia foi muitas vezes evocada pelos povos, em cortes ou por meio das câmaras, durante a época filipina. Contrapunham os donatários, porém, que o seu serviço ao rei devia ser prestado da forma que lhes era específica - o serviço militar [apesar da distinção que as Ordenações faziam entre concessões de bens da coroa e concessões feudais (Ordenações Filipinas, II, 35)]. É só com os apertos da Restauração que a ideia de tributar especialmente os donatários é parcialmente posta em prática. Assim, em 1652, manda-se pagar o quinto pelos comendadores das ordens e donatários da coroa, «incluindo neles a décima que já se pagava [decreto de 19 de novembro de 1652, J. J. Andrade e Silva, Collecção..., p. 107 (remissão, João Pedro Ribeiro, Indice Chronológico Remissivo da Legislação Portuguesa, Lisboa: Imprensa Nacional, 1805 et seq., vol. I, p. 173)], determinação que é renovada, passados três anos, pelo decreto de 29 de outubro de 1655 (João Pedro Ribeiro, Indice chronológico..., cit., vol. I, p. 177). Em 1668, este imposto deve ter terminado, com o fim da guerra, sendo reposto em vigor apenas nos finais do Antigo Regime (decreto de 24 de outubro de 1796, António Delgado da Silva, Colecção..., 304/5), sendo então expressamente estendido aos donatários eclesiásticos. 
$\mathrm{O}$ «subsídio literário» foi criado pela carta de lei de 10 de setembro de 1772, para sustento dos estudos menores, então oficialmente estabelecidos, substituindo as colectas do cabeção das sisas, destinadas aos mestres de ler e escrever, de solfa e gramática. Consistia na imposição de um real por canada de vinho, 4 réis pela de aguardente e 160 réis por pipa de vinagre, integrando-se numa ideia muito difundida na época pombalina acerca do excesso existente de terras dedicadas à vinicultura, ideia que, como se sabe, levou a medidas políticas muito mais drásticas ${ }^{52}$.

A peregrina invenção do papel selado - tão paradigmática da monarquia católica, que F. Chabod designa a cultura política e jurídica gerada à sua sombra como a civiltà della carta bollata - teve uma primeira tentativa de introdução em Portugal em 1637. À semelhança do que acontecera, por exemplo, na Biscaia, esse projecto provocou uma tal reacção, sobretudo «por parte dos ministros», que a sua execução veio a ser suspensa (Manuel Severim, Noticias..., Bib. Nac. Lisboa, cód. 241, fl. 319). Nas ânsias da Restauração - que, também aqui, acabou por dar corpo aos projetos fiscais olivaristas -, o papel selado acaba por ser introduzido pelo regimento de 24 de dezembro de $1660^{53}$, apesar dos pareceres daqueles que o consideravam «Castelhano». Com o fim da guerra, o imposto é levantado, só sendo restabelecido em 10 de março de 1797, embora por pouco tempo, pois é de novo abolido em 24 de janeiro de 1804. Já no período constitucional (leis de 31 de março e 24 de maio de 1827) é restabelecido, vigorando até à sua recente extinção.

Comparativamente com outros reinos europeus, Portugal parece ter sido um daqueles em que a carga fiscal da coroa era

\footnotetext{
${ }_{52}$ Cf. apreciação em José de Abreu Bacellar Chichorro, "Memória económica...", p. 73-75.

${ }^{53}$ V., sobre o tema, por último, João Alves Dias, «Para a história dos impostos em Portugal. O papel selado no séc. XVII». Nova História. Século XVII, n.․ 34, 1985, p. 41-78, José da Costa Gomes, Colecção de Leis da Dívida Pública Portuguesa, Lisboa. Imprensa Nacional, 1883, e Nuno E. Gomes da Silva, «Nascimento, vida e morte (ou colapso?) do papel selado», Scientia Juridica, n.. 37. 1988, p. 175-188.
} 
menos efetiva. No primeiro quartel do século XVII era, com Aragão, o menos tributado dos reinos da monarquia católica (v. infra). E, já nos finais do século XVIII, José Bacelar Chichorro diz o mesmo em relação a todos os reinos europeus, calculando a capitação da carga fiscal portuguesa em cerca de 1/10 da holandesa ou da inglesa ${ }^{54}$.

\section{Meios Extraordinários de Financiamento: os Juros}

Ao abordar a questão dos constrangimentos ao cálculo económico do Antigo Regime, já nos referimos aos juros, tendo então dito que, apesar das proibições da usura, estes constituíam um meio corrente de acorrer às necessidades financeiras da coroa. A licitude do recurso à venda de juros por parte desta decorria, para a teologia moral estabelecida, de uma das seguintes razões. A primeira era a de que maior do que o mal da usura era a falta de cumprimento dos deveres do rei, quer na defesa da república (mais ainda, da fé), quer no exercício da liberalidade e na retribuição dos serviços dos vassalos. Por isso é que as operações de vendas de juros são cuidadosamente justificadas nesta base, sendo tal justificação frequentemente incluída no próprio padrão de juros. A segunda era a da alegada proximidade entre o pagamento de um juro e o pagamento de uma tença, considerando o juro como uma liberalidade régia remuneratória de um serviço prestado ao rei ${ }^{55}{ }^{56}$. A terceira era

\footnotetext{
${ }^{54}$ José de Abreu Bacellar Chichorro, "Memória económica...", p. 88.

${ }^{55}$ Parece que o nome «juro» deriva da designação de certas tenças perpétuas obrigatórias («tenças de juro e herdade») (cf. José da Costa Gomes, Colecção..., cit.).

${ }^{56}$ Cf. o seguinte passo de um padrão de juros, em que esta intermutabilidade entre juros e mercê é usada para a legitimação do contrato: «E sendo caso que [...] se achasse ou determinasse que esta venda era usuraria [...] hei por bem [...] lhe fazer mercê dos ditos 20000 réis de tença para sempre [...]» (José da Costa Gomes, Colecção..., cit., p. 50-51).
} 
a apresentação dos juros como uma simples venda de rendas da coroa (José da Costa Gomes, Colecção de Leis da Dívida Pública Portuguesa, Lisboa: Imprensa Nacional, 1883, p. 49), ou seja, não como direitos de crédito, mas como bens de raiz ${ }^{57}$. A quarta, de legitimidade duvidosa (pois não se podia dispensar contra o direito divino), era a da dispensa da Ordenação do Reino que proibia as usuras (Ordenações Manuelinas, IV, 14, e Ordenações Filipinas, IV, 67).

E, de fato, os juros constituíram um recurso financeiro da coroa desde os inícios da segunda dinastia (D. Afonso V). Por vezes, os juros reais foram um modo de consolidar dívidas correntes (dívidas «a câmbios»), muito mais onerosas, tornando, por outro lado, inexigível o capital. Outras vezes, tinham origem em tenças perpétuas e obrigatórias («de juro e herdade») dadas pelo rei ou em outras obrigações por ele assumidas de pagamento de rendas, em virtude de, v.g., compras ou composições. Outras, finalmente, na necessidade de acorrer às urgências da coroa, como ocorre a partir de D. Manuel (embora precedendo parecer de «pessoas de ciência e consciência») (José da Costa Gomes, Colecção..., cit., p. 21 et seq.).

Os juros estavam «assentados» ou «situados» numa certa renda da coroa, que respondia pelo seu pagamento ${ }^{58}$, em termos tais que era reconhecida aos «juristas» uma correspondente acção executiva contra os almoxarifes dessa renda ${ }^{59}$. Em contrapartida, os juros situados numa renda podiam não ser integralmente ou absolutamente pagos, caso ela se esgotasse, não podendo ser exigidos sobre outra. Para aumentar as garantias

\footnotetext{
${ }^{57}$ Cf. Ordenações Filipinas, III, 47. Assim, incorporavam-se no património dos titulares, podendo por estes ser alienados ou onerados (art. 211 das Ordenações da Fazenda).

${ }^{58}$ Em certas rendas, por natureza consignadas a certos fins (como as décimas), o assentamento de juros não era possível (regimento de 9 de maio de 1645, tit. 4, § 13).

${ }^{59}$ Cf. alvará de 31 de outubro de 1602, revogado pelo decreto de 12 de março de 1665 (José da Costa Gomes, Colecção..., cit., p. 18, 65).
} 
dos «juristas», a lei (alvarás de 28 e 31 de janeiro de 1606) ou as cláusulas contratuais passaram a permitir a mudança de assentamento, embora ressalvando os direitos dos juros já anteriormente situados na nova renda (José da Costa Gomes, Colecção..., cit., p. 54 et seq.). Mas estas mudanças suscitavam sempre os protestos dos anteriores tencionários ou juristas da nova renda ${ }^{60}$, para além de não serem favoráveis à coroa, que, assim, não se podia eximir ao pagamento dos juros com fundamento no esgotamento das respectivas rendas.

Os juros eram vendidos sob condição de poderem ser remidos a todo o tempo pela coroa (pacto «de retrovendendo», correspondente à condição al quitar, usual nos juros espanhóis). E, de fato, a ideia de uma remissão ou distrate dos juros, como forma de aliviar as despesas da coroa, esteve sempre presente, dando origem a vários planos - sempre gorados - durante os séculos XVII e XVIII, desde a afetação de certas rendas a esse fim à criação de «tontinas» ou de fundos de amortização (José da Costa Gomes, Colecção..., cit., p. 92 et seq.). Diferente era a operação da redução dos juros, que consistia em remir juros de taxa mais elevada, substituindo-os por outros de taxa menor. Isto exigia, naturalmente, o acordo do «jurista»; e, como ele nem sempre se verificava, supunha também a disponibilidade de uma soma para distratar, pura e simplesmente, os juros dos que não aceitassem a redução (José da Costa Gomes, Colecção..., Lisboa: Imprensa Nacional, 1883, p. 75).

\footnotetext{
${ }^{60}$ A hierarquização normal dos juros no âmbito da renda em que se situam era a antiguidade. Na concorrência com outras rendas aí assentadas, a lei estabelecia a seguinte preferência: assentamentos da casa real e consignações, ordenados, juros e tenças por sua antiguidade (alvará de 17 de fevereiro de 1655; cf. antes o cap. 106 das Ordenações da Fazenda); mais tarde, a lei pombalina de reforma da Fazenda (de 22 de dezembro de 1761) dá preferência aos juros sobre as tenças. No início do século XVII, porém, o desejo de atrair compradores, nas épocas de grande aperto financeiro, levou a que se concedessem privilégios «de anterioridade» a certos juros (cf. José da Costa Gomes, Colecção..., cit., p. 40).
} 


\section{Outros Meios Extraordinários de Financiamento}

Como veremos, ao estudar as diferentes conjunturas financeiras, o fisco real recorria a meios extraordinários de financiamento nos casos de aperto financeiro. Recorria, desde logo, a dinheiro disponível, a cargo de outras instituições ou afetado a objetivos específicos. Tal era o caso, por exemplo, das arcas concelhias em que se depositava dinheiro pertencente a órfãos («arcas dos órfãos»), heranças jacentes ou bens deixados a favor dos cativos («arcas dos resíduos»). O mesmo acontecia com as somas cobradas nos almoxarifados para as obras pias $(1 \%$ das obras pias) - utilizadas, nomeadamente, para o pagamento de soldados na década de 30 do século XVII («soldados das pias») -, com as somas provenientes das terças dos concelhos (destinadas à reparação das muralhas ou das obras militares) ou com o produto do consulado, frequentemente desviado do seu objetivo de organização da armada de costa para outros fins. Também os recursos da Casa da Índia eram eventualmente mobilizados, não só como garantia de empréstimos (voluntários ou forçados), mas ainda, diretamente, obrigando os mercadores da praça de Lisboa a comprar a pimenta em armazém.

Os «pedidos» de subsídio voluntário, frequentes nas décadas de 20 e 30 do século XVII e dirigidos quer a estados isentos, como o eclesiástico, quer a grupos possidentes, como os mercadores da praça de Lisboa (ou a própria câmara), representavam outro meio importante de suprir os défices das receitas ordinárias. Estes pedidos nem sempre se reportavam a somas em dinheiro. Em 1639, v. g., é pedida à nobreza portuguesa (como também à espanhola) a organização de "coronelias», ou seja, o recrutamento e sustento de um certo número de soldados para as guerras da monarquia, nomeadamente a da Catalunha. E também se podem encontrar pedidos de armas e navios de guerra para o socorro das conquistas. 
Finalmente, aparecem, já no início do século XIX (em 1810 e 1811), contribuições extraordinárias, justificadas pelo estado de guerra, que, de alguma forma, são a continuação, embora sob um diferente modelo de entender a fiscalidade, dos antigos pedidos extraordinários ao Reino, correntes no século XVII, nomeadamente entre 1620 e o fim da Guerra da Restauração ${ }^{61}$. Às rendas do Reino há que acrescentar, naturalmente, as rendas das conquistas, de que aqui não poderemos tratar ${ }^{62}$.

\section{Regalia}

Relacionado com o poder de império do rei está um grupo de rendas que, no contexto das receitas da coroa portuguesa na época moderna, é modesto. Trata-se dos réditos da pena de confisco, nomeadamente das penas executadas pelos juízos do fisco dos três tribunais da Inquisição; das décimas das

${ }^{61}$ Ao lado dos anteriores, que são os principais, houve outros impostos menores e menos permanentes [como o tributo para a condução das águas para Lisboa (cf. Bib. Nac. Lisboa, cód. 1105, n.․51), os 4\% dos mercados para a reconstrução da alfândega (decreto de 14 de maio de 1756), o imposto para as fragatas (decreto de 2 de abril de 1805), o imposto para a iluminação da cidade (decreto de 14 de abril de 1804), etc.]. Durante os séculos XVII e XVIII, existem muitos alvitres sobre os modos de aumentar as rendas da coroa. Os mais importantes são os de criação de «montes de piedade», de «tontinas» (isto é, juros vitalícios que, por morte do titular, se repartiam pelos restantes investidores agrupados no banco; cf. exemplos em 1655 e 1688 em José da Costa Gomes, Coleç̧ão..., cit., p. 94 et seq.) e as «lotarias»; só o último destes meios é que acaba por ser efetivado em Portugal, já nos finais do século XVIII, mas não a favor do Tesouro Público.

${ }^{62}$ Sobre as rendas do Brasil (em 1588), v. cód. Bib. Nac. Lisboa, c. 637, fls. 17 vo-24; sobre as da Índia, Vitorino Magalhães Godinho, Les finances de l'État portugais des Indes Orientales (1517-1635) (Matériaux pour une étude structurale et conjoncturale), Paris, Fundação Calouste Gulbenkian, 1982; Artur Teodoro de Matos, O Estado da Índia nos Anos de 1581-1588. Estrutura Administrativa e Económica. Alguns Elementos para o Seu Estudo, Ponta Delgada, Universidade dos Açores, 1982; sobre as rendas do Atlântico e África, alguns elementos em Frédéric Mauro, Le Portugal et l'Atlantique au XVII siècle (1570-1670), Paris, Fundação Calouste Gulbenkian, 1982, 2.. ed. 
sentenças cobradas nas chancelarias dos tribunais de justiça, nomeadamente na Casa da Suplicação e na Casa do Cível; das penas do contrabando e das pensões dos tabeliães.

\section{Estancos}

Os estancos constituíam monopólios reais de venda de certos produtos. Alguns remontavam à Idade Média, como o do sabão (António Manuel Hespanha, As vésperas..., cit., vol. I, p. 109) ou o do solimão. Outros decorriam do monopólio régio sobre o comércio com as conquistas (como o da pimenta e o do pau-brasil $\left.{ }^{63}\right)$. Outros tinham sido importados de Espanha durante a época dos Áustrias, como o das cartas de jogar (ou naipes, desde 1604), ou o da repisa do bagaço de azeitona. Mas, para a época a que nos referimos, os mais importantes são, sem dúvida, o do sal ${ }^{64}$, o do tabaco e o do ouro e pedrarias do Brasil.

A renda do tabaco já existia, como estanco, desde a segunda década do século XVII (Azevedo, 1928, p. 269 et seq.). Em 1642, no entusiasmo antifiscal da Restauração, o estanco é extinto (alvará de 6 de setembro de 1649, J. J. Andrade e Silva, Colecção..., VII, passim), mas logo reposto em 1659; e, em 1674, é já aí que o rei situa os 500.000 cruzados que ofereceu do seu património para as necessidades do Reino (decreto de 19 de novembro de 1674, ibid., 370). Em 1698, as rendas do tabaco já permitem que aí se situem mais 1100000 cruzados (v. supra e Azevedo, 1928, p. 284). Dessa altura existem vários alvitres apresentados por ocasião das negociações sobre os meios de realizar o subsídio pedido às cortes que nos permitem avaliar a importância que a

\footnotetext{
${ }^{63}$ Cf. Azevedo, 1928, p. 249.

${ }^{64}$ O estanco do sal foi criado pelo alvará de 6 de dezembro de 1576 (cf. José Anastácio de Figueiredo, Synopsis Chronologica da Legislação Portuguesa (1143-1549), Lisboa, 1790, vol. I, p. 177); no período filipino reinstitui-se, sob nova forma, pelos alvarás de 30 de junho e 4 de agosto de 1631 (v. infra).
} 
renda do tabaco vinha a ganhar ${ }^{65}$. Segundo o papel 23 da fonte citada (Bib. Nac. Lisboa, cód. 1595), a estimativa da população fumadora seria a seguinte:

\begin{tabular}{l|l} 
Reino (400 000 casais) & 1000000 \\
Madeira & 60000 \\
Açores & 240000 \\
"Frades, freiras e vagabundos" & 30000 \\
\hline Total & 1330000
\end{tabular}

Já no alvitre de Filipe Rodrigues Pereira (papel 3) faz-se o seguinte cálculo do montante da capitação do tabaco (c. 1698):

\begin{tabular}{l|l|l|} 
População & Valor & Renda fiscal \\
\hline 100000 fogos a 1 arrátel & 100000 & \\
\hline 40000 a 2 arráteis & 80000 & \\
\hline 30000 a 3 arráteis & 180000 & \\
\hline 30000 a 16 arráteis & 480000 & \\
Total & 840000 & $\times 3$ crz. \\
& & 2050000 (sic)
\end{tabular}

Esta renda ia-se tomando, de fato, numa das componentes principais das receitas da coroa. Em relação ao cômputo geral das receitas da coroa, o crescimento da quota que cabe ao tabaco

\footnotetext{
${ }^{65}$ O cód. Bib. Nac. Lisboa, p. 1595, «Papéis políticos», c. 1698, contém vários alvitres sobre a forma de realizar o pedido de 600000 cruzados feito às Cortes de 1698. Entre eles, um de Filipe Rodrigues Pereira acerca do imposto sobre o tabaco para substituir os reais, sob forma de um imposto de um tostão por libra; segundo ele, o tabaco rendia 1600000 cruzados (papel 3); já o juiz do povo propõe que se acabe com o estanco e que se não tribute o tabaco reexportado (papel 6); outros propõem uma capitação de 3 cruzados por arrátel (papel 20).

${ }^{66}$ Fonte: Bib. Nac. Lisboa, 1595. "Papéis políticos", c. 1698, papel 3. O total é o apresentado na fonte. Mas o cálculo realmente dá 2520000 crz.
} 
pode ser apreciado no gráfico «Rendas do Reino (1588-1811) (deflacionadas a partir de 1681)». Não é, por isso, de estranhar a série de legislação tendente a garantir o monopólio da coroa e a privilegiar os seus contratadores (Manuel Fernandes Tomás, Repertorio geral ou indice alphabetico das leis extravagantes, 1815, s.v. «Tabaco»; e José Roberto de Campos Coelho e Sousa, Sistema, ou Coleção dos Regimentos Reais compilado por..., 1789, vol. IV, p. 80 et seq.).

Quanto ao ouro e pedraria, tratava-se de uma antiga regalia sobre os despojos (ou regalia dos metais?). A coroa oscila entre a política de monopólio da comercialização, de imposição do quinto sobre a extracção (regimento de 8 de agosto de 1618, J. J. Andrade e Silva, Collecção..., 330; e Regimento de 3 de dezembro de 1750) e de capitação da população das zonas auríferas (regimento de 24 de março de 1734). De 1618 a 1750 houve doze métodos de arrecadação, o que demonstra a dificuldade de estabelecer um sistema que evitasse o descaminho. De qualquer modo, a sua época de auge parece ser o período entre 1697 e $1765^{67}$.

\section{Conclusão}

Este rápido panorama sobre a organização das finanças públicas portuguesas nos meados do séc. XVII permite-nos detetar os traços estruturais do cálculo financeiro numa Monarquia Corporativa, nomeadamente, a rigidez das receitas e das despesas e, por detrás disso, a vinculação das

\footnotetext{
${ }^{67}$ Quanto aos diamantes, v. a seguinte legislação: alvarás de 26 de fevereiro de 1672 (J. J. Andrade e Silva, p. 203), de 24 de dezembro de 1734 (Coll. leg. extravag., p. 442), de 11 de agosto de 1753 (regulamento do contrato), de 2 de agosto de 1771, de 23 de maio de 1772 e de 13 de maio de 1803 e ordem de 4 de maio de 1801 (todos em António Delgado da Silva, Collecção...).
} 
finanças a um mundo de valores relativos ao bom governo. Também aqui, a política era muito menos arbitrária do que hoje e, por isso, o poder real muito menos absoluto do que se tendia a pensar.

\section{Referências}

AZEVEDO, João Lúcio de. Épocas de Portugal Económico: Esboço da Sua História. Lisboa: 1928.

CHICHORRO, José de Abreu Bacellar. Memória Economico-Política da Província da Estremadura. Ed. de Moses Bensabat Amzalak. Lisboa: 1943.

CARDOSO, José Luís. O Pensamento Económico em Portugal nos Finais do Séc. XVIII. 1780-1808. Lisboa: Estampa, 1989.

CLAVERO, Bartolomé. Antropologia católica de la economia moderna. Milano: Giuffrè, 1991.

CORTESÃO, Jaime. Alexandre de Gusmão e o tratado de Madrid. Rio de Janeiro: 1952-1956 (ed. consultada Lisboa: Livros Horizonte, 1984).

DIAS, João Alves. Um documento financeiro do século XVII. Nova História. Século XVII, n. 3/4, p. 41-78, 1985.

FIGUEIREDO, José Anastácio de. Synopsis Chronologica da Legislação Portuguesa (1143-1549). Lisboa: 1798. 2 v.

FRAGOSO, Baptista. Regimen reipublicae christianae... Collonia Allobrogum: 1641-1652. $3 \mathrm{v}$.

GOMES, José da Costa. Coleç̧ão de Leis da Dívida Pública Portuguesa. Lisboa: Imprensa Nacional, 1883.

HESPANHA, António Manuel. As vésperas do Leviathan: instituições e poder político. Portugal - Séc. XVII. Lisboa: [s. n.], 1986. 2 v.

.Vísperas del Leviathan: Instituciones y poder político. Portugal siglo XVII. Madrid: Taurus, 1989.

. Les autres raisons de la politique... In: L'État dans le monde ibérique. Paris, École Normale Supérieure; texto apresentado, em 1990, no colóquio "Ragion di Stato, ragione dello Stato". Napoli, Istituto di Studi Filosofici. 
MAGALHÃES, José Calvet de. História do pensamento econômico em Portugal. Boletim de Ciências Económicas, Coimbra, Faculdade de Direito, v. 9, 1965/1966, p. 65-179.

OLIVEIRA, Águedo de. As Finanças Portuguesas dos Séc. XVI e XVII. Lisboa: 1960.

OLIVEIRA, António de. Levantamentos populares no Algarve em 1637-1639. Revista Portuguesa de História, n. 20, p. 1-98, 1983.

. A contestação fiscal em 1629: as reacções de Lamego e do Porto. Revista da História das Ideias, n. 6, p. 259-300, 1984.

. Poder e Oposição Política em Portugal no Período Filipino (15801640). Lisboa: Difel, 1991.

OLIVEIRA, Eduardo F. de. Elementos para a História do Município de Lisboa. Lisboa: 1885-1897. $14 \mathrm{v}$.

PORTUGAL. Ministério das Finanças. Exposição Histórica do Ministério das Finanças. Ed. de A. Luiz Gomes. Lisboa: Ministério das Finanças, 1952.

RIBEIRO, João Pedro. Índice Chronológico Remissivo da Legislação Portuguesa. Lisboa: 1805-1818. 5 v.

SAMPAIO, Francisco C. de Sousa. Prelecções de Direito Pátrio... Coimbra: 1793.

SILVA, José Justino de Andrade. Colleç̧ão Chronologica da Legislação Portugueza. Lisboa: Imprensa Nacional, 1854 et seq.

SILVA, Luís A. Rebello da. História de Portugal nos Séculos XVII e XVIII. Lisboa: 1860-1871. 5 v. (reimp. Lisboa: INCM, 1981).

SOLIS, Duarte Gomes. Discursos sobre los comercios de las dos Indias. Madrid: 1622 (ed. cons. Lisboa: 1943).

(ed. util. Lisboa: 1955). . Alegación en favor de la Compania de la India Oriental. 1628. 


\section{Anexos}

\section{Gráficos demonstrando sinteticamente as rendas e despesas de Portugal (sécs. XVII e XVIII) ${ }^{68}$}
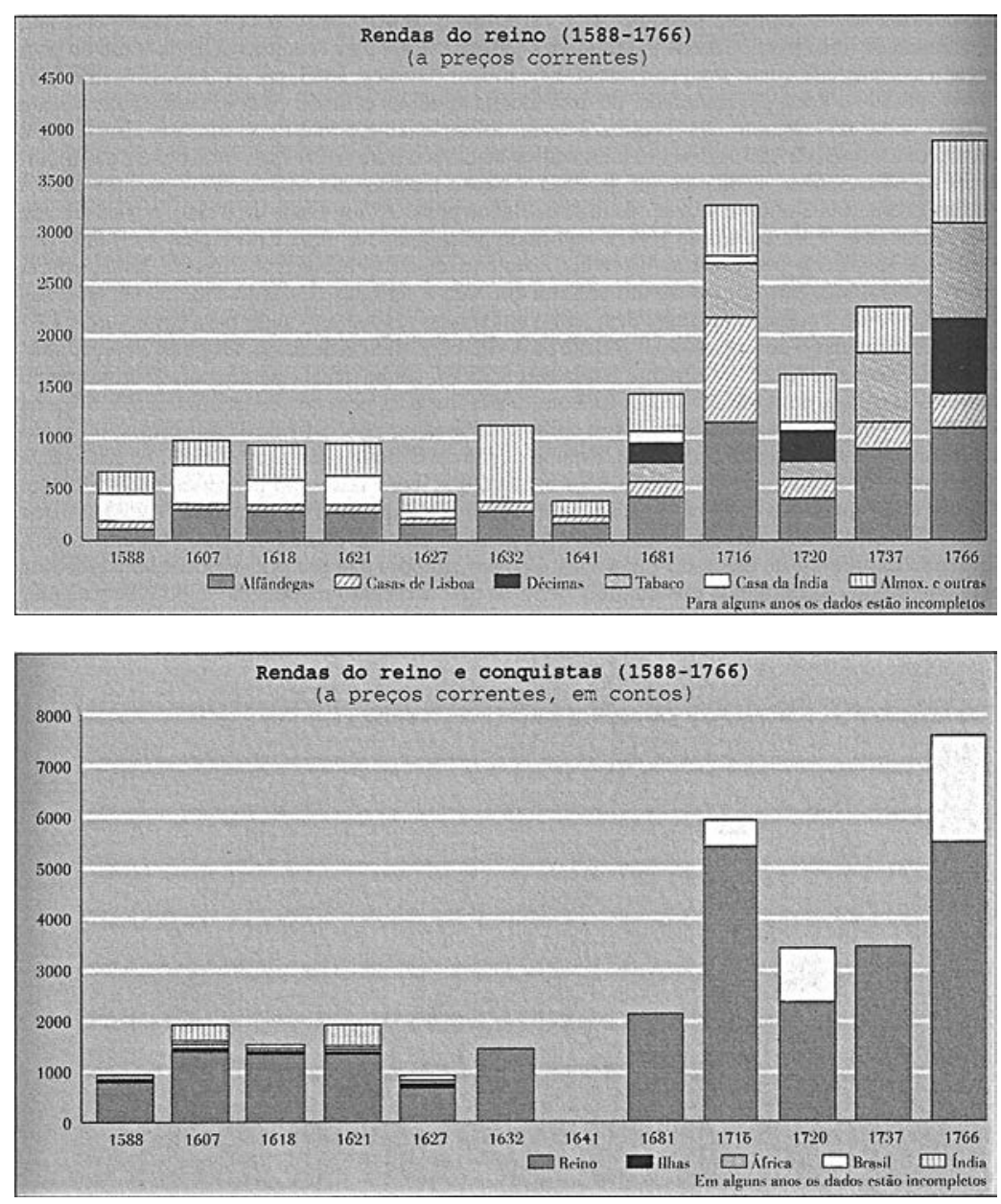

${ }^{68}$ Detalhes em António Manuel Hespanha, "A Fazenda", em J. Mattoso, História de Portugal. Vol. IV. “O Antigo Regime”, Lisboa, Círculo de Leitores-Editorial Estampa, ed. 1998 (foi também a fonte dos gráficos). 

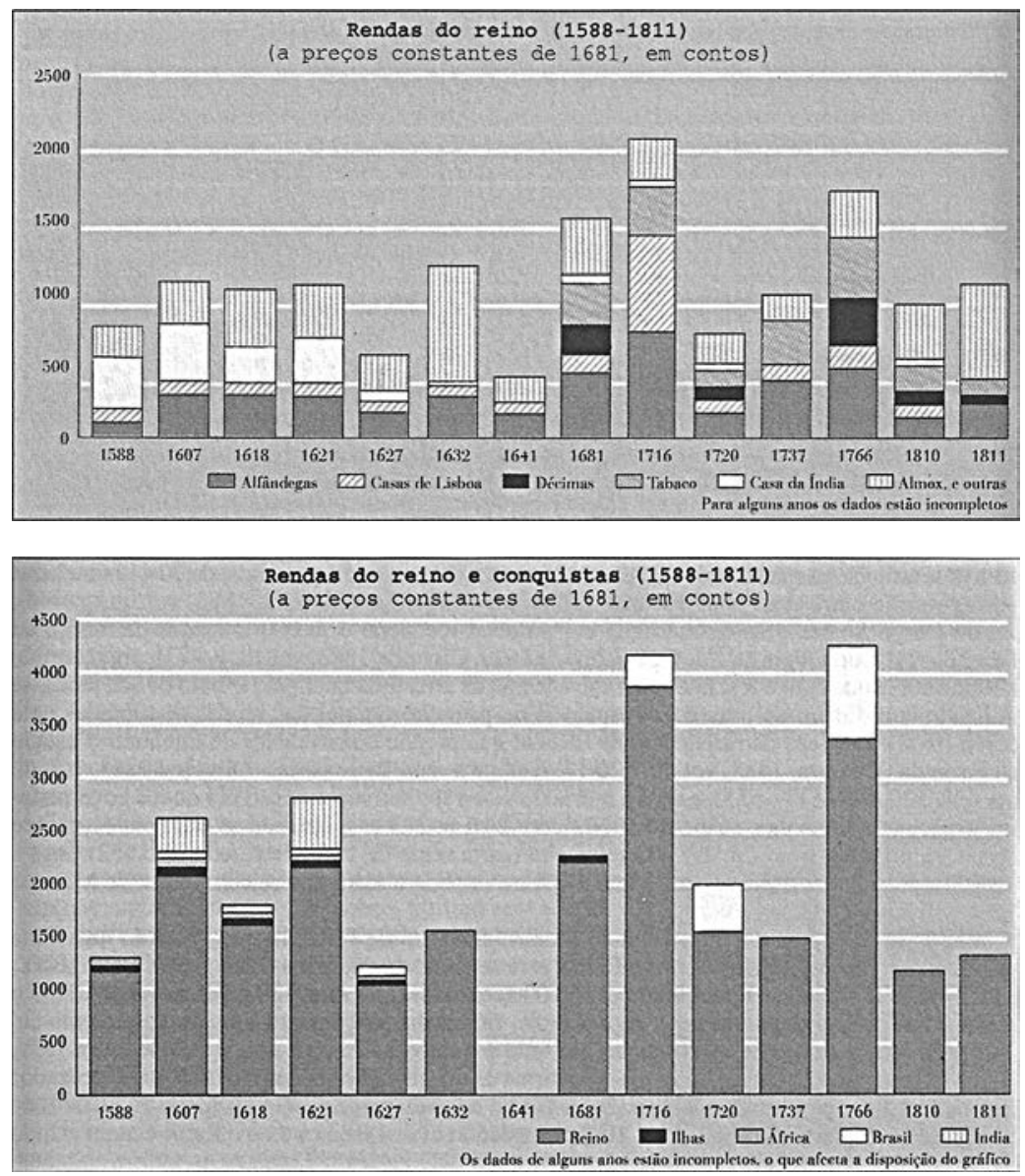

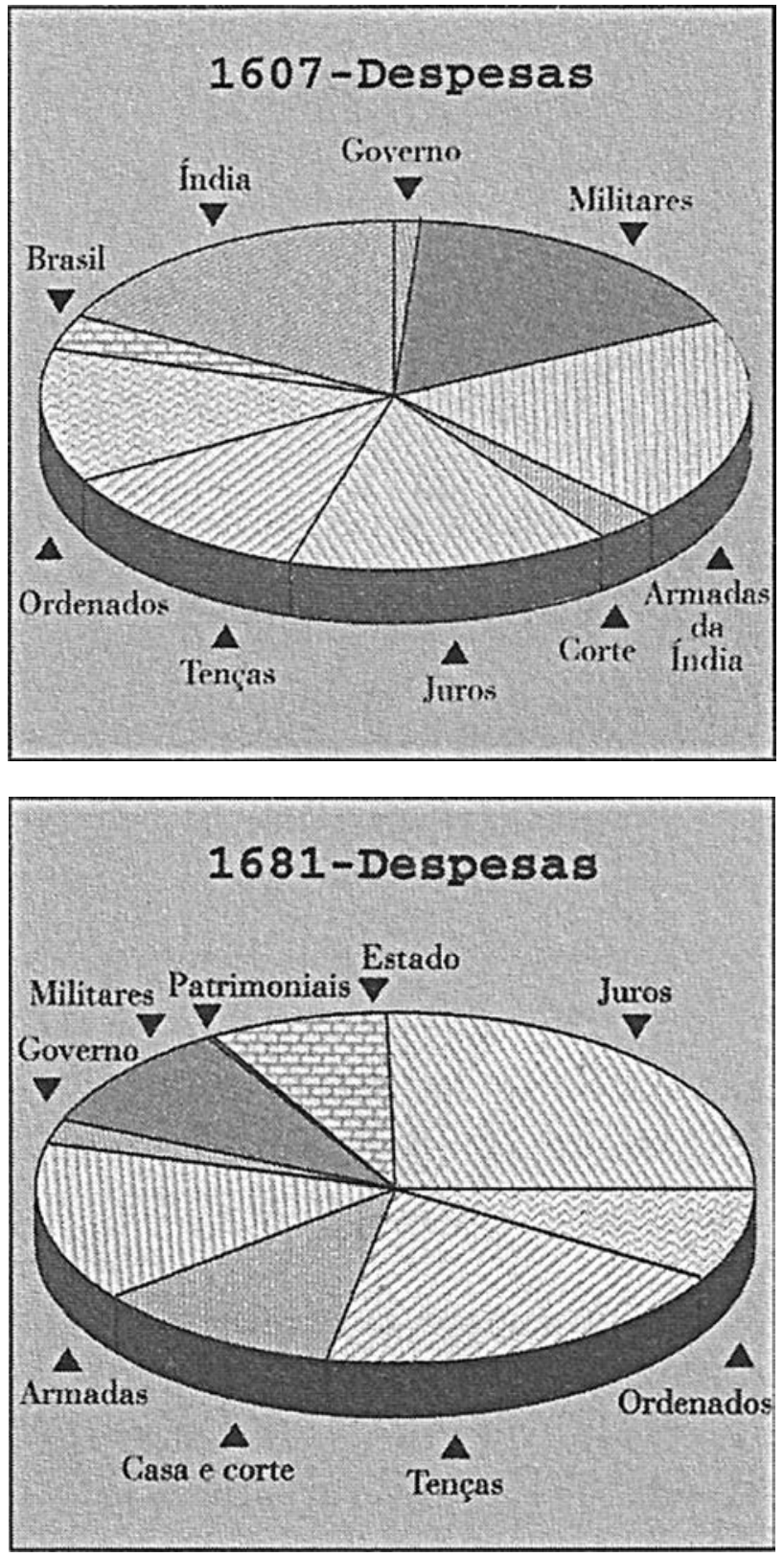


\section{6-Despesas}

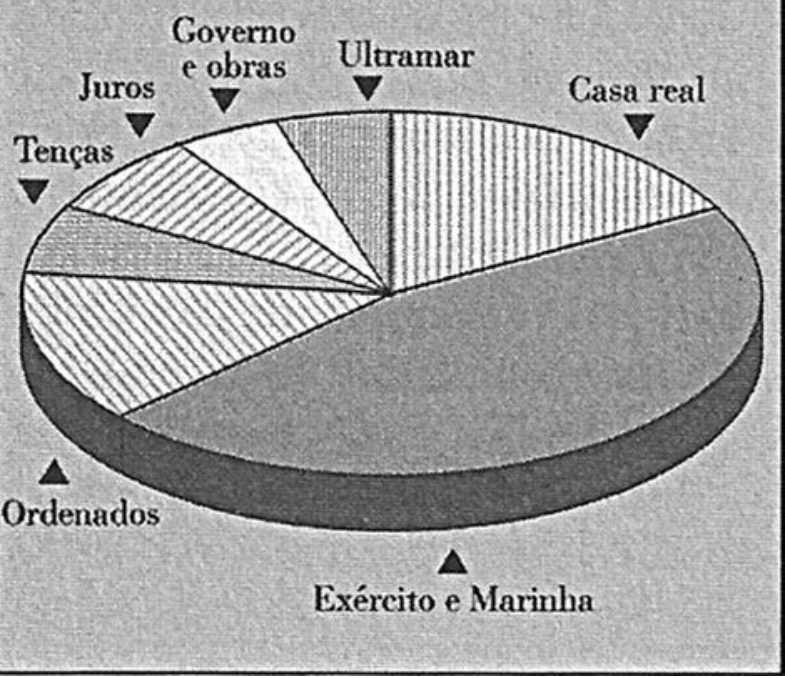




\title{
A Sociedade de Risco \\ e a Repercussão das Capacidades Individuais do Sujeito para a Culpa Não Imputável
}

\author{
Risk Society and the Implication of the Subject's \\ Individual Capacities for Non-Imputable Fault
}

Selma Pereira de Santana*

Resumo: A teoria da culpa permaneceu durante muito tempo à margem da evolução da dogmática jurídico-penal. Hoje, em razão das condições da sociedade de risco, assiste-se a um incremento da preocupação científica sobre ela. A doutrina penal tem mantido há alguns anos, e sob a perspectiva da determinação estritamente objetiva do dever de cuidado, a postura de buscar modelos médios de comportamento, intitulados de "homem ideal", ou "homem médio". Em face disso, tem sido objeto de discussão a questão de saber se é necessário levar-se em consideração, além dos aspectos objetivos, outros aspectos, os subjetivos, na linha da individualização da capacidade do agente na sociedade de risco, para se aferir a ocorrência, ou não, da culpa imputável.

Palavras-Chave: Sociedade de Risco. Teoria da Culpa. Homem Médio. Capacidade Individual. Culpa Imputável.

Abstract: Culpability theory remained for a long time on the sidelines of the evolution of the criminal-legal dogmatic. Today, due to the conditions of risk society, an increasing scientific concern about it is noted. Criminal doctrine has maintained for some years, and from the perspective of strictly objective determination of the duty of care,

* Universidade Federal da Bahia. 
A Sociedade de Risco e a Repercussão das Capacidades Individuais...

the attitude of seeking standard behavioral models, titled "ideal man" or "reasonable man". For this reason, it has been an object of discussion whether it is necessary to take into account, besides the objective aspects, other aspects, the subjective ones, in line with the individualization of the agent's capacity in the risk society, in order to assess the occurrence or not of attributable fault.

Keywords: Risk Society. Culpability Theory. Reasonable Man. Individual Capacity. Attributable Fault.

\section{Introdução}

A teoria da culpa, que constitui um dos temas mais importantes e debatidos no Direito Penal - sobretudo em razão das características de que a sociedade, hoje, se reveste, bem como das perspectivas que para ela se anteveem, evidenciadoras da necessidade de um novo tratamento para as questões relativas à culpa, a fim de que se deem soluções mais justas e adequadas -, mesmo contando com vasta literatura a seu respeito, talvez por isso não possui, ainda, um tratamento único capaz de uma generalidade convincente de sufrágios ${ }^{1}$.

Até há relativamente pouco tempo, o delito culposo ocupava uma posição de menor importância no Direito Penal, que reconhecia e cedia lugar fundamental ao delito doloso, de mais fácil apreensão conceitual e de maior dimensão estatística. Era um quasi delictum, mais afim com o Direito Civil do que com o Direito Penal propriamente dito ${ }^{2}$.

Esse tratamento diferenciado dado à teoria da culpa fez, redundantemente, com que esta permanecesse à margem da evolução da dogmática jurídico-penal. Hoje, em razão das

\footnotetext{
1 Selma Santana (2005, p. 145-158).

2 Assim, MUÑOZ CONDE (1989, p. 71).
} 
condições da sociedade moderna, marcada pelo avanço tecnológico, pela mecanização das atividades e pela ocorrência, cada vez mais crescente, de condutas consideradas perigosas ${ }^{3}-$ a ponto de ser nomeada "sociedade de risco"-, assiste-se a um incremento da preocupação científica com a teoria da culpa, buscando-se, como já fora afirmado, que o resultado de sua evolução cumpra o papel instrumental de oferecer soluções mais justas às questões que dela dimanam ${ }^{4}$.

Para o problema aqui tratado, tem-se antevisto desafio emergente e ainda maior, propiciador de impulsos catalisadores de um ritmo mais intenso na pesquisa jurídico-penal, qual seja, a evidente e radical transformação que sofre a sociedade moderna e que, na expressão do sociólogo Ulrich Beck, se poderá sintetizar como sendo a globalização dos riscos civilizatórios ${ }^{5}$.

Na sociedade em transformação, os riscos para a existência, individual ou comunitária, ou provinham de acontecimentos naturais, ou derivavam de ações humanas próximas e definidas, para a contenção das quais era bastante o catálogo puramente individualista dos bens jurídicos, modelando, assim, um Direito Penal antropocêntrico.

A forma da sociedade que se avizinha, tudo leva a crer, caracterizar-se-á por ser exasperadamente tecnológica, massificada e global, de que resultará conduta humana capaz de produzir riscos também globais, ou tendendo para tal, "susceptíveis

3 Tem-se como certo, pelo menos por um grande número de juristas, que, hoje, só se participa da vida social sob o ônus de expor bens jurídicos a inúmeras fontes de perigo - sem as quais a vida cotidiana seria inconcebível. Cabe ao Direito, por isso, estabelecer que espécies de riscos podem ser tolerados pela sociedade autorizada, portanto, sua criação - e que riscos não o podem ser, dando margem a que o seu surgimento dê ensejo à responsabilidade por culpa.

4 É clara a relação direta e proporcional entre o aumento do tipo de delinquência culposo e o progresso tecnológico, de sorte que se poderá afirmar que aquele constitui um signo característico das sociedades avançadas.

5 Ulrich Beck (1998, p. 42). 
A Sociedade de Risco e a Repercussão das Capacidades Individuais...

de serem produzidos em tempo e em lugar largamente distanciados da acção que os originou, ou para eles contribuiu, e de poderem ter como conseqüência, pura e simplesmente, a extinção da vida"'.

Não obstante a atual preocupação científica com o tema, poder-se-á afirmar, como o fez Gimbernart Ordeig, que o atraso da dogmática do delito culposo constitui uma das maiores contradições do Direito Penal, e assim permanecerá enquanto a ciência jurídica não for capaz de apreender, racionalmente, toda a complexidade de matizes que a realidade da culpa representa, pois, em que pesem no plano dogmático alguns notáveis avanços, o estado atual da teoria da culpa constitui um dos maiores fracassos da dogmática jurídico-penal?

\section{0 “Homem Médio" como Parâmetro de Conduta} na Aferição da Culpa Imputável

A doutrina penal tem mantido, já há alguns anos, e na linha da determinação estritamente objetiva ${ }^{8}$ do dever de cuidado - partindo-se da ideia de que o caráter normativo da

\footnotetext{
${ }^{6}$ Figueiredo Dias (2000, p. 7; 2001, p. 155 et seq.). Grifos do autor.

7 Apud González de Murillo (1991, p. 32).

8 Deve-se a Welzel, movido pelas críticas de seu discípulo Niese, a primeira formulação sistemática, com contornos precisos, da noção de cuidado objetivo. Com esse conceito, continua Welzel a linha iniciada por Engisch: o cuidado objetivo, como critério delimitador do injusto culposo, é aquele que houvera empregado o "homem prudente", impregnado com um importante componente de previsibilidade e evitabilidade objetivas, a juízo de um observador imparcial que contasse com os conhecimentos do autor. Segundo Welzel, o cuidado que faz decair a tipicidade prescreve deixar de realizar o risco, tendo em conta os efeitos de uma ação previsível para um juízo inteligente (objetivamente), excluindo, assim, os cursos causais não adequados. Por outro lado, o autor limita e complementa este primeiro critério com outro, de caráter normativo: contrário ao cuidado é somente o não adequado socialmente, o que excede a medida do risco permitido. Ver Welzel (1964, p. 71).
} 
culpa obriga a concretização do cuidado de acordo com critérios objetivos -, a postura de buscar modelos médios de comportamento, intitulados de "homem ideal", ou "homem médio", "agente modelo", "pessoa consciente e cuidadosa", "reasonable man test", "pessoa prudente e de discernimento", e tantas outras denominações que se prestem à função instrumental de servir como parâmetros para a determinação do dever objetivo de cuidado. $\mathrm{O}$ critério definidor do tipo de ilícito culposo, nessa perspectiva, é um critério puramente objetivo, generalizador, que não considera as capacidades pessoais do agente concreto.

Esses modelos têm sido concebidos por meio da busca da medida do usual, levando-se em conta fatores como, v.g., a experiência da sociedade, a conduta média exigida pela cultura geral, os valores específicos da profissão9 , com o objetivo de, como já fora afirmado, e agora mais especificamente - por meio da operação comparativa entre a conduta de um agente, numa situação concreta, e a conduta imaginária desse padrão -, concluir quanto à ocorrência, ou não, da culpa imputável.

Essa operação comparativa entre o modelo médio comportamental, idealizado dogmaticamente, e a concreta atitude do agente conduziria à conclusão de que, se porventura o cuidado expresso por este, por meio do seu atuar, se situasse abaixo daquele cuidado exigível do padrão médio, esse agente teria agido culposamente.

Diferentemente, caso o cuidado do agente fosse igual ou superior ao cuidado do padrão médio, a conclusão cingir-se-ia à ideia de que não haveria culpa imputável.

As críticas a esse modelo fictício, contudo, têm surgido dos mais diversos setores.

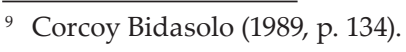


Uma das primeiras questões que se levantam é a de que a aceitação desse critério implicaria algumas consequências indesejáveis, como, v.g., uma suposta diminuição no grau de proteção dos bens jurídicos, uma vez que se termina tendo em conta o modelo de como atua a maioria, e não o de como se deve atuar.

Os partidários desse modelo objetam essa crítica, pronunciando-se no sentido de que, ao contrário do que se afirma, o modelo objetivo possui um acentuado caráter normativo, ou seja, não se limita a comparar a conduta do agente com os hábitos sociais, senão com o comportamento que teria observado uma pessoa diligente ${ }^{10}$.

Tem-se ressaltado, ainda em crítica, que, se fosse possível a criação de um homem médio, sua utilização, no caso concreto, suporia um ilícito privilégio para os indivíduos inteligentes e um reconhecimento dos maus costumes usuais do homem médio ${ }^{11}$. O problema contido no critério objetivo se apresenta não unicamente por supor um privilégio para os indivíduos especialmente capacitados, senão porque implica, ao mesmo tempo, um tratamento especialmente duro para aqueles outros

\footnotetext{
${ }^{10}$ González de Murillo (1991, p. 173-174).

${ }^{11}$ Corcoy Bidasolo (1989, p. 136). A autora acrescenta que a doutrina tem pretendido superar estes obstáculos situando o cuidado na categoria social do autor, transformando o "homem médio do cuidado absolutamente objetivo" no "desportista médio", no "médico médio". Chama a atenção a autora para o fato de que essas tentativas não têm eliminado todas as dificuldades; em primeiro lugar, porque, em muitos casos, não se trata de um problema de profissão, já que dentro desta as diferenças entre uns e outros são enormes. Por outro lado, a criação de uma figura retora sob considerações sobre essa área é sempre fictícia e, em certa medida, arbitrária. Por isso, busca-se uma maior individualização criando subáreas de apreciações, no sentido do "médico-chefe-cirurgião". Desta forma, a autora acrescenta, incorporam-se as capacidades superiores na medida da determinação do cuidado, chegando, por outro caminho, a conclusões muito próximas, porém não idênticas à da teoria dos poderes individuais, negando, ao mesmo tempo, sua validez (CORCOY BIDASOLO, 1989, p. 136-137).
} 
indivíduos escassamente dotados, já que os obrigaria a atuar segundo o padrão desse "homem médio"12.

Contra esse argumento, os partidários apresentam outro, de que o critério objetivo se mostra cuidadoso com o princípio da igualdade, uma vez que impede dirigir exageradas exigências ao indivíduo superdotado e permite à jurisprudência enunciar mandatos ou regras gerais de cuidado, com os quais se reforça a ideia de que as normas de conduta são padrões de comportamento mútuos, um mínimo pelo qual seus destinatários devem guiar-se, e que, ao injusto de comportamento, lhe é imprescindível um critério objetivo: "de outro modo não poderia se sustentar o princípio da confiança, que permite o fluido desenvolvimento da convivência"13.

Somando-se às críticas já expostas, mais um argumento contrário: o de que as dificuldades práticas de encontrar essa fórmula do "homem médio" se explicam por meio da simples constatação de que esse padrão em si é inalcançável; constitui uma medida não concretizável, no caso concreto. Quem seria, então, o homem razoável? Quem seria o homem consciencioso e prudente? Que aspectos deveriam ser selecionados para compor esse padrão?

Acresça-se, ainda, que, como acentua Juarez Tavares ${ }^{14}$, esse critério está em desacordo com a constituição do delito culposo

\footnotetext{
${ }^{12}$ Alguns finalistas partidários desse critério objetivo apresentam, a seu favor, os seguintes argumentos: com esse modelo se evita a mera responsabilidade pelo resultado; permite-se impor medidas de segurança, enquanto se infringe o cuidado objetivamente devido, porque se considera que concorre uma ação típica e antijurídica, ainda que, por não se haver infringido o cuidado individualmente possível, decaia posteriormente a culpabilidade (GONZÁLEZ DE MURILLO, 1991, p. 174).

${ }^{13}$ González de Murillo (1991, p. 174).

${ }^{14}$ Segundo Juarez Tavares, na aferição da tipicidade da conduta não se deve, em hipótese alguma, ter por base a figura do homem prudente, consciencioso e diligente, com cuja conduta imaginária dever-se-ia comparar a conduta realizada pelo agente. A figura do homem prudente nada mais é do que uma sofisticação
} 
A Sociedade de Risco e a Repercussão das Capacidades Individuais...

e fere o princípio da legalidade, uma vez que cria, paralelo à realidade típica, outro padrão de conduta a ser observado.

Em que pese a inteligência dos argumentos apresentados, é recomendável o abandono da utilização de figuras fictícias na aferição da ocorrência tipicamente culposa, cabíveis elas em qualquer tipo de circunstância. A composição do "homem médio" que venha a funcionar, como figura-modelo, para a determinação do dever objetivo de cuidado deve levar em consideração que ele tem de estar inserido nas condições concretas do agente, ou seja, pertencer à sua categoria intelectual e social, bem como ao seu círculo de vida.

\section{A Individualização da Capacidade do Agente: as Correntes Distintas}

Tem sido objeto de candente discussão ${ }^{15}$ a questão de saber se é necessário, para a aferição da culpa típica, levar-se em consideração, além dos aspectos objetivos, outros aspectos, os subjetivos ${ }^{16}$, na linha da individualização da capacidade do agente.

do conceito do homo medius da teoria causal, que tantos problemas já apresentou e que não possui qualquer fundamento científico. Na realidade dos fatos, a figura do homo medius será inferida de acordo com o juízo subjetivo-pessoal do próprio julgador, que, em vez de estabelecer padrão ou modelo orientador, se transfere, com todos os seus componentes, à situação do agente, determinando a conduta que deveria ser levada a efeito, segundo seu único e exclusivo entendimento do fato (1985, p. 137).

${ }^{15}$ Sobre o tema, Gabrio Forti (1990, p. 237-293).

${ }^{16}$ Carrara já enfrentava essa questão ao considerar que surge gravíssima dificuldade quanto a determinar se, nos casos concretos, o grau de culpa de um acusado deve ser medido com um critério subjetivo e individual, ou com um critério geral e abstrato: "Compreende-se, facilmente, que um mesmo fato possa representar uma desculpável culpa por parte de um roceiro ignorante e inculto e uma imperdoável e fortemente reprovável culpa, num homem instruído e civilizado. Deverá o juiz, em cada caso concreto, ponderar essas condições individuais ao determinar o 
Nessa perspectiva dogmática, têm sobressaído três correntes distintas: a primeira, e também majoritária, intitulada de Teoria da Dupla Posição; a segunda e minoritária, denominada Teoria da Individualização da Capacidade do Agente; e uma terceira corrente, que tem em Roxin seu mais representativo defensor, conhecida por Teoria Mista.

Apresentaremos a ideia basilar de cada uma dessas três correntes, na busca de evidenciar, ainda que sinteticamente, as aproximações e distanciamentos de cada uma, por meio, sobretudo, dos entendimentos individuais de seus mais destacados representantes, ao final do que cingiremos nossas conclusões.

\subsection{Teoria da Dupla Posição}

A Teoria da Dupla Posiçãa ${ }^{17}$ sustenta uma análise típica exclusivamente objetiva, relegando a totalidade dos aspectos subjetivos, referentes à capacidade individual do agente de responder à norma, para a apreciação da culpabilidade.

Como assevera Jescheck (1993, p. 512-513):

A culpa se determina conforme um duplo critério. De um lado, examina-se que comportamento seria o objetivamente devido para evitar a vulneração involuntária do bem jurídico em uma concreta situação de perigo; e de outro, se tal comportamento poderá ser exigido pessoalmente ao autor, segundo suas características e capacidades pessoais [...]. [...] Só quando se há constatado o aspecto objetivo do fato culposo, cabe examinar, ademais, se o mandato geral de cuidado e previsão haveria podido ser cumprido também

grau da culpa dos acusados? Sabemos que a qualidade das pessoas não deve ser averiguada como critério retor da medida de quantidade das penas. Mas aqui não se trata de uma quantidade de pena; trata-se, mais exatamente, de quantidade de imputação. E como negar o influxo das condições subjetivas sobre a imputabilidade do agente?" (1956, v. 1, p. 94).

${ }^{17}$ Fundamental Engisch. Apud DIAS (1999, p. 110). 
pelo autor individual, segundo sua inteligência e formação, sua habilidade e capacitação, sua experiência de vida e sua posição social (grifo do autor).

Sob essa forma de apreensão, explica Roxin (1997, p. 1014) que, se alguém provoca um acidente, mediante infrações de tráfego que não poderia evitar, em razão de que sua capacidade de conduzir o veículo era muito inferior à média, conclui-se que esse agente realizou, de modo antijurídico, o correspondente delito culposo. Contudo, por sua incapacidade individual, será excluída somente a culpabilidade culposa. Se, entretanto, o sujeito podia prever sua incapacidade, existe uma culpa objetiva e uma subjetiva no mero fato de haver conduzido (provocação culpável por empreendimento ou assunção).

Ainda nesse sentido, ver Eduardo Correia ${ }^{18}$ e Figueiredo Dias, se bem que o primeiro deles remeta os elementos autônomos da culpa para a culpabilidade.

${ }_{18}$ Eduardo Correia (1999, v. 1, p. 421-427): “Antes de tudo, a culpa é omissão de um dever objectivo de cuidado ou diligência [...].[...] Mas, se assim, da omissão daquele dever objectivo de cuidado adequado a evitar a realização de um tipo legal de crime, que impede que o agente preveja (ou preveja correctamente) os efeitos da sua conduta, intervém no problema da adequação causal da conduta o crime qual então o elemento da culpa que permite considerá-lo como parte integrante da teoria da culpa? É que a omissão do dever objectivo de cuidado, adequado a evitar a realização do tipo legal de crime, não justifica só por si, efectivamente, a censura a título de culpa. É ainda necessário que o agente possa ou seja capaz, segundo as circunstâncias do caso e as suas capacidades pessoais, de prever ou de prever correctamente a realização do tipo legal do crime. Pode, na verdade, o emprego de uma certa diligência ser exigido pela previsibilidade da produção de certo resultado, por uma conduta que se leva a cabo sem ela e, todavia, o agente, dadas as suas qualidades pessoais, não poder cumprir esse dever de diligência, v.g., porque é surdo ou porque é míope. Igualmente, pode um resultado ser normalmente previsível, mas, dada a inferioridade intelectual ou física do agente, ser-lhe de todo em todo impossível prever tal resultado. Ora, nestas hipóteses, é impossível imputar ao agente o resultado a título de culpa, já que esta é uma forma de culpabilidade e, portanto, de censura. Se o agente não pode, pois, concretamente, prever o resultado - ou não pode evitá-lo - apesar de a média das pessoas o poder fazer, não poderá ter lugar relativamente a ele qualquer censura, pois não é possível exigir-lhe outro comportamento [...]". 
Figueiredo Dias, considerando ser essa a forma teleologicamente mais correta e funcionalmente mais adequada, sustenta que a culpa - da mesma forma que o dolo - constitui uma entidade complexa, englobadora de um conjunto de elementos, dos quais uns relevam "ao nível do tipo de ilícito subjetivo", e outros, "ao nível do tipo de culpabilidade".

Exato é, segundo o autor, que a violação não dolosa do dever objetivo de cuidado deve ser considerada como elemento constitutivo do tipo de ilícito subjetivo culposo. Como, porém, a culpa não se esgota na violação não dolosa de um dever objetivo de cuidado, a ela acresce uma autônoma atitude interior, "um específico Gesinnung pessoal", que não pode ser retirado à culpabilidade: está em causa o elemento que torna a inobservância não dolosa do dever objetivo de cuidado em expressão, documentada no fato, de uma atitude pessoal descuidada ou leviana face à violação do bem jurídico ${ }^{19}$.

${ }_{19}$ Figueiredo Dias (1991, v.1, p. 52-53): “Como pode sustentar-se que dolo e culpa são entidades complexas, englobando um conjunto de elementos constitutivos dos quais uns relevam ao nível do tipo-de-ilícito subjectivo, outros ao nível do tipo-de-culpabilidade. Por minha parte, reputo esta última a forma mais correcta e funcionalmente mais adequada de decidir a questão sistemática aqui implicada, de harmonia com os dados jurídico-substanciais do problema. Considero exacto que o conhecimento e vontade de realização do tipo-de-ilícito objectivo (o "dolo-do-tipo" ou "dolo do facto") - correspondente, aliás, a uma das possíveis compreensões da categoria da finalidade - devem ser vistos como elementos constitutivos do tipo-de-ilícito subjectivo doloso; enquanto a violação do dever objectivo de cuidado deve ser tida como elemento constitutivo do tipo-de-ilícito subjectivo culposo. Por outra forma, não se dá resposta cabal e convincente às exigências de compreensão hoje postas por numerosos problemas da doutrina do crime. Mas, da mesma forma que - como é em geral reconhecido - a culpa se não esgota na violação de um dever objectivo de cuidado, também o dolo se não reduz ao conhecimento e vontade de realização do tipo-de-ilícito objectivo; antes, num caso como no outro, a estes elementos acresce uma autónoma atitude interior, um específico Gesinnung pessoal, que não podem ser retirados à culpabilidade. No dolo, trata-se do elemento que torna o conhecimento e vontade de realização do tipo-de-ilícito objectivo em expressão, documentada no facto de uma atitude pessoal contrária ou indiferente à violação do bem jurídico protegido; na culpa, do elemento que torna a inobservância do dever objectivo de cuidado em 


\subsection{Teoria da Individualização da Capacidade do Agente}

Uma opinião minoritária, mas em expansão, defendida por prestigiados autores, como Stratenwerth (1982, p. 324), Jakobs (1997, p. 380 et seq.), Gössel (1983, p. 230 et seq.), Zaffaroni (1991, p. 435), Corcoy Bidasolo (1989, p. 145), Choclán Montalvo (1998, p. 51), entre outros ${ }^{20}$, intitulada Teoria da Individualização da Capacidade ${ }^{21}$ do Agente, proclama que tanto os elementos objetivos quanto os subjetivos são imprescindíveis na análise do injusto típico.

Assim, de quem possui uma capacidade de rendimento superior ao participante habitual no tráfego jurídico, exige-se mais, de modo que, se causa um resultado por não empregar suas capacidades, pode ser castigado por culpa, embora a mesma conduta pudesse ser julgada adequada a uma pessoa normalmente capacitada. De forma diferente, se uma pessoa, em termos de capacitação, está aquém da capacidade de rendimento de uma figura-modelo, ou figura-padrão, e, nessas condições, produz um resultado típico, será considerada como quem não houvera atuado antijuridicamente, embora um indivíduo medianamente capacitado pudesse ser punido por culpa, na hipótese de concretização de conduta semelhante ${ }^{22}$. "Agora, se

expressão, documentada no facto, de uma atitude pessoal descuidada ou leviana face à violação do bem jurídico protegido".

${ }^{20}$ Segundo Roxin, ainda, Samson, Otto e Castaldo (1997, p. 1014).

${ }^{21}$ Em certas situações, não é fácil estabelecer uma linha de diferenciação entre conhecimento e capacidade, uma vez que se percebe que, às vezes, o conhecimento especial não depende da capacidade. Em face disso, um setor doutrinal renuncia à distinção e resolve o problema tratando-os conjuntamente sob o termo global capacidade. Assim, Corcoy Bidasolo (1989, p. 132 et seq.).

${ }^{22}$ Algumas críticas, naturalmente, têm sido endereçadas a essa forma de apreensão, e uma delas cinge-se à ideia de que essa teoria atentaria contra o princípio da igualdade. Quanto a esse ponto, argumenta-se, em defesa, que o que efetivamente atentaria contra o princípio da igualdade e o de justiça material seria tratar dois desiguais como iguais; exigir de todos o mesmo nível de cuidado, obrigar a que todos 
as capacidades do sujeito eram, de todo modo, suficientes para prever sua própria incapacidade, sua provocação culposa, por empreendimento ou assunção, conduz, também, na perspectiva dessa concepção, à punição por culpa"23.

Segundo seus defensores, essa teoria pode fazer supor, em princípio, que se privilegiariam o incapaz e o desatento e se obrigaria, em maior medida, ao indivíduo cuidadoso.

A correção a esse suposto equívoco baseia-se na ideia de que, nas hipóteses em que um indivíduo não tem capacidade para realizar uma determinada conduta perigosa, se fundamenta a responsabilidade culposa na aceitação dessa concreta atividade e na falta da preparação prévia. "Ao sujeito com capacidade inferior à média, não se lhe proíbe realizar a conduta sem atender ao cuidado que teria o 'homem médio', senão participar de uma atividade perigosa sem ter capacidade para tanto" ${ }^{24}$.

O mesmo raciocínio é aplicável diante da afirmação de que o sujeito com poderes inferiores pode criar mais perigo. "A vinculação dessa 'menor capacidade' ao conteúdo do cuidado necessário obriga o sujeito a atuar ou a não atuar com distintas medidas de atenção que o 'homem médio'”.

Tendo em conta, na concretização do dever objetivo de cuidado, os poderes inferiores do autor, não se prejudica ao sujeito com capacidade inferior à média, senão que, em certa medida, se lhe beneficia. Se se lhe permite realizar a atividade perigosa, ao não poder alcançar o cuidado exigido pelo modelo do homem médio, infringirá sempre o dever objetivo de cuidado ${ }^{25}$.

\footnotetext{
realizem o mesmo grau de esforço. O cuidado exigível só pode ser determinado sob considerações dos poderes reais. Ao homem, é mais acessível conhecer qual é o esforço que dele exige a sociedade do que aquele que se exigiria do "homem médio" (CORCOY BIDASOLO, 1989, p. 137).

${ }^{23}$ Roxin (1997, p. 1014).

${ }^{24}$ Corcoy Bidasolo (1989, p. 140).

${ }^{25}$ Corcoy Bidasolo (1989, p. 141).
} 
A Sociedade de Risco e a Repercussão das Capacidades Individuais...

As diferenças práticas até então citadas entre as duas teorias são bem menores do que faz supor "a veemência da polêmica sustentada a respeito" ${ }^{26}:$ 1) quando as capacidades individuais do agente estão aquém da média, estão ambas as teorias de acordo que ele não irá responder criminalmente, a saber, segundo a Teoria da Dupla Posição, pela exclusão da culpabilidade, e segundo a Teoria da Individualização da Capacidade do Agente, pela exclusão da tipicidade; 2) quando as condições pessoais do agente são superiores à média, concluem ambas diferentemente: segundo a Teoria da Dupla Posição, o agente não responderia pela razão de que teria a tipicidade afastada; segundo a Teoria da Individualização da Capacidade do Agente, o agente poderia ser responsabilizado, em razão de que os critérios de aferição da culpa seriam individualizados.

A esse respeito, manifesta-se Stratenwerth (1982, p. 324), que, ao invocar exemplos de delitos omissivos, menciona a hipótese de "se o marido de uma mulher que está se afogando somente emprega sua capacidade, como nadador, até o limite médio, apesar de ser um excelente nadador, nada duvidaria de sua responsabilidade".

E acrescenta que "o que dispõe de uma capacidade especial não tem que aplicar uma medida especial de esforço, no sentido de uma energia 'moral', senão somente suas próprias capacidades. É preciso evitar as conseqüências de elevar sempre, em geral, as exigências de cuidado até o nível de especialista excepcional, desculpando a dos demais cidadãos, precisamente por sua incapacidade".

Jakobs (1997, p. 388-389), por sua vez, sustenta que a previsibilidade objetiva não exerce nenhuma função que não desempenhe o risco permitido. Ela é tão supérflua, segundo pensa, como seria um "dolo objetivo". Ao injusto da culpa

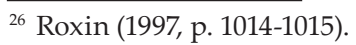


(e não somente à culpabilidade) pertence a previsibilidade subjetiva. O injusto depende, assim, das capacidades individuais do autor respectivo.

\subsection{Teoria Mista}

A última teoria, intitulada Teoria Mista, que tem em Roxin seu mais destacado representante ${ }^{27}$, tida como uma concepção intermediária entre as teorias até então apresentadas, propõe que se deva levar em consideração a capacidade individual do agente tão somente na hipótese de ser essa superior ${ }^{28}$ à média. Sendo ela, porventura, inferior ${ }^{29}$, há de ser mantido o padrão objetivo, relegando a análise individualizadora para o âmbito da culpabilidade.

Como fundamento, sustenta Roxin que é da própria estrutura sistemática do delito que deriva a conclusão de que as capacidades inferiores à média não podem excluir o injusto, senão só a culpabilidade. "A impossibilidade individual de atuar de outro modo é - ao menos nos delitos comissivos sempre um problema da culpabilidade."30 Ademais, restaria,

${ }^{27}$ E outros, como Mir Puig (1998, p. 278-279), Cramer, Kuhlen e Wieseler (apud ROXIN, 1997, p. 1015).

${ }^{28}$ Nesse sentido, Figueiredo Dias: “Preenche, por isso, aquele tipo de ilícito o médico que, dominando uma técnica cirúrgica altamente sofisticada, ou sendo mesmo o único no mundo que a domina, não usa a sua excepcional capacidade com um certo paciente que, em conseqüência, vem a falecer" (1999, p. 111).

${ }^{29}$ Ainda nesse sentido, Figueiredo Dias: “Também o automobilista que mata um peão, por erro de condução, devido a ter começado a sentir os efeitos de uma esclerose ou de um reumatismo, ou a encontrar-se diminuído nos reflexos por excesso de álcool, preenche o tipo de ilícito do homicídio negligente" (1999, p. 110).

${ }^{30}$ Roxin, a dirigir comentário à Teoria da Individualização, afirma que, para ela, restam a imputabilidade ou capacidade de culpabilidade, o conhecimento virtual da proibição e a exigibilidade como componentes de uma culpabilidade que há de se separar do injusto; porém, como a falta de imputabilidade faz diminuir 
A Sociedade de Risco e a Repercussão das Capacidades Individuais...

em parte, anulada a separação entre o injusto e a culpabilidade, se se fizesse a realização do tipo a modelos individualizadores.

Em contraposição aos adeptos da Teoria da Individualização, que defendem que o mandato legal só poderia dirigir-se a fazer o individualmente possível, aduz Roxin que a norma, na realidade, se dirige a todos, e isso se faz pela razão de deixar claro, àquele cuja capacidade de rendimento é duvidosa, o que dele se espera minimamente, e para fazê-lo abster-se de uma culpa por empreendimento ou assunção. “O que o indivíduo poderia evitar, sua infração da norma, é uma questão de culpabilidade, por regra geral, só constatável a posteriori; a infração da norma, como tal, não se elimina, pela deficiência de rendimento" ${ }^{\prime 31}$.

Finalmente, conclui, com razão ${ }^{32}$, o autor que, em matéria de tipo de ilícito culposo, vale um critério generalizador, referentemente aos indivíduos possuidores de capacidades iguais ou inferiores à média, e um critério individualizador, relativamente àqueloutros indivíduos dotados de especiais capacidades, superiores $^{33}$ à média.

decisivamente, também, o poder instrumental, ou seja, a capacidade de rendimento, a falta de culpabilidade conduz, contudo, de modo mediato, em tais casos, à exclusão do tipo (1997, p. 1015).

${ }^{31}$ Roxin (1997, p. 1016).

${ }^{32}$ Nesse sentido, Figueiredo Dias: “O critério definidor da integração do tipo de ilícito deveria pois, na culpa, ser sempre um critério individual ou individualizador, com o que, assinale-se, ter-se-ia acabado por pôr em causa a doutrina do duplo escalão sobre a qual temos feito repousar até agora todas as nossas considerações. Em nossa opinião, a razão na querela assiste a Roxin quando defende que capacidades individuais inferiores à média não podem relevar logo ao nível do tipo de ilícito culposo, no sentido de excluir a tipicidade da conduta, mas só devem ser consideradas ao nível do tipo de culpabilidade decorrente da culpa. Enquanto já as capacidades pessoais superiores à média devem ser tomadas em conta no sentido de poderem fundar o tipo de ilícito culposo" (2001, p. 369, grifos do autor).

${ }^{33}$ Roxin ressalta que, na hipótese do agente com capacidades superiores à média, dele se exige somente sua capacidade de rendimento superior, em termo médio, e não um esforço seu adicional (1997, p. 1018). 
E, segundo entendemos, uma série de razões justifica a circunstância de as capacidades inferiores à média não poderem relevar no sentido de excluir a tipicidade do delito culposo; antes, só devem relevar ao nível da culpabilidade.

Na esteira de Figueiredo Dias (2001, p. 369-370), não é exato admitir que a norma de ilicitude não se dirija, também, àqueles que não estão em condições pessoais de a cumprir; que ela possa, em suma, ser uma norma puramente individualizada, de tal modo que o Direito nunca poderia exigir senão aquilo que cada um, segundo as suas capacidades pessoais, está em condições de prestar.

Um outro argumento ressai de uma perspectiva preventiva e segundo exigências político-criminais primárias: que seria insustentável aceitar que o comportamento violador do dever objetivo daquele que não se encontre em condições pessoais de o cumprir pudesse ser considerado lícito, e contra ele não pudesse ser exercida uma ação defensiva, ou não fosse legítimo aplicar-lhe, em caso de perigosidade, uma medida de segurança ${ }^{34}$.

Por fim, adotar uma outra forma de apreensão significaria um "inadmissível esvaziamento do relevo da culpa a nível da culpabilidade, que assim ficaria reduzida ao 'puro juízo de censura' típico da doutrina mais ortodoxa da ação final: ao puro juízo de censura do qual faria parte a imputabilidade, a consciência (potencial) do ilícito, a exigibilidade, mas que não possuiria qualquer conteúdo de culpabilidade material - muito menos podendo constituir um 'tipo de culpabilidade' - e que, nesta medida, violaria irremissivelmente, como já deixamos explicado, o princípio da culpabilidade" ${ }^{\prime 35}$.

\footnotetext{
${ }^{34}$ Figueiredo Dias (2001, p. 370).

${ }^{35}$ Figueiredo Dias (2001, p. 370). Grifos do autor.
} 
Quanto às capacidades especiais, ou superiores à média, não podem elas se relevarem no sentido de excluir a tipicidade da conduta culposa, mesmo que não se revele violado o cuidado objetivamente devido - quando se tenham em vista, especificamente, as capacidades do "homem médio".

Tal afirmativa fica mais clara quando se observa o exemplo acenado por Roxin (1997, p. 1017), do cirurgião de primeiríssima qualidade, possuidor de conhecimentos técnicos e destreza que o tornam ímpar no plano internacional, que opera um paciente que vem a morrer, por não haver ele utilizado as capacidades de que dispunha, estando em condições de empregá-las, mas as capacidades correspondentes às do profissional médio. Nessa hipótese, seria inaceitável que não se imputasse a ele um comportamento tipicamente culposo ${ }^{36}$.

\footnotetext{
${ }^{36}$ Figueiredo Dias chama a atenção para a circunstância de que o agente dotado de capacidades especiais nem sempre estará em condições de as prestar, ou não lhe será exigível que esteja sempre pessoalmente disponível para um desempenho ou um rendimento máximo. "Mas, precisamente, isso revela que a circunstância de se individualizar o critério do dever de cuidado relativamente a pessoas dotadas de capacidades especiais não 'apaga' ou 'elimina' - contra o que, por vezes, se é tentado a pensar - a questão da culpabilidade por culpa, ou sequer a ela se sobrepõe: é, numa palavra, em sede de tipo de culpabilidade, não do tipo de ilícito culposo, que tem de ser considerada a questão da exigibilidade ao agente dotado de especiais capacidades de que, no caso, as tivesse efectivamente usado. Com o que fica defendida, também nesta sede, a 'doutrina do duplo escalão' na construção dogmática do delito culposo” (2001, p. 371).
} 


\section{Referências}

BECK, Ulrich. La sociedad del riesgo: Hacia una nueva modernidad. Traducción de Jorge Navarro, Daniel Jiménez e Maria Rosa Borrás. Barcelona, Buenos Aires, México: Paidós, 1998.

CARRARA, Francesco. Programa do Curso de Direito Criminal: Parte Geral. Traduzido por José Luis Franceschini e J. R. Prestes Maia. São Paulo: Saraiva, 1956. v. 1 e 2.

CHOCLÁN MONTALVO, José Antonio. Deber de cuidado y delito imprudente. Barcelona: Bosch, Casa Editorial S.A., 1998.

CORCOY BIDASOLO, Mirentxu. El delito imprudente: Critérios de imputación del resultado. Barcelona: PPU, 1989.

CORREIA, Eduardo Henriques da Silva. Direito Criminal. Reimpressão. Coimbra: Almedina, 1999. v. 1.

DIAS, Jorge de Figueiredo. Sobre o estado actual da doutrina do crime. 1a Parte: sobre os fundamentos da doutrina e a construção do tipo-de-ilícito. Revista Portuguesa de Ciência Criminal, 1, p. 9-54, 1991.

. Comentário ao artigo 137º do Código Penal. In: DIAS, Jorge de Figueiredo (Dir.). Comentário Conimbricense do Código Penal. Parte Especial. Tomo I, Artigos 131. a 201.․ Coimbra: Coimbra Editora, 1999. p. 106-115.

. Algumas reflexões sobre o Direito Penal e a Sociedade de Risco. In: SEMINÁRIO INTERNACIONAL DE DIREITO PENAL DA UNIVERSIDADE LUSÍADA. Lisboa: Universidade Lusíada, 2000.

. Temas Básicos da Doutrina Penal: Sobre os fundamentos da doutrina penal - Sobre a doutrina geral do crime. Coimbra: Coimbra Editora, 2001.

FORTI, Gabrio. Colpa ed evento nel diritto penale. Milano: Dott. A., Giuffrè Editore, 1990.

GONZÁLEZ DE MURILLO, José Luis Serrano. Teoría del delito imprudente (doctrina general y regulación legal). Madrid: Ministério de Justicia / Secretaria General Técnica - Centro de Publicaciones, 1991.

GÖSSEL, Karl-Heinz. Velhos e novos caminhos da doutrina da negligência. Boletim da Faculdade de Direito da Universidade de Coimbra, Coimbra, v. 54, p. 213-239, 1983. 
A Sociedade de Risco e a Repercussão das Capacidades Individuais...

JAKOBS, Günther. Derecho Penal: Parte General - Fundamentos y teoría de la imputación. 2. ed. Traduzido por Joaquin Cuello Contreras e José Luis Serrano Gonzalez de Murillo. Madrid: Marcial Pons, Ediciones Jurídicas S.A., 1997.

JESCHECK, Hans-Heinrich. Tratado de Derecho Penal: Parte General. 4. ed. Traducción de Luis Manzanares Samaniego. Granada: Comares, 1993.

MIR PUIG, Santiago. Derecho Penal: Parte General. 5. ed. Barcelona: Tecfoto, S.L., 1998.

MUÑOZ CONDE, Francisco. Teoría General del Delito. 2. ed. Valencia: Tirant lo Blanch, 1989.

ROXIN, Claus. Derecho Penal: Parte General. Fundamentos. La Estructura de la Teoría del Delito. n. 1. Traducción de la 2a․ edición alemana por Diego-Manuel Luzón Peña, Miguel Díaz y García Conlledo y Javier de Vicente Remesal. Madrid: Civitas, 1997.

SANTANA, Selma Pereira de. A Culpa Temerária: Contributo para uma construção no direito penal brasileiro. São Paulo: Revista dos Tribunais, 2005.

STRATENWERTH, Günter. Derecho Penal: Parte General - El hecho punible. n. 1. Traducción de la 2ª edición alemana (1976) por Gladys Romero. Madrid: Edersa, 1982.

TAVARES, Juarez. Direito Penal da Negligência: Uma Contribuição à Teoria do Crime Culposo. São Paulo: Revista dos Tribunais, 1985.

WELZEL, Hans. El nuevo sistema del Derecho Penal: Una introducción a la doctrina de la acción finalista. Traducción de José Cerezo Mir. Barcelona: Ariel, 1964.

ZAFFARONI, Eugenio Raúl. Manual de Derecho Penal: Parte General. 6. ed. Buenos Aires: Ediar, 1991.

Submissão: 26/12/2013

Aceito para Publicação: 26/12/2013 


\title{
Medidas Provisórias, Constituições Estaduais e Federação
}

\author{
Provisional Executive Orders, \\ States' Constitutions, and Federation
}

\author{
Álvaro Bettanin Carrasco*
}

Resumo: $O$ presente trabalho trata de investigar a possibilidade de se prever, nas constituições dos estados da República Federativa do Brasil, autorização para que os respectivos governantes editem medidas provisórias. Aborda, ainda que de modo sucinto, as características de uma Federação, assim como analisa alguns precedentes do Supremo Tribunal Federal acerca da questão. Considerando-se o ordenamento jurídico brasileiro e também o papel atual do Poder Executivo, não se encontra proibição à previsão, nas constituições dos estados federados, de medidas provisórias, conforme já decidiu, inclusive, a mais alta Corte do País. Entretanto, a necessidade de se observar o princípio da simetria parece enfraquecer a ideia de Federação, à semelhança do que já se verificou na ordem constitucional anterior.

Palavras-chave: Medidas Provisórias. Constituições dos Estados Federados. Poder Executivo. Federação. Princípio da Simetria.

Abstract: The present paper investigates the possibility of providing in the states' constitutions of the Federative Republic of Brazil for the authorization for the respective governors to enact provisional executive orders. It approaches, even though briefly, the features of a Federation, as well as analyses some precedents of the Brazilian Supreme Court on this matter. Considering the Brazilian legal system and also the current role of the Executive Branch, it is not prohibited

* Universidade Federal do Rio Grande do Sul. 
to provide for provisional executive orders in the states' constitutions, in accordance with what has already decided the national highest Court. However, the need to comply with the federal symmetry principle seems to weaken the idea of Federation, similarly to what has been verified in the previous constitutional order.

Keywords: Provisional Executive Orders. States' Constitutions. Executive Branch. Federation. Federal Symmetry Principle.

\section{Introdução}

A par dos eventuais abusos denunciados pela doutrina acerca da utilização de medidas provisórias, ${ }^{1}$ é inegável que esses atos normativos com força de lei acabam desempenhando um importante papel no desenvolvimento de estratégias governamentais, sobretudo quando há dificuldades para uma atuação coordenada e articulada entre Governo e Parlamento. Com efeito, além de constituírem um instrumento disponível ao governante para questões de urgência e relevância, as quais não podem esperar o natural debate político intrínseco ao processo de elaboração das leis, as medidas provisórias também configuram, atualmente, uma alternativa às situações de impasse entre o Executivo e o Legislativo.

É de se notar que as exigências do Estado Social tornam necessário o desenvolvimento de políticas públicas que reclamam uma aproximação entre o governante e o legislador, de modo que não há mais como se pensar numa separação de poderes (ou de funções estatais) enquanto simples mecanismo de "equilíbrio de forças políticas" (FERREIRA FILHO, 2009b, p. 253). O Estado intervencionista realça a função governamental do

1 Vejam-se, a propósito, as críticas realizadas por Manoel Gonçalves Ferreira Filho (2009a, p. 237-241). 
Executivo, ${ }^{2}$ que passa a ser proeminente e decisivo na escolha do projeto político que irá ditar os rumos do País (não se limitando, portanto, à mera execução desse projeto), sem prejuízo do controle que deve ser exercido pelo Parlamento (FERREIRA FILHO, 2009b, p. 262-268).

A descrição desse panorama, que evidentemente é passível de uma análise mais profunda, tem aqui o objetivo apenas de destacar a relevância do tema ora proposto. O que se pretende investigar neste trabalho, na verdade, é a possibilidade de utilização de medidas provisórias pelos estados da Federação e a concepção de sistema federativo subjacente a essa questão.

Para tanto, será realizado um pequeno estudo acerca da forma federativa de Estado, de extrema utilidade na busca de algumas possíveis respostas ao problema ora suscitado. Também é absolutamente pertinente observar-se a posição adotada pelo Supremo Tribunal Federal acerca da matéria, realizando-se, por fim, uma análise crítica dessa posição com base no referencial teórico adotado.

\section{Estado Federal: Ordem Jurídica Total e Ordens Jurídicas Parciais}

O estudo da forma de um Estado é, em linhas gerais, a verificação do modo como é repartido o poder no território desse Estado (SOUZA JUNIOR, 2002b, p. 23). Dentre as diversas hipóteses de estruturação territorial, há aquela que aqui interessa: o Estado Federal.

2 Sobre a distinção entre as funções de chefia de Estado, chefia de Governo e Chefia da Administração, todas concentradas no Poder Executivo, de acordo com a teoria clássica de tripartição dos poderes (que, por isso mesmo, é passível de ser superada), imprescindível é o estudo de Cezar Saldanha Souza Junior (2002a). 
Difícil é uma conceituação precisa de Estado Federal, tendo em vista as múltiplas formas de organização do espaço estatal assumidas ao longo da história, de acordo com as tradições, necessidades e peculiaridades dos povos (CARRAZZA, 2005, p. 124). Apesar disso, pode-se dizer que uma Federação caracteriza-se, essencialmente, por um Estado soberano composto de entes com certa autonomia política, constitucional, legislativa e administrativa, advinda diretamente de uma Constituição, na qual se fundamenta a unidade indissolúvel desses entes e a identidade de seu povo. ${ }^{3}$

Numa perspectiva estritamente jurídica, um Estado Federal pressupõe a existência conjunta de diversos ordenamentos distintos: uma ordem total, que se refere a toda a Federação e limita a autonomia das unidades federadas; uma ordem parcial central, que diz respeito às competências do poder centralizado; e várias ordens jurídicas parciais locais, as quais correspondem às competências distribuídas aos demais entes da Federação, e têm âmbito de vigência em frações do território nacional (KELSEN, 1934, p. 261-263).

No caso do ordenamento brasileiro, essa característica do Estado Federal pode ser claramente constatada. De fato, assim dispõe o artigo 18 da Constituição da República: “A organização político-administrativa da República Federativa do Brasil compreende a União, os Estados, o Distrito Federal e os Municípios, todos autônomos, nos termos desta Constituição".

Em outras palavras: a República Federativa do Brasil, isto é, a ordem total, compreende as ordens parciais da União, dos estados, do Distrito Federal e dos municípios. Os estados federados organizam-se por meio de suas constituições estaduais, enquanto o Distrito Federal e os municípios organizam-se

\footnotetext{
3 Nesse sentido, a compreensão de Carlos Eduardo Dieder Reverbel (2007, p. 53-54). Apesar da diversidade de entes federados, há uma nacionalidade federal (comum) dos indivíduos (KELSEN, 1979, p. 382).
} 
por meio de leis orgânicas, sempre observadas as limitações estabelecidas pela Constituição da República.

No tocante à União, a sua organização vem regulada na própria Constituição de 1988, de modo que no mesmo documento normativo é possível encontrar, além do conjunto de dispositivos aplicáveis ao Estado Federal, a ordem parcial específica do poder central (KELSEN, 1934, p. 273). ${ }^{4}$ É necessário, portanto, que se faça a distinção entre Constituição da República (ordem total) e Constituição Federal ou da União (ordem parcial), embora a determinação dos limites entre uma e outra certamente seja fonte de controvérsias e haja a utilização genérica da expressão "Constituição Federal".

Os dispositivos referentes à edição de medidas provisórias pelo Presidente da República, nesse contexto, parecem referir-se à Constituição da União, de maneira que tais normas constitucionais dizem respeito apenas à ordem jurídica central. Tal circunstância, por si só, não configura uma proibição constitucional à adoção de medidas provisórias pelos estados.

É preciso que se verifique, então, se a previsão de medidas provisórias nas constituições estaduais é incompatível com os princípios e regras da Constituição da República (ordem total). ${ }^{5}$ Oportuna, neste momento, uma busca a precedentes do Supremo Tribunal Federal sobre o assunto, uma vez que aquela Corte é a intérprete final das normas constitucionais.

\footnotetext{
4 À mesma conclusão parece ter chegado Geraldo Ataliba (1980, p. 69), também com base na teoria de Kelsen.

5 José Afonso da Silva, aliás, já afirmou que há violação ao princípio da separação de poderes: "E medidas provisórias, podem as Constituições estaduais instituí-las? Em edições anteriores, respondemos que nada justificava sua existência no âmbito estadual, mas não víamos proibição em que o fizessem. Até onde sabemos, os Estados (e também os Municípios) evitaram adotá-las. E hoje, re melius perpensa, achamos ponderável o argumento de que, sendo exceção ao princípio da divisão de poderes, só vale nos limites estritos em que foram elas previstas na Constituição Federal, ou seja, apenas no âmbito federal, não se legitimando seu acolhimento nem nos Estados nem nos Municípios" (1996, p. 578, grifo do autor).
} 


\section{A Posição do Supremo Tribunal Federal}

Três precedentes serão aqui considerados paradigmáticos para ilustrar o entendimento do Supremo Tribunal Federal acerca das medidas provisórias nas constituições estaduais.

No primeiro deles, tratava-se de medida cautelar na ação direta de inconstitucionalidade n. 812, na qual se impugnavam os seguintes dispositivos da Constituição do Estado de Tocantins:

Art. 27

[...]

§ 3ํ․ Em caso de relevância e urgência, o Governador do Estado poderá adotar medidas provisórias, com força de lei, devendo submetê-las de imediato à Assembléia Legislativa que, estando em recesso, será convocada extraordinariamente para se reunir no prazo de cinco dias.

$\S 4^{\mathrm{o}}$. As medidas provisórias perderão eficácia, desde a edição, se não forem convertidas em lei no prazo de trinta dias, a partir de sua publicação, devendo a Assembléia Legislativa disciplinar as relações jurídicas delas decorrentes.

Debruçando-se sobre a questão de maneira superficial, pois se analisava pedido de liminar, o Supremo Tribunal Federal considerou não haver, em princípio, violação da Constituição da República, tendo em vista a ausência de proibição expressa à previsão de medidas provisórias no âmbito estadual. O acórdão restou assim ementado:

Ação direta de inconstitucionalidade. PARS. 3. e 4. do artigo 27 da Constituição do Estado de Tocantins. Adoção de Medida Provisória no âmbito estadual. Pedido de liminar. - Não ocorrência, no caso, dos requisitos da concessão da cautelar. Pedido de liminar indeferido (BRASIL, STF, ADI 812 MC, Relator(a): Min. Moreira Alves, Tribunal Pleno, julgado em 01/04/1993, DJ 14-05-1993).

Essa ação direta acabou sendo julgada extinta sem resolução de mérito, sob o fundamento de que houve perda 
superveniente da legitimidade ativa do Partido Democrata Cristão, pois esse partido político deixou de ter representação parlamentar no Congresso Nacional.

De qualquer forma, as normas estaduais questionadas foram novamente objeto de análise pela Corte Constitucional, em sede de preliminar na ação direta de inconstitucionalidade n. 425. Nessa ação, o pedido não era exatamente o de julgar inconstitucional a previsão da edição de medidas provisórias pelo governo do Estado de Tocantins, eis que a demanda foi promovida para retirar do ordenamento determinadas leis estaduais resultantes da conversão daqueles atos normativos. Entretanto, dada a ligação dessa questão com a discussão acerca da competência para o governador valer-se de medidas provisórias, o Supremo Tribunal Federal acabou enfrentando o tema.

Como já sinalizado no precedente anteriormente citado, a Corte entendeu não haver restrição (vedação) constitucional quanto ao uso de medidas provisórias pelos estados federados, desde que adotadas as linhas básicas do modelo federal (aplicação do princípio da simetria quanto ao processo legislativo). De acordo com o voto do Ministro Relator, Maurício Correa, também nos estados pode haver a necessidade de o governador lançar mão do referido instrumento legislativo, à semelhança do que ocorre no âmbito da União, nada justificando a proibição cogitada.

Acrescentou o Ministro Celso de Mello que o artigo 25, $\S 2^{\circ}$, da Constituição da República não permite entendimento em sentido diverso, porquanto esse dispositivo veda aos estados federados a regulamentação, por meio de medidas provisórias, da exploração dos serviços locais de gás canalizado. Estaria autorizada, portanto, a utilização de medidas provisórias para outras matérias. 
Medidas Provisórias, Constituições Estaduais e Federação

A ementa da decisão é a seguinte:

AÇÃO DIRETA DE INCONSTITUCIONALIDADE. PRELIMINAR. CONSTITUIÇÃO DO ESTADO. PROCESSO LEGISLATIVO. MEDIDA PROVISÓRIA. COMPETÊNCIA DO GOVERNADOR PARA EDITÁ-LA. AUMENTO DE REMUNERAÇÃO DE SERVIDORES PÚBLICOS. INICIATIVA. DOAÇÃOO DE BENS DO ESTADO. MAJORAÇÃO DO PERCENTUAL DE PARTICIPAÇÃO DOS MUNICÍPIOS NA ARRECADAÇÃO DO ICMS. EFICÁCIA LEGAL LIMITADA NO TEMPO. PREJUDICIALIDADE. 1. Podem os Estadosmembros editar medidas provisórias em face do princípio da simetria, obedecidas as regras básicas do processo legislativo no âmbito da União (CF, artigo 62). 2. Constitui forma de restrição não prevista no vigente sistema constitucional pátrio (CF, $\S 1^{\circ}$ do artigo 25$)$ qualquer limitação imposta às unidades federadas para a edição de medidas provisórias. Legitimidade e facultatividade de sua adoção pelos Estadosmembros, a exemplo da União Federal. [...] (BRASIL, STF, ADI 425, Relator(a): Min. Maurício Corrêa, Tribunal Pleno, julgado em 04/09/2002, DJ 19-12-2003).

Essa posição restou consolidada no julgamento da ação direta de inconstitucionalidade n. 2.391, em que se questionava a constitucionalidade dos seguintes dispositivos da Constituição de Santa Catarina:

Art. 51. Em caso de relevância e urgência, o Governador do Estado poderá adotar medidas provisórias, com força de lei, devendo submetê-las de imediato à Assembléia Legislativa, que, estando em recesso, será convocada extraordinariamente no prazo de cinco dias.

$\S 1^{0}$ As medidas provisórias perderão eficácia, desde a edição, se não forem convertidas em lei no prazo de trinta dias a partir de sua publicação, devendo a Assembléia Legislativa disciplinar as relações jurídicas delas decorrentes.

$\S 2^{2}$ É vedada a edição de medida provisória sobre matéria que não possa ser objeto de lei delegada. 
$\S 3^{\circ}$ É vedada a reedição, na mesma sessão legislativa, de medida provisória não deliberada ou rejeitada pela Assembléia Legislativa. ${ }^{6}$

Após o ajuizamento da demanda proposta, os dispositivos constitucionais que regulavam as medidas provisórias editadas pelo Presidente da República sofreram profundas modificações, em razão da Emenda Constitucional n. 32, de 11 de setembro de 2001.

O Supremo Tribunal Federal, partindo da premissa de que deveria existir uma simetria com os citados dispositivos constitucionais (disciplina dada à matéria no âmbito da União), entendeu estar prejudicada a ação direta no tocante às regras constitucionais estaduais de processamento das medidas provisórias que estivessem em desacordo com as novas regras

6 Esse artigo foi alterado pela Emenda Constitucional n. 49, de 17 de julho de 2009, passando a ter a seguinte redação: "Art. 51. Em caso de relevância e urgência, o Governador do Estado poderá adotar medidas provisórias, com força de lei, devendo submetê-las de imediato à Assembléia Legislativa. $§ 1^{\circ}$ As medidas provisórias, ressalvado o disposto nos $\S \S 7^{\circ}$ e $8^{\circ}$, perderão eficácia, desde a edição, se não forem convertidas em lei no prazo de sessenta dias, prorrogável, nos termos do $\S$ 6o , uma vez por igual período, devendo a Assembléia Legislativa disciplinar, por decreto legislativo, as relações jurídicas delas decorrentes. $\S 2^{\circ}{ }^{\circ}$ vedada a edição de medida provisória sobre matéria que não possa ser objeto de lei delegada. § $3^{0}$ É vedada a reedição, na mesma Sessão Legislativa, de medida provisória não deliberada ou rejeitada pela Assembleia Legislativa. $\S 4^{\circ} \mathrm{O}$ prazo a que se refere o § 1ํ contar-se-á da publicação da medida provisória, suspendendo-se durante os períodos de recesso da Assembleia Legislativa. $§ 5^{\circ}$ Se a medida provisória não for apreciada em até quarenta e cinco dias, contados de sua publicação, entrará em regime de urgência, ficando sobrestadas, até que se ultime a votação, todas as demais deliberações legislativas da Assembleia Legislativa. § $6^{\circ}$ Prorrogar-se-á uma única vez por igual período a vigência de medida provisória que, no prazo de sessenta dias, contado de sua publicação, não tiver a sua votação encerrada na Assembleia Legislativa. $\S 7^{\circ}$ Não editado o decreto legislativo a que se refere o $\S 1^{\circ}$ até sessenta dias após a rejeição ou perda de eficácia de medida provisória, as relações jurídicas constituídas e decorrentes de atos praticados durante a sua vigência conservar-se-ão por ela regidas. $\S 8$ ํㅡㄹ Aprovado o projeto de lei de conversão alterando o texto original da medida provisória, esta manter-se-á integralmente em vigor até que seja sancionado ou vetado o projeto". 
estabelecidas para a União. Isso porque a mudança do parâmetro normativo teria acarretado a revogação dos dispositivos da Constituição Estadual.

Assim, remanesceu a discussão apenas acerca do caput do referido artigo 51, vale dizer, a discussão no Pretório Excelso acabou restringindo-se basicamente à possibilidade ou não de haver medidas provisórias no horizonte dos entes estaduais. O debate, aliás, foi bastante interessante, especialmente quanto ao conteúdo do princípio da separação de poderes e no que diz respeito ao papel atual do Executivo na organização estatal. ${ }^{7}$

Prevaleceu, por ampla maioria (vencido apenas o Ministro Carlos Ayres Britto), a tese de favorável à edição da Medida Provisória pelo governante estadual, sendo julgado improcedente o pedido formulado:

AÇÃO DIRETA DE INCONSTITUCIONALIDADE. ARTIGO 51 E PARÁGRAFOS DA CONSTITUIÇÃO DO ESTADO DE SANTA CATARINA. ADOÇÃO DE MEDIDA PROVISÓRIA POR ESTADO-MEMBRO. POSSIBILIDADE. ARTIGOS 62 E 84, XXVI DA CONSTITUIÇÃO FEDERAL. EMENDA CONSTITUCIONAL 32, DE 11.09.01, QUE ALTEROU SUBSTANCIALMENTE A REDAÇÃO DO ART. 62. REVOGAÇÃO PARCIAL DO PRECEITO IMPUGNADO POR INCOMPATIBILIDADE COM O NOVO TEXTO CONSTITUCIONAL. SUBSISTÊNCIA DO NÚCLEO ESSENCIAL DO COMANDO EXAMINADO, PRESENTE EM SEU CAPUT. APLICABILIDADE, NOS ESTADOS-MEMBROS, DO PROCESSO LEGISLATIVO PREVISTO NA CONSTITUIÇÃO FEDERAL. INEXISTÊNCIA DE VEDAÇÃO EXPRESSA QUANTO ÀS MEDIDAS PROVISÓRIAS. NECESSIDADE DE PREVISÃO NO TEXTO DA CARTA ESTADUAL E DA ESTRITA OBSERVÂNCIA DOS PRINCÍPIOS E LIMITAÇÕES IMPOSTAS PELO MODELO FEDERAL. 1. Não obstante a permanência, após o superveniente advento da Emenda Constitucional 32/01, do comando que confere ao Chefe do Executivo Federal o poder de adotar medidas provisórias com força de lei,

\footnotetext{
7 A leitura do acórdão, também por isso, é altamente recomendável.
} 
tornou-se impossível o cotejo de todo o referido dispositivo da Carta catarinense com o teor da nova redação do art. 62, parâmetro inafastável de aferição da inconstitucionalidade argüida. Ação direta prejudicada em parte. 2. No julgamento da ADI 425, rel. Min. Maurício Corrêa, DJ 19.12.03, o Plenário desta Corte já havia reconhecido, por ampla maioria, a constitucionalidade da instituição de medida provisória estadual, desde que, primeiro, esse instrumento esteja expressamente previsto na Constituição do Estado e, segundo, sejam observados os princípios e as limitações impostas pelo modelo adotado pela Constituição Federal, tendo em vista a necessidade da observância simétrica do processo legislativo federal. Outros precedentes: ADI 691, rel. Min. Sepúlveda Pertence, DJ 19.06.92 e ADI 812-MC, rel. Min. Moreira Alves, DJ 14.05.93. 3. Entendimento reforçado pela significativa indicação na Constituição Federal, quanto a essa possibilidade, no capítulo referente à organização e à regência dos Estados, da competência desses entes da Federação para "explorar diretamente, ou mediante concessão, os serviços locais de gás canalizado, na forma da lei, vedada a edição de medida provisória para a sua regulamentação" (art. 25, § $2^{\circ}$ ). 4 . Ação direta cujo pedido formulado se julga improcedente (BRASIL, STF, ADI 2391, Relator(a): Min. Ellen Gracie, Tribunal Pleno, julgado em 16/08/2006, DJ 16-03-2007).

Destaquem-se, por fim, as condições estabelecidas pelo Supremo Tribunal Federal para que o governador possa editar medidas provisórias: previsão expressa na Constituição Estadual e observância da simetria com o processo legislativo federal.

\section{Análise dos Precedentes}

De tudo o que se viu, pode-se inferir que o Supremo Tribunal privilegiou a Federação, garantindo, de certa forma, a autonomia dos entes estaduais. Além disso, é subjacente à posição do Pretório Excelso o reconhecimento de uma tendência a uma nova concepção do Poder Executivo, que passa a ser responsável pela condução da política nacional e pela satisfação 
das necessidades dos cidadãos, de modo que o Executivo, hoje, é Governo. ${ }^{8}$ Essa nova concepção - exigência do Estado Social - é decisiva para que não se vislumbre, na adoção de medidas provisórias pelas constituições estaduais, violação à divisão de poderes.

Apesar disso, importa notar que a referida autonomia, segundo as decisões acima citadas, sofre um balizamento bastante considerável, decorrente da aplicação do princípio da simetria. Na verdade, tal princípio acaba funcionando, ao mesmo tempo, como fundamento e limitador da utilização de medidas provisórias na esfera estadual. ${ }^{9}$

Importa ressaltar que a matéria não é tida como de reprodução compulsória. As constituições estaduais não precisam necessariamente estabelecer a possibilidade de edição de medidas provisórias pelo chefe do Executivo. Entretanto, se isso ocorrer, deve ser observado o modelo da União (a cópia desse modelo é não uma mera faculdade, como ocorre com as chamadas "normas de imitação"). ${ }^{10}$

8 Trata-se, segundo Manoel Gonçalves Ferreira Filho, de uma tendência do Direito Constitucional contemporâneo: "Se o Executivo hoje é Governo, isto resulta do fato de que é ele quem determina e conduz a política nacional. Zela pelo bem-estar do povo, regula a economia, assiste os cidadãos em muitas de suas necessidades, garante a ordem interna, a segurança internacional. Se ainda executa leis, o mais das vezes é quem as faz, legiferando por decretos-leis, medidas provisórias, leis delegadas, etc." (FERREIRA FILHO, 2009b, p. 300-301).

9 Roque Carrazza, a propósito, assim afirma: “Nada impede, porém, que, exercitando seus poderes constituintes decorrentes, os Estados, os Municípios e o Distrito Federal prevejam a edição de medidas provisórias, respectivamente, estaduais, municipais e distritais. A elas, mutatis mutandis, devem ser aplicados os princípios e limitações que cercam as medidas provisórias federais" (2005, p. 270-271, nota 35 , grifos do autor). Alexandre de Moraes (2006, p. 617), por sua vez, sustenta que as alterações do modelo federal referentes às medidas provisórias, especialmente as decorrentes da Emenda Constitucional n. 32/01, não podem ser contrariadas pelas constituições estaduais.

${ }^{10}$ De acordo com Raul Machado Horta, “A norma de reprodução não é, para os fins da autonomia do Estado-Membro, simples norma de imitação, freqüentemente encontrada na elaboração constitucional. As normas de imitação exprimem a cópia 
O entendimento de que é necessária a simetria com o processo legislativo federal talvez seja uma herança de dispositivos da Constituição de 1967. Com efeito, assim dispunha o seu artigo 13, III:

Art 13 - Os Estados se organizam e se regem pelas Constituições e pelas leis que adotarem, respeitados, dentre outros princípios estabelecidos nesta Constituição, os seguintes:

$[\ldots]$

III - o processo legislativo; redação:

O artigo 188 daquela Carta, por sua vez, tinha a seguinte

Art 188 - Os Estados reformarão suas Constituições dentro em sessenta dias, para adaptá-las, no que couber, às normas desta Constituição, as quais, findo esse prazo, considerar-se-ão incorporadas automaticamente às cartas estaduais.

Parágrafo único - As Constituições dos Estados poderão adotar o regime de leis delegadas, proibidos os decretos-leis.

Com o advento da Constituição de 1969 (Emenda Constitucional n. 1, de 17 de outubro de 1969), a situação não mudou. Ao contrário, além de ser mantida a norma do citado artigo 13, foi suprimido o prazo outrora estabelecido pelo artigo 188 acima transcrito:

Art. 200. As disposições constantes desta Constituição ficam incorporadas, no que couber, ao direito constitucional legislado dos Estados.

Parágrafo único. As Constituições dos Estados poderão adotar o regime de leis dêlegadas, proibidos os decretos-leis.

de técnicas ou de institutos, por influência de sugestão exercida pelo modelo superior. As normas de reprodução decorrem do caráter compulsório da norma constitucional superior, enquanto a norma de imitação traduz a adesão voluntária do constituinte [estadual] a uma determinada disposição constitucional"' (2002, p. 73). 
Como se pode observar, era efetivamente limitadíssima a autonomia dos estados federados, a ponto de José Afonso da Silva (1996, p. 101) referir que a Federação, naquela época, era apenas "nominal". ${ }^{11}$ De fato, quase nenhum espaço sobrava para a atividade do constituinte estadual, que se via obrigado a seguir uma padronização quase absoluta. Nesse contexto, era natural pensar-se na existência de uma simetria entre as "diversas" ordens jurídicas da Federação.

Esse quadro, entretanto, modificou-se substancialmente com a Carta de $1988 .^{12}$ Não há dúvidas de que os dispositivos constitucionais atualmente vigentes, correspondentes aos da ordem constitucional anterior, são menos uniformizadores.

O artigo 25 da Constituição da República, a propósito, tem o seguinte teor: "Os Estados organizam-se e regem-se pelas Constituições e leis que adotarem, observados os princípios desta Constituição". No mesmo sentido, o artigo 11 do Ato das Disposições Constitucionais Provisórias: “Cada Assembléia Legislativa, com poderes constituintes, elaborará a Constituição do Estado, no prazo de um ano, contado da promulgação da Constituição Federal, obedecidos os princípios desta."

${ }^{11}$ Cezar Saldanha Souza Junior, tratando da Constituição de 1969, explica: "Alguns, no campo do governo, falaram da adoção de um novo modelo de federalismo, mais centralizado, ofederalismo de integração. Outros, mais exaltados, no campo da oposição, chegaram a sustentar que a nova ordem abolira, pelo menos na prática, a Federação" (2002b, p. 75, grifos do autor).

${ }^{12}$ Nesse sentido, a posição de Manoel Gonçalves Ferreira Filho: "As regras estabelecidas para o processo legislativo no plano federal já não são obrigatórias para os Estados federados. Não há na Constituição em vigor norma equivalente ao art. 200 da Emenda n. 1/69, o qual incorporava, no que coubesse, ao Direito Constitucional estadual as disposições constantes da Lei Magna Federal. Ora, por julgamento unânime da doutrina e da jurisprudência, um dos pontos em que essa incorporação cabia era exatamente o processo legislativo, ex vi do art. 13, III, da Emenda n. 1/69" (2009a, p. 254). 
Da simples leitura e comparação entre os dispositivos transcritos é possível constatar que a autonomia dos entes estaduais é limitada, atualmente, apenas pelos princípios constitucionais, os quais, aliás, geralmente dizem respeito aos valores sobre os quais é construída a unidade nacional. ${ }^{13}$ Logo, tais princípios fazem parte da ordem total, a qual deve ser obedecida também pela ordem parcial da União. Não há mais a uniformização imposta pelo regime constitucional anterior, de modo que é questionável a aplicação do princípio da simetria com relação ao processo legislativo do poder central (FERREIRA FILHO, 2009a, p. 254-255). ${ }^{14}$

O próprio Supremo Tribunal Constitucional, após a promulgação da Constituição da República, cogitou a hipótese de garantir maior autonomia aos entes estatais quanto ao processo legislativo. É o que se pode extrair do voto prolatado pelo Ministro Célio Borja, no julgamento da Medida Cautelar na Ação Direta de Inconstitucionalidade n. 216, do qual se transcreve o seguinte trecho:

Dir-se-á que na Constituição Federal vigente permanece entre os princípios sensíveis, de obrigatória observância pelos Estados, o sistema representativo (art. 34, VII, a, da Constituição Federal).

Ora, no conceito de sistema representativo não está incluído, necessariamente, o de processo legislativo, mormente com

${ }^{13}$ Esses princípios, segundo Manuel Gonçalves Ferreira Filho, "são os enumerados no art. 34, VII [da Constituição da República], ou seja: 'a) forma republicana, sistema representativo e regime democrático; b) direitos da pessoa humana; c) autonomia municipal; d) prestação de contas da administração pública, direta e indireta; e) aplicação do mínimo exigido da receita resultante de impostos estaduais, compreendida a proveniente de transferências, na manutenção e desenvolvimento do ensino e nas ações e serviços públicos de saúde (acrescentado pela EC n. 29/00)"' (2009c, p. 60).

${ }^{14}$ Roger Stiefelmann Leal [entre 1996 e 2004] também aponta a forma centralizadora como tem sido interpretado o sistema federativo brasileiro, a despeito da maior autonomia estabelecida aos entes estaduais pela Constituição de 1988. 
o alcance e o conteúdo que a Constituição brasileira lhe dá - elaboração, redação, alteração e consolidação das leis (art. 59 e seu parágrafo único, grifos do autor). ${ }^{15}$

\section{Entretanto, como já se deixou transparecer, acabou preva- lecendo a tese mais centralizadora, mantendo-se o espírito da Constituição de 1969. Uma leitura das constituições estaduais ilustra essa situação, pois não é necessário muito esforço para}

${ }^{15}$ Eis a ementa do julgado: "AÇÃO DIRETA DE INCONSTITUCIONALIDADE CONSTITUIÇÃO ESTADUAL - PROCESSO LEGISLATIVO - A QUESTÃO DA OBSERVÂNCIA COMPULSÓRIA, OU NÃO, DE SEUS PRINCÍPIOS, PELOS ESTADOS-MEMBROS - NOVA CONCEPÇÃO DE FEDERALISMO CONSAGRADA NA CONSTITUIÇÃO DE 1988 - PERFIL DA FEDERAÇÃO BRASILEIRA - EXTENSÃO DO PODER CONSTITUINTE DOS ESTADOS-MEMBROS - RELEVO JURÍDICO DO TEMA - SUSPENSÃO LIMINAR DEFERIDA. O perfil da Federação brasileira, redefinido pela Constituição de 1988, embora aclamado por atribuir maior grau de autonomia aos Estados-membros, é visto com reserva por alguns doutrinadores, que consideram persistir no Brasil um federalismo ainda afetado por excessiva centralização espacial do poder em torno da União Federal. Se é certo que a nova Carta Política contempla um elenco menos abrangente de princípios constitucionais sensíveis, a denotar, com isso, a expansão de poderes jurídicos na esfera das coletividades autônomas locais, o mesmo não se pode afirmar quanto aos princípios federais extensíveis e aos princípios constitucionais estabelecidos, os quais, embora disseminados pelo texto constitucional, posto que não é tópica a sua localização, configuram acervo expressivo de limitações dessa autonomia local, cuja identificação - até mesmo pelos efeitos restritivos que deles decorrem - impõe-se realizar. A questão da necessária observância, ou não, pelos Estados-membros, das normas e princípios inerentes ao processo legislativo, provoca a discussão sobre o alcance do poder jurídico da União Federal de impor, ou não, às demais pessoas estatais que integram a estrutura da Federação, o respeito incondicional a padrões heterônomos por ela própria instituídos como fatores de compulsória aplicação. Esse tema, que se revela essencial à organização político-administrativa do Estado brasileiro, ainda não foi decidido pelo Supremo Tribunal Federal. Da resolução dessa questão central, emergirá a definição do modelo de Federação a ser efetivamente observado nas práticas institucionais. Enquanto não sobrevier esse pronunciamento, impõe-se, como medida de cautela, a suspensão liminar de preceitos inscritos em Constituições estaduais, que não hajam observado os padrões jurídicos federais, de extração constitucional, concernentes ao processo legislativo". (BRASIL, STF, ADI 216 MC, Relator(a): Min. Célio Borja, Relator(a) p/ Acórdão: Min. Celso de Mello, Tribunal Pleno, julgado em 23/05/1990, DJ 07-05-1993). O julgamento da referida ação foi tido como prejudicado, haja vista a perda superveniente do seu objeto. 
perceber a grande similaridade existente entre elas, apesar das dimensões continentais do País e das notáveis peculiaridades de cada região. ${ }^{16}$

Especificamente no que concerne às medidas provisórias, a necessidade de os entes estaduais copiarem o modelo estabelecido para o Presidente da República parece não se coadunar com o sistema federativo. A propósito, se a Federação pressupõe a coexistência de ordens jurídicas parciais fundamentadas em uma ordem jurídica total, então não há propriamente uma hierarquia entre a ordem jurídica parcial da União e as demais ordens jurídicas parciais.

Destarte, não se justifica a obrigatoriedade de as constituições estaduais observarem as regras e limitações impostas à edição de medidas provisórias pelo poder central. As unidades da Federação, na verdade, devem respeitar os princípios da Constituição da República (ordem total), e é com base nesses princípios que se pode manter a unidade nacional sem que ocorra necessariamente a abstração das diversas especificidades locais.

Dessas diferentes realidades brotam, aliás, as experiências indispensáveis para o conhecimento - sempre permanente dos valores sobre os quais se estrutura toda a sociedade.

\footnotetext{
${ }^{16}$ Apesar de Roque Carrazza parecer manifestar-se favoravelmente à regulação de medidas provisórias estaduais em conformidade com as medidas provisórias da União, ele sustenta que "cada Estado-membro, no Brasil, está autorizado a elaborar livremente sua Constituição, atendendo a suas características geográficas, sociais e históricas, bem como aos desejos e aptidões do povo que nele habita" (2005, p. 152-153). Acrescenta o autor, ainda, citando Ernesto Leme, que "não há por que as Constituições estaduais serem cópias servis da Constituição Federal. Basta que obedeçam aos preceitos capitulares que ela veicula (Federação, tripartição do poder, autonomia municipal etc). Por igual modo é de estranhar-se que, num país de dimensões continentais, como o nosso, as Constituições dos Estados sejam, se não idênticas, pelo menos vazadas nos mesmos moldes. Juridicamente, assim não precisaria ser (art. 25 da CF de 1988)" (2005, p. 153, nota 44).
} 


\section{Considerações Finais}

Não há vedação na Constituição da República para a previsão de medidas provisórias nas constituições estaduais. Nesse sentido já se manifestou o Supremo Tribunal Federal, acompanhando a circunstância de que uma tripartição de poderes, concebida simplesmente como uma separação e contrabalanço de forças, não cumpre as funções hoje esperadas do Estado.

Evidentemente, a utilização abusiva desses atos normativos não pode ser tolerada. As medidas provisórias são cabíveis em hipóteses específicas e com a observância de certos limites, de modo a evitar-se uma distorção desse importante instrumento de que dispõe o governante.

Também foi possível observar que não existe mais a imposição uniformizadora característica da ordem constitucional anterior, que praticamente retirava a autonomia do legislador constituinte estadual. Em que pese esse fato, a Corte Constitucional brasileira não abandonou a noção de simetria, exigindo-a no que se refere ao processo legislativo em geral e às medidas provisórias em particular.

Várias podem ser as razões pelas quais o Supremo Tribunal Federal tem adotado essa concepção centralizadora, e não cabe neste momento investigá-las. Há quem entenda, inclusive, que é mais provável a acentuação do caráter centrípeto da Federação brasileira, tendo em vista que muito é esperado do poder central no sentido de promover o desenvolvimento, reduzir desigualdades etc. (FERREIRA FILHO, 2009b, p. 295).

Embora essa realmente possa ser uma tendência (que inegavelmente mitiga a noção de ordens jurídicas parciais sem relação hierárquica entre elas), não é necessariamente a solução mais adequada para a harmonização das diversidades e a 
manutenção da unidade do Estado brasileiro. Cezar Saldanha Souza Junior resume a questão: “Nossa realidade reclama por uma técnica centrífuga e por maior flexibilidade, orientada pelo princípio da subsidiariedade, que hoje está produzindo uma nova concepção de Federação em todo o mundo" (2002b, p. 83).

\section{Referências}

ATALIBA, Geraldo. Regime Constitucional e Leis Nacionais e Federais. Revista de Direito Público, São Paulo, n. 53-54, p. 58-76, jan./jun. 1980.

CARRAZZA, Roque Antônio. Curso de direito constitucional tributário. 21. ed. São Paulo: Malheiros, 2005.

FERREIRA FILHO, Manoel Gonçalves. Do processo legislativo. 6. ed. São Paulo: Saraiva, 2009a.

Saraiva, 2009b. . Princípios fundamentais do direito constitucional. São Paulo: . Curso de direito constitucional. 35. ed. São Paulo: Saraiva, 2009c.

HORTA, Raul Machado. Direito constitucional. 3. ed. Belo Horizonte: Del Rey, 2002.

KELSEN, Hans. Teoría general del estado. Barcelona: Labor, 1934. . Teoría general del derecho y del estado. 2. ed. México: Universidad Nacional Autónoma de México, 1979.

LEAL, Roger Stiefelmann. A autonomia do estado-membro e o papel do Supremo Tribunal Federal. Porto Alegre, UFRGS, [entre 1996 e 2004]. Disponível em: <http://www.ppgd.ufrgs.br/doutrina/leal3.htm>. Acesso em: 12 ago. 2009.

MORAES, Alexandre de. Direito constitucional. 19. ed. São Paulo: Atlas, 2006.

REVERBEL, Carlos Eduardo Dieder. Federalismo, descentralização e subsidiariedade. In: SOUZA JUNIOR, Cezar Saldanha; AVILA, Marta Marques (coord.). Direito do estado: estudos sobre federalismo. Porto Alegre: Dora Luzzatto, 2007. 
Medidas Provisórias, Constituições Estaduais e Federação

SILVA, José Afonso da. Curso de direito constitucional positivo. 11. ed. São Paulo: Malheiros, 1996.

SOUZA JUNIOR, Cezar Saldanha. O tribunal constitucional como poder: uma nova teoria da divisão dos poderes. São Paulo: Memória Jurídica, 2002a.

. Constituições do Brasil. Porto Alegre: Sagra Luzzatto, 2002b.

Submissão: $21 / 12 / 2013$

Aceito para Publicação: 21/12/2013 


\section{Imposto sobre Serviços e Planos ou Convênios Funerários: Análise Crítica do Subitem 25.03 da Lista Anexa à Lei Complementar no 116/03}

Tax on Services and Funeral Insurance Plans:

Critical Analysis of the Sub-Item 25.03 of the List Attached to Complementary Law n. 116/03

Martha Toribio Leão*

Resumo: $\mathrm{O}$ artigo aborda o tema da incidência do Imposto sobre Serviços (ISS) sobre a venda de planos ou convênios funerários, enquanto contratos atípicos pelos quais uma pessoa contrata e paga, em vida, pelos serviços funerários que devem ser prestados quando do seu falecimento. Para isso, parte da análise do critério material da hipótese de incidência do ISS, bem como do papel da lei complementar dentro da estrutura desse imposto. Depois disso, examina de forma concreta a situação dos planos e convênios funerários a fim de demonstrar por que esse negócio jurídico não se enquadra no fato gerador do ISS.

Palavras-chave: Imposto sobre Serviços. Planos e Convênios Funerários. Serviço. Lei Complementar.

Abstract: The article approaches the issue of the Tax on Services (ISS) on the sale of funeral insurance plans, as atypical contracts by which a person hires and pays in life for the funeral services to be provided at the time of their death. For this purpose, it starts from

* Universidade de São Paulo. 
Imposto sobre Serviços e Planos ou Convênios Funerários...

the analysis of the substantial criterion of the incidence hypothesis of the ISS, as well as of the role of complementary law within the framework of this tax. After this, it concretely examines the situation of funeral insurance plans in order to demonstrate why this legal business does not fit in the taxable event of the ISS.

Keywords: Tax on Services. Funeral Insurance Plans. Service. Complementary Law.

\section{Introdução}

A diversidade dos negócios jurídicos sempre traz a necessidade de evolução e adaptação do Direito. É exatamente nessa linha que se insere a questão dos planos ou convênios funerários, enquanto contrato em que uma pessoa em vida paga pelos serviços funerários ou de cremação para o seu próprio

174 falecimento. Trata-se de negócio atípico, envolvendo a provável prestação futura, em data incerta, de serviços funerários e de cremação. Atento a essa recente modalidade negocial, o legislador complementar de 2003 incluiu um subitem específico sobre o tema na Lista Anexa à Lei Complementar nº. 116/03.

Ao fazê-lo, porém, parece ter indicado a possibilidade de que o Imposto sobre a Prestação de Serviços (ISS) incidisse tão logo fosse concretizada a contratação desse tipo de plano ou convênio funerário. O presente artigo, portanto, tem a intenção de analisar criticamente esse subitem, para ao fim demonstrar a impossibilidade de que a mera contratação de um serviço em potencial ou de uma utilidade seja considerada situação tributável para fins de ISS, à luz das regras de competência discriminadas na Constituição e no próprio Código Tributário Nacional.

Para isso, iniciaremos com a análise do critério material da hipótese de incidência do ISS e da própria função da lei complementar dentro da estrutura desse imposto. A partir 
daí, partiremos para a apreciação concreta do subitem 25.03 da Lista Anexa à Lei Complementar no. 116/03, analisando por que os planos ou convênios funerários não se consubstanciam em situação fática necessária e suficiente para a ocorrência do fato gerador do ISS. Além disso, ao final, ainda traremos alguns julgados sobre o tema, que servem como indicativo dos problemas que serão enfrentados na medida em que essas situações alcancem o Poder Judiciário.

\section{Critério Material da Hipótese de Incidência do ISS}

Em um sistema constitucionalizado como o sistema tributário brasileiro, qualquer análise acerca da possibilidade de instituição (ou não) de determinado tributo perante uma situação fática deve necessariamente partir da Constituição. Isso porque foi a própria Constituição que delimitou de forma minuciosa a discriminação das competências entre os entes federados, tendo ainda, muitas vezes, definido a própria materialidade do fato gerador.

Para o deslinde do tema ora proposto, portanto, partiremos do texto constitucional, até mesmo porque o Imposto sobre Serviços (ISS) é um desses tributos sobre os quais o constituinte já predefiniu, na outorga de competência, a delimitação do fato gerador. Nesse sentido, o artigo 156, inciso IV prevê que compete aos Municípios instituir impostos sobre serviços de qualquer natureza, não compreendidos no artigo 155, inciso I, alínea $b$ (norma de competência referente ao ICMS) e definidos em lei complementar. ${ }^{1}$ Resta claro, dessa forma, que a autorização constitucional para a tributação pelo ISS está limitada à existência de um serviço.

\footnotetext{
1 Art. 156. Compete aos Municípios instituir impostos sobre: [...] IV serviços de qualquer natureza, não compreendidos no art. 155, I, b, definidos em lei complementar.
} 
Imposto sobre Serviços e Planos ou Convênios Funerários...

Resta, então, definir qual o conceito de serviço para fins de delimitação do critério material da hipótese de incidência. No ponto, importante elucidarmos que nos filiamos à corrente que acredita que a Constituição, ao delimitar os campos de competência de cada um dos entes federados, trabalhou com conceitos e não com tipos. ${ }^{2}$ Entendemos, apesar de ilustres posicionamentos em contrário ${ }^{3}$, que o legislador constituinte discriminou a competência impositiva mediante referência a conceitos determinados. Com efeito, como já explicitado por Paulo Ayres, afirmar que é o legislador infraconstitucional quem vai definir as referências sígnicas constitucionais implicaria esvaziar, por completo, o esforço do constituinte de 1988 na repartição das competências impositivas. Seria o mesmo que dizer que ele teria elaborado uma discriminação de competências, para nada discriminar. ${ }^{4}$ Estabelecida essa premissa, podemos nos ater a definir qual é o conceito constitucional de serviço.

Ao utilizar o termo "serviços" na regra de competência tributária municipal, sem conceituá-lo de forma diversa, a Constituição incorporou o conceito infraconstitucional

2 Sobre o tema, vide, por todos: SCHOUERI, Luís Eduardo. Normas Tributárias Indutoras e Intervenção Econômica. Rio de Janeiro: Forense, 2005; DERZI, Misabel de Abreu Machado. Direito Tributário, Direito Penal e Tipo. São Paulo: Revista dos Tribunais, 1988.

${ }^{3}$ Nesse sentido, Luís Eduardo Schoueri é firme ao defender que o constituinte utilizou-se de tipos, e não conceitos, ao delimitar as esferas de competência, afirmando que os signos utilizados seriam "meros nomes dados historicamente a impostos já existentes. Por isso, afirmamos que o constituinte não conceituou os impostos pertencentes a cada esfera tributante, apenas nominou-os contemplando um todo. Valendo-nos das lições da teoria geral do direito, concluímos que o constituinte apenas contemplou a realidade a partir de tipos" (SCHOUERI, Luís Eduardo. Discriminação de Competências e Competência Residual. In: SCHOUERI, Luís Eduardo; ZILVETI, Fernando Aurélio (Org.). Direito Tributário: Estudos em Homenagem a Brandão Machado. São Paulo: Dialética, 1998. p. 115).

4 BARRETO, Paulo Ayres. Elisão Tributária: Limites Normativos. São Paulo: USP, 2008. p. 73. 
pré-constitucional de obrigação de fazer, cujo núcleo semântico é o esforço humano compreendido em benefício de outrem. ${ }^{5}$ O próprio Tribunal Pleno do Supremo Tribunal Federal já se manifestou sobre o tema, ao analisar a instituição do ISS relativamente aos contratos de locação, tendo decidido que o conceito de serviço seria aquele previsto no direito infraconstitucional pré-constitucional, qual seja, o conceito de obrigação de fazer previsto no Código Civil. ${ }^{6}$

Considerando esse ponto de partida e seguindo as lições de Paulo de Barros Carvalho, de que o critério material é o núcleo da hipótese de incidência e é formado, invariavelmente, por um verbo e seu complemento ${ }^{7}$, no caso do ISS, o critério material não pode ser outro senão a expressão "prestar serviço". Para configurá-lo, é necessário que ocorra o exercício, por parte de alguém (no caso, o prestador), de atuação que tenha por objetivo produzir uma utilidade relativamente a outra pessoa (no caso, o tomador), a qual remunera o prestador (preço do serviço).

Em outras palavras, trata-se de uma atividade irreflexiva, que reivindica um caráter bilateral e oneroso. ${ }^{8}$ Aires Barreto, na mesma direção, é firme em afirmar que a essência da hipótese

\footnotetext{
${ }^{5}$ Nesse sentido: AVILA, Humberto. Imposto sobre a Prestação de Serviços de Qualquer Natureza. ISS. Normas constitucionais aplicáveis. Precedentes do Supremo Tribunal Federal. Hipótese de incidência, base de cálculo e local da prestação. Leasing financeiro: análise da incidência. Revista Dialética de Direito Tributário, v. 182, São Paulo, p. 133-144, nov. 2010.

6 Recurso Extraordinário n⿳ำ 116.121-3, STF, Tribunal Pleno, Relator: Ministro Octávio Gallotti, Relator para acórdão: Ministro Marco Aurélio, julgado em 11.10.00, DJ 25.05.01, p. 17.

7 CARVALHO, Paulo de Barros. Curso de Direito Tributário. 23. ed. São Paulo: Saraiva, 2011. p. 325. Sobre o tema, vide também: ATALIBA, Geraldo. Hipótese de Incidência Tributária. São Paulo: Revista dos Tribunais, 1973. p. 111; SCHOUERI, Luís Eduardo. Direito Tributário. São Paulo: Saraiva, 2011. p. 446.

8 CARVAlHO, Paulo de Barros. Direito Tributário, Linguagem e Método. 3. ed. São Paulo: Noeses, 2009. p. 767-768.
} 
Imposto sobre Serviços e Planos ou Convênios Funerários...

de incidência do ISS não está no termo "serviço" isoladamente considerado, mas na atividade humana que dele decorre, vale dizer, na prestação de serviço. $\mathrm{O}$ aspecto material da hipótese de incidência é a conduta humana (prestação de serviço) consistente em desenvolver um esforço visando a adimplir uma obrigação de fazer. ${ }^{9}$

Nesse sentido, a prestação de serviço deve envolver necessariamente uma obrigação de fazer e não de dar. Essa constatação decorre não apenas da natureza do termo serviço, mas também da própria análise conjunta da discriminação de competências prevista na Constituição. O postulado da unidade do ordenamento jurídico implica a necessária relação entre parte e conjunto, de tal sorte que a interpretação da norma pressupõe a do sistema do qual ela faz parte e vice-versa. ${ }^{10}$

Para Humberto Ávila, o conjunto de normas pertencentes ao direito tributário será formado pela compreensão sistemática dos dispositivos que, expressa ou implicitamente, imediata ou mediatamente, entrem em contato com os bens jurídicos restringidos na concretização da relação obrigacional tributária. Sendo assim, a delimitação dos contornos do critério material também pode ser extraída da Constituição por meio da sua distinção relativamente a outras hipóteses de incidência que a própria Carta Magna estabelece, isto é, por meio de delimitação negativa das regras de competência. ${ }^{11}$

A Constituição atribuiu aos Estados e Municípios competência para tributar diferentes situações demonstrativas de capacidade econômica. Aos primeiros, permitiu a instituição

\footnotetext{
9 BARRETO, Aires F. Curso de Direito Tributário Municipal. São Paulo: Saraiva, 2009. p. 319-320.

${ }^{10}$ ALEXY, Robert. Juristiche Interpretation. In: Recht, Vernunft, Diskurs. Frankfurt am Main: Suhrkamp, 1995. p. 75.

${ }^{11}$ ÁVILA, Humberto. Conceito de renda e compensação de prejuízos fiscais. São Paulo: Malheiros. p. 14; 33.
} 
de impostos sobre "operações relativas à circulação de mercadorias" (art. 155, inciso II, da Constituição). Aos segundos, atribuiu o poder de tributar os "serviços de qualquer natureza, não compreendidos no art. 155, inciso II, definidos em lei complementar" (art. 156, inciso III, da Constituição). Sobre o ponto, Paulo Ayres e Eurico de Santi, em parecer exarado em conjunto, afirmam que a conotação do termo utilizado na definição constitucional das competências tributárias (renda, prestação de serviços, importação, exportação etc.) é que irá demarcar os lindes laterais da atuação legislativa dos entes tributantes. ${ }^{12}$

Na mesma linha, Roberto Quiroga Mosquera é firme ao apontar que a repartição de competências na Carta Magna elencou situações de vida distintas e que estes fatos representam realidades diferentes, apresentando características particulares e específicas. Logo, os conceitos diferentes utilizados pelo constituinte não podem ser misturados, indicando uma diferenciação que precisa ser respeitada. ${ }^{13}$ Em outras palavras, as situações fáticas passíveis de tributação já foram desenhadas e separadas pelo constituinte, cabendo ao legislador infraconstitucional se submeter a elas, sob pena de incorrer em inconstitucionalidade.

Diante disso, está claro que as regras constitucionais delimitaram as competências tributárias do seguinte modo:

\footnotetext{
${ }^{12}$ SANTI, Eurico Marcos Diniz de; BARRETO, Paulo Ayres. Contribuições para Previdência Privada - Dedutibilidade em face do Imposto sobre a Renda - Força da EC 20/98 - Aplicabilidade da Lei 9.532/97 no Tempo. Revista Dialética de Direito Tributário, v. 93, p. 125, jun. 2003.

${ }^{13}$ MOSQUERA, Roberto Quiroga. Os Impostos sobre Operações de Crédito, Câmbio, Seguro ou Relativos a Títulos ou Valores Mobiliários - Conceitos Fundamentais. In: SANTI, Eurico Marcos Diniz de; ZILVETI, Fernando Aurélio; MOSQUERA, Roberto Quiroga (Org.). Tributação Internacional e dos Mercados Financeiro e de Capitais. São Paulo: Quartier Latin, 2005. p. 103-104. Também nesse sentido: Renda e proventos de qualquer natureza: o imposto e o conceito constitucional. São Paulo: Dialética, 1996. p. 81.
} 
Imposto sobre Serviços e Planos ou Convênios Funerários...

o imposto sobre serviços incide sobre o esforço humano, isto é, sobre as obrigações de fazer (exceto sobre as prestações de serviços de transporte interestadual e intermunicipal e de comunicação), e o imposto sobre circulação de mercadorias incide sobre a transferência de bens, ou seja, sobre as obrigações de dar.

Não há dúvida, portanto, acerca da obrigatoriedade de que a atividade realizada pelo prestador apresente-se sob a forma de obrigação de fazer, só sendo possível a incidência de ISS se houver negócio jurídico mediante o qual uma das partes se obrigue a praticar certa atividade, de natureza física ou intelectual, recebendo, em troca, remuneração. ${ }^{14}$ Nessa linha, o artigo $1^{\circ}$ da Lei Complementar $n^{\circ}$. 116/03 nada mais fez do que explicitar o que já estava definido pela Constituição, ao afirmar que o fato gerador do ISS é a prestação de serviços, já em seu artigo 1o: "o Imposto Sobre Serviços de Qualquer Natureza, de competência dos Municípios e do Distrito Federal, tem como fato gerador a prestação de serviços constantes da lista anexa, ainda que esses não se constituam como atividade preponderante do prestador".

Em resumo, são intransponíveis os limites conceituais previstos nas regras de competência. Fora deles, não há poder de tributar. ${ }^{15}$ A esse respeito, já decidiu o próprio Supremo Tribunal Federal, ao asseverar que o intérprete "[...] não deve ir além dos limites semânticos, que são intransponíveis". ${ }^{16}$

\footnotetext{
${ }^{14}$ CARVALHO, Paulo de Barros. Direito Tributário, Linguagem e Método. 3. ed. São Paulo: Noeses. 2009. p. 768.

${ }^{15}$ Também nesse sentido: TORRES, Heleno. A Hipótese do ICMS sobre Operações Mercantis na Constituição e a Solução de Conflitos Normativos. In: SCHOUERI, Luís Eduardo (Org.). Direito Tributário: Homenagem a Paulo de Barros Carvalho. São Paulo: Quartier Latin, 2008. p. 321-342.

${ }^{16}$ Recurso Extraordinário no 71.758, Relator Ministro Thompson Flores, RTJ 66, p. 150.
} 


\section{O Papel da Lei Complementar n $116 / 03$}

A Constituição expressamente conferiu à lei complementar a competência para definir quais seriam os serviços de qualquer natureza compreendidos dentro da competência municipal. $\mathrm{O}$ artigo 146, inciso III, alínea $a^{17}$ já previa a competência desse instrumento legislativo para definir o fato gerador dos impostos; no caso do ISS, porém, a Constituição ratificou esse entendimento ao prever na própria norma de competência que os serviços seriam definidos em lei complementar (art. 156, inciso IV). ${ }^{18}$

Muito já se discutiu na doutrina o alcance das funções da lei complementar em matéria tributária ${ }^{19}$, mas o fato é que, como a sua própria designação já revela, cabe a essa espécie legislativa a complementação da Constituição, atuando como norma nacional, que permite uniformidade e estabilidade para as normas tributárias em nossa Federação. Evidente, no entanto -e, por mais óbvio que isso possa parecer, é importante frisá-lo-, que essas normas estão submetidas ao texto constitucional, não podendo de forma alguma contrariá-lo, como, aliás, qualquer espécie normativa do nosso ordenamento jurídico.

\footnotetext{
${ }^{17}$ Art. 146. Cabe à lei complementar:

[...] III - estabelecer normas gerais em matéria de legislação tributária, especialmente sobre:

a) definição de tributos e de suas espécies, bem como, em relação aos impostos discriminados nesta Constituição, a dos respectivos fatos geradores, bases de cálculo e contribuintes;

${ }^{18}$ Art. 156. Compete aos Municípios instituir impostos sobre:

[...] IV - serviços de qualquer natureza, não compreendidos no art. 155, I, b, definidos em lei complementar.

${ }^{19}$ A título exemplificativo: BORGES, José Souto. Lei Complementar Tributária. São Paulo: Editora da Universidade Católica, 1975; SANTI, Eurico Marcos Diniz. O Código Tributário e as normas gerais de Direito Tributário. In: SANTI, Eurico Marcos Diniz (Org.). Curso de Direito Tributário e Finanças Públicas: do fato à norma, da realidade ao conceito jurídico. v. 1. 1. ed. São Paulo: Saraiva, 2007; ATALIBA, Geraldo. Estudos e pareceres de direito tributário. v. III. São Paulo: Revista dos Tribunais, 1980.
} 
Imposto sobre Serviços e Planos ou Convênios Funerários...

Dessa forma, o legislador infraconstitucional, ainda que em sede de lei complementar, deve ater-se à tarefa de elucidar e reforçar os comandos veiculados pelo constituinte, gerando estabilidade e uniformidade ao ordenamento, estando terminantemente vedado a extrapolar tal função, inovando e prescrevendo condutas diversas daquelas expressamente autorizadas pelo texto da Carta Magna. Vale dizer que esse lembrete é importante também para o intérprete, na medida em que o orienta no sentido de que o exame da legislação complementar há de ser efetuado de acordo com as regras constitucionais de competência. Ou, noutro dizer, de acordo com uma visão sistemática do ordenamento, respeitando-se os limites impostos pela própria Constituição à disciplina do ISS. ${ }^{20}$

A expressão definidos em lei complementar (art. 156, inciso IV da Constituição), consequentemente, não pode ser entendida como um "cheque em branco" concedido ao legislador nacional. 182 De forma alguma, a Constituição autoriza o legislador infraconstitucional a conceituar como serviço o que serviço não é. ${ }^{21}$ Isso, nas palavras de Aires Barreto, equivaleria a dizer que a lei complementar pode, a seu talante, modificar a Constituição; que a limitação posta pela Constituição à competência municipal para só tributar atividades configuradoras de serviço não tem a menor relevância, já que pode ser desobedecida por lei complementar. ${ }^{22}$

Diante disso, mesmo que se reconheça o papel imprescindível da lei complementar para a instituição do ISS, em hipótese alguma se pode reconhecer a legitimidade para que

\footnotetext{
${ }^{20}$ Nesse sentido: BARRETO, Aires F. ISS na Constituição e na Lei. 2. ed. São Paulo: Dialética, 2005. p. 106; CARVALHO, Paulo de Barros. Direito Tributário, Linguagem e Método. 3. ed. São Paulo: Noeses, 2009. p. 764-765.

${ }^{21}$ Também nessa linha: CARVALHO, Paulo de Barros. Não-Incidência do ISS sobre Atividades de Franquia (Franchising). Revista de Estudos Tributários, v. 56, p. 65-79, jul./ago. 2007.

${ }^{22}$ BARRETO, Aires F. ISS na Constituição e na Lei. 2. ed. São Paulo: Dialética, 2005. p. 108.
} 
esta imponha esse imposto sobre situações que não configurem o núcleo do critério material da hipótese de incidência expressamente definido pelo constituinte, qual seja, a existência de prestação de serviço.

Desconsiderar os limites constitucionais impostos de forma rígida e, por vezes, repetitiva na Constituição seria o mesmo que dizer que ela teria uma condicionante que, em verdade, nada condicionaria; que teria pretensos limites jurídicos que não serviriam a nenhum propósito; teria um controle que nada controlaria, como já dispôs Paulo Ayres sob outra perspectiva, mas que serve perfeitamente para o caso em tela. ${ }^{23} \mathrm{~A}$ análise de quaisquer dos (sub)itens da Lista Anexa à Lei Complementar no. 116/03, portanto, precisa partir dessa perspectiva. É o que nos propomos a fazer em seguida com relação ao subitem 25.03, relativo aos planos e convênios funerários.

\section{A Inexistência de Serviço Tributável na Simples Contratação de Plano ou Convênio Funerário}

A Lista Anexa à Lei Complementar no 116/03 prevê, em seu subitem 25.03, a tributação pelo ISS sobre os planos ou convênios funerários, nos seguintes termos:

25 - Serviços funerários.

25.01 - Funerais, inclusive fornecimento de caixão, urna ou esquifes; aluguel de capela; transporte do corpo cadavérico; fornecimento de flores, coroas e outros paramentos; desembaraço de certidão de óbito; fornecimento de véu, essa e outros adornos; embalsamento, embelezamento, conservação ou restauração de cadáveres.

25.02 - Cremação de corpos e partes de corpos cadavéricos. 25.03 - Planos ou convênio funerários.

${ }^{23}$ BARRETO, Paulo Ayres. Contribuições: Regime Jurídico, Destinação e Controle. São Paulo: Noeses, 2006. p. 167. 
Imposto sobre Serviços e Planos ou Convênios Funerários...

Como se percebe, o legislador diferenciou serviços funerários gerais (previstos no subitem 25.01) e serviços de cremação (previstos no subitem 25.02) de planos ou convênios funerários. Nesse ponto, vale explicitarmos que os planos ou convênios funerários são uma forma de contrato para prestação de serviços futuros, contratados em vida, para custear os gastos funerários ou de cremação quando o beneficiário vier a falecer. São contratos pagos de forma antecipada e sem data para serem cumpridos. Noutro dizer, trata-se de uma compra antecipada de um serviço que será provavelmente prestado no futuro, ainda que sem data certa.

Dissemos "provavelmente" porque, ainda que a morte seja certa, não é certa a existência de um corpo para a realização dos eventos fúnebres. A título exemplificativo, basta citarmos os casos de acidentes aéreos e os desaparecimentos. Ou seja, mesmo que seja provável que o serviço seja prestado em algum momento posterior, não é possível afirmar que ele será certo. Esclarecida a natureza desse tipo de plano ou convênio, cabe analisarmos o texto legal.

Em uma primeira leitura do dispositivo citado, o legislador parece ter considerado que a contratação antecipada dos serviços funerários, que serão prestados no momento da morte do beneficiário, seria um serviço diferente daquele contratado no momento do falecimento, com prestação imediata do serviço (subitens 25.01 e 25.02). Com essa diferenciação em subitens separados, poder-se-ia entender que haveria a autorização legal para cobrar ISS no ato da contratação do plano ou convênio funerário, caracterizando esse negócio jurídico como a própria prestação de serviço.

Esse contrato em si, contudo, enquanto um contrato de provável prestação de serviços no futuro, não configura desde já uma prestação de serviço. Ainda que o serviço futuro só seja prestado devido a esse negócio jurídico já firmado e 
pago, não se pode afirmar que desde a contratação do plano ou convênio exista serviço.

Reitera-se: a prestação de serviço não se confunde com o negócio jurídico no qual ela está inserida. A competência municipal refere-se à tributação de serviços de qualquer natureza, e não de contratos prevendo a prestação de serviços ou da renda ou do lucro decorrente desses contratos. Nesse sentido, o posicionamento de Aires Barreto é expresso: "o ISS é devido pelo fato de prestar serviço e não pelo negócio jurídico de que decorre a prestação. $\mathrm{O}$ que revela considerar não é a causa jurídica, mas a atividade material em que consiste o serviço". ${ }^{24}$

A única situação de fato tributável no caso dos planos ou convênios funerários é a prestação dos serviços fúnebres e de cremação, caso estes venham, de fato, a ocorrer. Portanto, o pretenso serviço tributável aqui se confunde com os serviços previstos nos subitens 25.01 e 25.02, conforme o plano firmado diga respeito a serviços fúnebres em geral ou serviços de cremação. Em outras palavras, ainda que o legislador complementar tenha indicado que entende que o próprio plano ou convênio funerário já revela uma situação tributável para fins de ISS, na medida em que o diferenciou em um subitem à parte, a verdade é que o plano em si não configura nenhuma prestação de serviço e, nesse sentido, não se coaduna com a hipótese de incidência prevista constitucionalmente para o ISS.

Nessa linha, imperioso reconhecer que a mera contratação do plano não configura serviço e não se enquadra como o fato gerador (enquanto situação necessária e suficiente para a sua ocorrência, nos termos do art. 114 do $\mathrm{CTN}^{25}$ ) para fins

\footnotetext{
${ }^{24}$ BARRETO, Aires F. Curso de Direito Tributário Municipal. São Paulo: Saraiva, 2009. p. 332.

${ }^{25}$ Art. 114. Fato gerador da obrigação principal é a situação definida em lei como necessária e suficiente à sua ocorrência.
} 
Imposto sobre Serviços e Planos ou Convênios Funerários...

de tributação pelo ISS. No entanto, caso o serviço seja efetivamente prestado no futuro, nesse momento, estarão satisfeitas as condições para a incidência da norma e, portanto, haverá fato gerador passível de tributação. Até lá, o que existe é uma simples promessa de prestação de serviço, uma utilidade ou conforto no sentido de que, caso venha a falecer, a pessoa terá direito aos cortejos fúnebres acertados contratualmente. Essa promessa de utilidade, porém, não é suficiente para a tributação, uma vez que a outorga de competência refere-se a serviço, e não a simples utilidade.

Além disso, parte da doutrina entende que a mera contratação do plano ou convênio funerário não se caracterizaria como uma obrigação de fazer, o que também excluiria a possibilidade de tributação pelo ISS. Para esses autores, o plano ou convênio se aproximaria da noção de contrato de seguro. José Eduardo Soares de Melo, por exemplo, é claro ao expor que "planos ou convênios funerários não constituem nenhuma obrigação de fazer, em razão do que não deveriam sujeitar-se à incidência do ISS"26. O argumento é de que esses planos se aproximam de um plano de seguro, como planos de saúde e planos previdenciários, e de que, nesses casos, a obrigação assumida pela empresa é uma obrigação de dar e não de fazer.

Também Natália de Nardi Dácomo segue essa linha, afirmando que os planos ou convênios funerários têm a característica de seguro, só havendo o pagamento do valor acordado em caso de morte. E, considerando que as seguradoras estão fora da abrangência do campo do ISS, pois se trata de operação financeira e não relação de prestação de serviço, a autora também conclui pela impossibilidade de cobrança sobre esse tipo de plano. ${ }^{27}$

\footnotetext{
${ }^{26}$ MELO, José Eduardo Soares de. ISS - Aspectos Teóricos e Práticos. 4. ed. São Paulo: Dialética, 2005. p. 125.

${ }^{27}$ DÁCOMO, Natalia de Nárdi. Hipótese de Incidência do ISS. São Paulo: Noeses, 2007. p. 263.
} 
É preciso, contudo, diferenciar os casos em que o plano ou convênio funerário se caracteriza como uma verdadeira relação de seguro - em que a seguradora se obriga a pagar uma quantia preestabelecida caso ocorra o sinistro (morte) $)^{28}$ daqueles casos em que há verdadeiro pagamento antecipado do serviço que será prestado diretamente pela contratada quando o contratante vier a falecer. Nessa segunda hipótese, a empresa não se obriga a um pagamento em dinheiro, mas sim à própria prestação direta do serviço, com a única diferença de que o beneficiário o pagou de forma antecipada, ainda em vida. Apenas na primeira situação o plano ou convênio se aproxima da noção de seguro, sendo que na segunda ele nada mais é do que um pagamento antecipado de prováveis serviços futuros.

Esse tipo de plano ou convênio funerário, mesmo que se aproxime da figura de plano de seguro, tem características próprias, que o tornam bastante singular. Trata-se de uma promessa de obrigação de fazer com data incerta e grande probabilidade de ser realizada, mas sem certeza. Evidentes, portanto, as dificuldades de caracterizá-lo. O que importa é que, certamente, a simples contratação dessa "promessa de serviço" não serve como figura apta a caracterizar o critério material da hipótese de incidência do ISS, uma vez que não se caracteriza, por si só, como uma prestação de serviço. Haverá prestação de serviço, porém, quando o contratante vier a falecer e a empresa efetivamente prestar de forma direta os serviços relativos aos cortejos fúnebres, havendo aí a situação necessária e suficiente para o surgimento do fato gerador do ISS e sendo cabível, então, a cobrança do ISS.

\footnotetext{
${ }^{28}$ Nesse sentido, o Código Civil: Art. 757. Pelo contrato de seguro, o segurador se obriga, mediante o pagamento do prêmio, a garantir interesse legítimo do segurado, relativo a pessoa ou a coisa, contra riscos predeterminados.
} 
Imposto sobre Serviços e Planos ou Convênios Funerários...

Com isso, percebemos como a definição do núcleo do critério material é relevante para explicitar todos os demais aspectos do fato gerador. Aceitando-se que o critério material do ISS não pode ser outro senão a própria prestação de serviço, torna-se possível a verificação dos demais critérios da hipótese de incidência, especialmente os critérios temporal e local. $\mathrm{O}$ aspecto temporal, por exemplo, deverá ser necessariamente o momento da prestação de serviços. No caso dos planos ou convênios funerários essa questão cresce em importância, uma vez que, na data da contratação do plano ou convênio funerário, e mesmo na data do seu pagamento, ainda não é possível afirmar quando o serviço será efetivamente prestado, ou seja, quando irá ocorrer o fato gerador.

Questão muito discutida na doutrina e na jurisprudência, e que pode servir também para o presente caso, diz respeito à tributação dos serviços de diversão pública. Muitos Municípios pretenderam cobrar o ISS quando da chancela dos ingressos. Esse posicionamento, no entanto, foi repudiado na doutrina. Aires Barreto, por todos, foi enfático ao repudiar a prática, afirmando que o fato "prestação de serviço", no caso de diversão pública, embora tenha início com o efetivo exercício, pelos usuários, do direito de participar, ou de assistir aos espetáculos, só se conclui e se aperfeiçoa no momento em que, adentrando o recinto, o assistente (ou participante) exerce esse direito. $\mathrm{O}$ fato gerador não é consubstanciado no direito de assistir ou no de participar do início do espetáculo, pois só se desencadeia com o término do próprio espetáculo. Antes disso - qualquer que seja o momento antecedente -, não se tem nenhum fato gerador, porque prestação de serviços não há. ${ }^{29}$

Esse mesmo entendimento, portanto, é plenamente aplicável para o caso dos planos ou convênios funerários, já que

${ }^{29}$ BARRETO, Aires F. Curso de Direito Tributário Municipal. São Paulo: Saraiva, 2009. p. 335. 
também aqui o direito de ser enterrado ou cremado conforme acertado de forma prévia no contrato não se consubstancia como prestação de serviço, o que só ocorrerá quando da efetiva prestação dos serviços fúnebres ou de cremação.

Em sentido contrário, há quem defenda que a existência de capacidade contributiva já seria suficiente para justificar a tributação antecipada dos serviços nesses casos. ${ }^{30}$ Não podemos concordar com esse posicionamento, especialmente porque a nossa Constituição não autorizou a incidência tributária a partir da mera existência de capacidade contributiva, mas sim com base em uma rígida determinação de competências materiais que precisam ser respeitadas. Ora, se os entes federativos estivessem autorizados a cobrar tributos pela simples existência da capacidade contributiva, instalado estaria o caos e todo o sistema exaustivo previsto na Constituição perderia seu sentido.

Além disso, ainda que isso não fosse motivo suficiente para a tributação pelo ISS, imperioso dizer que esses valores recebidos pela empresa não ficam descobertos da tributação, já que são incluídos na base de cálculo dos tributos sobre a renda, a receita e o lucro. Como, no entanto, o ISS não tem como materialidade nenhuma dessas grandezas, e sim os valores recebidos a título de prestação de serviços, evidente que, enquanto esses não forem efetivamente prestados, esse imposto não poderá incidir.

\footnotetext{
${ }^{30}$ Esse posicionamento pode ser verificado na própria jurisprudência do STJ, que reconheceu a possibilidade de tributação pelo ISS incidente sobre os serviços de diversão pública já no momento da venda dos ingressos: TRIBUTÁRIO - ISS DIVERSÕES PÚBLICAS - FATO GERADOR - ARTIGOS 114 E 116 DO CTN. 1. O fato gerador do ISS reside na efetiva prestação de serviço, definido em lei complementar, constante da Lista de Serviços anexa ao Decreto-Lei 406/68. 2. Em se tratando de ISS incidente sobre diversões públicas, o fato imponível se configura no momento da venda do ingresso ao consumidor, pelo que ilegítima a antecipação do recolhimento, quando da chancela prévia dos bilhetes pelo município. (REsp 159.861/SP, Rel. Ministro HUMBERTO GOMES DE BARROS, PRIMEIRA TURMA, julgado em 13/10/1998, DJ 14/12/1998, p. 109.)
} 
Imposto sobre Serviços e Planos ou Convênios Funerários...

No que toca ao aspecto local da hipótese de incidência, importante perceber que a própria Lei Complementar nํ․ 116/03 foi coerente com o critério material ao prever que se considera estabelecimento prestador o local onde o contribuinte desenvolva a atividade de prestar serviços. ${ }^{31} \mathrm{Nem}$ faria sentido entender o contrário; uma vez que a competência municipal é para tributar a prestação de serviço, evidente que o único ente competente para fazê-lo é aquele no qual o serviço for efetivamente prestado.

Também aqui se demonstra por que a tributação não poderia incidir quando da simples contratação do plano ou convênio funerário, já que, nesse momento, ainda não é possível saber qual o Município competente para a cobrança do tributo. Imaginemos a situação de uma empresa que trabalha no ramo e atua com estabelecimentos permanentes em mais de um Município: não é incoerente imaginar que uma pessoa possa contratar o serviço na cidade em que reside (Município A), mas as cerimônias fúnebres ocorram em outro Município (B), por sua decisão ou até da própria família. Dessa forma, mesmo que o serviço tenha sido contratado no Município A, o Município competente para a tributação será o Município B, e isso será verificável tão somente quando da própria morte.

Em suma, constatado que o aspecto material da hipótese de incidência só ocorre quando da efetiva prestação dos serviços fúnebres nos planos ou convênios funerários, não há dúvida de que o ISS só poderá ser cobrado no momento da prestação do serviço e no local em que isso efetivamente ocorrer.

\footnotetext{
${ }^{31}$ Art. $4^{\circ}$ Considera-se estabelecimento prestador o local onde o contribuinte desenvolva a atividade de prestar serviços, de modo permanente ou temporário, e que configure unidade econômica ou profissional, sendo irrelevantes para caracterizá-lo as denominações de sede, filial, agência, posto de atendimento, sucursal, escritório de representação ou contato ou quaisquer outras que venham a ser utilizadas.
} 
Dessa forma, independentemente da indicação do legislador complementar, que entendeu por bem diferenciar os planos e convênios da efetiva prestação dos serviços funerários e de cremação, a verdade é que não há um serviço diferente nesse caso, mas sim uma simples promessa de prestação provável de serviços.

As dificuldades vinculadas à aferição da base de cálculo, uma vez que a ocorrência do fato gerador se dá em momento posterior àquele em que o serviço foi efetivamente pago (data da contratação), gerando questionamentos e dificuldades quanto à necessidade de correção do preço pago, não justificam o desrespeito à Constituição. Noutro dizer, não pode o legislador, em nome da simplificação e da praticidade, cobrar tributo sobre mera utilidade ou serviço potencial, uma vez que detém autorização tão somente para a tributação da prestação efetiva de serviços. Isto é, a simplicidade e a eficiência tributária não servem como fundamento para que se ignorem as diretrizes fundamentais do Texto Constitucional, sempre em prejuízo do contribuinte. ${ }^{32}$

Diante disso, o subitem 25.03 não cria uma nova hipótese de incidência e, na verdade, se mostra inútil, considerando que os possíveis serviços prestados nesse caso serão aqueles previstos nos subitens 25.01 e 25.02. A tentativa do legislador de tributação imediata desses planos ou convênios funerários, portanto, não se coaduna com as diretrizes impostas pela Constituição.

\footnotetext{
${ }^{32}$ BARRETO, Paulo Ayres. Tributação sobre o Consumo: Simplicidade e Justiça Tributária. In: SANTI, Eurico Marcos Diniz de (Org.). Tributação e Desenvolvimento: Homenagem ao Professor Aires Barreto. São Paulo: Quartier Latin, 2011. p. 532.
} 


\section{Análise Crítica da Jurisprudência do Tribunal de Justiça de São Paulo e do Superior Tribunal de Justiça}

O presente tema tem crescido em importância na medida em que não apenas mais empresas passaram a atuar nesse mercado, mas também os Municípios passaram a autuá-las com o objetivo de fazer incidir o ISS já na contratação desse tipo de plano ou convênio funerário. Em São Paulo, por exemplo, essa matéria foi recentemente debatida pelo Tribunal de Justiça em um caso envolvendo uma empresa que vendia planos funerários e o Município de Jaú, que pretendia tributá-la já no momento da contratação desses negócios jurídicos.

O Município obteve decisão favorável em primeira instância, mas a sentença foi reformada pelo Tribunal de Justiça de São Paulo, que reconheceu que a exigibilidade do imposto depende da efetiva prestação do serviço, e não apenas do pagamento adiantado das parcelas. Eis a ementa desse julgamento:

ISSQN - PLANOS OU CONVÊNIOS FUNERÁRIOS LEGALIDADE - EFETIVA PRESTAÇÃO DE SERVIÇOS NECESSIDADE Mesmo havendo previsão de incidência do ISSQN sobre planos ou convênios funerários (item 25.03 da lista anexa à Lei Complementar no 116/03), a exigibilidade do imposto deve ser compreendida à luz da determinação constitucional de que o seu fato gerador é a prestação de serviços (art. 156, III), de forma que, no caso concreto, para que seja possível a cobrança, é necessária a efetiva prestação do serviço e não apenas o pagamento adiantado das parcelas. RECURSO PROVIDO. ${ }^{33}$

Em seu voto, o Desembargador Relator Carlos Alberto Santos demonstra a lógica seguida na decisão, no sentido de que a mera existência do plano ou convênio funerário, por si só, não autoriza a cobrança do ISS, sendo necessária a efetiva

\footnotetext{
${ }^{33}$ Apelação com revisão n 990.10.104312-2, 18ª Câmara de Direito Público do Tribunal de Justiça de São Paulo, Relator Carlos Alberto Giarusso Lopes Santos, DJ 11/08/2011.
} 
prestação dos serviços funerários para tornar o tributo exigível. Observa ainda que o plano ou convênio funerário é negócio jurídico com eficácia condicionada à ocorrência da morte, oportunidade em que ocorre a prestação dos serviços, os quais já haviam sido remunerados de maneira parcelada pelo adquirente desde o momento da adesão ao plano. Nessa linha, os julgadores repudiaram a cobrança do ISS desde a contratação do plano.

Ainda que a questão dos planos ou convênios funerários seja bastante recente e, portanto, ainda não tenha uma jurisprudência consolidada, outros temas correlatos já foram analisados pelo Tribunal de Justiça de São Paulo e podem auxiliar na solução desse caso. Questão análoga a essa se refere à cobrança do ISS sobre contratos de assistência técnica, em que o contratante se obriga à possível prestação de serviços de reparo em equipamentos, em troca do pagamento antecipado de determinada quantia.

Ocorre que também nesse caso a prestação do serviço será eventual e futura, não se confundindo com a simples contratação no negócio jurídico. Analisando o tema, o Tribunal de Justiça de São Paulo mais uma vez se mostrou atento à Constituição, afastando a possibilidade de incidência do ISS no momento da simples contratação:

ISS - Contrato de manutenção - Fornecimento de peças sobressalentes e mão-de-obra para máquinas e aparelhos empregados no lar - Pagamento prévio ajustado, sem ônus adicional na eventual e futura prestação da assistência técnica - Incidência sobre a real prestação de serviços, e não sobre o contrato - Tributo que onera a prestação de serviços, e não eventual lucro - Fato gerador não apurado - Embargos à execução fiscal julgados procedentes [...] 3. A controvérsia reside em saber se incide ou não e em que momento o imposto sobre serviços em decorrência do contrato de manutenção celebrado entre a apelada e seus clientes, por meio do qual o adquirente do aparelho eletrodoméstico, mediante prévio 
Imposto sobre Serviços e Planos ou Convênios Funerários...

pagamento ajustado no instrumento e sem ônus adicional, passa a ter direito ao fornecimento de peças sobressalentes e mão-de-obra (conserto) por determinado período, com garantia de bom funcionamento do produto. Efetivamente, a razão está com a r. sentença e a apelada, entendendo que o imposto é devido sobre a efetiva prestação do serviço, com a solicitação feita pelo cliente, momento em que ocorre o fato gerador, e não sobre o contrato ou negócio jurídico de manutenção estabelecido. Ao contrário do pretendido pela Fazenda apelante não basta celebrar o contrato para eventual e futura realização do serviço nem era ônus da apelada provar que não houve a efetiva prestação da atividade. Se o serviço não foi prestado e, segundo os contratos (fls. 40/42), poderia até ocorrer a hipótese de não se concretizar a prestação, caso o bem não necessitasse de reparos, seja por aplicação de mão-de-obra, seja com substituição de peças, no período da garantia, a indigitada liqüidez e certeza das certidões de dívida ativa, uma vez impugnadas, reclamavam um mínimo de indícios da real prestação dos serviços como, por exemplo, relação de notas fiscais, de ordens de execução do serviço etc., que as cópias dos autos de infração não trazem (fls. 37/42 e 50/52), nem a Fazenda interessada cuidou de providenciar, fiando-se apenas em ilimitada mas, no caso, meramente teórica. ${ }^{34}$

Como se percebe, também aqui a fundamentação parte do respeito ao critério material da hipótese de incidência do ISS, preservando a rígida discriminação constitucional das competências, que, no caso dos Municípios, autoriza a incidência de ISS somente quando da efetiva prestação de serviços.

No Superior Tribunal de Justiça, decisões em casos similares envolvendo discussões sobre o ISS também podem servir de parâmetro para o caso dos planos ou convênios funerários, ainda não discutido nesse Tribunal. Por um lado, sobre o tema do ISS incidente sobre diversões públicas, a jurisprudência do STJ se mostrou mais vacilante, porque, ainda que tenha

\footnotetext{
${ }^{34}$ Apelação com Revisão 0063110-47.1998.8.26.0000, 1ํㅡㄹ Câmara (Extinto 1º TAC), Relator Correia Lima, DJ 24/09/2001.
} 
repudiado a cobrança do ISS quando da chancela dos ingressos, aceitou que esse incida no momento da venda dos ingressos. ${ }^{35}$

Por outro lado, decisões sobre outros serviços corroboram a impossibilidade de cobrança antecipada do ISS, quando ainda não há efetiva prestação de serviço. Analisando a incidência do ISS sobre serviços de assistência médica prestados mediante convênio, por exemplo, o STJ foi enfático ao afirmar "que o fato gerador do ISS, seu pressuposto de fato, dá-se no momento da prestação do serviço, e não quando do pagamento do serviço realizado". ${ }^{36}$

A questão relativa ao aspecto local da hipótese de incidência também já se encontra pacificada no Tribunal, tendo sido julgada na sistemática dos recursos repetitivos em 2011. Nesse julgado, em que se discutia sobre os serviços de manutenção e aluguel de maquinaria, o STJ pacificou seu entendimento no sentido de que "o ISS deve ser recolhido no local da efetiva prestação de serviços, pois é nesse local que se verifica o fato gerador (nos termos do art.12, letra "b", do DL n. 406/1968 e art. $3^{\circ}$, da LC n. 116/2003)". ${ }^{37}$

\footnotetext{
${ }^{35}$ REsp 159.861/SP, Rel. Ministro HUMBERTO GOMES DE BARROS, PRIMEIRA TURMA, julgado em 13/10/1998, DJ 14/12/1998, p. 109.

${ }^{36}$ Voto do Ministro Relator Teori Zavascki no seguinte julgamento: TRIBUTÁRIO. ISS. PRESTAÇÃO DE SERVIÇOS MÉDICOS MEDIANTE CONVÊNIOS. FATO GERADOR. MOMENTO DA OCORRÊNCIA. PECULIARIDADES. APRESENTAÇÃO E APROVAÇÃO DAS CONTAS PELO PRESTADOR À EMPRESA ADMINISTRADORA DO PLANO DE SAÚDE. RECURSO IMPROVIDO. (REsp 887.385/ RJ, Rel. Ministro TEORI ALBINO ZAVASCKI, PRIMEIRA TURMA, julgado em 14/12/2010, DJe 17/12/2010.)

${ }^{37}$ PROCESSUAL CIVIL E TRIBUTÁRIO. ISS. COMPETÊNCIA. LOCAL DA PRESTAÇÃO DO SERVIÇO. QUESTÃO PACIFICADA PELA PRIMEIRA SEÇÃO. RESP 1.117.121/SP. APLICAÇÃO DO ART. 543-C DO CPC. 1. A Primeira Seção desta Corte, consolidou o entendimento no sentido de que o ISS deve ser recolhido no local da efetiva prestação de serviços, pois é nesse local que se verifica o fato gerador (nos termos do art.12, letra "b", do DL n. 406/1968 e art. 3ㅇ, da LC n. 116/2003). 2. In casu, a empresa encontra-se sediada em Belo Horizonte, prestando serviços de manutenção e aluguel de maquinaria e equipamentos para indústrias em
} 
Imposto sobre Serviços e Planos ou Convênios Funerários...

Dessa forma, ainda que pendente de análise definitiva pelo STJ, órgão competente para decidir acerca da interpretação da legislação infraconstitucional, as decisões citadas indicam um caminho no sentido do reconhecimento pela jurisprudência da impossibilidade de tributação imediata pelo ISS na contratação de planos ou convênios funerários, na medida em que esse entendimento se mostre o único condizente com o Texto Constitucional.

\section{Considerações Finais}

Considerando que a Constituição brasileira tem como uma de suas principais características a discriminação rígida das competências tributárias, tendo por vezes delimitado o próprio critério material da hipótese de incidência, não há como fugir da análise constitucional de qualquer exação tributária. Esse desenho constitucional nada mais fez do que impor limites rígidos ao legislador infraconstitucional, estando ele necessariamente vinculado ao espaço de atuação delimitado pelas normas do Texto Constitucional.

O ISS não foge a essa regra, tendo a própria Constituição informado que a sua cobrança só estaria autorizada na existência de um serviço, enquanto uma obrigação de fazer em que alguém se obriga a realizar um esforço humano em benefício de outrem. Delimitado o núcleo do critério material da hipótese de incidência, evidente que a remissão ao legislador complementar, prevista no próprio texto da Constituição, não

diversos outros Municípios, dentre eles à MBR, em sua unidade denominada Mina do Pico, em Itabirito. Logo, o fato gerador ocorreu no Município de Itabirito e, assim, a ele cabe a cobrança do tributo. Agravo regimental improvido. (AgRg no Ag 1318064/MG, Rel. Ministro HUMBERTO MARTINS, SEGUNDA TURMA, julgado em 05/04/2011, DJe 13/04/2011.) 
significa um "cheque em branco" para que este defina qualquer atividade como serviço. O legislador tem competência para definir quais são os serviços tributáveis, mas não a tem para definir como serviço aquilo que serviço não é.

Firmadas essas premissas, partimos para a análise do subitem 25.03 da Lista Anexa à Lei Complementar no. 116, esperando termos demonstrado que, a par da tentativa do legislador complementar de diferenciar os planos ou convênios funerários dos demais serviços funerários gerais e de cremação, a simples contratação para a prestação provável de serviços futuros não se consubstancia como situação necessária e suficiente para o surgimento do fato gerador do ISS.

Primeiro, porque a prestação de serviços não se confunde com o negócio jurídico ao qual ela está vinculada. Ainda que a existência de uma relação jurídica onerosa seja um aspecto fundamental para a incidência do imposto, esta não se confunde com o núcleo do critério material, que é a própria prestação dos serviços. Os Municípios não foram autorizados a tributar negócios jurídicos envolvendo a prestação de serviços, mas sim a própria prestação, situações jurídicas que não se confundem. Também não foram autorizados a cobrar por serviços meramente potenciais. Em resumo, a utilidade e o benefício não se confundem com a existência de prestação de serviço.

Segundo, porque a mera existência de capacidade contributiva não serve como justificativa para a antecipação da cobrança. Por um lado, se os entes federados estivessem autorizados a instituir tributos sobre a simples existência de capacidade econômica, toda a rígida discriminação de competências prevista na Constituição perderia seu sentido. Por outro lado, vale dizer que esses valores integrarão a receita, a renda e o lucro das empresas, mas essas materialidades não fazem parte da outorga de competência dos Municípios. 
Imposto sobre Serviços e Planos ou Convênios Funerários...

Terceiro, enquanto não for efetivamente prestado o serviço funerário contratado, não é possível apontar qual o Município competente para o recolhimento do tributo. Isso porque é possível que a empresa atue em mais de uma localidade e que o local onde o contrato tenha sido firmado não seja o mesmo local em que o serviço será efetivamente prestado, podendo a empresa possuir estabelecimentos permanentes em ambos.

Não nos resta dúvida, portanto, de que os planos ou convênios funerários, previstos no subitem 25.03 da Lista Anexa à Lei Complementar no. 116/03, à luz da Constituição e das normas gerais do Código Tributário Nacional, só se consubstanciam como fatos geradores do ISS quando da efetiva prestação dos serviços funerários contratados. Até lá, existe mera promessa de prestação de serviços, utilidade essa que não é alcançada pela outorga de competência constitucional aos Municípios e, exatamente por isso, não pode ser alcançada pelo ISS.

\section{Referências}

ALEXY, Robert. Juristiche Interpretation. In: Recht, Vernunft, Diskurs. Frankfurt am Main: Suhrkamp, 1995.

ATALIBA, Geraldo. Estudos e pareceres de direito tributário. v. III. São Paulo: Revista dos Tribunais, 1980.

Tribunais, 1973.

Hipótese de Incidência Tributária. São Paulo: Revista dos

ÁVILA, Humberto. Conceito de renda e compensação de prejuízos fiscais. São Paulo: Malheiros, 2011.

. Imposto sobre a Prestação de Serviços de Qualquer Natureza. ISS. Normas constitucionais aplicáveis. Precedentes do Supremo Tribunal Federal. Hipótese de incidência, base de cálculo e local da prestação. Leasing financeiro: análise da incidência. Revista Dialética de Direito Tributário, São Paulo, v. 182, p. 133-144, nov. 2010. 
BARRETO, Aires Fernandino. Curso de Direito Tributário Municipal. São Paulo: Saraiva, 2009. . ISS na Constituição e na Lei. 2. ed. São Paulo: Dialética, 2005.

BARRETO, Paulo Ayres. Tributação sobre o Consumo: Simplicidade e Justiça Tributária. In: SANTI, Eurico Marcos Diniz de (Org.). Tributação $e$ Desenvolvimento: Homenagem ao Professor Aires Barreto. São Paulo: Quartier Latin, 2011. p. 529-545. . Elisão Tributária: Limites Normativos. São Paulo: USP, 2008. . Contribuiçães: Regime Jurídico, Destinação e Controle. São Paulo: Noeses, 2006.

BORGES, José Souto. Lei Complementar Tributária. São Paulo: Editora da Universidade Católica, 1975.

CARVALHO, Paulo de Barros. Curso de Direito Tributário. 23. ed. São Paulo: Saraiva, 2011. Noeses, 2009.

Direito Tributário, Linguagem e Método. 3. ed. São Paulo: . Não-Incidência do ISS sobre Atividades de Franquia (Franchising). Revista de Estudos Tributários, v. 56, p. 65-79, jul./ago. 2007. DÁCOMO, Natalia de Nárdi. Hipótese de Incidência do ISS. São Paulo: Noeses, 2007.

DERZI, Misabel de Abreu Machado. Direito Tributário, Direito Penal e Tipo. São Paulo: Revista dos Tribunais, 1988.

MELO, José Eduardo Soares de. ISS - Aspectos Teóricos e Práticos. 4. ed. São Paulo: Dialética, 2005.

MOSQUERA, Roberto Quiroga. Os Impostos sobre Operações de Crédito, Câmbio, Seguro ou Relativos a Títulos ou Valores Mobiliários Conceitos Fundamentais. In: SANTI, Eurico Marcos Diniz de; ZILVETI, Fernando Aurélio; MOSQUERA, Roberto Quiroga (Org.). Tributação Internacional e dos Mercados Financeiro e de Capitais. São Paulo: Quartier Latin, 2005. p. 101-175.

. Renda e proventos de qualquer natureza: o imposto e o conceito constitucional. São Paulo: Dialética, 1996. 
Imposto sobre Serviços e Planos ou Convênios Funerários...

SANTI, Eurico Marcos Diniz de; BARRETO, Paulo Ayres. Contribuições para Previdência Privada - Dedutibilidade em face do Imposto sobre a Renda - Força da EC 20/98 - Aplicabilidade da Lei 9.532/97 no Tempo. Revista Dialética de Direito Tributário, v. 93, p. 124-133, jun. 2003.

. O Código Tributário e as normas gerais de Direito Tributário. In: SANTI, Eurico Marcos Diniz (Org.). Curso de Direito Tributário e Finanças Públicas: do fato à norma, da realidade ao conceito jurídico. v. 1. 1. ed. São Paulo: Saraiva, 2007. p. 322-329.

SCHOUERI, Luís Eduardo. Direito Tributário. São Paulo: Saraiva, 2011. . Normas Tributárias Indutoras e Intervenção Econômica. Rio de Janeiro: Forense, 2005.

. Discriminação de Competências e Competência Residual. In: SCHOUERI, Luís Eduardo; ZILVETI, Fernando Aurélio (Org.). Direito Tributário: Estudos em Homenagem a Brandão Machado. São Paulo: Dialética, 1998. p. 82-115.

TORRES, Heleno. A Hipótese do ICMS sobre Operações Mercantis na Constituição e a Solução de Conflitos Normativos. In: SCHOUERI, 200 Luís Eduardo (Org.). Direito Tributário: Homenagem a Paulo de Barros Carvalho. São Paulo: Quartier Latin, 2008. p. 321-342.

Submissão: 05/09/2013

Aceito para Publicação: 21/11/2013 


\section{Créditos Não Tributários Estaduais, Prazo de Prescrição e Procedimento diante da Ausência de Lei Específica}

Federative States' Non-Fiscal Credits, Limitation of Action, and Procedure in case of Legal Loophole

Juliano Heinen*

Resumo: Os créditos não tributários constituem receitas de capital que não podem ser renunciadas. Contudo, em muitas situações, não existe legislação local ou regional que discipline a matéria, não sendo previsto o procedimento administrativo para apurar a referida receita, nem mesmo prazos de prescrição e/ou de decadência aplicáveis à espécie. Assim, diante desta conjuntura, é necessário que seja diagnosticada a forma de cobrar os valores oriundos desta relação jurídica, bem como qual o período que pode ser cobrado e que não está afetado pela prescrição e/ou decadência, quando inexistem normas legais específicas.

Palavras-chave: Créditos Não Tributários Estaduais. Prazo de Prescrição. Procedimento.

Abstract: Federative States' non-fiscal credits are capital revenues that cannot be waived. However, in many situations, there is no regional or local legislation that governs the matter not being provided the administrative procedure to determine the aforementioned revenue, not even limitation of action and/or lapse terms applicable to the species. So, faced with this situation, the form must be diagnosed to collect the amounts arising from this legal relationship, as well

\footnotetext{
* Universidade do Vale do Rio dos Sinos, Universidade de Santa Cruz do Sul, Faculdade IDC, Universidade de Caxias do Sul, Faculdade Metodista de Santa Maria.
} 
Créditos Não Tributários Estaduais...

as which period can be collected and is not affected by limitation of action and/or lapse, when there are no specific legal provisions.

Keywords: States' Credits. Limitation Period. Procedure.

\section{Introdução}

No âmbito federal, a União editou a Lei federal oㅜ 9.636/98, que disciplinou, entre outras matérias, a cobrança dos créditos não tributários, como, por exemplo, aqueles derivados do uso de bens públicos por particulares. Já nas administrações públicas dos outros entes da Nação (Estados, Distrito Federal e Municípios), não necessariamente existe legislação local ou regional que discipline a matéria. Logo, não é previsto procedimento administrativo para apurar a referida receita, nem mesmo

202 prazos de prescrição e/ou de decadência aplicáveis à espécie.

Assim, diante desta omissão legislativa local e regional, importante diagnosticar a forma de cobrar os valores oriundos desta relação jurídica, bem como o período que pode ser arrecadado e que não está afetado pela prescrição e/ou decadência, quando inexistem normas legais específicas tratando do tema. Impõe-se, a meu ver, a partir de uma verdadeira interpretação sistemática, saber qual a fonte normativa a se aplicar à espécie, ou seja, qual a regra de prescrição a subsumir-se nesta situação, caso ausente norma estadual, municipal ou distrital específica à espécie.

\section{Da Forma de Cobrança dos Créditos Não Tributários}

Para definir a forma de cobrança dos créditos não tributários, oriundos, por exemplo, da exploração onerosa de bens públicos, deve-se, antes de tudo, ter bem clara qual é a natureza desta receita. Veja que a exata noção a respeito da relação de 
direito material incidente é condição para saber as medidas processuais que dela derivam. Afinal, a pretensão de direito processual é um espelho da pretensão de direito substancial.

A fonte normativa própria incidente nesta relação jurídica é o art. 39 da Lei no 4.320/64:

Art. 39. Os créditos da Fazenda Pública, de natureza tributária ou não tributária, serão escriturados como receita do exercício em que forem arrecadados nas respectivas rubricas orçamentárias.

$\S 1^{\circ}$ - Os créditos de que trata este artigo, exigíveis pelo transcurso do prazo para pagamento, serão inscritos, na forma da legislação própria, como Dívida Ativa, em registro próprio, após apurada a sua liquidez e certeza, e a respectiva receita será escriturada a esse título.

$\S 2^{2}$ - Dívida Ativa Tributária é o crédito da Fazenda Pública dessa natureza, proveniente de obrigação legal relativa a tributos e respectivos adicionais e multas, e Dívida Ativa não Tributária são os demais créditos da Fazenda Pública, tais como os provenientes de empréstimos compulsórios, contribuições estabelecidas em lei, multa de qualquer origem ou natureza, exceto as tributárias, foros, laudêmios, alugueis ou taxas de ocupação, custas processuais, preços de serviços prestados por estabelecimentos públicos, indenizações, reposições, restituições, alcances dos responsáveis definitivamente julgados, bem assim os créditos decorrentes de obrigações em moeda estrangeira, de subrogação de hipoteca, fiança, aval ou outra garantia, de contratos em geral ou de outras obrigações legais.

Então, pode-se afiançar que os créditos não tributários decorrem de quaisquer débitos de terceiros perante a Fazenda Pública, os quais têm sua gênese em obrigações vencidas e previstas em lei, regulamento ou contrato, não possuindo natureza tributária. Um destes exemplos é o crédito derivado do uso oneroso de bem público ${ }^{1}$.

1 VITTA, Manoel Álvares; GARCIA, Heraldo; SOUZA, Maria Helena Rau de; CÂMERA, Miriam Costa Rebollo; SAKAKIHARA, Zuudi. FREITAS, Vladimir Passos de (Coord.). Execução Fiscal: doutrina e jurisprudência. São Paulo: Saraiva, 1998. p. 20. 
Nesse sentido, tendo em vista que o conceito de dívida ativa abarca também os débitos de qualquer natureza, todas as fontes de receita da Fazenda Pública, respeitados os atributos de certeza e liquidez, podem configurar créditos passíveis de execução fiscal, na forma da Lei no 6.830, de 22 de setembro de 1980 . Para tanto, é indispensável a prévia e regular inscrição em dívida ativa, com o cumprimento de todas as formalidades legais.

Sendo assim, é evidente que o crédito desta natureza deve ser reputado como dívida não tributária, relegada, então, a uma disciplina normativa específica ${ }^{2}$. Isso porque os montantes decorrentes da utilização do patrimônio estatal são típicas dívidas administrativas, sem fundo tributário.

Assim, na ausência de uma legislação local ou regional que compreenda um procedimento administrativo específico à espécie, podemos detalhar alguns parâmetros a serem seguidos pelo gestor público municipal ou estadual quando da cobrança administrativa. A constituição de um crédito em favor da Fazenda Pública consiste em um procedimento vinculado e obrigatório, garantindo, na mesma medida, o respeito aos direitos fundamentais. Logo, a finalidade principal deste procedimento é constituir a liquidez e a certeza da dívida, até para dar azo à inserção deste crédito em título executivo extrajudicial.

Dessa forma, uma lógica básica pode ser aplicada ao caso em pauta, ou seja, às dívidas não tributárias em favor dos Estados, dos Municípios ou do Distrito Federal, quando ausentes regras específicas voltadas a esta situação:

1) verificação da existência da hipótese de incidência,
ou seja, da presença de um direito de crédito

2 Perceba que o próprio art. 139, do CTN, dá cabo de fornecer uma resposta exata à espécie: "O crédito tributário decorre da obrigação principal e tem a mesma natureza desta." 
constituído em favor da Fazenda Pública, derivada da lei ou de um contrato;

2) verificação da ocorrência concreta e específica do fato gerador não tributário, ou seja, de que o fato concreto efetivamente ocorreu;

3) verificação da não ocorrência de quitação voluntária do devedor;

4) notificação do devedor para ciência do débito, concedendo-lhe prazo para, querendo, impugnar a obrigação imputada;

5) caso exista impugnação administrativa, esta deve ser instruída e julgada, sendo observados os parâmetros do devido processo legal, especialmente o direito à ampla defesa e ao contraditório (art. $5^{\circ}$, inciso $\mathrm{LV}$, da CF/88);

6) o crédito deve ser, então, constituído definitivamente, sendo o devedor notificado deste ato administrativo.

(Obs.: A segunda notificação é necessária, independentemente de o devedor ter ofertado defesa ou ter permanecido inerte. Considera-se o crédito constituído após o primeiro dia útil posterior ao término do prazo de defesa) ${ }^{3}$.

Ademais, destaca-se que a constituição definitiva do crédito será o marco divisório entre os prazos de decadência e de prescrição, ou seja, o primeiro corre até este evento, e o segundo inicia a partir dele. Sistematizando, pode-se dizer que a decadência terá como ponto de partida a ocorrência do

\footnotetext{
3 A segunda notificação é exigida pela jurisprudência: STJ, REsp. 1.015.297, Rel. Min. José Delgado, Corte Especial, j. 22/4/2008.
} 
fato gerador e, como termo final, a constituição definitiva do crédito. Já a prescrição começa a fluir a partir deste último evento e termina com o exercício da pretensão. Desta forma, a minuta do procedimento ora sugerido aos entes federados que não possuem legislação específica sobre o tema pode ser demonstrada de modo didático da seguinte maneira:

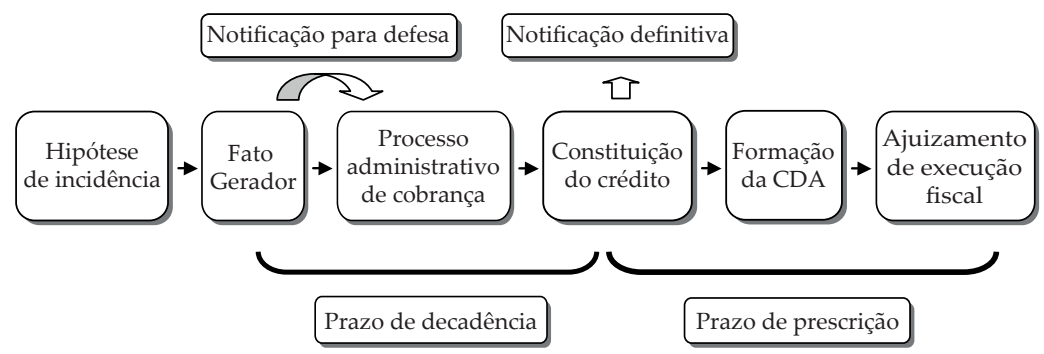

Assim, o fluxograma apresentado pode ser aplicado no limiar do procedimento de constituição e cobrança dos créditos derivados do uso oneroso de bem público. A inscrição em dívida ativa pode, claro, seguir rito específico disposto por normas administrativas pertinentes, desde que compatível com as observações feitas no que se refere ao respeito às garantias fundamentais. Por fim, importante mencionar que o referido montante devido deverá ser inscrito em dívida ativa e poderá ser cobrado pela via judicial regulada pela Lei $n^{0}$ 6.830/80.

Em termos objetivos, intenciona-se conceber um esboço de rotina administrativa para a cobrança dos créditos não tributários por aqueles entes federados que não possuem legislação específica. Para tanto, foi estabelecido um marco legal a partir da legislação federal que disciplina o tema. 


\section{Decadência e Prescrição Incidentes}

No Brasil, era obscura a distinção e, por conseguinte, a aplicação de prazos prescricionais e decadenciais, dada a confusão gerada pelas disposições (ou pela falta delas) do Código Civil de $1916^{4}$, até a publicação do célebre artigo de autoria de Agnelo Amorim Filho ${ }^{5}$. Em seu trabalho, o jurista fez uma associação entre prescrição e decadência e as respectivas cargas de eficácia das ações processuais, vinculando a primeira às ações condenatórias (relacionadas a direitos subjetivos), restando a última associada a direitos potestativos e às ações constitutivas, negativas ou positivas.

Antes disso, foi a partir da monografia de Windscheid que a noção de prescrição tomou corpo e passou a estar arraigada no direito material. A ideia do Klageverjährung ${ }^{6}$ cedeu espaço à compreensão de que a prescrição atinge a exigibilidade, ou seja, está catalogada na seara do direito substantivo (Anspruchsverjährung). Tanto isso é verdade que o Bürgerliches Gesetzbuch (BGB) ${ }^{7}$ acabou por expressamente incluir a concepção de pretensão em seu bojo (Anspruch) ${ }^{8}$, o que, por consequência, fez surgir um dispositivo específico sobre a prescrição, qual seja, o § $199^{9}$.

4 TARTUCE, Flávio. Manual de direito civil. Rio de Janeiro: Forense; São Paulo: Método, 2012. p. 258.

5 AMORIM FILHO, Agnelo. Critério científico para distinguir a prescrição da decadência e para identificar as ações imprescritíveis. Revista de Direito Processual Civil, São Paulo, v. 3, p. 95-132, jan./jun. 1961.

6 Expressão que pode ser traduzida como um instituto jurídico limitador ao exercício de uma ação.

7 Código Civil alemão.

8 BGB, § 194.

9 TONIOLO, Ernesto José. A prescrição do Crédito Fiscal e seus Fundamentos Constitucionais. Revista da Procuradoria-Geral do Estado, Porto Alegre: Corag, v. 32, n. 68, p. 16, jul./dez. 2011. 
Nesse contexto, teria a prescrição “[...] relação com deveres, obrigações e com a responsabilidade decorrente da inobservância das regras ditadas pelas partes ou pela ordem jurídica". A decadência, ao revés, referir-se-ia a "[...] um estado de sujeição, próprio dos direitos potestativos"10. Essa orientação foi conspícua e sapientemente adotada pelo Código Civil de 2002 ${ }^{11}$, cuja base está justamente no BGB germânico - mencionado anteriormente -, dando vazão ao paradigma da operabilidade, visando a facilitar a utilização do sistema jurídico vigente ${ }^{12}$.

O Código Civil atual, então, com o fito de indicar não se tratar de um direito subjetivo público, perfilhou a tese da prescrição da pretensão ${ }^{13}$. Reza o seu art. 189: “Violado o direito, nasce para o titular a pretensão, a qual se extingue, pela prescrição, nos prazos a que aludem os arts. 205 e $206^{\prime \prime 14}$.

Apenas os direitos subjetivos patrimoniais submetem-se à prescrição, por conferirem ao titular uma pretensão de exigir de outrem determinado comportamento, sendo este "apreciável economicamente". Quando não é executada voluntariamente

${ }^{10}$ Op. cit., p. $258-259$.

${ }^{11}$ Ibidem.

${ }^{12}$ FARIAS, Cristiano Chaves de; ROSENVALD, Nelson. Direito Civil - Teoria Geral. Rio de Janeiro: Lumen Juris, 2009. p. 637.

${ }^{13}$ TARTUCE, Flávio. Op. cit., p. 261. "A prescrição extintiva, fato jurídico em sentido estrito, constitui, nesse contexto, uma sanção ao titular do direito violado, que extingue tanto a pretensão positiva quanto a negativa (exceção ou defesa). Trata-se de um fato jurídico stricto sensu justamente pela ausência de vontade humana, prevendo a lei efeitos naturais, relacionados com a extinção da pretensão. A sua origem está no decurso do tempo, exemplo típico de fato natural. Na prescrição, nota-se que ocorre a extinção da pretensão; todavia, o direito em si permanece incólume, só que sem a proteção jurídica para solucioná-lo."

${ }^{14}$ Além disso, importante notar que a prescrição admite uma dualidade conceitual em que estão compreendidas as noções de extinção de situações jurídicas - a chamada prescrição extintiva - e de consolidação de relações que se perpetuam no tempo - a prescrição aquisitiva. (FARIAS, Cristiano Chaves de; ROSENVALD, Nelson. Op. cit., p. 638). 
a conduta esperada, poderá ser exercida a pretensão do titular. O prazo prescricional tem início com o surgimento da pretensão, que decorre da exigibilidade do direito subjetivo. Seu transcurso pode ser impedido, suspenso e/ou interrompido, conforme previsão legal.

A decadência, ao seu tempo, também chamada de caducidade, faz perecer o próprio direito, atingindo-o na essência ${ }^{15}$. Tal instituto encontra origem na lei (decadência legal), mas pode ser estabelecido mediante convenção entre as partes (decadência convencional), no exercício da autonomia privada. Aos prazos decadenciais não se aplicam, salvo exceção prevista expressamente em lei, as normas que impedem, suspendem ou interrompem a prescrição ${ }^{16}$.

Especificamente em direito administrativo, a dicotomia entre prescrição e decadência não é tranquila. E a influência do direito alemão contribuiu para isso, porque ele não distingue entre prescrição e decadência (tudo se baseia no instituto da Verjährung). Mesmo os franceses não apresentam a dicotomia entre prescrição e decadência, porque só tratam a matéria sob a rubrica da prescrição ${ }^{17}$. Contudo, no Brasil, a distinção veio

\footnotetext{
15 “A decadência está atrelada, fundamentalmente, aos direitos potestativos. É que sendo exercidos através de mera manifestação de vontade do próprio titular, independendo da submissão de terceiros, inadmitem os direitos potestativos violação e, via de consequência, não trazem consigo pretensão (típica dos direitos subjetivos - que, por isso, submetem-se a prazos prescricionais). Ora, em se tratando de um direito potestativo - e, por conseguinte, cujos efeitos podem ser obtidos diretamente pela manifestação de vontade do titular - não se pode falar em prescrição (que, por sua vez, é a perda da pretensão de exigir de alguém um comportamento). O exercício dos direitos potestativos depende, tão só, da vontade de seu próprio titular."(FARIAS, Cristiano Chaves de; ROSENVALD, Nelson. Op. cit., p. 668).

${ }^{16}$ TARTUCE, Flávio. Op. cit., p. 277.

${ }^{17}$ Por todos: WALINE, Marcel. Précis de droit administratif. Paris: Montchrestien, v. 1, p. 389.
} 
plasmada de forma completamente desestruturada, ou seja, casuisticamente e sem qualquer sistematicidade ${ }^{18}$.

O que importa notar é que o direito administrativo nacional, apesar de toda a confusão estabelecida pelas normas jurídicas, admite bem o convívio de ambos os institutos jurídicos, e mesmo concomitantemente, como se pode ver a partir da dicção do art. 47 da Lei no 9.636/98. E outros exemplos podem ser fornecidos: no âmbito da violação de prestações em contratos e na seara da responsabilidade civil extracontratual, está-se a tratar de casos de prescrição, uma vez que a pretensão a ser obtida via juízo possui carga de eficácia predominantemente condenatória a uma prestação da outra parte, enquanto que a anulação dos atos administrativos submete-se, como dito, à caducidade do direito.

A rigor, poder-se-ia pensar que inexiste prescrição no direito administrativo, porque as regras até agora existentes estabelecem, em suma, a perda de direito, e não mera extinção de uma pretensão. Contudo, como visto, isso não procede. Em inúmeros casos, o ordenamento jurídico disciplinou, de forma expressa, prazos de prescrição relacionados à relação jurídico-administrativa (v.g. Decreto-lei no 20.910/32). Veja que, no caso, será a estrutura do suporte fático de cada categoria jurídica quem fará previsão de um prazo de decadência ou de prescrição, ou de ambos, até porque não importa o nomen juris conferido pela legislação.

Há casos em que se percebem, claramente, na linha do direito tributário, por exemplo, dois momentos bem distintos:

${ }^{18}$ Veja que os Decretos no 20.910/32 e no 4.597/42 apontam que a Administração Pública submete-se a prazos de prescrição, sem mencionar qualquer prazo de decadência a respeito. Mais recentemente, a Lei no 9.784/99 (art. 54) apenas traz ao bojo do seu texto prazo de decadência, sem fomentar qualquer disciplina jurídica sobre a prescrição. 
uma sucessão de atos para a constituição do crédito, bem como, posteriormente, uma etapa muito distinta que se assenta na sucessão de atos para o exercício de pretensão desse crédito. Assim, ter-se-iam constituído dois prazos: um de decadência e outro de prescrição.

E os créditos decorrentes do uso oneroso de bem público bem refletem esta dualidade: geram um crédito à Administração Pública, que deve, primeiro, constituí-lo e, depois, cobrá-lo, na forma do que foi estabelecido no âmbito federal - Lei nº 9.636/98. Surge, aqui, verdadeiro procedimento administrativo de constituição da receita (liquidação do crédito), lançamento em dívida ativa e, depois disso, sucessiva cobrança. Originam-se, então, dois prazos distintos para o exercício do direito e da pretensão, ou seja, percebe-se que, neste caso, convivem, paralelamente, a decadência e a prescrição.

Em conclusão a este tópico: no caso de cobrança de créditos não tributários, como, por exemplo, aqueles derivados do uso oneroso de bem público, percebe-se que podem conviver, de maneira concomitante, os prazos de decadência e de prescrição. Para tanto, foi exposto um esboço de como deveria ser estruturado o procedimento administrativo de cobrança dessas receitas.

\section{Lacuna Normativa. Incidência da Lei Federal no 9.636/98. Postulado da Segurança Jurídica como Marco Hermenêutico ao Caso Concreto}

A segurança jurídica é, possivelmente, um dos temas do direito que mais têm, na atualidade, rendido textos doutrinários e debates nos tribunais brasileiros. E o tema não se esgota, porque, contemporaneamente, a segurança jurídica acaba perpassando todas as relações jurídicas. A garantia generalizada e congruente das expectativas de comportamento originadas 
no seio das interações sociais sempre teve o Direito como seu fiador. Sua finalidade era justamente minimizar a contingência das ações individuais, possibilitando que cada um pudesse prever, com um mínimo de certeza e garantia, o comportamento do outro ${ }^{19}$.

Percebe-se que o mundo atual é marcado pela desconfiança. A administração pública tende, assim, a resgatar uma necessária aproximação para com os administrados, realçando valores como a transparência, a boa-fé, a manutenção das expectativas legítimas etc. ${ }^{20}$ Tais meios procuram deixar menos complexas as relações postas em conflito ${ }^{21}$.

O Estado, nesse sentido, em "[...] quaisquer de seus atos tanto mais porque cumpre a função de ordenador da vida social - tem de emergir como interlocutor sério, veraz, responsável,

19 "O direito vigente garante, de um lado, a implementação de expectativas de comportamento sancionadas pelo Estado e, com isso, segurança jurídica; de outro lado, os processos racionais da normatização e da aplicação do direito prometem a legitimidade das expectativas de comportamento assim estabilizadas - as normas merecem obediência jurídica e devem poder ser seguidas a qualquer momento, inclusive por respeito à lei." (HABERMAS, Jürgen. Direito e democracia: entre facticidade e validade. v. 1. Rio de Janeiro: Tempo Brasileiro, 1997. p. 246).

20 "O ordenamento jurídico protege a confiança suscitada pelo comportamento do outro e não tem mais remédio que protegê-la, porque poder confiar [...] é condição fundamental para uma pacífica vida coletiva e uma conduta de cooperação entre os homens e, portanto, da paz jurídica." (LARENZ, Karl. Derecho Justo: Fundamentos de Ética Jurídica. Madrid: Civitas, 1985. p. 91).

${ }^{21}$ Como bem refere Jesús González Pérez: “En el ámbito del Derecho administrativo, el principio de buena fe ha permitido otorgar al administrado una protección similar a la que há otorgado fuera no nuestro Ordenamiento jurídico el principio de confianza legítima. Quizás, después de muchos esfuerzos, puedan, extremando la pulcritud de conceptos, encontrar esferas a las que no llega la protección del principio da la confianza legítima y sí el da la buena fe, y esferas a las que no llega la protección de éste, pero sí el de aquél. Pero siempre podrá la jurisprudencia utilizar uno u otro para extender debidamente la protección de la confianza legítima, de modo que no quede inmune ningún ámbito de las relaciones. Al fin y al cabo es lo que hizo nuestra jurisprudencia antes de la recepción formal del principio de la confianza legítima." (El Principio General de la Buena Fe en el Derecho Administrativo. Madrid: Civitas, 1989. p. 54). 
leal e obrigado aos ditames da boa-fé"'22. E quanto aos administrados: "De seu turno, os administrados podem agir fiados na seriedade, responsabilidade, lealdade e boa-fé do Poder Público, maiormente porque a situação dos particulares é, em larguíssima medida, condicionada por decisões estatais, ora genéricas, ora provenientes de atos concretos" 23 .

O próprio Kelsen antecipava que os Tribunais poderiam atuar na maximização da segurança jurídica ${ }^{24}$. A questão pode ser posta na pergunta feita por Habermas: "O problema da racionalidade da jurisprudência consiste [...] em saber como a aplicação de um direito contingente pode ser feita internamente e fundamentada racionalmente no plano externo, a fim de garantir simultaneamente a segurança jurídica e a correção"25. Uma das respostas encontradas pelo autor baseia-se no seguinte entendimento: “Os paradigmas se coagulam em ideologias, na medida em que se fecham sistematicamente contra novas interpretações da situação e contra outras interpretações de direitos e princípios, necessárias à luz de novas experiências históricas"26. Daí por que se conclui que a segurança jurídica passa, especialmente no período contemporâneo, a fazer parte do cotidiano das relações jurídico-administrativas ${ }^{27}$.

\footnotetext{
${ }^{22}$ MELLO, Celso Antônio Bandeira de. Segurança jurídica, boa-fé e confiança legítima. Revista Trimestral de Direito Público. São Paulo: Malheiros, n. 51-52, s/d, p. 7.

${ }^{23}$ Idem, ibidem.

24 "A Criação de normas jurídicas gerais pelos tribunais: o juiz como legislador; flexibilidade do Direito e segurança jurídica." (KELSEN, Hans. Teoria Pura do Direito. São Paulo: Martins Fontes, 1995. p. 274). Além disso, o autor austríaco conclui que: "[...] o tribunal que cria o precedente funciona como legislador, talqualmente o órgão a que a Constituição confere poder para legislar." (Op. cit., p. 278).

${ }^{25}$ HABERMAS, Jürgen. Op. cit., p. 247.

${ }^{26}$ Op. cit., p. 275.

${ }^{27}$ PÉREZ, Jesús González. El principio general de la buena fé en el derecho administrativo. Madrid: Civitas, 1989. p. 89. Ainda, consultar a obra de: BIGOLIN, Giovani. Segurança jurídica: a estabilização do ato administrativo. Porto Alegre: Livraria do Advogado, 2007.
} 
O princípio da estabilidade das relações jurídicas, sendo um aspecto do chamado princípio da segurança jurídica, possui fundamento naquilo "[...] sobre que se apoia quer um dado domínio do ser, quer uma teoria ou um conjunto de conhecimentos (e então o fundamento é o conjunto de proposições das quais esses conhecimentos se deduzem)" ${ }^{\prime 28}$, a ponto de ser considerado elemento nodal no Estado de Direito ${ }^{29}$. Modernamente, o fundamento máximo da segurança jurídica não está na legalidade estrita $^{30}$, mas sim assenta-se no seio dos direitos fundamentais, dada sua força normativa, conferida pela jurisdição constitucional $^{13}$. E este giro hermenêutico modifica substancialmente a forma de encarar as fontes deste instituto ${ }^{32}$.

Não é à toa que este é "[...] um valor constitucional que se qualifica como subprincípio do princípio maior do Estado

${ }^{28}$ CALMES, Sylvia. Du principe de protection de la confiance légitime en droits allemand, communautaire et français. Paris: Dalloz, 2001. p. 166.

${ }^{29}$ O Estado de Direito possui as seguintes características: (a) existência de mecanismos de participação no procedimento de formação do ato administrativo; (b) imperiosa a motivação do ato administrativo; (c) dever de informação; (d) existência de recursos; (e) existência de notificações - ciência do ato ou decisão administrativa (CORREIA, Fernando Alves. Alguns conceitos de Direito Administrativo. Coimbra: Almedina, 2001. p. 10). No mesmo sentido: STF, MS 24.268-MG, Rel. Min. Ellen Gracie, Rel. para o acórdão Min. Gilmar Mendes, Pleno, j. 05/02/2004. No STF, MS 24.781-DF, Pleno, Relator p/ Acórdão Min. Gilmar Mendes, DJe de 08/06/2011, Ministro Gilmar Mendes se manifestou no sentido de que “[...] é nessas hipóteses que incide o princípio da segurança jurídica, como subprincípio do Estado de Direito, no sentido da proteção das situações jurídicas criadas pelo Poder Público e estabilizadas pelo transcurso do tempo em que o próprio Poder Público quedou-se inerte".

${ }^{30}$ Não que a legalidade deixe de ser um fundamento à segurança jurídica, mas perde o papel principal neste sentido.

${ }^{31}$ Tanto que Heleno Taveira Torres (Direito constitucional tributário e segurança jurídica: metódica da segurança jurídica do sistema constitucional tributário. São Paulo: Revista dos Tribunais, 2011. p. 186-187) considera que a segurança jurídica seria uma espécie de garantia material para a concretização de direitos e liberdades fundamentais. Tem por base três elementos: certeza, estabilidade sistêmica e proteção às expectativas de confiança legítimas.

32 STF, Pet 2.900 QO-RS, Rel. Min. Gilmar Mendes, Segunda Turma, j. 27/05/2003. 
de Direito, ao lado e no mesmo nível hierárquico do outro subprincípio do Estado de Direito, que é o da legalidade. Segurança jurídica e legalidade são, sabidamente, os dois pilares de sustentação do Estado de Direito" ${ }^{\prime 33}$. Impõe-se, pois, que a legalidade seja ponderada com outros valores constitucionais não menos relevantes, como, p. ex., a segurança jurídica. Não se pode, portanto, ver a atuação do Estado dissociada desse paradigma.

Humberto Ávila, ao seu turno, destacou que a expressão "segurança jurídica" pode ter variados sentidos. Para tanto, adotou dois critérios: quanto ao fim ou quanto ao fundamento ${ }^{34}$. Para o autor, o instituto em foco deve dar lugar à controlabilidade semântico-argumentativa, em vez de se optar por preencher o conteúdo por meio de determinação normativa. Isso porque a segurança não deve ser um bem retirado do ordenamento jurídico, mas sim originar-se a partir de processos de legitimação, argumentação e de fundamentações normativas ${ }^{35}$.

Um julgado importante na construção do primado deste instituto jurídico é encontrado no arrêt Cachet, exarado pelo Conselho de Estado francês, em 1923. Em verdade, o direito daquele país encara a segurança jurídica a partir da sua dicotomia para com a legalidade. E é desse conflito que surgiram as bases do instituto em questão. Uma apresentação muito clara dessa dialética pode ser vista, como dito, no famoso caso affaire Dame Cachet. Então, a partir dessa data, na França, firmou-se o entendimento no sentido de que o direito que a

\footnotetext{
${ }^{33}$ SILVA, Almiro do Couto. O princípio da Segurança Jurídica (Proteção à Confiança) o Direito Público Brasileiro e o Direito da Administração Pública de anular seus próprios atos administrativos: o prazo decadencial do art. 54 da Lei do processo administrativo da União (Lei no 9.784/99). Revista da Procuradoria-Geral do Estado, n. 57, p. 35-78, dez. 2003.

${ }_{34}$ ÁVILA, Humberto. Segurança jurídica. Entre permanência, mudança e realização no direito tributário. São Paulo: Malheiros, 2011. p. 122-138.

${ }^{35}$ Op. cit., p. 279.
} 
Administração Pública tem de anular de ofício seus próprios atos decai no mesmo prazo que o cidadão tem para questionar o tal vício, o que se faz por meio de recurso contencioso. O prazo para promover a referida medida era fixado em dois meses. Assim, o aresto francês colocou limites ao livre exercício, pelo Poder Público, de anular os próprios atos, fixando balizas nesse sentido ${ }^{36}$.

Modernamente, então, com lastro em vários eventos, estruturou-se a Administração Pública em um padrão dialógico. Ao atingir esse patamar, o Estado passou a promover inúmeros mecanismos que viabilizavam o diálogo entre todos os sujeitos que se relacionavam com o Poder Público ${ }^{37}$. Importante dizer que o dialogismo é exercido por ferramentas jurídicas espalhadas no texto constitucional.

Já no limiar da Administração Pública brasileira, a segurança jurídica cumpre um papel essencial. Tanto que o art. $2^{\circ}$, “caput", da Lei no 9.784/99 (Lei do Processo Administrativo Federal) deu cabo de positivar a segurança jurídica como uma diretriz de observância obrigatória ${ }^{38}$. Esse valor está ligado a inúmeros outros institutos, que nada mais são do que a ferramentaria jurídica para alcançar esse bem juridicamente tutelado. Em

\footnotetext{
${ }^{36} \mathrm{Na}$ Alemanha, o princípio da confiança legítima estrutura-se principalmente a partir da decisão do Tribunal Administrativo de Berlim, de 14 de novembro de 1956 (DVBL 1957, 503) - BVerwGE 9, 251. Na Argentina, a jurisprudência consagrou os requisitos da estabilidade administrativa no caso Carman de Cantón, em 1936.

37 A Administração Pública dialógica atende ao "princípio da boa administração", sendo esta premissa dissecada, entre nós, por Juarez Freitas (Discricionariedade administrativa e direito fundamental à boa administração. São Paulo: Malheiros, 2007). O autor defende que a boa administração impõe que esta seja dialógica, porque exige a manutenção do contraditório e da ampla defesa, consectários do devido processo (Op. cit., p. 20).

${ }^{38}$ Lei no 9.784/99, art. 2: "A Administração Pública obedecerá, dentre outros, aos princípios da legalidade, finalidade, motivação, razoabilidade, proporcionalidade, moralidade, ampla defesa, contraditório, segurança jurídica, interesse público e eficiência."
} 
verdade, recorre-se a esses instrumentos para conferir efetividade à segurança das relações (v.g., ao instituto da decadência, da prescrição ou da preclusão administrativas).

Nesse exemplo, esses institutos jurídicos devem ser aplicados quando se pretende manter situações que foram, ao longo do tempo, consolidadas, ofertando efeitos benéficos a alguém. As regras de decadência ou de prescrição, assim, procuram ofertar um nivelamento nos estágios de afronta a direitos $^{39}$. Dessa perspectiva, um dos pontos cardeais do dito balanceamento de valores constitucionais que se faz entre a legalidade e a segurança jurídica consiste na fixação da delimitação prazal para que a Administração Pública exerça a potestade das funções públicas que lhe são afetas ${ }^{40}$.

No presente caso, quando há uma lacuna normativa estadual, municipal e distrital no sentido de dizer qual é o prazo prescricional dos créditos não tributários, como, v.g., ocorre com aqueles oriundos da exploração onerosa de bens públicos, deve se procurar um limite à exação do Estado, em homenagem, como visto, à segurança jurídica. Em outros termos: quando não existe uma lei estadual que diga qual é o prazo de decadência e/ou de prescrição incidente à espécie, deve-se definir um marco à espécie, porque a segurança jurídica impõe que se tenha um limite temporal a essa exação, ou seja, que essas situações não fiquem ao alvedrio de um futuro incerto, de um infinito deletério.

\footnotetext{
${ }^{39}$ Exemplo ofertado por Judith Martins Costa (Almiro do Couto e Silva e a Re-significação do Princípio da Segurança Jurídica na relação entre o Estado e os cidadãos. In: ÁVILA, Humberto (Org.). Fundamentos do Estado de Direito: Estudos em Homenagem ao Professor Almiro do Couto e Silva. São Paulo: Malheiros, 2005. p. 123).

${ }^{40}$ MAFFINI, Rafael Da Cás. Atos administrativos sujeitos a registro pelos Tribunais de Contas e a decadência da prerrogativa anulatória da administração pública. Revista Brasileira de Direito Público - RBDP, Belo Horizonte: Fórum, ano 3, n. 10, p. 143-163, jul./set. 2005.
} 
Logo, a tarefa do jurista, nesse caso, consiste em definir qual o prazo de prescrição/decadência incidente à espécie a ser retirado da legislação extravagante, até porque esses institutos jurídicos não podem ser presumidos, porque derivam de norma vigente e regularmente ditada. Neste caso, os métodos hermenêuticos de integração e de interpretação, como corolários da compreensão jurídica, devem incidir à situação em causa, a fim de dar uma resposta específica ao tema ${ }^{41}$. Dessa forma, concebe-se que a prática da interpretação, diante do panorama narrado, será compreendida como uma atitude de mediação pela qual o intérprete deverá trazer o não entendimento de um texto a um nível de compreensão. Em outras palavras, interpretar não se resume à mera explicação do significado daquele dispositivo, mas consiste igualmente na construção de um sentido, qual seja, a definição do prazo extintivo incidente à espécie ${ }^{42}$.

A partir daí, filiamo-nos à corrente doutrinária que formula a teoria da coerência e da completude, o que significa dizer que um ordenamento não deve ser interpretado de maneira antagônica, incoerente ou dissociada, ou mesmo possuir essas

\footnotetext{
${ }^{41}$ Nelson Saldanha destaca as diferenças e semelhanças entre o termo "hermenêutica" e o termo "interpretação". Ambos os verbetes designam "[...] o trabalho de entender significações." (Pequeno dicionário da Teoria do Direito e Filosofia Política. Porto Alegre: Sérgio Antônio Fabris, 1987. p. 161).

${ }^{42}$ HEINEN, Juliano. Interpretação conforme a constituição: análise a partir da doutrina e da jurisprudência. Porto Alegre: Verbo Jurídico, 2011. p. 13. Ainda: “Essas considerações levam ao entendimento de que a atividade do intérprete - quer julgador, quer cientista - não consiste em meramente descrever o significado previamente existente dos dispositivos. Sua atividade consiste em constituir esses significados. Em razão disso, também não é plausível aceitar a idéia de que a aplicação do Direito envolve uma atividade de subsunção entre conceitos prontos antes mesmo do processo de aplicação." (ÁVILA, Humberto. Teoria dos princípios: da definição à aplicação dos princípios jurídicos. São Paulo: Malheiros, 2004. p. 24). Ou, para ser mais claro: "Interpretação é, se nos ativermos ao sentido das palavras, 'desentranhamento', difusão e exposição do sentido disposto no texto, mas, de certo modo, ainda oculto." (LARENZ, Karl. Metodologia da Ciência do Direito. Lisboa: Fundação Calouste Gulbenkian, 1997. p. 441). Conferir, ainda: DEMO, Pedro. Metodologia Científica em Ciências Sociais. Editora Atlas: São Paulo, 1995. p. 247-248.
} 
idiossincrasias. O todo deve ser harmonizado, a fim de evitar que, em um mesmo ordenamento jurídico, coexistam, simultaneamente, duas normas antinômicas, bem como que não existam lacunas no sistema jurídico positivado ${ }^{43}$. $\mathrm{O}$ conceito de integração, por sua vez, permite que se tragam elementos externos ao ordenamento, para que possam suprir as lacunas existentes. Então, não há um sistema de autointegração, isto é, a completude e a harmonia do complexo de regras não estão prontas e acabadas, mas devem ser (eternamente) construídas, a fim de garantir a autossuficiência do sistema jurídico, sem recorrer a elementos estranhos ao Direito. A integração se vale de elementos exteriores, como as outras fontes jurídicas, tais quais os princípios gerais do direito - não positivados -, a equidade etc. ${ }^{44}$

Portanto, desde já rechaçamos a tese de que, na ausência de normas de prescrição e/ou de decadência, não se teria evidenciado qualquer prazo extintivo para o exercício da constituição do crédito e da pretensão de cobrança. A segurança das relações jurídicas, de acordo com o que foi apresentado, não se compadece com a noção de imprescritibilidade, por exemplo. Assim, não temos dúvidas em afirmar que, no caso, a cobrança desses créditos não pode ser eternizada.

Dessa forma, na ausência de uma regra estadual, municipal ou distrital específica de prescrição e/ou de decadência aplicável ao caso, qual seria o prazo a ser conferido para dar segurança jurídica à matéria? Em resposta, visualizamos dois caminhos possíveis a serem tomados. Apresentamos ambos, sendo que o segundo é aquele que se mostra sistematicamente mais lógico e coerente com a noção de completude do sistema jurídico.

\footnotetext{
${ }^{43}$ Por todos: BOBBIO, Norberto. O positivismo jurídico: lições de filosofia do direito. São Paulo: Ícone, 1995. p. 132-133.

${ }^{44}$ MAXIMILIANO, Carlos. Hermenêutica e aplicação do Direito. Rio de Janeiro: Forense, 1997. p. 220.
} 


\section{4 "Trilhas Jurídicas" a Serem Seguidas}

Em primeiro lugar, poder-se-ia pensar em aplicar à presente situação, a contrario sensu, o art. 1ํํㄹ do Decreto-lei $\mathrm{n}^{\mathrm{o}}$ 20.910/32, ou seja, o prazo prescricional de cinco anos. O raciocínio, nessa hipótese, daria conta de empregar ao Estado o mesmo prazo que é destinado aos particulares para exigirem suas pretensões da Fazenda Pública. Então, os cinco anos de prescrição englobariam os atos de constituição e exigência do crédito público.

Veja que o Decreto-lei no 20.910/32 se refere a "dívidas passivas" da União, Estados e Municípios. Todavia, no presente caso, cuida-se de dívida não tributária, enfim, de uma pretensão administrativa dos Estados federados, dos Municípios ou do Distrito Federal contra um particular, ou seja, um crédito da Administração Pública para com um administrado. Logo,

220 o problema desta tese consiste no fato de que ela esqueceria que, na realidade, a receita em questão possui duas fases muito claras: uma etapa de constituição, seguida da fase de exigência da pretensão, na mesma linha do que ocorre com os créditos tributários. Em síntese, as duas etapas conferem efeitos jurídicos completamente diversos, reclamando prazos extintivos diferentes.

Na hipótese, a aplicação do prazo de prescrição de cinco anos, pura e simplesmente, afeta tão somente a fase de cobrança (exigibilidade). A etapa constitutiva do crédito deve merecer a incidência de eventual prazo decadencial, o que não existiria caso se aplicasse pura e simplesmente, como dito, o prazo de cinco anos do art. 1o do Decreto-lei n⿳丷ㅡ 20.910/32. O correto entendimento sobre o tema visualiza que o prazo prescricional terá início somente no momento em que se torna exigível a dívida a ser cobrada, ou seja, no dia seguinte ao do vencimento do prazo para pagamento, quando, então, há a possibilidade 
de reclamar o crédito não tributário fazendário. Antes disso, correm os prazos de caducidade.

Em linhas gerais, a aplicação a contrario sensu da legislação mencionada esqueceria que existem duas fases muito claras nos planos de constituição e exigibilidade dos valores aqui envolvidos. Enfim, negaria, no caso, que existe a necessidade de fazermos frente a um prazo de decadência, cuja concepção é plenamente aceita no âmbito dos vários sistemas jurídicos apresentados - de acordo com a exposição feita no item precedente.

Preliminarmente, concluo, pois, que a situação narrada reclama a incidência de dois prazos distintos: decadência e prescrição, até pela similitude que este caso tem para com o sistema de direito tributário. Sendo assim, penso que se deve aplicar, por analogia, um sistema normativo que atende ao disposto. Para tanto, o art. 47 da Lei n 9.636/98 fornece prazos específicos ao caso em concreto.

Então, indo ao ponto: na ausência de normas administrativas estaduais, municipais ou distritais que digam quais são os prazos de prescrição elou decadência para a cobrança de créditos não tributários, como, por exemplo, aqueles oriundos da ocupação onerosa de bens públicos, poder-se-ia aplicar a legislação federal que disciplina a matéria, no caso, a Lei $n^{-}$9.636/98, e alterações posteriores, tudo em homenagem à segurança jurídica.

Frente à situação narrada, a jurisprudência do Superior Tribunal de Justiça oferta uma resposta muito tranquila: é possível aplicar a legislação federal aos Estados-membros (e, por consequência lógica, aos Municípios e ao Distrito Federal) na ausência de normas de prescrição ou de decadência, conferindo a devida segurança às relações jurídicas. No caso, a Corte Superior está a tratar, mais especificamente, da possibilidade de aplicação do art. 54 da Lei no 9.784/99 ao âmbito local (não que não tenha 
permitido a incidência, no âmbito regional ou local, de outros dispositivos da Lei do Processo Administrativo Federal) ${ }^{45}$. E não é de hoje que a referida Corte vem decidindo desta maneira ${ }^{46}$. No julgamento do STJ, RMS 16.776-PR, decidido em 25 de maio de 2004, p. ex., o Superior Tribunal de Justiça já anunciava a aplicação subsidiária da Lei no 9.784/99 no âmbito interno dos Estados-membros. No caso em questão, o Ministro Felix Fischer foi mais além: supriu a lacuna de um prazo não previsto no Regimento Interno do Tribunal de Justiça do Estado do Paraná, aplicado à Lei do Processo Administrativo Federal.

Essa linha hermenêutica benevolente com a interpretação favorável à aplicação da lei federal aos Estados, Municípios e Distrito Federal diante de um "vazio legal" (local ou regional) é amparada pelo Supremo Tribunal Federal em decisões concretas. Aliás, a Suprema Corte nem mesmo determina ou se manifesta no sentido de que esses entes federados se sintam compelidos a elaborar, urgentemente, normas próprias ${ }^{47}$.

Então, muitas vezes a Lei federal no 9.784/99 é aplicada em outras esferas da Federação brasileira, na ausência de uma legislação local ou regional pertinente. Logo, considera-se possível aplicar o mesmo raciocínio à Lei no 9.636/98, também de natureza federal, tendo por base a segurança jurídica, sendo este o entendimento que deve prevalecer para a hipótese investigada neste trabalho.

\footnotetext{
${ }_{45}$ STJ, AgRg no AREsp 263.635-RS, Rel. Min. Herman Benjamin, 2ª Turma, j. 16/5/2013. Conferir, ainda: STJ, AgRg no RMS 20.038-RS, Rel. Min. Og Fernandes, $6^{a}$ Turma, j. $18 / 4 / 2013$.

${ }^{46}$ STJ, Resp. 1.148.460-PR, Rel. Min. Castro Meira, Segunda Turma, j. 19/10/2010; STJ, Resp. 1.200.981-PR, Rel. Min. Arnaldo Esteves Lima, Primeira Turma, j. 5/10/2010; STJ, RMS 21.070-SP, Rel. Min. Laurita Vaz, julgado em 17/11/2009; STJ, REsp 645.856/ RS, Rel. Min. Laurita Vaz, Quinta Turma, DJ 13/9/04.

${ }^{47}$ STF, Rp 1.153/RS, Rel. Min. Aldir Passarinho, Pleno, j. 16/5/1985. Conferir, ainda: OLIVEIRA, Antônio Flávio de. Interpretação dos arts. 42 a 49 do Estatuto das microempresas e empresas de pequeno porte. FCGP, ano 6, n. 69, p. 71-77, 2007.
} 
Naturalmente, conclui-se que a Lei no 9.636/98 é ato normativo de natureza federal, porque instaura dispositivos específicos à União, e não a todos os entes federados. Assim, em princípio, não se poderia transportar essa legislação ao âmbito local. Apesar disso, a conclusão (quase que cartesiana) apresentada não vem a ser facilmente aceita. Logo, a partir da mesma lógica aplicada à Lei do Processo Administrativo Federal, consideramos possível a incidência da Lei federal nº 9.636/98 no âmbito estadual, distrital ou municipal, como paradigma aos prazos-limite de cobrança dos créditos não tributários.

O próprio Almiro do Couto e Silva ${ }^{48}$, muito embora não admita a aplicação da Lei nº 9.784/99 aos demais entes federados, entende que o art. 54, p. ex., poderia ser um indicativo aos Estados e aos Municípios na ausência de norma específica. $\mathrm{O}$ que significa dizer que, frente à ausência de legislação sobre o tema, pode-se buscar, no âmbito da legislação federal (tipicamente voltada à União), um paradigma ${ }^{49}$.

Então, ratificando o raciocínio aqui exposto e de forma singela, entende-se possível aplicar a mesma lógica desenvolvida pelas Cortes nacionais, quando da integração feita a partir da Lei federal no 9.784/99 (Lei do Processo Administrativo Federal) aos demais entes federados, quando estes não tiverem editado regras específicas sobre o caso. Este panorama deve, portanto, ser transposto à presente situação.

Em melhores termos: quando os Estados, os Municípios ou o Distrito Federal não editaram lei específica que discipline a situação dos créditos não tributários, ou seja, não há uma regra

\footnotetext{
${ }^{48}$ Op. cit., p. 74, itens "59" a "60".

${ }^{49}$ Nesse contexto, a fim de permitir uma coerência conceitual, tomar-se-á por base a obra de Thomas Kuhn, no sentido de definir que paradigma: "[...] é aquilo que os membros de uma comunidade partilham e, inversamente, uma comunidade científica consiste em homens que partilham um paradigma". (KUHN, Thomas. A estrutura das revoluções científicas. São Paulo: Perspectiva, 2000. p. 219).
} 
que diga exatamente qual é o procedimento aplicável à espécie, ou o prazo prescricional ou decadencial para a cobrança destes montantes, podem-se tomar por base, em analogia, as disposições federais sobre o tema. Significa dizer que, no cenário de ausência completa de uma disciplina normativa estadual, distrital ou municipal sobre tais prazos, podem-se aplicar, em homenagem à segurança das relações jurídicas, as disposições constantes na Lei no 9.636/98 (art. 47) e alterações posteriores ${ }^{50}$.

No que se refere ao prazo de decadência, a Lei no 9.636/98 regulamentou exatamente a matéria em pauta no âmbito da União. Confira:

Art. 47. O crédito originado de receita patrimonial será submetido aos seguintes prazos: (Redação dada pela Lei no 10.852 , de 2004)

I - decadencial de dez anos para sua constituição, mediante lançamento; e (Incluído pela Lei n⿳ำ 10.852, de 2004)

II - prescricional de cinco anos para sua exigência, contados do lançamento. (Incluído pela Lei n⿳o 10.852, de 2004)

$\S 1^{\circ} \mathrm{O}$ prazo de decadência de que trata o caput conta-se do instante em que o respectivo crédito poderia ser constituído, a partir do conhecimento por iniciativa da União ou por solicitação do interessado das circunstâncias e fatos que caracterizam a hipótese de incidência da receita patrimonial, ficando limitada a cinco anos a cobrança de créditos relativos a período anterior ao conhecimento. (Redação dada pela Lei n⿳9 9.821, de 1999)

$\S 2^{\underline{O}}$ Os débitos cujos créditos foram alcançados pela prescrição serão considerados apenas para o efeito da caracterização da ocorrência de caducidade de que trata o parágrafo único do art. 101 do Decreto-Lei nº 9.760, de 1946, com a redação dada pelo art. 32 desta Lei. (Redação dada pela Lei nº 9.821, de 1999)

${ }^{50}$ Tudo de acordo, como dito, com o mesmo raciocínio praticado em relação à Lei no 9.784/99. 
Dessa forma, diante da ausência de norma estadual específica - regional ou local -, ou seja, verificada lacuna legislativa, impende buscar uma solução jurídica para a questão na regra mencionada. Até porque não se aplicam à dívida ativa não tributária as regras de prescrição e de decadência previstas no Código Tributário Nacional.

A jurisprudência, ao nosso ver, não confere maior profusão à tese específica desta exposição (v.g. aplicação da Lei n ${ }^{\circ}$ 9.636/98 ao âmbito estadual), ou, por vezes, baralha conceitos e legislações. No Recurso Especial (REsp.) nº 1.133.696, de relatoria do Min. Luiz Fux, representativo de controvérsia, o STJ decidiu da seguinte forma a questão posta em debate:

1. O prazo prescricional, para a cobrança da taxa de ocupação de terrenos de marinha, é de cinco anos, independentemente do período considerado, uma vez que os débitos posteriores a 1998, se submetem ao prazo quinquenal, à luz do que dispõe a Lei 9.636/98, e os anteriores à citada lei, em face da ausência de previsão normativa específica, se subsumem ao prazo encartado no art. 1ํ do Decreto-Lei 20.910/1932.

2. A relação de direito material que enseja o pagamento da taxa de ocupação de terrenos de marinha é regida pelo Direito Administrativo, por isso que inaplicável a prescrição delineada no Código Civil.

(a) o prazo prescricional, anteriormente à edição da Lei 9.363/98, era quinquenal, nos termos do art. $1^{\circ}$, do Decreto 20.910/32;

(b) a Lei 9.636/98, em seu art. 47, institui a prescrição quinquenal para a cobrança do aludido crédito;

(c) o referido preceito legal foi modificado pela Lei 9.821/99, que passou a vigorar a partir do dia 24 de agosto de 1999, instituindo prazo decadencial de cinco anos para constituição do crédito, mediante lançamento, mantendo-se, todavia, o prazo prescricional quinquenal para a sua exigência;

(d) consectariamente, os créditos anteriores à edição da Lei no 9.821/99 não estavam sujeitos à decadência, mas somente a prazo prescricional de cinco anos (art. $1^{\circ}$ do Decreto $n^{\circ}$ 20.910/32 ou 47 da Lei no 9.636/98); 
(e) com o advento da Lei 10.852/2004, publicada no DOU de 30 de março de 2004, houve nova alteração do art. 47 da Lei 9.636/98, ocasião em que foi estendido o prazo decadencial para dez anos, mantido o lapso prescricional de cinco anos, a ser contado do lançamento.

A decisão versa sobre ocupação de terrenos de marinha, portanto, de imóveis pertencentes à União. Para a cobrança destes emolumentos, entendia-se que o prazo prescricional era de cinco anos antes da edição da Lei nº 9.636/98, a partir da interpretação retirada dos dispositivos constantes no Decreto-lei $n^{-}$20.910/32. E continuou sendo de cinco anos mesmo após a edição da Lei n⿳0 9.636/99, porquanto esse foi o prazo prescricional estabelecido por ela para cobrança de receitas patrimoniais. Até então, não havia previsão de prazo decadencial, que foi estabelecido pela Lei no 9.821/99. Este último interregno de tempo foi aumentado para dez anos pela Lei n⿳ $10.852 / 04$, só incidindo sobre fatos geradores ocorridos a partir do início de sua vigência. Eis o objeto deste leading case, o que revela uma completa ausência de cognição judicial a respeito do caso em pauta.

Logo, a cobrança de "taxa de ocupação" - que, em verdade, tributo não é (apesar de ter a denominação de "taxa"), porque é típica receita oriunda de preço público - tem por base uma relação de Direito Administrativo. Por isso, não se aplicam à espécie as disposições do Código Civil ou do Código Tributário Nacional.

No âmbito do Tribunal de Justiça do Estado do Rio Grande do Sul, podemos citar a Apelação no 70026553487 , de relatoria do Des. Marco Aurélio Heinz.

De conformidade com o art. 47 da Lei n.. 9.636/1998, a cobrança decorrente de receita patrimonial não tributária se sujeita à prescrição qüinqüenal.

Em todo o caso, a jurisprudência do STJ vem entendendo que, se a relação que deu origem ao crédito em cobrança 
tem assento no Direito Público, não tem aplicação a prescrição constante do Código Civil. Aplicação do disposto no Decreto n.․ 20.910/1932.

Ao nosso sentir, a decisão não traz elementos seguros. Ao contrário. Primeiro, declara que o prazo prescricional à cobrança de receitas não tributárias seguirá o que dita o art. 47 da Lei no 9.636/1998, sem, contudo, manifestar categoricamente se incide sobre receitas patrimoniais do Estado ou do Município. Em um segundo momento, manda aplicar o Decreto-lei nº 20.910/1932, que, face à aplicação do princípio da simetria, também impõe prazo prescricional (e só prescricional) de cinco anos, tal qual dispõe o art. 47 da lei federal mencionada.

É certo que, até então, não havia diferenças substanciais entre os dois diplomas normativos. A dissonância surgiu, como visto, com as Leis no 9.821/99 e no 10.852/04, quando foi estabelecido prazo decadencial. Contudo, o julgado não adentra nessa questão, ou seja, não declara se o prazo de decadência de dez anos é aplicado ao âmbito estadual.

Dessa forma, partindo do mesmo raciocínio conferido à Lei federal $n^{0}$ 9.784/99, consideramos que eventual lacuna encontrada em âmbito normativo estadual, distrital ou municipal pode ser suprida pela Lei federal no 9.636/98. Destaca-se que a aplicação do citado art. 47 deve seguir as diretrizes temporais definidas pelo Superior Tribunal de Justiça:

1. O art. 47 da Lei 9.636/98 instituiu a prescrição qüinqüenal para a cobrança da taxa de ocupação de terreno de marinha. A Lei 9.821/99, que passou a vigorar a partir do dia 24 de agosto de 1999, estabeleceu em cinco anos o prazo decadencial para constituição do crédito, mediante lançamento, mantendo-se o prazo prescricional qüinqüenal para a sua exigência. Com o advento da Lei 10.852/2004, publicada em 30 de março de 2004, houve nova alteração do art. 47 da Lei 9.636/98, para estender o prazo decadencial de cinco para dez anos, mantido o lapso prescricional de cinco anos, a ser contado do lançamento. 
2. No período anterior à vigência da Lei 9.636/98, em razão da ausência de previsão normativa específica, deve-se aplicar o prazo de prescrição quinquenal previsto no art. $1^{\mathrm{o}}$ do Decreto 20.910/32. Orientação da Primeira Seção nos EREsp 961.064/CE, julgado na sessão de 10 de junho de 2009.

3. A relação de direito material que dá origem à taxa de ocupação de terrenos de marinha é regida pelo Direito Administrativo, tornando inaplicável a prescrição de que trata o Código Civil.

4. Assim, o prazo prescricional para a cobrança da taxa de ocupação de terrenos de marinha é de cinco anos, independentemente do período considerado.

5. Embargos de divergência não providos.

(Emb. de Div. Em Resp. 961.064-CE, Rel. Min. Teori Albino Zavascki, j. 10/6/2009).

Ademais, deve ser mencionado que, para as relações creditícias constituídas antes da vigência da Lei no 9.636/98, devem ser aplicados os prazos de prescrição e de decadência constantes no Código Civil, na linha do que já foi decidido pelo Superior Tribunal de Justiça: "[...] a) antes da vigência do art. 47 da Lei 9.636/98 (18/05/1998), em sua redação original, a cobrança da taxa de ocupação de terreno da marinha sujeitava-se, enquanto preço público, ao prazo prescricional vintenário estabelecido no Código Civil de 1916." (STJ, Resp. 1.015.297, Rel.

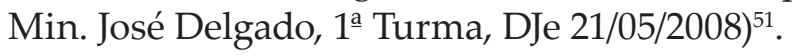

\footnotetext{
${ }^{51}$ Ou ainda: "ADMINISTRATIVO. TERRENO DE MARINHA. TAXA DE OCUPAÇÃO. PRESCRIÇÃO. - No tocante à taxa de ocupação, trata-se de preço público e não tributo, sendo uma contra prestação que o particular deve pagar à União Federal em virtude da utilização de um terreno de marinha. - Considerando as dívidas discriminadas na Certidão de Dívida Ativa que instrui a execução, as taxas de ocupação ali referidas não se encontram prescritas, haja vista a incidência do prazo de 20 anos previsto

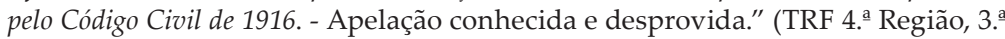
Turma, AC 200471010015691/RS, Rel. Des. Carlos Eduardo Thompson Flores Lenz, DJU 19.10.2005, p. 1000) [grifo nosso].
} 
Ainda permeando o tema, imperioso ter em mente que o prazo prescricional dos créditos desta espécie passa por uma suspensão de 180 (cento e oitenta) dias, entre a inscrição em dívida ativa e a execução fiscal. Então, este período de carência de seis meses deve ser levado em conta à espécie $\left(\S 3^{\circ}\right.$ do art. $2^{\underline{0}}$ da Lei $n^{\mathrm{o}}$ 6.830, de 22 de setembro de $1980^{52}$ ).

Evidentemente que o referido dispositivo aplica-se aos créditos não tributários da Fazenda pública, na medida em que a estes não se aplica o lançamento previsto no art. 173 do Código Tributário Nacional, porque, neste último caso, trata-se de receita oriunda de relação calcada no direito tributário. Já as receitas, p. ex., que advêm da exploração onerosa de bem público possuem como pano de fundo o direito administrativo.

1. A suspensão do lapso prescricional de 180 (cento e oitenta) dias prevista no art. $2^{\circ}, \S 3^{\circ}$, da Lei 6.830 somente é aplicável às dívidas de natureza não tributária. Em hipóteses como a dos autos, em que se trata de execução de crédito relativo a Imposto de Renda, a matéria é regulada pelo art. 174 do Código Tributário Nacional. 2. Agravo Regimental não provido (STJ, AgRg no AI no 1.054.859, Segunda Turma, Rel. Min. Herman Benjamin, j. 14/10/2008).

Dessa forma, o termo inicial do prazo de prescrição, observado o disposto no art. $2^{\circ}, \S 3^{\circ}$, da Lei $n^{\circ} 6.830 / 80$, será o primeiro dia seguinte aos 180 (cento e oitenta) dias posteriores à inscrição em dívida ativa, salvo se, antes, não tiver sido distribuída pertinente execução fiscal. Considerado esse contexto,

${ }^{52}$ Lei no 6.830/80, art. $2^{\circ}$ : “Constitui Dívida Ativa da Fazenda Pública aquela definida como tributária ou não tributária na Lei no 4.320, de 17 de março de 1964, com as alterações posteriores, que estatui normas gerais de direito financeiro para elaboração e controle dos orçamentos e balanços da União, dos Estados, dos Municípios e do Distrito Federal. [...] § $3^{\circ}$ A inscrição, que se constitui no ato de controle administrativo da legalidade, será feita pelo órgão competente para apurar a liquidez e certeza do crédito e suspenderá a prescrição, para todos os efeitos de direito, por 180 dias, ou até a distribuição da execução fiscal, se esta ocorrer antes de findo aquele prazo." 
destaca-se com ênfase que todos os atos tendentes a tornar líquidos e certos tais créditos, assim como os procedimentos relacionados à posterior inscrição em dívida ativa e à consequente propositura da ação de cobrança, se necessária, devem ser ultimados em tais prazos, sob pena de restar caracterizada a consumação da prescrição.

\section{Considerações Finais}

Diante do exposto, opino:

a) que a constituição de créditos não tributários deve ser feita pela via de procedimento administrativo que garanta a incidência dos direitos fundamentais, expondo-se, no corpo deste trabalho, fluxograma específico. A inscrição em dívida ativa seguirá, claro, o rito disposto pelas normas administrativas, desde que compatível com as observações feitas no que se refere ao respeito ao devido processo legal;

b) que o referido montante devido e não pago deve ser inscrito em dívida ativa e cobrado pela via judicial da Lei $\mathrm{n}^{-}$6.830/80;

c) que a Lei no 9.636/98, de natureza federal, disciplinou a forma e os prazos prescricionais/decadenciais para a cobrança de créditos não tributários. Contudo, muitos Estados e Municípios não editaram regras específicas sobre o tema. Sendo assim, na ausência de legislação estadual nesse sentido, devem ser aplicados, por analogia, os prazos prescricional e decadencial do art. 47 da Lei $n^{\circ}$ 9.636/98 e alterações posteriores, em homenagem à segurança jurídica. Utiliza-se, 
para tanto, a mesma lógica hermenêutica ofertada à Lei federal no 9.784/99, de que, antes da Lei no 9.636/98, devem ser aplicados os prazos constantes no Código Civil, ou seja, devem ser observados os prazos de prescrição previstos no art. 177 da legislação anterior (CC/1916) e no art. 205 do novo Código (2002), observada a regra de transição especificada no artigo 2.028 deste último. Assim, se já transcorrido mais da metade do prazo da lei anterior, estabelecido em vinte anos (art. 177), aplica-se o lapso temporal do Código revogado; se ainda não decorrido tal lapso de tempo, aplica-se o prazo prescricional do novo Código, estabelecido em dez anos (art. 205), cuja contagem deve ser feita a partir do início da sua vigência;

d) que o termo inicial do prazo prescricional, observado o disposto no art. $2^{\circ}, 3^{\circ}{ }^{\circ}$, da Lei $n^{\circ}$ 6.830/80, será o primeiro dia seguinte aos 180 (cento e oitenta) dias posteriores à inscrição em dívida ativa, salvo se, antes, não tiver sido distribuída a execução fiscal pertinente.

\section{Referências}

AMORIM FILHO, Agnelo. Critério científico para distinguir a prescrição da decadência e para identificar as ações imprescritíveis. Revista de Direito Processual Civil, São Paulo, v. 3, p. 95-132, jan./jun. 1961.

ÁVILA, Humberto. Segurança jurídica. Entre permanência, mudança e realização no direito tributário. São Paulo: Malheiros, 2011.

BIGOLIN, Giovani. Segurança jurídica: a estabilização do ato administrativo. Porto Alegre: Livraria do Advogado, 2007. 
Créditos Não Tributários Estaduais...

BOBBIO, Norberto. O positivismo jurídico: lições de filosofia do direito. São Paulo: Ícone, 1995.

CALMES, Sylvia. Du principe de protection de la confiance légitime en droits allemand, communautaire et français. Paris: Dalloz, 2001.

CORREIA, Fernando Alves. Alguns conceitos de Direito Administrativo. Coimbra: Almedina, 2001.

COSTA, Judith Martins. Almiro do Couto e Silva e a Re-significação do Princípio da Segurança Jurídica na relação entre o Estado e os cidadãos. In: ÁVILA, Humberto (Org.). Fundamentos do Estado de Direito: Estudos em Homenagem ao Professor Almiro do Couto e Silva. São Paulo: Malheiros, 2005.

DEMO, Pedro. Metodologia Científica em Ciências Sociais. São Paulo: Editora Atlas, 1995.

FARIAS, Cristiano Chaves de; ROSENVALD, Nelson. Direito Civil Teoria Geral. Rio de Janeiro: Lumen Juris, 2009.

FREITAS, Juarez. Discricionariedade administrativa e direito fundamental 232 à boa administração. São Paulo: Malheiros, 2007.

HABERMAS, Jürgen. Direito e democracia: entre facticidade e validade. Rio de Janeiro: Tempo Brasileiro, 1997. v. 1.

HEINEN, Juliano. Interpretação conforme a constituição: análise a partir da doutrina e da jurisprudência. Porto Alegre: Verbo Jurídico, 2011.

KELSEN, Hans. Teoria Pura do Direito. São Paulo: Martins Fontes, 1995.

KUHN, Thomas. A estrutura das revoluções científicas. São Paulo: Perspectiva, 2000.

LARENZ, Karl. Derecho Justo: Fundamentos de Ética Jurídica. Madrid: Civitas, 1985.

. Metodologia da Ciência do Direito. Lisboa: Fundação Calouste Gulbenkian, 1997.

MAFFINI, Rafael Da Cás. Atos administrativos sujeitos a registro pelos Tribunais de Contas e a decadência da prerrogativa anulatória da administração pública. Revista Brasileira de Direito Público - RBDP, Belo Horizonte: Fórum, ano 3, n. 10, p. 143-163, jul./set. 2005. 
MAXIMILIANO, Carlos. Hermenêutica e aplicação do Direito. Rio de Janeiro: Forense, 1997.

MELLO, Celso Antônio Bandeira de. Segurança jurídica, boa-fé e confiança legítima. Revista Trimestral de Direito Público, São Paulo: Malheiros, n. 51-52, s/d.

PÉREZ, Jesús González. El Principio General de la Buena Fe en el Derecho Administrativo. Madrid: Civitas, 1989.

SALDANHA, Nelson. Pequeno dicionário da Teoria do Direito e Filosofia Política. Porto Alegre: Sérgio Antônio Fabris, 1987.

SILVA, Almiro do Couto. O princípio da Segurança Jurídica (Proteção à Confiança) no Direito Público Brasileiro e o Direito da Administração Pública de anular seus próprios atos administrativos: o prazo decadencial do art. 54 da Lei do processo administrativo da União (Lei no 9.784/99). Revista da Procuradoria-Geral do Estado, Porto Alegre, n. 57, p. 35-78, dez. 2003.

TARTUCE, Flávio. Manual de direito civil. Rio de Janeiro: Forense; São Paulo: Método, 2012.

TONIOLO, Ernesto José. A prescrição do Crédito Fiscal e seus Fundamentos Constitucionais. Revista da Procuradoria-Geral do Estado, Porto Alegre: Corag, v. 32, n. 68, jul./dez. 2011.

TORRES, Heleno Taveira. Direito constitucional tributário e segurança jurídica: metódica da segurança jurídica do sistema constitucional tributário. São Paulo: Revista dos Tribunais, 2011.

VITTA, Manoel Álvares; GARCIA, Heraldo; SOUZA, Maria Helena Rau de; CÂMERA, Miriam Costa Rebollo; SAKAKIHARA, Zuudi. FREITAS, Vladimir Passos de (Coord.). Execução Fiscal: doutrina e jurisprudência. São Paulo: Saraiva, 1998. 


\title{
O Realismo Jurídico como Meio de Garantia da Justiça Ambiental
}

\author{
Legal Realism as a Way \\ of Assuring Environmental Justice
}

Manuela Braga Fernandes*

Resumo: A questão da justiça ambiental tem estado em pauta nas últimas décadas no Brasil como forma de garantir uma distribuição igualitária dos ônus e bônus da exploração do meio ambiente. Mas como tem se dado essa garantia de justiça ambiental no mundo e, especialmente, no Brasil? O problema do trabalho é, nesses termos, entender a questão da garantia de justiça ambiental no ordenamento jurídico brasileiro. A resposta inicial para essa proposição é que o realismo jurídico lança o melhor enfoque sobre a temática, uma vez que promove o desapego da lei e permite ao juiz fazer como for necessário para que se garanta justiça de fato, proporcionando um respaldo teórico para essa posição mais ativista do magistrado. Essa hipótese será testada analisando alguns casos jurisprudenciais exemplificativos, em que o juiz se desvinculou da norma jurídica para julgar o caso, de forma a provar se o realismo, afinal, pode promover ou não a garantia da justiça ambiental.

Palavras-chave: Justiça Ambiental. Encargos Ambientais. Teoria da Decisão. Realismo Jurídico. Decisão Judicial.

Abstract: The matter of environmental justice has been in evidence on the last decades in Brazil as a way of assuring an egalitarian distribution of the onus and bonus of the environment exploration. But how this assurance of environmental justice has been occurring in the world and, most especially, in Brazil? The object

* Universidade Federal da Paraíba. 
O Realismo Jurídico como Meio de Garantia...

of the present work is, in these terms, to understand the guarantee of environmental justice on the Brazilian legal order. The initial answer for this proposition is that legal realism casts a better light over the theme once it allows the detachment from law and allows the judge to make whatever is necessary to assure justice, providing a theoretical support for this more activist judge's attitude. This hypothesis will be tested analyzing some exemplary legal cases in which the judge detached himself from the legal norm to judge the case, in order to prove if realism, after all, can promote or not the assurance of environmental justice.

Keywords: Environmental Justice. Environmental Duties. Decision Theory. Legal Realism. Judicial Decision.

\section{Introdução}

A preocupação com o meio ambiente saudável começou, efetivamente, na década de 70, com a Conferência de Estocolmo. A partir daí, a questão da justiça ambiental entrou em pauta do ponto de vista do direito internacional.

No entanto, a partir dos anos 80 começou a se formar nos EUA um movimento que buscava igualdade na distribuição de ônus ambientais e que levantou a questão de tratamentos diferentes para diferentes grupos sociais. $\mathrm{O}$ movimento foi chamado de justiça ambiental e promoveu, finalmente, o entendimento de que diferentes problemáticas dentro da questão ambiental devem ser tratadas de formas diferentes. Até aqui se tratavam as questões ambientais como se fossem uma matéria só. A partir da discussão trazida pela justiça ambiental, entendeu-se que meio ambiente é só um gênero ao qual pertencem várias discussões. Assim, a questão do lixo passou a ser tratada separadamente da questão da água e da energia, assim como de todas as outras. 
Outra questão dentro da problemática de proteção ao meio ambiente é a efetivação da garantia legal, ou mesmo a efetivação de justiça ambiental quando não há esta garantia. Muitas vezes a mera legislação não se faz suficiente para garantir a proteção do meio ambiente. Um dos vieses da própria temática da justiça ambiental é a garantia que se faz dentro do Judiciário. Dessa forma, o papel do magistrado como principal agente de decisão nas ações relacionadas ao meio ambiente é por si só matéria de discussão de proteção ambiental.

Assim, o realismo jurídico, uma tese que enxerga no próprio juiz o principal agente de feitura de direito, pode promover o respaldo teórico necessário para incentivar uma postura positiva do magistrado no sentido de garantir justiça ambiental.

Dessa forma, com a temática da justiça ambiental e do realismo jurídico, tem-se a problemática do presente trabalho. A hipótese inicial é a de que o realismo jurídico pode fundamentar uma postura proativa do magistrado para garantir justiça ambiental.

Nesses termos, vai-se, inicialmente, desvendar o que vem a ser justiça ambiental nos seus dois vieses: como movimento contra o racismo ambiental e como feitura de justiça dentro do Judiciário nas questões que envolvem o meio ambiente.

Em seguida, é preciso entender o realismo jurídico e como sua proposta de abordagem do direito pode servir para fundamentar a justiça ambiental.

Por fim, faz-se necessário testar a hipótese de que o realismo jurídico pode explicar e fundamentar uma atitude proativa do magistrado no sentido de sair do lugar comum da lei para garantir justiça ambiental. Esse teste é realizado por meio da análise de jurisprudências que podem exemplificar a tese defendida. 


\section{Os Paradigmas da Justiça Ambiental e Ferramentas para sua Efetivação}

A temática da justiça ambiental lato sensu não vai tratar apenas da questão da escassez ou da preservação do meio ambiente, mas também da distribuição de recursos e dos ônus ambientais.

Assim, justiça ambiental é mais que falar em jurisprudência ambiental; é, em verdade, um movimento social que nasceu nos EUA dos anos 80. A população negra americana começou a perceber uma política pública ambiental que desfavorecia as suas comunidades, sofrendo com o despejo de dejetos ou mesmo o esquecimento completo das suas necessidades. Nasceu, então, a chamada justiça ambiental, um conjunto de princípios que clamam pelos direitos ambientais sem qualquer distinção de cor. A partir daí, o movimento globalizou-se e passou a agregar não só comunidades negras, mas todos os cidadãos que lutam pela devida garantia de direitos ambientais e se sentem inferiorizados, arcando com os prejuízos de políticas públicas prejudiciais ${ }^{1}$.

Dessa forma, o conceito de justiça ambiental está mais relacionado à justiça distributiva, uma vez que tem como principal fundamento a distribuição equitativa dos danos ambientais. O enfoque aqui é que todos arquem com os danos; não se fala nem em riquezas ou bônus, mas em ônus.

O movimento não só critica o crescimento econômico desenfreado, que não se preocupa com as questões ambientais, mas também quer promover uma ampliação das discussões dentro da matéria ambiental. Promove um discurso de divisão

1 CASTILHO, Adriana Guedes de. Entre a justiça e a injustiça ambiental: atuação do poder judiciário nos conflitos ambientais. 2013. 114 f. Dissertação (Mestrado em Ciências Jurídicas) - Universidade Federal da Paraíba, João Pessoa, 2013. 
das problemáticas ambientais, pois não existe um meio ambiente único, homogêneo: ele tem diferentes vieses, que devem ser discutidos de maneiras diferentes. $\mathrm{O}$ que o movimento quer dizer é que a questão da água é diferente da questão da energia e esta, por sua vez, é diferente da dos resíduos... Todas essas temáticas têm peculiaridades que devem ser tratadas separadamente, mas juntas formam as questões de direito ambiental. É fazendo essa devida separação que se vai atingir a verdadeira justiça ambiental.

O oposto da justiça ambiental é a injustiça ambiental, ou racismo ambiental, que se configura na distribuição desigual dos benefícios e dos impactos negativos das políticas ambientais entre os diferentes grupos da sociedade. Quando se tem uma situação em que um determinado grupo social não tem acesso aos recursos e, ao mesmo tempo, arca com todas as custas dos impactos ambientais negativos, tem-se consolidada a injustiça ambiental.

As discussões acerca da justiça ambiental começam a acontecer no Brasil no ano 2000, com publicações e pesquisas na área. Em 2001, criou-se a Rede Brasileira de Justiça Ambiental (RBJA), que se instituiu assumindo o compromisso de garantir que nenhum grupo social ou étnico suporte uma parcela desproporcional das consequências ambientais negativas, bem como o acesso justo de todos aos recursos, o acesso às informações relevantes sobre o tema e o favorecimento da criação de novos grupos de proteção².

A Rede tem investido em pesquisas que tentam relacionar a degradação ambiental com a desigualdade social e conclui que a exposição desproporcional da população a danos

2 PACHECO, Tânia. Rede Brasileira de Justiça Ambiental. 2012. Disponível em: $<$ http://racismoambiental.net.br/tag/rede-brasileira-de-justica-ambiental/>. Acesso em: 16 ago. 2013. 
O Realismo Jurídico como Meio de Garantia...

ambientais não decorre de uma condição natural geográfica, mas de processos sociais e políticos que promovem uma proteção desigual.

Um caso paradigmático de injustiça ambiental se deu em 1991, quando o chefe do Banco Mundial na época, Lawrence Summers, propôs, em um memorando que vazou na mídia internacional, o despacho dos impactos ambientais negativos para países mais pobres. Propunha, no documento, encorajar a migração da indústria poluidora para países subdesenvolvidos da África, de modo a resolver o problema dos resíduos tóxicos livrando-se deles no terceiro mundo. Ele segue dizendo que os países subpovoados da África são "subpoluídos"; afirma que haver boa qualidade do ar nesses lugares é ineficiente, sendo a melhor qualidade do ar mais proveitosa em cidades como Los Angeles ou Cidade do México ${ }^{3}$.

Não é só a África que sofre com a condição de ser área de descarte de rejeitos de países mais ricos. O Brasil tem registrados diversos casos de recepção de contêineres de lixo hospitalar e urbano dos EUA e Inglaterra, como o emblemático caso das 46 toneladas de lixo hospitalar recebidas em Suape em 2011. É o que se chama de colonialismo tóxico.

A justiça ambiental vem então para combater essas práticas, garantindo equidade e igualdade. O conceito social deve estar implícito na expressão justiça ambiental, pois não há verdadeira justiça sem que haja as garantias sociais dos cidadãos.

No entanto, uma corrente neomalthusiana tenta, nos dias de hoje, negar a injustiça ambiental. Se a teoria malthusiana defendia que o crescimento populacional acelerado era causador de fome e miséria, a teoria neomalthusiana defende que a

3 CASTILHO, Adriana Guedes de. Entre a justiça e a injustiça ambiental: atuação do poder judiciário nos conflitos ambientais. 2013. 114 f. Dissertação (Mestrado em Ciências Jurídicas) - Universidade Federal da Paraíba, João Pessoa, 2013. 
crise ambiental se dá em razão de o crescimento populacional não acompanhar os recursos naturais finitos do planeta, que não consegue se regenerar a tempo. Essa ideia é facilmente refutável com um dado do Programa das Nações Unidas para o Desenvolvimento, que revela que $20 \%$ da população consome $70 \%$ dos recursos do mundo ${ }^{4}$. Assim, é a população mais abastada a responsável pela escassez dos recursos naturais.

Há ainda nesse campo os ultraliberais, que acreditam que a melhor forma de combater a superexploração dos recursos naturais é privatizá-los. Desse modo, os interesses econômicos das empresas promoveriam a preservação do meio ambiente. Para eles, a falta de definição de propriedade privada sobre os recursos é que causa a degradação. No entanto, não discutem o fato de que, ao colocar um dono nos recursos que são de todos, estão negando o acesso da sociedade a eles.

Nesses termos, uma vez estabelecida a temática da justiça ambiental como um movimento internacional de distributividade de encargos negativos de recursos ambientais, faz-se mister dizer que o termo também vai significar a atuação do Poder Judiciário nacional no sentido de melhor garantir a efetividade dos direitos ambientais da sociedade. Assim, na mesma medida, a justiça ambiental é também a jurisprudência que se forma no dia a dia do Judiciário, de modo a promover a efetivação das previsões legais acerca da proteção ambiental e dos princípios gerais do tema.

No seu comportamento, o Judiciário deve levar em consideração as responsabilizações penal, civil e administrativa que decorrem do dano ambiental. A responsabilidade civil deve ser objetiva, isto é, pouco importa se houve culpa ou dolo no evento danoso; havendo nexo de causalidade entre conduta do sujeito e dano, está configurada a responsabilidade.

4 Ibidem. 
Sobre a responsabilidade penal, esta precisa de dois pressupostos para se configurar. Primeiramente, é preciso que a infração ambiental tenha sido resultante de uma decisão do representante da empresa; em seguida, é necessário que a decisão traga benefícios para essa companhia, que traga vantagens.

Os crimes ambientais estão regulamentados na Lei 9.605/98, tendo sido revogados os crimes previstos no Código Penal e na legislação esparsa, sem prejuízo da aplicação subsidiária dos dispositivos do Código de Processo Penal e do Código Penal.

A responsabilização administrativa também é prevista na Lei 9.605/98, art. 70, que considera infração administrativa ambiental toda ação ou omissão que viole as regras de proteção e recuperação do meio ambiente.

Como regra geral na proteção ambiental, o ordenamento 242 jurídico promove alguns princípios ambientais que dão a ideia central do sistema. O princípio do ambiente ecologicamente equilibrado é um importante fundamento de proteção, reconhecido internacionalmente por meio da Declaração de Estocolmo. O princípio do poluidor-pagador aplica medidas coercitivas e sanções financeiras para o ente poluidor. Os princípios de prevenção e precaução orientam no sentido de evitar o dano ambiental antes que aconteça, seja ele já definido (prevenção) ou não exatamente diagnosticado (precaução). O princípio da informação vai garantir a participação do cidadão no processo decisório em medidas ambientais. O princípio da reparação vem para garantir a obrigação de reparar daquele que causou dano, mitigando os impactos causados. O princípio do acesso equitativo tem importante papel na justiça ambiental, ao promover que todos tenham acesso aos recursos ambientais sem quaisquer distinções. O princípio do respeito à identidade vem para garantir o respeito à memória social e antropológica do meio cultural que se forma dentro do meio ambiental. E, por 
fim, o princípio do desenvolvimento sustentável busca um equilíbrio entre crescimento econômico, social e ambiental ${ }^{5}$.

Comungando com esses princípios gerais, a legislação nacional prevê quatro atores sociais que vão exercer no Poder Judiciário a função de tutela da proteção ambiental ${ }^{6}$. Esses sujeitos vêm para garantir a justiça ambiental como movimento social, mas também no sentido de promover decisões do dia a dia que respeitem o meio ambiente e promovam a longevidade dos recursos naturais. Esses atores são o Ministério Público, a polícia, o Terceiro Setor e o próprio Poder Judiciário, na figura do magistrado, o que promove um importante elemento de conexão com o Realismo Jurídico, a ser abordado mais adiante.

A defesa do meio ambiente é tarefa, em primeiro lugar, do parquet. Essa mudança veio com a Lei 6.938/81, que atribuiu ao Ministério Público a faculdade de propor ações judiciais de natureza civil com o objetivo de reparar ou evitar danos ao meio ambiente. Essa lei também instituiu a responsabilidade objetiva do poluidor, independente de culpa, que se tem hoje. Mas foi a Lei 7.347/85 que efetivou a possibilidade de intervenção do Ministério Público Federal ou Estadual na tutela ambiental, instituindo a ação civil pública.

Os anos 1980 trouxeram essas duas leis que colocam o Ministério Público no centro da proteção ambiental, mas também foram criados órgãos de proteção ao meio ambiente dentro do Ministério Público, de modo a promover a garantia desses direitos difusos.

No entanto, é a Ação Civil Pública o principal mecanismo de proteção ambiental, podendo-se ainda mencionar a importância do mandado de segurança e da ação popular. Têm

\footnotetext{
5 MILARÉ, Édis. Direito do ambiente: A gestão ambiental em foco. 5. ed. São Paulo: RT, 2009. p. 678.

6 Ibidem, p. 1153.
} 
competência para propor a ACP, além do Ministério Público, a Defensoria Pública, União, estados, Distrito Federal, municípios, autarquias, empresas públicas ou sociedade de economia mista e associações. A ação deve ser proposta no foro em que ocorreu o fato danoso e pode ter como objeto a condenação pecuniária ou o cumprimento de obrigação de fazer ou não fazer. A coisa julgada vai ter efeito erga omnes.

Foi criado pela Lei 7.347/85, juntamente com a Ação Civil Pública, o Fundo de Defesa de Direitos Difusos, que recolhe os recursos advindos das sentenças condenatórias ou de multa e que devem ser revertidos para a reparação dos danos.

É possível ainda que as partes cheguem a um comum acordo, chamado transação, que deve ser homologado judicialmente e impõe o compromisso de reparação do dano.

Existe ainda a possibilidade do compromisso de ajusta244 mento de conduta, que não é um instrumento processual, em que o sujeito que causa dano ambiental se compromete a ajustar suas atividades aos padrões das normas ambientais. Uma vez celebrado, ele assume a natureza de título executivo extrajudicial, em caso de descumprimento. Os mesmos legitimados para ACP podem executar esse título extrajudicial.

O poder da polícia também é uma ferramenta de proteção ambiental. A polícia administrativa, que está presente na fiscalização dos órgãos administrativos (autos de infração), e a polícia judiciária, que são a própria polícia civil e militar (inquéritos policiais), vão atuar na defesa do ambiente.

O Terceiro Setor, as entidades sem fins lucrativos, tem um papel complementar junto ao Estado na garantia do meio ambiente equilibrado 7 . Ele pode fazer valer essas garantias por meio de Ação Civil Pública, mandado de segurança coletivo e

7 Ibidem, p. 1134. 
ação popular. Há a possibilidade também de intervir em âmbito administrativo interpondo recursos em processos licitatórios e participando de órgãos de controle ambiental como CONAMA ou SISNAMA. Ajuda ainda na pesquisa e educação ambiental, sendo esta uma das principais atividades das ONGs, seu trabalho de conscientização.

Por fim, o Poder Judiciário deve ser o maior garantidor de justiça ambiental, já que a previsão legal é de que nenhuma ameaça ou lesão a direito pode ser subtraída de sua apreciação; e as ameaças ambientais se incluem aqui. A Ação Civil Pública é a maior ferramenta no sistema processual para efetivar os direitos ambientais; é o instrumento que vai acionar o Judiciário e incitar o momento da garantia efetiva de um direito que vem sendo desrespeitado. É o Judiciário, representado pelo magistrado, que vai efetivar o disposto em lei ou normas gerais.

Ele vai também garantir a proteção coletiva em casos de danos muito fragmentados (como o consumo de produto estragado). É relevante o papel social do Judiciário na apreciação de ações coletivas e na garantia dos direitos ambientais.

O juiz tem também o papel de educador ambiental, na medida em que está em posição de ser ouvido. Watanabe diz: "é o recrutamento mais aprimorado de juízes e seu permanente aperfeiçoamento cultural, face à crescente complexidade das relações sociais, transformações sociais rápidas e profundas, criação assistemática de leis [...]". O Poder Judiciário deve fazer do ambiente equilibrado sua luta particular.

A melhor maneira de justificar teoricamente essa atuação positiva do magistrado na feitura da justiça ambiental se dá por meio do Realismo Jurídico e do pragmatismo filosófico, pois essas correntes propõem um modo de pensar o direito que abarca posições pessoais como forma de fazer justiça, desprendendo-se da lei sempre que for considerado necessário. 


\section{O Pragmatismo Filosófico e o Realismo Jurídico como Formas de Entender a Promoção da Justiça Ambiental no Ordenamento Nacional}

Neste capítulo, vai-se entender o que são propriamente o pragmatismo filosófico e o Realismo Jurídico, de modo a explicar o fenômeno do atingimento da justiça ambiental no ordenamento brasileiro. O que se defende é que o método realista de enxergar e operar o direito promove uma explicação mais condizente com os fatos no que concerne ao dia a dia da justiça ambiental nos tribunais nacionais.

O pragmatismo não é uma filosofia do direito, mas uma forma geral de entender a sociedade. O pragmatismo é uma filosofia de resultados ${ }^{8}$. Os conceitos buscados são definidos como verdades por meio da experimentação. Se algo não é passível de experimento ou não produz resultados práticos, não

246 existirá, não será real. Em suma, só é verdadeiro aquilo que traz consequências práticas. É o que defende Peirce quando diz que "Para determinar o sentido de uma concepção intelectual devem-se considerar as consequências práticas pensáveis como resultantes necessariamente da verdade da concepção; e a soma dessas consequências constituirá o sentido total da concepção." ${ }^{\prime \prime}$

O que se diz é que, se algo não produz resultado, não é relevante. Trazendo para o âmbito do direito, o conceito de eficácia da lei pode ser trabalhado. É possível que uma lei tenha vigência, mas não seja usada, pelo motivo que for. Nesse caso,

\footnotetext{
8 Essa busca de resultados, no entanto, diferencia-se da busca de resultados do utilitarismo. Os utilitaristas acreditam na avaliação de resultados práticos, mas a análise da concretização das verdades utilitaristas se dá para satisfazer seu hedonismo, isto é, eles tentam descobrir os resultados para entenderem se trazem a felicidade de muitos e se estão desvinculados de dor. Dessa forma, a busca do resultado final para o utilitarismo serve para determinar a concepção moral.

9 PEIRCE, Charles Sanders. Escritos Coligidos: Conferências Sobre Pragmatismo. 2. ed. São Paulo: Abril Cultural, 1980. p. 7.
} 
a lei, apesar de estar livre de vícios, não produz resultados práticos. Assim, do ponto de vista pragmático, ela não existe.

Ambos Peirce e James desenvolveram o pragmatismo filosófico, um método voltado para a determinação de verdades de todas as espécies. James, em especial, estudou o pragmatismo do ponto de vista da religião, da psicologia, da ética e da sociedade. Sua ciência, pela própria natureza dos estudos, produziu continuação mais específica no âmbito do direito.

O pragmatismo preocupa-se com o processo do conhecimento das ideias por meio dos efeitos práticos constatados na experimentação da tese. Se não há consequências práticas, a ideia é falsa. Na mesma linha, conceitos que trazem o mesmo resultado são, na realidade, uma só verdade.

A filosofia de James visava a resolver problemas da vida prática. Ele desejava que seus estudos servissem para o dia a dia e arguia, acima de tudo, que um indivíduo deve fazer aquilo que acha que deve, o que o deixa feliz ${ }^{10}$. Para James, a consciência individual está acima de qualquer outro fator: é preciso agir da maneira que se acredita mais certa. Ora, partindo da ideia de que esse indivíduo pode ser um magistrado, vê-se como a filosofia jamesiana serve para fundamentar o pragmatismo jurídico ${ }^{11}$.

O que James proporciona é a escapatória perfeita para fundamentar a variedade de condutas dos juízes ao argumentar que cada um deve fazer aquilo que o fará satisfeito. $\mathrm{O}$ que se tem aqui é o passo anterior da teoria de Benjamin Cardozo, que proclama que não se pode fugir da sua consciência no momento do julgamento ${ }^{12}$. Ao defender que o indivíduo deve agir da

\footnotetext{
${ }^{10}$ JAMES, William. What Pragmatism Means. New York: Dover Publications, 1995. p. 30-31.

${ }^{11}$ CARDOZO, Benjamin Nathan. The nature of the Judicial Process. New York: Dover Publications, 2005. p. 99-100.

12 Ibidem, p. 163.
} 
O Realismo Jurídico como Meio de Garantia...

forma que melhor o satisfaça, conduzido pela sua consciência, ele entrega o melhor fundamento para o magistrado que se desprende da lei em favor de crenças pessoais.

Dentre os pragmatistas, James é o que mais coloca o subjetivismo na análise de seus conceitos. Ele coloca a pessoa como fator da equação filosófica. Peirce acredita que a filosofia é uma forma de aperfeiçoamento intelectual, mas James a vê como aperfeiçoamento humano. A teoria jamesiana é embasada nos sentimentos humanos; a crença de cada um é o próprio fundamento do que se analisa.

Para James, a verdade depende unicamente do interlocutor ${ }^{13}$. Existem tantas verdades quanto existem pessoas que acreditem nelas. $\mathrm{O}$ fato de um conceito ser verdadeiro ou não depende da disposição de alguém de acreditar que ele é verdadeiro ou falso. James não afasta a crença baseada na fé ${ }^{14}$, ao contrário de Peirce, que acredita que não se pode crer em algo que não se pode constatar por meio de análise intelectual.

Para Peirce, a verdade é resultado de uma série de análises que devem ser postas a prova. Uma vez atingido o resultado lógico daquela inquirição, tem-se a opinião final. Essa opinião final, acredita ele, é a única verdade possível para todos. Ele admite ser possível que a opinião final anteriormente atingida seja mudada, mas isso indica apenas que aquela verdade era prematura; em princípio, a verdade não é mutável.

As concepções de verdade de James e de Peirce são bastante diferentes. Uma maneira de demonstrar exatamente como esses dois pragmatistas têm entendimentos destoantes é analisando a maneira como concebem o fenômeno da transubstanciação.

\footnotetext{
${ }^{13}$ JAMES, William. Pragmatism's Conceptions of Truth. New York: Dover Publications, 1995. p. 86.

${ }^{14} \mathrm{STROH}$, Guy H. A Filosofia Americana: uma introdução (de Edwards a Dewey). Trad. Jamir Martins. São Paulo: Cultrix, 2009. p. 184.
} 
Trata-se da prática católica de, durante as cerimônias religiosas, por meio de uma bênção do sacerdote, transformar o pão e o vinho em corpo e sangue de Jesus Cristo. Ora, para Peirce $^{15}$, isso não existe. É plenamente possível dizer, ao olhar o pão e o vinho, que estes não se transformaram em carne e sangue. Dessa forma, a transubstanciação carece de respaldo prático, não se podendo dizer que seja fenômeno verdadeiro. Para Peirce, então, a transubstanciação não é uma verdade em caráter absoluto.

No entanto, James ${ }^{16}$ aborda a temática sob ângulo diferente. Sim, de fato não há transformação real, mas ela existirá, ela será verdadeira para aqueles que acreditam que a bênção de um sacerdote pode transformar vinho em sangue ou pão em carne. A transubstanciação será uma verdade desde que o indivíduo acredite nela; ela será uma verdade para aquela pessoa; e não vai deixar de ser verdade se não for para outra.

A verdade de Peirce é muito mais estática, é aquilo para que todas as opiniões ou representações convergiram indefinidamente no tempo. Pode-se dizer que ela é dotada de certo caráter de mutabilidade, pois, para Peirce, é possível que a verdade mude, mas trata-se muito mais de um refinamento da opinião final a que se chegou anteriormente e que se mostrou defeituosa. James toma o caminho oposto: existem várias verdades para várias pessoas e em vários momentos diferentes. São nada mais que equilíbrios temporários dentro do processo de aprendizado. Tem-se aí o falibilismo.

É possível dizer que Peirce é falibilista ${ }^{17}$, pois ele não afasta a ideia de que a verdade, ou a opinião final, pode mudar. No entanto, é James o mais falibilista de todos. Para ele, nenhuma

\footnotetext{
${ }^{15}$ WAAL, Cornelis de. Sobre Pragmatismo. São Paulo: Loyola, 2007. p. 42.

${ }^{16}$ Ibidem, p. 43.

${ }^{17}$ Ibidem, p. 45.
} 
O Realismo Jurídico como Meio de Garantia...

ideia fica no mesmo lugar por muito tempo e é impossível esperar que uma pessoa pense da mesma forma para sempre. Da maneira como James enxerga o mundo, um conceito, qualquer que seja, está fadado à superação.

Ora, similarmente, um juiz não está obrigado a pensar da mesma forma para sempre, ou um ordenamento não pode ter para sempre o mesmo posicionamento. As verdades mudam porque as pessoas mudam e o entendimento jurídico deve mudar da mesma maneira. A posição de James sobre a verdade parece ser a que melhor explica o funcionamento dos ordenamentos jurídicos, ou até o da organização dos Estados, ao longo do tempo.

Dessa forma, o que se tem de James é que cada indivíduo deve enxergar o que se dá ao seu redor de acordo com suas necessidades; ele não deve jamais transcender ou abdicar de suas necessidades. Do mesmo modo, verdades são disposições que dependem do interlocutor, podendo mudar não apenas de acordo com ele, mas a qualquer tempo. Partindo da ideia de que o juiz é esse indivíduo, está justificado o funcionamento do direito por meio do Realismo Jurídico.

Essas concepções do pragmatismo filosófico influenciaram o modo de pensar de diversos juristas nos Estados Unidos. Esses operadores do direito, eminentes juízes da Suprema Corte americana, desenvolveram o que se chama, então, propriamente de Realismo Jurídico. Dentre seus maiores representantes, estão Oliver Wendell Holmes Jr. e Benjamin Cardozo ${ }^{18}$.

Holmes absorveu a ideia do pragmatismo arguindo que não se pode procurar lógica no direito, pois muitas vezes seu

\footnotetext{
${ }_{18}$ Oliver Wendel Holmes Jr. foi juiz da Suprema Corte Americana de 1902 a 1932 e grande defensor do afastamento dos tribunais americanos do formalismo. Benjamin Cardozo foi sucessor de Holmes na Suprema Corte, tendo passado os anos antecessores na Corte de Apelações de Nova York.
} 
comportamento difere do que seria esperado. Para ele, direito é uma questão de experiência. Nada mais pragmático que afirmar que, para entender o direito, é necessário analisar seu dia a dia, as experiências práticas resultantes da sua manipulação.

Para entender melhor a questão da experiência no direito, as ideias de Cardozo, retiradas, em especial, das Conferências realizadas por ele na Universidade de Yale, explicam o porquê de o direito não se comportar de maneira lógica. Ora, o fato é que, de acordo com Cardozo, o juiz define suas posições de acordo com suas crenças ${ }^{19}$. Para o magistrado, é impossível separar suas concepções pessoais do seu trabalho; a decisão judicial é uma decisão pessoal fundamentada, a posteriori, em direito.

Cardozo acredita que cada indivíduo não apenas tem suas próprias crenças, sua filosofia de vida, mas é impossível separar essa filosofia do seu trabalho de magistrado. Descrevendo a sutileza das forças subconscientes que regulam a infusão de nossas decisões, Cardozo recorda James quando diz que:

Cada um tem uma filosofia básica de vida, mesmo aqueles para os quais os nomes e as noções de filosofia são desconhecidos ou constituem anátema. Há em cada um de nós uma torrente de tendências, quer se queira chamá-la filosofia ou não, que dá coerência e direção ao pensamento e à ação. Os juízes não podem escapar a essa corrente. ${ }^{20}$

A remissão a James cita a segunda conferência. Esta, porém, não pode ser discutida com o intuito de vê-la como referencial teórico para a tese do elemento subconsciente de Cardozo, senão antes da $1^{\underline{a}}$ conferência, $\mathrm{O}$ atual dilema da filosofia, onde está a tese dos temperamentos humanos.

${ }^{19}$ CARDOZO, Benjamin Nathan. Lecture 3: The Method of Sociology: The Judge as a Legislator. In: The Nature of the Judicial Process. New York: Dover Publications, 2005. p. 99-100.

${ }^{20}$ CARDOZO, Benjamin Nathan. The Nature of the Judicial Process. New York: Dover Publications, 2005. p. 8. 
O Realismo Jurídico como Meio de Garantia...

James diz que todos têm uma filosofia e observa que é interessante a maneira como ela determina a perspectiva de mundo de cada um. Assim, "o temperamento não é a razão convencionalmente admitida, com o que lança mão das razões impessoais só para as conclusões" ${ }^{21}$, pelo que a mais poderosa de nossas premissas - esses temperamentos - jamais é mencionada, o que dá uma certa "insinceridade" às discussões. Esta mesma insinceridade, ou os temperamentos dos juízes, são poços onde se banha uma gama de elementos subconscientes, como diz Cardozo.

O mais especial da teoria de Cardozo é que ele defende que isso é algo positivo; é uma defesa da ideia de que a feitura da justiça depende da liberdade do juiz. O fato é que a lei, por vezes, é lacunosa e, noutras tantas, está eivada de descompassos que escaparam ao legislador. A letra morta não é capaz de abarcar todas as possibilidades que advêm da realidade e 252 cabe ao juiz suprir a falta da lei de acordo com o que ele acha que seria a vontade do legislador. O juiz, para Cardozo, vai ser o mediador da boa justiça. Será o instrumento por meio do qual a lei se molda ao caso concreto para fazer o que é certo. Nas palavras de Ehrlich, "garantia de justiça é a personalidade do juiz"22.

O direito nasce das relações de fato que existem entre os interlocutores. Para fazer justiça, o magistrado precisa entender isso e, mais importante, é necessário que ele possa arbitrar com liberdade para o ordenamento funcionar. De acordo com Gray $^{23}$, o direito é aquilo que os juízes declaram; leis escritas,

\footnotetext{
${ }^{21}$ JAMES, William. Pragmatism. New York: Dover Publications, 1995. p. 27.

${ }^{22}$ Nota explicativa: Observe-se que Cardozo cita com especificidade uma frase de Ehrlich que expressa fielmente sua ideia de que o juiz é a peça-chave na feitura da justiça. Apud CARDOZO, Benjamin N. A natureza do processo e a evolução do direito. Trad. Lêda Boechat Rodrigues. São Paulo: Editora Nacional de Direito, 1956. p. 5.

${ }^{23}$ John Chipman Gray, membro da Harvard Law School.
} 
precedentes, doutrina, costume e moral são nada mais que fontes do direito. $\mathrm{O}$ juiz deve ter o poder de inovar se quiser atender às necessidades sociais. Não há conclusão mais realista que essa. Sem a liberalidade do magistrado se desprender do precedente não há evolução prática. A adesão ao precedente deve ser regra, isso não se questiona, mas a liberdade de não o fazer sempre que se julgar necessário deve existir. $O$ fato é que os costumes mudam; uma lei é feita num tempo e os juízes devem ter a liberdade de adaptá-la à época, se necessário.

Todo processo vai se construindo e desconstruindo aos poucos, não está lá para ser descoberto, mas vai sendo criado ao longo do tempo. O mais interessante é que essa criação não pare no tempo. O processo jurídico deve ser sucessivo e infinito.

As teorias de Holmes e Cardozo, que prelecionam o fato de que direito é uma questão de experiência, podem ser vistas como outra forma de expressão do caráter útil e pragmático de verdade, como tratam Peirce e James, não obstante as diferenças. Além disso, são a prova proporcionada pelo pragmatismo da falsa neutralidade do Judiciário. O fato de o juiz, como homem, não ser capaz de afastar suas crenças da decisão, atesta que não se pode falar em imparcialidade completa. A neutralidade absoluta é utopia.

Por entender esse funcionamento do Judiciário, Holmes afirmava que o direito era nada mais que "As profecias sobre o que os tribunais farão de fato [...]"24. O que Holmes quer dizer é que boa parte do trabalho do advogado é antever o que vai acontecer, baseado numa análise de casos similares do passado, seu caso concreto e o comportamento do juiz em cada momento ${ }^{25}$.

\footnotetext{
${ }^{24}$ MORRIS, Clarence (Org.). Os Grandes Filósofos do Direito (Oliver Wendell Holmes, Jr.). 1. ed. São Paulo: Martins Fontes, 2002. p. 427.

${ }^{25}$ Ibidem, p. 426.
} 
Holmes, assim como Cardozo e James antes dele, acredita que as verdades são mutáveis. Para ele, o direito não é matemática: se dois juízes discordam de um caso comum não significa que um deles não fez as somas certas ${ }^{26}$; no direito nem sempre há um só entendimento sobre algo. Os oráculos do direito, os juízes, nem sempre têm a mesma posição sobre uma mesma matéria.

Para os pragmatistas jurídicos, o direito é concebido do ponto de vista da decisão. Considerando que o magistrado vai aplicar ao caso concreto o que sua consciência indica, conclui-se que nem sempre o direito é o que está disposto em lei. $\mathrm{O}$ Realismo enxerga o direito do ponto de vista da decisão, e esta decisão está absolutamente adstrita a quem a profere.

Diz-se que o Realismo toma doses de ceticismo por adotar essa postura mais crítica acerca da percepção da realidade, dispondo-se a descobrir os pontos de partida exatos que produzem conhecimento por meio da experimentação ${ }^{27}$ e negando-se a aceitar conceitos filosóficos meramente metafísicos. Essa noção muito se aproxima da perspectiva pragmatista de descobrir verdades por meio de experimentação e da noção realista de aceitar que a produção de direito advém da realidade fática, do cotidiano da aplicação das leis pelos magistrados.

O Realismo se propõe a fazer nada mais que uma crítica ao modo de pensar o direito. Falar que os juízes julgam com suas consciências para depois buscar a lei que fundamente seu entendimento é nada mais que uma maneira diferente de conceber o funcionamento do ordenamento jurídico, maneira esta focada nas teorias da decisão, ao contrário da tradicional teoria da norma.

\footnotetext{
${ }^{26}$ Ibidem, p. 430.

${ }^{27}$ LANDSMAN, Charles. Ceticismo e o afastamento do Realismo. São Paulo: Loyola, 2006. p. 26.
} 


\section{Análise Jurisprudencial: Testando a Hipótese do Realismo Jurídico como Fundamento para Garantia da Justiça Ambiental}

Tomando-se um parâmetro realista, é possível analisar decisões judiciais que parecem divergir entre si ou que fazem ressalvas quanto à aplicação da legislação cabível, de modo a encontrar o respaldo teórico para esse comportamento dos magistrados. Aqui se vai testar a hipótese do trabalho, qual seja, descobrir se o realismo jurídico pode explicar o fenômeno da justiça ambiental.

A tese defendida é que, para que se possa, de fato, garantir justiça ambiental, é preciso permitir ao juiz - o aplicador e, por isso, efetivador da lei - que faça os contornos necessários para que seja justo no caso concreto. A legislação é letra morta e não é capaz de acompanhar as peculiaridades que o dia a dia propõe para o magistrado. Assim, usando de sua própria consciência, permitindo a sua personalidade aflorar na sentença, é possível garantir justiça ambiental. O fato é que a decisão judicial é uma decisão pessoal fundamentada, a posteriori, em direito. Assim, a garantia da justiça ambiental vai acontecer na medida em que o juiz responsável pela causa esteja disposto a assim fazer.

Tem-se o exemplo do Habeas Corpus 124.820 julgado pelo STJ e advindo do DF. Trata-se de um caso de construção de moradia realizada em área de conservação ${ }^{28}$. O Ministro relator,

\footnotetext{
${ }^{28}$ PENAL. DANO AO MEIO AMBIENTE (ART. 40 DA LEI N. 9.605/98). CONSTRUÇÃO DE CASA DE ADOBE. DELITO INSTANTÂNEO DE EFEITOS PERMANENTES CONDUTA ANTERIOR À LEI INCRIMINADORA. PRINCÍPIO DA LEGALIDADE. CRIME. INEXISTÊNCIA. DOLO DE DANO. AUSÊNCIA. MORADIA. DIREITO SOCIAL FUNDAMENTAL. ÁREA CONSTRUÍDA. 22 (VINTE E DOIS) METROS QUADRADOS. INSIGNIFICÂNCIA. PROCESSO PENAL. JUSTA CAUSA. AUSÊNCIA. 1. A construção de casa de adobe em área de preservação ambiental constitui dano direto instantâneo de efeitos permanentes. Precedentes. 2. Não há
} 
O Realismo Jurídico como Meio de Garantia...

no entanto, entendeu pela impossibilidade de responsabilização por dano ambiental, em razão de a construção ter acontecido antes da vigência da Lei 9.605/98, não podendo aplicar o disposto no art. 40 da referida lei.

A postura do magistrado se fundamenta no art. $1^{\circ}$ do Código penal, que diz que "Não há crime sem lei anterior que o defina. Não há pena sem prévia cominação legal." Dessa forma, se a construção aconteceu antes de 1998, à época, a construção da residência não constituía crime, não se podendo, hoje, responsabilizar o cidadão.

Mas também, da análise da ementa, nota-se uma fundamentação de caráter mais subjetivo. $O$ magistrado quer garantir o direito social da moradia e entende que o dano ambiental não deve se sobrepor ao direito de ter um teto, como coloca no acórdão nos termos de "direito fundamental ao chão e ao teto".

Contrapondo-se a esse caso, temos o Habeas Corpus 89.386, originário do RJ e julgado pelo STJ. Aqui se tem um sócio de uma empresa que, por anos a fio, causou poluição fora dos parâmetros aceitáveis ${ }^{29}$. A defesa do empresário demonstrava que a emissão desses gases poluidores se deu, em boa parte,

crime sem lei anterior que o defina (art. 1ํ do Código Penal). 3. Conduta anterior à vigência da Lei n. 9.605/1998. 4. A construção de casa para servir de moradia ao acusado e sua família não configura dolo de dano ao meio ambiente, pois traduz necessidade e direito fundamental ao chão e ao teto (art. $6^{\circ}$ da Constituição Federal). 5. O direito penal não é a prima ratio; o dano causado ao meio ambiente decorrente da edificação de casa com 22 (vinte e dois) metros quadrados não ultrapassa os limites do crime de bagatela e pode ser resolvido por meio de instrumentos previstos em outros ramos do Direito Civil. 6. Ordem concedida para cassar o acórdão e restaurar a sentença absolutória.

${ }^{29}$ EMENTA HABEAS CORPUS, CRIMES CONTRA O MEIO AMBIENTE. CAUSAR POLUIÇÃO ATMOSFÉRICA COM DANOS À SAÚDE DA POPULAÇÃO E POLUIÇÃO POR LANÇAMENTO DE RESÍDUOS GASOSOS (ART. 54, § 2o., II, IN FINE C/C ART. 15, II, a, E ART. 54, § 2o., V C/C ART. 15, II, a, AMBOS DA LEI 9.605/98). TRANCAMENTO DA AÇÃO PENAL. INÉPCIA DA DENÚNCIA NÃO EVIDENCIADA. DESCRIÇÃO DOS FATOS DE FORMA A VIABILIZAR O PLENO EXERCÍCIO DO DIREITO DE DEFESA. INDIVIDUALIZAÇÃO PORMENORIZADA 
antes da vigência da lei 9.605/98, e por isso não se configuraria crime. O Ministro Napoleão Nunes Maia Filho, ao contrário da decisão anterior, entende que o fato de as emissões terem acontecido antes da previsão legal não é importante e afasta de todo a incidência do art. $1^{\underline{0}}$ do Código penal, imputando a responsabilidade sobre o dano ambiental.

Ora, o caso é o mesmo, duas condutas efetuadas antes que se configurassem crime; no entanto, a conduta dos magistrados foi absolutamente oposta. No segundo caso, do HC 89.386, o que fundamentou o afastamento da norma de exclusão penal foi, como explica o Ministro em seu acórdão, o fato de as emissões terem continuado no tempo, até depois da previsão legal. No 124.820, no entanto, aconteceu da mesma forma, mas mesmo assim foi mantido o afastamento da responsabilização penal.

O que pode, então, explicar essas condutas díspares dos ministros, senão a aceitação de que o juiz julga de acordo com sua consciência, com suas próprias concepções do que é justo, para depois fundamentá-las em lei? E mais, deixar passar um dano ambiental contraposto ao direito de moradia e em seguida não perdoar a emissão de poluentes por uma empresa soa bastante justo do ponto de vista dos princípios gerais do direito. É como se o afastamento da lei ou a incidência da lei pudessem, de maneira alternada, trazer mais justiça do que sua aplicação ou não aplicação definitiva.

DAS CONDUTAS QUE PODE SER FEITA NO CURSO DA AÇÃO PENAL. PRECEDENTES DO STJ. CRIMES PERMANENTES. ORDEM DENEGADA.

Dada a natureza permanente dos delitos em apuração, desimportante se mostra, em princípio, a alegação de que a denúncia narra como crime condutas supostamente praticadas em período anterior à vigência da Lei 9.605/98, na medida em que as atividades poluidoras continuaram até julho de 2004, conforme anotado expressamente na peça acusatória. 
O Realismo Jurídico como Meio de Garantia...

Da mesma forma, tem-se a Apelação Criminal nํㅜㄴ.0023. 10.001345-9/00130 em que o Tribunal de Justiça de Minas Gerais aplica o princípio da insignificância num caso de pesca proibida, afastando a responsabilização penal sobre o dano. Essa Apelação foi julgada pela Segunda Câmara Criminal do TJ de Minas Gerais.

Em contraposição a ela, traz-se a Apelação Criminal no 1.0069.08.022594-4/001 ${ }^{31}$ da 6 $6^{\text {a }}$ Câmara Criminal do mesmo TJ de Minas Gerais. Aqui, o desembargador relator afasta a incidência do princípio da insignificância por não acreditar que ele possa ser usado. Trata-se de uma posição pessoal no sentido de não usar do princípio da bagatela nas suas decisões.

${ }^{30}$ EMENTA: APELAÇÃO CRIMINAL. ART. 34, INC. II, DA LEI 9.605/95. CRIME AMBIENTAL. UTILIZAÇÃO DE PETRECHOS PROIBIDOS NA PESCA AMADORA DE PEQUENA QUANTIDADE DE PEIXE. INCIDÊNCIA DO PRINCÍPIO DA INSIGNIFICÂNCIA. CABIMENTO. MÍNIMA OFENSIVIDADE DA CONDUTA DO AGENTE. AUSÊNCIA DE PERICULOSIDADE SOCIAL DA AÇÃO. REDUZIDÍSSIMO GRAU DE REPROVABILIDADE DO COMPORTAMENTO E INEXPRESSIVA A LESÃO JURÍDICA PROVOCADA. RISCO DO EQUILÍBRIO ECOLÓGICO NÃO EXPOSTO. CARÊNCIA DE TIPICIDADE MATERIAL DA CONDUTA. ABSOLVIÇÃO DECRETADA. HABEAS CORPUS DE OFÍCIO. EXTENSÃO DOS EFEITOS DA DECISÃO AOS CORRÉUS, NOS TERMOS DO ART. 580 DO CÓDIGO DE PROCESSO PENAL. RECURSO PROVIDO - É cabível o reconhecimento do princípio da insignificância em crime contra o meio ambiente caso comprovada a atipicidade material da conduta, diante da utilização de petrechos comuns de pesca amadora, com apreensão de pequena quantidade de pescado, se revelando insignificante a ofensa.

${ }^{31}$ EMENTA: APELAÇÃO CRIMINAL - CRIME AMBIENTAL - CORTE DE ÁRVORES EM ÁREA DE PRESERVAÇÃO PERMANENTE - ABSOLVIÇÃO - AUTORIA E MATERIALIDADE DEMONSTRADAS - IMPOSSIBILIDADE - INCIDÊNCIA DO PRINCÍPIO DA INSIGNIFICÂNCIA - INAPLICABILIDADE - RECURSO PROVIDO. - Amoldando-se a conduta do acusado ao tipo penal previsto no art. 39 da Lei 9.605/98, estando demonstradas a autoria e a materialidade, impossível a absolvição. - O princípio da insignificância (bagatela) não foi recepcionado pelo ordenamento jurídico pátrio. A insignificância é princípio orientador do Legislativo ao tipificar criminalmente as condutas, portanto, desarrazoada sua utilização pelo Judiciário, sob pena de violação dos princípios constitucionais da reserva legal e da independência dos Poderes. 
Da mesma forma, é exemplificativo o caso da Apelação Criminal de noo. 0004679-82.2008.8.26.015732, Tribunal de Justiça de São Paulo, em que o desembargador admite a inviabilidade de aplicação do princípio da insignificância em razão da natureza do dano ambiental. A justificativa de afastamento de aplicação do princípio é a natureza do bem jurídico, que implica um esforço de proteção mais expressivo que os demais, como entende o magistrado. Vê-se que é julgamento bastante subjetivo do papel do juiz, que deve tutelar algo mais.

Mais uma vez, fica comprovada a tese realista de que as posições pessoais podem influenciar nas decisões judiciais. Essa comprovação é ainda mais exemplificativa uma vez que se tem o mesmo Tribunal assumindo posições divergentes quanto à mesma matéria.

${ }^{32}$ EMENTA: APELAÇÃO RECURSOS DA DEFESA: CRIME AMBIENTAL DANO À UNIDADE DE CONSERVAÇÃO - ABSOLVIÇÃO IMPOSSIBILIDADE ERRO DE TIPO INOCORRÊNCIA - Materialidade e autoria comprovadas e que não são objeto de insurgência nos apelos defensivos Tese de erro de tipo que não pode ser acolhida Circunstâncias que revelam a impossibilidade de os réus desconhecerem o fato de a área desmatada ser de proteção integral PRINCÍPIO DA INSIGNIFICÂNCIA RECONHECIMENTO INVIABILIDADE Princípio que tem sido visto com reservas quando se trata de crimes ambientais, diante da expressão do bem jurídico tutelado Indisponibilidade do meio ambiente, único bem de natureza transgeracional previsto na Constituição da República Dano que, ademais, não pode ser considerado de pouca monta, eis que avaliado pelo órgão ambiental em valor expressivo, $R \$ 50.000,00$ Teses defensivas refutadas Condenação mantida PENA REDUÇÃO POSSIBILIDADE Exasperação sobre a pena-base que não contou com fundamentação idônea Afastamento que se impõe. Reconhecimento da atenuante prevista no artigo 14, inciso I, da Lei dos Crimes ambientais, diante da baixa escolaridade dos réus Compensação dessa atenuante com a agravante prevista no artigo 15, inciso II, alínea "a", da mesma lei, reconhecida pelo juiz sentenciante Sentença reformada neste particular RECURSOS DEFENSIVOS PARCIALMENTE PROVIDOS. 


\section{Considerações Finais}

Nesses termos, é possível concluir que o realismo jurídico pode ser visto como um mecanismo de análise de proteção ao meio ambiente e proporciona uma justificativa de atingimento de justiça ambiental, na medida em que permite enxergar decisões que são perfeitamente possíveis mas não têm necessariamente uma adstrição irrestrita à lei.

A partir do fundamento teórico do pragmatismo filosófico e do realismo jurídico e da análise das decisões de viés ambiental, é possível verificar um posicionamento do Judiciário pró justiça ambiental. Assim, o realismo parece ser a medida que faltava no desentranhamento da questão ambiental no ordenamento interno, pois proporciona uma visão garantista acerca do direito em análise.

Importante frisar que o que o realismo faz é proporcionar o fundamento teórico para essas decisões de cunho protecionista ambiental que precisam se afastar da lei para preservar o direito à sustentabilidade. $O$ realismo não quer promover qualquer mudança de postura ou muito menos uma reforma no sistema legal e processual. Ele está apenas observando a realidade e admitindo uma verdade que o positivismo parece esquecer.

A verdade é que o positivismo e seu apego absoluto à lei não consideram uma das mais importantes fontes de direito, qual seja, o juiz. Como aplicador final da norma, ele tem a possibilidade de também fazer direito, na medida em que há a liberdade de escolher qual norma acha mais pertinente, afastando uma em favor de outra.

Do mesmo modo, é possível concluir que esses privilégios do magistrado também incumbem a ele uma função muito especial: a de educar. O juiz tem a prerrogativa de ser ouvido e sua decisão vai trazer consequências muito práticas 
para a realidade ambiental. Assim, ele não deve esquecer sua função social de criar conscientização, além da de respeitar esses princípios ambientais.

Nesses termos, fica estabelecida a importância do realismo jurídico para explicar o fenômeno da justiça ambiental no ordenamento nacional, uma vez que ele promove a fundamentação teórica para os casos em que o magistrado deve sair do caminho comum para, de fato, promover justiça.

\section{Referências}

CARDOZO, Benjamin Nathan. A natureza do processo e a evolução do direito. Trad. Lêda Boechat Rodrigues. São Paulo: Editora Nacional de Direito, 1956.

. Lecture 3: The Method of Sociology: The Judge as a Legislator. In: _. The Nature of the Judicial Process. New York: Dover Publications, 2005. 2005. . The Nature of the Judicial Process. New York: Dover Publications,

CASTILHO, Adriana Guedes de. Entre a justiça e a injustiça ambiental: atuação do poder judiciário nos conflitos ambientais. 2013. $114 \mathrm{f}$. Dissertação (Mestrado em Ciências Jurídicas) - Universidade Federal da Paraíba, João Pessoa, 2013.

JAMES, William. What Pragmatism Means. New York: Dover Publications, 1995. . Pragmatism. New York: Dover Publications, 1995.

. Pragmatism's Conceptions of Truth. New York: Dover Publications, 1995.

LANDSMAN, Charles. Ceticismo e o afastamento do Realismo. São Paulo: Loyola, 2006.

MILARÉ, Édis. Direito do ambiente: A gestão ambiental em foco. 5. ed. São Paulo: RT, 2009. 
O Realismo Jurídico como Meio de Garantia...

MORRIS, Clarence (Org.). Os Grandes Filósofos do Direito (Oliver Wendell Holmes, Jr.). 1. ed. São Paulo: Martins Fontes, 2002.

PACHECO, Tânia. Rede Brasileira de Justiça Ambiental. 2012. Disponível em: $<$ http://racismoambiental.net.br/tag/rede-brasileira-de-justica-ambiental/>. Acesso em: 16 ago. 2013.

PEIRCE, Charles Sanders. Escritos Coligidos: Conferências Sobre Pragmatismo. 2. ed. São Paulo: Abril Cultural, 1980.

STROH, Guy H. A Filosofia Americana: uma introdução (de Edwards a Dewey). Trad. Jamir Martins. São Paulo: Cultrix, 2009.

WAAL, Cornelis de. Sobre Pragmatismo. São Paulo: Loyola, 2007.

Submissão: 05/09/2013

Aceito para Publicação: 23/12/2013 


\section{A Autopoiese no Direito \\ e o Funcionalismo Sistêmico \\ de Günther Jakobs \\ na Aplicação da Lei Penal}

Autopoiesis in Law and Günther Jakobs's

Systemic Functionalism in Criminal Law Enforcement

Daniela Portugal ${ }^{*}$

Resumo: $\mathrm{O}$ presente artigo tem por objetivo a promoção de uma reflexão crítica acerca da compreensão do direito como um sistema autopoiético, enfocando-se, especialmente, a aplicação da lei penal. Assim, serão estudados dois modelos penais funcionalistas antagônicos, de modo a verificar qual deles melhor resolve os problemas modernos relativos à aplicação da lei penal, destacando-se a imputação objetiva da norma penal e aceitação dos tipos penais de perigo abstrato.

Palavras-chave: Autopoiese. Funcionalismo. Lei Penal. Imputação. Risco.

Abstract: This article aims to promote a critical reflection about the understanding of law as an autopoietic system, focusing, in particular, the application of criminal law. Thus, two opposing functionalists currents in criminal law will be studied, in order to see which one best solves modern problems related to the application of criminal law, highlighting the objective imputation of criminal legal norm and the acceptance of criminal types of abstract danger.

Keywords: Autopoiesis. Functionalism. Criminal Law. Imputation. Risk.

* Universidade Federal da Bahia. 


\section{Introdução}

O presente artigo tem por objetivo investigar se o modelo de sistema autopoiético pode ser aplicado ao estudo do direito e, mais especificamente, quais impactos esta forma de estudo acarreta para a aplicação de normas penais.

Assim, no primeiro tópico, será feito um estudo sobre as características do sistema autopoiético, investigando-se se o pensamento sistemático pode ser aplicado a ciências sociais e, sobretudo, ao direito. Primeiramente, será analisado o paradigma autopoiético, a sua auto-organização e sua forma de relação paradoxalmente autônoma e dependente em relação ao entorno.

Posteriormente, analisa-se o direito como um sistema autopoiético, quando serão avaliados os elementos responsáveis por diferenciar o sistema jurídico do entorno social que o circunda. Passa-se, em seguida, a examinar se o direito possui um sistema operacional fechado capaz de viabilizar o seu estudo como sendo um sistema autopoiético.

No tópico seguinte de desenvolvimento, serão expostas duas importantes correntes finalistas do direito penal - o funcionalismo teleológico e o funcionalismo sistêmico, como forma de avaliar o impacto da teoria dos sistemas no direito penal. Para tanto, as duas mencionadas correntes, absolutamente antagônicas, serão apresentadas, para que se examine, mais adiante, qual delas serve melhor à aplicação da lei penal.

No último capítulo, serão estudados a teoria da imputação objetiva e os tipos penais de perigo abstrato, cujo tratamento possui respostas distintas a depender do modelo funcionalista que se adote, para que se examine qual das correntes se adapta melhor à realidade do direito penal.

Ao final, avalia-se qual modelo sistemático melhor se adapta ao estudo do direito penal - a autopoiese ou a alopoiese-, 
repercutindo, por consequência, na corrente funcionalista que deve prevalecer para fins de aplicação da lei penal - o funcionalismo sistêmico ou o funcionalismo teleológico.

\section{A Autopoiese no Direito}

Nas seguintes linhas, tratar-se-á da (im)possibilidade de aplicação da teoria dos sistemas ao direito, utilizando como base principal a concepção de sistema autopoiético desenvolvida por Niklas Luhmann. Serão expostas as principais caracterísicas do sistema autopoiético e, em seguida, será feita uma análise sobre a forma como as características são reproduzidas no sistema jurídico.

\subsection{Sobre o Paradigma Autopoiético}

Niklas Luhmann desenvolve a sua teoria dos sistemas a partir da influência de modelos sistemáticos nos diversos campos do saber entre o final da década de cinquenta e o início da década de sessenta, tais como a cibernética, as ciências cognitivas, a teoria da comunicação, a teoria da evolução, dentre outras teorias ${ }^{1}$.

Luhmann busca superar a tradicional contraposição entre ciências naturais e ciências do espírito, é dizer, entre hard sciences e humanities por intermédio da identificação das características com base nas quais essas ciências se diferenciam do meio em que são formadas ${ }^{2}$.

1 LUHMANN, Niklas. La sociedad de la sociedad. México: Universidad Iberoamericana Biblioteca Francisco Xavier Clavigero, 2006. p. 40.

2 Id. Ibid. p. 40-44. 
Nesse sentido, o autor entende a sociedade como um sistema complexo. Para tanto, explica o surgimento do sistema a partir da diferenciação deste em relação ao seu entorno. Esclarece que a dependência e a independência são características que coexistem na relação entre o sistema e o meio ${ }^{3}$. A dependência deriva do fato de o sistema emergir do meio, entretanto, o sistema adquire independência em razão do seu desenvolvimento, pautado na inclusão de relações autorreferenciais, produzindo uma espécie de auto-organização ${ }^{4}$.

Significa dizer que a formação de um sistema surge do meio que lhe cerca e deste se destaca ao adquirir autonomia. Desse modo, o sistema depende do meio sem, todavia, estar determinado por ele, uma vez que constitui a sua própria forma de organização ${ }^{5}$.

Neste sentido, Luhmann desenvolve o conceito de autopoiese, explicando, inicialmente, não se tratar da produção sistemática de um determinado modelo, mas da capacidade de produção de uma diferenciação entre o sistema e o seu entorno ${ }^{6}$. Assim, quando o sistema destaca-se do seu entorno, ele ganha um espaço interno de liberdade, o que corresponderia à produção de uma "indeterminação interna"7.

Significa dizer que o surgimento do sistema é marcado, em um primeiro momento, por um processo de diferenciação - quando o sistema destaca-se do todo - e, em seguida, pela construção de um espaço de indeterminação - quando o interior do sistema mostra-se livre para ser auto-organizado, rompendo-se,

${ }^{3}$ LUHMANN, Niklas. La sociedad de la sociedad. México: Universidad Iberoamericana Biblioteca Francisco Xavier Clavigero, 2006. p. 44.

${ }^{4}$ Id. Ibid. p. 45.

${ }^{5}$ Id. Ibid. loc. cit.

6 Id. Ibid. p. 45.

7 Id. Ibid. p. 46. 
com isso, a tradicional dicotomia entre sistemas abertos e sistemas fechados para tratar de um sistema complexo.

O espaço indeterminado do interior do sistema é, gradativamente, preenchido por estruturas próprias e sentidos comunicativos peculiares, de modo que o sistema social tem como característica a produção do seu próprio modelo de comunicação ${ }^{8}$.

Em sentido semelhante, de acordo com Leonel Severo Rocha, o sistema autopoiético supera um paradoxo entre o passado e o futuro, entre o aberto e o fechado. Isto porque sistema autopoiético emerge do meio - de onde se extrai sua origem e parcela de dependência com o passado - e, simultaneamente, destaca-se desse entorno ao se diferenciar, criando um modelo próprio de organização - que irá pautar a relação do sistema com o futuro, condicionando relações que sequer foram firmadas?.

Trata-se, portanto, de uma forma de atuação voltada para o passado em sua origem, mas também voltada para o futuro, em razão da construção de uma auto-organização. O sistema autopoiético é também fechado e aberto porque se, por um lado, emerge do entorno e com ele se relaciona durante seu processo evolutivo $^{10}$, por outro, diferencia-se do meio, criando estruturas próprias de comunicação, fora das quais não é possível travar relações previsíveis ${ }^{11}$.

8 Id. Ibid. loc. cit.

9 ROCHA, Leonel Severo; SCHWARTZ, Germano; CLAM, Jean. Introdução à teoria do sistema autopoiético de direito. Porto Alegre: Livraria do Advogado, 2005. p. 38.

${ }^{10}$ Segundo o autor, "um sistema fechado é impossível, não pode haver um sistema que se auto-reproduza somente nele mesmo". Por outro lado, "se falamos em sistema aberto, já nem falamos mais em sistema, podemos falar de outra coisa". Op. cit. p. 38.

${ }^{11}$ LUHMANN, Niklas. La sociedad de la sociedad. México: Universidad Iberoamericana Biblioteca Francisco Xavier Clavigero, 2006. p. 39. 
A Autopoiese no Direito e o Funcionalismo Sistêmico...

É possível perceber, portanto, que a concepção autopoiética de Luhmann não se confunde com a elaboração de um modelo sistemático fechado, uma vez que admite relações externas entre o sistema e o entorno - relações estas, porém, que são travadas de forma inespecífica, já que a previsibillidade da forma e da organização só se mostra possível dentro de uma estrutura sistemática ${ }^{12}$.

A especificação de relações pressupõe, portanto, a autonomia entre o sistema e o meio - processo que Luhmann chama de diferenciação $0^{13}$. A mencionada autonomia, por sua vez, está presente tanto no âmbito estrutural quanto na esfera operacional, do que se extrai o conceito de autopoiese como sendo a possibilidade de construção de operações próprias, garantindo, inclusive, a previsibilidade de operações futuras ${ }^{14}$.

Ao definir a sociedade como um sistema complexo, Luhmann especifica tratar-se de um sistema capaz de abranger todos os demais sistemas sociais, resgatando, em um sentido aproximativo, a noção de "Política" desenvolvida por Aristóteles, em que este se refere à possibilidade de uma comunidade conter outras ${ }^{15}$. Note-se que, em ambos os casos, é estabelecida uma relação sistema/entorno, base em que é construída a teoria geral dos sistemas ${ }^{16}$.

É importante perceber, ainda, que, quando um sistema passa a conter outros sistemas que dele se diferenciam, o próprio sistema abrangente é, a um só tempo, sistema e entorno, a depender do ponto de vida de observação ${ }^{17}$. Por tal razão que

\footnotetext{
${ }^{12}$ Id. Ibid. p. 46.

${ }^{13}$ Id. Ibid. p. 46.

${ }^{14}$ Id. Ibid. p. 46.

${ }^{15}$ Id. Ibid. p. 55.

${ }^{16}$ Id. Ibid. loc. cit.

${ }^{17}$ LUHMANN, Niklas. La sociedad de la sociedad. México: Universidad Iberoamericana Biblioteca Francisco Xavier Clavigero, 2006. p. 471.
} 
Luhmann explica que o processo de diferenciação não corresponde a uma decomposição do todo em partes, especialmente porque cada sistema parcial, de certo modo, reproduz o sistema total, só que com uma diferenciação própria ${ }^{18}$.

Após definir a sociedade como um sistema, Luhmann passa para uma análise no plano dos sistemas autopoiéticos, caracterizados, como já se viu, por serem autorreferenciais e operacionalmente fechados ${ }^{19}$. Explica, nesse sentido, que a comunicação é a base operacional de uma sociedade, acrescentando que, dentre os diversos meios de comunicação, tais como escrita, imprensa e meios eletrônicos, a linguagem é o meio comunicativo que mais se destaca ${ }^{20}$.

A clausura operacional deve-se ao fato de não ser possível estabelecer, em uma operação própria do sistema, um contato com o entorno, além da impossibilidade de outros sistemas, também situados no entorno, interferirem em processos autopoiéticos de um sistema operacionalmente fechado ${ }^{21}$. Significa que um mesmo meio pode dar origem a mais de um sistema e, sendo estes sistemas autopoiéticos, a operação de um não interfere no funcionamento do outro: todos coexistem mantendo, em si, sua autonomia.

A mencionada clausura operacional, por sua vez, conduz à auto-organização do sistema, já que suas estruturas não podem ser construídas ou transformadas senão por meio de operações próprias do sistema ${ }^{22}$. É por esta razão que a “[...] linguagem só pode se modificar com a comunicação, e não de forma imediata como o fogo ${ }^{\prime 23}$. Desse modo, a sociedade é um

\footnotetext{
${ }^{18}$ Id. Ibid. p. 473.

${ }^{19}$ Id. Ibid. p. 56.

${ }^{20}$ Id. Ibid. loc. cit.

${ }^{21}$ Id. Ibid. p. 66.

${ }^{22}$ Id. Ibid. p. 67.

${ }^{23}$ Id. Ibid. loc. cit. Tradução livre.
} 
sistema comunicativamente fechado, pois a comunicação só pode ser produzida por meio da própria comunicação, sendo a linguagem o meio essencial de comunicação, responsável por garantir a regular e contínua autopoiese de toda a sociedade ${ }^{24}$.

\subsection{O Direito Autopoiético}

De acordo com Leonel Severo Rocha, Luhmann supera a analítica de Kelsen e a hermenêutica de Hart ao desenvolver a concepção de direito como um sistema autopoiético, cuja função é a de exigir "[...] a realização de graduações que possibilitem expectativas comportamentais recíprocas e que são orientadas a partir de expectativas sobre tais expectativas". ${ }^{25}$

Significa dizer que a diferenciação do direito (sistema parcial) em face do entorno social (sistema total) tem por principal

270 objetivo garantir uma estabilização das relações por meio da produção de expectativas, criando uma organização própria, que difere, por exemplo, do modelo de organização pautado nas noções de moralidade e de pecado.

José Galindo Monteagudo, ao apresentar a obra Die Gesellschaft der Gesellschaft, de Luhmann, destaca que as ações humanas, em si, são desprovidas de sentido, necessitando que um observador a (re)construa como um fato significativo. Esta atribuição de significado pode se operar tanto por meio de um sistema psíquico quanto por meio de um sistema social ${ }^{26}$.

Monteagudo exemplifica relatando o caso de uma testemunha que observa um autor sair correndo de uma casa e

\footnotetext{
${ }^{24}$ Id. Ibid., passim.

${ }^{25}$ ROCHA, Leonel Severo; SCHWARTZ, Germano; CLAM, Jean. Introdução à teoria do sistema autopoiético de direito. Porto Alegre: Livraria do Advogado, 2005. p. 31.

${ }^{26}$ LUHMANN, Niklas. La sociedad de la sociedad. México: Universidad Iberoamericana Biblioteca Francisco Xavier Clavigero, 2006. p. XXXI.
} 
especula ter ocorrido um roubo: essa atribuição de sentido pode estar inserida em um sistema psíquico (caso o observador guarde para si a significação) ou em um sistema social (caso ele comunique à polícia a sua especulação) ${ }^{27}$. Na hipótese de haver comunicação do fato às autoridades públicas, a hipótese do roubo é um fenômeno social já tratado por um sistema social funcionalmente especializado - o direito ${ }^{28}$.

Desse modo, um dos grandes méritos da teoria luhmanniana está em superar a mera observação de atores e avançar para o estudo das comunicações que são travadas entre os atores sociais, ocasião em que o direito passa a figurar um meio capaz de viabilizar a estabilização das relações.

É nesse sentido que Niklas Luhmann, na obra Das Recht der Gesellschaft, afirma a clausura operacional do direito ${ }^{29}$. De acordo com o autor, deve-se mudar o foco de atenção - atualmente voltado para a busca pela legitimação do direito positivo, ou mesmo para a distinção entre este e o direito natural - para a análise da insuficiência do conceito de positividade ${ }^{30}$.

Não se pode entender por sistema jurídico um simples conjunto de regras, mas como um conjunto de operações fáticas dispostas sobre a forma de comunicações, de modo que o ponto de partida para a análise do direito não deve ser a norma ou uma tipologia de valores, mas a já referida distinção entre sistema e entorno ${ }^{31}$.

${ }^{27}$ Id. Ibid. loc. cit.

${ }^{28}$ Id. Ibid. p. XXXI.

${ }^{29}$ LUHMANN, Niklas. El Derecho de la Sociedad. Formatação eletrônica de João Protásio Farias Domingues de Vargas, Marjorie Corrêa Marona e Juliana Neuenschwander Magalhaes. Brasil, 2002, passim.

${ }^{30}$ Id. Ibid. p. 24.

${ }^{31}$ Id. Ibid. loc. cit. 
O direito atuaria, conforme explica Luhmann em Sociologia do Direito I, entre a complexidade e a contingência de experiências, produzindo expectativas sociais ${ }^{32}$. Isto porque, para cada experiência humana, há uma infinidade de possibilidades (complexidade) e, dentre essas possibilidades, existem aquelas que não são esperadas (contingência) ${ }^{33}$.

Assim, explica o autor, resumidamente, que "[...] complexidade significa seleção forçada, e contingência significa perigo de desapontamento e necessidade de assumir-se riscos" ${ }^{\prime \prime 3}$. É a partir desta relação em que são construídas estruturas estabilizadas que visam a impedir os mencionados desapontamentos ${ }^{35}$.

Em Sociologia do Direito II, o autor acrescenta que o processo de normatização deve estar acompanhado na organização das suas formas de imposição, de modo que estará tão mais organizado quanto maior for a suposição de que, uma vez transgredida a norma, será imposta a consequência jurídica, pautando-se o sistema jurídico, pois, na previsibilidade ${ }^{36}$.

Desse modo, a autopoiese corresponderia a uma nova forma de estudo de antigos problemas, tais como a relação entre a estrutura posta e o processo; entre a norma e a decisão ${ }^{37}$, pois não mais se questiona o tipo de estrutura que se deve aceitar (problema da legitimação do direito), mas sim se as relações

\footnotetext{
${ }^{32}$ LUHMANN, Niklas. Sociologia do Direito I. Coleção dirigida por Eduardo Portella. Trad. Gustavo Bayer. Série Biblioteca Tempo Universitário n. 75/Série Estudos Alemães. Rio de Janeiro: Tempo Brasileiro, 1983. p. 45.

${ }^{33}$ Id. Ibid. loc. cit.

${ }^{34}$ Id. Ibid. p. 46.

${ }^{35}$ Id. Ibid. p. 47.

${ }^{36}$ LUHMANN, Niklas. Sociologia do Direito II. Coleção dirigida por Eduardo Portella. Trad. Gustavo Bayer. Série Biblioteca Tempo Universitário n. 75/Série Estudos Alemães. Rio de Janeiro: Tempo Brasileiro, 1985. p. 20.

${ }^{37}$ LUHMANN, Niklas. El Derecho de la Sociedad. Formatação eletrônica de João Protásio Farias Domingues de Vargas, Marjorie Corrêa Marona e Juliana Neuenschwander Magalhaes. Brasil, 2002. p. 24.
} 
travadas obedecem aos critérios de reconhecimento estabelecidos no próprio sistema jurídico.

Nesse mesmo sentido, Jean Clam explica que o direito autopoiético produz os critérios que irão conformar sua autodefinição, tais como "unidade", "autonomia", dentre outros critérios, de modo que a positividade passa a ser insuficiente para explicar o sistema jurídico ${ }^{38}$.

O autor ainda trata da lógica de autoprodução do direito, pautada no "reconhecimento dos processos de geração do direito a partir do direito"39. É a partir desse processo que o direito evolui e se autorreproduz ${ }^{40}$.

Marcelo Neves critica a compreensão luhmanniana de direito como um sistema autopoiético, advertindo a impossibilidade deste modelo de estudo ser transposto à modernidade periférica, referindo-se, especialmente, à realidade brasileira, em razão da sobreposição de interesses particulares às operações reconhecidas pelo sistema jurídico ${ }^{41}$.

A partir de tal visão, Neves subverte a tese de Luhmann ao dizer que não será o sistema jurídico que irá conformar as relações privadas futuramente traçadas, mas o interesse particular que irá se sobrepor ao próprio direito, conformando-o, impossibilitando, assim, a construção de uma identidade no sistema jurídico ${ }^{42}$.

\footnotetext{
${ }^{38}$ ROCHA, Leonel Severo; SCHWARTZ, Germano; CLAM, Jean. Introdução à teoria do sistema autopoiético de direito. Porto Alegre: Livraria do Advogado, 2005. p. 113.

${ }^{39}$ Id. Ibid. loc. cit.

${ }^{40}$ Id. Ibid. loc. cit.

${ }^{41}$ NEVES, Marcelo. Luhmann, Habermas e o estado de direito. Lua Nova: Revista de Cultura e Política, n. 37, São Paulo, 1996. Disponível em: <http://www.scielo.br/scielo. php?pid=S0102-64451996000100006\&script=sci_arttext $>$. Acesso em: 3 abr. 2013.

${ }^{42}$ Id. Ibid.
} 
Por tal razão, Neves sustenta que, em vez de autopoiese, caberia tratar do direito como um sistema alopoiético ${ }^{43}$. Isto significa, segundo o autor, que não há "[...] uma esfera de juridicidade apta a, de acordo com seus próprios critérios e de forma congruentemente generalizada, reciclar as influências advindas do seu contexto econômico e político" ${ }^{\prime \prime 4}$.

Desse modo, o problema não está na falta de abertura cognitiva, mas no "insuficiente fechamento operacional (autorreferência)" ${ }^{\prime \prime 5}$, que se apresenta como um obstáculo à identidade do sistema jurídico. Por consequência, também não se pode esperar por uma generalização das expectativas sociais a partir dos textos legais, inviabilizando, reflexamente, a própria distinção entre o lícito e o ilícito "[...] seja por falta de institucionalização (consenso) ou de identificação do sentido das normas" ${ }^{\prime \prime 4}$.

274 De acordo com Marcelo Neves, não há como negar a autonomia do direito, mas também não se pode acreditar no ideal ilusório de estabilização e de autorreferência, dada a evidente sobreposição "de poder e dinheiro ao direito"

Já Benedito Hespanha, de forma mais moderada, atenta para o fato de a concepção de um sistema autopoiético de direito depender, necessariamente, da Constituição como fonte

\footnotetext{
${ }^{43}$ Id. Ibid.

${ }^{44}$ Id. Ibid.

${ }^{45}$ NEVES, Marcelo. Luhmann, Habermas e o estado de direito. Lua Nova: Revista de Cultura e Política, n. 37, São Paulo, 1996. Disponível em: <http://www.scielo.br/scielo. php?pid=S0102-64451996000100006\&script=sci_arttext $>$. Acesso em: 3 abr. 2013.

${ }^{46}$ Id. Ibid.

${ }^{47}$ Id. Ibid.
} 
reguladora e produtora, mas portadora de uma função real de criação, e não de simples valor simbólico ${ }^{48}$.

Com isso, muito embora não se possa afirmar a inexistência de uma influência de condicionantes sociais e políticas do meio na produção do direito, as ações e decisões produzidas em um sistema jurídico autopoiético devem ser autoproduzidas a partir de um sistema constitucional substancial ${ }^{49}$.

Em sentido semelhante, Germano Schwartz esclarece que a Constituição surge, precisamente, a partir da diferenciação funcional entre o jurídico e o político, apresentando-se como uma "[...] aquisição evolutiva da sociedade, pois substitui o direito natural pelo direito da razão, tornando-os operacionalizáveis" ${ }^{\prime \prime}$.

No tópico seguinte, serão analisadas duas perspectivas funcionalistas distintas acerca do direito penal, sendo uma delas de orientação sistêmica, como forma de avaliar se este modelo, aplicado ao direito penal, concretiza um ideal de segurança jurídica e de estabilização social ou se, ao revés, torna a aplicação da lei penal insegura e instável.

O presente estudo, portanto, propõe-se a transitar entre essas duas percepções distintas acerca do direito, como forma de avaliar se o direito penal, mais especificamente, existe em razão de um fim ou para cumprir uma determinada missão, resgatando o problema da legitimação na aplicação da lei ao fato.

\footnotetext{
${ }^{48}$ HESPANHA, Benedito. A autopoiese na construção do jurídico e do político de um sistema constitucional. Revista dos Tribunais - Cadernos de Direito constitucional e Ciência Política. São Paulo, ano 7, n. 27, abr./jun. 1999. p. 62.

${ }^{49}$ Id. Ibid. p. 62.

${ }^{50}$ SCHWARTZ, Germano. Autopoiese e constituição: os limites da hierarquia e as possibilidades da circularidade. Revista Brasileira de Direito Constitucional (RBDC): Revista do Programa de Pós-Graduação Lato Sensu em Direito Constitucional. Escola Superior de Direito Constitucional (ESDC). São Paulo, n. 6, 2005. p. 215.
} 


\section{Direito Penal e o Funcionalismo}

A doutrina penal apresenta uma série de correntes funcionalistas que, em comum, possuem o fato de buscarem atribuir ao direito penal uma função específica, divergindo, por sua vez, sobre qual seria essa função. Por questões de delimitação temática, o presente estudo não se ocupará senão do estudo das correntes funcionalistas sustentadas por Claus Roxin e por Günther Jakobs, não chegando a tratar de outras concepções não menos importantes, tais como o funcionalismo reducionista de Eugenio Raúl Zaffaroni ${ }^{51}$ e o funcionalismo do controle social de Hassemer ${ }^{52}$.

\subsection{O Funcionalismo Teleológico de Claus Roxin}

Ensina Luís Greco que o funcionalismo teleológico propõe uma revisão de toda a teoria do delito, a fim de que esta seja (re)compreendida à luz da política criminal, permitindo que decisões valorativas sejam introduzidas no sistema do direito penal ${ }^{53}$.

Explica o autor que o funcionalismo teleológico possui como base metodológica a jurisprudência dos valores (Wertungsjurisprudenz), segundo a qual "[...] construções jurídicas devem ser conscientemente guiadas por determinados valores

${ }^{51}$ Cf. ZAFFARONI, Eugenio Raul; ALAGIA, Alejandro; SLOKAR, Alejandro. Derecho penal: parte general. Buenos Aires: Ediar, 2001.

${ }^{52}$ Cf. HASSEMER, Winfried. Perspectivas de uma moderna política criminal. Revista Brasileira de Ciências Criminais, São Paulo, n. 8, out./dez. 1994. p. 41-51.

${ }^{53}$ GRECO, Luís. A teoria da imputação objetiva: uma introdução. In: ROXIN, Claus. Funcionalismo e imputação objetiva no direito penal. Trad. Luís Greco. Rio de Janeiro/ São Paulo: Renovar, 2002. p. 62. 
e finalidades" ${ }^{\prime 54}$. A jurisprudência dos valores, nesse sentido, teria superado o modelo neokantista, o qual, malgrado tenha referido a importância dos valores para o direito, não chegou a lhes atribuir uma posição teleológica objetivamente válida ${ }^{55}$.

É nesse sentido que Claus Roxin utiliza-se da política criminal do Estado Social e Democrático de Direito para restringir a esfera de atuação do direito penal, atribuindo-se a função de tutela subsidiária de bens jurídicos, impondo, inclusive, limites de atuação para o intérprete e o legislador, superando a tradicional concepção segundo a qual somente o legislador trabalha com política criminal ${ }^{56}$.

De acordo com Roxin, desde, aproximadamente, 1970, tem sido buscado o desenvolvimento de um sistema "jurídico-penal teleológico-racional ou funcional" ${ }^{27}$, buscando-se superar, definitivamente, o modelo científico-natural ou lógico de causalidade por um conjunto de regras orientadas a uma valoração jurídica - projeto que se iniciou com o neokantismo, na década de trinta, mas acabou por ficar esquecido, em razão da Segunda Guerra Mundial ${ }^{58}$.

Nesse sentido, como esclarece Raquel Lima Scalcon, o estudo do pensamento sistemático foi fundamental para que a Escola de Munique construísse a teoria funcionalista do direito penal, estruturando o sistema de forma teleológica, utilizando

\footnotetext{
${ }^{54}$ Id. Ibid. p. 63.

${ }^{55}$ GRECO, Luís. A teoria da imputação objetiva: uma introdução. In: ROXIN, Claus. Funcionalismo e imputação objetiva no direito penal. Trad. Luís Greco. Rio de Janeiro/ São Paulo: Renovar, 2002. p. 63.

${ }^{56}$ Id. Ibid. p. 64-65.

${ }^{57}$ ROXIN, Claus. Funcionalismo e imputação objetiva no direito penal. Trad. Luís Greco. Rio de Janeiro/São Paulo: Renovar, 2002. p. 205.

${ }^{58}$ Id. Ibid. p. 206-207.
} 
A Autopoiese no Direito e o Funcionalismo Sistêmico...

valores como o pondo de partida para um redimensionamento de tradicionais elementos da teoria do delito ${ }^{59}$.

Assim, conforme esclarecem Alice Bianchini, Antonio García-Pablos de Molina e Luiz Flávio Gomes, de acordo com essa corrente funcionalista, a intervenção do direito penal somente legitima-se quando estiver a cumprir a função de proteção de um bem jurídico ${ }^{60}$. O bem jurídico, seja ele material ou imaterial, corresponde a um interesse social juridicamente tutelado, o qual, em razão de sua relevância e da insuficiência de proteção por parte de outros ramos do direito, ganha, no direito penal, uma proteção substancial.

A proteção desempenhada por parte do direito penal, todavia, somente justifica-se quando excepcional (princípio da intervenção mínima), uma vez que a sanção penal é, de todas as dispostas no direito, a mais drástica, em razão de atingir, como regra geral, o direito fundamental de liberdade.

É, também, por essa razão que a seleção dos bens jurídicos que irão compor a esfera jurídico-penal de tutela é feita com base na observância dos princípios da fragmentariedade e da subsidiariedade ${ }^{61}$. Em razão do primeiro, entende-se que a justiça penal não se aplica à tutela de todo e qualquer bem, mas tão somente daqueles mais preciosos para o ordenamento

\footnotetext{
${ }^{59}$ SCALCON, Rachel Lima. Funcionalismo penal da Escola de Munique: contributos e inconsistências de uma construção do conceito de crime a partir dos fins de política criminal. Revista Síntese Direito Penal e Direito Processual Penal. Continuação da Revista IOB de Direito Penal e Processual Penal. Porto Alegre, v.1, n.1, abr./ maio 2000. p. 80-81.

${ }^{60}$ BIANCHINI, Alice; MOLINA, Antonio García-Pablos; GOMES, Luiz Flávio. Direito Penal: introdução e princípios fundamentais. 2. ed. São Paulo: Revista dos Tribunais, 2009. p. 232-235.

${ }^{61}$ BIANCHINI, Alice; MOLINA, Antonio García-Pablos; GOMES, Luiz Flávio. Direito Penal: introdução e princípios fundamentais. 2. ed. São Paulo: Revista dos Tribunais, 2009. p. 235-236.
} 
jurídico, tais como a vida, a dignidade sexual, a liberdade, a integridade física, dentre outros.

Já o princípio da subsidiariedade afirma o direito penal como ultima ratio, isto é, última esfera de proteção, de modo que a criminalização de uma conduta só se legitima quando se verificar que as consequências jurídicas previstas por outros ramos do direito como forma de coibir a lesão ao bem não são suficientes para impor o desestímulo à prática criminosa.

De acordo com Roxin, portanto, a lesão a um bem jurídico é pressuposto de punibilidade, afastando-se do direito penal as meras imoralidades, as contravenções, ideologias, arbitrariedades, dentre outras situações em que não se apresente um risco jurídico substancialmente relevante a justificar a aplicação da lei penal ${ }^{62}$.

Nesse sentido, ao se entender o direito penal como veículo de proteção exclusiva de bens jurídicos, o que se pretende, em última análise, é restringir o seu conteúdo, tratando-se, portanto, de um direito penal mínimo, e, com isso, aprimorar-lhe a efetividade no desempenho da sua função de tutela.

Ocorre que inexiste um conceito seguro, preciso e objetivado de bem jurídico, o que serve de motivo para diversas críticas acerca da inexistência de uma real função limitadora por parte da teoria, já que, a depender dos bens eventualmente selecionados para compor a esfera de proteção de uma determinada sociedade, a teoria funcionalista teleológica pode passar a funcionar, ao revés, como critério de expansão do direito penal.

É por essa razão que se passa a trabalhar com a Constituição como referencial axiológico para o processo de seleção desses bens que passarão a compor a esfera penal de tutela, não se

${ }^{62}$ ROXIN, Claus. Derecho Penal - Parte General. Tomo I. La estructura de la teoría del delito. Trad. Diego-Manuel Luzon Peña; Miguel Díaz y García Conlledo; Javier de Vicente Remesal. Madrid: Civitas, 1997. p. 52-53. 
A Autopoiese no Direito e o Funcionalismo Sistêmico...

chegando, todavia, a um consenso sobre esta forma de escolha - se apenas os bens expressos na Constituição poderiam ser alcançados ou se aqueles implícitos, ou mesmo não contrários ao modelo constitucional, poderiam ser agregados ao rol de tutela.

É essa a opinião de Claus Roxin, para quem a seleção de bens jurídicos deve derivar da Constituição, de modo a evitar a criminalização condicionada a concepções morais dominantes, como foi o caso da punição da homossexualidade com base em um suposto bem jurídico da "estrutura heterossexual das relações sexuais" ${ }^{\prime 63}$.

Em que pesem as críticas, o funcionalismo teleológico proposto por Claus Roxin ainda é o modelo funcionalista mais amplamente aceito no Brasil, repercutindo, inclusive, em um redimensionamento da acepção de tipicidade, que passa a ser entendida não só como tipicidade formal, mas também como tipicidade material.

Desse modo, para que um fato seja considerado típico, deve haver tipicidade formal - entendida como a correspondência entre a conduta praticada e os elementos objetivos e subjetivos relacionados ao tipo penal - e tipicidade material - efetiva lesão a um bem jurídico.

Esta análise valorativa deve-se, sobretudo, ao fato de o tipo penal ter o seu conteúdo desenvolvido em um campo de tensão formado entre o fim da lei e a determinação da lei, reclamando, a um só tempo, uma interpretação dogmática e valorativa, de modo que certos comportamentos legalmente desaprovados, após análise teleológica, possam ser compreendidos pelo direito ${ }^{64}$.

\footnotetext{
${ }^{63}$ ROXIN, Claus. Derecho Penal - Parte General. Tomo I. La estructura de la teoría del delito. Trad. Diego-Manuel Luzon Peña; Miguel Díaz y García Conlledo; Javier de Vicente Remesal. Madrid: Civitas, 1997. p. 54.

${ }^{64}$ ROXIN, Claus. Funcionalismo e imputação objetiva no direito penal. Trad. Luís Greco. Rio de Janeiro/São Paulo: Renovar, 2002. p. 234.
} 
Para Günther Jakobs, por outro lado, se proteção a bem jurídico há, esta é apenas incidental, pois a função do direito penal jamais poderia estar edificada em uma base imprecisa e instável ${ }^{65}$. Segundo o autor, fosse a função genérica do direito penal a proteção, por exemplo, do patrimônio, teria de haver a incidência da lei penal diante de um automóvel corroído pela ferrugem, mas não é o que ocorre, precisamente porque “[...] o direito não é um muro construído para proteger os bens, é, sim, a estrutura que garante a relação entre as pessoas" ${ }^{\prime 66}$. Desse modo, sustenta o autor que a função do direito penal é a proteção de suas normas.

Além disso, o funcionalismo teleológico não seria, segundo Jakobs, um modelo teórico capaz de atender a todo e qualquer ordenamento jurídico, ao contrário de um modelo funcionalista sistêmico, a ser tratado nas seguintes linhas, capaz de ser destinado à proteção de qualquer organização normativa ${ }^{67}$.

\subsection{O Funcionalismo Sistêmico de Günther Jakobs}

Günther Jakobs utiliza como ponto de partida para o desenvolvimento do funcionalismo sistêmico ou normativista a teoria dos sistemas de Niklas Luhmann e a concepção do

${ }^{65}$ CALLEGARI, André Luís; LYNETT, Eduardo Montealegre; JAKOBS, Günther; MELIÁ, Manoel Cancio. Direito penal e funcionalismo. Coord. CALLEGARI, André Luís; NEREU, José Giacomolli. Trad. André Luís Callegari, Nereu José Giacomolli e Lúcia Kalil. Porto Alegre: Livraria do Advogado, 2005, passim.

${ }^{66}$ CALLEGARI, André Luís; LYNETT, Eduardo Montealegre; JAKOBS, Günther; MELIÁ, Manoel Cancio. Direito penal e funcionalismo. Coord. CALLEGARI, André Luís; NEREU, José Giacomolli. Trad. André Luís Callegari, Nereu José Giacomolli e Lúcia Kalil. Porto Alegre: Livraria do Advogado, 2005. p. 33.

${ }^{67}$ GÜNTHER, Jakobs. Qué protege el derecho penal: bienes jurídicos o la vigencia de la norma? Mendoza: Cuyo, 2002. p. 53. 
direito como um sistema autopoiético ${ }^{68}$. Nesse sentido, a função do direito, mais especialmente, a função do direito penal é a de proteção das suas próprias normas ${ }^{69}$.

Nesse sentido, o direito penal é operacionalmente fechado, sem deixar, entretanto, de se apresentar como um sistema mutável, uma vez que as mudanças sociais que caracterizam o tempo em que se situam o sistema e o entorno, são aptas a produzir mudanças normativas e, somente assim, modifica-se uma lei penal.

Significa dizer que, antes da mencionada mudança, não é possível afastar a incidência da norma penal violada, já que o direito penal trabalha a partir da estrutura lícito/ilícito, de modo que a ocorrência da ofensa a uma norma, tenha ela atingido ou não um determinado bem jurídico, tem a força de impor a sanção penal.

Esclarece Lúcio Antônio Chamon Junior que o funcionalismo sistêmico proposto por Jakobs está pautado em uma descrição neutra do direito penal, mas se distancia, em certos aspectos, da teoria luhmanniana, sobretudo no que diz respeito à noção de norma jurídica adotada por Jakobs e nos tipos de comunicação por este desenvolvidos ${ }^{70}$.

Segundo Chamon Junior, o funcionalismo sistêmico jurídico-penal está orientado a proteger a identidade normativa, sendo a função do direito penal a manutenção de um sistema, o que se verifica por meio da contradição a uma contradição das normas determinantes (seguindo Jakobs, nesse aspecto, o

\footnotetext{
${ }^{68}$ JAKOBS, Günther. A imputação objetiva no direito penal. Trad. André Luís Callegari. São Paulo: Revista dos Tribunais, 2000, passim.

${ }^{69}$ Id. Ibid. passim.

${ }^{70}$ CHAMON JUNIOR, Lúcio Antônio. Do giro finalista ao funcionalismo penal: embates de perspectivas dogmáticas decadentes. Porto Alegre: Sergio Antônio Fabris, 2004. p. 71-72.
} 
pensamento de Hegel acerca da negação da negação do direito como um processo de afirmação deste $)^{71}$.

A pena funciona, portanto, como uma confirmação ou autocomprovação da norma, promovendo, no plano comunicativo, o restabelecimento da vigência da norma jurídica violada ${ }^{72}$. O citado restabelecimento, todavia, não é passível de comprovação empírica ${ }^{73}$.

A sanção penal, assim, corresponde à reafirmação da validade da norma violada, assumindo um caráter de prevenção geral positiva do delito perante a sociedade, supondo-se que o conhecimento da norma e de suas consequências jurídicas tem a força de produzir uma certa previsibilidade comportamental e, com isso, manter a estabilidade das relações sociais mesmo após violada uma das normas jurídicas do sistema.

O direito penal, então, assume a missão de garantia de uma identidade normativa da sociedade e, reconhecendo que a constituição da sociedade se desenvolve por intermédio de normas, entende-se que o ataque à norma corresponde, em última análise, a um ataque a esta identidade social ${ }^{74}$.

Jakobs reconhece, todavia, a existência de defeitos volitivos capazes de produzir uma falta de fidelidade ao ordenamento jurídico, situação em que mesmo o conhecedor do sistema de normas do Estado recusa-se a reconhecê-lo ${ }^{75}$. Tal fato ocorre porque as normas sociais não são absolutas, mas débeis - e quanto mais débil é a norma, mais forte deve ser a

\footnotetext{
${ }^{71}$ Id. Ibid. p. 72.

${ }^{72}$ Id. Ibid. loc. cit.

${ }^{73}$ Id. Ibid. loc. cit.

${ }^{74}$ Id. Ibid. p. 73.

${ }^{75}$ JAKOBS, Günther. Fundamentos do Direito Penal. Trad. André Luís Callegari. São Paulo: Revista dos Tribunais, 2003. p. 30.
} 
A Autopoiese no Direito e o Funcionalismo Sistêmico...

respectiva pena, para que não se opere a morte da norma no ordenamento jurídico ${ }^{76}$.

Jakobs propõe, portanto, a aplicação da teoria do direito como um sistema autopoiético ao direito penal na justificação da incidência da lei penal diante da violação da norma, prescindindo, pois, da análise da ocorrência de efetiva lesão ou não a um determinado bem jurídico.

Não fosse assim, as normas juridicamente previstas não teriam mais a aptidão de garantir a estabilidade social, pois as condutas que se delineariam a partir de então não mais estariam fundamentadas na possibilidade de imposição da consequência jurídica, ocasionando-se a completa desordem social.

Criticando o funcionalismo normativista, Roxin discorda da concepção segundo a qual o direito não deve ceder diante do injusto, advertindo que os interesses de autoproteção não justificam o desprezo à necessidade de ponderação de bens, que está respaldada em princípios reitores do ordenamento jurídico, tais como o da proporcionalidade ${ }^{77}$.

Fábio da Silva Bozza critica a concepção de prevenção geral positiva no funcionalismo sistêmico de Jakobs, sustentando que este não explica o porquê é a pena criminal - e não meio menos violento - a forma de garantia das expectativas sociais $^{78}$. Bozza ainda destaca que, observando as estatísticas criminais, a regra é a da frustração das expectativas normativas,

\footnotetext{
${ }^{76}$ Id. Ibid. p. 31.

${ }^{77}$ ROXIN, Claus. Politica criminal y sistema del derecho penal. 2. ed. Buenos Aires: Hammurabi, 2002. p. 78-79.

${ }^{78}$ BOZZA, Fábio da Silva. Uma análise crítica da prevenção geral positiva no funcionalismo sistêmico de Günther Jakobs. Revista Brasileira de Ciências Criminais, São Paulo, ano 16, n. 70, jan./fev. 2008. p. 57.
} 
e não o contrário, o que prova a pena não cumprir, efetivamente, uma função de prevenção geral positiva ${ }^{79}$.

Bozza ainda lança críticas à teoria sistêmica de Niklas Luhmann, atestando que o referido modelo "[...] permite a instrumentalização do direito" ${ }^{80}, \operatorname{logo}$ "[...] não condiz com um direito penal democrático" ${ }^{\prime 81}$.

\section{O Funcionalismo Sistêmico e a Aplicação da Lei Penal}

O funcionalismo sistêmico proposto por Jakobs, dentre outras consequências, tem como impacto marcante, na aplicação da lei penal, a criação de uma nova percepção de "risco" para o direito penal, além de servir de justificativa para a aceitação dos chamados tipos penais de perigo abstrato, conforme ver-se-á nas linhas seguintes.

\subsection{A Teoria da Imputação Objetiva e a Noção de "Risco" no Direito Penal}

Günther Jakobs desenvolve uma nova noção de "risco" para o direito penal, pautada na quebra da confiança de expectativas sociais de conduta. Nesse sentido, a quebra de confiança, seja ela intencional (dolo) ou decorra da inobservância de um dever de cuidado (culpa) justificaria a incidência da pena com o fim de prevenção geral positiva.

Segundo Juliana Cardoso Benedetti, a teoria da imputação objetiva proposta por Jakobs está fundada na “[...] atribuição

\footnotetext{
${ }^{79}$ Id. Ibid. p. 57.

${ }^{80}$ Id. Ibid. p. 59.

${ }^{81}$ Id. Ibid. loc. cit.
} 
A Autopoiese no Direito e o Funcionalismo Sistêmico...

de papéis sociais, com o que se tem que só é possível responsabilizar alguém penalmente se esta pessoa atuou extrapolando os limites do seu âmbito de organização" ${ }^{22}$

Jakobs analisa os comportamentos uniformes em massa a partir da compreensão de que a sociedade moderna é uma sociedade complexa, que precisa saber administrar "comportamentos de massa distintos mas também uniformes dos cidadãos $^{\prime \prime 83}$. A administração dos riscos está relacionada, dentre outros fatores, a um tratamento rigoroso dos indivíduos chamados "não alinhados", conceituados como sendo aqueles que, não de maneira incidental, utilizam-se do crime como elemento comportamental ou como atividade habitual - sujeitos que abandonaram o direito e, por tal razão, ameaçam a segurança social $^{84}$.

Desse modo, em que pese o risco seja inerente à vida em sociedade, cabe ao Estado o gerenciamento dos riscos permitidos e dos riscos proibidos por intermédio da atuação do sistema penal.

O risco permitido, segundo Jakobs, está vinculado à configuração da própria sociedade, tratando-se de uma concreção da adequação social, a exemplo da legítima defesa e do estado de necessidade ${ }^{85}$. O risco permitido, portanto, está situado nas hipóteses normais de interação dos indivíduos em sociedade ${ }^{86}$.

\footnotetext{
82 BENEDETTI, Juliana Cardoso. As raízes sociológicas do funcionalismo penal: uma aproximação entre Émile Durkheim e Günther Jakobs. Revista Brasileira de Ciências Criminais, São Paulo, ano 16, n. 73, jul./ago. 2008. p. 30.

${ }^{83}$ JAKOBS, Günther. Ciência do direito e ciência do direito penal. Trad. Maurício Antônio Ribeiro Lopes. Estudos de Direito Penal. v. 1. São Paulo: Manole, 2003. p. 44.

${ }^{84}$ Id. Ibid. p. 57.

${ }^{85}$ JAKOBS, Günther. A imputação objetiva no direito penal. Trad. André Luís Callegari. São Paulo: Revista dos Tribunais, 2000. p. 35.

${ }^{86}$ Id. Ibid. loc. cit.
} 
A distinção entre risco permitido e risco proibido, em certos casos, dependerá de um cálculo de custos e benefícios, em que "[...] o benefício estaria constituído pela liberdade de comportamento que se obtém com a ajuda da permissão de riscos, enquanto os custos seriam a perda daqueles bens a cuja destruição conduz o risco, devendo ambos os lados manter uma relação adequada" ${ }^{\prime 87}$.

É o caso, por exemplo, daquele que conduz uma ambulância a uma velocidade de 75 quilômetros por hora em uma via cuja velocidade máxima permitida é de 70 quilômetros por hora: viola-se uma expectativa, mas esta violação é tolerável, em razão de uma análise dos custos e dos benefícios da conduta ${ }^{88}$.

O problema, todavia, está nos extremos a que a concepção funcionalista sistêmica de Jakobs pode conduzir a partir da distinção entre risco permitido e risco proibido decorrente da quebra ou não de expectativas sociais. Um exemplo claro é o do estudante de biologia que ganha um dinheiro extra trabalhando como garçom e um dos clientes solicita uma fruta exótica: o estudante, em razão de seus conhecimentos especiais em biologia, sabe que a fruta é venenosa, mas, ainda assim, serve o alimento, vindo o cliente a falecer ${ }^{89}$.

Segundo Jakobs, o estudante de biologia não poderá ser punido, pois não violou nenhum papel social, já que, no momento em que o fato ocorreu, estava atuando tão somente como garçom, tratando-se, portanto, de um risco permitido.

\footnotetext{
${ }^{87}$ Id. Ibid. p. 36.

${ }^{88}$ Id. Ibid. p. 39.

${ }^{89}$ Id. Ibid. p. 49.
} 


\subsection{Os Tipos Penais de Perigo Abstrato e a Proteção da Norma Penal}

Os tipos de perigo abstrato são aqueles em que a incidência da lei penal prescinde da ocorrência de um dano material efetivo, ou mesmo de um perigo concreto de dano a um determinado bem jurídico.

Em tais espécies delitivas, o risco criado está não na conduta em si, mas presumido no próprio tipo incriminador, de modo que a simples prática da conduta prevista em lei como crime justifica, por si só, a aplicação da pena.

Tome-se, como exemplo na legislação brasileira, o porte ilegal de arma desmuniciada, delito previsto no art. 14, caput, da Lei n. 10.826/2003, situação em que o Superior Tribunal de Justiça tem se pronunciado, reiteradamente, pela dispensabilidade do laudo pericial destinado a aferir a potencialidade lesiva do objeto material do crime, por se tratar de tipo penal de perigo abstrato ${ }^{90}$.

É o caso, também, do crime de embriaguez ao volante, art. 306 da Lei n. 9.503/97, que, após a alteração promovida pela Lei n. 11.705/08 objetivou o conceito legal de embriaguez definindo a concentração de álcool a partir da qual se impõe a incidência do tipo incriminador, quantidade esta hoje em dia regulada por meio da Lei n. 12.760, de 2012, que disciplina ser criminosa a condução do veículo sob concentração igual ou superior a seis decigramas de álcool por litro de sangue ou igual ou superior a 0,3 miligrama de álcool por litro de ar alveolar. Nesse sentido, o Supremo Tribunal Federal manifestou-se pela desnecessidade de comprovação, para além da já referida concentração, de perda de capacidade motora por parte do motorista ${ }^{91}$.

\footnotetext{
${ }_{90}$ STJ, EDcl no AgRg no AREsp 130342 / SC, 5a Turma, DJe 22/03/2013.

${ }^{91}$ STF, RHC 110258 / DF, 1a Turma, PUBLIC 24-05-2012.
} 
Segundo Jakobs, os tipos penais de perigo abstrato são necessários ao controle social, uma vez que determinadas modalidades de comportamento, aparentemente inócuas, podem se apresentar como perigosas ${ }^{92}$. Resta saber, conforme esclarece o autor, se há fundamentos suficientes para tratar tais condutas não como mera infração contra a ordem pública, mas sim como delito criminal $^{93}$.

Outro argumento apresentado pelo autor é o fato de a segurança se apresentar não como um mero reflexo da atividade policial, mas como um direito essencial de cada indivíduo, de modo que os delitos de perigo abstrato "[...] não apenas perturbam a ordem pública, mas lesionam um direito à segurança" - segurança essa entendida no sentido normativo ${ }^{94}$.

\section{Considerações Finais}

A partir do conceito de sistema jurídico autopoiético apresentado no primeiro tópico, bem como de suas críticas, além das duas correntes funcionalistas antagônicas, teleológica e normativista, é possível tecer as seguintes considerações críticas a respeito da aplicação do modelo autopoiético de direito aplicado ao direito penal:

a) O direito, especialmente em sistemas jurídicos "periféricos", não pode ser estudado sob uma perspectiva autopoiética, uma vez que a política e a economia correspondem a fatores reais capazes

\footnotetext{
${ }_{92}$ JAKOBS, Gunther. Sociedade, norma e pessoa: teoria de um direito penal funcional. Trad. Maurício Antônio Ribeiro Lopes. Estudos de Direito Penal. v. 6. São Paulo: Manole, 2003. p. 24-25.

${ }^{93}$ Id. Ibid. p. 25.

${ }^{94}$ JAKOBS, Gunther. Sociedade, norma e pessoa: teoria de um direito penal funcional. Trad. Maurício Antônio Ribeiro Lopes. Estudos de Direito Penal. v. 6. São Paulo: Manole, 2003. p. 26-27.
} 
de subverter a ordem jurídica e de conformar as estruturas do ordenamento jurídico, de modo que seu sistema organizacional passa a operar de modo meramente simbólico, sem garantir a estabilidade, auto-organização e autonomia esperadas de um sistema autopoiético.

b) O direito, concretamente, assume a forma de um sistema alopoiético, uma vez que sua abertura cognitiva não está atrelada a um fechamento operacional capaz de conter a força condicionante desempenhada por interesses de ordem privada.

c) Reconhecendo-se o direito como sistema condicionado por interesses políticos e econômicos, cabe ao direito penal desempenhar uma função de garantia, restringindo o seu âmbito de incidência e questionando, criticamente, a imposição da sanção penal.

d) Cumpre questionar o conteúdo das estruturas sistemáticas, não sendo a produção de leis conforme os critérios predefinidos de reconstrução suficientes para lhes justificar a incidência, somente legitimando-se a aplicação de uma sanção criminal caso tenha havido, para além da ofensa à norma, uma lesão ou perigo concreto de lesão a um bem jurídico.

e) A teoria do bem jurídico, em que pese não seja passível de uma objetivação absoluta quanto ao seu conteúdo, não deve ser abandonada enquanto modelo reitor do direito penal, uma vez que funciona como um princípio limitador do âmbito de incidência da lei penal. 
f) A noção de risco proibido deve ser construída tendo como base a ofensa a um bem jurídico relevante, e não a quebra de confiança decorrente da frustração de uma expectativa generalizada de comportamento.

g) Não se pode admitir a aplicação de sanção criminal a condutas em que não se comprove, ao menos, a ocorrência de um risco concreto para o ordenamento jurídico, não podendo a acusação se desincumbir do ônus de provar a lesividade - concreta ou potencial - da conduta, de modo que condutas como porte ilegal de arma ou embriaguez ao volante persistem como figuras puníveis, mas desde que o sujeito ativo tenha apresentado, pelo menos, um risco concreto ao bem juridicamente tutelado. 


\section{Referências}

BENEDETTI, Juliana Cardoso. As raízes sociológicas do funcionalismo penal: uma aproximação entre Émile Durkheim e Günther Jakobs. Revista Brasileira de Ciências Criminais, São Paulo, ano 16, n. 73, jul./ago. 2008.

BIANCHINI, Alice; MOLINA, Antonio García-Pablos; GOMES, Luiz Flávio. Direito Penal: introdução e princípios fundamentais. 2. ed. São Paulo: Revista dos Tribunais, 2009.

BOZZA, Fábio da Silva. Uma análise crítica da prevenção geral positiva no funcionalismo sistêmico de Günther Jakobs. Revista Brasileira de Ciências Criminais, São Paulo, ano 16, n. 70, p. 41-70, jan./fev. 2008.

CALLEGARI, André Luís; LYNETT, Eduardo Montealegre; JAKOBS, Günther; MELIÁ, Manoel Cancio. Direito penal e funcionalismo. Coord. CALLEGARI, André Luís; NEREU, José Giacomolli. Trad. André Luís Callegari, Nereu José Giacomolli e Lúcia Kalil. Porto Alegre: Livraria do Advogado, 2005.

292 CHAMON JUNIOR, Lúcio Antônio. Do giro finalista ao funcionalismo penal: embates de perspectivas dogmáticas decadentes. Porto Alegre: Sergio Antônio Fabris, 2004.

GRECO, Luís. A teoria da imputação objetiva: uma introdução. In: ROXIN, Claus. Funcionalismo e imputação objetiva no direito penal. Trad. Luís Greco. Rio de Janeiro/São Paulo: Renovar, 2002.

GÜNTHER, Jakobs. Ciência do direito e ciência do direito penal. Trad. Maurício Antônio Ribeiro Lopes. Coleção Estudos de Direito Penal. v. 1. São Paulo: Manole, 2003.

. Sociedade, norma e pessoa: teoria de um direito penal funcional. Trad. Maurício Antônio Ribeiro Lopes. Coleção Estudos de Direito Penal. v. 6. São Paulo: Manole, 2003.

. O direito de resistência: à legítima defesa, ao estado de necessidade e ao consentimento. In: FÖPPEL, Gamil (Org.). Novos desafios do direito penal no terceiro milênio: estudos em homenagem ao prof. Fernando Santana. Rio de Janeiro: Lumen Juris, 2008.

. A imputação objetiva no direito penal. Trad. André Luís Callegari. São Paulo: Revista dos Tribunais, 2000. 
- Qué protege el derecho penal: bienes jurídicos o la vigencia de la norma? Mendoza: Cuyo, 2002.

. Fundamentos do Direito Penal. Trad. André Luís Callegari. São Paulo: Revista dos Tribunais, 2003.

HASSEMER, Winfried. Perspectivas de uma moderna política criminal. Revista Brasileira de Ciências Criminais, São Paulo, n. 8, p. 41-51, out./dez. 1994.

HESPANHA, Benedito. A autopoiese na construção do jurídico e do político de um sistema constitucional. Revista dos Tribunais Cadernos de Direito constitucional e Ciência Política, São Paulo, ano 7, n. 27, p. 59-78, abr./jun. 1999.

LUHMANN, Niklas. Sociologia do Direito I. Coleção dirigida por Eduardo Portella. Trad. Gustavo Bayer. Série Biblioteca Tempo Universitário n. 75/Série Estudos Alemães. Rio de Janeiro: Tempo Brasileiro, 1983.

. Sociologia do Direito II. Coleção dirigida por Eduardo Portella. Trad. Gustavo Bayer. Série Biblioteca Tempo Universitário n. 75/Série Estudos Alemães. Rio de Janeiro: Tempo Brasileiro, 1985.

. La sociedad de la sociedad. México: Universidad Iberoamericana Biblioteca Francisco Xavier Clavigero, 2006.

. El Derecho de la Sociedad. Formatação eletrônica de João Protásio Farias Domingues de Vargas, Marjorie Corrêa Marona e Juliana Neuenschwander Magalhaes. Brasil, 2002.

NEVES, Marcelo. Luhmann, Habermas e o estado de direito. Lua Nova: Revista de Cultura e Política, n. 37, São Paulo, 1996. Disponível em: <http://www.scielo.br/scielo.php?pid=S0102-64451996000100006\&script=sci_arttext $>$. Acesso em: 3 abr. 2013.

ROCHA, Leonel Severo; SCHWARTZ, Germano; CLAM, Jean. Introdução à teoria do sistema autopoiético de direito. Porto Alegre: Livraria do Advogado, 2005.

ROXIN, Claus. Funcionalismo e imputação objetiva no direito penal. Trad. Luís Greco. Rio de Janeiro/São Paulo: Renovar, 2002.

. Politica criminal y sistema del derecho penal. 2. ed. Buenos Aires: Hammurabi, 2002. 
A Autopoiese no Direito e o Funcionalismo Sistêmico...

. Derecho Penal - Parte General. Tomo I. La estructura de la teoría

del delito. Trad. Diego-Manuel Luzon Peña; Miguel Díaz y García Conlledo; Javier de Vicente Remesal. Madrid: Civitas, 1997.

SCALCON, Rachel Lima. Funcionalismo penal da Escola de Munique: contributos e inconsistências de uma construção do conceito de crime a partir dos fins de política criminal. Revista Síntese Direito Penal e Direito Processual Penal: Continuação da Revista IOB de Direito Penal e Processual Penal, Porto Alegre, v. 1, n. 1, p. 72-93, abr./maio 2000.

SCHWARTZ, Germano. Autopoiese e constituição: os limites da hierarquia e as possibilidades da circularidade. Revista Brasileira de Direito Constitucional (RBDC): Revista do Programa de Pós-Graduação Lato Sensu em Direito Constitucional, Escola Superior de Direito Constitucional (ESDC), São Paulo, n. 6, p. 211-224, 2005.

ZAFFARONI, Eugenio Raul; ALAGIA, Alejandro; SLOKAR, Alejandro. Derecho penal: parte general. Buenos Aires: Ediar, 2001. 


\section{O Conceito de Eficácia como Fundamento do Sistema Penal}

The Concept of Effectiveness as Background of Criminal System

Ana Gabriela Souza Ferreira*

Resumo: O presente artigo visa a esboçar um panorama sobre o desenvolvimento do conceito de eficácia no direito penal ao longo das mais diversas teorias penais e criminológicas. Objetiva-se o questionamento das noções sancionatórias sob a ótica da eficácia como preceito norteador da resposta jurisdicional estatal. Por meio da análise da dogmática jurídica atual, questiona-se a aplicabilidade real e a (des)preocupação com a eficácia na criação e aplicação da sistemática penal. Parte-se da análise das mais diversas escolas e acepções críticas do sistema e buscando encontrar ao menos um referencial seguro nas ideias embrionárias de um novo modelo de visão criminal, a partir de perspectiva construtivista.

Palavras-chave: Eficácia. Direito Penal. Sanção. Paradigma. Nova Dogmática Jurídica.

Abstract: The present article aims to outline an overview of the development of the concept of effectiveness in criminal law on several punishment and criminological theories. Its intent is to question the sanctionative notions from the perspective of effectiveness as a guiding precept of the state jurisdictional response. Through analysis of current legal doctrine, it is questioned the real applicability and the (mis)concern with the effectiveness in the creation and application of criminal law. It starts of the analysis of the most diverse schools and critical understandings of the system, trying to find at least one

* Universidade Federal da Bahia. 
O Conceito de Eficácia como Fundamento...

safe referential in embryonic ideas for a new model of criminal view, from a constructivist perspective.

Keywords: Efficiency. Criminal Law. Sanction. Paradigm. New Legal Doctrine.

\section{Introdução}

A quebra de paradigmas penais é uma das muitas dimensões de ruptura aceleradas pelo ritmo pós-global de convívio intersubjetivo. ${ }^{1}$ Dentre as muitas perspectivas revistas, pode-se perceber uma crescente sensação de inabilitação dos paradigmas punitivos atuais face às premissas de contraestímulo, exemplo e ressocialização do indivíduo ofensor.

A análise de incapacidade e insuficiência dos sistemas penais quanto à facilitação da estabilidade social - prevenção e minoração do conflito, além da atenuação de seus efeitos - tem fomentado a rediscussão, em maior ou mais intensa e divulgada escala, de qual a real funcionalidade da pena. É sobre a análise da eficácia ${ }^{2}$ da pena como seu fundamento e finalidade precípuos que se intenta tratar neste trabalho.

Para tanto, inicia-se uma revisão conceitual quanto a finalidades e fundamentos da sanção, desde a sistemática perspectiva da Escola Clássica até os debates calorosos no âmbito de estudos penalísticos relacionados ao poder punitivo e à sanção dos dias atuais. Das perspectivas retribucionistas originárias ao abolicionismo, inúmeros fatores agregam-se à visão doutrinária sobre a pena.

\footnotetext{
1 Sobre o tema, cf. ZAFFARONI, Eugenio Raúl. Em busca das penas perdidas: a perda de legitimidade do sistema penal. Tradução: Vania Romano Pedrosa e Amir Lopez da Conceição. Rio de Janeiro: Revans, 1991.

2 Eficácia, neste trabalho, é um conceito multidimensional, que será devidamente explicitado e justificado em capítulo próprio.
} 
Num primeiro momento, os escritores clássicos apegavam-se aos conceitos contratualistas, vendo na pena uma reafirmação do poder estatal e desestímulo à conduta criminosa, considerando o crime um ato de livre vontade que violava o pacto social - numa maior busca por um fim à pena que por uma razão do crime. Tal acepção de "ato de livre vontade", notoriamente vinculada à ascensão de uma burguesia ${ }^{3}$, equiparava formalmente (e de modo surreal) as condições concedidas a todos, não as considerando na análise dos fatores de propensão à lesão dos bens jurídicos.

No entanto, o sistema originalmente pensado demonstrou-se incapaz de evitar a prática de crimes. A contramotivação pautada no temor, pura e simplesmente, não foi capaz de desestimular suficientemente o comportamento lesivo. Passamos, então, à análise de teorias subsequentes. Sob influência do cientificismo, vieram os positivistas, mudando o enfoque, observando pela primeira vez as características do criminoso em si considerado como relevantes no cometimento do crime.

Se, por um lado, pecaram ao criar um sofisma - partindo da premissa de relação atávica entre características biopsíquicas ou sociológicas que determinavam a conduta ofensiva - por outro foram os responsáveis pela primeira grande modificação na visão da funcionalidade da pena em correlação com o indivíduo que praticou o crime. Ainda assim, contudo, a visão era limitada.

Das doutrinas psicanalíticas e sociológicas seguintes ao positivismo, surgiram novos horizontes na busca de explicações para a criminalidade. No entanto, o paradigma punitivo continuou pautado em retribuição e prevenção, somente aprimorando os elementos caracterizadores do indivíduo, sem que fosse capaz de lhe dar um retorno efetivo de restauração.

3 Sobre a situação de marginalização desigual já no início do processo de expansão burguesa, cf. HOBSBAWM, Eric. A Era do Capital - 1848-1875. Rio de Janeiro: Paz e Terra, 1982. 
A crise de legitimidade dos paradigmas ${ }^{4}$ penais atuais culminou em reações diversas. Da ratificação do pensamento Law and Order como premissa de funcionamento do sistema penal em determinados países, a exemplo dos Estados Unidos da América ${ }^{5}$, à pretensão abolicionista de alguns autores, tem-se buscado as mais diversas formas de alternativas ao sistema atual, que se não são capazes de solucionar os problemas existentes, servem de comprovação da incapacidade da visão atual de política criminal e sistemática penal para promover modificações realmente eficazes.

Neste ínterim, propõe-se uma perspectiva distinta, amplificada, de pensamento voltado para a busca de soluções que demonstrem real capacidade na minoração e reparação de conflitos no seio social. Daí origina-se a propositura de um conceito mais desenvolvido e extenso de resultado eficaz para a sanção penal, com base em fundamentos de uma nova perspectiva da sanção.

${ }^{4}$ ZAFFARONI, Eugenio Raúl. Em busca das penas perdidas: a perda de legitimidade do sistema penal. Tradução: Vania Romano Pedrosa e Amir Lopez da Conceição. Rio de Janeiro: Revans, 1991.

5 Neste país, tornou-se comum a prática do "plea bargaining", uma negociação de antessalas, em que o Ministério Público oferta um benefício ao réu, desde que este se declare culpado. O objetivo é limitar a necessidade de comprovação, muitas vezes difícil, dos fatos aduzidos pela acusação e dar um retorno social de pretensa efetividade do Estado na persecução criminal. Nesse sentido, posiciona-se Selma Pereira de Santana: “O 'guilty plea' (confissão) constitui a forma de resolução da maioria dos casos, exatamente porque muitos dos infratores negociam as suas culpabilidades, implicando essa negociação na admissão de todos os elementos de prova do fato de que se é acusado, e na circunstância de que o Estado não se encontra diante da necessidade de provar que os infratores sejam culpados." SANTANA, Selma Pereira de. Justiça Restaurativa. A Reparação como consequência jurídico-penal autônoma do delito. Rio de Janeiro: Lumen Juris, 2010. p. 174. 


\section{Uma Visão sobre as Perspectivas Críticas do Sistema de Aplicação Penal: Funcionalismo e Labeling Approach na Análise da Eficácia Penal}

Na persecução do real sentido da aplicação penal, é preciso observar que há pontos de partida já bem estruturados em termos dogmáticos, que se apresentam como verdadeiras potências na construção da noção de eficácia. Dentre as mais diversas teorias, algumas possuem caráter notoriamente questionador dos parâmetros utilizados para a definição e aplicabilidade das penas - utilizam-se da política criminal, análise factual, portanto, como ângulo por meio do qual se busca definir um escopo à sistemática penal.

No viés criminológico, o Labeling Approach ${ }^{6}$ questionou a fundamentação e aplicação do sistema por meio de um viés prático. Partindo do plano real, a Teoria do Etiquetamento, como é conhecida, observa que o criminoso seria criado por meio do estigma - não pelo ato que pratica em si, mas pela pré-definição do comportamento do grupo a que pertence como um perigo social. Assim, defende-se que não há sequer busca de eficácia no sistema penal. O que ocorreria é a predefinição de quais cidadãos segregar e, a partir de então, a mácula a determinadas formas de expressão cultural padrões de tais grupos. A ação somente será vista como perigosa se e quando praticada por esses "pré-selecionados". Nos dizeres de Augusto Thompson":

Idênticas características, apresentadas como negativas ao se ligarem a um criminoso, ganharão sentido positivo se estiverem vinculadas a uma pessoa prestigiada pela ordem vigente.

6 Cf. BARATTA, Alessandro. Criminologia Crítica e Crítica do Direito Penal: introdução à sociologia do Direito Penal. Tradução de Juarez Cirino dos Santos. Rio de Janeiro: Revan, Instituto Carioca de Criminologia, 2002.

7 THOMPSON, Augusto. Quem são os criminosos? - O crime e o criminoso: entes políticos. 2. ed. Rio de Janeiro: Lúmen Júris, 2007. 
Eficiente como crítica ao sistema atual, o Labeling ainda parece insuficiente quanto à definição de soluções que confiram possibilidades de um maior êxito na aplicação das penas. Isso porque busca uma análise da fundamentação do sistema penal, não demonstrando uma real preocupação com seu fim. Concentrando-se na possível causa de muitas falhas na aplicação das penas, pouco se demora em analisar os momentos nos quais efetivamente a conduta é gravosa ao meio e se faz necessária a reprimenda. Desse modo, muito embora seja útil como ponto de partida, não é a resposta final à busca a que se destina a presente pesquisa.

Também questionando a sistemática penal, sua fundamentação e aplicabilidade, deparamo-nos com o funcionalismo. A partir de uma associação entre direito penal e política criminal, exsurgindo da escola alemã numa associação entre a perspectiva do direito relacionada e o viés sociológico, o funcionalismo busca uma espécie de adequação entre a sistemática penal e a realidade, com ênfase na finalidade jurídico-penal.

Numa síntese: o finalista pensa que a realidade é unívoca (primeiro engano), e que basta conhecê-la para resolver os problemas jurídicos (segundo engano - falácia naturalista); o funcionalismo admite serem várias as interpretações possíveis da realidade, de modo que o problema jurídico só pode ser resolvido através de considerações axiológicas, isto é, que digam respeito à eficácia e a legitimidade da atuação do direito penal. ${ }^{8}$

Trata-se de perspectiva também crítica, que confronta a visão meramente ontológica do finalismo vigente até então, buscando uma solução viável às falhas do sistema de penas e o real fundamento da punição, com um embasamento axiológico e pautado no plano de adequação à realidade. Não há sistema penal apenas teórico para o funcionalismo, de modo que a

${ }^{8}$ GRECO, Luis. Introdução à dogmática funcionalista do delito. Revista Jurídica, Porto Alegre, jul. 2002. p. 39. 
justificação do sistema também não poderia se dar apenas no plano lógico-jurídico. Consoante explana Vives Antón?:

De ese modo, el aseguramiento de expectativas por medio de normas, si bien puede ser descrito como definición de valores, no es más que un procedimiento de estabilización que puede fracasar. El sistema social y también el propio sistema jurídico han de poder dar una respuesta a ese fracaso. Cómo puede la dogmática jurídica (orientada en principio, al pasado) afrontar esa exigencia es un problema al que Luhmann ha dedicado importantes reflexiones. Pero, lo que importa destacar aquí es que la relación del sistema jurídico con su entorno comporta un reto para la dogmática conceptual, que atiente, para determinar el sentido de la norma al significado de las palabras. El sentido último de la norma vendrá, más bien, dado en última instancia por esa relación sistema-entorno, por naturaleza variable, y no podrá resolverse sino apelando a una racionalidad estratégica, consustancial a la idea de autopoiesis.

No plano crítico, também o funcionalismo serve de esteio à busca pela eficácia. Em verdade, a própria perspectiva de autores como Claus Roxin corrobora com o entendimento de que a visão (ao menos teleológica) de tal corrente objetiva de certo modo a estruturação de um direito penal mais voltado ao plano de efetivação das normas na realidade. ${ }^{10}$ Contudo, se neste estudo opta-se pela não adequação total aos parâmetros funcionalistas, explica-se a razão de ser - muito embora haja preocupação teórica em efetivar a norma penal, o funcionalismo volta-se a uma perspectiva mais atada à justificação do sistema que à sua aplicação. Ora, neste ponto, aproxima-se de tantas outras teses que não propõem uma solução, mas um fundamento.

9 VIVES ANTÓN, Tomás S. Fundamentos Del sistema penal. Acción Significativa y Derechos Constitucionales. 2. ed. Valencia: Tirant lo Blanch, 2011. p. 442.

${ }^{10}$ Nesse sentido, Roxin e Jackobs encontram-se em suas distintas perspectivas do funcionalismo. Mesmo que por vieses distintos, ambos os autores funcionalistas preocupam-se com a efetivação da norma no plano prático, realçando a certo modo a busca do funcionalismo por um direito eficaz. 
Cumpre, pois, buscar neste projeto não a resposta pronta, mas um esboço razoavelmente sólido do conceito de eficácia com base nos mais diversos fundamentos dogmáticos a que se teve acesso.

\section{Fundamentos x Finalidades: Variações Históricas nas Perspectivas do Punir}

A percepção de que os sistemas jurídicos possuem um comportamento anacrônico quanto à produção e aplicação de sanções não é recente. Apesar de o fenômeno global ter macrodimensionado a repercussão das falhas oriundas de reprimendas do poder Estatal diante das ofensas perpetradas por indivíduos em suas sociedades, já se poderia notar uma inclinação à crítica e sobreposição dos preceitos utilizados na forma de punir ${ }^{11}$ desde as variações iniciais dentro da Escola Clássica de pensamento penal, que foi precursora na análise crítica aos paradigmas punitivos.

Não é de se estranhar o caminhar continuado de confrontamentos. Ora, a "marcha moral" que vivencia o indivíduo, esta contínua, influencia na acepção individual e global de fatos-problema e na acepção da melhor maneira de desenredá-los em benefício comum. E se é verdade que moral e direito não se confundem, não se pode dizer que não se influenciem reciprocamente ${ }^{12}$.

${ }^{11}$ Sobre considerações críticas iniciais acerca do poder punitivo, cf. BECCARIA, Cesare Bonesana Marchesi di. Dos delitos e das penas. São Paulo: Revista dos Tribunais, 1999.

${ }^{12}$ Selma Santana, sobre a seleção e proteção de bens jurídicos na seara penal, afirma: “Desse princípio (subsidiariedade) decorre a conclusão sobre o papel do Direito Penal, no sentido de que ele pode, e deve, intervir para a proteção de bens jurídicos, e não para a tutela de normas morais ou de uma qualquer moral. Nessa acepção, tem-se do bem jurídico uma visão funcional que o identifica como unidade de aspectos 
As concepções dos indivíduos dentro de uma sociedade, embora permeadas por peculiaridades relacionadas aos grupos que a compõem, formam sensos comuns capazes de provocar modificações legislativas sensíveis.

Logicamente, havendo modificações culturais aceleradas, como as vivenciadas em plano hodierno, podemos notar um maior florescimento de consciências críticas distintas quanto ao sistema punitivo à medida que se tem maior comunicação de informações distintas sobre um mesmo tema.

Se, num plano inicial, na Escola Clássica, buscou-se a caracterização criminológica por meio de análise dos efeitos do crime, de forma ostensiva, portanto, no momento atual de choques culturais e distintos sistemas de funcionamento sociais, há uma ampliação do campo de análise quando se intenta verificar por que, para que e como punir, sob a perspectiva de análise intensiva, mediata e multidimensional ${ }^{13}$.

É perceptível a variação entre os vislumbres primordiais de questionamento penal e as noções a que se caminha atualmente. No entanto, advirta-se, o caminhar das percepções é cíclico, revolve acepções comuns de tempos em tempos, e baseia-se, via de regra, em caminhos alternativos saídos da mesma origem, maculados dos mesmos preceitos. ${ }^{14}$

ônticos e axiológicos, através da qual se exprime o interesse da pessoa ou da comunidade, na manutenção ou integridade de um certo estado, objeto ou bem em si mesmo socialmente relevante e por isso 'valioso'". SANTANA, Selma Pereira de. Justiça Restaurativa. A Reparação como consequência jurídico-penal autônoma do delito. Rio de Janeiro: Lumen Juris, 2010. p. 184, grifos insertos.

${ }^{13}$ GONÇALVES, Vanessa Chiari. Dilemas e Utopias quanto aos Fundamentos da Pena: Uma Reflexão a partir do Debate entre Carlos Santiago Nino e Eugenio Raul Zafaronni. Anais do XVII Congresso Nacional do CONPEDI. Brasília, 20, 21 e 22 de novembro de 2008. p. 3094.

${ }^{14}$ Sobre o tema, percepção interessante marcou os estudos para o embasamento teórico deste trabalho. Percebeu-se que a nova criminologia retoma e renova preceitos do viés liberal clássico dos estudos sobre o crime. Isso porque, a escola clássica deteve-se particularmente sobre o delito entendido como violação ao 


\subsection{Contratualistas Clássicos e Positivistas}

Dos primórdios contratualistas aos atuais paradigmas de justiça ainda afigura-se presente o imperativo sancionatório pautado em valores essencialmente relacionados à retribuição e ao exemplo, bem como à ratificação do poder estatal de reprimenda.

O castigo foi e ainda é uma espécie de "purificação" no ver comum, indispensável como meio de assegurar o retorno do sofrimento imputado pela ofensa e a criação do "bode expiatório" que reprimirá os desejos de potenciais ofensores pela ratificação do poder de supressão dos desvios de comportamento causadores de ofensas. Nos dizeres de Baratta ${ }^{15}$ :

De fato, a escola liberal clássica não considerava o delinquente como um ser diferente dos outros, não partia da hipótese de um rígido determinismo, sobre a base do qual a ciência tivesse por tarefa uma pesquisa etiológica sobre a criminalidade, e se detinha principalmente sobre o delito, entendido como conceito jurídico, isto é, como violação do direito e, também, daquele pacto social que estava, segundo a filosofia política do liberalismo clássico na base do Estado e do direito. Como comportamento, o delito surgia da livre vontade do indivíduo, não de causas patológicas, e por isso, do ponto de vista da liberdade e da responsabilidade moral pelas próprias ações, o delinquente não era diferente, segundo

direito - ou ao pacto social que lhe servia de base - entendendo que o direito penal e a pena tinham a função de instrumento de defesa da sociedade quanto ao crime, não de correcionalismo individual. O delito era encarado com um ente jurídico, não fático, porque se tratava de violação ao direito. Do mesmo modo, os ideais modernos de prevenção concebem a pena como instrumento de prevenção - seja geral ou especial - tendo uma visão mais elaborada dos mesmos preceitos-base já visualizados desde o Iluminismo pós-abolicionista, o direito penal como proteção à norma e ao sistema jurídico.

${ }^{15}$ BARATTA, Alessandro. Criminologia Crítica e Crítica do Direito Penal: introdução à sociologia do Direito Penal. Tradução de Juarez Cirino dos Santos. Rio de Janeiro: Revan, Instituto Carioca de Criminologia, 2002. p. 31. 
a Escola clássica, do indivíduo normal. Em consequência, o direito penal e a pena eram considerados pela Escola clássica não tanto como meio para intervir sobre o delinquente, modificando-o, mas sobretudo como instrumento legal para defender a sociedade do crime, criando, onde fosse necessário, um dissuasivo, ou seja, uma contramotivação em face do crime.

Essa ratificação é perceptível quando se analisa pontualmente alguns dos conceitos basilares correlacionados à finalidade da pena. Das primeiras abordagens analíticas aos fundamentos da sanção, partidas da Escola Clássica, temos a percepção de autores como Beccaria ${ }^{16}$ e Romagnosi ${ }^{17}$, para os quais o fim da pena seria a defesa social.

Tratava-se de um contraestímulo ao impulso criminoso, cuja existência asseguraria a coadunação de interesses distintos, uma ratificação do contrato social, desencorajando a conduta criminosa. Francesco Carrara ${ }^{18}$, por sua vez, corrobora com este entendimento, entendendo o delito como violação ao direito, ente jurídico, não fático.

Até este momento, não se verifica uma fundamentação claramente delineada do sistema punitivo. Muito embora se possa definir com clareza a finalidade da pena neste momento - a defesa social - a explicação sobre o porquê do crime, que tem vínculo lógico imprescindível à análise de porquê e como punir, é vaga e superficial ${ }^{19}$. O contratualismo clássico, por si só, não foi capaz de minorar os fatores de eclosão criminológica.

\footnotetext{
${ }^{16}$ BECCARIA, Cesare, Op. Cit.

${ }^{17}$ ROMAGNOSI, apud BARATTA, op. cit., p. 33-36.

${ }^{18}$ CARRARA, Francesco. Programa do Curso de Direito Criminal: Parte Geral. v. I. Tradução de José Luiz V. de A. Franceschini e J. R. Prestes Barra. São Paulo: Saraiva, 1956.

${ }^{19}$ BARATTA, Alessandro. Op. Cit, p. 38-39.
} 
Com um sistema punitivo que não controlava o boom criminógeno, mostrava-se inábil a simples observação do resultado final penal para a aplicação de penas eficazes. A eclosão do cientificismo do século XIX repercutiu no campo jurídico. E a Escola Positivista exsurge, propiciando o enfoque às causas da ofensa.

O método sancionatório utilizado para realizar o controle social na fase pré-moderna tinha total influencia eclesiástica. A principal pena utilizada era a de banimento e as execuções sumárias em praça pública. Com o advento da revolução burguesa e da centralização dos Estados na Europa o banimento tornou-se uma espécie de pena contraproducente, pois banidos começam paulatinamente a galgar de Estado Centralizado para estado e essa regulamentação vai ser um dos primeiros objetos de tratados após a paz de Westfália (1648). A pena privativa de liberdade tornou-se o modelo prioritário de controle social neste contexto. As execuções sumárias traziam muita revolta da população e o banimento acabava por gerar o incomodo de aparecer banidos de outros estados em território de terceiros. A sociedade necessitava de uma mudança nos seus padrões sociais. Métodos dedutivos Universais precisavam ser impostos ao controle social. A sociedade precisava se precaver da delinquência. Nesse momento médicos, psiquiatras, engenheiros, estatísticos começam a se ocupar de formular teorias para o controle social. Surge o braço do positivismo de influencia Comtiana, Sperciana, Darwiniana, no que tange o controle social: A escola criminológica positivista cujos principais representantes na segunda metade do século XIX foram, Ferri, Lombroso, e Garofalo. ${ }^{20}$

Não se estava, com isso, negando a função finalística de controle que os ideais clássicos atribuíam à pena, já que esta era pré-constituída ao crime e, portanto, fugiria, sob a perspectiva

${ }^{20}$ MAIA, Fábio Fernandes. A Dimensão Epistemológica do Discurso da Doutrina da Segurança Nacional no Contexto das Ditaduras da América Latina. Anais do XIX Encontro Nacional do CONPEDI. Fortaleza, 09, 10, 11 e 12 de junho de 2010. p. 5637-5638. 
positivista, do âmbito de estudos criminológicos ${ }^{21}$. Não obstante, a lente dos positivistas estava voltada com afinco às origens do problema.

Em sua busca, a Escola Positivista debruçou-se sobre a punição por meio da ótica científica etiológica, seja na análise de caracteres biofísicos, psíquicos ou sociológicos do ofensor. Se, por um lado, os vislumbres lombrosianos resultaram num temor posterior ao determinismo criminológico, por outro, a escola positivista foi essencial para a percepção do ofensor na análise da causa do crime e contribuiu, assim, para um novo viés na análise funcional da pena. ${ }^{22}$

A pena, de acordo com os positivistas, tinha como objetivo inicial a prevenção da sociedade contra o individuo "anormal" responsável pela violação dos valores sociais. Assim, o caráter preventista, ainda presente no direito penal hodierno, era uma característica básica do positivismo. Não bastava que o direito penal servisse como um instrumento retribuição do mal que o indivíduo fez à sociedade, mas que contribuísse para a não ocorrência de um delito futuro. A prevenção dos atos criminosos consistia justamente na análise dos fatores realmente determinantes para que o criminoso delinquisse. O sistema penal deveria atua com eficiência justamente na repressão destes fatores e conter previamente os impulsos dos indivíduos potencialmente criminosos para que a ordem orgânica não fosse abalada.

Apesar de abrir espaço para a discussão sobre a origem do fato ofensivo, conformando em conjunto com o ideal clássico uma teoria pautada na ideia de defesa social, cujos frutos se

\footnotetext{
${ }^{21}$ Sobre o tema: RIBEIRO, Homero Bezerra. A necessidade de Superação do Paradigma Criminológico Tradicional: A Criminologia Crítica como Alternativa à Ideologia da "Lei e Ordem". Anais do XIX Encontro nacional do CONPEDI. Fortaleza, 09, 10, 11 e 12 de junho de 2010. p. 956.

${ }^{22}$ Idem, p. 955-956.
} 
percebem até nas modernas teorias de estudo da sanção, as teorias deterministas pecavam pelo atavismo e também se demonstraram insuficientes para a resolução do conflito social criminoso.

Ao qualificar os indivíduos criminosos como "defeituosos" e concentrar as possíveis soluções numa tentativa de "conserto" bio-psicológico, como meio de tratamento da pretensa patologia criminógena, olvidou-se fatores de relevância notória à percepção do fato criminoso no plano real. O erro original da escola clássica repetiu-se neste plano, pois a premissa anterior, de pretensa igualdade de condições, manteve-se fiel, destoando apenas a busca pelos caracteres específicos do indivíduo ofensor, analisado isoladamente.

E tais falhas culminaram em novas buscas, agregando aos olhares anteriores elementos trazidos pela modificação de panorama vivenciada época a época.

\subsection{Teorias Psicanalíticas e Teorias Sociológicas}

Na senda de evolução dos estudos acerca do conflito, seguindo o curso das teorias que buscavam a funcionalidade da sanção, e sob influência da profusão de ciências pautadas no estudo das relações humanas - seja sob o viés intra ou intersubjetivo - aprofunda-se o movimento interdisciplinar que agrega outras áreas do conhecimento como fontes dogmáticas acerca da origem do sistema punitivo e da melhor forma de punir.

No decorrer das descobertas relacionadas ao mundo interior do indivíduo, capitaneadas pelos estudos de Freud ${ }^{23}$,

${ }^{23}$ Cf. FREUD, Sigmund. Totem And Taboo. Translated by James Strachey. London: Routledge and Kegan Paul, 1950. 
as teorias psicanalíticas do crime tiveram a atenção de diversos autores, dentre os quais Reik, Alexander e Staub. Tratam essencialmente do crime como um impulso incontido para o qual a pena exerce um efeito racionalizante ${ }^{24}$ - uma satisfação inconsciente da necessidade de punição que evita a prática do impulso criminoso - seja pela presença masoquista do id de cada indivíduo, que necessita da punição como instrumento de satisfação, seja pelo desejo coletivo de punição que satisfaz, também de forma neurótica, a repressão à identificação com o delinquente.

Juarez Cirino dos Santos ${ }^{25}$ descreve as teorias psicanalíticas da seguinte maneira:

As explicações psicanalíticas da agressividade humana apontam distúrbios no desenvolvimento da libido, com projeções destrutivas do instinto de morte, nas seguintes situações:

a) por falhas a identificação com o pai na experiência do Édipo, que continua como rival (e não modelo) objeto de agressão e protótipo de agressividade social;

b) por repressão excessiva da experiência edipiana, produzindo inconsciente sentimento de culpa e necessidade de punição para reduzir ou excluir o sentimento de culpa, com liberação de agressividade pela prática de crimes (o chamado criminoso por sentimento de culpa).

Não obstante a tentativa de compreensão do conflito interno individual que culminaria no crime, as teorias psicanalíticas continuaram devendo quanto à possibilidade concreta de uma noção global do crime. Tal visão requereria uma análise mais extensa, não voltada somente às labaredas interiores do ser

\footnotetext{
${ }^{24}$ BARATTA, Alessandro. Criminologia Crítica e Crítica do Direito Penal: introdução à sociologia do Direito Penal. Tradução de Juarez Cirino dos Santos. Rio de Janeiro: Revan, Instituto Carioca de Criminologia, 2002. p. 51.

${ }^{25}$ CIRINO DOS SANTOS, Juarez. Os Discursos Sobre Crime e Criminalidade. p. 13.

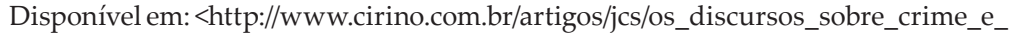
criminalidade.pdf $>$. Acesso em: 30 mar. 2013.
} 
humano, mas por meio de visualização da realidade de conjunto na qual o indivíduo se encontra inserido. Nesse sentido, mais uma vez se pronuncia Juarez Cirino dos Santos ${ }^{26}$ :

As explicações psicanalíticas podem ser importantes em casos individuais, mas são incapazes de explicar a criminalidade como fenômeno de massa, ou a criminalização como programa político nas sociedades de classes sociais antagônicas do capitalismo contemporâneo.

Na busca por uma visão geral do comportamento do indivíduo criminoso, sob a influência dos movimentos sociais classistas e de um adensamento dos estudos sociais, eclodem as teorias sociológicas da criminalidade, com bases originárias estabelecidas pelas obras de Durkheim ${ }^{27}$ e Merton ${ }^{28}$. Para estas teses, que seguiram caminhos voltados a diferentes aspectos mesmo se atrelando à base sociológica como cerne, 310 camadas sociais.

As desestruturas que culminam no crime, num viés sociológico, ensejam as mais distintas interpretações, que se sobrepõem compondo um esteio lógico para a quebra de paradigmas jurídico-penais diante da ineficácia da ideologia de defesa social.

A priori, Durkheim ${ }^{29}$ entende que o desvio é fato comum a toda estrutura, mas seu crescimento exponencial denotaria a disfunção no convívio dos indivíduos naquela sociedade. A

${ }^{26}$ CIRINO DOS SANTOS, Juarez. Op. Cit. p. 13.

${ }^{27}$ Cf. DURKHEIM, Émile. As regras do método sociológico. 3. ed. Trad. Paulo Neves. São Paulo: Martins Fontes, 2007.

${ }^{28}$ Cf. MERTON, Robert K. Social theory and social structure. New York: The Free Press, 1968.

${ }^{29}$ DURKHEIM, Émile. O suicídio: estudo de sociologia. Tradução de Monica Stahel. São Paulo: Martins Fontes, 2000. p. 472-473, grifos aditados. 
disfunção decorre não da superexpansão do conflito, mas de sua capacidade de demonstrar que o sistema de contenção em voga já não é capaz de resolvê-lo e ainda não vigora outro sistema capaz de resolver a expansão de lesões - uma anacronia clássica. É este o modelo que apresenta:

Ora, não há sociedade conhecida em que, sob formas diferentes, não se observe uma criminalidade mais ou menos desenvolvida. Não há povo cuja moral não seja cotidianamente violada. Devemos dizer, portanto, que o crime é necessário, que ele não pode deixar de existir, que as condições fundamentais da organização social, tais como são conhecidas, o implicam logicamente. Por conseguinte, ele é normal. É inútil invocar aqui as imperfeições inevitáveis da natureza humana e sustentar que o mal, embora não possa ser impedido, não deixa de ser o mal; isso é linguagem de pregador, não de cientista. Uma imperfeição necessária não é doença; caso contrário, deveríamos colocar doença em toda parte, porque a imperfeição existe em toda parte. [...] O que é condição indispensável da vida não pode deixar de ser útil, a menos que a vida não seja útil. Não há como escapar disso. [...] Contudo ele só é útil se reprovado e reprimido. Acreditou-se erroneamente que o simples fato de o catalogar entre os fenômenos de sociologia normal implicaria sua absolvição. Se é normal que haja crimes, é normal que sejam punidos. A penalidade e o crime são os dois termos de um par inseparável. Um não pode faltar mais do que o outro. Qualquer afrouxamento anormal do sistema repressivo tem por efeito estimular a criminalidade e the conferir um grau de intensidade anormal.

Robert Merton aprofunda os estudos de Durkheim e chega a compreensões que serviram de base a uma grande revolução do pensamento criminológico. Da análise cultural associada aos fatores econômicos, observa que a discrepância entre os valores propostos e os meios de alcance destas finalidades enseja o surgimento de vias alternativas de acesso. Nos dizeres do autor:

[...] it appears from our analysis that the greatest pressures toward deviation are exerted upon the lower strata. Cases in point permit us to detect the sociological mechanisms 
involved in producing these pressures. Several researches have shown that specialized areas of vice and crime constitute a "normal" response to a situation where the cultural emphasis upon pecuniary success has been absorbed, but where there is little access to conventional and legitimate means for becoming successful. The occupational opportunities of people in these areas are largely confined to manual labor and the lesser white-collar jobs. Given the American stigmatization of manual labor which has been found to hold rather uniformly in all social classes, and the absence of realistic opportunities for advancement beyond this level, the result is a marked tendency toward deviant behavior. ${ }^{30}$

Não obstante o grande avanço em termos de percepção global da criminalidade, num esboço capaz de captar as disfunções entre cultura e meios de acesso como fundamentos de determinados crimes, a teoria funcionalista, capitaneada por Durkheim e desenvolvida por Merton, manteve em aberto os questionamentos relativos à criminalidade de colarinho branco e demonstrou-se incapaz de observar as cifras negras do sistema.

Partindo de um posicionamento crítico destas lacunas, aprofunda-se um estudo funcionalista mais compatível com os problemas da moderna sistemática penal, culminando numa

\footnotetext{
30 "[...] parece, pela nossa análise, que as maiores pressões no sentido do desvio são exercidas sobre as camadas inferiores. Casos em questão nos permitem detectar os mecanismos sociológicos envolvidos na produção destas pressões. Várias pesquisas têm mostrado que áreas especializadas de conduta imoral e crime constituem uma resposta "normal" para uma situação onde a ênfase cultural no sucesso pecuniário foi absorvida, mas onde há pouco acesso aos meios convencionais e legítimos para tornar-se bem sucedido. As oportunidades ocupacionais das pessoas nestas áreas estão em grande parte confinadas ao trabalho manual e aos empregos inferiores de colarinho branco. Dadas a estigmatização americana do trabalho manual, que tem sido vista como permanecendo disseminada antes uniformemente em todas as classes sociais, e a ausência de oportunidades realistas para o progresso além deste nível, o resultado é uma tendência manifesta no sentido do comportamento desviante." MERTON, Robert K. Social theory and social structure. New York: The Free Press, 1968. p. 198-199. Tradução livre.
} 
verdadeira ruptura do conceito de eficácia da pena diante do surgimento de um novo paradigma punitivo.

Isso porque, com o aprofundamento de estudos sociológicos, ascende-se à noção de subculturas - os espaços de legitimação inseridos em microestruturas sociais, nos quais as finalidades são similares, mas os meios de alcance ao fim estabelecido culturalmente são baseados em legitimações internas, certas vezes em conflito com a macrolegitimação.

A teoria das subculturas abre espaço para a discussão sobre o pluralismo diante de teses de penalização que presumem haver consenso de valores. Nem mesmo numa comunidade específica poder-se-ia falar, observando as subculturas, num imperativo moral, tampouco num estudo global de referenciais penais. Desse modo, há uma deslegitimação do discurso de que a codificação penal refletiria valores sociais consensuais.

A demonstração factual dessa deslegitimação teve por ápice o surgimento de uma nova perspectiva denominada labeling approach. O modelo denominado Teoria do Etiquetamento inverte os conceitos de fundamento e finalidade da sanção. A partir da perspectiva do etiquetamento, não é o desvio em si que faz ser necessária uma norma caracterizadora da conduta ilícita e, a seguir, incide na necessidade da sanção como forma de reprimenda. Antes pelo contrário - pautada numa necessidade de manutenção do status quo estratificado, a norma é que torna o comportamento ilícito, e a sanção é meio de corroborar com o rechaço social à conduta - a marginalização, portanto, acontece de fora para dentro dos microssistemas.

Desse modo, é o poder que determina o objeto e a finalidade da sanção, não o intento de prevenção da criminalidade ou proteção do bem jurídico. Trata-se de um sistema formalmente forjado para manutenção do status quo estrutural. O impacto desta percepção é absurdo. Se já havia questionamentos quanto 
à ineficiência dos sistemas paradigmáticos, a noção de um ciclo de cancelas $^{31}$ torna ainda mais gravosos os questionamentos quanto à urgência de se aprimorar a sanção de forma efetivamente capaz de cumprir suas finalidades teóricas.

A crise paradigmática amplia-se com tal percepção, pois além de visivelmente falho quanto aos crimes de poder, ostensivos na modernidade, o sistema demonstra-se vinculado à ineficácia como meio de sobrevida das estruturas sociais de acordo com os parâmetros atuais. O questionamento da eficiência da pena eclode como pedra fundamental da construção de sanções modernas. Não se trata, aqui, de buscar a eliminação do fato criminógeno nas sociedades, mas da busca de uma solução tão eficaz quanto seja possível. Nos dizeres de Durkheim ${ }^{32}$ :

[...] se o crime é uma doença, a pena é seu remédio e não pode ser concebida de outro modo; assim, todas as discussões que ela suscita tem por objeto saber o que ela deve ser para cumprir seu papel de remédio. Mas, se o crime nada tem de mórbido, a pena não poderia ter por objeto curá-lo e sua verdadeira função deve ser buscada em outra parte.

Havendo um delineamento da crise de legitimidade ${ }^{33}$, surge espaço para o questionamento frontal quanto ao próprio

\footnotetext{
${ }^{31}$ Perceba-se que a sistemática penal, nos moldes atuais, atua como cancela a determinadas classes, impedindo a coadunação de culturas distintas que ameacem as relações de poderio. O labeling approach explica também a relutância quase inconsciente da criminologia em aprofundar os estudos face aos crimes de colarinho branco e de empresas - o sistema não foi pensado para lidar com a criminalidade de poder.

32 DURKHEIM, Émile. As regras do método sociológico. Tradução de Paulo Neves. 3. ed. São Paulo: Martins Fontes, 2007. p. 73.

${ }^{33}$ Sobre o tema, explica Zaffaroni que apesar de formalmente vigentes, pautadas num dever jurídico, as sanções penais não possuem o condão realístico que as legitimaria. A existência do dever-ser não seria um escopo suficientemente forte para legitimar um sistema que se demonstra aplicado seletiva e esporadicamente e os próprios fundamentos - de repressão e disciplina vertical. Desse modo, há uma verdadeira crise de legitimidade do sistema penal. ZAFFARONI, Eugenio Raul.
} 
conceito de eficiência das sanções. Indispensável à caracterização da base teórica de punições e à própria execução das penas, a busca pelo resultado eficaz da sanção, mais do que necessária, é imprescindível ao paradigma que pretende se firmar em detrimento do anterior, notoriamente falido.

\section{A Preocupação com a Eficiência da Sanção à Luz do Pensamento Jurídico Moderno}

A insuficiência ${ }^{34}$ dos parâmetros atuais para sanar de forma eficaz os conflitos advindos da expansão delitiva pós-globalização é cristalina. Essencialmente baseado em ideais revanchistas $^{35}$ e fundado no ideal clássico de crime, o sistema punitivo convive agora com novos protagonistas no delito e novos objetos de lesão, necessitando da revisão ${ }^{36}$ de seus conceitos como via de revitalização.

O enunciado da fundamentação ${ }^{37}$ da sanção, carente de solidez, é frontalmente açoitado pela moderna concepção de seu serviço à manutenção estrutural ${ }^{38}$, que denota a absoluta

Em busca das penas perdidas: a perda de legitimidade do sistema penal. Tradução: Vania Romano Pedrosa e Amir Lopez da Conceição. Rio de Janeiro: Revans, 1991. p. 107.

${ }^{34}$ ZAFFARONI, Eugenio Raúl. Op. Cit., p. 15. "Neste estudo, o sentido de 'crise' refere-se a uma brusca aceleração do descrédito do discurso jurídico-penal."

${ }^{35}$ SICA, Leonardo. Justiça Restaurativa e Mediação Penal. O novo modelo de Justiça Criminal e de Gestão do Crime. Rio de Janeiro: Lumen Juris, 2007. p. 66.

${ }^{36}$ Sobre a revisão de paradigmas por meio do rompimento com conceitos anteriores e releituras de elementares, um dos cernes deste projeto, cf. KUHN, Thomas S. A estrutura das revoluções científicas. Tradução de Beatriz Viana Boeira e Nelson Boeira. 5. ed. São Paulo: Perspectiva, 1998.

${ }^{37}$ Cf. ZAFFARONI, Eugenio Raúl. Em busca das penas perdidas: a perda de legitimidade do sistema penal. Tradução: Vania Romano Pedrosa e Amir Lopez da Conceição. Rio de Janeiro: Revans, 1991.

${ }^{38}$ Nesse sentido, COPETTI, André. Direito Penal e Estado Democrático de Direito. Porto Alegre: Livraria do Advogado, 2000. p. 91-105. 
disfunção quanto ao pretenso intento de reinserção do ofensor e, bem assim, de ratificação da disciplina individual face à sociedade (representada pelo poder estatal).

Ao mesmo tempo, também aquele paradigma revanchista da finalidade da sanção, seja de defesa ou prevenção, como fim e embasamento da resolução conflitual demonstrou-se incapaz de lidar de forma eficaz com a criminalidade em expansão. ${ }^{39} \mathrm{~A}$ mudança de perspectiva quanto à criminalidade, com o surgimento de novas figuras delitivas, requereu uma sistemática moderna mais resolutiva que teórica, sob pena de absoluta insatisfação das pretensões penais. Nos dizeres de Jesús María Silva Sánchez ${ }^{40}$ :

Isso significa que a reflexão jurídico-penal tem pela primeira vez como objeto essencial de estudo delitos claramente diversos do paradigma clássico (o homicídio ou a delinquência patrimonial tradicional). Trata-se de delitos qualificados criminologicamente como crimes of the powerful; de delitos que têm uma regulação legal insuficientemente assentada; e de delitos cuja dogmática se acha parcialmente pendente de elaboração. E tudo isso há de redundar em uma configuração dos mesmos sobre bases significativamente diversas daquelas do Direito Penal clássico (da delinquência passional ou dos crimes of the powerless).

Os fundamentos jurídico-penais correntes, essencialmente baseados na sanção imediata como finalidade precípua ${ }^{41}$,

\footnotetext{
${ }^{39}$ SANTANA, Selma Pereira de. Justiça Restaurativa. A Reparação como consequência jurídico-penal autônoma do delito. Rio de Janeiro: Lumen Juris, 2010. p. 5.

${ }^{40}$ SILVA SÁNCHEZ, Jesús María. A expansão do Direito Penal. Aspectos da política criminal nas sociedades pós-industriais. Tradução de Luiz Otavio de Oliveira Rocha. São Paulo: Revista dos Tribunais, 2002. p. 99.

${ }^{41}$ Nesse sentido, Guadalupe Sanzberro afirma que "a concentração do discurso penal no aspecto punitivo tem atingido como consequência que - expressado simbolicamente - a atenção às 'árvores' (as penas) não permite ver 'o bosque' (o sistema penal em sua complexidade) [...]". SANZBERRO, Guadalupe Pérez. Reparación y conciliación en el sistema penal. ¿Apertura de una nueva vía? Granada: Comares, 1999. p. 338.
} 
não acometem as outras possibilidades de alcance do sistema penal, que poderia atuar não somente na sanção, mas também na formação do preceito ${ }^{42}$ jurídico aplicável a médio e longo prazo.

Esta atuação, mais que uma pretensão idílica, é uma necessidade para a quebra do ciclo vicioso "ofensa-punição-reincidência-punição..." que não somente não cumpre seu micropotencial - reforma da conduta do ofensor e resposta social - mas também olvida em absoluto da necessidade de retorno à vítima.

Em conjunto com as disfunções de fundamentação e finalidade, a aplicabilidade das sanções é altamente questionada, quando percebe-se que têm efeito nulo ou, pior, negativo sobre o indivíduo e o seio social em que este se encontra. Não se está a discutir somente a necessidade de modificação cultural, mas a ineficácia do próprio sistema processual penal atual. É necessária, mais do que a simples modificação instrumental, a modificação do conceito de eficácia da sanção. Sobre a percepção desta falha, Selma Pereira de Santana ${ }^{43}$ aduz:

Sabe-se que ultimamente diversos ordenamentos jurídicos têm introduzido formas de simplificação e de diversificação nas reformas das suas legislações processuais penais, em razão da verificação da perda de eficiência desse setor. Paradoxalmente, contudo, permanece pouco tratada a relevante questão de apurar se essas formas de diversão seriam compatíveis com a necessidade de garantia.

A busca primordial do sistema jurídico-penal não pode se confundir com a pena ou mesmo com a prevenção - muito além disso, é mister que se analise o intento de efetivação da finalidade estatal, constitucionalmente designada, em âmbito

\footnotetext{
${ }^{42}$ EUSEBI apud SICA, Leonardo. Justiça Restaurativa e Mediação Penal. O novo modelo de Justiça Criminal e de Gestão do Crime. Rio de Janeiro: Lumen Juris, 2007. p. 128.

${ }^{43}$ SANTANA, Selma Pereira de. Justiça Restaurativa. A Reparação como consequência jurídico-penal autônoma do delito. Rio de Janeiro: Lumen Juris, 2010. p. 138.
} 
ainda mais aprofundado, da integração dos entes cerne do conflito ("paz jurídica"44), da reparação do dano e da efetivação das garantias constitucionais.

\subsection{Das Teorias à Prática: Funcionalidade e o Resultado Eficaz}

Percebidas as disfunções quanto à aplicação da sistemática penal, que culminam na deslegitimação de seus meios e na insuficiência de suas proposições, cumpre tentar um esboço do que poderia ser, em tempos hodiernos, o resultado eficaz da sistemática em estudo. Para tanto, é indispensável a observação de conceitos alavancados por estudiosos do tema. Nos dizeres de Paulo Queiroz ${ }^{45}$ :

A missão do direito penal é a missão de todo o direito: possibilitar a vivência social, assegurar níveis minimamente toleráveis de violência, resolver, enfim, conflitos de interesses de modo pacífico, segundo normas e processo previamente conhecidos. Não obstante seja esta a sua missão, de cujos demais ramos somente se distingue pelo maior rigor das sanções que adota para fazer em face dos comportamentos declarados criminosos, o direito penal, porque preso ainda, fortemente, à idéia de retribuição, responde aos conflitos de forma sensivelmente menos racional que os demais ramos. Não sem razão, tem se afirmado que a justiça criminal "decide" conflitos, mas não os "resolve".

O estudo isolado de uma única vertente de observação da estruturação penal demonstra-se, via de regra, incapaz de habilitar uma ou outra ciência em separado à percepção adensada de soluções eficazes face ao crime. A própria observação do caminhar de estudos sobre o tema demonstra a soma

\footnotetext{
${ }^{44}$ BAUMANN apud SICA, Leonardo. Justiça Restaurativa e Mediação Penal. O novo modelo de Justiça Criminal e de Gestão do Crime. Rio de Janeiro: Lumen Juris, 2007.

${ }^{45}$ QUEIROZ, Paulo de Souza. Para além da filosofia do castigo. Disponível em: <http:// pauloqueiroz.net/para-alem-da-filosofia-do-castigo/>. Acesso em: 3 abr. 2013.
} 
de percepções científicas distintas como trajeto evolutivo do pensamento sistemático penal.

Numa busca de correlações dogmáticas, traz-se à tona a conceituação de Robert Alexy ${ }^{46}$ e Andre Copetti ${ }^{47}$, para os quais a sistemática penal é uma esfera de efetivação de garantias fundamentais. Tal acepção é uma das muitas elementares de compreensão do que seria e eficácia de resultado da sanção.

Entende-se, neste estudo, que é imprescindível que se tornem efetivas as possibilidades normativas e políticas que possui o Direito Penal, em seu âmbito de atuação, para a instrumentalização de garantias fundamentais. Aqui, abre-se espaço especialmente para a efetivação de dois preceitos máximos que norteiam o processo enquanto instrumento de resposta social - a dignidade da pessoa humana e o acesso à justiça. É dizer, propõe-se que o direito seja, de fato, um instrumento útil para a qualificação da vida humana em sociedade.

Trata-se de uma modificação conceitual que encontra vozes reverberantes na doutrina moderna. Claus Roxin ${ }^{48}$ afirma que "[...] o estabelecimento da paz jurídica é o único que legitima a pena". Pautado nos preceitos de legalidade e dignidade da pessoa humana ${ }^{49}$, estende-se também tal acepção à efetivação da potencialidade da sanção de garantir ao indivíduo a utilidade de um processo penal, muito além da simples formalização procedimental que culmina numa restrição.

${ }^{46}$ Para Robert Alexy, a tutela penal configura-se um direito prestacional. Cf. ALEXY, Robert. Teoria dos Direitos Fundamentais. Tradução de Virgílio Afonso da Silva. 5. ed. São Paulo: Malheiros, 2008. p. 450-470.

${ }^{47}$ COPETTI, André. Direito Penal e Estado Democrático de Direito. Porto Alegre: Livraria do Advogado, 2000. p. 90.

${ }^{48}$ ROXIN, Claus. Problemas Fundamentais de Direito Penal. Tradução de Ana Paula dos Santos e Luis Natscheradetz. Lisboa: Veja, 1993. p. 32.

${ }^{49}$ SICA, Leonardo. Justiça Restaurativa e Mediação Penal. O novo modelo de Justiça Criminal e de Gestão do Crime. Rio de Janeiro: Lumen Juris, 2007. p. 162. 
Ora, uma restrição disfuncional, ainda que aplicada e cumprida por inteiro, não repara, minora os danos, restaura ou ressocializa. É absolutamente disfuncional, portanto. E aqui verifica-se uma complementaridade indispensável - somente é correto conceber o pleno acesso à justiça se, muito além do processo formalizado, há um resultado que modifique a estrutura lesada.

Tal modificação não pode significar - e isso se percebe de mera cognição empírica - apenas o resultado sancionatório, quando este é incapaz de trazer à vítima uma restauração ou minoração plena da lesão, ao ofensor a revisão conceitual sobre seu ato lesivo e potencialidade de reinserção aprimorada no seio social e ao Estado a maior garantia possível do refrear de lesões repetitivas.

\section{3.2 A Eficácia do Resultado Penal como Soma de Valores}

Numa análise breve da correlação entre a história do pensamento penal e as distintas visões da funcionalidade da punição, pode-se observar que da escola clássica às modernas concepções do labeling approach, a soma de diferentes acepções científicas ${ }^{50}$ tem-se demonstrado o caminho idôneo à resolução mais vasta e efetiva do conflito.

A sociologia jurídico-criminal, a criminologia, a dogmática penal, a política criminal e o direito processual penal caminham, ao que parece, em paralelo, mas de mãos dadas ${ }^{51}$. E a linha que une as diferentes perspectivas de estudos é a

\footnotetext{
${ }^{50}$ BARATTA, Alessandro. Criminologia Crítica e Crítica do Direito Penal: introdução à sociologia do Direito Penal. Tradução de Juarez Cirino dos Santos. Rio de Janeiro: Revan, Instituto Carioca de Criminologia, 2002. p. 219.

${ }^{51}$ FERNANDES, Fernando. O Processo Penal como Instrumento de Política Criminal. Coimbra: Almedina, 2007.
} 
busca por uma sistemática mais eficaz de penalização. É nesta soma de instrumentos em busca de uma melhor aplicação da pena que se verifica a atual noção de acesso à justiça na prática penal. $\mathrm{O}$ resultado eficaz, instrumentalizado pela soma dos meios mais assertivos de alcance de um objetivo reparatório na sanção.

Muito embora não se possa afirmar que já há um panorama bem estruturado capaz de noticiar com precisão qual a noção prática de pena eficaz, se é que se poderá algum dia falar em precisa da subjetiva ciência da punição, neste estudo se entende possível compreender e delinear em caráter de esboço uma noção de eficácia para a sanção, como lume na busca de práticas e procedimentos que alcancem um resultado satisfatório na aplicação da sanção.

Diz-se eficácia, neste estudo, da capacidade multifacetada que tem a política criminal adotada por um sistema penal de reparar danos, minorar efeitos e evitar a renovação da prática ofensiva no seio social. Trata-se da potencialidade de harmonização do núcleo atingido pela ofensa, se não em busca de um status quo ante dificilmente alcançável, ao menos a um estado de conformação entre a medida adotada e reparação das dimensões afetadas, não somente no viés formalista da proporcionalidade gravosa.

Esta reparação de dimensões lesadas pelo ato ofensivo perpassa distintos aspectos - a atenuação dos efeitos lesivos à vítima; a renovação de confiança social na segurança que o Estado busca proporcionar quanto à diminuição de conflitos; a tentativa de conscientização e "reforma" de potencialidades do ofensor. Não se está a afirmar a possibilidade de reforma da personalidade, eivada de peculiaridades explicáveis somente em âmbito supramaterial. Contudo, acredita-se na possibilidade de, em muitos casos, revigorar na vítima e no agressor, ambos relacionados à lesão criminal, seu potencial construtivo. 
O resultado eficaz seria, portanto, uma soma de potencialidades da sanção, num aspecto muito mais positivo e abrangente que a simples repressão da conduta danosa e da perpetuação da reprimenda social. Ora, se é possível observar no ofensor a capacidade de reconhecer seu erro, a razão de ser da sanção pode ir muito além de simples afastamento da sociedade e supressão temporária do potencial agressivo do indivíduo.

É certo que haverá uma inicial resistência à observação da pena com um viés positivo. De suas origens de clausura e expiação, a sanção herdou a imagem de penitência devida por qualquer um que extrapolar sua liberdade e originar uma lesão ao bem jurídico alheio. Contudo, o resultado eficaz não se limita à exploração do potencial positivo de modificação do indivíduo ofensor. A acepção de resultado eficaz aqui buscada envolve uma soma de fatores.

A reparação do dano, ou minoração de seus efeitos, que se estende para além da noção material de reparação, mas pode englobar a responsabilidade pelo quantum lesivo; a análise da ótica da vítima no processo sancionatório, que envolve muito além do que a simples condenação do ofensor; a busca pela maior proximidade possível com o status quo ante - o ofensor e a vítima aproximando-se da qualidade de indivíduos normais; a possibilidade de qualificação do ofensor para melhorar a comunidade na qual gerou o dano, sempre que possível reinseri-lo.

Por oportuno, deve-se ressaltar que nem toda espécie de crime ou de criminoso alcançará a eficácia plena dos moldes penais positivos a que se intenta neste trabalho. Para casos específicos, é necessária uma moldagem específica. A saber, o psicopata clinicamente identificado não pode ser enquadrado 
em mesma sanção do indivíduo consciencioso ${ }^{52}$. O sexualmente disfuncional não pode ser submetido ao mesmo tratamento daquele capaz de refrear seus impulsos. A eficácia da sanção tem por pressuposto a especificidade do tratamento dado à qualidade do ofensor e à necessidade da vítima.

Defende-se, portanto, uma nova moldagem de sanções que agregue em si as diversas percepções galgadas no decorrer dos estudos do crime, nas mais diversas ciências, de um modo sistemático, que permita uma normatização capaz de dar à sociedade um retorno não somente formal de penalização, mas efetivamente capaz de promover a resolução conflitual que originou a problemática vigente.

Não haveria, a priori, um molde de sanção eficaz a todo e qualquer crime. Ora, se a proposição de um resultado eficaz envolve a busca pela reparação efetiva e ampla, multidimensional, dos efeitos da ofensa, não se poderia estabelecer, ao menos de início, uma fórmula penal indistinta que abarcasse a profusão de crimes da modernidade. Mas as bases para o traçado preciso da sanção agrupada pelo potencial de dano causado, pela natureza da ofensa e do ofensor, estes sim podem e devem ser observados na construção de um novo modelo penal.

${ }^{52}$ Sobre o tema, cf. CAVALHEIRO, Bárbara Lazzari. A (in)eficácia da sanção penal aplicada ao deliquente psicopata no ordenamento jurídico brasileiro. Monografia apresentada à UNIJUÍ - Universidade Regional do Noroeste do Estado do Rio Grande do Sul, 2012. 


\section{Considerações Finais}

Diante da pesquisa elaborada e dos argumentos trazidos à tela, pode-se concluir que:

a) No decorrer histórico, tanto fundamentação quanto funcionalidades da pena demonstraram-se conceitos fluidos, questionados e complementados pelas mais diversas ciências circundantes, num ciclo de expansão ou retração influenciado pelo momento sociopolítico do Estado;

b) não obstante a constante modificação de visões acerca do direito de punir, os ideais retribucionistas continuaram a permear a visão sistemática penal até as mais modernas teorias;

c) num panorama de modificações sociais densas e surgimento de novos conflitos aos quais não houve resposta eficaz, inicia-se um movimento de questionamento da própria legitimidade do sistema penal, em função da incapacidade da sanção de cumprir os objetivos a que se propôs;

d) com a inversão da percepção das origens do crime e da fundamentação das penas, iniciada pelos movimentos finalísticos e aprofundada pela acepção do labeling approach, a legitimidade já questionada demonstra-se mais formal que material, exigindo-se um novo paradigma de justiça;

e) diante da eclosão de novos paradigmas punitivos, faz-se necessário questionar qual a real fundamentação e finalidade da pena; 
f) o resultado eficaz pelo qual se clama é não somente um elemento, mas uma soma multidimensional de fatores, que compreendem desde a reparação e minoração dos efeitos da lesão à vítima, à reinstrumentalização de potencialidades positivas do ofensor, quando possível, e sua resposta à sociedade na qual se originou o conflito;

g) sendo o resultado eficaz esta soma, não se pode conformar uma fórmula una de sanção aplicável a todo e qualquer crime, é necessário que se utilize o delineamento da eficácia para encontrar uma sistemática por meio do agrupamento das ofensas de acordo com suas características próprias, e as características do agressor.

\section{Referências}

ALEXY, Robert. Teoria dos Direitos Fundamentais. Tradução de Virgílio Afonso da Silva. 5. ed. São Paulo: Malheiros, 2008.

BARATTA, Alessandro. Criminologia Crítica e Crítica do Direito Penal: introdução à sociologia do Direito Penal. Tradução de Juarez Cirino dos Santos. Rio de Janeiro: Revan, Instituto Carioca de Criminologia, 2002.

BECCARIA, Cesare Bonesana Marchesi di. Dos delitos e das penas. São Paulo: Revista dos Tribunais, 1999.

CAPPELLETTI, Mauro. Processo, ideologias e sociedade. Tradução de Elicio de Cresci Sobrinho. Porto Alegre: S. A. Fabris, 2008.

CAPPELLETTI, Mauro; GARTH, Bryant. Acesso à justiça. Tradução de Ellen Gracie Northfleet. Porto Alegre: Fabris, 1988.

CARRARA, Francesco. Programa do Curso de Direito Criminal: Parte Geral. v. I. Tradução de José Luiz V. de A. Franceschini e J. R. Prestes Barra. São Paulo: Saraiva, 1956. 
O Conceito de Eficácia como Fundamento...

CAVALHEIRO, Bárbara Lazzari. A (in)eficácia da sanção penal aplicada ao deliquente psicopata no ordenamento jurídico brasileiro. Monografia apresentada à UNIJUÍ - Universidade Regional do Noroeste do Estado do Rio Grande do Sul, 2012.

CIRINO DOS SANTOS, Juarez. Os Discursos Sobre Crime e Criminalidade. Disponível em: <http://www.cirino.com.br/artigos/jcs/os_discursos_sobre_crime_e_criminalidade.pdf $>$. Acesso em: 30 mar. 2013.

COPETTI, André. Direito Penal e Estado Democrático de Direito. Porto Alegre: Livraria do Advogado, 2000.

DURKHEIM, Émile. As regras do método sociológico. Tradução de Paulo Neves. 3. ed. São Paulo: Martins Fontes, 2007.

. O suicídio: estudo de sociologia. Tradução de Monica Stahel. São Paulo: Martins Fontes, 2000.

FERNANDES, Fernando. O Processo Penal como Instrumento de Política Criminal. Coimbra: Almedina, 2007.

FREUD, Sigmund. Totem And Taboo. Translated by James Strachey. London: Routledge and Kegan Paul, 1950.

GOMES, Roberto. Violência e crime - O vértice da Psicanálise. Trabalho apresentado no Congresso Internacional de Criminologia da PUC-RS, em 13/04/2000. CIVITAS - Revista de Ciências Sociais, ano 1, n. 2, p. 67-78, dez. 2001; Revista de Psicanálise da Sociedade Psicanalítica de Porto Alegre, v. 8, n. 3, p. 549-560, dez. 2001.

GONÇALVES, Vanessa Chiari. Dilemas e Utopias quanto aos Fundamentos da Pena: Uma Reflexão a partir do Debate entre Carlos Santiago Nino e Eugenio Raul Zafaronni. Anais do XVII Congresso Nacional do CONPEDI. Brasília, 20, 21 e 22 de novembro de 2008. p. 3093-3108.

GRECO, Luis. Introdução à dogmática funcionalista do delito. Revista Jurídica, Porto Alegre, p. 35-63, jul. 2002.

HOBSBAWM, Eric. A Era do Capital - 1848-1875. Rio de Janeiro: Paz e Terra, 1982.

KUHN, Thomas S. A estrutura das revoluções científicas. Tradução de Beatriz Viana Boeira e Nelson Boeira. 5. ed. São Paulo: Perspectiva, 1998. 
MAIA, Fábio Fernandes. A Dimensão Epistemológica do Discurso da Doutrina da Segurança Nacional no Contexto das Ditaduras da América Latina. Anais do XIX Encontro Nacional do CONPEDI. Fortaleza, 09, 10, 11 e 12 de junho de 2010. p. 5635-5646.

MARINONI, Luiz Guilherme. Teoria geral do processo. 4. ed., rev. e atual. São Paulo: Revista dos Tribunais, 2010.

MERTON, Robert K. Social theory and social structure. New York: The Free Press, 1968.

QUEIROZ, Paulo de Souza. Para além da filosofia do castigo. Disponível em: <http://pauloqueiroz.net/para-alem-da-filosofia-do-castigo/>. Acesso em: 3 abr. 2013.

RIBEIRO, Homero Bezerra. A necessidade de Superação do Paradigma Criminológico Tradicional: A Criminologia Crítica como Alternativa à Ideologia da "Lei e Ordem". Anais do XIX Encontro nacional do CONPEDI. Fortaleza, 09, 10, 11 e 12 de junho de 2010. p. 951-979.

ROXIN, Claus. Problemas Fundamentais de Direito Penal. Tradução de Ana Paula dos Santos e Luis Natscheradetz. Lisboa: Veja, 1993.

SANTANA, Selma Pereira de. Justiça Restaurativa. A Reparação como consequência jurídico-penal autônoma do delito. Rio de Janeiro: Lumen Juris, 2010.

SANZBERRO, Guadalupe Pérez. Reparación y conciliación en el sistema penal. ¿Apertura de una nueva vía? Granada: Comares, 1999.

SICA, Leonardo. Justiça Restaurativa e Mediação Penal. O novo modelo de Justiça Criminal e de Gestão do Crime. Rio de Janeiro: Lumen Juris, 2007.

SILVA SÁNCHEZ, Jesús María. A expansão do Direito Penal. Aspectos da política criminal nas sociedades pós-industriais. Tradução de Luiz Otavio de Oliveira Rocha. São Paulo: Revista dos Tribunais, 2002.

SOUZA, Wilson Alves de. Acesso à justiça. Salvador: Dois de Julho, 2011.

TAVARES, João Paulo Lordelo Guimarães. Acesso à justiça e hipossuficiência organizacional: fundamentos e amplitude da legitimação da Defensoria Pública na tutela dos direitos metaindividuais. Dissertação (Mestrado em Direito Público) - Faculdade de Direito, Universidade Federal da Bahia, Salvador, 2013. 
O Conceito de Eficácia como Fundamento...

THOMPSON, Augusto. Quem são os criminosos? - O crime e o criminoso: entes políticos. 2. ed. Rio de Janeiro: Lumen Juris, 2007.

VIVES ANTÓN, Tomás S. Fundamentos del sistema penal. Acción Significativa y Derechos Constitucionales. 2. ed. Valencia: Tirant lo Blanch, 2011.

ZAFFARONI, Eugenio Raúl. Em busca das penas perdidas: a perda de legitimidade do sistema penal. Tradução: Vania Romano Pedrosa e Amir Lopez da Conceição. Rio de Janeiro: Revans, 1991.

ZANETI JR., Hermes. A teoria circular dos planos: (direito material e direito processual). In: DIDIER JR., Fredie (Coord.). Leituras complementares de processo civil. 5. ed. Salvador: JusPODIVM, 2007. 


\section{Os Efeitos da Unificação do Regime das Obrigações pelo Código Civil de 2002: Estudo do Contrato de Comodato na Relação de Distribuição de Derivados de Petróleo}

Effects of the Unification of the Obligation's Regime by the 2002 Civil Code: Study of the Commodate Contract in the Relation of Distribution of Oil Derivatives

Luciano Zordan Piva*

Resumo: Uma das maiores transformações promovidas pelo Código Civil foi concretizar a tendência histórica do Direito brasileiro no sentido da unificação do regime das obrigações. Tendo em conta os dez anos de vigência da "constituição do homem comum", este artigo procura identificar as consequências práticas da unificação, isto é, examinar qual o impacto provocado nos julgamentos de casos envolvendo situações limites, em que, por exemplo, um contrato civil típico tenha sido utilizado numa operação intrinsecamente empresarial. Nesse sentido, analisar-se-á o contrato de comodato inserido na atividade de distribuição de derivados de petróleo, sempre atento aos novos dispositivos do Código Civil que originaram regras para a solução de casos como o supramencionado. Aproveitando as indispensáveis reflexões acerca da dualidade Direito Civil-Direito Comercial para a produção deste artigo, ao final provoca-se a discussão a respeito da necessidade ou não de um novo Código Comercial, em virtude da proposta do Projeto de Lei n. 1.572, de 2011.

* Universidade Federal do Rio Grande do Sul. 
Os Efeitos da Unificação do Regime das Obrigações...

Palavras-chave: Direito Comercial. Código Civil. Unificação das Obrigações. Comodato. Projeto de Código Comercial.

Abstract: One of the most important changes promoted by the Civil Code was to materialize the historical tendency of Brazilian Law towards the unification of Obligation's regime. Taking into account the ten years of entering into force of this Code, this paper aims to identify the practical consequences of the unification, that is to say, to examine what is the real impact provoked in the trials involving threshold situations between Civil Law and Commercial Law, as for example, when a typical civil contract has been used in an intrinsically commercial transaction. In this sense, it shall be analyzed the commodate contract inserted in the oil's derivative distribution activity, always looking up to the Civil Code new provisions that originated rules for the solution of cases like the above-named. Taking the indispensable reflections about the duality between Civil Law Commercial Law, in the end of this paper, we provoke a discussion about the necessity of a new Commercial Code, due to the recent 2011 Draft Bill n. 1.572.

Keywords: Commercial Law. Civil Code. Unification of Obligation's Regime. Commodate Contract. Draft of Commercial Civil Code. 
"Há em cada empresa, afeição ou idade um ciclo inteiro da vida humana."

(Machado de Assis, Memórias PÓSTUMAS DE BRÁS CUBAS)

\title{
Introdução
}

\begin{abstract}
Para Machado de Assis e para a História do Direito ${ }^{1}$, dez anos pode não ser considerado um tempo de análise razoável para verificar o impacto transformador de uma nova regulamentação para a sociedade. Segundo o autor brasileiro, cada evento vivido contém em si o tempo de toda uma vida, e, para a História do Direito, sua missão é "[...] antes a de problematizar o pressuposto implícito e acrítico das disciplinas dogmáticas", como afirma António Manuel Hespanha².
\end{abstract}

1 Este artigo resultou da investigação científica realizada no Grupo de Pesquisa $\mathrm{CNPq}$ “O Regime da Autonomia Privada, Liberdade de Iniciativa e Função Social nos Contratos Empresariais", coordenado pelo Prof. Dr. Gerson Luiz Carlos Branco, na Faculdade de Direito da UFRGS. Fundamental, também, a concessão pela UFRGS de bolsa de Iniciação Científica para o desenvolvimento e a apresentação da pesquisa. O autor agradece, outrossim, aos Professores Lisiane Ody, Jorge Cesa Ferreira da Silva e Eugênio Facchini Neto pelas críticas e pelos comentários feitos por ocasião da apresentação no Salão de Iniciação Científica da Faculdade de Direito da UFRGS.

2 HESPANHA, António Manuel. Panorama histórico da cultura jurídica europeia. Lisboa: Publicações Europa-America, 1997. p. 15. Ainda sobre História do Direito, ilustrativa a doutrina do Prof. Waldemar Ferreira: "Não consiste a história do direito, por certo, na súmula cronológica das leis que lhe tomaram a essência e enredaram a trama dos institutos em que se cristalizou. Trabalho seria esse a um tempo de paciência e de cópia, nem sempre de valor histórico pela existência de inúmeras leis e atos de governo de apoucada valia para a história do direito. Pode esta certamente ocupar-se de certos institutos que sem a sua coadjuvança poderiam parecer esdrúxulos e permanecer incompreendidos. Diversos títulos do direito seriam ininteligíveis a não ser quando encarados à luz da história, pois é da história que lhes vem o impulso que configurará seu desenvolvimento subsequente". FERREIRA, Waldemar. A História do Direito nos Cursos Jurídicos do Brasil. Revista da Faculdade de Direito da USP, São Paulo, v. XLV, "Fascículo em honra do Professor Waldemar Ferreira", 1950. p. 445.

Volume VIII, n. 2, 2013 
Os Efeitos da Unificação do Regime das Obrigações...

Entretanto, para o Direito na História, dez anos já podem demonstrar a evolução dos efeitos na sociedade oriundos de uma nova regulamentação. Assim, através de uma perspectiva macrojurídica ${ }^{3}$, em que se levam em conta os efeitos da regulamentação na economia global da sociedade, este artigo ambiciona verificar e analisar a variação na aplicação legislativa das decisões dos Tribunais, a fim de perquirir as consequências da unificação do regime das obrigações, bem como os seus efeitos para a sociedade, no transcorrer desses dez anos, desde a edição do Código Civil brasileiro vigente.

Se a tarefa é extensa, o corte metodológico realizado através da pesquisa de casos específicos relacionados ao Direito Comercial não diminui a importância do tema ${ }^{4}$. Pelo contrário, afunilar o campo de análise demanda uma execução ainda mais cuidadosa, tendo em vista a responsabilidade em verificar os efeitos de cada caso à luz de uma nova legislação. E nessa perspectiva, o Direito Empresarial é rico em casos, consequências e efeitos, ${ }^{5}$ embora deve-se deixar claro que a pesquisa jurisprudencial teve um caráter qualitativo e não puramente quantitativo: foram selecionadas aquelas decisões judiciais representativas do objeto da investigação.

3 MARTINS-COSTA, Judith. O regime dos juros no novo direito privado brasileiro. Revista da AJURIS, Porto Alegre, v. 34, n. 105, mar. 2007. p. 241.

4 "No caso do direito comercial, desafiar o gosto pela pesquisa histórica assume caráter ainda mais complexo. Convencer da importância de conhecimentos distantes perante o dinamismo da economia e do tráfico comercial atual soa aparentemente irrazoável. Inúmeras razões levam a crer, entretanto, que um eventual desestímulo mais diz com o equívoco da abordagem do tema, do que com seu conteúdo". MIRAGEM, Bruno N. B. Do direito comercial ao direito empresarial. Formação histórica e tendências do direito brasileiro. Revista de Direito Privado, v. 5, n. 17, jan./mar. 2004. p. 56.

5 “O direito comercial não existe sem julgados; e, por sua vez, o resultado dessa corrente de decisões condiciona a atuação dos agentes econômicos, fechando um ciclo que não pode ser ignorado pelo intérprete do Direito". FORGIONI, Paula A. A unicidade do regramento jurídico das sociedades limitadas e o art. 1.053 do CC. Usos e costumes e regência supletiva. Revista de Direito Mercantil, v. 147, jul./set. 2007. p.7. 
Um grande grupo desses casos diz respeito à utilização de diversos tipos de contratos, oriundos tanto do Direito Civil como da atividade comercial. Muito devido ao fenômeno conhecido como "comercialização do Direito Civil", esses contratos passaram a ser considerados como integrantes de uma rede conexa de contratos (conexão contratual) 6 , atenuando os limites existentes entre o Direito Comercial e o Direito Civil, e acentuando a histórica tendência do ordenamento jurídico brasileiro para uma unificação das obrigações civis e mercantis?.

Muitos são os exemplos que expressam essa dualidade entre Direito Civil e Direito Comercial, tais como a "multifuncionalidade do contrato de compra e venda" ${ }^{\prime \prime}$, a possibilidade de a locação ser civil ou comercial, os contratos nominados tipificados no Código Civil que regulam atividades empresariais (comissão, agência, seguro e transporte).

Mais especificamente, um exemplo que se destaca é o do contrato de distribuição de derivados de petróleo. Na prática,

6 Ao julgar a Apelação Cível n. 79.863, em 10.10.1972, o relator Des. Antônio Pereira Pinto bem discorreu a respeito da conexão contratual: “Quando as prestações características dos contratos de comodato (de equipamentos e utensílios) e de compra e venda (de gasolina) se encontram em relação de recíproca 'coordenação', temos um contrato misto, pois o que o configura é a coexistência de obrigações pertinentes a tipos diferentes de contratos enlaçados pelo caráter unitário da operação econômica". Tribunal de Justiça da Guanabara.

7 Sylvio Marcondes já acenava para essa tendência na exposição de motivos do Anteprojeto de Código de Obrigações, apresentado em junho de 1964: "A elevação e disseminação da cultura, o enorme progresso científico, a expansão da produção e circulação de toda sorte de bens, conduzem a um processo de democratização da riqueza, favorável à multiplicação dos atos econômicos e da sua prática por pessoas em número cada dia maior. Negócios jurídicos quase privativos de uma classe, como a dos comerciantes, passam a constituir rotina cotidiana de todos. Acelera-se o que, tão ao gosto da doutrina francesa, se tem admitido chamar 'comercialização do direito civil', corroborando um 'civilismo do direito comercial'". MARCONDES, Sylvio. Problemas de Direito Mercantil. São Paulo: Max Limonad, 1970. p. 130.

8 BRANCO, Gerson Luiz Carlos. O regime obrigacional unificado do Código Civil brasileiro e seus efeitos sobre a liberdade contratual. A compra e venda como modelo jurídico multifuncional. Revista dos Tribunais, a. 97, v. 872, jun. 2008. p. 11-42. 
Os Efeitos da Unificação do Regime das Obrigações...

ele envolve uma rede complexa de contratos integrados para atingir a atividade comercial fim de distribuição, todavia, vale-se para isso de contratos tipicamente civis, como o contrato de comodato, objeto da nossa análise no presente artigo.

O interesse em analisar o contrato de comodato, instituto civil típico, numa relação evidentemente comercial, como é o caso da distribuição de derivados de petróleo, justifica-se exatamente porque, sob a veste de ser uma categoria histórica', o Direito Empresarial coexistiu ao lado do Direito Civil como um direito especial. Isto é, por muitos anos, as roupas do Direito Empresarial foram giacca e cravatta, numa alusão ao direito de uma determinada categoria profissional: os comerciantes.

Muito em razão da tendência de o Direito Civil apresentar certa superioridade científica em relação ao Direito Comercial, visto que naquele "[...] prevalecem as exigências de uma profunda coesão e de uma disciplina sistemática dos conceitos mais gerais", como afirma Cesare Vivante ${ }^{10}$, o Direito Comercial foi, em verdade, um direito tão somente aplicado - e estudado - no ambiente de negócios ${ }^{11}$.

9 A constatação de que nunca existiram critérios precisos para, cientificamente, delimitar o Direito Civil e o Direito Comercial é hoje em dia acatada por grande parte da doutrina. Especificamente, quem melhor explicou a evolução do Direito Comercial desde sua origem foi Tullio Ascarelli: "É na civilização das comunas que o Direito Comercial começa a afirmar-se, em contraposição à civilização feudal, mas também distinguindo-se do Direito Romano comum que, quase simultaneamente, se constitui e se impõe. O Direito Comercial aparece, por isso, como um fenômeno histórico, cuja origem é ligada à afirmação de uma civilização burguesa e urbana, na qual se desenvolvem um novo espírito empreendedor e uma nova organização dos negócios". ASCARELLI, Tullio. Origem do direito comercial. Trad. e notas de Fabio Konder Comparato. Revista de direito mercantil, industrial, econômico e financeiro, nova série, v. 35, n. 103, jul./set. 1996. p. 88.

${ }^{10}$ VIVANTE, Cesare. Tratado de direito comercial. v. 1 (Introdução: “Os comerciantes”). Tradução em VIVANTE, Cesare. Introdução: Os comerciantes. Trad. Haroldo Malheiros Duclerc Verçosa. Revista de direito mercantil, industrial, econômico e financeiro, n. 102, abr.jun. 1996. p. 109.

11 Todavia, juristas como o gaúcho Hernani Estrella consideravam como essencial a intersecção entre o Direito Comercial e as ciências econômicas, que dariam substrato 
Aliado a isso - a reclusão acadêmica do Direito Comercial ${ }^{12}$-, no sistema jurídico brasileiro, desenvolvia-se a ideia de promulgar um Código Civil que fosse "eixo do Direito Privado"13, daí que, com a edição da Constituição de 1988 e a retomada de confiança do legislador brasileiro, um Projeto que desde os anos setenta vinha sendo lapidado e postergado pode ser retomado para, em 2002, ser promulgado. Entrava em vigor, em 2003, o Código Civil, revogando o antigo Código Civil de 1916, arraigado em um substrato social totalmente distinto, e parte considerável do vetusto Código Comercial de 1850.

O Código Civil de $2002^{14}$, embora com diversas novidades principalmente na sua Parte Geral e na parte concernente ao

necessário para o ofício regulatório: "Partindo de dados fornecidos pela ciência econômica, a ciência jurídica poderá construir os quadros legais que facilitarão a produção e a circulação dos bens, sempre consideradas, uma e outra, em relação aos indivíduos. Esta foi, e parece continuar a ser, a missão a que foi chamado a desempenhar o Direito Comercial". ESTRELLA, Hernani. Comercialização do Direito Civil. Revista Forense, n. 185, 1957. p. 86.

${ }_{12}$ Inclusive, retrata-se Cesare Vivante, na introdução de seu Tratado de Direito Comercial, v. I, a respeito da proposta de reunir o Direito Comercial ao Direito Civil em um único Código, afirmando que essa teve inspiração no "embaraço científico no qual se encontrava nossa disciplina, condenada a viver a meio caminho entre o empirismo da prática e as doutrinas tradicionais consagradas pelo Direito Civil, bloqueando-se na impotência jurídica dos contratos sui generis". E prossegue: "Mas a minha frequente participação nas reformas legislativas e, especialmente, na do Código de Comércio, durante os numerosos anos transcorridos desde a mencionada iniciativa, convenceram-me de que aquela fusão dos dois códigos em um único teria trazido um grave prejuízo ao progresso do direito comercial". VIVANTE, Cesare. Introdução: Os comerciantes. Trad. Haroldo Malheiros Duclerc Verçosa. Revista de direito mercantil, industrial, econômico e financeiro, n. 102, abr./jun. 1996. p. 108.

${ }^{13}$ BRANCO, Gerson Luiz Carlos. Função Social dos Contratos: interpretação à luz do Código Civil. São Paulo: Saraiva, 2009. p. XXXI da Introdução. Nas palavras do Coordenador do Anteprojeto, Professor Miguel Reale: "lei básica, mas não global, do direito privado". REALE, Miguel. O Projeto de Código Civil: situação atual e seus problemas fundamentais. São Paulo: Saraiva, 1986. p. 71.

${ }^{14}$ É de se ressaltar, entretanto, que alguns doutrinadores não consideram essa expressão "novo Código" como verdade absoluta, uma vez que o tempo entre o Projeto inicial - datado de 1975 - e a promulgação do Código Civil ultrapassou 23 


\section{Direito de Família15, deve à unificação das obrigações civis e mercantis o posto de grande inovação promovida. Isso porque a unificação do regime obrigacional, pelo menos no que tange à possibilidade de concretizá-la no plano regulatório, foi movi- mento histórico nascido no direito brasileiro ${ }^{16}$, especialmente nas ideias precursoras de Teixeira de Freitas.}

anos. Nesse sentido, Rachel Sztajn: “Demais disso, anote-se o significativo lapso temporal que medeia entre a última versão do anteprojeto e a redação final do Código Civil, sem que se atentasse para as significativas mudanças da base social sobre a qual a lei se aplica, o desenvolvimento da economia incluído o agronegócio, com o que deixaram de ser pensados os incentivos corretos para que as friç̧ões sociais fossem reduzidas". SZTAJN, Rachel. Codificação, decodificação, recodificação: a empresa no Código Civil Brasileiro. Revista de Direito Mercantil, v. 143, jul./set. 2006. p. 11.

${ }^{15}$ Como definiu o Coordenador-Geral do Código, o Professor Miguel Reale: “Se considerarmos que, depois, houve a apreciação de mais de mil emendas na Câmara dos Deputados, e de mais de quatrocentas no Senado Federal, com novo retorno à Câmara dos Deputados, para novos estudos e discussões, pode-se proclamar o caráter coletivo que veio assumindo o Projeto, não se perdendo, ao longo de mais de três décadas, oportunidade alguma para atualiza-lo, em razão de fatos e valores supervenientes, como se deu, por exemplo, com as profundas alterações que a Constituição de 1988 introduziu em matéria de Direito de Família". REALE, Miguel. Visão geral do novo Código Civil. Jus Navigandi, Teresina, ano 7, n. 54, 1 fev. 2002. Disponível em: <http://jus.com.br/revista/texto/2718>. Acesso em: 13 dez. 2011.

${ }^{16}$ Reconhece-se que a doutrina alemã já realizava estudos sobre o assunto desde o séc. XVII, como leciona o Professor Norberto Mac-Donald: "A partir do Código Comercial alemão de 1861, passa-se a favorecer o comerciante. A nova orientação teve vasta e crescente difusão com a progressiva ascensão da classe mercantil: no conflito entre os dois Códigos, prevalecia o Direito Comercial, cujo campo de aplicação adquiriu amplas proporções. [...] A tendência expansiva do Direito Comercial no continente europeu manifesta-se sob dúplice aspecto: - extensão do campo de aplicação dos códigos comerciais (das relações entre comerciantes, segundo o modelo francês, passam a regular as relações mistas, segundo o modelo alemão); - comercialização, em diversos graus, dos Códigos Civis, com o acolhimento, para regular relações também entre não comerciantes, de alguns princípios originariamente próprios das relações comerciais". MAC-DONALD, Norberto da Costa Caruso. A unificação do direito das obrigações no novo código civil. Revista Síntese de Direito Civil e Processual Civil, Porto Alegre, v. 4, n. 20, nov./dez. 2002. p. 27-40. Todavia, os estudos de Teixeira de Freitas conseguiram reunir considerações no âmbito regulatório, ao passo que os alemães, especificamente quanto à unificação das obrigações, restringiram-se tão somente à questão doutrinária. 
Assim, para que as pretensões deste texto sejam atendidas, a primeira parte do artigo volta-se para traçar o panorama histórico que albergou a possibilidade da concretização da unificação do regime obrigacional, movimento delineado há pelo menos 130 anos no cenário jurídico nacional.

Todavia, ao invés de limitar-se a reflexões históricas acerca do tema, o texto, na segunda parte, avança para o ponto central da pesquisa desenvolvida, qual seja a análise empírica das decisões dos principais Tribunais brasileiros ao julgarem casos de Direito Comercial - TJ/RS, TJ/SP, TJ/RJ -, a fim de verificar se a mudança no plano legislativo acarretou alterações substanciais na orientação jurisprudencial.

Por fim, em razão da tramitação, no Congresso Nacional, do Projeto de Lei n. 1.572 que encaminha proposta de um novo Código Comercial, a terceira parte desse artigo propõe-se a examinar o cabimento e a real necessidade dessa medida legislativa, tendo em vista os resultados da pesquisa jurisprudencial que relaciona a aplicação do novo Código Civil a casos tipicamente empresariais (distribuição de derivados de petróleo).

\section{A Dualidade Direito Civil - Direito Comercial como Base da Pesquisa}

\subsection{Apontamentos sobre a Evolução Histórica da Unificação do Direito Privado Brasileiro}

Em oposição ao Código Comercial de 1850, promulgado às pressas devido à ansiedade dos comerciantes cariocas em ter alguma regulação frente ao dinâmico mercado do século XIX ${ }^{17}$,

\footnotetext{
${ }^{17}$ Um bom panorama histórico sobre o ativo comércio do Rio de Janeiro no século XIX é apresentado por Jorge Caldeira na obra Mauá, Empresário do Império. São Paulo: Companhia das Letras, 1995.
} 
Os Efeitos da Unificação do Regime das Obrigações...

o Código Civil de 1916 teve origem em mandamento constitucional, visto que a Constituição Federal de 1824 determinava a organização de um Código Civil ${ }^{18}$.

Na ocasião, Teixeira de Freitas fora contratado pelo Governo Imperial para realizar trabalho preparatório para o que seria o futuro Código Civil. Surge, em 1857, a Consolidação das Leis Civis, pedra fundamental do que seria o famoso Esboço, de Teixeira de Freitas.

Tal Esboço, como afirma o próprio autor, tinha como objetivo "[...] a feitura de um Projeto de Código Civil para reger como subsídio ao complemento de um Código do Comércio"19. Imiscuído nessas ideias, Teixeira de Freitas propõe, em 1867, a elaboração de dois Códigos: "[...] o Geral que contivesse, quanto às causas e aos efeitos jurídicos, as noções preliminares que serviriam para a interpretação das leis; e o Civil, em que se unificaria o direito privado com a unificação das normas de direito civil e de direito comercial"20. A explanação do jurista não deixa dúvidas quanto à sua intenção:

Não há mesmo alguma razão de ser para tal seleção de Leis; pois que, em todo o decurso dos trabalhos de um CC aparecem raros casos, em que seja de mister distinguir o fim comercial dos atos, por motivo da diversidade nos efeitos jurídicos ${ }^{21}$.

${ }^{18}$ MOREIRA ALVES, José Carlos. A Unificação do Direito Privado Brasileiro - de Teixeira de Freitas ao Novo Código Civil. In: JUNQUEIRA DE AZEVEDO, Antônio (Org.). Princípios do Novo Código Civil Brasileiro e Outros Temas: homenagem a Tullio Ascarelli. São Paulo: Quartier Latin, 2008. p. 310.

${ }^{19}$ FERREIRA COELHO. Código Civil dos Estados Unidos do Brasil. v. I (Formação do Direito Escrito). n. 613. Rio de Janeiro: Oficinas Gráficas do “Jornal do Brasil”, 1920. p. 267. Apud MOREIRA ALVES. Op. cit., p. 312.

${ }^{20}$ MOREIRA ALVES. Op. cit., p. 313.

${ }^{21}$ FERREIRA COELHO. Código Civil dos Estados Unidos do Brasil. v. I (Formação do Direito Escrito). n. 613. Rio de Janeiro: Oficinas Gráficas do "Jornal do Brasil", 1920. p. 267. 
Apesar de receber parecer favorável da Seção de Justiça do Conselho de Estado, o Governo Imperial não aprovou a elaboração dos dois Códigos, como propunha Teixeira de Freitas. Por essa razão, seu contrato acabou sendo rescindindo, e a sua inovadora ideia postergada cerca de 130 anos.

Todavia, o legado deixado por "um dos maiores jurisconsultos da latinidade moderna"22 influenciou pelo menos três relevantes Projetos de regulação que tinham como objetivo a unificação do direito privado.

Em 1911, a Inglês de Souza fora delegada a tarefa de redigir um projeto de unificação do direito privado, bem como um Projeto que teria como ambição substituir o Código Comercial de $1850^{23}$. Nenhum dos projetos prosperou e, em 1915, o Projeto de Código Civil de Clóvis Bevilaqua, fora aprovado pelo Congresso.

Ainda no século XX, em 1940, um projeto de Código de Obrigações fora colocado em pauta para elaboração por três juristas: Orozimbo Nonato, Philadelpho Azevedo e Hahnemann Guimarães. Como pano de fundo, estava a ideia de "[...] unificar os princípios gerais sobre as obrigações e a disciplina dos contratos em espécie", a fim de "[...] resolver o problema da reforma do direito mercantil, que ficará, assim, reduzido a um restrito núcleo de preceitos reguladores da atividade profissional dos comerciantes; a matéria relativa às sociedades e ao transporte comportará, ainda, codificações autônomas"24.

${ }^{22}$ CARVALHO, Orlando de. Teixeira de Freitas e a unificação do direito privado. Boletim da Faculdade de Direito de Coimbra, n. 60, 1984. p. 3.

${ }^{23}$ MOREIRA ALVES, José Carlos. A Unificação do Direito Privado Brasileiro - de Teixeira de Freitas ao Novo Código Civil. In: JUNQUEIRA DE AZEVEDO, Antônio (Org.). Princípios do Novo Código Civil Brasileiro e Outros Temas: homenagem a Tullio Ascarelli. São Paulo: Quartier Latin, 2008. p. 317.

${ }^{24}$ NONATO, Orozimbo; AZEVEDO, Philadelpho; GUIMARÃES, Hahnemann. Anteprojeto de Código de Obrigações (Parte Geral), n. 2, 1941. p. 5. Apud MOREIRA ALVES, op. cit., p. 320. 
Os Efeitos da Unificação do Regime das Obrigações...

Apesar de explicitamente ressalvarem a manutenção do Direito Comercial $^{25}$, o Projeto não prosperou devido às críticas de comercialistas que temiam a extinção dessa área do Direito.

A ideia da unificação só voltaria à tona com a proposição de Caio Mário da Silva Pereira, Sylvio Marcondes e Theófilo Santos em unificar o direito obrigacional tal qual o modelo suíço à época vigorava ${ }^{26}$. Em específico, Caio Mário da Silva Pereira era enérgico quanto à necessidade de cristalizar a proposta lançada anteriormente por Teixeira de Freitas:

Este Projeto, com tais características, se convertido em lei porá o Brasil na linha dos sistemas contemporâneos que repelem a dicotomia incongruente do Direito Privado, e consagrará uma ideia, que antes de ser posta em prática na codificação de sistemas jurídicos de povos do mais elevado conceito, já era nossa, preconizada que fora, antes de todos, pelo mais genial de nossos civilistas, Teixeira de Freitas ${ }^{27}$.

Fulminado por críticas na parte correspondente ao Direito de Família no Código Civil, o Governo acabou por retirar ambos os Projetos ${ }^{28}$.

Por essas razões, somente após 122 anos da inovadora proposta de Teixeira de Freitas um Projeto com semelhante intenção prosperou: em 1969, a Comissão para o Anteprojeto do Código Civil, liderada por Miguel Reale, iniciava os trabalhos que resultariam no Código Civil de 2002, cuja principal

25 “Com a unificação do direito das obrigações, o direito comercial não desaparecerá; não desaparecerá o Código Comercial". Idem, p. 67.

${ }^{26}$ À semelhança do modelo suíço, cabia a Orlando Gomes a elaboração de um novo Código Civil.

${ }^{27}$ PEREIRA DA SILVA, Caio Mário. A unidade do direito obrigacional. Revista Forense, v. 97, p. 5. Apud MOREIRA ALVES, José Carlos. A Unificação do Direito Privado Brasileiro - de Teixeira de Freitas ao Novo Código Civil. In: JUNQUEIRA DE AZEVEDO, Antônio (Org.). Princípios do Novo Código Civil Brasileiro e Outros Temas: homenagem a Tullio Ascarelli. São Paulo: Quartier Latin, 2008. p. 329.

${ }^{28}$ MOREIRA ALVES. Op. cit., p. 330. 
mudança em relação ao Código Civil de 1916 estava justamente na unificação do direito privado, mediante o regramento único da disciplina das Obrigações.

\subsection{Técnica de Pesquisa e Corte Metodológico: o Contrato de Comodato na Relação de Distribuição de Derivados de Petróleo}

A técnica de pesquisa utilizada trouxe, numa primeira busca, uma gama considerável de "casos-limite", em que a dualidade civil-comercial estava presente, tendo em vista a impossibilidade de delimitar uma única disciplina ao regramento de situações como no caso do contrato de compra e venda (que pode ser mercantil, civil ou consumerista) ${ }^{29}$, o contrato de locação, que pode ter características civis ou comerciais, e ainda alguns contratos nominados no Código Civil que regulam atividades tipicamente empresariais, como os de seguro, transporte, comissão e agência. Daí a necessidade de empregar um corte metodológico, a fim de extrair, dentre as possibilidades encontradas, apenas uma categoria e sobre ela traçar distinções, o que, ao fim e ao cabo, é a tarefa principal do pesquisador de Direito ${ }^{30}$.

${ }^{29}$ Sobre a multifuncionalidade do contrato de compra e venda, v. BRANCO, G. L. C. O regime obrigacional unificado do Código Civil brasileiro e seus efeitos sobre a liberdade contratual. A compra e venda como modelo jurídico multifuncional. Revista dos Tribunais, a. 97, v. 872, jun. 2008. p. 11-42.

${ }^{30}$ Além de traçar distinções, cumpre ao pesquisador, no âmbito do Direito, vestir as roupas do historiador que, nas palavras do Professor Paolo Grossi, tem "um papel exclusivo: civilização significa história, um contexto histórico determinado em toda a riqueza de suas expressões. E é prática característica do historiador a de colocar o dado que opera no interior do contexto que o gerou e que lhe imprime vida. É o historiador quem pode e deve recordar aos privatistas e publicistas todos eles presos nos próprios textos legislativos - o fato de que o texto em si é sempre uma representação de uma realidade de fundo, uma representação parcial e artificiosa por somatória". Sendo assim, lembrando essa preciosa lição, cumpre 
Os Efeitos da Unificação do Regime das Obrigações...

Relevante para a especialização do objeto de análise foi o texto clássico do comercialista Arnoldo Wald que, em 1979, publicou o parecer Os contratos de concessão exclusiva para distribuição de gasolina no Direito brasileiro ${ }^{31}$. A obra citada refere-se, em síntese, aos diversos contratos celebrados entre distribuidores de derivados de petróleo com os revendedores (postos de gasolina). A principal crítica apresentada no parecer dirigia-se às empresas distribuidoras ("distribuidores"), tendo em vista que essas se valiam do conjunto de contratos integrados (complexo de contratos que viabilizavam a operação econômica de distribuição) para manterem o vínculo com as empresas revendedoras ("revendedores"), mesmo sob condições ilícitas e contratualmente desproporcionais.

Não obstante a pioneira linha de pensamento de Arnoldo Wald no que concerne à reflexão a cerca do princípio da função social (ainda que sem mencionar expressamente tal princípio), o comercialista não se deteve em analisar a coligação contratual existente entre os diversos contratos que se integram na relação de distribuição de derivados de petróleo. Isso torna-se relevante na medida em que, in casu por força do conteúdo contratual, os contratos "[...] encontram-se em relação de dependência unilateral ou recíproca" ${ }^{\prime 2}$, gerando obrigações acessórias que vinculam os contratantes independentemente de a relação principal ser comercial ou civil. A justificativa para a vinculação

mergulhar no denso universo das obrigações civis e mercantis para "apreciar a substância efetiva do fenômeno" regulado pelo Código Civil de 2003. Os trechos foram extraídos de GROSSI, Paolo. O Ponto e a Linha. História do Direito e Direito Positivo na Formação do Jurista do Nosso Tempo. Tradução de Mônica Sol Glik. Revista Sequencia, n. 51, dez. 2005. p. 31-45.

${ }^{31} \mathrm{O}$ texto original está publicado em WALD, Arnoldo. Os contratos de concessão exclusiva para distribuição de gasolina no direito brasileiro. Estudos e pareceres de direito comercial: problemas comerciais e fiscais da empresa contemporânea. $2^{\mathrm{a}}$ série. São Paulo: Revista dos Tribunais, 1979.

32 MARINO, Francisco Paulo De Crescenzo. Contratos Coligados no Direito Brasileiro. São Paulo: Saraiva, 2009. p. 99. 
está, nesse sentido, no nexo funcional-econômico ${ }^{33}$ que tais contratos estabelecem na relação de distribuição de derivados de petróleo, sendo necessário para o perfeito adimplemento da obrigação principal contida no contrato de distribuição.

A partir dos estudos debatidos no Grupo de Estudos Obrigações e Contratos Mercantis e no Grupo de Pesquisa $O$ Regime da Autonomia Privada, Liberdade de Iniciativa e Função Social nos Contratos Empresariais, na Faculdade de Direito da UFRGS, iniciou-se a pesquisa de jurisprudência pautada pela seguinte pergunta: a natureza da relação obrigacional subjacente seria relevante para a aplicação de determinado modelo jurídico?

Com isso, pretender-se-ia compreender se o contexto econômico-social em que determinada relação contratual se encontrava inserida determinaria o grupo de regras que incidiriam numa eventual discussão judicial daqueles contratos ${ }^{34}$, a fim de polarizar e determinar os riscos aos quais os empresários, cidadãos e a sociedade podem correr e quantificar para celebrar contratos de distribuição de derivados de petróleo ${ }^{35}$.

${ }^{33}$ KONDER, Carlos Nelson. Contratos Conexos: Grupos contratuais, redes contratuais e contratos coligados. Rio de Janeiro: Renovar, 2006. p. 132.

${ }^{34}$ A Professora Paula Forgioni desenvolveu pesquisa na Universidade de São Paulo com preocupações similares, quando procurou estabelecer parâmetros mínimos de interpretação nas hipóteses em que o contrato de distribuição era discutido no Poder Judiciário: “Quando se celebra um contrato atípico, não há a incidência de um regramento específico que discipline a relação entre as partes. De certa forma, isso gera insegurança, na medida em que não se tem certeza sobre a hipótese normativa que irá se compor e sobre as conseqüências jurídicas que serão produzidas". FORGIONI, Paula A. O posicionamento dos Tribunais perante os contratos de distribuição (1980-2000). EAESP/FGV/NPP - Núcleo de Pesquisas e Publicações, p. 9. Disponível em: $<$ http://gvpesquisa.fgv.br/sites/gvpesquisa.fgv.br/files/publicacoes/ Rel\%2043-2001.pdf >. Acesso em: 2 ago. 2012. Pode-se acrescentar, ainda, que esse comentário esboça um dos principais motivos pelos quais a presente pesquisa ganha relevo, uma vez que das diversas variáveis "obscuras" do mercado, a possibilidade de estabelecer padrões razoáveis de interpretação das decisões é de fundamental importância para os empresários desenvolverem o seu ofício.

${ }^{35}$ Tal como lembra a Professora Rachel Sztajn: “Outro risco tão importante quanto o econômico, é denominado pelos economistas de 'risco jurídico' ou 'incerteza 
Os Efeitos da Unificação do Regime das Obrigações...

Assim, inicialmente a investigação traçou três critérios para padronizar e aperfeiçoar a pesquisa de jurisprudência no site dos principais Tribunais que julgam casos envolvendo Direito Comercial ${ }^{36}$ : (i) especificar, na ferramenta de pesquisa, as palavras "contrato", "comodato", "distribuição" e "petróleo"; (ii) identificar o fundamento preponderante nos acórdãos para a construção do dispositivo nos casos em que o contrato tipicamente civil (e.g. comodato) estava inserido na relação comercial de distribuição de derivados de petróleo; e (iii) buscar decisões anteriores à vigência do Código Civil de 2003, a fim de traçar um paralelo com possíveis transformações na jurisprudência.

\subsection{Da Utilização do Contrato de Comodato como Paradigma para a Investigação: Contrato Tipicamente Civil numa Relação Empresarial}

Percebe-se, da leitura realizada até aqui, que a palavra comodato foi utilizada como critério de busca na pesquisa de jurisprudência. A justificativa para refinar ainda mais os parâmetros de pesquisa está relacionada à necessidade de afunilar o amplo campo de análise que a investigação acerca da dualidade civil-comercial oferece. Isso porque, o contrato de comodato

jurídica', pois, prende-se à legislação, à forma pela qual o Judiciário aplica ou interpreta os textos legais, à aderência das regras as instituições e práticas socialmente aceitas, sua estabilidade. [...]. O risco jurídico, criado pela redação e interpretação das normas de direito positivo é menos aparente e mais difícil de estimar e, usualmente, não percebido pelos operadores do direito formados na visão formalista ou legalista do sistema". SZTAJN, Raquel. Notas sobre o conceito de empresário e empresa no código civil brasileiro. Revista Pensar, UNIFOR, Fortaleza, v. 11, p. 192-202, fev. 2006. p. 200.

${ }^{36}$ Uma vez que a pesquisa de caso se baseia principalmente nas diferentes interpretações acerca dos contratos inseridos na relação de distribuição de derivados de petróleo, a investigação restringiu-se aos Tribunais estaduais, não se estendendo aos julgados do Superior Tribunal de Justiça. 
é um instrumento tipicamente civil, utilizado para que "[...] alguém entregue a outrem alguma coisa infungível para que este dela se utilize, gratuitamente, com o encargo, porém, de restituí-la depois" ${ }^{\prime 37}$, sendo, todavia, também utilizado em outros negócios jurídicos.

Diante da definição de Beviláqua, resta evidente a função tipicamente civil do contrato de comodato, uma vez que é regulado no Código Civil a partir do art. 579 até o art. 585 e estabelece a gratuidade do ato como elementar ao instituto. Dessa forma, não há, à primeira vista, possibilidade de inserção desse contrato em operações comerciais.

Entretanto, tanto a doutrina quanto a práxis mercantil apontam a possibilidade de utilizar esse instrumento nas relações comerciais - mais especificamente, nas relações empresariais de distribuição de bebida e combustíveis ${ }^{38}$.

Daí importância da presente pesquisa, pois, se o comodato é utilizado nessas relações, principalmente associado ao contrato de distribuição, como antes realçado, é relevante destacar qual é o conjunto de normas e regras aplicáveis quando ocorre a discussão judicial desses contratos. Isto é, uma vez que a possibilidade de previsão do posicionamento dos Tribunais (previsibilidade) é questão crucial no desenvolvimento dos negócios, é extremamente importante para os empresários saber se ao contrato de comodato inserido na relação de distribuição de derivados de petróleo, apesar de tipicamente civil, podem ser aplicadas regras comerciais, dada a natureza da obrigação subjacente.

\footnotetext{
${ }^{37}$ BEVILÁQUA, Clóvis. Direito das obrigações. Rio de Janeiro: Freitas Bastos, 1936. $\S 95$, p. 227. Apud SANSEVERINO, Paulo de Tarso. Contratos Nominados II. 2. ed. São Paulo: Revista dos Tribunais, 2011. p. 273.

${ }^{38}$ SANSEVERINO. Op. cit., p. 274.
} 


\section{Resultados: Inclinação Jurisprudencial no Sentido de Evidenciar a Autonomia do Direito Comercial}

A amostragem final consubstanciou-se em sessenta acórdãos coletados nos Tribunais do Rio Grande do Sul, de São Paulo e do Rio de Janeiro. Esse conjunto, todavia, não representa apenas um determinado número: as decisões foram analisadas de forma profunda e crítica, de maneira a identificar, em cada caso, o critério utilizado para a aplicação do conteúdo normativo adequado ao contrato de comodato no contexto da relação de distribuição.

Por essa razão, preferiu-se a forma de tabelas para agrupar as decisões sob critérios semelhantes, procedimento que resultou em três tabelas finais de acordo com os seguintes critérios: (i) afirmação da autonomia do Direito Comercial, ao relativizar as regras do comodato existente no Código Civil, apesar da unificação do regime obrigacional; (ii) aplicação das regras civis ao contrato de comodato, mesmo inserido em relação tipicamente empresarial de distribuição; (iii) análise de decisões anteriores à vigência do Código Civil de 2002.

Diante dessa divisão, para não alongar o texto com comentários individuais de cada acórdão, passa-se à análise desses três grupos de casos.

\subsection{Análise das Decisões que Consideram o Contexto de Inserção do Contrato para Configuração da sua Função Social e Econômica Típica}

Para esse primeiro grupo de decisões ${ }^{39}$, trata-se de situações em que uma empresa distribuidora de produtos derivados de petróleo propõe a um revendedor a comercialização desses

\footnotetext{
${ }^{39}$ Segue, ao final deste item, a tabela de decisões como Tabela 1.
} 
produtos e, ao celebrarem os contratos necessários para o desenvolvimento da atividade empresarial, especialmente no que toca ao contrato de comodato, essa distribuidora, segundo as decisões coletadas, não tem a intenção de gratuidade típica do instrumento.

Pelo contrário, o contrato de comodato, nesse caso, é instrumento viabilizador do próprio negócio, consistindo sua função social e econômica tipicamente ${ }^{40}$ empresarial, exigindo um afastamento das regras comuns e típicas do contrato de comodato civil regulado pelo Código Civil de 2002.

Assim, a consideração de que há necessidade de temperamento das regras previstas no Código Civil com princípios e regras empresarias é levada em conta em diversos acórdãos, os quais se agruparam nesse primeiro bloco. Destaca-se, nesse sentido, o entendimento no julgado cujo acórdão coube à lavra do Des. Eugênio Facchini Neto:

O contrato de comodato de bens necessário ao funcionamento de um posto de combustível é um contrato especial, que se diferencia do comodato típico, em que somente o comodatário aufere vantagens e, portanto, deve assumir as despesas inerentes à restituição do bem recebido em comodato. No caso em tela, também o comodante aufere vantagens com o negócio celebrado, pois o mesmo é muitas vezes condição para viabilizar o complexo relacionamento entre as partes. Assim, diante do interesse recíproco das partes, não tendo elas disciplinado a questão das despesas relacionadas à restituição dos bens objeto do comodato, devem as mesmas serem repartidas entre ambas, por igual ${ }^{41}$.

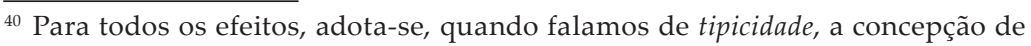
Joaquim de Sousa Ribeiro. Para o Professor português, a tipicidade do contrato relaciona-se ao "desvio social típico", isto é, o contrato que, uma vez inserido num contexto fático que desvirtue sua função de ordenação da vida privada, fazendo surgir situações desiguais, sendo essas percebidas empiricamente na sociedade. RIBEIRO, Joaquim de Sousa. O Problema do Contrato: as Cláusulas Contratuais Gerais e o Princípio da Liberdade Contratual. Coimbra: Almedina, 2003.

${ }^{41}$ Apelação Cível № 70034883397, Décima Nona Câmara Cível, Tribunal de Justiça do RS, Relator: Eugênio Facchini Neto, Julgado em 04/10/2011. 
Os Efeitos da Unificação do Regime das Obrigações...

Extrai-se do voto do magistrado que o comodato em questão "é um contrato especial", uma vez que "também o comodante aufere vantagens com o negócio celebrado", devendo "as despesas relacionadas à restituição dos bens objeto do comodato".

É relevante assinalar que, a teor do art. 584 do Código Civil $^{42}$, em sendo a relação obrigacional subjacente estritamente civil, ficaria apenas por conta do comodatário-revendedor, "serem repartidas entre ambas, por igual".

Resta claro, portanto, o realce dado pelo julgador à autonomia da relação comercial, tendo em vista a harmonização da regra civil com o contexto de inserção do contrato de comodato: uma vez que a função do instrumento é destinada para um fim ${ }^{43}$ distinto daquele preconizado pelo legislador, muda-se o substrato lógico que sustentava a orientação da aplicação normativa ${ }^{44}$.

${ }^{42}$ Art. 584. O comodatário não poderá jamais recobrar do comodante as despesas feitas com o uso e gozo da coisa emprestada.

43 "Segundo Bobbio, sempre que se faz uma análise normativa e se busca a "função" de um determinado instituto, esta é feita através da identificação da sua "teleologia": uma análise funcional busca descobrir "para que o direito serve e não "como é feito o direito". BOBBIO, Norberto. Dalla struttura alla funzione. Milano: Edizioni di Comunità, 1977. p. 63. Apud BRANCO, Gerson. O regime obrigacional unificado do Código Civil brasileiro e seus efeitos sobre a liberdade contratual. A compra e venda como modelo jurídico multifuncional. Revista dos Tribunais, a. 97, v. 872, jun. 2008. p. 13.

${ }^{44}$ Da mesma forma entende Wald, no texto que serviu de matriz teórica para esse trabalho: "Nas hipóteses de contratos de distribuição de gasolina, o que a financiadora desejou não foi realizar um comodato, mas emprestar dinheiro e receber, como contrapartida complementar do mútuo, um direito de exclusividade na venda dos seus produtos no posto de gasolina construído pela mutuária". WALD, Arnoldo. Os contratos de concessão exclusiva para distribuição de gasolina no direito brasileiro. Estudos e pareceres de direito comercial: problemas comerciais e fiscais da empresa contemporânea. $2^{\mathrm{a}}$ série. São Paulo: Revista dos Tribunais, 1979. p. 189. 
Essa possibilidade, embora não tenha sido expressamente citada pelo magistrado na decisão supramencionada, está em plena consonância com o ordenamento jurídico estruturado pelo Código Civil de 2002. Isso porque, se por um lado o Código unificou as obrigações civis e mercantis, por outro, garantiu a "mobilidade e unidade ao sistema", a partir das cláusulas gerais e pela concepção culturalista adotada pelo Professor Miguel Reale - representada nas diretrizes que nortearam a redação do Projeto.

Um exemplo de cláusula geral que se adapta perfeitamente para o caso do contrato de comodato inserido na relação de distribuição de derivados de petróleo é a função social dos contratos, regulada no Código Civil pelo art. 421. A função social dos contratos atua como um limitador da liberdade de contratar, pois a identificação do elemento "social" da atividade fim de distribuição é evidentemente comercial, o que exige do julgador trocar as lentes na análise daquele contrato de comodato, uma vez que a incidência direta das regras do Código Civil que regulam esse contrato não teria o substrato imaginado pelo legislador. 
Os Efeitos da Unificação do Regime das Obrigações...

Tabela 1: Casos sobre a Aplicação de Regras Comerciais ao Contrato de Comodato

\begin{tabular}{|c|c|c|c|}
\hline Tribunal & $\begin{array}{l}\text { Tipo e Número } \\
\text { do Recurso }\end{array}$ & Relator & $\begin{array}{c}\text { Data do } \\
\text { Julgamento }\end{array}$ \\
\hline $\mathrm{TJ} / \mathrm{RS}$ & $\begin{array}{l}\text { Apelação Cível } \\
\text { n. } 70048112650\end{array}$ & $\begin{array}{l}\text { Des. Pedro Celso Dal } \\
\text { Prá }\end{array}$ & $14 / 06 / 2012$ \\
\hline $\mathrm{TJ} / \mathrm{RS}$ & $\begin{array}{l}\text { Apelação Cível } \\
\text { n. } 70034883397\end{array}$ & $\begin{array}{l}\text { Des. Eugênio } \\
\text { Facchini Neto }\end{array}$ & 04/10/2011 \\
\hline $\mathrm{TJ} / \mathrm{RS}$ & $\begin{array}{l}\text { Apelação Cível } \\
\text { n. } 70019144492\end{array}$ & $\begin{array}{l}\text { Des. Cláudio Augusto } \\
\text { Rosa Lopes Nunes }\end{array}$ & $17 / 02 / 2011$ \\
\hline $\mathrm{TJ} / \mathrm{RS}$ & $\begin{array}{l}\text { Agravo de } \\
\text { Instrumento } \\
\text { n. } 70024745556\end{array}$ & $\begin{array}{l}\text { Des. Ergio Roque } \\
\text { Menine }\end{array}$ & $02 / 10 / 2008$ \\
\hline $\mathrm{TJ} / \mathrm{RS}$ & $\begin{array}{l}\text { Apelação Cível } \\
\text { n. } 70039804604\end{array}$ & $\begin{array}{l}\text { Des. Mylene Maria } \\
\text { Michel }\end{array}$ & 27/09/2011 \\
\hline $\mathrm{TJ} / \mathrm{RS}$ & $\begin{array}{l}\text { Apelação Cível } \\
\text { n. } 70047054226\end{array}$ & $\begin{array}{l}\text { Des. Mário Crespo } \\
\text { Brum }\end{array}$ & 13/02/2012 \\
\hline TJ/RJ & $\begin{array}{l}\text { Apelação Cível } \\
\text { n. 2007.001.27258 }\end{array}$ & $\begin{array}{l}\text { Des. Elton M. C. } \\
\text { Leme }\end{array}$ & 02/08/2007 \\
\hline TJ/SP & $\begin{array}{l}\text { Apelação Cível } \\
\text { n. 9232073- } \\
\text { 10.2008.8.26.0000 }\end{array}$ & $\begin{array}{l}\text { Des. Sebastião } \\
\text { Junqueira }\end{array}$ & $23 / 11 / 2010$ \\
\hline
\end{tabular}

\begin{tabular}{|c|c|c|c|}
\hline $\mathrm{TJ} / \mathrm{SP}$ & $\begin{array}{l}\text { Apelação } \\
\text { n. 0175472- } \\
\text { 40.2008.8.26.0000 }\end{array}$ & Des. Renato Nalini & $12 / 03 / 2009$ \\
\hline TJ/SP & $\begin{array}{l}\text { Apelação } \\
\text { n. } 9120799- \\
\text { 12.2006.8.26.0000 }\end{array}$ & Des. Pedro Ablas & $30 / 11 / 2011$ \\
\hline
\end{tabular}


Agravo de

TJ/SP $\begin{aligned} & \text { Instrumento } \\ & \text { n. 0139521- } \\ & \text { 43.2012.8.26.0000 }\end{aligned} \quad$ Des. Clovis Castelo $\quad$ 03/09/2012

\begin{tabular}{|c|c|c|c|}
\hline $\mathrm{TJ} / \mathrm{SP}$ & $\begin{array}{l}\text { Apelação } \\
\text { n. 9164477- } \\
\text { 72.2009.8.26.0000 }\end{array}$ & Des. Carlos Nunes & $27 / 02 / 2012$ \\
\hline
\end{tabular}

Apelação

TJ/SP n. 9072930-

Des. Romeu Ricupero 18/08/2011

53.2006.8.26.0000

\begin{tabular}{|c|c|c|c|}
\hline $\mathrm{TJ} / \mathrm{SP}$ & $\begin{array}{l}\text { Apelação } \\
\text { n. 0136880- } \\
9.2007 .8 .26 .0100\end{array}$ & Des. Kiotsi Chicuta & 02/08/2012 \\
\hline
\end{tabular}

Fonte: Tabela elaborada com base nos sites $<$ http://www.tjrs.jus.br/site/ $>$, $<$ http://www.tjsp.jus.br/Default.aspx> e <http://www.tjrj.jus.br/>.

\subsection{Relação de Decisões que Aplicaram Regras Civis ao Contrato de Comodato Inserido na Relação de Distribuição de Derivados de Petróleo}

O segundo grupo de decisões ${ }^{45}$, tendo como pano de fundo a mesma situação apresentada anteriormente, isto é, a discussão judicial do contrato de comodato quando inserido na relação de distribuição de derivados de petróleo, revela uma perspectiva distinta daquela encontrada nos acórdãos já comentados.

É bem verdade que um número menor de decisões foi encontrado, se comparado com o primeiro grupo, todavia, pode-se

\footnotetext{
$\overline{45}$ Segue, ao final desse item, a tabela com as decisões como Tabela 2.
} 
Os Efeitos da Unificação do Regime das Obrigações...

considerar que alguns juízes interpretam ter a unificação das obrigações civis e mercantis, pelo Código Civil de 2003, promovido uma espécie de absorção do Direito Comercial pelo Direito Civil, uma vez que, na produção dos seus votos, dissociam o negócio subjacente do contrato pactuado, aplicando as regras do Código Civil ao contrato de comodato.

Essa constatação fica evidente ao lermos o trecho extraído do voto do Des. Cláudio Hamilton:

O licenciamento se refere aos estabelecimentos de venda de combustível, ou seja, aos postos de abastecimento. Nesse caso, não há razão para ser imputada responsabilidade àqueles que fornecem o combustível para a venda. Ainda que os tanques e outros instrumentos inerentes a essa atividade sejam de propriedades da ré [distribuidora], e estejam emprestados em regime de comodato, a obrigação de regularização é do empreendedor, vez que ele utilizará o referido licenciamento. Ainda, não há previsão legal ou contratual no sentido de que seria obrigação da autora a manutenção ou a substituição dos equipamentos fornecidos em comodato. Há, por outro lado, a obrigação do autor [revendedor], em conservar os equipamentos ${ }^{46}$.

O excerto destacado denota ter sido a relação econômica - distribuição de combustível - desconsiderada na análise do contrato de comodato, uma vez que foram aplicadas diretamente as regras do Código Civil ao caso, incidindo na espécie o art. 582, segundo o qual o "[...] comodatário é obrigado a conservar, como se sua própria fora, a coisa emprestada, não podendo usá-la senão de acordo com o contrato ou a natureza dela, sob pena de responder por perdas e danos. O comodatário constituído

\footnotetext{
${ }^{46}$ Apelação Cível № 9291592-13.2008.8.26.0000, 27ำ Câmara de Direito Privado, Tribunal de Justiça de SP, Relator: Cláudio Hamilton, Julgado em 28/02/2012.
} 
em mora, além de por ela responder, pagará, até restituí-la, o aluguel da coisa que for arbitrado pelo comodante".

Nesse sentido, procedem as angústias de Vivante ao temer um "grave prejuízo ao progresso do direito comercial" decorrente das consequências de uma unificação das obrigações civis e mercantis pelo Código Civil, tendo em vista o substrato em que estava inserido aquele contrato de comodato fora totalmente desconsiderado em prol da aplicação genérica das regras civis.

Assim, ao encontrarem-se decisões, como as constantes na Tabela 2, que desconsideram a natureza da relação obrigacional subjacente e aplicam indistintamente as regras do Código Civil, conclui-se não ter a unificação legislativa do regime das obrigações correspondido à realidade dos contratos empresariais. Isso porque esses se diferenciam dos demais quanto à atividade que viabilizam, isto é, relações economicamente interessadas, para os quais as regras comerciais devem ser levadas em consideração.

${ }^{47}$ E prossegue: “Unificando os dois Códigos, formar-se-ia, provavelmente, um único Código de regras gerais, provido daquele tecnicismo jurídico que é o fruto mais vivo da atividade comercial; regras gerais que, por sua própria e mesma generalidade, formariam um guia muito vago para as decisões dos magistrados. Não se poderia renunciar àquela tormentosa atualização da matéria comercial sem atraiçoar, por amor da construção lógica, a construção realista". VIVANTE, Cesare. Introdução: Os comerciantes. Trad. Haroldo Malheiros Duclerc Verçosa. Revista de direito mercantil, industrial, econômico e financeiro, n. 102, abr.jun. 1996. p. 109. 
Os Efeitos da Unificação do Regime das Obrigações...

Tabela 2: Casos sobre a Aplicação de Regras Civis ao Contrato de Comodato quando Inserido na Relação Empresarial de Distribuição

\begin{tabular}{|l|l|l|c|} 
Tribunal & $\begin{array}{c}\text { Tipo e Número } \\
\text { do Recurso }\end{array}$ & \multicolumn{1}{c|}{ Relator } & $\begin{array}{c}\text { Data do } \\
\text { Julgamento }\end{array}$ \\
\hline TJ/RS & $\begin{array}{l}\text { Apelação Cível } \\
\text { n. } 70037890936\end{array}$ & $\begin{array}{l}\text { Des. Lúcia de Castro } \\
\text { Boller }\end{array}$ & $14 / 04 / 2011$ \\
\hline
\end{tabular}

\begin{tabular}{l|l|l|l} 
& $\begin{array}{l}\text { Apelação Cível } \\
\text { TJ. 9149514- } \\
\text { 93.2008.8.26.0000 }\end{array}$ & Des. Gomes Varjão & 04/07/2011
\end{tabular}

$\begin{array}{llll}\text { TJ/SP } & \begin{array}{l}\text { Apelação Cível } \\ \text { n. 9291592- }\end{array} & \text { Des. Claudio } & \text { 28/02/2012 } \\ & \text { 13.2008.8.26.0000 } & \text { Hamilton } & \end{array}$

\begin{tabular}{l|l|l|l} 
TJ/RS & $\begin{array}{l}\text { Apelação Cível } \\
\text { n. 70026697623 }\end{array}$ & $\begin{array}{l}\text { Des. José Francisco } \\
\text { Pellegrini }\end{array}$ & 31/03/2009 \\
\cline { 1 - 2 } TJ/RS & $\begin{array}{l}\text { Apelação Cível } \\
\text { n. } 70044548154\end{array}$ & $\begin{array}{l}\text { Des. Jorge Luiz Lopes } \\
\text { do Canto }\end{array}$ & 28/09/2011
\end{tabular}

\begin{tabular}{l|l|l|l}
\multicolumn{1}{c|}{ TJ/RJ } & Agravo de & Des. Marco Antonio & 20/05/2009 \\
& Instrumento & Ibrahim 2008.002 .12351 &
\end{tabular}

Fonte: Tabela elaborada com base nos sites $\langle$ http://www.tjrs.jus.br/site/ $>$, $<$ http://www.tjsp.jus.br/Default.aspx> e <http://www.tjrj.jus.br/>.

\subsection{Análise de Decisões Anteriores à Vigência do Código Civil de 2002}

Cabe ainda detalhar se posicionamento jurisprudencial no que concerne à identificação da obrigação subjacente como comercial, a despeito de o contrato ser civil, como ocorre no comodato inserido na relação de distribuição de derivados de 
petróleo, variou consideravelmente após a vigência do Código Civil de $2002^{48}$. Outra hipótese a ser testada, refere-se à possibilidade de o Código, no que tange ao contexto ressaltado, ter concretizado posição que já vinha sendo aplicados pelos Tribunais brasileiros.

Tendo em vista que até 1990 o mercado brasileiro não estava completamente aberto, não se encontram muitas demandas judiciais que tenham como objeto contratos firmados entre distribuidores e revendedores ${ }^{49}$, como o de comodato para distribuição de derivados de petróleo.

O julgado que melhor sintetiza o montante de casos analisados nesse item refere-se à Apelação Cível n. 33796, resenhada pelo Des. Cristiano Graeff Júnior, no Tribunal de Justiça do Rio Grande do Sul. In casu, a discussão central tocava à possibilidade de ajustar multa devido ao inadimplemento do contrato de concessão (contrato principal), ainda que esse tenha sido convencionado em instrumentos distintos, um mútuo e um comodato. A argumentação do magistrado vai ao sentido dos outros julgados analisados: uma vez que os contratos são coligados, pois visam a viabilizar a atividade de distribuição (relação econômica subjacente a todos os contratos), é lícito ajustar a multa referente ao respectivo inadimplemento.

Nesse sentido, apesar da unificação do regime das obrigações ter efetivamente ocorrido no plano legal, conclui-se a partir da leitura dos acórdãos pesquisados anteriormente à vigência do Código Civil de 2002, que a elaboração desse Diploma esteve atenta ao posicionamento jurisprudencial e

${ }_{48}$ Segue, ao final desse item, a tabela com as decisões como Tabela 3.

${ }^{49}$ AMARAL, Caroline; DELGADO, Maria. Uma análise da exclusividade nas relações contratuais entre revendedor e empresa distribuidora no mercado de combustíveis. Instituto Brasileiro de Petróleo e Gás, 2005. p. 4. Disponível em: <http://www. portalabpg.org.br/PDPetro/3/trabalhos/IBP0155_05.pdf>. Acesso em: 26 nov. 2013. 
Os Efeitos da Unificação do Regime das Obrigações...

à construção doutrinária até então. A principal contribuição do Código, portanto, foi cristalizar mediante os artigos relacionados à aplicação de princípios contratuais como a função social dos contratos, a possibilidade de reconhecimento pelo magistrado da relação obrigacional subjacente, se comercial, por exemplo, ainda que o contrato em espécie utilizado seja tipicamente civil.

Tabela 3: Casos Envolvendo o Contrato de Comodato Inserido no Contexto de Distribuição de Derivados de Petróleo antes da Vigência do Código Civil de 2002

\begin{tabular}{|l|c|c|c|} 
Tribunal & $\begin{array}{c}\text { Tipo e Número } \\
\text { do Recurso }\end{array}$ & Relator & $\begin{array}{c}\text { Data do } \\
\text { Julgamento }\end{array}$ \\
\hline TJ/RS & $\begin{array}{c}\text { Apelação Cível, } \\
\text { no } 70001639996\end{array}$ & 16ª Câmara Cível & $04 / 04 / 2001$ \\
\hline
\end{tabular}

\begin{tabular}{|c|c|c|c|}
\hline $\mathrm{TJ} / \mathrm{RS}$ & $\begin{array}{l}\text { Apelação Cível } \\
\text { n. } 590072880\end{array}$ & $\begin{array}{l}\text { Des. Celeste Vicente } \\
\text { Rovani }\end{array}$ & $11 / 12 / 1990$ \\
\hline TJDFT & $\begin{array}{l}\text { Apelação Cível } \\
\text { n. 2001.01.1.057158-0 }\end{array}$ & $5^{\text {a }}$ Turma Cível & $12 / 08 / 2002$ \\
\hline $\mathrm{TJ} / \mathrm{RS}$ & $\begin{array}{l}\text { Apelação Cível } \\
\text { n. } 33796\end{array}$ & $\begin{array}{l}\text { Des. Cristiano Graeff } \\
\text { Júnior }\end{array}$ & 09/10/1979 \\
\hline $\begin{array}{l}1^{\mathrm{o}} \mathrm{TAC} / \\
\mathrm{SP}\end{array}$ & $\begin{array}{l}\text { Agravo } \\
\text { de Instrumento } \\
\text { n. } 941.027-5\end{array}$ & Des. Álvares Lobo & 08/08/2000 \\
\hline
\end{tabular}

\begin{tabular}{llll}
$2^{\text {o }} \mathrm{TAC} /$ & $\begin{array}{l}\text { Apelação Cível } \\
\text { SP }\end{array}$ & Des. Antonio Maria & 18/08/1999 \\
\hline $\begin{array}{l}1^{\circ} \mathrm{TAC} / \\
\mathrm{SP}\end{array}$ & $\begin{array}{l}\text { Agravo } \\
\text { de Instrumento } \\
\text { n. } 808.792-2\end{array}$ & $\begin{array}{l}\text { Des. Carlos Paulo } \\
\text { Travan }\end{array}$ & 01/09/1998 \\
& & &
\end{tabular}

Fonte: Tabela elaborada com base nos sites <http://www.tjrs.jus.br/site/ $>$, $<$ http://www.tjsp.jus.br/Default.aspx> e $<$ http://www.tjr.jus.br/>. 


\section{Um Novo Código Comercial é Necessário?}

Ao refletir sobre a necessidade da formação de um corpo de leis unitário e sistematizado para alguma área do Direito, principalmente após os estudos de Natalino Irti que, se resumidos a uma palavra, seria a sua difundida expressão "decodificação" substrato histórico enseja a produção de uma nova codificação, motivado por um contexto histórico de mudança ${ }^{51}$, isto é, se há alguma particularidade histórica ou até mesmo um clamor social que justifique essa proposição.

Isso porque, historicamente no civil law, os Códigos surgem como respostas, reações a sistemas sociais, instituições e formas de governo que não mais aderem ao substrato social existente. Daí a afirmação de Van Caenegem de que

[...] [h]istoricamente, a codificação foi uma arma contra o judiciário, ou a casta da noblesse de robe, que possuía os seus cargos e invocava nebulosos princípios gerais que não

${ }^{50}$ IRTI, Natalino. L'Età della Decodificazione. 2. ed. Milano: Giuffrè, 1979. p. 33.

${ }^{51}$ Sobre o fenômeno histórico da Codificação: “La Codificación significó para la historia jurídica, y por vez primera, un brusco cambio de sentido. El detentador del poder político demostró una psicología profundamente distinta en relación con el derecho: comprendió su importancia, se atribuyó su producción, estableció un rigidísimo monopolio sobre el mismo. La experiencia jurídica, que, por lo que respecta al derecho privado, suponía efectivamente una pluralidad de ordenamientos dentro de la propia experiencia estatal, se vio obligada a coincidir con el Estado y quedó comprendida dentro de él, anquilosada". [...] “La Codificación fue todo esto también, y el historiador tiene el deber elemental de ponerlo de relieve. Lo peor, sin embargo, estaba por suceder en el plano cultural: toda esta gran operación de política del derecho que hemos llamado absolutismo jurídico, una operación de poder, históricamente relativa, de solución contingente que era propia de un juego determinado de fuerzas históricas, gracias a las potencialidades iusnaturalistas de las que se impregnó, fue proyectada hacia el paraíso de los modelos absolutos, y se convirtió en la mejor solución posible para el hoy y el mañana". GROSSI, Paolo. Absolutismo jurídico y derecho privado en el siglo XIX. Discurso para o recebimento do título "Doctor Honoris Causa" na Universidat Autònoma de Barcelona. Bellaterra, 1991. p. 13-15. 
Os Efeitos da Unificação do Regime das Obrigações...

estavam escritos em lugar nenhum. Serviu também contra os doutores da lei, que brandiam citações eruditas de livros com mil anos de idade ou de outros doutores, que enterravam a justiça sob pesados tomos, cheios de contradições e que serviam apenas para desencaminhar o homem comum ${ }^{52}$.

Mesmo que hoje em dia essa perspectiva possa ser considerada ultrapassada, a reflexão sobre a passagem supramencionada oferece elementos para discutirmos a real necessidade de um novo Código Comercial. Nesse sentido, observemos ser o principal argumento do redator do Projeto de Lei n. 1.572/11 o da necessidade de valorização do Direito Comercial, que teria "perdido sua história" com a revogação de parte substancial do Código Comercial de 1850 a partir da vigência do Código Civil de 2002.

Ora, como visto da relação de casos analisada no presente trabalho, é de se ressaltar que o Código Civil de 2002, embora tenha unificado o regime das obrigações em um único diploma, permitiu, através da técnica legislativa das cláusulas gerais e da perspectiva de ser um "código culturalista"53, a necessária dinamicidade - essencial ao Direito Comercial. Este permaneceu não só com a sua história, tendo em vista o reconhecimento da autonomia substancial do Direito Mercanti1 ${ }^{54}$, mas também com

${ }^{52}$ CAENEGEM, Raoul Charles van. Juízes, legisladores e professores: capítulos de história jurídica europeia. Trad. Luiz Carlos Borges. Rio de Janeiro: Elsevier, 2010. p. 106.

${ }^{53}$ Sobre a Codificação e a matriz culturalista do Código Civil de 2002, v. MARTINSCOSTA, Judith: "Nenhum Código provém do nada, nenhum código opera no vazio. O seu modelo sempre expressa uma reflexão e uma tomada de posição diante dos problemas do mundo - isto é, uma filosofia. As matrizes teóricas do novo Código Civil tem origem, justamente, no culturalismo de Reale, na sua concepção acerca dos modelos jurídico e da concreção, no que chama, enfim, de 'normativismo concreto'." MARTINS-COSTA, Judith. Culturalismo e experiência no novo Código Civil brasileiro. Boletim da Faculdade de Direito da Universidade de Coimbra, v. LXXVIII, 2002. p. 604.

${ }^{54}$ Sobre a tese da autonomia substancial, v. BARROS LEÃES, Luiz Gastão Paes de. A disciplina do direito de empresa no novo Código Civil brasileiro. Revista de direito mercantil, industrial, econômico e financeiro, n. 128, out./dez. 2002. p. 9: “O Código 
a possibilidade de desenvolvimento contínuo, como o reconhecimento da atipicidade dos chamados contratos comerciais.

Desta reflexão resulta não haver necessidade de uma sistematização própria para a consideração de regras intrínsecas a essa área do Direito. Isto é, uma vez que a relação jurídica subjacente é comercial, há, sim, institutos disponíveis aos magistrados que autorizam o afastamento da aplicação direta das regras civis em prol da conservação do Direito Comercial. Exemplo destes institutos é a função social dos contratos, explicitada na parte geral da disciplina dos contratos e, portanto, incidente inclusive sobre os contratos comerciais e os contratos a eles conexos.

Embora o Código Civil tenha trazido alguns problemas para o Direito Comercial, como o engessamento das sociedades limitadas, devido à excessiva burocratização e a consequente onerosidade desse tipo societário que é o mais utilizado entre os empresários, considera-se nessa análise não ser esse, de per si, um argumento capaz de ensejar a promulgação de um novo Código Comercial, que consegue trazer ainda mais problemas ${ }^{55}$.

acompanha, portanto, a tese da autonomia substancial do Direito Mercantil e adota o processo de unificação parcial do Direito Privado, na parte relativa ao Direito das Obrigações, deixando para leis esparsas as matérias que reclamam disciplina especial autônoma (in primis, falência, concorrência etc.), certo de que os institutos do chamado Direito Comercial, estejam normatizados em um Código único, conjuntamente com os de Direito Civil, ou incorporados a legislações extravagantes, sempre serão substancialmente distintos dos do Direito Civil, posto que informados por princípios próprios".

${ }^{55}$ Apenas para não passar em branco, visto que não é o objetivo central deste artigo, alguns dos muitos defeitos do Projeto de Lei: (i) consegue retroceder duzentos anos ao usar um conceito formal para considerar quem é empresário ("Art. 9o․ Empresário é quem, sendo pessoa física ou sociedade, está inscrito como tal no Registro Publico de Empresas.), revivendo o art. $4^{\circ}$ do Código Comercial de 1850; (ii) no art. $4^{\circ}$, o Projeto enumera uma lista de "princípios gerais" que informam todo o Código ("Art. 4․ São princípios gerais informadores das disposições deste Código: I - Liberdade de iniciativa; II - Liberdade de competição; e III - Função social da empresa."). Todavia, no art. $8^{\circ}$, afasta a aplicação de todo e qualquer 


\title{
Considerações Finais
}

\begin{abstract}
Apesar de o Código Civil de 2002 ter concretizado uma vocação histórica do Direito brasileiro ao unificar o regime das obrigações ${ }^{56}$, isso não promoveu a absorção do Direito Comercial pelo Direito Civil, uma vez que para haver justiça, no sentido da razoabilidade das decisões nas relações comerciais, é necessária a aplicação de regras adequadas à realidade dos contratos empresariais.
\end{abstract}

Disso decorre, como visto da análise dos acórdãos supracolacionados, a constatação de que na prática houve a manutenção da autonomia científica do Direito Comercial, uma

princípio ("Art. $8^{\circ}$. Nenhum princípio, expresso ou implícito, pode ser invocado para afastar a aplicação de qualquer disposição deste Código ou da lei.). (iii) reputa ao Ministério Público a possibilidade de anulação de qualquer negócio jurídico, caso não cumpra a função social ("Art. 317. O Ministério Publico e os demais legitimados podem pleitear a anulação do negócio jurídico, provando o descumprimento da função social. $\S 1^{\circ}$ Os contratantes podem, em sua resposta, apresentar ao juiz proposta de alteração do contrato, que assegure, reforce ou reestabeleça o cumprimento da função social. Caso a proposta seja aceita pelo juiz, a ação será extinta sem julgamento de mérito e sem condenação sucumbencial. $\S 2^{\circ} \mathrm{O}$ juiz poderá rejeitar o pedido de anulação, se considerar que o contrato empresarial implicou, ou pode implicar, benefícios para algum interesse coletivo, difuso ou individual homogêneo, superiores ao prejuízo apontado. $\S 3^{\circ}$ Se acolher pedido de indenização, o juiz distribuirá a obrigação entre os contratantes, proporcionalmente ao proveito que cada um deles obteria do contrato anulado.").

56 "Confessadamente inspirado no Código Civil italiano de 1942, a ponto de repetir alguns artigos do Código peninsular relativos à disciplina da empresa (inserida no Capítulo relativo ao Direito do Trabalho), o novo Código mostra-se fiel à longa tradição do Direito brasileiro, consagrando a ideia da unificação da matéria obrigacional e inscrevendo no âmbito do Direito das Obrigações a disciplina do Direito das Empresas, considerado como um desdobramento imediato e natural daquele. De fato, a unificação das obrigações no Direito brasileiro já se mostrava praticamente instaurada em nosso meio, em pleno Império, desde o seu primeiro monumento legislativo, ou seja, o Código Comercial de 1850, cujo art. 121 estabelecia, faz mais de 150 anos, que, salvo modificações e restrições nele estabelecidas, 'as regras e disposições do Direito Civil para os contratos em geral são aplicáveis aos contratos comerciais'". BARROS LEÃES, Luiz Gastão Paes de. A disciplina do direito de empresa no novo Código Civil brasileiro. Revista de direito mercantil, industrial, econômico e financeiro, n. 128, out./dez. 2002. p. 7. 
vez que a desconsideração da relação obrigacional subjacente ocasiona decisões injustas sob o ponto de vista do ordenamento jurídico vigente.

Para chegar a essa conclusão, o grupo de casos analisados exigiu corte metodológico considerável, na medida em que circunscreveu a análise das decisões aos casos envolvendo discussão a respeito do contrato de comodato inserido na relação de distribuição de produtos derivados de petróleo. Como bem ressaltou o Professor Arnoldo Wald, no seu parecer publicado que inspirou a elaboração deste trabalho, "[...] evidencia-se a relação entre os vários contratos, pois uns se referem aos outros, complementando-se reciprocamente, havendo, na realidade, um único negócio, embora concretizado em vários instrumentos". Ao passo que "[...] o contrato de financiamento contém cláusula obrigando o financiado a assinar o contrato de comodato, e este estipula que o comodatário só poderá utilizar os equipamentos para medir, guardar, vender e anunciar os produtos da financiadora, que é também a comodante (distribuidora)" ${ }^{\prime 57}$.

Nessa perspectiva, a justificativa para essa operação está justamente na complexidade dos contratos empresariais, que revelam a necessidade de um estudo aprofundado em cada caso concreto. A guisa de exemplo, o feito pelo Des. Kioitsi Chicuta, do Tribunal de Justiça de São Paulo, ao temperar o art. 582, do Código Civil, entendendo a relação empresarial subjacente ao contrato de comodato, e não aplicando literalmente a regra de que o comodante não tem responsabilidade sobre o uso do bem dado em comodato:

Assim, tendo em vista se tratar de comodato de tanques e bombas para armazenamento e venda de produtos combustíveis e, considerando os termos do contrato firmado, a

${ }^{57}$ WALD, Arnoldo. Os contratos de concessão exclusiva para distribuição de gasolina no direito brasileiro. Estudos e pareceres de direito comercial: problemas comerciais e fiscais da empresa contemporânea. $2^{\underline{a}}$ série. São Paulo: Revista dos Tribunais, 1979. p. 182. 
Os Efeitos da Unificação do Regime das Obrigações...

revendedora tinha o uso privativo, todavia a manutenção e reparação era de responsabilidade da distribuidora. Ademais, diante da constatação de problemas com os tanques ou sua instalação, deveria a apelante providenciar a necessária substituição, até porque proibida a comodatária de removê-los, de acordo com a disposição contratual. Vale salientar que, nos termos do pactuado, a Esso se comprometeu a emprestar ao revendedor os equipamentos e utensílios de sua propriedade, necessários e suficientes ao satisfatório funcionamento do estabelecimento, o que equivale afirmar que a apelante deveria fornecer o suporte necessário e manutenção adequada ao funcionamento da revendedora, logo, tendo a CETESB exigido a troca dos equipamentos que causaram a alegada contaminação ambiental, não vinga o argumento da apelante acerca da desnecessidade da substituição dos equipamentos, até porque pleiteada sua troca dentro do prazo determinado no contrato. ${ }^{58}$

Entretanto, é relevante afirmar que esse movimento legislativo do Código Civil de 2002 não teve o intuito de absorver o direito comercial ${ }^{59}$. Daí a importância de compreender-se a necessidade da análise da função social e econômica dos contratos empresariais, visto que essa é uma ferramenta que o próprio Código dispõe, na Parte Geral dos Contratos, para interpretação e aplicação de regras.

Ao entender a função social e econômica do contrato como sendo a finalidade típica negocial que aquele contrato pretende desenvolver, dependendo do contexto socioeconômico em que está inserido, pode-se aplicar com mais razoabilidade as normas de direito material ${ }^{60}$. Isso ocorre no caso do contrato de

\footnotetext{
${ }^{58}$ Apelação Cível n. 0136880-49.2007.8.26.0100.

59 “Não há, pois, que falar em unificação do Direito Privado, a não ser em suas matrizes, isto é, com referência aos institutos básicos". REALE, Miguel. Exposição de Motivos. Diário do Congresso Nacional (Seção I) Suplemento 14.09.1983. p. 98.

60 "Penso que assim ocorre porque o Código configura um sistema aberto e móvel, sendo dotado das válvulas de abertura axiologicamente orientadas. Daí que o Código enseja ao intérprete/aplicador do Direito o dever, e a responsabilidade de
} 
comodato inserido no contexto da atividade de distribuição de derivados de petróleo, uma vez que não cabe exclusivamente ao comodatário os riscos e prejuízos dessa contratação, tendo em vista o incontestável entrosamento entre os instrumentos (contratos de financiamento para a construção de postos, de comodato de tanques e de bombas e de promessa de compra e venda para revenda de quantidades mínimas de derivados de petróleo), pois, a partir da assinatura do primeiro, os outros dois decorrem obrigatoriamente, sob pena de responsabilidade civil ${ }^{61}$.

Todavia, não decorre puramente da função social e econômica do contrato a necessidade de adimplir as obrigações acessórias ao contrato de comodato de equipamentos para a distribuição de combustíveis. Nesse sentido, como mencionado anteriormente, é a teoria da coligação contratual que sustenta a extensão dos efeitos jurídicos para aqueles contratos "conexos" ao contrato principal, isso porque há uma "união com dependência", na qual os "[...] contratos completam-se, formando, no caso de dependência bilateral, uma unidade econômica"62.

Por isso a importância de utilizar o próprio Código Civil para fins de aplicação das normas, uma vez que, se não se pode ignorar a unificação, também não é possível afastar a autonomia do Direito Comercial, tanto que a maioria das decisões colacionadas e aqui apresentadas consideraram que, ao contrato de

formular, a cada caso, a estatuição, para o que deve percorrer o ciclo do reenvio, buscando em outras normas do sistema ou em valores e padrões extra-sistemáticos, os elementos que possam preencher e especificar a moldura vagamente desenhada na cláusula geral". MARTINS-COSTA, Judith. Culturalismo e experiência no novo Código Civil brasileiro. Boletim da Faculdade de Direito da Universidade de Coimbra, v. LXXVIII, 2002. p. 625.

${ }^{61}$ WALD, Arnoldo. Os contratos de concessão exclusiva para distribuição de gasolina no direito brasileiro. Estudos e pareceres de direito comercial: problemas comerciais e fiscais da empresa contemporânea. $2^{\underline{a}}$ série. São Paulo: Revista dos Tribunais, 1979. p. 183.

${ }^{62}$ MARINO, Francisco Paulo De Crescenzo. Contratos Coligados no Direito Brasileiro. São Paulo: Saraiva, 2009. p. 94. 
Os Efeitos da Unificação do Regime das Obrigações...

comodato inserido na relação de distribuição de derivados de petróleo, não podem ser aplicadas indistintamente as regras que lhe cabem por força do Código Civil, sob pena de afastar a incidência de regras do Direito Comercial justamente numa relação tipicamente comercial, que é naturalmente distinta das premissas civis, como o caso de privilégio do credor, nas relações comerciais, em oposição ao privilégio do devedor (favor debitoris), nas relações civis.

Nesse contexto, após o período de dez anos de aplicação do Código Civil de 2002, podemos concluir que, em relação à centenária discussão a respeito da dicotomia Direito Civil Direito Comercial, apenas houve uma "mudança nas vestes", no sentido da escolha de um novo critério para a caracterização do que é, agora, empresarial. Isso atesta a autonomia substancial do Direito Comercial, sendo a unificação formal apenas 364 jurídico brasileiro.

Além disso, a análise de casos anteriores à vigência do Código Civil de 2002 demonstra que a unificação não alterou substancialmente a lente que a maioria dos magistrados utilizava para entender o contrato de comodato na relação de distribuição de derivados de petróleo. Para eles, o comodato não desempenhava seu típico papel (como contrato civil), mas sim como contrato necessário para o sucesso da atividade empresarial, devendo suas regras ser interpretadas a partir de um temperamento comercial. No Código vigente, essa possibilidade foi consagrada através do princípio da função social dos contratos, que permite a identificação da obrigação principal através da leitura da relação econômica subjacente àquela operação comercial.

Por essa razão, um novo Código Comercial que tenha como principal argumento a necessidade de resgatar a autonomia do Direito Comercial não recebe respaldo histórico para 
sua promulgação, nem mesmo tem clamor social para sua redação. Por essa razão, o novo Código Comercial apresentado no Projeto de Lei n. 1.572, de 2011 mais se assemelha a um retalho de artigos muitas vezes sem coerência e coesão, porque desvinculado de uma mudança social que albergue sua edição.

\section{Referências}

AMARAL, Caroline; DELGADO, Maria. Uma análise da exclusividade nas relações contratuais entre revendedor e empresa distribuidora no mercado de combustíveis. Instituto Brasileiro de Petróleo e Gás, 2005. Disponível em: <http://www.portalabpg.org.br/PDPetro/3/trabalhos/ IBP0155_05.pdf >. Acesso em: 26 nov. 2013.

ASCARELLI, Tullio. Origem do direito comercial. Trad. e notas de Fabio Konder Comparato. Revista de direito mercantil, industrial, econômico e financeiro, nova série, v. 35, n. 103, p. 87-100, jul./set. 1996.

BARROS LEÃES, Luiz Gastão Paes de. A disciplina do direito de empresa no novo Código Civil brasileiro. Revista de direito mercantil, industrial, econômico e financeiro, n. 128, p. 7-13, out./dez. 2002.

BEVILÁQUA, Clóvis. Direito das obrigações. Rio de Janeiro: Freitas Bastos, 1936.

BOBBIO, Norberto. Dalla struttura alla funzione. Milano: Edizioni di Comunità, 1977.

BRANCO, Gerson Luiz Carlos. Função Social dos Contratos: interpretação à luz do Código Civil. São Paulo: Saraiva, 2009.

. O regime obrigacional unificado do Código Civil brasileiro e seus efeitos sobre a liberdade contratual. A compra e venda como modelo jurídico multifuncional. Revista dos Tribunais, a. 97, v. 872, p. 11-42, jun. 2008.

CAENEGEM, Raoul Charles van. Juízes, legisladores e professores: capítulos de história jurídica europeia. Trad. Luiz Carlos Borges. Rio de Janeiro: Elsevier, 2010.

CALDEIRA, Jorge. Mauá, Empresário do Império. São Paulo: Companhia das Letras, 1995. 
Os Efeitos da Unificação do Regime das Obrigações...

CARVALHO, Orlando de. Teixeira de Freitas e a unificação do direito privado. Boletim da Faculdade de Direito de Coimbra, n. 60, p. 1-86, 1984.

ESTRELLA, Hernani. Comercialização do Direito Civil. Revista Forense, n. 185, 1957.

FERREIRA COELHO. Código Civil dos Estados Unidos do Brasil. vol. I (Formação do Direito Escrito). n. 613. Rio de Janeiro: Oficinas Gráficas do "Jornal do Brasil", 1920.

FERREIRA, Waldemar. A História do Direito nos Cursos Jurídicos do Brasil. Revista da Faculdade de Direito da USP, São Paulo, v. XLV, "Fascículo em honra do Professor Waldemar Ferreira", p. 429-446, 1950.

FORGIONI, Paula A. O posicionamento dos Tribunais perante os contratos de distribuição (1980-2000). EAESP/FGV/NPP - Núcleo de Pesquisas e Publicações. Disponível em: <http://gvpesquisa.fgv.br/sites/ gvpesquisa.fgv.br/files/publicacoes/Rel\%2043-2001.pdf >. Acesso em: 2 ago. 2012.

. A unicidade do regramento jurídico das sociedades limitadas e o art. 1.053 do CC. Usos e costumes e regência supletiva. Revista de 366 Direito Mercantil, v. 147, p. 7-12, jul./set. 2007.

GROSSI, Paolo. Absolutismo jurídico y derecho privado en el siglo XIX. Discurso para o recebimento do título "Doctor Honoris Causa" na Universidat Autònoma de Barcelona. Bellaterra, 1991.

. O Ponto e a Linha. História do Direito e Direito Positivo na Formação do Jurista do Nosso Tempo. Tradução de Mônica Sol Glik. Revista Sequencia, n. 51, p. 31-45, dez. 2005.

HESPANHA, António Manuel. Panorama histórico da cultura jurídica europeia. Lisboa: Publicações Europa-America, 1997.

IRTI, Natalino. L'Età della Decodificazione. 2. ed. Milano: Giuffrè, 1979. JUNQUEIRA DE AZEVEDO, Antônio (Org.). Princípios do Novo Código Civil Brasileiro e Outros Temas: homenagem a Tullio Ascarelli. São Paulo: Quartier Latin, 2008.

KONDER, Carlos Nelson. Contratos Conexos: Grupos contratuais, redes contratuais e contratos coligados. Rio de Janeiro: Renovar, 2006.

MAC-DONALD, Norberto da Costa Caruso. A unificação do direito das obrigações no novo código civil. Revista Síntese de Direito Civil e Processual Civil, Porto Alegre, v. 4, n. 20, p. 27-40, nov./dez. 2002. 
MACHADO DE ASSIS, Joaquim Maria. Memórias Póstumas de Brás Cubas. Literatura Luso-Brasileira. Rio de Janeiro: Editora Dicopel, 1942. p. 199.

MARCONDES, Sylvio. Problemas de Direito Mercantil. São Paulo: Max Limonad, 1970.

MARINO, Francisco Paulo De Crescenzo. Contratos Coligados no Direito Brasileiro. São Paulo: Saraiva, 2009.

MARTINS-COSTA, Judith. Culturalismo e experiência no novo Código Civil brasileiro. Boletim da Faculdade de Direito da Universidade de Coimbra, v. LXXVIII, p. 603-607, 2002.

. O regime dos juros no novo direito privado brasileiro. Revista da AJURIS, Porto Alegre, v. 34, n. 105, p. 237-264, mar. 2007.

MIRAGEM, Bruno N. B. Do direito comercial ao direito empresarial. Formação histórica e tendências do direito brasileiro. Revista de Direito Privado, v. 5, n. 17, p. 71-98, jan./mar. 2004.

MOREIRA ALVES, José Carlos. A Unificação do Direito Privado Brasileiro - de Teixeira de Freitas ao Novo Código Civil. In: JUNQUEIRA DE AZEVEDO, Antônio (Org.). Princípios do Novo Código Civil Brasileiro e Outros Temas: homenagem a Tullio Ascarelli. São Paulo: Quartier Latin, 2008.

NONATO, Orozimbo; AZEVEDO, Philadelpho; GUIMARÃES, Hahnemann. Anteprojeto de Código de Obrigações (Parte Geral), n. 2, 1941.

PEREIRA DA SILVA, Caio Mário. A unidade do direito obrigacional. Revista Forense, v. 97, p. 5.

REALE, Miguel. Exposição de Motivos. Diário do Congresso Nacional (Seção I) Suplemento 14.09.1983.

. O Projeto de Código Civil: situação atual e seus problemas fundamentais. São Paulo: Saraiva, 1986.

. Visão geral do novo Código Civil. Jus Navigandi, Teresina, ano 7, n. 54, 1 fev. 2002. Disponível em: <http://jus.com.br/revista/ texto/2718>. Acesso em: 13 dez. 2011.

RIBEIRO, Joaquim de Sousa. O Problema do Contrato: as Cláusulas Contratuais Gerais e o Princípio da Liberdade Contratual. Coimbra: Almedina, 2003. 
Os Efeitos da Unificação do Regime das Obrigações...

SANSEVERINO, Paulo de Tarso. Contratos Nominados II. 2. ed. São Paulo: Revista dos Tribunais, 2011.

SZTAJN, Raquel. Notas sobre o conceito de empresário e empresa no código civil brasileiro. Revista Pensar, UNIFOR, Fortaleza, v. 11, p. 192-202, fev. 2006.

Codificação, decodificação, recodificação: a empresa no Código Civil Brasileiro. Revista de Direito Mercantil, v. 143, p. 11-20, jul./set. 2006.

VIVANTE, Cesare. Introdução: Os comerciantes. Trad. Haroldo Malheiros Duclerc Verçosa. Revista de direito mercantil, industrial, econômico e financeiro, n. 102, abr./jun. 1996.

WALD, Arnoldo. Os contratos de concessão exclusiva para distribuição de gasolina no direito brasileiro. Estudos e pareceres de direito comercial: problemas comerciais e fiscais da empresa contemporânea. $2^{2}$ série. São Paulo: Revista dos Tribunais, 1979.

Submissão: 30/09/2013

Aceito para Publicação: 25/12/2013 


\section{Parâmetros Racionais}

\section{de Aferição do Real Conteúdo} das Hipóteses que Ensejam o Julgamento Monocrático do Art. 557 do Código de Processo Civil Brasileiro à Luz do Princípio da Colegialidade

Rational Parameters of Measurement of the Real Content of the Hypotheses that Give Rise to the Monocratic Judgment of the Brazilian Code of Civil Procedure Article 557 in the Light of the Principle of Collegiality

Ludmilla Camacho Duarte Vidal

Resumo: O presente estudo propõe uma imersão nos fundamentos inerentes ao princípio da colegialidade, destacando sua natureza jurídica de norma constitucional implícita em caso de inconformismo e, portanto, passível de ponderação com outras garantias constitucionais, com o fito de demonstrar que as hipóteses que ensejam o julgamento monocrático, notadamente aquelas previstas no artigo 557, caput, do CPC, padecem de melhor hermenêutica. Procede-se à superação dos conceitos jurídicos indeterminados veiculados pelo dispositivo, com ênfase na terminologia jurisprudência dominante, face à dificuldade contemporânea de estabelecer o seu real conteúdo, bem assim o modo de aferi-la no caso concreto; atentando-se, ainda, para a nova metodologia trazida pelo Código de Processo Civil projetado.

\footnotetext{
* Universidade Federal de Juiz de Fora.
} 
Parâmetros Racionais de Aferição do Real Conteúdo...

Palavras-chave: Ampliação dos Poderes do Relator. Art. 557 do CPC. Princípio da Colegialidade. Manifesta Improcedência. Jurisprudência Dominante.

Abstract: The present article proposes a deepening of the fundamentals inherent to the principle of collegiality, highlighting its juridical nature of an implied constitucional norm in cases of nonconformity and, therefore, subject to balancing with other constitutional guarantees in order to show that the hypothesis which allows the monocratic trial by the judge rapporteur, notedly those established in Article 557 of the Civil Process Code, need better hermeneutics. It proceeds to overcome the indeterminate legal concepts contained in the norm, with emphasis on the prevailing jurisprudence terminology, due to the contemporary difficulty of establishing its real content, as well as the way to measure it in an individual case; it pays attention, furthermore, to the new methodology brought by the Code of Civil Procedure drafted.

Keywords: Expansion of the Powers of the Judge Rapporteur. Article

370557 of the Civil Process Code. Principle of Collegiality. Manifestly Unfounded. Prevailing Jurisprudence.

\section{Introdução}

É cediço que o sistema recursal brasileiro se descortina num dos principais agentes causadores da morosidade do aparato de prestação jurisdicional, frente à impossibilidade, na atual conjuntura, de a máquina judiciária atender às múltiplas pretensões que lhe são requeridas a todo tempo, aliado ao momento de transição em que a civil law começa a se valer de mecanismos processuais solidificados pela common law, como o notório e crescente prestígio aos precedentes judiciais. A conjugação destes fatores desencadeou inúmeras reformas iniciadas desde a década de noventa, voltadas para a garantia fundamental da construção de um instrumento processual acessível a todos, com respostas tempestivas e resultados justos. 
Nesse rumo, flagrante foi o advento de alterações legislativas no sentido de otimizar o julgamento dos recursos perante os tribunais, como, verbi gratia, a criação da súmula vinculante, a repercussão geral em sede de recurso extraordinário, o julgamento dos recursos por amostragem e, notadamente, a considerável ampliação dos poderes do relator para exercer, em hipóteses previstas na legislação, o juízo de mérito nos recursos, desde que reservada a possibilidade de impugnação desta decisão por meio da interposição do agravo interno ao órgão colegiado, o qual seria competente para o julgamento do recurso inaugural.

No mesmo panorama, as Leis n. 9.139/1995 e 9.756/1998 foram responsáveis pelo ajuste do art. 557 do CPC aos moldes da tendência anteriormente demonstrada, a qual já vinha sendo prevista em diplomas normativos esparsos, como na Lei Orgânica da Magistratura Nacional; no Regimento Interno do Supremo Tribunal Federal (RISTF) - art. 21, §2º com redação atribuída pela Emenda Regimental 2/85 -, bem como no Regimento Interno do Superior Tribunal de Justiça (RISTJ) art. 34, XVIII. $^{1}$

Com o advento da reforma traçada pela Lei n. 9.756/1998, manteve-se a redação do caput do art. 557 do CPC, sendo inserido o $\S 1^{\circ} \mathrm{A}$ ao art. 557 do $\mathrm{CPC}$; e como uma dentre outras providências de atribuir legitimidade à decisão singular, fez por bem o legislador ao disponibilizar a possibilidade de interposição do agravo interno à parte detentora de interesse recursal, nos termos do art. 557, $\S 1^{1}$ do CPC, fazendo com que a última palavra pertença ao juiz natural do recurso, que é sempre o órgão colegiado.

1 CIANCI, Mirna. A Lei 9.756/1988 (arts. 544, $3^{\circ}$ e 557, $\S \S 1^{\circ}$ A e $3^{\circ}$ do CPC) e a ampliação dos poderes do relator - dez anos depois. Revista dos Tribunais, São Paulo, n. 157, março 2008. p. 165. 
Parâmetros Racionais de Aferição do Real Conteúdo...

A pesquisa em questão mostra-se necessária neste momento processual em que, passados mais de quatorze anos da edição da Lei n. 9.756/1998, as hipóteses que ensejam o julgamento monocrático do art. 557 do CPC ainda requerem a fixação de parâmetros racionais de compreensão e balizamento, que será efetivada após a superação dos conceitos jurídicos indeterminados veiculados pela norma, sobretudo, jurisprudência dominante e manifestamente improcedente; bem como pela demonstração da postura mais adequada do magistrado singular na oportunidade em que não provê o recurso manifestamente improcedente e não conhece da pretensão recursal destoante de entendimento sumulado ou da tese jurídica dominante do tribunal local, Supremo Tribunal Federal (STF) ou Tribunal Superior (STJ).

Outrossim, no presente momento de finalização do trâmite do Novel Código perante o Plenário do Congresso Nacional, a questão posta ainda se torna mais séria frente aos anseios da sociedade por uma nova codificação, hábil a propiciar, nas palavras de Luiz Fux², “[...] um processo mais ágil, capaz de dotar o país de um instrumento que possa enfrentar de forma célere, sensível e efetiva, as misérias e as aberrações que passam pela Ponte da Justiça". Será que mais uma vez, sob o argumento de atribuir celeridade aos feitos, o princípio da colegialidade será comprometido? Qual a melhor técnica a ser empreendida para que, além da limitação do âmbito de incidência do caput

2 FUX, Ministro Luiz. Carta de encaminhamento do Anteprojeto do Novo Código de Processo Civil ao Senado Federal. Anteprojeto do Código de Processo Civil. Brasil. Congresso Nacional. Senado Federal: Presidência da República. Brasília, 2010. Disponível em: $<$ http://www.senado.gov.br/senado/novocpc/pdf/anteprojeto.pdf $>$. Acesso em: 8 maio 2013. 
do art. 557 do atual CPC, possa se contribuir para a eficácia da norma ${ }^{3}$ prevista pela nova legislação que se desponta?

\section{Princípio da Colegialidade}

Inicialmente, cumpre investigar a natureza jurídica do princípio da colegialidade, e, por conseguinte, de onde são emanados seus fundamentos racionais axiológicos, tal como os dispositivos que lhe dão suporte. Será o princípio da colegialidade uma garantia fundamental? Poderá sofrer ponderação com outros princípios constitucionais? Até que ponto poderá ser restringido? Buscando responder as duas primeiras indagações levantadas, sendo certo que a última será enfrentada mais adiante, recorre-se inicialmente ao princípio da separação dos Poderes, uma das garantias mais importantes à estrutura da

3 Registra-se que o PLS no . 166/2010 trata da implementação do novo código, tendo como relator geral o Senador Valter Pereira. O projeto revisado na Câmara dos Deputados, correspondente ao PL n⿳. 8.046/2010, de relatoria do Deputado Paulo Teixeira, obteve aprovação do seu texto-base pelo plenário da Câmara em 05 de novembro de 2013, adquirindo a presente redação: “Art. 945. Incumbe ao relator: [...] III - não conhecer de recurso inadmissível, prejudicado ou que não tenha impugnado especificamente os fundamentos da decisão recorrida; IV - negar provimento a recurso que for contrário a: a) súmula do Supremo Tribunal Federal, do Superior Tribunal de Justiça ou do próprio tribunal; b) acórdão proferido pelo Supremo Tribunal Federal ou pelo Superior Tribunal de Justiça em julgamento de recursos repetitivos; c) entendimento firmado em incidente de resolução de demandas repetitivas ou de assunção de competência. V - depois de facultada, quando for o caso, a apresentação de contrarrazões, dar provimento ao recurso se a decisão recorrida for contrária a: a) súmula do Supremo Tribunal Federal, do Superior Tribunal de Justiça ou do próprio tribunal; b) acórdão proferido pelo Supremo Tribunal Federal ou pelo Superior Tribunal de Justiça em julgamento de recursos repetitivos; c) entendimento firmado em incidente de resolução de demandas repetitivas ou de assunção de competência [...] Parágrafo único. Antes de considerar inadmissível o recurso, o relator concederá o prazo de cinco dias ao recorrente para que seja sanado vício ou complementada a documentação exigível". Disponível em: <http://s.conjur.com.br/dl/minuta-cpc-votada-camara. pdf>. Acesso em: 30 nov. 2013. 
Parâmetros Racionais de Aferição do Real Conteúdo...

atual organização política, destacando-se os ensinamentos de Gilmar Ferreira Mendes ${ }^{4}$, no sentido de reconhecer que tal norma-princípio consiste no alicerce básico inerente ao Estado de Direito:

O princípio da separação dos poderes adquiriu o status de uma forma que virou substância no curso do processo de construção e de aprimoramento do Estado de Direito, a ponto de servir de pedra de toque para se dizer da legitimidade dos regimes políticos, como se infere do célebre artigo XVI da Declaração dos Direitos do Homem e do Cidadão, de 1789, onde se declara que não tem constituição aquela sociedade em que não estejam assegurados os direitos dos indivíduos, nem separados os poderes estatais. Na Constituição do Brasil, esse princípio que está estampado no seu art. $2^{\circ}$, onde se declara que são Poderes da União - independentes e harmônicos - o Legislativo, o Executivo e o Judiciário, é de tamanha importância que possui o status de cláusula pétrea, imune, portanto, a emendas, reformas ou revisões que tentem aboli-lo da Lei Fundamental. (Grifos nossos).

O princípio da separação dos Poderes, consagrado pelas ideias preconizadas por Montesquieu no Século das Luzes, notadamente, em sua obra $O$ Espírito das Leis, possui duas dimensões complementares ${ }^{5}$, apontadas por J. J. Gomes Canotilho ${ }^{6}$ : 1. a separação como "divisão", "controle" e "limite" do poder - dimensão negativa; 2 . a separação como "constitucionalização", "ordenação" e "organização" do poder do Estado tendente a decisões funcionalmente eficazes e materialmente justas (dimensão positiva). A sutileza retórica reside no arremate entre a separação e a independência dos Poderes e a colegialidade,

4 BRANCO, Paulo Gustavo Gonet; COELHO, Inocêncio Mártires; MENDES, Gilmar Ferreira. Curso de Direito Constitucional. 4. ed. São Paulo: Saraiva, 2009. p. 177-178.

5 CARVAlHO FILHO, José dos Santos. Manual de Direto Administrativo. 23. ed. Rio de Janeiro: Lumen Juris, 2010. p. 3.

6 CANOTILHO, J. J. Gomes. Direito Constitucional e Teoria da Constituição. Coimbra: Almedina, 2007. p. 251-252. 


\title{
justamente por esta consagrar aquela ${ }^{7}$, questão trazida por Diogo Ferraz Lemos Tavares $^{8}$ e merecedora de realce:
}

\begin{abstract}
A Colegialidade indica a necessidade de que, tanto quanto possível, os julgamentos sejam tomados por mais de uma pessoa, obviamente em número ímpar para se evitar dissensos ou atribuições arbitrárias de maior peso a um dos julgadores. Tal necessidade é justificada por motivos tão singelos quanto poderosos, que encerram o seguinte círculo virtuoso: (a) um órgão colegiado está menos sujeito a pressões externas (provenientes de outro órgão de poder, por exemplo) do que uma única pessoa; (b) essa blindagem frente às pressões torna o órgão judicante mais independente $e$ autônomo, pois as suas decisões, ainda que contrárias a interesses poderosos - mas não agasalhados pelo ordenamento jurídico -, não lhe ensejarão represálias; (c) tais independência e autonomia tornam possível que o órgão colegiado paute suas decisões apenas e tão somente no ordenamento jurídico, ou seja, naquilo que aquele órgão considere como a solução verdadeiramente justa para o caso, e não em determinações impostas por terceiros ou mesmo por uma das partes; (d) todos esses fatores, aliados ao fato de que é mais provável que a melhor solução surja no debate plural do que na imposição unipessoal, incutem nos cidadãos-partes a confiança no sistema e a ideia de que a solução emanada do órgão colegiado, ainda que lhe seja contrária, surgiu exclusivamente da análise do caso concreto à luz do ordenamento jurídico, e não em razão da vontade de um dos envolvidos, o que contribui para o reconhecimento e aceitação social daquelas decisões, imprescindíveis para o funcionamento da sociedade. (Grifos nossos).
\end{abstract}

7 COHENDET, Marie-Anne. La Collégialité des Juridictions: un principe en voie de disparition. Revue Française de Droit Constitutionnel, Paris, n. 68, 2006. p. 713-735, apud MENDONÇA, Henrique Guelber de. O princípio da colegialidade e o papel do relator no processo civil brasileiro. Revista Eletrônica de Direito Processual, Rio de Janeiro, 1. ed., out. 2007. Disponível em: <http://www.redp.com.br/arquivos/ redp_1a_edicao_rj.pdf $>$. Acesso em: 10 jun. 2013.

8 TAVARES, Diogo Ferraz Lemos. Princípio da Colegialidade: fundamento constitucional e necessidade de sua observância nos processos judiciais e administrativos - legitimidade/ilegitimidade de exceções. Revista Eletrônica de Direito Processual, Rio de Janeiro, a. 5, v. VIII, jul. 2011. Disponível em: <http://www.redp.com.br/ arquivos/redp_8a_edicao.pdf $>$. Acesso em: 8 jul. 2013. 
Parâmetros Racionais de Aferição do Real Conteúdo...

Entrementes, registra-se que além do respaldo demonstrado anteriormente, a colegialidade também decorre da garantia dada ao jurisdicionado em receber uma tutela justa e adequada aos princípios balizadores do devido processo legal. $\mathrm{O}$ direito ao processo justo ${ }^{9}$ - giusto processo ${ }^{10}$, fair trial - é assegurado de forma expressa pela Carta Republicana, conforme depreende-se da redação do art. 5을 incisos XXXV, LV, LXXVIII.

Portanto, preciosa é a compreensão de que os cuidados dedicados pelo legislador originário ao princípio da colegialidade provêm, certamente, da conjugação entre a máxima da Separação e Independência tripartite dos Poderes, aliada à garantia constitucional da tutela justa e efetiva, sendo este último o cerne de todo o Processo Civil cuja função consiste, em última análise, na concretização do acesso à ordem jurídica justa ${ }^{11}$. Observa-se que o direito ao processo justo e efetivo $^{12}$ deverá comportar os juízos de proporcionalidade

\footnotetext{
9 "O direito ao processo justo visa a assegurar a obtenção de uma decisão justa. Ele é o meio pelo qual se exerce pretensão à justiça (Justizanspruch) e pretensão à tutela jurídica (Rechtsschutzanspruch). Esse é o seu objetivo central dentro do Estado Constitucional" (MITIDIERO, Daniel. Direito Fundamental ao processo justo. p. 5. Disponível em: $<$ http://www.rkladvocacia.com/arquivos/artigos/art_srt_arquivo20130419164953.pdf >. Acesso em: 28 nov. 2013.)

No mesmo sentido: OLIVEIRA, Carlos Alberto Alvaro de. Os Direitos Fundamentais à Efetividade e à Segurança em Perspectiva Dinâmica. p. 2-25. Disponível em: <http:// www.oab.org.br/editora/revista/users/revista/1222961767174218181901.pdf $>$. Acesso em: 20 nov. 2013

${ }^{10}$ A observação do direito ao processo justo consiste em condição necessária e indispensável para obtenção de decisões justas (TARUFFO, Michele. Idee per una Teoria della Decisione Giusta, Sui Confini - Scritti sulla Giustizia Civile. Bologna: Il Mulino, 2002. p. 224, apud MITIDIERO, Daniel. Op. cit., p. 5.)

${ }^{11}$ Não é suficiente que o ordenamento jurídico garanta a igualdade formal dos homens perante a lei quando as partes não puderem participar, em igualdade de condições, do complexo aparato de tutela de direitos que é o processo (CAPPELLETTI, Mauro; GARTH, Bryant. Acesso à Justiça. Tradução de Ellen Gracie Northfleet. Porto Alegre: Fabris, 1988, reimpresso em 2002.).

12 "Processo efetivo é aquele que, observado o equilíbrio entre os valores segurança e celeridade, proporciona às partes o resultado desejado pelo Direito material. Pretende-se aprimorar o instrumento estatal destinado a fornecer a tutela
} 
e razoabilidade ${ }^{13}$ e, é justamente este viés inexoravelmente axiológico o responsável pelo enquadramento da colegialidade como norma-princípio, passível de proteção adequada pelo ordenamento.

Partindo da ideia de ser um princípio constitucional não expresso, porém verdadeiro sustentáculo da efetivação de Direitos Fundamentais, necessário se faz observar que é emanado dos art. 93, incisos X e XI; 94; 101; 104 e 107 da Constituição Federal $^{14}$. Não demanda esforço constatar que a colegialidade é expressamente assegurada pelo CPC, notadamente pelo art. 476 e seguintes. Pois bem, o próprio art. 557, caput, do CPC, tema desta dissertativa, reconhece a força normativa da colegialidade,

jurisdicional. Mas constitui perigosa ilusão pensar que simplesmente conferir-lhe celeridade é suficiente para alcançar a tão almejada efetividade. Não se nega a necessidade de se reduzir a demora, mas não se pode fazê-lo em detrimento do mínimo de segurança, valor também essencial ao processo justo". (BEDAQUE, José Roberto dos Santos. Efetividade do Processo e Técnica Processual. 3. ed. São Paulo: Malheiros, 2010. p. 49.).

${ }^{13}$ ÁVILA, Humberto. O que é “devido processo legal”. In: DIDIER JR., Fredie (Org.). Leituras complementares de Processo Civil. 5. ed. Salvador: Jus Podivm, 2010. p. 354.

14 "Art. 93 [...] X: as decisões administrativas dos tribunais serão motivadas e em sessão pública, sendo as disciplinares tomadas pelo voto da maioria absoluta de seus membros. XI: nos tribunais com número superior a vinte e cinco julgadores, poderá ser constituído órgão especial, com o mínimo de onze e o máximo de vinte e cinco membros, para o exercício das atribuições administrativas e jurisdicionais delegadas da competência do tribunal pleno, provendo-se metade das vagas por antiguidade e a outra metade por eleição pelo tribunal pleno [...] Art. 94. Um quinto dos lugares dos Tribunais Regionais Federais, dos Tribunais dos Estados, e do Distrito Federal e Territórios será composto de membros, do Ministério Público, com mais de dez anos de carreira, e de advogados de notório saber jurídico e de reputação ilibada, com mais de dez anos de efetiva atividade profissional, indicados em lista sêxtupla pelos órgãos de representação das respectivas classes. [...] Art. 101. O Supremo Tribunal Federal compõe-se de onze Ministros, escolhidos dentre cidadãos com mais de trinta e cinco e menos de sessenta e cinco anos de idade, de notável saber jurídico e reputação ilibada [...] Art. 104. O Superior Tribunal de Justiça compõe-se de, no mínimo, trinta e três Ministros. [...] Art. 107. Os Tribunais Regionais Federais compõem-se de, no mínimo, sete juízes, recrutados, quando possível, na respectiva região e nomeados pelo Presidente da República dentre brasileiros com mais de trinta e menos de sessenta e cinco anos". 
Parâmetros Racionais de Aferição do Real Conteúdo...

na medida em que firma critérios que autorizam o julgamento monocrático em sede recursal. Leonardo $\mathrm{Greco}^{15}$ vislumbra seu viés estrutural e assevera:

Vejo na colegialidade não só uma garantia individual do jurisdicionado, mas uma garantia estrutural, especialmente nos sistemas, com o nosso, de juiz monocrático de $1^{\circ}$ grau. Que probabilidade de acerto e de justiça tem uma decisão de um só juiz, revista também por um só juiz? O aumento da probabilidade de acerto e de justiça das decisões que constitui um dos fundamentos do princípio do duplo grau de jurisdição fica grandemente comprometido pela monocratização dos julgamentos das instâncias superiores, fenômeno recentemente agravado entre nós com a vulgarização dos julgamentos por despacho unipessoais do relator, com fundamento nas alterações que a lei $n^{0}$ 9.756/98 introduziu no art. 557 do CPC. A colegialidade é também um importante fator de busca da legitimidade do judiciário, ou seja, de persuasão do jurisdicionado de que a sua causa foi julgada por uma junta de juízes, que discutiram a matéria procurando em conjunto encontrar a solução mais justa: juízes que revelaram o direito das partes no exercício mais autêntico do mandato recebido do povo e sob o mais eficaz mecanismo de controle, aquele que cada julgador exerce sobre o comportamento dos demais, porque a decisão que todos buscam vai influir na reputação de cada um. (Grifos nossos).

Desta feita, o multicitado princípio da colegialidade deve ser compreendido como verdadeira garantia constitucional implícita, pois, além de consagrar, efetivar e confirmar dois princípios inerentes ao Estado Democrático de Direito, conta com previsão expressa na legislação processual civil e, pelo fato de possuir elevada carga valorativa, passível será de adequação - juízo de ponderação - aos fins preconizados pelo Estado em determinado momento histórico. Resta saber até que ponto.

${ }^{15}$ GRECO, Leonardo. A falência dos sistemas de recursos. Revista dialética de direito processual, São Paulo, v. 1, abr. 2003. p. 103. 


\section{O Princípio da Colegialidade e as Decisões Judiciais}

Conforme extrai-se das normas de competência recursal e de composição dos tribunais pátrios asseguradas pela Magna Carta Federal de 1988 (v.g, artigos 93, 94, 101, 104 e 107), bem assim da sistemática delineada no CPC e dos regimentos internos dos tribunais ${ }^{16}$, os recursos deverão, em tese, ser analisados pelo órgão colegiado em sessão pública na sede do tribunal ad quem. Estes, por sua vez, estruturam-se justamente para a emissão de decisões plurais e, em face da impossibilidade de todos os membros apreciarem pessoalmente as demandas submetidas ao crivo da Corte, figura-se medida dotada de mais elevado grau de eficiência a sua divisão em órgãos fracionários, sendo cada caso atribuído primeiramente a um de seus componentes: o relator.

Feita a distribuição, são os autos encaminhados ao relator competente, o qual possui a função de averiguar a contenda e fixar os pontos controvertidos por meio de um relatório que irá fazer parte do acórdão ${ }^{17}$. Elaborado o memorial pertinente,

\footnotetext{
${ }^{16}$ Ad exemplum, o regimento interno do Tribunal de Justiça de Minas Gerais - TJMG, especificamente no art. 37, faz a seguinte previsão: "art. 37: Compete às câmaras cíveis processar e julgar: [...] II - em turma de três julgadores: a) o mandado de segurança contra o ato ou decisão do juiz de direito, desde que relacionados com processos cujo julgamento, em grau de recurso, seja de sua competência, excetuada a hipótese prevista na alínea $b$ do inciso II do art. 39 deste regimento; b) em feito de sua competência, restauração de autos perdidos, habilitação incidente, suspeição oposta a desembargador, a procurador de justiça e a juiz de direito, além de outros incidentes que ocorrerem; c) recurso de decisão de primeira instância [...]" (Grifo nosso). Nesse mesmo sentido é a redação do art. 19 do regimento interno do Tribunal de Justiça do Rio Grande do Sul - TJRS: “Compete, ainda, às Câmaras Separadas: [...] II julgar: os recursos das decisões dos Juízes de primeiro grau [...]".

17 Art. 121 do regimento interno do TJMG: “O acórdão será lavrado pelo relator e conterá: I - a ementa, que terá início com a palavra ou expressão designativa do tema principal, objeto do julgamento, bem como a súmula do que ficou decidido" [...] Na mesma linha prevê o art. 202 do regimento interno do TJRS: "Art. 202. O acórdão será redigido pelo Relator e apresentado para publicação no prazo de trinta (30) dias [...]".
} 
Parâmetros Racionais de Aferição do Real Conteúdo...

caberá ao relator o encaminhamento dos autos ao Presidente do órgão colegiado, que designará o dia certo para o julgamento em tribuna, no que mandará publicar a pauta no Órgão Oficial, sendo esta também afixada na entrada da sala em que for realizada a votação.

Contudo, tal procedimento tradicional e suas garantias fundamentais processuais vêm se revelando alvo de mitigação pelo legislador pátrio face à intensa multiplicação do apelo às instâncias de revisão das decisões proferidas no primeiro grau, aliada à crescente valorização dos precedentes firmados pelos Tribunais Superiores; fatores que desencadearam a proliferação de diplomas normativos que trazem em seu bojo a outorga de poderes ao relator para apreciar previamente os pressupostos de admissibilidade, sendo adiante acentuada tal orientação com autorização de adentrar no mérito monocraticamente. Nesse rumo, despontaram as Leis n. 9.139/1995 e 9.756/1998 com, dentre outras incumbências, a de atribuir nova redação ao art. 557 do CPC, passando a assentir não só a apreciação das questões que precedem ao mérito, mas também o exame da própria tese jurídica defendida, desde que, obviamente, atentadas certas condições, que por ora se dizem flagrantemente fluidas e carentes de delimitação objetiva.

Muito questionou-se ${ }^{18}$ acerca dessa tomada de decisão adotada pelo legislador ordinário, sobretudo por representar

\footnotetext{
${ }^{18}$ Nesse rumo, por exemplo: MOREIRA, José Carlos Barbosa. Comentários ao Código de Processo Civil. vol. V. 11. ed. Rio de Janeiro: Forense, 2003. p. 680-682; CARNEIRO, Athos Gusmão. Poderes do relator e Agravo Interno - Art. 557, 544 e 545 do CPC. Doutrinas essenciais de Processo Civil. v. 7. São Paulo: Revista dos Tribunais, 2011; DINAMARCO, Cândido Rangel. O relator, a jurisprudência e os recursos. In: WAMBIER, Teresa Arruda Alvim; NERY JÚNIOR, Nelson (Org.). Aspectos polêmicos e atuais dos recursos cíveis de acordo com a Lei 9.756/98. São Paulo: Revista dos Tribunais, 1998. p.132; FRANÇOLIN, Wanessa de Cássia. A ampliação dos poderes do relator nos recursos cíveis. Rio de Janeiro: Forense, 2006.

No mesmo sentido, também encontra-se o voto do Ministro Celso de Mello no julgamento que deu origem ao informativo 285 do STF, verbis: “[...] Cumpre
} 
uma progressiva relativização da colegialidade e do princípio do juiz natural em sede recursal. Isso porque, o princípio da colegialidade, analisado sob a perspectiva jurisdicional, apresenta íntima relação com o princípio do juiz natural ${ }^{19}$ - pois o juiz natural dos recursos é o órgão colegiado - e, sendo assim, poderiam restar ambos violados no caso de haver decisão monocrática pelo relator, se este passa a representar a vontade do órgão colegiado.

Contudo, já restou demonstrado que o princípio da colegialidade poderá, em casos específicos, ser relativizado em nome de outros princípios constitucionais - porém jamais suprimido - o que, em última análise, implicaria também a flexibilização, nestas hipóteses, do princípio do juiz natural.

A relativização destas garantias fundamentais ocorre, sobretudo, nos casos previstos no artigo 557 do CPC, desde que assegurada a possibilidade de a decisão do relator ser questionada pela via do agravo interno, eis que, de acordo com Barbosa

acentuar, neste ponto, que o Pleno do Supremo Tribunal Federal reconheceu a inteira validade constitucional da norma legal que inclui, na esfera de atribuições do Relator, a competência para negar trânsito, em decisão monocrática, a recursos, pedidos ou ações, quando incabíveis, estranhos à competência desta Corte, intempestivos, sem objeto ou que veiculem pretensão incompatível com a jurisprudência predominante do Tribunal (RTJ 139/53 - RTJ 168/174-175). Nem se alegue que esse preceito legal implicaria transgressão ao princípio da colegialidade, eis que o postulado em questão sempre restará preservado ante a possibilidade de submissão da decisão singular ao controle recursal dos órgãos colegiados no âmbito do Supremo Tribunal Federal, consoante esta Corte tem reiteradamente proclamado (RTJ 181/1133-1134, Rel. Min. CARLOS VELLOSO - AI 159.892-AgR/ SP, Rel. Min. CELSO DE MELLO)".

${ }^{19}$ O princípio do juiz natural garante que ninguém poderá ser privado do julgamento por juiz independente e imparcial, indicado pelas normas constitucionais e legais. Isso porque a Constituição proíbe os chamados tribunais de exceção, instituídos para o julgamento de determinadas pessoas ou de crimes de determinada natureza, sem previsão constitucional - art. 5o, inc. XXXVII (CINTRA, Antônio Carlos Araújo; DINAMARCO Cândido Rangel; GRINOVER Ada Pellegrini. Teoria Geral do Processo. 26. ed. São Paulo: Malheiros, 2010. p. 158). 
Parâmetros Racionais de Aferição do Real Conteúdo...

Moreira $^{20}$ "[...] não seria possível subtrair de forma definitiva a apreciação do recurso ao órgão ad quem sem pôr em xeque a garantia do juiz natural".

É de se notar com total espanto que a doutrina ainda se revela tímida - conforme será demonstrado - na imposição de parâmetros de cognição restritiva à compreensão das hipóteses permissivas de julgamento monocrático do art. 557, caput, do CPC, deixando a cargo dos magistrados a difícil tarefa de estabelecer o real conteúdo dos pressupostos de aplicação.

Nessa medida, abre-se espaço para a exposição do princípio da colegialidade inserido nas decisões judiciais no almejar de adiante se traçar os contornos hermenêuticos necessários à assimilação do real conteúdo das disposições constadas no art. 557 do CPC, caput, com o fito de garantir a máxima atuação, a mínima restrição e a inconcebível supressão desta garantia constitucional.

É sabido que a atuação do juiz solitário, baseada na representação da vontade estatal, obtém legitimação na oportunidade em que o magistrado expõe, pormenorizadamente, as razões de decidir utilizadas no enfretamento do caso apreciado, conforme preceitua o art. 93, IX da Constituição Federal de 1988. De fato, é justamente a fundamentação esposada pelo órgão julgador que o reconhece ser "porta-voz" do Estado, isto porque, conforme se tem conhecimento, os integrantes do Poder Judiciário não são eleitos pelo povo, mas habilitados por meio da aprovação em Concurso Público de provas e títulos, nos termos do art. 93, I da Magna Carta.

Com efeito, em que pese o juízo do primeiro grau ser efetivado pelo desempenho do magistrado singular, impera na seara recursal a regra tradicional de observância ao princípio da

${ }^{20}$ MOREIRA, José Carlos Barbosa. Comentários ao Código de Processo Civil. vol. V. 11. ed. Rio de Janeiro: Forense, 2003. p. 683. 
colegialidade, na medida em que os julgamentos em tribuna são essencialmente caracterizados pela atuação de no mínimo três julgadores que compõem as turmas ou câmaras, dependendo do tribunal. Outra característica peculiar de estruturação dos tribunais brasileiros refere-se à sua formatação ideal, em virtude da notável mescla dos critérios de promoção do magistrado a quo, sendo que ora é ascendido pelo merecimento, ora pela antiguidade, alternadamente.

Pela observância destes requisitos impostos pelo Constituinte, figura-se lógica a conclusão de que pretendeu o legislador conceder aos tribunais a possibilidade de extrair da técnica somada à maturidade a prolação de decisões finais mais ajustadas à realidade casuística do que aquela impugnada e, além disso, por se a decisão proferida em segunda instância fruto de um consenso tomado a partir de um discurso lógico e racional, apresentará maior possibilidade de êxito e adequação à realidade casuística, sendo que ainda, os critérios de merecimento e antiguidade exigidos para a composição do órgão colegiado alentam tanto o jurisdicionado quanto os aplicadores do Direito, por saberem que da técnica e da experiência, sairão, indubitavelmente, decisões mais acertadas.

É forçoso ressaltar que o exame colegiado constitui o verdadeiro traço, essência, da atuação dos tribunais, haja vista que o debate travado entre aqueles que apreciam o caso concreto constitui fator imprescindível à reflexão e ao amadurecimento da causa; porém, desde que se dê coligado com a atuação de fato das partes litigantes, que devem participar efetivamente do feito (ao menos ter essa possibilidade) na defesa de suas teses jurídicas, tanto na peça recursal redigida quanto oralmente, pela via da sustentação oral.

Insta esclarecer que a composição dos tribunais de segunda instância, que atuam de uma maneira geral como Cortes revisoras das matérias de fato e de direito, segue os moldes dos 
Parâmetros Racionais de Aferição do Real Conteúdo...

artigos 94 e 115 da Suprema Carta, em que se tem expressamente estabelecido que os Tribunais de Justiça dos Estados, do Distrito Federal e os Tribunais Regionais Federais serão compostos por magistrados oriundos do primeiro grau, pelo reconhecimento dos critérios já mencionados: merecimento e antiguidade. $^{21}$

Merece destaque, ainda, que consiste em determinação constitucional que precisamente um quinto das vagas ocupadas pelos desembargadores serão destinadas aos advogados indicados pela $\mathrm{OAB}$, bem como aos membros do Ministério Público, o que denota o objetivo de estimular a dialética necessária ao consenso final do colegiado, considerando que cada um de seus componentes traz consigo realidades e contextos de atuação diversos, porém, essenciais à construção do mais justo desfecho ao caso apreciado. Nesse rumo, já se restou induvidosa a constatação de que a colegialidade - verdadeiro princípio constitucional implícito - é requisito crucial da atuação dos tribunais, justamente pela segurança de que as teses jurídicas defendidas serão alvo de apreciação "qualitativa e quantitativa"; alinhando-se nesse viés, Henrique Guelber de Mendonça ${ }^{22}$ :

O que o julgamento por órgão colegiado pode propor aos recorrentes é um aumento da probabilidade de acerto. É o mesmo que alargar e solidificar a base sobre a qual se edifica uma construção qualquer. O recurso é o remédio utilizado pelo vencido na ânsia de se ver livre de uma sentença desafinada com sua própria justiça. Não há garantia de que seu ponto de vista prevalecerá ou não. O fato de alguém recorrer não pode conduzir ao raciocínio de que o recorrente tem mais razão do

${ }^{21}$ MENDONÇA, Henrique Guelber de. O princípio da colegialidade e o papel do relator no processo civil brasileiro. Revista Eletrônica de Direito Processual, Rio de Janeiro, 1. ed., out./dez. 2007. p. 208. Disponível em: <http://www.redp.com.br/ arquivos/redp_1a_edicao_rj.pdf $>$. Acesso em: 10 jun. 2013.

${ }^{22}$ Idem, Ibidem. 
que o recorrido ou vice-versa. A decisão tomada de forma conjunta é imprescindível em um país de primeira instância monocrática. Não há razão para que os tribunais se componham de juizes monocráticos revisores, o que afrontaria nossa própria Constituição, fugindo de seu espírito. (Grifos nossos).

Colaciona-se, ainda, o posicionamento adotado por Leonardo Greco ${ }^{23}$ :

A colegialidade protege a independência dos julgadores que, por ela, se tornam menos suscetíveis de sucumbirem a pressões. Ademais, é garantia de maior igualdade nos julgamentos, que não representam a opinião de uma só pessoa; estimula decisões mais refletidas e moderadas, porque resultantes da troca de opiniões e de pontos de vista entre os julgadores; goza de maior legitimidade política, porque é pluralista na aplicação da lei, como o é o Parlamento, na sua elaboração. (Grifos nossos).

Logo, não se mostra adequado, muito menos razoável, que o nosso sistema de prestação jurisdicional, em que o primeiro grau é representado pela técnica de apenas um juiz solitário, seja conivente com um arranjo recursal que permita a reapreciação da matéria de Direito unicamente por um julgador; é necessário que a doutrina e jurisprudência reconheçam a importância de se lutar contra a "monocratização" das decisões tomadas em tribuna, pois o princípio da colegialidade jamais poderá ser olvidado por aqueles que detêm a incumbência da produção legiferante, tal como pelos que fazem justiça.

${ }^{23}$ GRECO, Leonardo. Princípios de uma teoria geral dos recursos. Revista Eletrônica de Direito Processual, Rio de Janeiro, ano 4, vol. V, 2010. p. 36. Disponível em: <http:// www.redp.com.br/edicao_05.htm>. Acesso em: 17 jul. 2013. 


\section{Hipóteses de Aplicação do Art. 557 do CPC}

Conforme extrai-se dos ensinamentos de Luiz Guilherme Marinoni e Sérgio Cruz Arenhart ${ }^{24}$, o texto legal (caput) abarca basicamente duas modalidades de outorga de poderes ao relator para agir solitariamente: 1 . manifesto descabimento; e 2. manifesta improcedência. Tal divisão proposta é justificada pelo inadequado enquadramento estabelecido pelo texto normativo acerca das situações que o recurso se mostre manifestamente improcedente, bem assim que apresente tese jurídica confrontante com súmula ou jurisprudência dominante do tribunal local e dos Tribunais Superiores, como hipóteses pertinentes ao juízo de admissibilidade, em razão de constar o vocábulo "negar seguimento". Ademais, no que tange ao recurso manifestamente prejudicado, por padecer de interesse recursal, adapta-se perfeitamente às situações de manifesta inadmissibilidade.

\subsection{Manifesto Descabimento}

\subsubsection{Recurso Manifestamente Inadmissível}

Indagar-se acerca da admissibilidade do recurso, significa perquirir se este possui os requisitos indispensáveis ao devido prosseguimento à análise meritória. Este exame, atinente à verificação dos pressupostos genéricos impostos pela lei para os recursos em geral e dos pressupostos específicos referentes a cada espécie recursal, realiza-se tanto pelo juízo a quo quanto ad quem, devendo os órgãos jurisdicionais velar por sua verificação precisa, na medida em que envolve matéria de ordem pública.

${ }^{24}$ ARENHART, Sergio Cruz; MARINONI, Luiz Guilherme. Curso de Processo Civil. v. 2. São Paulo: Revista dos Tribunais, 2013. p. 585. 
Na presente pesquisa, adota-se a divisão proposta por Barbosa Moreira, que procede à separação dos pressupostos de admissibilidade recursal em dois grupos distintos: 1. intrínsecos, que dizem respeito à decisão recorrida em si mesma considerada: cabimento, legitimidade em recorrer e o interesse recursal; e 2. extrínsecos, referentes aos fatos supervenientes à decisão recorrida: regularidade formal, inexistência de fato impeditivo, modificativo ou extintivo do poder de recorrer e preparo. Em sede meritória, o órgão ad quem manifesta-se pelo improvimento ou provimento, seja para reformar (error in judicando) ou invalidar (error in procedendo) a decisão recorrida.

A primeira possibilidade de julgamento monocrático previsto pelo dispositivo em destaque refere-se ao recurso manifestamente inadmissível, logo, aquele que padece de um ou mais requisitos de admissibilidade, o que por certo não demanda maiores cuidados deste estudo, máxime à atuação essencialmente objetiva do relator.

\subsubsection{Recurso Manifestamente Prejudicado}

Inserida no conceito de recurso manifestamente inadmissível que será alvo de decisão monocrática, encontra-se a hipótese de o relator negar seguimento ao recurso quando este se restar manifestamente prejudicado - ou seja, em caso de perda do objeto da pretensão recursal ${ }^{25}$-, desde que assentada num suporte fático incontroverso, resultando absolutamente evidente a desnecessidade do prosseguimento do feito. ${ }^{26}$

\footnotetext{
${ }^{25}$ Ver CAMBI, Acácio. Aspectos polêmicos na aplicação do art. 557 do CPC. In: WAMBIER, Teresa Arruda Alvim; NERY JÚNIOR, Nelson (Org.). Aspectos polêmicos e atuais dos recursos cíveis e de outros meios de impugnação às decisões judiciais. v. 7. São Paulo: Revista dos Tribunais, 2003. p. 5.

${ }^{26}$ CIANCI, Mirna. A Lei 9.756/1988 (arts. 544, $3^{\circ}$ e 557, $\S \S 1^{\circ}$ A e $3^{\circ}$ do CPC) e a ampliação dos poderes do relator - dez anos depois. Revista dos Tribunais, São Paulo, n. 157, mar. 2008. p. 167.
} 
Parâmetros Racionais de Aferição do Real Conteúdo...

Chega-se à constatação de que as hipóteses de descabimento da peça recursal apresentadas não exprimem maiores complexidades, notadamente por seu viés objetivo, fato que não ocorre com o recurso manifestamente improcedente e aquele que apresenta manifesto confronto com súmula ou jurisprudência dominante, adiante examinado.

\subsection{Manifesta Improcedência}

\subsubsection{Recurso Manifestamente Improcedente}

Ademais, mediante uma leitura perfunctória do caput, verifica-se que a norma prevê a possibilidade de o juiz monocrático negar seguimento ${ }^{27}$ ao recurso manifestamente improcedente, confrontante com súmula ou jurisprudência dominante do respectivo tribunal, STF ou de Tribunal Superior, sendo certo que manifesta improcedência não é o mesmo que confronto com súmula ou jurisprudência dominante, pois se assim o fosse, o legislador não firmaria previsão destas duas espécies de improcedência e, justamente, é nesse ponto que reside grande parte de toda a gravidade da situação.

A compreensão acerca da manifesta improcedência submete-se à averiguação da natureza jurídica inerente à decisão monocrática. Pelo raciocínio que vem sendo traçado, tendo em vista as razões já expostas, o colegiado corresponde ao órgão dotado de competência para apreciar as demandas processadas nos tribunais e, por conseguinte, o poder do relator é apenas

\footnotetext{
27 "Pode o relator negar seguimento ao recurso, considerando-o manifestamente improcedente, hipótese em que se está diante de exercício de juízo de mérito negativo, apesar de o legislador usar a expressão negar seguimento" (WAMBIER, Teresa Arruda Alvim. Os agravos no CPC brasileiro. 4. ed. São Paulo: Revista dos Tribunais, 2004. p. 548).
} 
derivado e outorgado em hipóteses extremamente pontuais, o que significa dizer que, em tese, o juiz solitário deveria adotar a mesma postura que seria tomada por seu delegante. Nesse sentido, arremata Nagib Slaibi Filho ${ }^{28}$ : “[...] o provimento relatorial antecipa a cognição que seria feita pelo órgão competente (como diz a lei) forçando o decisor monocrata a projetar o seu espírito no adiantamento daquilo que razoavelmente seria decidido por seus pares".

Para Sérgio Cruz Arenhart ${ }^{29}$, manifestamente improcedente significa hipótese de improcedência da tese jurídica sustentada em sede recursal "[...] em que esta evidência será revelada exatamente pela existência do contraste do recurso com súmula ou jurisprudência dominante do próprio tribunal ou dos Tribunais Superiores".

Perquire-se sobre a postura mais adequada do relator frente aos requisitos de manifesta improcedência e de manifesto confronto com jurisprudência dominante. Considerar, isoladamente, a manifesta improcedência como uma justificativa para a aplicação dos poderes monocráticos do relator encerra uma situação de excessiva subjetividade. Poderá o relator, o qual atua como delegado do colegiado, aplicar o posicionamento do ente delegante, mesmo se este não se enquadrar no segundo requisito? Ou melhor: o prestígio da opinião que prevalece no órgão fracionário, ou mesmo no próprio tribunal em si, poderá prevalecer em detrimento do posicionamento majoritário (jurisprudência dominante) adotado pelos tribunais de cúpula? É cabível que o magistrado singular utilize de sua discricionariedade ao escolher o paradigma?

${ }^{28}$ SLAIBI FILHO, Nagib. Notas sobre o art. 557 do CPC. Competência do relator de prover e de negar seguimento a recurso. Jus Navigandi, Teresina, ano 8, n. 62, 1 fev. 2003. Disponível em: <http://jus.com.br/artigos/3792>. Acesso em: 13 out. 2013.

${ }^{29}$ ARENHART, Sérgio Cruz. A nova postura do relator no julgamento dos recursos. Revista de Processo, São Paulo, a. 26, n. 103, jul./set. 2001. p. 37. 
Mediante breve leitura da norma e destaque de alguns posicionamentos supra, poderia entender-se que sim. Porém, tal concepção não se harmoniza com a finalidade preconizada pelo legislador ordinário, que é justamente fixar requisitos taxativos concedentes de atuação solitária de modo a atribuir coerência ao sistema processual como um todo. A interpretação literal também não se coaduna com a intenção constitucional de estabelecer o julgamento colegiado como a regra, de sorte a tornar excepcionalíssimas as hipóteses legais de julgamento recursal monocrático.

Para resolver este primeiro impasse, sustenta-se que o requisito da manifesta improcedência não deverá ser interpretado como uma hipótese permissiva autônoma. Assim, para que seja um recurso julgado monocraticamente por sua manifesta improcedência, necessário se faz averiguar se a tese jurídica sustentada também se encontra em manifesta dissonância com o posicionamento dominante dos Tribunais Superiores. ${ }^{30}$ Partindo-se do pressuposto de que a manifesta improcedência recursal depende da configuração do confronto com a jurisprudência dominante do respectivo tribunal, STF e dos Tribunais Superiores ${ }^{31}$, passa-se à busca do real conteúdo deste conceito jurídico tão indeterminado.

\footnotetext{
30 "Melhor teria posto o legislador se tivesse reunido essas duas situações, de molde a exigir, expressamente, que a consideração como "manifestamente improcedente" tivesse o significado de confronto entre as razões recursais e a reiterada postura do colegiado ou das Cortes Superiores. Do modo como consta, revelou-se fluido o conceito, parecendo que seria a juízo único do relator a análise do mérito recursal, exceto se fosse possível admitir que a lei poderia conter expressão inútil, a ponto de trazer em seu contexto dois pressupostos idênticos e, ao mesmo tempo, alternativos" (CIANCI, Mirna. A Lei 9.756/1988 (arts. 544, $\S^{\circ}$ e 557, $\S \S 1^{\circ}$ A e $3^{\circ}$ do CPC) e a ampliação dos poderes do relator - dez anos depois. Revista dos Tribunais, São Paulo, n. 157, mar. 2008. p. 167).

31 “O 'tribunal superior' de que fala a lei só pode ser o próprio STJ, já que, em função de regras delimitadoras da competência, o TST, o STM e o TSE dificilmente terão súmula ou jurisprudência que possa influir em julgado da justiça cível"
} 


\subsubsection{Recurso em Confronto com Súmula ou Jurisprudência Dominante}

Tendo em vista que o objeto da presente pesquisa é fixar parâmetros mais claros para a aplicação do art. 557, caput, do CPC, acredita-se ser desnecessário o enquadramento da hipótese do recurso destoar de súmula do respectivo tribunal, do STF ou de Tribunal Superior num tópico próprio, pelo fato de a lei e os regimentos internos dos tribunais já definirem as hipóteses em que determinada questão deva ser súmula. Assim, conforme preceitua o art. 479, caput, do CPC "[...] o julgamento, tomado pelo voto da maioria absoluta dos membros que integram o Tribunal, será objeto de súmula e constituirá precedente na uniformização da jurisprudência". Já o art. 122, §1º, parte final, do RISTJ preceitua, exemplificativamente: “Também poderão ser inscritos na súmula os enunciados correspondentes às decisões firmadas por unanimidade dos membros componentes da Corte Especial ou da Seção, em um caso, ou por maioria absoluta em pelo menos dois julgamentos concordantes."

Prosseguindo, cumpre indagar sobre o real significado, bem como o meio de se avaliar sua presença casuisticamente. Pelo posicionamento adotado por Sérgio Cruz Arenhart e Luiz Guilherme Marinoni ${ }^{32}$, seria extremamente superficial assimilar que a jurisprudência dominante de certo tribunal fosse "[...] aquela que predomina naquela específica instância. Porém, essa resposta esconde inúmeras perguntas que poderia formular e deixa em aberto toda a caracterização do que seria jurisprudência dominante".

(WAMBIER, Teresa Arruda Alvim. Os agravos no CPC brasileiro. 4. ed. São Paulo: Revista dos Tribunais, 2004. p. 549).

${ }^{32}$ ARENHART, Sergio Cruz; MARINONI, Luiz Guilherme. Curso de Processo Civil. v. 2. São Paulo: Revista dos Tribunais, 2013. p. 588-589. 
Parâmetros Racionais de Aferição do Real Conteúdo...

É cediço que jurisprudência dominante não equivale à jurisprudência pacífica, haja vista que a última se refere à inexistência de relevante oposição, e dominante indica a jurisprudência que predomina na orientação do órgão colegiado, ainda que pese contra ela outra ideia ou concepção. ${ }^{33}$

No estudo mais profundo do real conteúdo inerente ao vocábulo, Priscila Kei Sato ${ }^{34}$ debruça-se sobre a definição de jurisprudência dominante, com o fito de auferir sua verdadeira ótica, estabelecendo como válidos dois meios de verificação: 1. a existência de um número plural de acórdãos que manifeste o posicionamento em questão ou, alternativamente: 2. a ocorrência de decisão do pleno em um determinado sentido, mesmo que de forma não unânime. No que concerne aos Tribunais de Justiça dos Estados, em função de seu maior fracionamento, visualiza-se ser necessária a adoção de outros padrões.

Já Sérgio Cruz Arenhart ${ }^{35}$ sustenta que, pelo fato da súmula refletir justamente o entendimento consolidado pela Corte, razoável é a compreensão de o vocábulo jurisprudência dominante, circunstância que permite a aplicação do art. 557 do CPC possa ser assimilado como uma "[...] decisão objeto de incidente de uniformização de jurisprudência onde não se logrou atingir o quórum especial, exigido para a elaboração de uma súmula".

Conquanto tais constatações apresentem critérios razoáveis à conceituação de jurisprudência dominante, estes ainda não se mostram suficientes: no primeiro caso - critérios adotados

\footnotetext{
${ }^{33}$ ARENHART, Sergio Cruz; MARINONI, Luiz Guilherme, loc. cit.

${ }^{34}$ SATO, Priscilla Kei. Jurisprudência (pre)dominante. In: WAMBIER, Teresa Arruda Alvim; NERY JÚNIOR, Nelson (Org.). Aspectos polêmicos e atuais dos recursos. São Paulo: Revista dos Tribunais, 2000. p. 583.

${ }^{35}$ ARENHART, Sergio Cruz; MARINONI, Luiz Guilherme. Curso de Processo Civil. v. 2. São Paulo: Revista dos Tribunais, 2013. p. 586.
} 
por Kei Sato - porque os requisitos quantitativo e qualitativo são alternativos, o que nem sempre se afigura satisfatório, e, no segundo, porquanto somente alude à existência de um quórum mínimo, desprezando outras situações em que a jurisprudência possa ser considerada dominante. Deve-se ter em mente que a norma insculpida no art. 557 do CPC faz referência ao entendimento do STJ ou STF por ser destes as funções nomofilácica e uniformizadora sobre a matéria federal e constitucional; por tal motivo é que só deverão os tribunais locais firmar interpretação própria quando esta se fizer estritamente alinhada ao entendimento daquelas Cortes ou se a jurisprudência for dominante no âmbito do tribunal local e não houver enfrentamento da questão no tribunal de superposição, ocorrendo uma situação de ausência de conflito de entendimentos. Em síntese, a jurisprudência do tribunal local só será considerada dominante se em conformidade com a do STJ ou do STF, ou, pelo menos, se com ela não conflitar.

Ainda, é importante que a jurisprudência do tribunal local não esteja em contraste com o entendimento de outros tribunais locais. Nesses casos, embora a lei dê a entender que seja suficiente a predominância no tribunal local, o fato de haver entendimento em contrário em outros tribunais locais sinaliza a possibilidade de reforma nos tribunais Superiores ${ }^{36}$. E, para este fim, o interessado será obrigado a interpor agravo interno, obter uma decisão colegiada para, depois, interpor o recurso excepcional. Só por esta razão, o julgamento monocrático já

\footnotetext{
36 "Se o que marca o sistema do art. 557, caput, e $\S 1^{\circ}$., é ser manifesto, parece que, havendo jurisprudência dominante, mas diferente dos diversos Tribunais, ou mesmo súmulas antagônicas o relator não deverá agir individualmente, devendo, então, sempre, remeter o processo a julgamento colegiado. Se as orientações de jurisprudência forem congruentes ou se as súmulas forem do mesmo sentido, constata-se a presença de um referencial seguro para decidir" (WAMBIER, Teresa Arruda Alvim. Os agravos no CPC brasileiro. 4. ed. São Paulo: Revista dos Tribunais, 2004. p. 560).
} 
perde a utilidade do ponto de vista prático, porque pode gerar irresignação justificada ${ }^{37}$.

É preciso verificar, outrossim, se o entendimento é predominante ao tempo em que se julga ou se houve algum julgado que esboçasse razões suficientes para considerá-lo superado (como no overruling da common law). ${ }^{38}$ Ainda, pode ocorrer de o caso apresentar especificidades que tornem a jurisprudência dominante inaplicável ou de difícil aplicação àquele caso (possível distinguishing), ${ }^{39}$ hipóteses em que não será possível o julgamento monocrático.

${ }^{37}$ De acordo com o posicionamento adotado pelo STJ, “a expressão 'jurisprudência dominante do respectivo tribunal' somente pode servir de base para negar seguimento a recurso quando o entendimento adotado estiver de acordo com a jurisprudência do STJ e do STF, sob pena de negar às partes o direito constitucional de acesso às vias extraordinárias" (STJ, REsp 193.189/CE, Relator Ministro FRANCIULLI NETTO, SEGUNDA TURMA, DJU: 21 de agosto de 2000).

${ }^{38} \mathrm{O}$ overruling refere-se ao mecanismo hábil ao reconhecimento de fundamentação suficiente ao abandono de determinado precedente utilizado em razão da modificação de interpretação da ratio decidendi da decisão que formou o precedente. Sendo assim, o próprio Tribunal que firmou determinado posicionamento poderá abandoná-lo futuramente, declarando-o superado (Novas súmulas do STF e alguns reflexos sobre o mandado de segurança. Mundo Jurídico. Disponível em: <http:// www.mundojuridico.adv.br/sis_artigos/artigos.asp?codigo=238>. Acesso em: 27 maio 2013).

39 O conceito de distinguishing refere-se ao cotejo analítico realizado pelo magistrado, por meio do qual verifica se o caso em julgamento pode ou não ser considerado ao paradigma. (CRUZ e TUCCI, José Rogério. Precedente Judicial como Fonte do Direito. São Paulo: Revista dos Tribunais, 2004. p. 170).

Em pesquisa aprofundada sobre o tema, Daniela Pereira Madeira entabula duas ocasiões passíveis de utilização do distinguishing: 1. para designar o método de comparação entre o caso concreto e o paradigma (distinguish-método); e 2. para designar o resultado desse confronto, nos casos em que se conclui haver entre eles alguma diferença (distinguish-resultado) (MADEIRA, Daniela Pereira. A força da jurisprudência. O Novo Processo Civil Brasileiro, Direito em Expectativa: Reflexões acerca do Projeto do Novo Código de Processo Civil. Coordenação: Luiz Fux. Rio de Janeiro: Forense, 2011. p. 539). 
Outro parâmetro de aplicação razoável é aquele destacado por Luiz Rodrigues Wambier ${ }^{40}$, no sentido de ser reputado dominante, por exemplo, um posicionamento do STF ou do STJ demonstrado por meio de reiteradas decisões em uma ordem mínima de $70 \%$, dentro de um período de cinco anos (ou de outro determinado período fixado), computados retroativamente.

Para o alcance do objetivo quanto à fixação de balizas à aferição do real conteúdo do vocábulo jurisprudência dominante, um dos requisitos que autorizam a decisão monocrática do art. 557 do CPC, esta pesquisa organiza os critérios anteriormente demonstrados em duas modalidades: parâmetros qualitativos e quantitativos.

Qualitativamente, a jurisprudência será dominante após a observação de três diretrizes: 1. reputar dominante tão somente a jurisprudência do STJ e do STF, sendo também possível considerar dominante a jurisprudência do tribunal em que tramita o recurso no caso desta guardar sintonia com posicionamento manifestado pelos órgãos de cúpula ou se destes não se destoar e, desde que outro tribunal não firme posicionamento em outro sentido; 2 . deve ser respeitado o quórum qualificado ou de maioria simples do pleno ou órgão especial, na oportunidade em que não se logrou êxito em atingir o número suficiente à elaboração de súmula e; 3 . a ausência de overruling ou distinguishing deve ser compreendida como requisito negativo.

Ademais, também é possível a submissão da análise do conceito a um critério quantitativo, que considera a proporção das decisões exaradas em torno de uma dada disciplina e o tempo em que determinada orientação permanece passível

\footnotetext{
${ }^{40}$ WAMBIER, Luiz Rodrigues. Uma proposta em torno do conceito de jurisprudência dominante. Revista Jurídica Mater Dei, Pato Branco-PR, v. 1, n. 1, jul./dez. 2001, p. 9-18. Disponível em: <http://www.materdei.edu.br/Arquivos/Revistas/7/19_08_201310_ 41_41REVISTAJURDICAMATERDEIvolume1.pdf >. Acesso em: 10 ago. 2013.
} 
Parâmetros Racionais de Aferição do Real Conteúdo...

de ser conservada como formadora de uma jurisprudência dominante ${ }^{41}$. Este critério, porém, deve ser cumulado com os parâmetros qualitativos descritos nos números 1 e 3, supra.

Tal questão adquire ainda mais relevo, pois, dentre os critérios de aplicação já mencionados, o relator somente poderá julgar o recurso se acerca de casos semelhantes já houver posicionamento sedimentado e respeitado pelas Cortes Superiores acerca da matéria, havendo um comprometimento da liberdade decisória do magistrado, por relativizar sua independência em função do prestígio à uniformização e celeridade.

Observa-se que a norma passa a ser assimilada não mais pela lei que a estabelece, mas sim pela interpretação que os tribunais Superiores realizam; o que significa dizer que o jurisdicionado contemporâneo passa a se valer não somente da hermenêutica pessoal que exerce, mas do posicionamento jurisprudencial. Fala-se, então, na igualdade perante a jurisprudência, não apenas perante a lei. Frise-se com convicção que o vocábulo jurisprudência dominante, constante do art. 557 do CPC, reflete um dos sintomas mais notórios de que o ordenamento jurídico pátrio começa a caminhar para a uniformização da jurisprudência; entretanto, para alcançar seu mais alto grau de eficácia e de unidade sistêmica, imprescindível é que saibamos avaliar as circunstâncias determinadamente e que não nos quedemos inertes, aplicando o conceito de modo tão inconsequente e irresponsável, como atualmente ${ }^{42}$.

\footnotetext{
${ }^{41}$ Ademais, quanto ao conceito de jurisprudência dominante, não parece exagero se sustentar que a jurisprudência dominante é aquela que já poderia estar sumulada. É aquela que diz respeito a um tal número de acórdãos, que permite a inferência no sentido de que a opinião do tribunal àquele respeito não deve alterar-se (WAMBIER. Teresa Arruda Alvim. Os agravos no CPC brasileiro. 4. ed. São Paulo: Revista dos Tribunais, 2004).

${ }^{42}$ Colaciona-se um julgado que veicula hipótese em que o recurso não deveria sequer ter sido admitido, porque a sua regularidade esbarrava em súmula (ou seja, o relator julgou contra a súmula):
} 


\begin{abstract}
Aliada a esses fatores, a aplicação desse instituto necessita do redimensionamento da regra da motivação. Logo, toda vez que o magistrado solitário for julgar o caso, terá que se valer de uma motivação que permita abraçar casos semelhantes àquele, de modo a não gerar dúvidas futuras quanto à interpretação dos precedentes, investigando se aquele determinado caso reúne as circunstâncias necessárias à incidência daquela jurisprudência dominante.
\end{abstract}

EMENTA: “AGRAVO REGIMENTAL. RECURSO ESPECIAL. PROCESSO CIVIL. VIOLAÇÃO DO ART. 535 DO CPC. INVOCAÇÃO DE DISPOSITIVOS QUE NÃO SUSTENTAM A TESE DEFENDIDA. NÃO OCORRÊNCIA. SÚMULA N. 284/ STF.1. Afasta-se a alegada violação do art. 535 do CPC quando o acórdão recorrido, integrado pelo julgado proferido nos embargos de declaração, dirime, de forma expressa, congruente e motivada, as questões suscitadas nas razões recursais. 2. Incide o óbice previsto na Súmula n. 284 do STF na hipótese em que a deficiência da fundamentação do recurso não permite a exata compreensão da controvérsia. 3. Agravo regimental provido em parte para não conhecer do recurso especial por novos fundamentos." (STJ - AgRg no REsp 1214795/PE - Rel. Ministro JOÃO OTÁVIO DE NORONHA - TERCEIRA TURMA - julgado em 25/06/2013, DJE 28/06/2013). Disponível em: <http://www.stj.gov.br/SCON/jurisprudencia/toc.jsp>. Acesso em: 19 ago. 2013.

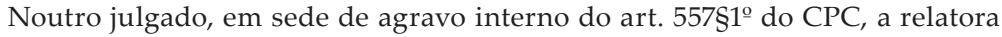
constatou que jamais poderia ter sido a apelação decidida monocraticamente por envolver matéria fática na questão recorrida, não fazendo-se presentes as hipóteses que ensejam a decisão singular prevista no dispositivo sob análise. Veja-se: VOTO: “[...] No caso em questão, verifica-se que a decisão recorrida trata, em grande parte, de matéria fática e, portanto, diversa da prevista nos estritos limites do art. 557 do Código de Processo Civil. Desse modo, a matéria enfocada nos presentes autos deve ser submetida ao órgão colegiado competente, eis que para a análise das questões que compõe o objeto do pedido, não se fazem presentes as hipóteses do art. 557 e §1 $1^{\circ}$-A do Código de Processo Civil [...] O artigo 557 §1-A refere-se à decisão recorrida que esteja em manifesto confronto com súmula ou jurisprudência dominante no Supremo Tribunal Federal ou Tribunal Superior. A meu ver, a r. sentença de fls. 258/260 não contém essas características. Ao contrário, analisa a extensa matéria de fato encontrada na documentação acostada aos autos e aplica os dispositivos legais nos quais subsumida a questão [...] Por conseguinte, dou provimento ao agravo legal para declarar a nulidade da decisão monocrática, impondo-se o prosseguimento do recurso, afim de ser julgado pelo Órgão Colegiado, razão pela qual conheço da apelação, passando à sua análise." (TRF3 - AgRg 20060399.011042-4 na AC 1099301/ SP - Rel. Desembargadora Federal LEIDE POLO - SÉTIMA TURMA - DJE DA 3ª REGIÃO - DECISÃO DE FLS. 280/303 - Data de Divulgação: 18/02/2009). 


\section{Tendências e Expectativas do Novo Código e a Força da Jurisprudência}

Sabe-se que o Senado Federal instaurou (ato no. 379 de 30 de setembro de 2009) uma Comissão de pensadores do Direito, à busca da confecção de um Anteprojeto do Novo Código de Processo Civil.

Dessa forma, o PLS de n⿳o. 166, após haver sofrido alterações, seguiu à Câmara dos Deputados (PL 8.046/2010), sendo aprovado em 17.07.2013, com a conclusão dos destaques pela Comissão Especial incumbida de apreciar o projeto.

Inspirada nos ensinamentos de Mauro Cappelletti e Bryan Garth ${ }^{43}$, a Comissão encabeçada por seu Presidente, o Ministro Luiz Fux e Tereza Arruda Alvim Wambier (Relatora), dedicou-se a aprofundar a investigação acerca dos fatores que dificultam o amplo acesso à justiça, obtendo, por fim, a compreensão de que os aspectos inerentes à estrutura ao aparato processual apresentavam "[...] solenidades obrigatórias que por si só contribuíam para a demora da resposta judicial ${ }^{44 \prime}$. E prossegue o Ministro Luiz Fux ${ }^{45}$.

Ressoa evidente que as três causas importantes reclamam ser enfrentadas: as excessivas solenidades processuais, das quais o processo civil brasileiro encontrava-se prenhe; o excesso número de demandas e a prodigalidade recursal na ótica antes apontada. O desafio releva-se tanto maior na medida em que impunha supressões no sistema processual mercê de garantias constitucionais dirigidas ao legislador ordinário; como v.g, o contraditório, o devido processo legal, a ampla defesa e os recursos a ela inerentes, dentre outros.

\footnotetext{
${ }^{43}$ CAPPELLETTI, Mauro; GARTH, Bryant. Acesso à Justiça. Tradução de Ellen Gracie Northfleet. Porto Alegre: Fabris, 1988, reimpresso em 2002.

${ }^{44}$ FUX, Luiz. O Novo Processo Civil Brasileiro, Direito em Expectativa: Reflexões acerca do Projeto do Novo Código de Processo Civil. Rio de Janeiro: Forense, 2011. p. 2.

${ }^{45}$ Idem, ibidem, loc. cit.
} 
Afirma-se com clareza que dentre as modificações mais notáveis do pensamento crítico expressado pelo Código Projetado, duas tendências pontuais impactaram diretamente: 1. a constatação de que o princípio é norma jurídica e muitos foram positivados pela nova legislação processual; e 2. a circunstância de que a jurisprudência predominante consiste em norma jurídica distinta da lei, sendo que faz parte da função jurisdicional a aplicação dessa norma jurisprudencial.

Incumbido, outrossim, da tarefa de avaliar a postura do Projeto do Novo Código de Processo Civil em relação às hipóteses que autorizam a decisão monocrática veiculadas pelo art. 557 do atual CPC, constata-se que os argumentos até aqui utilizados são corroborados com as novas tendências trazidas, nos moldes do projetado art. 945 (presente redação do dispositivo dada após a aprovação pelo órgão especial da Câmara dos Deputados):

Art. 945. Incumbe ao relator:

\section{$[\ldots]$}

III: não conhecer de recurso inadmissível, prejudicado ou que não tenha impugnado especificamente os fundamentos da decisão recorrida;

IV: negar provimento a recurso que for contrário a:

a) súmula do Supremo Tribunal Federal, do Superior Tribunal de Justiça ou do próprio tribunal;

b) acórdão proferido pelo Supremo Tribunal Federal ou pelo Superior Tribunal de Justiça em julgamento de recursos repetitivos;

c) entendimento firmado em incidente de resolução de demandas repetitivas ou de assunção de competência.

$\mathrm{V}$ : depois de facultada, quando for o caso, a apresentação de contrarrazões, dar provimento ao recurso se a decisão recorrida for contrária a:

a) súmula do Supremo Tribunal Federal, do Superior Tribunal de Justiça ou do próprio tribunal; 
Parâmetros Racionais de Aferição do Real Conteúdo...

b) acórdão proferido pelo Supremo Tribunal Federal ou pelo Superior Tribunal de Justiça em julgamento de recursos repetitivos;

c) entendimento firmado em incidente de resolução de demandas repetitivas ou de assunção de competência.

[...]

Parágrafo único. Antes de considerar inadmissível o recurso, o relator concederá o prazo de cinco dias ao recorrente para que seja sanado vício ou complementada a documentação exigível.

Percebe-se que o Projeto do Novo CPC não mantém em sua redação que equivale ao dispositivo em análise, as terminologias jurisprudência dominante e manifesta improcedência, além de riscar a expressão manifestamente - no que já não indicava alguma vantagem em permanecer na legislação.

Além disso, o termo não conhecer passa a se referir, tão somente, às hipóteses de recurso inadmissível ou prejudicado, caminhando no rumo certo em deixar a expressão de maior técnica - negar provimento - quando o relator adentrar na análise meritória. Nota-se que esta hipótese exige o mesmo raciocínio desenvolvido ao longo do texto, uma vez que, mesmo sendo substituído jurisprudência dominante por "[...] a decisão proferida pelo Supremo Tribunal Federal ou por Tribunal Superior em casos repetitivos [...]", esta última passa a exigir a aplicação dos critérios quantitativos e qualitativos destacados.

\section{Considerações Finais}

A busca pela exegese restritiva das circunstâncias que autorizam a decisão monocrática, sobretudo no que se refere ao art. 557, caput, do CPC realizou-se à luz do princípio da colegialidade, compreendido como verdadeira garantia constitucional implícita, decorrente dos postulados da separação e 
independência dos Poderes e do direito à prestação jurisdicional justa e efetiva. Foi demonstrado, ainda, que a colegialidade corresponde justamente ao combustível que propicia a reflexão, interferindo de tal modo que as decisões exaradas pelos órgãos plurais estão mais tendentes ao acerto.

Face ao viés inexoravelmente axiológico que comporta, o princípio da colegialidade será passível de ponderação com outras garantias constitucionais, como, v.g, o princípio da celeridade e economia processual, mas, para tanto, figura-se medida necessária adotar as seguintes premissas, hábeis a propiciar o julgamento monocrático em sede recursal previsto pelo art. 557 do CPC: 1 . o requisito manifestamente improcedente não constitui pressuposto autônomo veiculador de fundamentação que autorize a atuação singular do relator; 2. o magistrado solitário permanece adstrito ao posicionamento predominante das Cortes Superiores, em caso de confronto entre a pretensão recursal e a jurisprudência, o que significa dizer que a boa exegese da norma não o autoriza em prestigiar o direcionamento prevalente no tribunal local em detrimento do entendimento consolidado pelo STJ, STF, tratando-se de matéria federal e constitucional respectivamente; 3 . a terminologia jurisprudência dominante refere-se apenas ao posicionamento majoritário dos tribunais de superposição ou dos tribunais locais desde que não confrontantes com o posicionamento majoritário de outros Tribunais de Justiça, STF e STJ, em determinado lapso temporal, devendo ser respeitado o quorum qualificado ou de maioria simples do pleno ou órgão especial, na oportunidade em que não se logrou êxito em atingir o número suficiente à elaboração de súmula; 4 . sendo que a ausência de overruling ou distinguishing deverá ser compreendida como requisito negativo à aplicação da orientação dominante - aspectos qualitativos e quantitativos, constatação que precisa se pautar em acessos a sistemas de dado eficientes, disponibilizados pelos tribunais. 
Parâmetros Racionais de Aferição do Real Conteúdo...

Ainda, também é possível a submissão da análise do conceito a um critério quantitativo, que considera a proporção das decisões exaradas em torno de uma dada disciplina e o tempo em que determinada orientação permanece passível de ser conservada como formadora de uma jurisprudência dominante. Este critério, porém, deve ser cumulado com os parâmetros qualitativos descritos nos números 1, 2 e 4, retro.

Chegou-se à conclusão de que a atuação monocrática desenfreada, sem a observância de parâmetros bem traçados, jamais poderá ser admitida e quiçá justificada sob a perspectiva da celeridade e economia processual, sob pena de se desrespeitarem os princípios constitucionais basilares do Estado Democrático de Direito, bem como de contribuir para a fossilização da jurisprudência, pois, como já dizia o mestre Barbosa Moreira ${ }^{46}$ : “[...] a lei do menor esforço não é necessariamente, sob quaisquer condições, boa conselheira".

Finalmente, porém não menos importante, não se pode fechar os olhos para a nova codificação que se aproxima. Percebeu-se que este movimento de reorganização dos institutos processuais decorre do raciocínio empreendido pelos juristas destes novos tempos, os quais passam a desenhar a estrutura normativa conforme a forma de se pensar o Direito hodiernamente. Uma das grandes inovações refere-se à força normativa da jurisprudência, que no decorrer do trabalho foi analisada como uma das justificativas de se autorizar que o relator julgue monocraticamente o recurso, sendo potencializada de tal forma que os parâmetros ora mencionados são fundamentais para que se comece a compreender a metodologia trazida pelo Código Projetado, a qual passa a exigir o mínimo de sofisticação do operador ao aplicá-la.

${ }^{46}$ MOREIRA, José Carlos Barbosa. Comentários ao Código de Processo Civil. vol. V. 11. ed. Rio de Janeiro: Forense, 2003. p. 663. 
Considerando os argumentos e constatações expostas, fica o seguinte convite à reflexão: será que a comunidade jurídica está realmente preparada para tamanha mudança de paradigma?

\section{Referências}

ARENHART, Sérgio Cruz. A nova postura do relator no julgamento dos recursos. Revista de Processo, São Paulo, a. 26, n. 103, p. 37-58, jul./set. 2001.

ARENHART, Sérgio Cruz; MARINONI, Luiz Guilherme. Curso de Processo Civil. v. 2. São Paulo: Revista dos Tribunais, 2013.

ÁVILA, Humberto. O que é “devido processo legal”. In: DIDIER JR., Fredie (Org.). Leituras complementares de Processo Civil. 5. ed. Salvador: Jus Podivm, 2010.

BEDAQUE, José Roberto dos Santos. Efetividade do processo e técnica processual. 3. ed. São Paulo: Malheiros, 2010.

BRANCO, Paulo Gustavo Gonet; COELHO, Inocêncio Mártires; MENDES, Gilmar Ferreira. Curso de Direito Constitucional. 4. ed. São Paulo: Saraiva, 2009.

CAMBI, Acácio. Aspectos polêmicos na aplicação do art. 557 do CPC. In: WAMBIER, Teresa Arruda Alvim; NERY JÚNIOR, Nelson (Org.). Aspectos polêmicos e atuais dos recursos cíveis e de outros meios de impugnação às decisões judiciais. v. 7. São Paulo: Revista dos Tribunais, 2003.

CANOTILHO, José Joaquim Gomes. Direito Constitucional e Teoria da Constituição. Coimbra: Almedina, 2007.

CAPPELLETTI, Mauro; GARTH, Bryant. Acesso à Justiça. Tradução de Ellen Gracie Northfleet. Porto Alegre: Fabris, 1988, reimpresso em 2002.

CARNEIRO, Athos Gusmão. Poderes do relator e Agravo Interno - Art. 557, 544 e 545 do CPC. Doutrinas essenciais de Processo Civil. v. 7. São Paulo: Revista dos Tribunais, 2011.

CARVALHO FILHO, José dos Santos. Manual de Direto Administrativo. 23. ed. Rio de Janeiro: Lumen Juris, 2010. 
Parâmetros Racionais de Aferição do Real Conteúdo...

CIANCI, Mirna. A Lei 9.756/1988 (arts. 544, $3^{\circ}$ e e 557, §§ $1^{\circ}$ A e $3^{\circ}$ do CPC) e a ampliação dos poderes do relator - dez anos depois. Revista dos Tribunais, São Paulo, v. 33, n. 157, p. 165-181, mar. 2008.

CINTRA, Antônio Carlos Araújo; DINAMARCO, Cândido Rangel; GRINOVER, Ada Pellegrini. Teoria Geral do Processo. 26. ed. São Paulo: Malheiros, 2010.

COHENDET, Marie-Anne. La Collégialité des Juridictions: un principe en voie de disparition. Revue Française de Droit Constitutionnel, Paris, n. 68, p. 713-735, 2006.

CRUZ e TUCCI, José Rogério. Precedente Judicial como Fonte do Direito. São Paulo: Revista dos Tribunais, 2004.

DINAMARCO, Cândido Rangel. O relator, a jurisprudência e os recursos. In: WAMBIER, Teresa Arruda Alvim; NERY JÚNIOR, Nelson (Org.). Aspectos polêmicos e atuais dos recursos cíveis de acordo com a Lei 9.756/98. São Paulo: Revista dos Tribunais, 1998.

FRANÇOLIN, Wanessa de Cássia. A ampliação dos poderes do relator nos recursos cíveis. Rio de Janeiro: Forense, 2006.

FUX, Luiz. Carta de encaminhamento do Anteprojeto do Novo Código de Processo Civil ao Senado Federal. Anteprojeto do Código de Processo Civil. Brasil. Congresso Nacional. Senado Federal: Presidência da República. Brasília, 2010. Disponível em: <http://www.senado.gov. $\mathrm{br} /$ senado/novocpc/pdf/anteprojeto.pdf $>$. Acesso em: 8 maio 2013.

. O Novo Processo Civil Brasileiro, Direito em Expectativa: Reflexões acerca do Projeto do Novo Código de Processo Civil. Rio de Janeiro: Forense, 2011.

GRECO, Leonardo. A falência dos sistemas de recursos. Revista dialética de direito processual, São Paulo, v. 1, p. 93-108, abr. 2003.

. Novas súmulas do STF e alguns reflexos sobre o mandado de segurança. Mundo Jurídico. Disponível em: <http://www.mundojuridico.adv.br/sis_artigos/artigos.asp? $\operatorname{codigo}=238>$. Acesso em: 27 maio 2013.

. Princípios de uma teoria geral dos recursos. Revista Eletrônica de Direito Processual, Rio de Janeiro, ano 4, vol. V, p. 5-62, 2010. Disponível em: $<$ http://www.redp.com.br/edicao_05.htm>. Acesso em: 17 jul. 2013. 
MADEIRA, Daniela Pereira. A força da jurisprudência. In: FUX, Luiz (Org.). O Novo Processo Civil Brasileiro, Direito em Expectativa: Reflexões acerca do Projeto do Novo Código de Processo Civil. Rio de Janeiro: Forense, 2011.

MENDONÇA, Henrique Guelber de. O princípio da colegialidade e o papel do relator no processo civil brasileiro. Revista Eletrônica de Direito Processual, Rio de Janeiro, 1. ed., p. 208-225, out./dez. 2007. Disponível em: <http://www.redp.com.br/arquivos/redp_1a_edicao_rj.pdf>. Acesso em: 10 jun. 2013.

MITIDIERO, Daniel. Direito Fundamental ao Processo Justo. Disponível em: <http://www.rkladvocacia.com/arquivos/artigos/art_srt_arquivo20130419164953.pdf >. Acesso em: 28 nov. 2013.

MOREIRA, José Carlos Barbosa. Comentários ao Código de Processo Civil. vol. V. 11. ed. Rio de Janeiro: Forense, 2003.

NERY JÚNIOR, Nelson. Teoria geral dos Recursos. 6. ed. São Paulo: Revista dos Tribunais, 2004.

OLIVEIRA, Carlos Alberto Alvaro de. Os Direitos Fundamentais à Efetividade è Segurança em Perspectiva Dinâmica. Disponível em: <http:// www.oab.org.br/editora/revista/users/revista/1222961767174218181901. pdf $>$. Acesso em: 28 nov. 2013.

SATO, Priscilla Kei. Jurisprudência (pre)dominante. In: WAMBIER, Teresa Arruda Alvim; NERY JÚNIOR, Nelson (Org.). Aspectos polêmicos e atuais dos recursos. São Paulo: Revista dos Tribunais, 2000.

SLAIBI FILHO, Nagib. Notas sobre o art. 557 do CPC. Competência do relator de prover e de negar seguimento a recurso. Jus Navigandi, Teresina, ano 8, n. 62, 1 fev. 2003. Disponível em: <http://jus.com.br/ artigos/3792>. Acesso em: 13 out. 2013.

TARUFFO, Michele. Idee per una Teoria della Decisione Giusta, Sui Confini - Scritti sulla Giustizia Civile. Bologna: Il Mulino, 2002.

TAVARES, Diogo Ferraz Lemos. Princípio da Colegialidade: fundamento constitucional e necessidade de sua observância nos processos judiciais e administrativos - legitimidade/ilegitimidade de exceções. Revista Eletrônica de Direito Processual, Rio de Janeiro, a. 5, v. VIII, p. 233-259, jul. 2011. Disponível em: <http://www.redp.com.br/arquivos/redp_8a_edicao.pdf $>$. Acesso em: 8 jul. 2013. 
Parâmetros Racionais de Aferição do Real Conteúdo...

WAMBIER, Luiz Rodrigues. Uma proposta em torno do conceito de jurisprudência dominante. Revista Jurídica Mater Dei, Pato Branco-PR, v. 1, n. 1, p. 9-18, jul./dez. 2001. Disponível em: <http://www.materdei. edu.br/Arquivos/Revistas/7/19_08_201310_41_41REVISTAJURDICA MATERDEIvolume1.pdf>. Acesso em: 10 ago. 2013.

WAMBIER, Teresa Arruda Alvim. Os agravos no CPC brasileiro. 4. ed. São Paulo: Revista dos Tribunais, 2004.

Submissão: $15 / 10 / 2013$

Aceito para Publicação: 24/12/2013 


\title{
O Desenvolvimento dos Direitos da Personalidade, sua Aplicação às Relações de Trabalho e o Exercício da Autonomia Privada
}

\author{
The Development of Personality Rights, \\ its Application to Labor Relations, \\ and the Private Autonomy's Exercise
}

Fábio Siebeneichler de Andrade* Andressa da Cunha Gudde**

Resumo: A longa trajetória percorrida pelo Direito até o reconhecimento dos direitos da personalidade e sua elevação ao status de direitos fundamentais ajudam a compreender as matizes e os contornos do seu conjunto de valores. No ordenamento jurídico pátrio, os direitos da personalidade caracterizam-se pela indisponibilidade e pelo seu caráter absoluto, ainda que temperados pela necessária convivência com o direito fundamental à liberdade, do que a autonomia privada é uma de suas mais conhecidas facetas. É a partir de tal reconhecimento, e utilizando-se do método dedutivo e dialético, que o presente artigo busca explorar a aplicação dos direitos da personalidade ao contexto das relações de trabalho, no qual os mesmos adquirem contornos próprios, haja vista ser o Direito do Trabalho, no Brasil, fortemente calcado no princípio da proteção e da irrenunciabilidade, em especial. Todavia, por tratarem-se os direitos da personalidade e do trabalho de direitos fundamentais, é natural que os mesmos estejam submetidos ao exercício de ponderação, sempre que entrarem em conflito com outros direitos de igual

* Pontifícia Universidade Católica do Rio Grande do Sul.

** Pontifícia Universidade Católica do Rio Grande do Sul. 
O Desenvolvimento dos Direitos da Personalidade...

estatura constitucional-fundamental, conforme o caso concreto. É assim que a casuística fornece valiosos exemplos de situações em que os direitos da personalidade e do trabalho cedem espaço a outros direitos fundamentais, como a propriedade, sendo a autonomia privada e o respeito ao núcleo essencial da dignidade da pessoa humana elementos imprescindíveis à sua legitimação.

Palavras-chave: Direitos da Personalidade. Autonomia Privada. Direitos Fundamentais. Ponderação. Relações de Trabalho.

Abstract: The long journey travelled by the Law to the personality rights recognition and its elevation to fundamental rights status helps to understand the hues and contours of its set of values. In Brazilian legal system, the personality rights are characterized by its unavailability and absoluteness, albeit tempered by the necessary interaction with the fundamental right to freedom, of which private autonomy is one of its best-known facets. It is from this recognition, and using deductive and dialectical method, that this article aims to explore the application of personality rights to the context of labor relations, in which they acquire proper contours, having in mind that, in Brazil, the Labor Law is heavily based on the principle of protection and unavailability, specially. Nonetheless, considering that personality and labor rights are fundamental rights, it is natural that both are subjected to balancing test every time they collide with other fundamental-constitutional rights of same status, as the case. This is how casuistry gives us great examples of situations where personality and labor rights give way to other fundamental rights, such as propriety right, being the private autonomy and the respect to the essential core of the human dignity indispensable constituents to its legitimation.

Keywords: Personality Rights. Private Autonomy. Fundamental Rights. Balancing. Labor Relations. 


\section{Introdução}

Passados vinte e cinco anos da promulgação da Constituição Federal e mais de dez anos da promulgação do Código Civil de 2002, cumpre, inicialmente, expressar a convicção de que uma das principais inovações contempladas ao ordenamento jurídico brasileiro se constitui na disciplina dos Direitos de Personalidade. Poucos são os assuntos de Direito Civil que, em curto espaço de tempo, tiveram uma trajetória tão fulgurante: relegados a uma tratativa tópica na codificação do final do século XIX, como no caso do BGB, ou mesmo ignorados pelo codificador, como no caso brasileiro, alcançaram o status de direito fundamental antes do final do século XX. Nesse sentido, no Direito brasileiro os direitos da personalidade foram tratados, inicialmente, no art. 5ㅇ, X, da Constituição Federal de 1988. Na esfera do Direito Civil, coube ao Código Civil de 2002, nos artigos 11 a 21, introduzir uma tratativa acerca desta matéria.

A afirmação dos direitos da personalidade não se restringe, porém, à topografia e ao seu status. Concebido como instrumento de tutela de interesses tópicos da pessoa, a fim de impedir o ataque de outrem à esfera privada do indivíduo, o direito da personalidade passa a ser utilizado também em outros campos, alcançando novas projeções, a fim de regular casos em que a pessoa se relaciona com terceiros.

Um exemplo recente dessa circunstância constitui a vinculação existente entre os direitos da personalidade e o Direito do Trabalho. Sendo este um ramo social do Direito, cujos objetivos iniciais eram precipuamente a tutela dos interesses do trabalhador frente ao empregador, debate-se igualmente a necessidade de proteger a personalidade do empregado, especial e relativamente a novas práticas adotadas no mercado de trabalho. 
No Direito brasileiro, não contempla a Consolidação das Leis do Trabalho, ou mesmo a legislação especial, um tratamento específico quanto à proteção da personalidade do empregado. Trata-se de situação que se distingue da de outros países, em que se legislou especificamente sobre essa matéria ${ }^{1}$ e que tem sua explicação no momento histórico em que se desenvolveu a disciplina do Direito do Trabalho na ordem jurídica nacional.

Em face de regra expressa no parágrafo único do artigo $8^{\underline{0}}$ da Consolidação das Leis do Trabalho, admite-se que o Direito comum seja fonte subsidiária do Direito do Trabalho no que não for incompatível com os seus princípios fundamentais. Por conseguinte, sendo o Direito Civil um dos ramos admitidos como Direito Comum ao Direito do Trabalho, constitui-se em ponto relevante a análise não somente da aplicabilidade dos elementos da teoria dos Direitos da Personalidade, especialmente os elencados no Código Civil de 2002, às relações trabalhistas², como também de seu desenvolvimento na jurisprudência nacional. Com efeito, a aplicação dos direitos da personalidade ao contexto das relações de trabalho passa a ser reconhecida, e em tal cenário que há que discutir acerca da possibilidade de livre disposição dos direitos da personalidade, como o direito à intimidade, à livre manifestação do pensamento, à vida privada e à imagem, em essência, assim como a autonomia do trabalhador acerca desses direitos fundamentais.

No presente estudo, por meio dos métodos dedutivos e dialéticos, busca-se, primeiramente, pontuar os principais momentos da evolução e desenvolvimento da temática dos

1 É o caso do Direito italiano que, no denominado Statuto dei Diritti dei Lavoratori, de 1970, contempla regras específicas sobre a dignidade e liberdade do trabalhador.

2 Ver, por exemplo, GUNTHER, Luiz Eduardo Gunther; ZORNIG, Cristina Maria Navarro. O Direito da Personalidade do Novo Código Civil e o Direito do Trabalho. In: NETO, José Affonso Dallegrave Neto; GUNTHER, Luiz Eduardo (Org.). O Impacto do Novo Código Civil no Direito do Trabalho. São Paulo: LTr, 2003. p. 124 et seq. 
direitos da personalidade, bem como apontar a relevância do reconhecimento de um direito geral de personalidade no ordenamento nacional. Num segundo momento, analisa-se a relação dos direitos da personalidade relativamente a temas pontuais do Direito do Trabalho, em especial para verificar a pertinência do tratamento dado à tutela dos direitos específicos de personalidade no Direito brasileiro.

\section{A Tutela da Personalidade como Direito Fundamental: Conceito e Evolução no Ordenamento Jurídico Pátrio}

A omissão do Código de 1916 acerca de um tema intrinsecamente vinculado à noção de pessoa, centro de irradiação jurídica do Direito, e particularmente do Direito Civil ${ }^{3}$, explica-se, primeiramente, pelo fato de o seu anteprojeto ter sido redigido por Beviláqua ainda no século XIX, em 1899, período em que a dogmática dos direitos da personalidade ainda não havia se cristalizado. É certo que é possível estabelecer uma preocupação com a defesa de interesses relevantes da esfera pessoal já no Direito Romano. A defesa da honra aparece como um exemplo oportuno nesse sentido ${ }^{4}$. Contudo, o espírito romano era avesso à elaboração de teorias ${ }^{5}$, razão pela qual não se configura uma teoria dos direitos da personalidade nesse período.

${ }^{3}$ HATTENHAUER, Hans. Persona und personae acceptio - Christlicher Beitrag zur römischen Personenlehre. In: AVENARIUS, Martin; MEYER-PRITZL, Rudolf; MÖLLER, Cosima (Hrsg.). Ars Iuris, Festschrift für Okko Behrends zum 70 Geburtstag. Göttingen: Wallstein Verlag, 2009. p. 193.

4 CHIUSI, Tiziana. A dimensão abrangente do Direito privado romano. In: MONTEIRO, António Pinto; NEUNER, Jörg; SARLET, Ingo Wolfgang (Org.). Direitos fundamentais e direito privado. Coimbra: Almedina, 2007. p 11-25.

${ }^{5}$ CHIUSI, Tiziana. Op. cit., p. 15. 
O Desenvolvimento dos Direitos da Personalidade...

Muito embora seja defendida a tese de que a teoria dos direitos da personalidade remonte a autores do século XVI, como Donellus ${ }^{6}$, somente ao final do século XIX foram efetivamente delineados, pela doutrina, os contornos dos direitos da personalidade 7 . Reconhecia-se que os direitos da personalidade consistiriam em um direito fundamental subjetivo, sobre o qual estariam fundados todos os direitos subjetivos e que em si abrigava todos os direitos ${ }^{8}$. Mas o debate em torno dos precisos contornos dogmáticos dos direitos da personalidade ainda não havia cessado plenamente. À época, constituíam-se em minoria os autores que já afirmavam, expressamente, a existência e autonomia desta figura e os definiam como os direitos que tinham por objeto garantir o domínio sobre a própria esfera pessoal ${ }^{9}$.

Há que se ter presente que as características essenciais da codificação, no século XIX, eram a totalidade e a sistematização ${ }^{10}$. O código representava, de um lado, um sistema, isto é, um modo de ordenar as matérias do Direito. De outro, possuía a aspiração de conter o conjunto de normas jurídicas sobre uma determinada matéria ${ }^{11}$. Neste quadro, ao final do século XIX

${ }^{6}$ MUTZENBECHER, Franz. Zur Lehre vom Persönlichkeitsrecht. Hamburg: Lütcke und Wulff, 1909. p. 15.

7 WHITMAN, James Q. The Two Western Cultures of Privacy: Dignity versus Liberty. Yale Law Journal, v. 113, 2004. p. 1171 et seq.; HATTENHAUER, Hans. Grundbegriffe des Bürgerlichen Rechts. 2. Aufl. München: Beck Verlag, 2000. p. 14.

8 GIERKE, Otto. Deutsches Privatrecht. Erster Band. München und Leipzig: Duncker und Humblot, 1936. p. 703. No original: "Es ist das einheitliche subjetive Grudrecht, dass alle bensonderen subjektive Rechte fundamentirt um in sie alle hinreinreicht".

9 GIERKE, Otto. Op. cit., p. 702.

${ }^{10} \mathrm{O}$ ideal de plenitude encontra-se representado no Código da Prússia (Allgemeines Landrecht), de 1794, que abrangia tanto o Direito Privado quanto o Direito Público e cujo número de artigos era de 19.194.

${ }^{11}$ A este respeito, ver ANDRADE, Fábio Siebeneichler de. Da Codificação - crônica de conceito. Porto Alegre: Livraria do Advogado, 1997. p. 25. 
- época áurea do conceitualismo e individualismo no Direito faltavam as condições necessárias para a devida inserção da matéria dos direitos da personalidade nas codificações oitocentistas, como foi o caso em relação ao BGB, de 1896, e o Código Civil brasileiro de 1916.

Neste ponto, é de crucial importância observar a transmutação dos valores consagrados originariamente pelo Estado Moderno, período histórico cujo marco referencial pode ser identificado na Revolução Francesa (1789), no qual se verifica aparente predomínio do direito privado sobre o público como forma de atender aos anseios econômico-burgueses de igualdade formal, máxima valorização da autonomia privada e da liberdade contratual como premissas ao desenvolvimento econômico (outorgando-se ao Estado o mero dever de conter e, ao mesmo tempo, abster-se de injustas intervenções na esfera privada $)^{12}$. No século $X X$, porém, a concepção preconizadora da máxima valorização do individualismo mostrou-se incapaz de superar a noção de liberdade formal e contribuir plenamente para a justiça material, configurando-se a partir dessa percepção uma alteração profunda do paradigma jurídico-político, com efeitos radicais em todas as áreas do Direito ${ }^{13}$.

Paralelamente, portanto, à evolução da teoria dos Direitos da Personalidade no Direito Civil, configurou-se a extraordinária evolução do Direito Público no século XX. Trata-se de um fenômeno tão relevante que, em decorrência de sua evolução e da

\footnotetext{
${ }^{12}$ Por exemplo, WALINE, Marcel. L'Individualisme et le Droit. Paris: DomatMontchrestien, 1945. p. 19.

${ }^{13}$ Ver, por exemplo, KHALIL, M.S. Le Dirigisme économique et les contrats. Paris: LGDJ, 1967. p. 381; RAISER, Ludwig. Die Aufgabe des Privatrechts. Kronberg/Ts.: Athenaum-Verlag, 1977. p. 33; FACCHINI NETO, Eugênio. Reflexões histórico-evolutivas sobre a constitucionalização do direito privado. In: SARLET, Ingo Wolfgang (Org.). Constituição, Direitos Fundamentais e Direito Privado. 3. ed. rev. e ampl. Porto Alegre: Livraria do Advogado, 2010. p. 42.
} 
O Desenvolvimento dos Direitos da Personalidade...

irradiação de seus princípios, surge uma crescente interação da esfera pública com o setor privado, que origina, no direito privado, uma profunda modificação em relação ao ideário existente no século XIX. Estabelece-se, em suma, entre estas duas áreas uma tensão dialética, que conduz à noção de constante inter-relação entre os dois grandes setores do Direito ${ }^{14}$.

Uma de suas facetas consiste na disciplina pela Constituição sobre temas originariamente pertencentes ao direito privado. $\mathrm{O}$ objetivo da Constituição deixa de ser, única e exclusivamente, o de estabelecer a unidade política, o Estado de Direito - ao limitar o poder político - e colmatar a ordem jurídica de uma comunidade estatal ${ }^{15}$, como também contém os direitos fundamentais, que moldam um sistema normativo valorativo ${ }^{16}$, com irradiação no Direito Civil, em face de cláusulas gerais ${ }^{17}$. Ela se transforma seja em centro de direção para a legislação ordinária, como em lei fundamental do direito privado - e dos demais ramos do Direito - e passa a estabelecer a moldura da atividade dos indivíduos. Faz-se aqui menção à problemática da constitucionalização do Direito Civil e de seu reverso, a civilização

${ }^{14}$ Alguns autores propugnaram que se abandonasse a distinção entre Direito Público e Direito Privado em favor de um direito comum. V. BULLINGER, Martin. Derecho Público y Privado. Madrid: IEA, 1976. p. 120-171. Ludwig Raiser, por sua vez, defendeu que o grau de publicidade ou privacidade, seria fundamental para determinar se uma figura pertenceria a um deste dois ramos do Direito. RAISER, Ludwig. Die Aufgabe des Privatrechts. Kronberg/Ts.: Athenaum-Verlag, 1977. p. 223.

${ }^{15}$ HESSE, Konrad. Grundzüge des Verfassungsrechts der Bundesrepublik Deutschalands, 20. Aufl. Heidelberg: Müller, 1995. p. 5.

${ }^{16}$ HESSE, Konrad. Op. cit., p. 17.

17 Sobre este tema, ver, por exemplo, SCHWAB, Dieter. Einführung in das Zivilrecht. 15. Aufl. Heidelberg: C. F. Müller Verlag, 2002. p. 37. Na doutrina nacional, ver, por todos, SARLET, Ingo Wolfgang. A Eficácia dos Direitos Fundamentais: uma teoria geral dos direitos fundamentais na perspectiva constitucional. 10. ed. rev. atual. ampl. Porto Alegre: Livraria do Advogado, 2009. 
do Direito Constitucional ${ }^{18}$. É neste contexto histórico que as constituições deixam, portanto, de ser meras cartas políticas para carregarem em seu bojo os princípios de solidariedade social e da dignidade da pessoa humana, os quais passam a ser reputadas como fatores de legitimidade e justificação para uma eventual regulação estatal nos vínculos econômicos-privados ${ }^{19}$.

O tema dos direitos da personalidade serve como expressiva ilustração para esta inter-relação entre as esferas da Constituição e da Codificação, pois ao longo do século XX passa a ser ele objeto de tutela constitucional. Emblemática quanto ao novo patamar dos direitos de personalidade é a Constituição alemã de 1949, que dispõe, no seu artigo $2^{\circ}$, $\S 1^{\circ}$, sobre o direito ao livre desenvolvimento da personalidade (freie Entfaltung der Persönlichkeit) ${ }^{20}$. De forma ainda mais significativa, a Constituição alemã expressamente positiva a dignidade humana (Menschenwürde) como direito fundamental no artigo $1^{\circ}, \S 1^{1021}$.

Desse modo, no plano civilístico, a matéria dos direitos da personalidade aparecerá apenas em codificações do século XX, como servem de exemplo o Código Civil italiano de 1942 e o

${ }^{18}$ CANOTILHO, José Joaquim Gomes. Civilização do Direito Constitucional ou Constitucionalização do Direito Civil. In: GRAU, Eros Roberto; GUERRA FILHO, Willis Santiago (Org.). Direito Constitucional: estudos em homenagem a Paulo Bonavides. São Paulo: Malheiros, 2001. p. 108-113.

${ }^{19}$ FACCHINI NETO, Eugênio. Reflexões histórico-evolutivas sobre a constitucionalização do direito privado. In: SARLET, Ingo Wolfgang (Org.). Constituição, Direitos Fundamentais e Direito Privado. 3. ed. rev. e ampl. Porto Alegre: Livraria do Advogado, 2010. p. 45-46.

${ }^{20}$ HESSE, Konrad. Grundzüge des Verfassungsrechts der Bundesrepublik Deutschalands, 20. Aufl. Heidelberg: Müller, 1995. p. 183.

${ }^{21}$ Segundo a jurisprudência alemã (BverfG 32, 98/108), a dignidade da pessoa humana constitui-se no mais alto valor da Constituição alemã (obersten Wert des Grundgesetzes). Ver a respeito, MANSSEN, Gerrit. Grundrechte. München: Beck Verlag, 2000. p. 48. 
O Desenvolvimento dos Direitos da Personalidade...

Código Civil português de $1966^{22}$. Já no Direito brasileiro, ainda na vigência do Código Civil de 1916, a matéria dos direitos da personalidade havia sido versada pela doutrina brasileira ${ }^{23}$, e objeto de tratamento pelo Anteprojeto de Código Civil de 1963, elaborado pelo Professor Orlando Gomes. No entanto, a positivação dos direitos da personalidade no Direito brasileiro ocorreu somente mediante a Constituição de 1988. Em seu

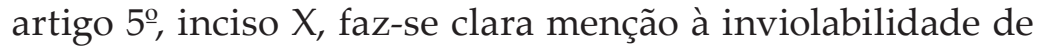
determinados direitos da personalidade ${ }^{24}$. O artigo $1^{\circ}$, inciso III, por sua vez, fixa a dignidade da pessoa humana entre os fundamentos da República.

Tendo alcançado relevo constitucional, é de se destacar que os direitos da personalidade estão albergados pela proteção conferida pelo artigo 60, $\S 4^{\circ}$, inciso IV da Constituição Federal, figurando dentre os direitos que possuem aplicabilidade imediata, conforme comando do artigo $5^{\circ}, \S 1^{\circ}$ da Carta Maior. Ainda nesta esteira, é possível afirmar que os direitos da personalidade, tal qual esculpidos no artigo $5^{\circ}$, inciso $X$, da Constituição Federal, sujeitam os particulares no âmbito de suas relações privadas, ainda que se discuta se tal vinculação deriva de uma eficácia direta ou indireta. Acerca da eficácia dos direitos fundamentais no âmbito das relações entre particulares, pode-se sustentar que devam ser aplicados nas relações entre

\footnotetext{
${ }^{22}$ Ver CORDEIRO, António Menezes. Tratado de Direito Civil Português. 3. ed. Coimbra: Almedina, 2005. p. 49.

${ }^{23}$ Exemplificativamente, ver MIRANDA, Pontes de. Tratado de Direito Privado. v. 7. Rio de Janeiro: Borsoi, 1955. GOMES, Orlando. Direitos da Personalidade. Revista Forense, Rio de Janeiro, v. 216, out./nov./dez. 1966. p. 5; FERNANDES, Milton Fernandes. Os Direitos da Personalidade. In: BARROS, Hamilton de Moraes e et al. (Org.). Estudos jurídicos em homenagem ao Professor Caio Mário da Silva Pereira. São Paulo: Forense, 1984. p. 131.

${ }^{24}$ Artigo 5o, $\mathrm{X}$ - são invioláveis a intimidade, a vida privada, a honra e a imagem das pessoas, assegurado o direito à indenização pelo dano material ou moral decorrente de sua violação.
} 
particulares de forma indireta, ou mediata, seja porque apenas o Estado figura como destinatário dos direitos fundamentais (por assumir o dever de proteção - mandado de tutela), seja pela proibição de intervenção (direito de defesa dos cidadãos); dessa forma, na relação entre particulares, havendo ofensa de um perante o outro, o Estado pode (deve) intervir em defesa dos particulares, como expressão de seu poder de proteção ${ }^{25}$.

Em sentido diverso, encontra-se a posição que defende a eficácia direta dos direitos fundamentais no âmbito das relações privadas, ponderada a necessidade de serem observadas as circunstâncias do caso concreto, as peculiaridades dos direitos fundamentais em jogo, bem como seu âmbito de proteção, as disposições legais vigentes e os métodos de interpretação e solução de conflitos entre direitos fundamentais (proporcionalidade e concordância prática ${ }^{26}$. Quanto a este ponto, sustenta-se que a proporcionalidade, a razoabilidade, a análise do maior ou menor poder econômico-social dos agentes particulares (como forma de justificar a restrição da autonomia privada dos atores sociais, quando verificado manifesto desequilíbrio entre as partes), a salvaguarda da dignidade da pessoa humana e a proteção do núcleo essencial dos direitos fundamentais, devem ser utilizados como critérios para viabilização da propugnada eficácia direta dos direitos fundamentais no âmbito dos particulares ${ }^{27}$.

\footnotetext{
${ }^{25}$ A propósito, CANARIS, Claus-Wilhelm. A influência dos direitos fundamentais sobre o direito privado na Alemanha. In: SARLET, Ingo Wolfgang (Org.). Constituição, Direitos Fundamentais e Direito Privado. 3. ed. Porto Alegre: Livraria do Advogado, 2010.

${ }^{26}$ Assim, SARLET, Ingo Wolfgang. Neoconstitucionalismo e influência dos direitos fundamentais no direito privado: algumas notas sobre a evolução brasileira. In: SARLET, Ingo Wolfgang (Org.). Constituição, Direitos Fundamentais e Direito Privado. 3. ed. Porto Alegre: Livraria do Advogado, 2010.

${ }^{27}$ SARLET, Ingo Wolfgang. A Eficácia dos Direitos Fundamentais: uma teoria geral dos direitos fundamentais na perspectiva constitucional. 10. ed. rev. atual. ampl. Porto Alegre: Livraria do Advogado, 2009. p. 379.
} 
O Desenvolvimento dos Direitos da Personalidade...

Conforme adiante pretender-se-á demonstrar, o problema da eficácia dos direitos fundamentais no âmbito das relações entre particulares assume relevo e contornos próprios quando se discute a aplicabilidade dos direitos da personalidade, pelo menos em seu conteúdo incontroversamente tido como fundamental ${ }^{28}$, nas relações de trabalho, na medida em que, como já dito, a CLT não contempla tal temática, assim como nem mesmo o próprio Código Civil brasileiro esgota suas facetas. Antes, porém, faz-se indispensável analisar as características que delineiam os direitos da personalidade, a fim de melhor compreender em que bases o diálogo com o Direito do Trabalho é desenvolvido.

\section{As Características dos Direitos da Personalidade no Código Civil de 2002}

O Código Civil Brasileiro de 2002 não se apresentou indiferente às profundas mudanças provocadas pela promulgação da Constituição Federal de 1988 no ordenamento jurídico pátrio; com efeito, o Código Civil não apenas incorporou a disciplina dos direitos da personalidade, como ampliou a gama de bens jurídicos tutelados. Dessa forma, é possível afirmar que a leitura

\footnotetext{
${ }^{28}$ Neste aspecto cumpre destacar existir relevante controvérsia acerca da fundamentalidade dos direitos da personalidade. Para Jorge Miranda tratam-se os direitos fundamentais e os direitos da personalidade de gamas de direitos distintos, em que pese possuam constantes interconexões. MIRANDA, Jorge; RODRIGUES JUNIOR, Otávio Luiz; FRUET, Gustavo Bonato. Principais problemas dos direitos da personalidade e estado-da-arte da matéria no direito comparado. In: MIRANDA, Jorge; RODRIGUES JUNIOR, Otávio Luiz; FRUET, Gustavo Bonato (Org.). Direitos da personalidade. São Paulo: Atlas, 2012. p. 16-17. Ainda, ASCENSÃO, José de Oliveira. Direito Civil: teoria geral. v. 1. Coimbra: Coimbra Editora, 1997. p. 92-96. Advogando em sentido diverso: CANTALI, Fernanda Borghetti. Direitos da personalidade: disponibilidade relativa, autonomia privada e dignidade humana. Porto Alegre: Livraria do Advogado, 2009. p. 104. SCHREIBER, Anderson. Direitos da Personalidade. São Paulo: Atlas, 2011. p. 14.
} 
conjunta da Constituição Federal e do Código Civil permite identificar como direitos da personalidade o direito à vida, à integridade física (incluído o direito ao corpo vivo ou morto), à integridade psíquica ou intelectual (aqui podendo ser compreendidos os direitos à liberdade, à liberdade de pensamento, às criações intelectuais, à privacidade e à intimidade ${ }^{29}$ ) e à integridade moral (direito à honra, à imagem, à identidade e à personalidade) ${ }^{30}$.

Da análise do capítulo II do Código Civil brasileiro, destinado à temática e de nítida tendência tipificadora, pode-se verificar a pertinência da crítica feita por significativa doutrina à ausência de uma cláusula geral expressa dos direitos da personalidade ${ }^{31}$, ainda que alguns doutrinadores atribuam aos artigos $12^{32}$ e 21 este papel orientador. Em que pese o princípio da dignidade da pessoa humana venha sendo invocado por

${ }^{29}$ Aqui faz-se justa menção à teoria alemã dos círculos concêntricos, a qual distinguia os conceitos de vida privada e intimidade pelo avanço nas esferas da vida privada, da confidencialidade e do segredo. Uma breve abordagem do tema pode ser encontrada em RUARO, Regina Linden; RODRIGUEZ, Daniel Piñeiro. O direito à proteção dos dados pessoais: uma leitura do sistema europeu e a necessária tutela dos dados sensíveis como paradigma para um sistema jurídico brasileiro. Direitos Fundamentais e Justiça, Porto Alegre, ano 4, n. 11, abr./jun. 2011. p. 163-180.

${ }^{30}$ Ainda que com algumas distinções, semelhante classificação é feita por Carlos Alberto Bittar, o qual, por exemplo, desloca o direito às criações intelectuais ao âmbito dos "direitos morais", sendo estes pertinentes aos atributos valorativos do indivíduo perante a sociedade. BITTAR, Carlos Alberto. Direitos da personalidade. 6. ed. rev. e atual. Rio de Janeiro: Forense Universitária, 2003. p. 17. A propósito da classificação dos direitos da personalidade, válida a menção ao apanhado exposto por BORGES, Roxana Cardoso Brasileiro. Direitos da personalidade e autonomia privada. 2. ed. rev. São Paulo: Saraiva, 2007. p. 30-32.

${ }^{31}$ TEPEDINO, Gustavo. Temas de direito civil. 3. ed. atual. Rio de Janeiro: Renovar, 2004. p. 37.

${ }^{32}$ ANDRADE, Fábio Siebeneichler de. O desenvolvimento da tutela dos direitos da personalidade nos dez anos de vigência do Código Civil de 2002. In: LOTUFO, Renan; NANNI, Giovani Ettore; MARTINS, Fernando Rodrigues (Org.). Temas Relevantes de Direito Civil Contemporâneo - Reflexões sobre os 10 anos do Código Civil. São Paulo: Atlas, 2012. p. 58. 
O Desenvolvimento dos Direitos da Personalidade...

autores como sendo a cláusula geral dos direitos da personalidade $^{33}$, uma vez que constitui o eixo central de sua matéria, atuando como norte, fundamento e justificativa de sua proteção (e, portanto, podendo ser identificado como a "primeira" cláusula geral dos direitos da personalidade), é apropriada a ressalva no sentido de que a ausência de uma tutela geral dos direitos da personalidade em nosso sistema conduz a um excesso de invocação à noção de dignidade (já que utilizado como arcabouço de proteção a toda e qualquer violação aos direitos da personalidade), não sendo esta a finalidade de um princípio constitucional $^{34}$. Assevera-se, ainda, que ao não definir e conceituar a proteção jurídica estendida aos direitos da personalidade em sua totalidade, o Código Civil relega exclusivamente à doutrina e à jurisprudência esta tarefa, bem como a árdua missão de definir a sua aplicabilidade ao caso concreto e sua conformação a todas as demais hipóteses de violação que não aquelas previstas nos artigos 11 a $21^{35}$ - partindo-se do reconhecimento de que tal categoria de direitos não encerra um rol taxativo ${ }^{36}$.

33 SARMENTO, Daniel. Direitos fundamentais e relações privadas. Rio de Janeiro: Lumen Juris, 2006. p. 99. O autor faz menção, “[...] em apoio a esta tese, à abertura sistemática do Código nesta matéria, propiciada pela cláusula geral de responsabilidade por dano moral, encartada no seu art. 186".

${ }^{34}$ Quanto a este ponto, há que se referir também a orientação de que a matéria da dignidade da pessoa humana não deve comportar todos os significados, devendo ser afastado uma aproximação hermenêutica voluntarista e arbitrária, que implicaria uma visão constitucional ilegítima. Ver, por todos, SARLET, Ingo W. Dignidade da pessoa humana e direitos fundamentais na Constituição Federal de 1988. 8. ed. rev. atual. e ampl. Porto Alegre: Livraria do Advogado, 2010. p. 163.

${ }^{35}$ ANDRADE, Fábio Siebeneichler de. Considerações sobre o desenvolvimento dos direitos da personalidade e sua aplicação às relações de trabalho. Direitos Fundamentais e Justiça, ano 3, n. 6, 2009. p. 162-176.

${ }^{36}$ Também nesse sentido, SCHREIBER, Anderson. Direitos da Personalidade. São Paulo: Atlas, 2011. p. 14-16. 
Acrescente-se que o reconhecimento de que os artigos que disciplinam os direitos da personalidade não se tratam de numerus apertus, mas de numerus clausulus, é apenas uma das vantagens que a previsão de uma cláusula geral dos direitos da personalidade traria em seu bojo, às quais se somam outros argumentos, como a identificação de que tal dispositivo poderia servir de elemento expresso de conexão ao princípio da dignidade da pessoa humana, conferindo maior efetividade à proteção de tais direitos, além de possuir maior aptidão para solução de controvérsias (inclusive futuras, de acordo com o caminhar do desenvolvimento sociotecnológico), resguardando-se o princípio da dignidade da pessoa humana a situações que efetivamente demandem a sua invocação ${ }^{37}$.

No que diz respeito às suas características, são atribuídos aos direitos da personalidade atributos como: inalienabilidade, irrenunciabilidade, indisponibilidade, imprescritibilidade, vitaliciedade, generalidade (direitos inatos ou necessários), impenhorabilidade, bem como um caráter absoluto e não patrimonial $^{38}$. De todos estes, ao presente estudo, importam destacar os atributos relativos ao caráter absoluto e à indisponibilidade, tendo em vista a convergência de tais características com os princípios aplicáveis às relações de trabalho, conforme adiante será examinado.

Com relação ao seu caráter absoluto, vale lembrar que tal característica pressupõe serem os direitos da personalidade oponíveis a todos e em face de todos, possuindo, portanto, eficácia

\footnotetext{
${ }^{37}$ ANDRADE, Fábio Siebeneichler de. O desenvolvimento da tutela dos direitos da personalidade nos dez anos de vigência do Código Civil de 2002. In: LOTUFO, Renan; NANNI, Giovani Ettore; MARTINS, Fernando Rodrigues (Org.). Temas Relevantes de Direito Civil Contemporâneo - Reflexões sobre os 10 anos do Código Civil. São Paulo: Atlas, 2012. p. 56-57.

${ }^{38}$ Vide BORGES, Roxana Cardoso Brasileiro. Direitos da personalidade e autonomia privada. 2. ed. rev. São Paulo: Saraiva, 2007. p. 32-35, e BITTAR, Carlos Alberto. Direitos da personalidade. 6. ed. rev. e atual. Rio de Janeiro: Forense Universitária, 2003.
} 
O Desenvolvimento dos Direitos da Personalidade...

erga omnes ${ }^{39}$ e impondo um dever jurídico positivo e negativo: positivo porque impõe ao Estado e aos particulares o dever de sua promoção; negativo porque impõe a estes mesmos agentes um dever de respeito e abstenção ${ }^{40}$. Todavia, tal característica não torna os direitos da personalidade imunes ao exercício de relativização (ponderação), especialmente quando da aplicabilidade de seus preceitos verificar-se colisão com outros direitos de igual estatura constitucional-fundamental, como o direito ao exercício da autonomia privada, um dos componentes do direito fundamental à liberdade ${ }^{41}$. A propósito, é justamente no conflito entre esses direitos fundamentais, no caso concreto, que a problemática da vinculação dos particulares melhor se faz sentir, de tal forma que a sua convivência, somente possível pelo exercício de ponderação de valores, depende de equilíbrio e "concordância prática", sintetizados pelo "[...] não sacrifício completo de um dos direitos fundamentais, bem como pela preservação, na medida do possível, da essência de cada um"42.

Em tal esteira de raciocínio, vê-se, desde logo, que a indisponibilidade dos direitos da personalidade (do qual decorre a compreensão de que são os mesmos intransmissíveis e irrenunciáveis), em verdade, pode arrefecer frente a outros direitos fundamentais, estando os mesmos, portanto, sujeitos a exercícios de relativização e ponderação, a depender das circunstâncias

39 TEPEDINO, Gustavo. Temas de direito civil. 3. ed. atual. Rio de Janeiro: Renovar, 2004. p. 33.

${ }^{40}$ CANTALI, Fernanda Borghetti. Direitos da personalidade: disponibilidade relativa, autonomia privada e dignidade humana. Porto Alegre: Livraria do Advogado, 2009. p. 136.

${ }^{41}$ SARMENTO, Daniel. Direitos fundamentais e relações privadas. Rio de Janeiro: Lumen Juris, 2006. p. 142.

${ }^{42}$ SARLET, Ingo Wolfgang. A Eficácia dos Direitos Fundamentais: uma teoria geral dos direitos fundamentais na perspectiva constitucional. 10. ed. rev. atual. ampl. Porto Alegre: Livraria do Advogado, 2009. p. 383. 
que permeiam o caso concreto ${ }^{43}$. A impossibilidade de renúncia, em determinadas situações, pode inviabilizar a própria tutela dos direitos da personalidade, sendo certo que a maior ou menor aproximação do conteúdo dos direitos postos em conflito com o princípio da dignidade da pessoa humana poderá servir de fundamento e justificativa da prevalência de um sobre o outro no caso concreto. Quer-se acreditar que, não por outro motivo, o próprio Código Civil preveja a possibilidade de restrição dos direitos da personalidade (vide artigo $11^{44}$, dentre outros ${ }^{45}$ ).

A indisponibilidade, enquanto qualidade intrínseca dos direitos da personalidade, será melhor desenvolvida em conjunto e também sob a ótica do princípio da irrenunciabilidade, norteador do Direito do Trabalho. Feitas tais considerações, e por não ser objeto do presente estudo a análise crítica e pormenorizada de cada um dos direitos da personalidade, permite-se avançar para o exame da existência, ou não, de espaço para exercício da autonomia privada, assim como do reconhecimento da possibilidade (necessidade) de relativização dos direitos da personalidade no contexto das relações de trabalho.

${ }^{43}$ CANTALI, Fernanda Borghetti. Direitos da personalidade: disponibilidade relativa, autonomia privada e dignidade humana. Porto Alegre: Livraria do Advogado, 2009. p. 146.

${ }^{44}$ Art. 11. Com exceção dos casos previstos em lei, os direitos da personalidade são intransmissíveis e irrenunciáveis, não podendo o seu exercício sofrer limitação voluntária.

45 Ainda no capítulo destinado aos direitos da personalidade, o artigo 20, caput, assim dispõe: "Salvo se autorizadas, ou se necessárias à administração da justiça ou à manutenção da ordem pública, a divulgação de escritos, a transmissão da palavra, ou a publicação, a exposição ou a utilização da imagem de uma pessoa poderão ser proibidas, a seu requerimento e sem prejuízo da indenização que couber, se lhe atingirem a honra, a boa fama ou a respeitabilidade, ou se se destinarem a fins comerciais". 


\section{Direitos da Personalidade Aplicados às Relações de Trabalho. Proteção e Indisponibilidade. Autonomia Privada e Ponderação de Valores nas Relações de Trabalho. Casuística}

Como anteriormente referido, as relações privadas podem caracterizar-se pelo desequilíbrio de posição e de exercício do poder normativo, sendo as relações de trabalho um cenário significativo para a representação das desigualdades de poder econômico e social entre particulares. Esta circunstância explica que este ramo do direito privado tenha sido erigido sobre bases e princípios de inequívoca inclinação protecionista em favor do trabalhador, com o objetivo de alcançar-se uma igualdade substancial e verdadeira entre as partes contratantes na esfera juslaboralista. Assim é que, conforme clássica e amplamente aceita ${ }^{46}$ definição proposta por Américo Plá Rodriguez ${ }^{47}$, o Direito do Trabalho alicerça-se sobre seis princípios básicos ${ }^{48}$, todos orientados para produzirem o abrandamento do presumido desequilíbrio entre empregado e empregador: princípio da proteção, da irrenunciabilidade, da continuidade, da primazia

\footnotetext{
${ }^{46}$ Assim, por exemplo, para a magistrada mineira Alice Monteiro de Barros. Vide BARROS, Alice Monteiro de. Curso de Direito do Trabalho. 9. ed. São Paulo: LTr, 2013. p. 141-142.

${ }^{47}$ RODRIGUEZ, Américo Plá. Princípios do Direito do Trabalho. São Paulo: LTr, 1978.

${ }^{48}$ Indispensável ressaltar o magistério de Maurício Godinho Delgado, para quem o Direito do Trabalho é formado por um grupo de nove princípios especiais, quais sejam: princípio da proteção, da norma mais favorável, da imperatividade das normas trabalhistas, da indisponibilidade dos direitos trabalhistas, da condição mais benéfica, da inalterabilidade contratual lesiva, da intangibilidade salarial, da primazia da realidade sobre a forma e da continuidade da relação de emprego. DELGADO, Mauricio Godinho. Curso de Direito do Trabalho. 12. ed. São Paulo: LTr, 2013. p. 189. Não obstante o respeito a tal entendimento, compreende-se que tais princípios, em maior ou menor medida, encontram expressão nos princípios propostos por Américo Plá Rodriguez, razão pela qual se adota a categorização por este proposta.
} 
da realidade, da razoabilidade e da boa-fé. Desses, por estarem alinhados aos objetivos do presente estudo, destacam-se os princípios da proteção e da irrenunciabilidade.

O princípio da proteção pode ser resumido como a expressão primeira do objetivo que se visa a alcançar, por meio da disciplina do Direito do Trabalho, qual seja, o de máxima proteção ao trabalhador. Nas palavras de Maurício Godinho Delgado, é por ter como base este princípio que o Direito do Trabalho constrói “[...] com suas regras, institutos, princípios e presunções próprias, uma teia de proteção à parte hipossuficiente na relação empregatícia - o obreiro -, visando retificar (ou atenuar), no plano jurídico, o desequilíbrio inerente ao plano fático" ${ }^{\prime \prime 4}$.

Para Américo Plá Rodriguez, esse princípio encontra aplicação sob três formas distintas: a) a regra in dubio, pro operario, segundo a qual, havendo dúvida acerca do sentido possível de uma determinada norma, o juiz ou intérprete deverá privilegiar aquele que for mais favorável ao trabalhador; b) a regra da norma mais favorável, determinando que sendo possível a aplicação, no caso concreto, de mais de uma norma jurídica, deverá ser escolhida aquela que melhor favoreça o trabalhador, ainda que não sejam observados os critérios comuns de hierarquia das normas; e c) a regra da condição mais benéfica, por meio da qual a aplicação de uma norma trabalhista jamais deve diminuir condições mais favoráveis nas quais está inserido o trabalhador ${ }^{50}$. Como facilmente pode-se perceber, o princípio da proteção encerra um comando bastante claro em matéria de hermenêutica: no campo das relações trabalhistas, todo e

${ }^{49}$ DELGADO, Mauricio Godinho. Curso de Direito do Trabalho. 12. ed. São Paulo: LTr, 2013. p. 190.

${ }^{50}$ RODRIGUEZ, Américo Plá. Princípios do Direito do Trabalho. São Paulo: LTr, 1978. p. $42-43$. 
O Desenvolvimento dos Direitos da Personalidade...

qualquer exercício de interpretação de normas deve ser orientado para proteção do trabalhador - note-se, por oportuno, que os princípios, tal qual propostos pelo jurista uruguaio, não fazem distinção entre normas de matriz juslaboral e normas de outros campos do Direito.

O princípio da irrenunciabilidade, por seu turno, pode ser traduzido pela “[...] inviabilidade técnico-jurídica de poder o empregado despojar-se, por sua simples manifestação de vontade, das vantagens e proteções que lhe asseguram a ordem jurídica e o contrato" ${ }^{\prime 2}$. Américo Plá Rodriguez, ao relacionar as formas por meio das quais o princípio da irrenunciabilidade se desenvolve, invoca o princípio da indisponibilidade, enquanto impossibilidade de renúncia e transação, bem como faz menção à imperatividade das normas (no sentido de que as normas aplicáveis às relações de trabalho não excluem a autonomia privada, mas cercam-na de garantias à sua livre formação e manifestação), ao caráter de ordem pública próprio das normas trabalhistas (porque transcendem o interesse puramente individual para realizar-se também de acordo com o interesse social), à limitação da autonomia da vontade (a qual, a fim de evitar-se o seu abuso, é transplantada do terreno individual para o terreno coletivo) e ao vício de consentimento presumido - em relação ao trabalhador, naturalmente (justificado pelo fundado receio em perder o emprego ou, ainda, por ignorar os seus direitos) ${ }^{52}$.

Estabelecidas estas premissas, cumpre evidenciar o reconhecimento do status de direitos fundamentais aos direitos dos

\footnotetext{
${ }^{51}$ DELGADO, Mauricio Godinho. Op. cit., p. 193.

${ }^{52}$ RODRIGUEZ, Américo Plá. Princípios do Direito do Trabalho. São Paulo: LTr, 1978. p. 66-82.
} 
trabalhadores ${ }^{53}$. Tal constatação é pertinente na medida em que os mesmos, assim como os direitos da personalidade, também estão submetidos a exercícios de ponderação e relativização sempre que estiverem em colisão com outros direitos fundamentais, conforme já visto em item precedente. Contudo, não é apenas a condição de direito fundamental que tais matérias do direito privado compartilham; mais do que isso: ambos cumprem importante função social e, por isso mesmo, são fortemente protegidos contra atos de indisponibilidade que lhe reduzam o conteúdo e a aplicação. Neste contexto, como e em que bases se opera o exercício de ponderação entre os direitos fundamentais do trabalho e da personalidade quando, no caso concreto, do outro lado estiver o direito fundamental à autonomia privada, são perguntas que a seguir se buscará responder.

O primeiro passo para o cumprimento de tal finalidade passa pela definição de autonomia privada, que se conceitua como a capacidade do sujeito de direito de determinar seu próprio comportamento individual, envolvendo tantos aspectos negociais, como existenciais, constituindo "[...] uma das dimensões fundamentais da noção mais ampla de liberdade" e despontando como um contraponto necessário à eficácia dos direitos fundamentais nas relações privadas ${ }^{54}$. A autonomia privada é um dos valores fundantes da atual ordem jurídica (uma vez que une ao princípio da dignidade da pessoa humana o direito fundamental à liberdade) e instrumento para o livre desenvolvimento

\footnotetext{
${ }^{53}$ Nesse sentido, SANTOS JUNIOR, Rubens Fernando Clamer dos. A eficácia dos direitos fundamentais dos trabalhadores. São Paulo: LTr, 2010; ROMITA, Arion Sayão. Direitos fundamentais nas relações de trabalho. 4. ed. rev. e ampl. São Paulo: LTr, 2012. p. 212.

54 SARMENTO, Daniel. Direitos fundamentais e relações privadas. Rio de Janeiro: Lumen Juris, 2006. p. 142-143.
} 
da personalidade ${ }^{55}$, tendo sido seu alcance e finalidade redefinidos pelo princípio da dignidade da pessoa humana - como expressão de tal constatação, pode ser mencionada a (necessária) releitura do direito à liberdade, de forma a harmonizar-se com o direito à igualdade e à solidariedade ${ }^{56} 57$.

No que diz respeito à restrição dos direitos da personalidade pelo exercício do direito fundamental à autonomia privada, vem sendo esta hipótese admitida pela doutrina a partir de alguns pressupostos: atender, genuinamente, ao propósito de realização da personalidade do seu titular ${ }^{58}$; consideração das condições efetivas de liberdade do sujeito de direito no mundo da vida ${ }^{59}$; manifestação de consentimento livre e esclarecido

${ }^{55}$ Sobre o tema, PINTO, Paulo Mota. Notas sobre o direito ao livre desenvolvimento da personalidade e os direitos da personalidade no direito português. In: SARLET, Ingo Wolfgang (Org.). A Constituição concretizada: construindo pontes com o público e o privado. Porto Alegre: Livraria do Advogado, 2000. p. 61-83.

${ }^{56}$ CANTALI, Fernanda Borghetti. Direitos da personalidade: disponibilidade relativa, autonomia privada e dignidade humana. Porto Alegre: Livraria do Advogado, 2009. p. 206-23.

${ }^{57}$ Semelhante caminho trilha Maria Celina Bodin de Moraes ao definir o princípio da dignidade da pessoa humana a partir dos postulados que o compõem: a igualdade, a integridade física e moral, a liberdade e a solidariedade, todos interdependentes. MORAES, Maria Celina Bodin de. Danos à pessoa humana: uma leitura civil-constitucional dos danos morais. Rio de Janeiro: Renovar, 2003. p. 81-116.

${ }^{58}$ SCHREIBER, Anderson. Direitos da Personalidade. São Paulo: Atlas, 2011. p. 26-29. Para esse autor, a restrição dos direitos da personalidade pelo exercício da autonomia privada depende da análise de aspectos como a duração e o alcance da restrição - uma vez que não se pode admitir a autolimitação de caráter irrestrito ou permanente, aos quais se somam a análise da intensidade desta autolimitação (grau de restrição) e da finalidade (vinculação direta e imediata a um interesse do seu próprio titular; exemplo: a inserção na pele de um microchip por motivos de saúde difere, em sua finalidade, da mesma inserção para fins de fiscalização do horário de trabalho pelo empregador). Interessante, aqui, destacar que o próprio autor lembra que o artigo 11 do Código Civil não deve ser interpretado de forma literal, tanto que a comunidade jurídica vem, de maneira geral, aceitando a limitação voluntária ao exercício dos direitos da personalidade em numerosas citações, como é o caso, citado pelo autor, dos reality shows exibidos no país.

${ }^{59}$ SARMENTO, Daniel. Direitos fundamentais e relações privadas. Rio de Janeiro: Lumen Juris, 2006. p. 143. Sobre tal pressuposto: “[...] parece-nos anacrônica a rejeição 
(enquanto instrumento para o exercício da autodeterminação dos interesses pessoais) e revogabilidade a qualquer tempo (como forma de proteção da própria personalidade humana) ${ }^{60}$. Como se vê, em que pese não se desconheçam outras concepções para definição dos pressupostos de restrição dos direitos da personalidade pela autonomia privada ${ }^{61}$, é inconteste estar tal problemática, de matriz originalmente civilista, amplamente influenciada pelo princípio da dignidade da pessoa humana.

Em sentido diametralmente oposto, encontra-se a doutrina trabalhista. Tome-se como exemplo a lição de Maurício Godinho Delgado, para quem a disponibilidade dos direitos trabalhistas se expressa somente por meio da prescrição, da decadência e em limitadas hipóteses de transação (vide a possibilidade de compensação do excesso de jornada de trabalho por meio de banco de horas previsto em instrumento coletivo) e renúncia (como a renúncia ao direito à garantia provisória no emprego por dirigente sindical que solicita a sua transferência para outra base territorial), e, ainda assim, desde que não se verifique prejuízo ao empregado (conforme exegese do artigo 468 da

à ideia da liberdade positiva, diante da inevitável constatação de que a pessoa humana não é minimamente livre enquanto suas necessidades vitais não são satisfeitas, ou quando ela se sujeita à opressão nas relações sociais que vivencia" (Ibid., p. 150).

${ }^{60}$ CANTALI, Fernanda Borghetti. Direitos da personalidade: disponibilidade relativa, autonomia privada e dignidade humana. Porto Alegre: Livraria do Advogado, 2009. p. 160-170. Acerca do consentimento livre e esclarecido: “O consentimento do titular pode legitimar ato restritivo dos direitos fundamentais da personalidade, desde que, no caso concreto, se verifique que o ato dispositivo não atinge o núcleo essencial da dignidade e resulte em alguma finalidade ao interessado", p. 163.

${ }^{61}$ Nesse sentido, BORGES, Roxana Cardoso Brasileiro. Direitos da personalidade e autonomia privada. 2. ed. rev. São Paulo: Saraiva, 2007. p. 138. Para essa autora, a lei, a ordem pública, a moral e os bons costumes são os limites à autonomia privada, reconhecendo, quanto a estes dois últimos, não poderem os mesmos constituir fatores isolados para restrição das liberdades pessoais, especialmente quanto aos direitos da personalidade. 
O Desenvolvimento dos Direitos da Personalidade...

Consolidação das Leis do Trabalho) ${ }^{62}$. Nesta esteira de raciocínio, Alice Monteiro de Barros chega a afirmar, acerca da transação, que a mesma "É restrita a direitos patrimoniais de caráter privado, sobre os quais recaia o litígio ou a suscetibilidade do litígio"63 (grifo nosso).

Sem dúvida, não se trata de aqui defender a ampla flexibilidade dos direitos trabalhistas pelo exercício da autonomia privada - do contrário, estar-se-ia negando conhecimento ao fundamento axiológico de tal ramo do Direito e, até mesmo, a sua eficácia e efetividade. Questões como a presunção de hipossuficiência do empregado, de onde extraem-se dúvidas acerca da legítima, livre e esclarecida manifestação de vontade na formação do contrato de trabalho, não passam aqui despercebidas $^{64}$. Todavia, tampouco entende-se razoável permanecer o Direito do Trabalho alheio aos avanços feitos em matéria de convivência de direitos fundamentais, como que a negar a possibilidade de relativização dos direitos fundamentais dos trabalhadores quando em colisão com outros direitos de igual matriz constitucional, como é o caso do direito fundamental ao

${ }_{62}$ DELGADO, Mauricio Godinho. Curso de Direito do Trabalho. 12. ed. São Paulo: LTr, 2013. p. 207-211.

${ }^{63}$ BARROS, Alice Monteiro de. Curso de Direito do Trabalho. 9. ed. São Paulo: LTr, 2013. p. 160.

${ }^{64}$ Nesse sentido: “Ao considerar a viabilidade da renúncia a direitos fundamentais, tem-se condicionado expressamente essa possibilidade ao caráter inequívoco do consentimento, a fim de que dele se extraia a determinação de renunciabilidade. Além disso, leva-se em consideração a natureza dos direitos fundamentais, bem como a qualidade das partes envolvidas, mais precisamente a questão de saber se se trata de uma relação entre iguais ou uma envolvendo pessoas em desigualdade material. Nesse quadro, se é certo que o trabalhador possui liberdade para celebrar o contrato de trabalho, há que se ponderar o desequilíbrio de forças existente na relação de trabalho, bem como a natureza do direito que ele renuncia." ANDRADE, Fábio Siebeneichler de. Considerações sobre o desenvolvimento dos direitos da personalidade e sua aplicação às relações de trabalho. Direitos Fundamentais e Justiça, ano 3, n. 6, 2009. p. 171. 
exercício da autonomia privada ${ }^{65}$. O exame da aplicabilidade dos direitos da personalidade no âmbito das relações laborais permite identificar esta sinergia, bem como a atualidade do necessário exercício de ponderação de valores expressos em direitos fundamentais também na seara trabalhista, senão vejamos.

Doutrina $^{66}$ e jurisprudência ${ }^{67}$ vêm admitindo a licitude da revista no ambiente do trabalho sempre que existirem circunstâncias que a justifiquem (como a existência, na empresa, de bens suscetíveis de subtração) e desde que preenchidos requisitos como a submissão à revista por todos os empregados, independente do nível hierárquico, sem discriminações de qualquer espécie, de forma aleatória e, preferencialmente, realizada apenas de forma visual nos pertences pessoais

${ }^{65}$ Por oportuno, não se pode deixar de referir que a própria Constituição Federal prevê, de forma expressa, a possibilidade de flexibilização dos direitos dos trabalhadores (artigo 7º , incisos VI, XIII e XIV), ainda que mediante negociação coletiva. Nesta mesma esteira, a Consolidação das Leis do Trabalho - CLT, em seu artigo 444, prevê "As relações contratuais de trabalho podem ser objeto de livre estipulação das partes interessadas em tudo quanto não contravenha às disposições de proteção ao trabalho, aos contratos coletivos que lhes sejam aplicáveis e às decisões das autoridades competentes".

${ }^{66}$ ROMITA, Arion Sayão. Direitos fundamentais nas relações de trabalho. 4. ed. rev. e ampl. São Paulo: LTr, 2012. p. 284.

${ }^{67}$ Assim tem se posicionado o Tribunal Superior do Trabalho, conforme bem se pode verificar da análise da ementa do processo RR-742-60.2010.5.09.0014, julgado em 30 de novembro de 2011 e publicado em 02 de dezembro de 2011 no Diário Eletrônico da Justiça do Trabalho, de lavra da Ministra Relatora Maria de Assis Calsing: "DANO MORAL. REVISTA VISUAL EM BOLSAS E SACOLAS. PODER DE FISCALIZAÇÃO DO TRABALHADOR. Segundo o entendimento dominante no âmbito desta Corte Superior Trabalhista, "[...] a revista de bolsas e sacolas daqueles que adentram no recinto empresarial não constitui, por si só, motivo a denotar constrangimento nem violação da intimidade da pessoa. Retrata, na realidade, o exercício pela empresa de legítimo exercício regular do direito à proteção de seu patrimônio, se ausente abuso desse direito, quando procedida a revista moderadamente, não há se falar em constrangimento ou em revista íntima e vexatória, a atacar a imagem ou a dignidade do empregado". Precedente citado. No ponto, emerge como óbice à revisão pretendida o disposto na Súmula n. 933 do TST. Recurso de Revista parcialmente conhecido e provido". 
O Desenvolvimento dos Direitos da Personalidade...

dos empregados ${ }^{68}$. Como se vê, a possibilidade conferida ao empregador de proceder à revista dos pertences pessoais de trabalhadores encerra verdadeira hipótese de ponderação de valores, prevalecendo o direito fundamental à propriedade em face do direito fundamental à intimidade, por entender-se que tal prática não restringe seu conteúdo em dignidade humana.

Na mesma esteira de raciocínio, porém em colisão com direito fundamental diverso, vem sendo aceita a submissão de empregados a testes e a programas de controle de uso de droga e de bebida alcoólica, inclusive por empresas que não se enquadram ao âmbito de incidência da Lei n. 12.619, de 30 de abril de 2012 (a qual prevê ser dever dos motoristas profissionais a realização de testes de tal natureza), a depender de alguns pressupostos para sua prática, tais como a sua realização de forma randômica e em local reservado. Novamente, é possível verificar a restrição do direito à privacidade e à intimidade (já que a realização de testes de tal natureza possibilita o conhecimento, pelo empregador, do consumo de substâncias lícitas e ilícitas pelo empregado) e, em certa medida, à honra e à inviolabilidade corporal, no âmbito da relação laboral, por privilegiar-se a proteção de outros direitos fundamentais, igualmente indisponíveis, como a vida, a integridade física e a segurança no ambiente de trabalho ${ }^{69}$. Note-se que, em ambos os casos, um

\footnotetext{
${ }^{68} \mathrm{Na}$ Itália, o tema pertinente às revistas de empregados encontra-se pacificado pela Lei n. 300, de 20 de maio de 1970 (Statuto dei Diritti dei Lavoratori), sendo permitida a sua realização nas hipóteses em que imprescindível à preservação do patrimônio do empregador, na saída do trabalho, mediante a utilização de processo de seleção aleatória e dependente de negociação sindical ou aprovação da comissão interna de trabalhadores, na ausência de entidade sindical representativa.

${ }^{69}$ Neste mesmo sentido é o acórdão do processo 0000848-98.2011.5.04.0281 - RO, julgado pelo Tribunal Regional do Trabalho da $4^{\underline{a}}$ Região, $2^{\underline{a}}$ Turma, em 02 de agosto de 2012, cujo trecho do voto se passa a transcrever: "O procedimento adotado pela segunda reclamada visa à segurança do ambiente de trabalho. A adoção da medida tem o objetivo de prevenir a ocorrência de acidentes que podem vitimar,
} 
dos pressupostos de legitimidade é a observância ao direito fundamental à isonomia de tratamento, pela necessidade de submissão a tais práticas por todos os integrantes de um determinado grupo de trabalhadores, de forma indiscriminada.

Outro exemplo interessante de restrição dos direitos da personalidade consubstanciados na proteção da privacidade e da intimidade (este último, inclusive, pela inviolabilidade de sigilo das correspondências e comunicações) é o da fiscalização de correspondências eletrônicas (e-mails) pelo empregador. A jurisprudência, amparada pela doutrina especializada ${ }^{70}$, já consolidou o entendimento segundo o qual mensagens eletrônicas enviadas a partir de endereço de e-mail corporativo (de domínio do empregador, portanto) estão submetidas ao poder de fiscalização e controle patronal, desde que haja o consentimento expresso do empregado para tanto ${ }^{71}$. Trata-se da prevalência do direito ao exercício do poder de fiscalização e controle pelo empregador, reflexo do seu direito de propriedade, diante de inequívocos direitos da personalidade dos trabalhadores ${ }^{72}$.

tanto os trabalhadores envolvidos no processo de produção, quanto aqueles que frequentam o canteiro de obras para a prestação de serviços. A proteção abarca, da mesma forma, a segurança de toda a população que habita, trabalha ou apenas circula nas imediações da empresa, frente aos riscos naturais advindos da atividade da segunda demandada (envolvida na produção e no transporte de produtos combustíveis). Ponderados esses aspectos, resta afastada a hipótese de violação à honra, à boa fama ou à dignidade do obreiro".

${ }^{70}$ Para aprofundar o tema, HAINZENREDER JUNIOR, Eugênio. Direito à privacidade e poder diretivo do empregador: o uso do e-mail no trabalho. São Paulo: Atlas, 2009. Para o autor, é lícito o monitoramento do correio eletrônico corporativo pelo empregador, na medida em que: "[...] quando não há uma razoável expectativa de privacidade, originada através de regramento cristalino de controle e de verificação do correio eletrônico corporativo, pode-se sustentar a prevalência do poder diretivo do empregador em relação ao direito à privacidade do empregado" (Ibid., p. 167).

${ }^{71}$ GEDIEL, José Antônio Peres. A irrenunciabilidade a direitos da personalidade pelo trabalhador. In: SARLET, Ingo Wolfgang (Org.). Constituição, direitos fundamentais e direito privado. Porto Alegre: Livraria do Advogado, 2010. p. 155.

${ }^{72}$ Interessante ressaltar que vem sendo admitida, inclusive, a licitude da prova obtida por meio de monitoramento eletrônico, como bem demonstra o quanto julgado 
Por outro lado, é certo que não há que se falar em renúncia ou transação em matéria de direitos da personalidade quando se está diante de situações que, por exemplo, ofendam o direito fundamental à honra ${ }^{73}$ por práticas de assédio moral, em vista do ataque direto ao princípio da dignidade da pessoa humana (por ferir a esfera íntima e moral dos trabalhadores, causando-lhes, inclusive, danos à saúde, especialmente à integridade psíquica ${ }^{74}$ ). A propósito, é pertinente a menção a julgado proferido pelo Tribunal Regional do Trabalho da 9ª Região (Paraná), em ação na qual o autor obteve a condenação de seu empregador ao pagamento de indenização por danos morais, bem como à obrigação de reconduzi-lo ao Departamento de Filosofia e à cátedra análoga a que vinha proferindo até ser afastado do ensino da disciplina Introdução à Filosofia e Metodologia da Pesquisa em Filosofia I. Entendeu o mencionado tribunal que as críticas dirigidas pelo autor em face da universidade empregadora, bem como sua forte atuação sindical, motivaram atitudes persecutórias

pelo Tribunal Superior do Trabalho, no processo RR-613/2000-013-00.7, julgado em 18 de maio de 2005 e publicado em 10 de junho de 2005, no Diário da Justiça, de lavra do Ministro Relator João Oreste Dalazen, cuja ementa segue transcrita: “PROVA ILÍCITA. 'E-MAIL' CORPORATIVO. JUSTA CAUSA. DIVULGAÇÃO DE MATERIAL PORNOGRÁFICO. 1. Os sacrossantos direitos do cidadão à privacidade e ao sigilo de correspondência, constitucionalmente assegurados, concernem à comunicação estritamente pessoal, ainda que virtual ('e-mail' particular). Assim, apenas o e-mail pessoal ou particular do empregado, socorrendo-se de provedor próprio, desfruta da proteção constitucional e legal de inviolabilidade. 2. Solução diversa impõe-se em se tratando do chamado 'e-mail' corporativo, instrumento de comunicação virtual mediante o qual o empregado louva-se de terminal de computador e de provedor da empresa, bem assim do próprio endereço eletrônico que lhe é disponibilizado igualmente pela empresa. Destina-se este a que nele trafeguem mensagens de cunho estritamente profissional. Em princípio, é de uso corporativo, salvo consentimento do empregador. Ostenta, pois, natureza jurídica equivalente à de uma ferramenta de trabalho proporcionada pelo empregador ao empregado para a consecução do serviço".

${ }^{73}$ Vale lembrar que no âmbito das relações de trabalho a ofensa à honra importa em causa legítima à rescisão do contrato pelo empregado, conforme artigo 483, alínea "e" da Consolidação das Leis do Trabalho.

${ }^{74}$ SCHREIBER, Anderson. Direitos da Personalidade. São Paulo: Atlas, 2011. p. 90. 
e desonrosas, caracterizadoras de assédio moral. Em seu voto, o relator do acórdão destaca o direito à livre manifestação do pensamento, à honra (já que ao ser direcionado para lecionar em disciplinas básicas de filosofia em outros cursos de graduação, viu-se o autor humilhado perante a comunidade acadêmica após mais de vinte anos à frente do Departamento de Filosofia) e à saúde (por haver nos autos laudos médicos atestando que as doenças mentais que acometem o autor têm como causa os acontecimentos vivenciados em sua esfera laboral), como fundamentos das condenações impostas ${ }^{75}$.

De igual forma, há casos em que, ainda que verificada a renúncia expressa a determinados direitos, a tal ato de disposição não é reconhecida validade, especialmente nas hipóteses em que verificado o desrespeito a direitos da personalidade. Nesse sentido, cita-se decisão proferida pelo Tribunal Regional do Trabalho da $4^{a}$ Região (Rio Grande do Sul), na qual conhecida loja de vestuário jovem foi condenada ao pagamento de indenização pelo uso de imagem. Trata-se de ação na qual a autora, muito embora tenha assinado documento denominado “Termo de Cessão de Direitos e Autorização para Veiculação de Imagem", viu reconhecido o direito à indenização pelo uso de sua imagem, tendo em vista que a destinação da mesma se deu para fins comerciais (campanhas publicitárias e outdoors). Nessa hipótese, a renúncia da autora à remuneração pelo uso de sua imagem cedeu frente ao argumento segundo o qual a exploração da imagem do empregado "[...] com claros fins comerciais, como a ocorrida - outdoors e cromos - não pode ser gratuita, ainda que permitida, sob pena de permitir que o patrão explore não só o trabalho mas também o homem que a

${ }^{75}$ Processo no. 1409100-39.2004.5.09.0014, julgado em 09 de março de 2010, publicado no Diário da Justiça em 11 de junho de 2010, de lavra do Desembargador Relator: Ana Carolina Zaina, 2 ${ }^{\underline{a}}$ Turma do Tribunal Regional do Trabalho da 9aㅡ Região. 
O Desenvolvimento dos Direitos da Personalidade...

colocou a seu dispor" ${ }^{\prime \prime 6}$. Tal decisão imprime um novo prisma à posição comumente adotada pela doutrina, a qual propugna pela excepcionalidade da cessão de direito da imagem, sempre interpretada de forma restritiva ${ }^{77}$ - denota-se, aqui, a supremacia do valor da dignidade da pessoa humana sobre o exercício da autonomia nas relações de trabalho.

Ainda no que diz respeito ao direito à imagem, porém sob os contornos do direito ao livre desenvolvimento da personalidade, são muitas as ações judiciais a discutir regras empresariais que proíbem o uso de barba, piercings e tatuagens, sendo que as decisões diferem conforme o caso concreto, especialmente levando em consideração a natureza da atividade laboral desenvolvida. Neste passo, o Tribunal Superior do Trabalho reconheceu validade ao regulamento de empresa de segurança e transporte de valores que proíbe a utilização de barba e cabelos compridos em ação civil pública movida pelo Ministério Público do Trabalho da 5 $5^{\mathrm{a}}$ Região (Bahia). Entendeu o tribunal superior trabalhista que tal prática não caracteriza ofensa ao princípio da dignidade da pessoa humana ou à valorização social do trabalho, tendo em vista que a atividade empresarial em comento, por sua natureza, assemelha-se à atividade policial, em que são exigidas indumentárias e apresentação pessoal diferenciada ${ }^{78}$.

\footnotetext{
${ }^{76}$ Processo n⿳o. 0086500-86.2007.5.04.0002, julgado em 26 de março de 2009, publicado no Diário da Justiça Eletrônico em 07 de abril de 2009, de lavra do Desembargador Relator: Ana Luiza Heineck Kruse, $8^{\underline{a}}$ Turma do Tribunal Regional do Trabalho da $4^{\mathrm{a}}$ Região.

77 ANDRADE, Fábio Siebeneichler de. O desenvolvimento da tutela dos direitos da personalidade nos dez anos de vigência do Código Civil de 2002. In: LOTUFO, Renan; NANNI, Giovani Ettore; MARTINS, Fernando Rodrigues (Org.). Temas Relevantes de Direito Civil Contemporâneo - Reflexões sobre os 10 anos do Código Civil. São Paulo: Atlas, 2012. p. 72.

${ }^{78}$ Processo no. TST-RR-115700-62.2004.5.05.0020, julgado em 17 de março de 2010, publicado no Diário Eletrônico da Justiça do Trabalho em 30 de março de 2010,
} 
Nesta mesma linha, o Tribunal Superior do Trabalho negou conhecimento a Recurso de Revista interposto contra decisão proferida pelo Tribunal Regional do Trabalho da $2^{\text {a }}$ Região (São Paulo), a qual, mantendo sentença de primeiro grau, entendeu pela legitimidade de despedida por justa causa em razão do uso de piercing em desobediência a regulamento de empresa que proíbe a utilização de tal adorno. De acordo com o tribunal regional, a proibição de uso de adornos deste tipo em ambiente de trabalho voltado ao atendimento ao público (rede de supermercados) não se mostra abusiva, na medida em que se trata de expressão do poder organizacional do empregador por meio da fixação de regra que busca não agredir nenhuma parcela do seu público consumidor, sendo lícita, portanto, restrições de tal natureza ("Em tais casos, não me parece abusiva a proibição do uso de 'piercing' 'na boca', pelo empregado, uma vez que, se uma parte da população vê tal uso com absoluta normalidade, é de conhecimento público que outra parte não o aceita", trecho extraído do acórdão) ${ }^{79}$, não sendo permitido ao empregado deixar de observar referida regra sob o argumento de ofensa ao direito ao próprio corpo e à imagem.

Como se observa, são muitas as hipóteses em que não admitida a flexibilização dos direitos da personalidade no âmbito das relações de trabalho, especialmente quando sua renúncia estiver calcada na natural desigualdade de poder entre as partes e quando seu fundamento não for legítimo ou fundado em outro direito de igual estatura constitucional (como o direito à saúde e segurança no ambiente laboral e o

de lavra do Desembargador Relator: Emmanoel Pereira, 5ª Turma do Tribunal Superior do Trabalho.

79 Processo no . TST-RR-1400-87.2007.5.02.0401, julgado em 03 de março de 2010, publicado no Diário Eletrônico da Justiça do Trabalho em 12 de março de 2010, de lavra do Desembargador Relator: Emmanoel Pereira, 5a Turma do Tribunal Superior do Trabalho. 
O Desenvolvimento dos Direitos da Personalidade...

direito à propriedade, exercido de acordo com os limites de sua função social) - mais, a renúncia a direitos da personalidade não pode acarretar ofensa ao princípio da dignidade da pessoa humana. Entretanto, não se pode desconsiderar a circunstância de que o exercício da autonomia privada é, em si mesmo, uma das expressões da dignidade da pessoa humana - nesse sentido, cumpre destacar a compreensão de Ingo Sarlet, para quem “[...] o elemento nuclear da noção de dignidade da pessoa humana parece continuar sendo reconduzido [...] à matriz kantiana, centrando-se, portanto, na autonomia e no direito à autodeterminação da pessoa [de cada pessoa]"80.

Assim é que muitos são e serão os desafios da doutrina e jurisprudência em matéria de convivência dos direitos da personalidade dos trabalhadores com outros direitos fundamentais e mesmo frente às diversas situações que as relações laborais proporcionam, especialmente em razão das novas tecnologias, as quais têm provocado diversas alterações na forma com o que o trabalho é medido e vivenciado. Tome-se como exemplo o reconhecimento de que as fronteiras entre os horários de trabalho e de lazer são cada vez mais tênues - ao mesmo tempo em que a utilização de telefones celulares com conexão à Internet (smartphones), assim como tablets e laptops, permitem ao trabalhador acessar páginas da Internet não relacionadas ao trabalho, conectando-se a redes sociais e e-mails pessoais durante a jornada de trabalho, igualmente permite que o trabalhador seja contatado por seu empregador, inclusive respondendo a e-mails profissionais, em períodos destinados ao descanso. Os efeitos da constante utilização de equipamentos eletrônicos de comunicação na saúde da população e, em especial, dos trabalhadores, bem como os reflexos

${ }^{80}$ SARLET, Ingo Wolfgang. Dignidade da pessoa humana e direitos fundamentais na Constituição Federal de 1988. 8. ed. rev. atual. e ampl. Porto Alegre: Livraria do Advogado, 2010. p. 53. 
na produtividade ao longo do horário de trabalho, já são objeto de estudos científicos, com resultados surpreendentes ${ }^{81}$. Sem dúvida, está-se diante de um novo contexto social, no qual se faz necessária uma releitura dos direitos da personalidade dos trabalhadores, seus contornos e amplitude.

Neste mesmo passo, já é possível identificar na jurisprudência brasileira diversas decisões envolvendo a interação entre as relações de trabalho e o uso de redes sociais na Internet. As mais comuns dizem respeito a insultos manifestados em redes sociais como o Facebook - quando proferidos por prepostos do empregador, levam à condenação destes ao pagamento de indenizações por danos morais ${ }^{82}$; quando proferidos por empregados, à despedida por justa causa ${ }^{83}$ - em todos os casos o fundamento é a lesão à honra e à imagem, de um ou de outro lado. Porém, resta saber: como caracterizar o ambiente das redes sociais? Extensão da vida privada ou espaço público? O que dizer da liberdade de pensamento em tal cenário? Sob semelhante viés, o que dizer do acesso a informações pessoais

\footnotetext{
${ }^{81}$ No artigo Brain Interrupted é divulgado estudo recente da Carnegie Mellon University's Human-Computer Interaction Lab, concluindo que o hábito de executar múltiplas tarefas durante o horário de trabalho, levando a diversas interrupções para os diversos trabalhos que estão sendo executados, além de impactos na produtividade, possui reflexos na qualidade do trabalho entregue. Por outro lado, verificou-se, mediante testes, que o cérebro é capaz de se adaptar às constantes interrupções, de tal forma que é capaz de melhorar seu desempenho. SULLIVAN, Bob; THOMPSON, Hugh. Brain Interrupted. The New York Times, May 3, 2013. Disponível em: <http://www.nytimes.com/2013/05/05/opinion/sunday/a-focus-on-distraction.html?_r=0 $>$. Acesso em: 22 jul. 2013.

${ }^{82}$ Processo no. 0000798-82.2011.5.04.0019 (RO), julgado em 06 de junho de 2013, publicado no Diário Eletrônico da Justiça do Trabalho em 14 de junho de 2013, de lavra do Desembargador Relator: Raul Zoratto Sanvicente, $2^{2}$ Turma do Tribunal Regional do Trabalho da $4^{a}$ Região.

${ }^{83}$ Processo no. 0000544-81.2012.5.04.0405 (RO), julgado em 13 de junho de 2013, publicado no Diário Eletrônico da Justiça do Trabalho em 21 de junho de 2013, de lavra do Desembargador Relator: Leonardo Meurer Brasil, 5 ${ }^{\mathbf{a}}$ Turma do Tribunal Regional do Trabalho da 4를 Região.
} 
O Desenvolvimento dos Direitos da Personalidade...

disponibilizadas em redes sociais na Internet (como o Facebook e o Twitter) no processo de seleção de candidatos a uma vaga de emprego ${ }^{84}$ ? Seria esta uma forma lícita de discriminação no processo seletivo?

Se a tais questionamentos ainda não é possível afirmar que existam respostas seguras, é forçoso reconhecer que haverá situações nas quais se legitimará pontual restrição aos direitos fundamentais do trabalho e da personalidade dos trabalhadores, por intermédio do exercício da autonomia privada e frente ao adequado exercício de ponderação de valores. Tal circunstância, contudo, importará não em violação ao princípio da dignidade da pessoa humana, mas ao contrário, em recurso indispensável à sua promoção.

\section{Considerações Finais}

As relações de trabalho enfrentam antigos e novos desafios; antigos, porque ainda não foram superadas as desigualdades que lhes justificam o alto grau de proteção; novos, porque os avanços tecnológicos contêm em seu bojo situações até agora não enfrentadas e que impõem um exercício hermenêutico sistemático e transdisciplinar como única forma de o Direito fornecer-lhes respostas adequadas e em conformidade com a contemporânea ordem constitucional. Exemplo emblemático desse desafio a ser enfrentado constitui-se na tutela dos direitos da personalidade nas relações de trabalho.

\footnotetext{
${ }^{84}$ Neste ponto, convém ressaltar que recentemente esteve em voga a prática norte-americana de solicitar a senha do Facebook a candidatos a vagas de trabalho, abrindo-se espaço para debate do tema, conforme ampla repercussão mundial, por meio de notícias divulgadas em 2012. EMPRESAS pedem senha de perfil em redes sociais para candidatos a vagas. Jornal da Globo, 29 mar. 2013. Disponível em: $<$ http://g1.globo.com/jornal-da-globo/noticia/2012/03/empresas-pedem-senha-de-perfil-em-redes-sociais-para-candidatos-vagas.html>. Acesso em: 28 out. 2012.
} 
Isso porque a dinâmica das relações de trabalho gera situações nas quais os direitos da personalidade dos trabalhadores são postos em confrontos com outros direitos de igual condição constitucional-fundamental, como o direito à vida, à saúde e segurança no trabalho e à propriedade. Em tais situações, o respeito à autonomia privada, assim como o indispensável exercício de ponderação dos valores em jogo, são os principais vetores de harmonização dos direitos fundamentais em colisão.

Em que pese os direitos da personalidade do trabalhador representarem, a um só tempo, o resultado de longa conquista social, negar-lhes a possibilidade de ser, pontual e finalisticamente, objeto de disposição, pode significar, em determinadas situações, uma diminuição de sua capacidade de conformação a outros valores constitucionais.

Em tais contextos, uma adequada compreensão dos contornos próprios ao exercício do direito fundamental à liberdade, em especial da autonomia privada, é imprescindível, na medida em que a verificação de seus pressupostos de legitimação (realização da personalidade do seu titular, exame das efetivas condições de liberdade, livre e esclarecido consentimento e revogabilidade a qualquer tempo) se faz imperativa no âmbito das relações de trabalho, dada a natural desigualdade de forças dos seus agentes sociais. Por tratarem-se de direitos de matriz fundamental e de amplo caráter social, é indispensável à validade do ato de disposição que o direito topicamente restringido tenha respeitado o seu conteúdo mínimo em matéria de dignidade da pessoa humana. 


\section{Referências}

ANDRADE, Fábio Siebeneichler de. Da Codificação - crônica de conceito. Porto Alegre: Livraria do Advogado, 1997.

. O desenvolvimento da tutela dos direitos da personalidade nos dez anos de vigência do Código Civil de 2002. In: LOTUFO, Renan; NANNI, Giovani Ettore; MARTINS, Fernando Rodrigues (Org.). Temas Relevantes de Direito Civil Contemporâneo - Reflexões sobre os 10 anos do Código Civil. São Paulo: Atlas, 2012.

. Considerações sobre o desenvolvimento dos direitos da personalidade e sua aplicação às relações de trabalho. Direitos Fundamentais e Justiça, ano 3, n. 6, p. 162-176, 2009.

ASCENSÃO, José de Oliveira. Direito Civil: teoria geral. v. 1. Coimbra: Coimbra Editora, 1997.

BARROS, Alice Monteiro de. Curso de Direito do Trabalho. 9. ed. São Paulo: LTr, 2013.

442 BELTRÃO, Silvio Romero. Direitos da personalidade: de acordo com o Novo Código Civil. São Paulo: Atlas, 2005.

BITTAR, Carlos Alberto. Direitos da personalidade. 6. ed. rev. e atual. Rio de Janeiro: Forense Universitária, 2003.

BORGES, Roxana Cardoso Brasileiro. Direitos da personalidade e autonomia privada. 2. ed. rev. São Paulo: Saraiva, 2007.

BULLINGER, Martin. Derecho Público y Privado. Madrid: IEA, 1976.

CANARIS, Claus-Wilhelm. A influência dos direitos fundamentais sobre o direito privado na Alemanha. In: SARLET, Ingo Wolfgang (Org.). Constituição, Direitos Fundamentais e Direito Privado. 3. ed. Porto Alegre: Livraria do Advogado, 2010.

CANOTILHO, José Joaquim Gomes. Civilização do Direito Constitucional ou Constitucionalização do Direito Civil. In: GRAU, Eros Roberto; GUERRA FILHO, Willis Santiago (Org.). Direito Constitucional: estudos em homenagem a Paulo Bonavides. São Paulo: Malheiros, 2001.

CANTALI, Fernanda Borghetti. Direitos da personalidade: disponibilidade relativa, autonomia privada e dignidade humana. Porto Alegre: Livraria do Advogado, 2009. 
CHIUSI, Tiziana. A dimensão abrangente do Direito privado romano. In: MONTEIRO, António Pinto; NEUNER, Jörg; SARLET, Ingo Wolfgang (Org.). Direitos fundamentais e direito privado. Coimbra: Almedina, 2007.

CORDEIRO, António Menezes. Tratado de Direito Civil Português. 3. ed. Coimbra: Almedina, 2005.

DELGADO, Mauricio Godinho. Curso de Direito do Trabalho. 12. ed. São Paulo: LTr, 2013.

EMPRESAS pedem senha de perfil em redes sociais para candidatos a vagas. Jornal da Globo, 29 mar. 2013. Disponível em: <http://g1.globo. com/jornal-da-globo/noticia/2012/03/empresas-pedem-senha-de-perfil-em-redes-sociais-para-candidatos-vagas.html>. Acesso em: 28 out. 2012.

FACCHINI NETO, Eugênio. Reflexões histórico-evolutivas sobre a constitucionalização do direito privado. In: SARLET, Ingo Wolfgang (Org.). Constituição, Direitos Fundamentais e Direito Privado. 3. ed. rev. e ampl. Porto Alegre: Livraria do Advogado, 2010.

FERNANDES, Milton Fernandes. Os Direitos da Personalidade. In: BARROS, Hamilton de Moraes e et al. (Org.). Estudos jurídicos em homenagem ao Professor Caio Mário da Silva Pereira. São Paulo: Forense, 1984.

GAGLIANO, Pablo Stolze; PAMPLONA FILHO, Rodolfo. Novo curso de direito civil, volume I: parte geral. 12. ed. rev. atual. São Paulo: Saraiva, 2010.

GEDIEL, José Antônio Peres. A irrenunciabilidade a direitos da personalidade pelo trabalhador. In: SARLET, Ingo Wolfgang (Org.). Constituição, direitos fundamentais e direito privado. Porto Alegre: Livraria do Advogado, 2010.

GIERKE, Otto. Deutsches Privatrecht. Erster Band. München und Leipzig: Duncker und Humblot, 1936.

GOMES, Orlando. Direitos da Personalidade. Revista Forense, Rio de Janeiro, v. 216, p. 5-10, out./nov./dez. 1966.

GUNTHER, Luiz Eduardo Gunther; ZORNIG, Cristina Maria Navarro. O Direito da Personalidade do Novo Código Civil e o Direito do Trabalho. In: NETO, José Affonso Dallegrave Neto; GUNTHER, Luiz Eduardo (Org.). O Impacto do Novo Código Civil no Direito do Trabalho. São Paulo: LTr, 2003. 
O Desenvolvimento dos Direitos da Personalidade...

HAINZENREDER JUNIOR, Eugênio. Direito à privacidade e poder diretivo do empregador: o uso do e-mail no trabalho. São Paulo: Atlas, 2009.

HATTENHAUER, Hans. Persona und personae acceptio - Christlicher Beitrag zur römischen Personenlehre. In: AVENARIUS, Martin; MEYER-PRITZL, Rudolf; MÖLLER, Cosima (Hrsg.). Ars Iuris, Festschrift für Okko Behrends zum 70 Geburtstag. Göttingen: Wallstein Verlag, 2009.

HATTENHAUER, Hans. Grundbegriffe des Bürgerlichen Rechts. 2. Aufl. München: Beck Verlag, 2000.

HESSE, Konrad. Grundzüge des Verfassungsrechts der Bundesrepublik Deutschalands, 20. Aufl. Heidelberg: Müller, 1995.

KHALIL, Magdi S. Le dirigisme économique et les contrats. Paris: LGDJ, 1967.

MANSSEN, Gerrit. Grundrechte. München: Beck Verlag, 2000.

MIRANDA, Pontes de. Tratado de Direito Privado. v. 7. Rio de Janeiro: Borsoi, 1955.

44. MIRANDA, Jorge; RODRIGUES JUNIOR, Otávio Luiz; FRUET, Gustavo Bonato. Principais problemas dos direitos da personalidade e estado-da-arte da matéria no direito comparado. In: MIRANDA, Jorge; RODRIGUES JUNIOR, Otávio Luiz; FRUET, Gustavo Bonato (Org.). Direitos da personalidade. São Paulo: Atlas, 2012.

MORAES, Maria Celina Bodin de. Danos à pessoa humana: uma leitura civil-constitucional dos danos morais. Rio de Janeiro: Renovar, 2003.

MUTZENBECHER, Franz. Zur Lehre vom Persönlichkeitsrecht. Hamburg: Lütcke und Wulff, 1909.

PINTO, Paulo Mota. Notas sobre o direito ao livre desenvolvimento da personalidade e os direitos da personalidade no direito português. In: SARLET, Ingo Wolfgang (Org.). A Constituição concretizada: construindo pontes com o público e o privado. Porto Alegre: Livraria do Advogado, 2000.

RAISER, Ludwig. Die Aufgabe des Privatrechts. Kronberg/Ts.: AthenaumVerlag, 1977.

RODRIGUEZ, Américo Plá. Princípios do Direito do Trabalho. São Paulo: LTr, 1978. 
ROMITA, Arion Sayão. Direitos fundamentais nas relações de trabalho. 4. ed. rev. e ampl. São Paulo: LTr, 2012.

RUARO, Regina Linden; RODRIGUEZ, Daniel Piñeiro. O direito à proteção dos dados pessoais: uma leitura do sistema europeu e a necessária tutela dos dados sensíveis como paradigma para um sistema jurídico brasileiro. Direitos Fundamentais e Justiça, Porto Alegre, ano 4, n. 11, p. 163-180, abr./jun. 2011.

SANTOS JUNIOR, Rubens Fernando Clamer dos. A eficácia dos direitos fundamentais dos trabalhadores. São Paulo: LTr, 2010.

SARLET, Ingo Wolfgang. A Eficácia dos Direitos Fundamentais: uma teoria geral dos direitos fundamentais na perspectiva constitucional. 10. ed. rev. atual. ampl. Porto Alegre: Livraria do Advogado, 2009.

. A Constituição concretizada: construindo pontes com o público e o privado. Porto Alegre: Livraria do Advogado, 2000.

. Constituição, Direitos Fundamentais e Direito Privado. 3. ed. rev. e ampl. Porto Alegre: Livraria do Advogado, 2010.

. Dignidade da pessoa humana e direitos fundamentais na Constituição Federal de 1988. 8. ed. rev. atual. e ampl. Porto Alegre: Livraria do Advogado, 2010.

. Neoconstitucionalismo e influência dos direitos fundamentais no direito privado: algumas notas sobre a evolução brasileira. In: SARLET, Ingo Wolfgang (Org.). Constituição, Direitos Fundamentais e Direito Privado. 3. ed. Porto Alegre: Livraria do Advogado, 2010.

SARMENTO, Daniel. Direitos fundamentais e relações privadas. Rio de Janeiro: Lumen Juris, 2006.

SCHREIBER, Anderson. Direitos da Personalidade. São Paulo: Atlas, 2011.

SCHWAB, Dieter. Einführung in das Zivilrecht. 15. Aufl. Heidelberg: C. F. Müller Verlag, 2002.

SULLIVAN, Bob; THOMPSON, Hugh. Brain Interrupted. The New York Times, May 3, 2013. Disponível em: <http://www.nytimes.com/2013/05/05/ opinion/sunday/a-focus-on-distraction.html?_r=0>. Acesso em: 22 jul. 2013.

SZANIAWSKI, Elimar. Direitos da personalidade e sua tutela. 2. ed. rev. atual. e ampl. São Paulo: Revista dos Tribunais, 2005. 
O Desenvolvimento dos Direitos da Personalidade...

TEPEDINO, Gustavo. Temas de direito civil. 3. ed. atual. Rio de Janeiro: Renovar, 2004.

WALINE, Marcel. L'Individualisme et le Droit. Paris: Domat-Montchrestien, 1945.

WHITMAN, James Q. The Two Western Cultures of Privacy: Dignity versus Liberty. Yale Law Journal, v. 113, p. 1151-1221, 2004.

Submissão: 15/10/2013

Aceito para Publicação: 25/12/2013 


\title{
Pluralismo Jurídico: o Palimpsesto Político e Jurídico em Moçambique e Direito de Pasárgada no Brasil
}

\author{
Legal Pluralism: the Political and Legal Palimpsest \\ in Mozambique and the Pasárgada Law in Brazil
}

Custódio Vique Jossia Júnior*

Resumo: A proposta de trabalho é fazer uma reflexão paralela a respeito da construção do pluralismo jurídico em Moçambique e no Brasil, com ênfase na teoria do estudo feito por Boaventura de Sousa Santos (o palimpsesto político, jurídico e Direito de Pasárgada). A ideia de pluralismo jurídico é decorrente da existência de dois ou mais sistemas jurídicos, dotados de eficácia, concomitantemente em um mesmo ambiente espaço-temporal. Em Moçambique estudos sobre a matéria reconheceram a presença de direito fora do Estado, onde era fácil identificar a presença de diferentes ordens jurídicas: de um lado, o direito europeu; do outro, os direitos costumeiros dos povos nativos. Já no contexto histórico do surgimento de pluralismo jurídico no Brasil, este surge com o Direito de Pasárgada, na década de 1930, na cidade do Rio de Janeiro.

Palavras-chave: Pluralismo Jurídico. Monismo. Palimpsesto. Pasárgada.

\begin{abstract}
The work proposal is to reflect about the parallel construction of legal pluralism in Mozambique and in Brazil, with emphasis on the theory of the study made by Boaventura de Sousa Santos (the political and legal Palimpsest and the Pasárgada law). The idea of legal pluralism follows the existence of two or more legal systems, endowed with effectiveness, concurrently in the same space-time environment. In Mozambique studies on the subject recognized the
\end{abstract}

\footnotetext{
* Universidade Federal de Alagoas.
} 
Pluralismo Jurídico: o Palimpsesto Político e Jurídico em Moçambique...

presence of law outside the state where it was easy to identify the presence of different legal systems: on the one hand, European law, and on the other, customary rights of indigenous peoples. In the historical context of the emergence of legal pluralism in Brazil, this arises with the Law of Pasárgada in 1930 in the city of Rio de Janeiro.

Keywords: Legal Pluralism. Monism. Palimpsest. Pasárgada.

\section{Introdução}

O objeto deste trabalho é fazer uma reflexão paralela a respeito da construção do Pluralismo jurídico em Moçambique e no Brasil, com ênfase na teoria no estudo feita por Boaventura de Sousa Santos (o palimpsesto ${ }^{1}$ político, jurídico e Direito de Pasárgada).

O objetivo principal é discutir a forma como se apresenta e o Pluralismo Jurídico em Moçambique e no Brasil (Teoria Crítica), problematizando-os e mostrando a diferença na postura de aplicação (se é que as normas postas estão de fato tendo aplicabilidade) desse direito e a sua evolução histórica no caso de Moçambique.

Fundamenta-se este trabalho nos estudos realizados por Boaventura de Sousa Santos, a fim de salientar que o direito emerge da sociedade e para trazer a crítica do direito positivado.

O motivo para a realização deste estudo foi justamente a possibilidade de discutir um tema que está em evidência no

\footnotetext{
1 Boaventura de Sousa Santos no estudo que fez sobre o pluralismo jurídico em Moçambique serviu-se de uma metáfora para pretender mostrar como as diferentes culturas políticas e jurídicas que perpassaram o Estado Moçambicano ao longo da sua história continuam a se cruzar na realidade política e judiciária moçambicana, apelidou esse fenômeno de palimpsesto de políticas e culturas jurídicas. Um palimpsesto é um pergaminho ou outro material sobre o qual se escreve a segunda vez, mas cuja primeira escrita não desaparece totalmente.
} 
direito de dois países com alguma semelhança cultural, visto que ambos foram colônias portuguesas. Por isso, é de suma importância o debate acerca desse assunto, para que mais pessoas tomem conhecimento de como é tratado o direito no Brasil e em Moçambique, tomando ciência também da importância do direito alternativo. Dentre as preocupações mais significativas, é preciso salientar: o que é o direito alternativo; quais as posturas de aplicação do direito alternativo em Moçambique e no Brasil.

Para desenvolver o trabalho, necessário se fez realizar um estudo sobre o pluralismo jurídico em Moçambique e no Brasil, a partir de uma revisão da literatura, dando ênfase às obras de Boaventura de Sousa Santos. No caso de Moçambique, foi explorada também alguma legislação atual (Constituição da República de Moçambique de 2004) e colonial e feita abordagem do estudo de Sara Araújo em Moçambique. Portanto, para esse efeito, o texto divide-se em três pontos:

No primeiro, analiso os conceitos de monismo jurídico e de pluralismo jurídico e interlegalidade.

No segundo, de pluralismo jurídico em Moçambique (o palimpsesto político, jurídico) onde se faz uma resenha histórica do surgimento do pluralismo jurídico em Moçambique, apresento algumas das principais linhas de debate que têm alimentado a discussão sobre estratégias que têm vindo a ser usadas pelo Estado para integrar ou excluir pluralidade e também o tratamento constitucional que foi dado ao pluralismo jurídico em Moçambique e em alguns países do mundo. Essa parte do texto encerra com uma apresentação sintética de alguns resultados de um trabalho de campo realizado no bairro Jorge Dimitrov, em Maputo, sobre esta temática.

Finalmente, no terceiro ponto, centro-me no contexto histórico do pluralismo no Brasil, onde tratar-se-á de forma sucinta a resolução de conflitos no Direito de Pasárgada, bem 
Pluralismo Jurídico: o Palimpsesto Político e Jurídico em Moçambique...

como as relações entre o estado brasileiro e seu direito com a forma de organização social e jurídica, o caso dos Juizados Especiais de Pequenas Causas.

\section{Do Monismo Jurídico ao Pluralismo Jurídico: Crise e Emergência do Pensamento Jurídico Moderno}

\subsection{Monismos Jurídicos}

O monismo é uma doutrina que floresceu no modernismo, portanto, a partir dos séculos XVI e XVII, cujo pressuposto fundamental é o Estado como único e universal criador da norma jurídica, aqui não se admite a ideia de qualquer outra jurídica que não a emanada do Estado. Wolkmer estudou a corrente monista e afirmou que "[...] tal concepção atribuiu ao Estado Moderno o monopólio exclusivo da produção das normas jurídicas, ou seja, o Estado é o único agente legitimado capaz de criar legalidade para enquadrar as formas de relação social que vão se impondo"2 2 .

Sendo que o Estado é a fonte única do Direito, uma vez que somente ele pode dar vida ao Direito por meio da sua força coativa. Logo, para esta teoria, só as normas emanadas do Estado é que se consideram Direito. O Estado é entendido como sendo o "[...] centro único do poder e detentor do monopólio de produção de normas jurídicas"3.

\footnotetext{
2 WOLKMER, Antonio Carlos. Pluralismo Jurídico: fundamentos de uma nova cultura no direito. 3. ed. São Paulo: Alfa Omega, 2001. p. 46.

3 CARVALHO, Lucas Borges de. Caminhos (e descaminhos) do pluralismo jurídico no Brasil. In: WOLKMER, Antonio Carlos; VERNAS NETO, Francisco Q.; LIXA, Ivone M. (Org.). Pluralismo jurídico: os novos caminhos da contemporaneidade. São Paulo: Saraiva, 2010. p. 14.
} 
Neste contexto, como ensina Carvalho, no monismo "[...] a lei se vale pelo simples fato de ser lei, de modo que sua legitimidade advém da mera observância dos procedimentos previamente estabelecidos, isto é, das normas que regulam o processo legislativo"'.

Assim, Arnaldo Vasconcelos "[...] entende que o monismo jurídico foi responsável pela crise que culminou com o descrédito do Positivismo, por uma razão de ordem político-ideológica: faltavam condições ao Positivismo monista para legitimar a ordem jurídica, já que, para a doutrina monista, não havia espaço para as questões de justiça e de legitimidade ${ }^{\prime \prime}$. Em contraposição ao monismo, surge a teoria do pluralismo jurídico.

\subsection{Pluralismo: Conceito e Origem}

Existe uma grande indefinição acerca do conceito de pluralismo jurídico. O dissenso dá-se, inicialmente, em face de um problema conceitual fundamental: a dificuldade de se definir o que é direito para fins de pluralismo jurídico e, portanto, de quais regras devem ser consideradas no espectro analisado como sendo "Direito".

Boaventura de Sousa Santos identifica duas origens possíveis para o surgimento do pluralismo: uma origem colonial e outra não colonial. ${ }^{7}$ No primeiro caso, o pluralismo desenvolveu-se em países que foram dominados econômica e

\footnotetext{
${ }^{4}$ Ibid., p. 13-36.

5 VASCONCELOS, Arnaldo. Teoria da Norma Jurídica. 6. ed. São Paulo: Malheiros, 2006. p. 257-258.

6 TAMANAHA, Brian. Understanding Legal Pluralism: Past to Present, Local to Global. Sidney Law Review, v. 30, n. 3, Sept. 2008. p. 376.

7 SANTOS, Boaventura de Sousa. O discurso e o poder: Ensaios sobre a sociologia retórica jurídica. Porto Alegre: SAFE, 1988. p. 73-75.
} 
Pluralismo Jurídico: o Palimpsesto Político e Jurídico em Moçambique...

politicamente e onde, por isso, vigorou o ordenamento jurídico do estado colonizador paralelamente ao direito tradicional (caso de Moçambique $)^{8}{ }^{9}$

No segundo caso, o autor identifica três situações diferenciadas: o caso dos países com cultura e tradição jurídicas próprias, mas que adotaram o direito europeu como forma de modernização e de consolidação do poder do Estado (Turquia, Tailândia e Etiópia), e que não eliminaram, no plano sociológico, o direito tradicional; o caso dos países que, após passarem por uma revolução social, continuaram mantendo o direito tradicional, muito embora se conflitasse com o direito revolucionário (Repúblicas da Ásia Central, de tradição islâmica, incorporadas pela antiga URSS); e, por último, os casos das populações indígenas ou nativas que foram dominadas por uma metrópole, mas tiverem permissão, implícita ou explícita para, em certos domínios, manterem seu direito tradicional 452 (populações indígenas da América do Norte, da Oceania etc. $)^{10}$.

Na Europa, o pluralismo jurídico teve sua origem no contexto da antiguidade clássica, em que existia uma grande predominância de normais legais de caráter espontâneo e comunitário, elaboradas pela população sem controle estatal. Destacam-se aqui as sociedades que se encontravam sob domínio do império romano, cuja principal característica era a tolerância com os povos que dominava.

Nesse aspecto, os romanos eram mais tolerantes e não tinham o hábito de não impor rigidamente suas leis aos povos que conquistava, permitindo a continuidade da aplicação do direito local desses povos, e eram muito flexíveis quanto à resolução de conflitos que surgiam envolvendo ambas as jurisdições.

\footnotetext{
8 Grifo nosso.

9 SANTOS, Boaventura de Sousa. Op. cit., p. 73-75.

${ }^{10}$ Loc. cit.
} 
Já na idade média, houve uma multiplicidade de manifestações normativas devido a enorme descentralização territorial que se deu com as invasões bárbaras. O conceito de direito na idade média é perfeitamente caracterizado conforme definição de Wolkmer:

Na idade média, a descentralização territorial e a multiplicidade de centros de poder configuram em cada espaço social um amplo espectro de manifestações normativas concorrentes, composto de costumes locais, foros municipais, estatutos das corporações de ofício, ditames reais, Direito Canônico e Direito Romano. Certamente foi com a decadência do Império Romano no Ocidente e com a fixação política dos povos nórdicos na Europa, que se solidificou a ideia de que a cada indivíduo seria aplicado o Direito de seu povo e de sua comunidade local ${ }^{11}$.

Via-se dessa forma uma completa descentralização dos costumes jurídicos, sendo estes peculiares a cada reino e a cada povo, com o intuito de obter maior eficácia. O fim da idade média foi marcado pelo início das formações nacionais absolutistas dos séculos XVII e XVIII, em que pouco a pouco as monarquias absolutistas estruturaram seu direito baseado no monismo centralizado.

O Estado que melhor exemplifica essa estrutura monista de direito foi o Estado francês pós-revolução francesa, integrando o direito francês sob uma legislação comum a todos os cidadãos. Segundo Boaventura de Sousa Santos:

No século XIX e primeiras décadas do nosso século, o problema do pluralismo jurídico teve amplo tratamento na filosofia e na teoria do direito. Foi sendo depois progressivamente suprimido pela ação de um conjunto de fatores em que se deve distinguir: as transformações na articulação dos modos de produção no interior das formações capitalistas

${ }^{11}$ WOLKMER, Antonio Carlos. Pluralismo Jurídico: fundamentos de uma nova cultura no direito. 3. ed. São Paulo: Alfa Omega, 2001. p. 184-185. 
Pluralismo Jurídico: o Palimpsesto Político e Jurídico em Moçambique...

centrais, de que resultou o domínio cada vez maior do modo de produção capitalista sobre o modo de produção pré-capitalista; a consolidação da dominação política do estado burguês nomeadamente através da politização progressiva da sociedade civil; o avanço concomitante das concepções jus-filosóficas positivistas ${ }^{12}$.

Este fenômeno é uma realidade social concreta, encontrada em diversos Estados, e percebida especificamente em países marginalizados economicamente (como exemplo de Moçambique). Boaventura de Sousa Santos explicita que: “[...] o pluralismo jurídico surge para preencher a lacuna promovida pela ausência do Estado em determinadas localidades"13.

A ideia de pluralismo jurídico é decorrente da existência de dois ou mais sistemas jurídicos, dotados de eficácia, concomitantemente em um mesmo ambiente espaço-temporal.

Na África, os primeiros estudos sobre a matéria reconhe454 ceram a presença de direito fora do Estado. Era fácil identificar a presença de diferentes ordens jurídicas: de um lado, o direito europeu; do outro, os direitos costumeiros dos povos nativos.

A história da África, bem como o contexto em que foram elaboradas as primeiras etnografias, está fortemente presente na discussão contemporânea sobre a pluralidade jurídica deste continente. Já o pluralismo na América Latina só começou a ser pensado na sociedade contemporânea, surgindo como necessidade do direito resolver questões jurídicas no intuito principalmente de defender os direitos dos menos favorecidos, já que a realidade da América Latina, tal como na África, é marcada por grande desigualdade e pluralidade de etnias inferiorizadas socialmente.

\footnotetext{
${ }^{12}$ SANTOS, Boaventura de Sousa. O discurso e o poder: Ensaios sobre a sociologia retórica jurídica. Porto Alegre: SAFE, 1988. p. 73.

${ }^{13}$ Ibidem, p. 75.
} 
Hoje em dia, admite-se que a pluralidade jurídica existe virtualmente em todas as sociedades, mas reconhecem-se especificidades a vários níveis ${ }^{14}$.

Ora, com o advento do fenômeno globalização caracterizado por uma flexibilidade jurídica “[...] procedente de negociações, de mesas redondas etc., constitui uma tentativa para encontrar uma nova forma de regulação social, outorgando ao Estado e ao direito um papel de guia (e não de direção) da sociedade", cujo caráter neofeudal de regulamentação social, enfatizado por Noël Roth, sinaliza a infinidade de foros de negociações descentralizados, em que é possível o reconhecimento de um pluralismo jurídico ${ }^{15}$.

Boaventura de Sousa Santos distingue o pluralismo jurídico em sentido amplo do pluralismo jurídico interno. $\mathrm{O}$ primeiro é o que acabou de ser mencionado. O segundo diz respeito ao pluralismo interno ao Estado e deriva da condição heterogénea do mesmo. O conceito de Estado heterogéneo “[...] requer a coexistência de diferentes lógicas de regulação executadas por diferentes instituições do Estado com muito pouca comunicação entre si"16. A heterogeneidade do Estado deriva em grande medida da porosidade anteriormente referida, que é tanto maior quanto mais intensa é a globalização.

Desse modo, pode-se dizer que o pluralismo jurídico questiona, portanto, os alicerces da teoria política e da jurisprudência liberais, principalmente no que diz respeito à congruência

${ }^{14}$ GRIFFITHS, John. What is Legal Pluralism? Journal of Legal Pluralism and Unofficial Law, n. 24, 1986. p. 1-55, passim.

${ }^{15}$ NOËL ROTH, André. O Direito em Crise: Fim do Estado Moderno? In: FARIA, José Eduardo (Org.). Direito e Globalização Econômica: Implicações e Perspectiva. São Paulo: Malheiros, 1996. p. 24-25.

16 SANTOS, Boaventura de Sousa. O Estado heterogéneo e o pluralismo jurídico. In: SANTOS, Boaventura de Sousa; TRINDADE, João Carlos (Org.). Conflito e Transformação Social: Uma Paisagem das Justiças em Moçambique. v. I. Porto: Afrontamento, 2003. p. 63. 
Pluralismo Jurídico: o Palimpsesto Político e Jurídico em Moçambique...

entre o território, o Estado e o direito, ou seja, a centralidade do direito elaborado pelo Estado e a exigência de exclusividade no ordenamento normativo da vida social ${ }^{17}$.

Assim, o Pluralismo Jurídico apresenta-se como o fenômeno que possibilita o surgimento de "direitos" extraestatais, ou seja, a possibilidade que existe do Estado não ser o único a emanar/deter normas. "Esse fenômeno reconhece como legítimas, as relações jurídicas criadas por grupos "marginais", no plano da luta social por direitos e pela democracia, como por exemplo, as lutas dos grupos pró-moradia, pró-cidadania" etc. ${ }^{18}$ Pode-se afirmar, por outro lado, que o pluralismo jurídico consiste em um conjunto de diferentes sistematizações, sob a forma plural, que coexistem em um mesmo espaço social e período histórico, nos quais se encontram presentes o direito estatal e também manifestações não oficiais de ordenação legal. Francis Snyder menciona que os sistemas plurais são parte do mesmo sistema, cada qual em um contexto particular, comumente interligados pelos mesmos microprocessos sociais ${ }^{19}$.

Portanto, o pluralismo jurídico caracteriza-se por uma aparente "[...] multiplicidade das fontes e das soluções de direito bem dentro de uma ordem jurídica, o que é descrito, em termos de sistemas, como sendo a presença de subsistemas no interior

\footnotetext{
${ }^{17}$ RANDEIRA, Shalino. Pluralismo Jurídico, soberania fraturada e direitos de cidadania diferenciados: instituições internacionais, movimentos sociais e Estado pós-colonial na Índia. Trad. de Ana Cláudia Jorge. In: SANTOS, Boaventura de Sousa (Org.). Reconhecer para Libertar: os caminhos do cosmopolitismo multicultural. Rio de Janeiro: Civilização Brasileira, 2003. p. 467.

${ }^{18}$ MEDRADO, Luiz Flávio Matos. Do monismo ao pluralismo jurídico. JurisWay. Disponível em: $<$ http://www.jurisway.org.br/v2/dhall.asp?Id_dh=4280 $>$. Acesso em: 5 mar. 2013.

19 SNYDER, Francis apud MERRY, Sally Engle. Legal pluralism. Law \& Society Review, v. 22, n. 5,1988 . p. 873 .
} 
de um mesmo sistema jurídico." ${ }^{20}$ Depois desta breve resenha sobre o conceito e a origem do pluralismo jurídico, passa-se agora a analisar este fenômeno no contexto moçambicano.

\section{Pluralismo Jurídico em Moçambique}

\subsection{O Pluralismo Jurídico Moçambicano: o Palimpsesto de Políticas e Culturas Jurídicas}

Boaventura de Sousa Santos serve-se de uma metáfora para caracterizar a sociedade moçambicana: o palimpsesto de políticas e culturas jurídicas. Entre o período colonial e o presente, o Estado Moçambicano passou por uma série de modelos políticos, cujas rupturas não os apagaram de vez.

Desde 1975 até hoje, foram várias as transformações radicais, como o fim do modelo colonial; a construção do Estado socialista; e a criação de uma economia neoliberal capitalista e de uma democracia multipartidária. Três culturas político-jurídicas eurocêntricas (colonial, socialista/revolucionária, capitalista/democrática) cruzam-se entre si e com as tradicionais, mostrando que o binómio tradicional/moderno é muito mais complexo do que à primeira vista se poderia pensar.

\subsubsection{O Estado Colonial}

No período de implantação colonial efetiva no território de Moçambique, cujo impulso histórico pode ser definido a partir da histórica Conferência de Berlim (que teve lugar entre os dias 19 de novembro de 1884 e 26 de fevereiro de 1885), em

${ }^{20}$ ARNAUD, André-Jean; FARINÃS DULCE, Maria José. Introdução à análise sociológica dos sistemas jurídicos. Rio de Janeiro: Renovar, 2000. p. 362. 
Pluralismo Jurídico: o Palimpsesto Político e Jurídico em Moçambique...

que uma das principais decisões assentou-se na premissa de "[...] dominar e administrar os territórios efetivamente". ${ }^{21}$

A colonização em Moçambique inicialmente foi um processo que teve a suposta missão de expandir a então chamada civilização "superior" europeia para as populações colonizadas, consideradas primitivas, selvagens ou atrasadas, mas que encobria, de fato, objetivo associados à obtenção de matéria-prima e mão de obra escrava. Serra narra que:

[...] a suposta missão civilizacional está patente, a título de exemplo, no artigo 2 do Ato Colonial aprovado pelo Decreto-Lei n.o 22 465, de 11 de Abril de 1933, segundo o qual “É da essência orgânica da Nação Portuguesa desempenhar a função histórica de possuir e colonizar domínios ultramarinos e de civilizar as populações indígenas que neles se compreendam, exercendo também a influência moral que lhe é adstrita pelo Padroado do Oriente ${ }^{22}$.

Este instrumento legal tinha por objetivo vincar a diferenciação do tratamento jurídico dos europeus e dos indígenas. Assim, por meio desse instrumento, foi criada a Secretaria de Negócios Indígenas (SNE),

[...] entidade à qual competia administrar a organização da justiça indígena, regulamentar os deveres dos "régulos" ${ }^{23} \mathrm{e}$

${ }^{21}$ MAR, Eli J. E. Exploração Portuguesa em Moçambique 1500 - 1973. Esboço Histórico. v. I. Kastrup: African Studies, 1974, p. 62 apud SERRA, Carlos Manuel. Estado, Pluralismo Jurídico e Recursos Naturais. Disponível em: <http://www.cfjj.org.mz/ $\mathrm{img} / \mathrm{pdf} / \mathrm{microsoft}$ wword_-_trabalho_pluralismo_juridico_1_.pdf $>$. Acesso em: 25 fev. 2013.

22 SERRA, Carlos Manuel. Estado, Pluralismo Jurídico e Recursos Naturais. Disponível em: $<$ http://www.cfjj.org.mz/img/pdf/microsoft_word_-_trabalho_pluralismo_juridico_1_.pdf $>$. Acesso em: 25 fev. 2013.

${ }^{23}$ Essa expressão pretendeu originalmente diminuir a carga semântica da palavra rei quando aplicada a africanos, tendo designado detentores de posições políticas com estatutos tão díspares como os imperadores de Gaza (um império moçambicano que abrangia, no seu apogeu, toda a área costeira entre os rios Zambeze e Maputo, e tinha a sua capital em Manjacaze, na atual província moçambicana de Gaza) e os chefes subalternos que administravam pequenas partes do território liderado 
outras atividades gentílicas, providenciar a codificação dos usos e "costumes cafreais", determinar e fixar terrenos que deveriam ficar exclusivamente reservados para os indígenas, organizar o fornecimento de trabalhadores indígenas para os serviços públicos e particulares, entre outros. ${ }^{24}$

Assim, a política colonial em Moçambique apresentava seis principais características que diziam respeito à relação como era o modo de vida das populações locais - "(1) o pluralismo jurídico na era colonial; (2) a rede de lideranças locais; (3) o estatuto jurídico das populações locais; (4) o trabalho forçado; (5) a codificação dos direitos costumeiros; (6) e, por último, a terra e recursos naturais ao serviço dos interesses do Estado colonial." 25

O pressuposto da dominação colonial portuguesa em Moçambique estava assentado em bases raciais, e as populações de origem africana eram, até a fase última da colônia, tratadas de forma pejorativa por "nativas" ou "indígenas", como se fossem pessoas de nível inferior. O colonialismo assentou-se em um postulado rácico, "[...] ainda que juridicamente não tenha ganhado contornos expressos como na vizinha África do Sul, na qual foi implantada uma política e legislação sobre a separação racial”26, o racismo era a principal característica. Daí que se pode afirmar que o pluralismo jurídico no período colonial constituiu "[...] um projecto no qual o Estado colonial se assumiu como pólo ordenador da diversidade, com a correspondente 'missão' de fixar não apenas as regras reguladoras do

pelos seus chefes de linhagem. No século XX, essa figura veio a ser integrada na estrutura administrativa colonial para efeitos de recolha de impostos, de controle e de mobilização laboral de "indígenas".

${ }^{24}$ MAR, Eli J. E. Exploração Portuguesa em Moçambique 1500-1973. Esboço Histórico. v. I. Kastrup: African Studies, 1974. p. 65-66.

${ }^{25}$ SERRA, Carlos Manuel. Op. cit., p. 7-8.

${ }^{26}$ Ibid., p. 8. 
Pluralismo Jurídico: o Palimpsesto Político e Jurídico em Moçambique...

funcionamento dos sistemas jurídicos plurais, como também os estatutos jurídicos das populações neles envolvidas, face à ordem jurídica hegemónica"27.

O exemplo mais paradigmático foi a aprovação do Código Civil Português (Código de SEABRA), aprovado por Carta de Lei em 1 de julho de 1887, que foi tornado extensivo ao espaço colonial, incluindo Moçambique, em 1869, por meio de Decreto de 18 de novembro de 1869, ressalvando-se os usos e costumes das populações indígenas que não se opusessem à moral e à ordem pública. O preâmbulo do Decreto $\mathrm{n}^{\mathrm{o}} 12$ 533, de 27 de novembro de 1926, que promulgou o Estatuto Político, Civil e Criminal dos Indígenas de Angola e Moçambique, disse o seguinte: "Não se atribuem aos indígenas, por falta de significado prático, os direitos relacionados com as nossas instituições constitucionais" 28 .

Foi nesse contexto que em 1914 foi aprovado o primeiro código de indigenato, o Estatuto Político Civil e Criminal dos Indígenas das Colônias de Angola e Moçambique, por meio do Decreto $n^{\circ} 12$ 533, de 23 de outubro de 1926, e que, três anos mais tarde, deu origem a um novo Estatuto, aprovado por meio do Decreto no 16 473, de 6 de fevereiro de 1929, que manteve, quase na íntegra, os princípios e as regras fundamentais da política colonial estatuídos na Lei no 277 , de 15 de agosto de $1914^{29}$.

\footnotetext{
${ }^{27}$ SILVA, Cristina Nogueira da. Codificação de Usos e Costumes na Doutrina Colonial. Quaderni Fiorentini per la Storia del Pensiero Giuridico Moderno, n. 33-34, t. II, 2004-2005. p. 901.

${ }^{28}$ SERRA, Carlos Manuel. Estado, Pluralismo Jurídico e Recursos Naturais. Disponível em: $<$ http://www.cfjj.org.mz/img/pdf/microsoft_word_-_trabalho_pluralismo_juridico_1_.pdf $>$. Acesso em: 25 fev. 2013.

${ }^{29}$ CUNHA, Joaquim Moreira da Silva. Questões Ultramarinas e Internacionais (Direito e Política), p. 16-18 apud SERRA, Carlos Manuel. Estado, Pluralismo Jurídico e Recursos Naturais.p. 16. Disponível em: <http://www.cfjj.org.mz/IMG/pdf/Microsoft_Word_Trabalho_Pluralismo_Juridico_1_.pdf >. Acesso em: 25 fev. 2013.
} 
Influenciada pelo modelo francês de colonização, a partir de 1917, a Administração colonial portuguesa criou uma categoria nova - o assimilado, categoria social não sujeita ao trabalho forçado, com base no chamado modelo de assimilação, que caracterizou igualmente as relações entre a França e as suas colônias, em contraposição aos modelos da autonomia e da sujeição, que caracterizou, tendencialmente, as políticas coloniais do Reino Unido e do Reino dos Países Baixos, respectivamente ${ }^{30}$.

Eli Mar, citado por Serra, refere-se assim à instauração de um sistema baseado na agregação da população em três categorias ou castas distintas: os "assimilados", os "civilizados" e os "indígenas" 31.

Outro instrumento que delineava o estatuto dos indígenas foi o Ato Colonial de 1933, aprovado pelo Decreto-Lei $\mathrm{n}^{\mathrm{o}}$ 22 465, de 11 de abril de 1933, que estabelecia no artigo 22 que

[...] nas colônias atender-se-á ao estatuto de evolução dos povos nativos havendo estatutos especiais dos indígenas que estabeleçam para estes, sob influência do direito público e privado português, regimes de contemporização com os seus usos e costumes individuais, domésticos e sociais, que não sejam incompatíveis com a moral e com os ditames da humanidade. ${ }^{32}$

Silva Cunha, ao analisar o quadro jurídico colonial saído da Constituição Portuguesa de 1933, justificou a opção por um estatuto jurídico especial para os indígenas da seguinte maneira:

\footnotetext{
${ }^{30}$ Loc. cit.

${ }^{31}$ MAR, Eli J. E. Exploração Portuguesa em Moçambique 1500-1973. Esboço Histórico. v. I. Kastrup: African Studies, 1974. p. 135 apud SERRA, Carlos Manuel. Estado, Pluralismo Jurídico e Recursos Naturais. p. 17. Disponível em: <http://www.cfjj.org. $\mathrm{mz} / \mathrm{img} / \mathrm{pdf} / \mathrm{microsoft}$ _word_-_trabalho_pluralismo_juridico_1_pdf $>$. Acesso em: 25 fev. 2013.

32 SERRA, Carlos Manuel. Estado, Pluralismo Jurídico e Recursos Naturais. p. 17-18. Disponível em: $<$ http://www.cfjj.org.mz/img/pdf/microsoft_word_-_trabalho_pluralismo_juridico_1_.pdf $>$. Acesso em: 25 fev. 2013.
} 
Pluralismo Jurídico: o Palimpsesto Político e Jurídico em Moçambique...

[...] os indígenas estão sujeitos a uma ordem jurídica especial porque o seu estado de civilização o impõe. É com fundamento em considerações tiradas da observação do estado pessoal de facto dos indígenas que se criam para eles estatutos especiais, em nome das necessidades práticas da política e administração colonial e com o objectivo de proteger as suas pessoas e bens, evitando que os não indígenas, valendo-se da superioridade de cultura e de prestígio que sempre cerca os pertencentes ao grupo colonizador, cometeram contra eles abusos e espoliações..$^{33}$

Em 1954 foi aprovado o Decreto-Lei de 20 de maio de 1954, uma lei que visava à "assimilação" dos indígenas na cultura colonial (ocidental). Consequentemente, em 1961, por reformas introduzidas por Adriano Moreira quando foi Ministro do Ultramar, tendo presente a conjuntura internacional caracterizada pela emergência do movimento independentista ou de descolonização, bem como pela emergência de nacionalismo no seio das colônias portuguesas, por meio do Decreto-Lei no 43 893, de 6 de setembro de 1961, procedeu à abolição do Estatuto do Indigenato.

\subsubsection{Monismo Estadualista no Período Pós-Independência: Estado, o Único Criador do Direito}

Após a proclamação da República de Moçambique, no dia 25 de junho de 1975, iniciou-se um período histórico de um autêntico Estadualismo jurídico, com contornos de positivismo, no sentido de que só se reconhecia ao Estado o papel de criador de direito, bem como apenas competia às instâncias formais representadas pelos tribunais populares e às novas estruturas

${ }^{33}$ CUNHA, Joaquim Moreira da Silva. Questões Ultramarinas e Internacionais (Direito e Política). p. 214, citado por SERRA, Carlos Manuel. Estado, Pluralismo Jurídico e Recursos Naturais. p. 17-18. Disponível em: <http://www.cfjj.org.mz/IMG/pdf/ Microsoft_Word_-_Trabalho_Pluralismo_Juridico_1_.pdf $>$. Acesso em: 25 fev. 2013. 
político-administrativas criadas ao nível da base - os grupos dinamizadores, a função de resolução de litígios ${ }^{34}$.

Em 1975, o projeto socialista moçambicano, com alicerces no Marxismo, “[...] passava pelo 'escangalhamento' ${ }^{35}$ de todos os vestígios coloniais e pela construção de uma nova sociedade" ${ }^{\prime 36}$.

No período que se seguiu à independência, houve um processo radical de «escangalhamento do aparelho do estado colonial, suas normas, sua filosofia». Tal processo que se desencadeou sob o signo de «combate ao burocratismo» redundou numa verdadeira «desracionalização» do Aparelho do Estado, cujos traços mais salientes foram: «a desnormatização, a ideologização, a desprofissionalização e a desrotinização». Verificou-se, portanto neste momento, a substituição das normas pelos princípios políticos, domínio da gestão dos recursos humanos na substituição de critérios meritocráticos por critérios substantivos. O modelo de organização e funcionamento do aparelho do estado com as características que atrás descrevemos revelou profundas fragilidades nos mecanismos operacionais ${ }^{37}$.

Com o escangalhamento do aparelho de Estado Colonial ${ }^{38}$, Moçambique foi conhecendo uma evolução jurídica em especial às normas judiciais, apesar da Constituição de 1975 tratar de forma bastante genérica a organização judiciária, consagrando as seguintes regras e princípios: reserva da função judicial

\footnotetext{
${ }^{34}$ SERRA, Carlos Manuel. Estado, Pluralismo Jurídico e Recursos Naturais. p. 31. Disponível em: <http://www.cfjj.org.mz/img/pdf/microsoft_word_-_trabalho_pluralismo_juridico_1_.pdf $>$. Acesso em: 25 fev. 2013.

${ }^{35}$ A expressão usada pela Frente de Libertação de Moçambique (FRELIMO) logo após conquistar a independência de Portugal em 1975 significava a destruição do sistema de administração colonial vigente.

${ }^{36}$ ARAÚJO, Sara; JOSÉ, André. Pluralismo jurídico, legitimidade e acesso à justiça. Instâncias comunitárias de resolução de conflitos no Bairro de Inhagoia «B»Maputo. Oficina do CES. n. 284. Coimbra: CES, 2007. p. 7.

${ }^{37}$ POMBAL, António. O Poder Executivo na Experiência Moçambicana. In: Controle Social do Poder Político em Moçambique: Divisão de Poderes. Nampula: Centro de Pesquisa Konrad Adenauer, 2003. p. 22.

${ }^{38}$ Loc. cit.
} 
Pluralismo Jurídico: o Palimpsesto Político e Jurídico em Moçambique...

para os tribunais; subordinação dos tribunais ao poder político, particularmente à Assembleia da República a quem prestavam contas; principio da legalidade; prevenção e educação no cumprimento da lei; independência dos juízes e obediência à lei no exercício das suas funções; organização hierárquica do Ministério Público e subordinação ao Procurador-Geral da República; e o princípio de que o Tribunal Supremo (que viria a ser constituído anos mais tarde) seria dotado da função de garantir a aplicação uniforme da lei nos tribunais.

A Resolução sobre Justiça do Comitê Central da FRELIMO ${ }^{39}$ (8 $8^{\text {a }}$ Sessão, 1976) definiu a prioridade política de destruir a estrutura judicial colonial, como um dos meios de combate ao "Estado colonial-capitalista". Assim, instituiu-se o princípio da participação popular na administração da justiça, intervindo nos tribunais juízes leigos (eleitos) ao lado dos juízes profissionais. Desse modo, “[...] o novo sistema judiciário [devia] exprimir o poder da aliança operário-camponesa e refletir a ditadura da maioria explorada". Esta opção levou a que fossem afastadas da administração da justiça as entidades conotadas com o poder colonial, como é o caso das autoridades tradicionais.

Assim, o Decreto-Lei no 4/75, de 16 de agosto, proibiu o exercício da advocacia e das funções de consultoria jurídica, solicitadoria, procuradoria judicial ou extrajudicial, a título privado. Criou o Serviço Nacional de Consulta e Assistência Jurídica (SNCAJ), na dependência da Procuradoria-Geral da República, que deveria cumprir aquelas funções. Esse decreto nunca chegou a ser regulamentado e, por isso, o SNCAJ jamais entrou em funcionamento. Posteriormente, por meio da Lei nº 3/86, de 16 de abril, foi criado, em sua substituição, o Instituto Nacional de Assistência Jurídica (INAJ), subordinado ao

${ }^{39}$ Partido que dirigiu a luta armada de libertação nacional de Moçambique e que governa o país até a data. 
Ministério da Justiça, cujo Estatuto Orgânico foi previsto no Decreto no 8/86, de 30 de dezembro. Só os membros do INAJ poderiam praticar atos próprios da profissão, designadamente exercer o mandato judicial ou consulta jurídica.

No âmbito do INAJ estavam previstas três categorias de defensores, com diferentes competências: advogados, com licenciatura em direito; técnicos jurídicos, com bacharelato em direito ${ }^{40}$; assistentes jurídicos, habilitados com cursos de formação específica.

No entanto, a inscrição como advogado só podia ser efetuada pelos licenciados em direito depois de completarem o estágio com aproveitamento. Para a inscrição como técnico jurídico, exigia-se o bacharelato em direito ou equivalente e igualmente um estágio. A inscrição como assistente jurídico era permitida àqueles que estivessem habilitados com cursos de formação jurídica reconhecidos por entidade competente.

Por outro lado, registrou-se a abrangência excessiva do âmbito de ação; indefinição do modelo de organização caráter centralista do Estado, verticalização de relacionamento entre os órgãos de administração, propagação territorial, operação setorial, reprodução dos órgãos centrais e abrangência absorvente no âmbito da economia. O Estado procurou pôr fim à justiça dualista e às autoridades tradicionais, vistas como aliadas do poder colonial, e criar um sistema de justiça que se pretendia indígena, mas não tribal. Assim, em 1978, foi aprovada a Lei Orgânica dos Tribunais Populares, que previa a criação de tribunais populares em diferentes escalões territoriais, em que juízes profissionais trabalhavam ao lado de juízes eleitos pela população.

${ }^{40}$ Entende-se por bacharéis em direito estudantes de direito que não tenham terminado o curso, mas que tenham feito no mínimo o terceiro ano do curso. 
Pluralismo Jurídico: o Palimpsesto Político e Jurídico em Moçambique...

Na década de 1980, ocorreu o fracasso econômico do projeto socialista. Em 1984, o governo moçambicano aderiu às Instituições de Breton Woods (IBWs), nomeadamente ao Banco Mundial e ao Fundo Monetário Internacional. Mais tarde, em 1990, foi aprovado um novo texto constitucional instituindo o multipartidarismo.

A Constituição da República de Moçambique de 1990, nesse

[...] contexto de construção de uma democracia liberal, consagrou os princípios da separação de poderes, da independência, da imparcialidade, da irresponsabilidade e da legalidade, lançando bases para a produção de alterações substanciais na organização judiciária. Assim, a Lei dos Tribunais Populares foi substituída pela Lei Orgânica dos Tribunais Judiciais de 1992. ${ }^{41}$

No mesmo ano foram criados os tribunais comunitários que funcionavam com juízes eleitos pela comunidade e a desem466 penhar o papel que cabia aos tribunais populares de localidade e de bairro ${ }^{42}$. No entanto, não chegaram a ser regulamentados.

Os tribunais comunitários são classificados por Boaventura de Sousa Santos como o híbrido jurídico por excelência, por encontrarem-se num limbo institucional, na medida em que são reconhecidos por lei, mas estão fora do sistema judicial e não estão, até hoje, regulamentados ${ }^{43}$. As profissões jurídicas

\footnotetext{
${ }^{41}$ ARAÚJO, Sara. O Estado moçambicano e as justiças comunitárias: Uma história dinâmica de imposições e respostas locais diferenciadas. 7.ํㅡ Congresso Ibérico de Estudos Africanos, 2010. p. 7. Disponível em: <http://www.ces.uc.pt/myces/UserFiles/ encontros/1097_CIEA7_29_ARA\%DAJO_O\%20Estado\%20mo\%E7ambicano\%20 e\%20as\%20justi\%E7as\%20comunit\%E1rias.pdf>. Acesso em: 5 mar. 2013.

${ }^{42}$ TRINDADE, João Carlos. Rupturas e continuidades nos processos políticos e jurídicos. In: SANTOS, Boaventura de Sousa; TRINDADE, João Carlos (Org.). Conflito e Transformação Social: Uma Paisagem das Justiças em Moçambique. v. I. Porto: Afrontamento, 2003. p. 97-128.

${ }^{43}$ SANTOS, Boaventura de Sousa. O Estado heterogéneo e o pluralismo jurídico. In: SANTOS, Boaventura de Sousa; TRINDADE, João Carlos (Org.). Conflito e
} 
foram liberalizadas por força da Constituição de 1990, deixando de ser proibido o exercício privado da advocacia. Assim, em 1994, foram publicados dois diplomas que regulam os serviços jurídicos e o sistema de assistência judiciária: a Lei no 7/94, de 14 de setembro, que cria a Ordem dos Advogados de Moçambique (OAM) e aprova o respectivo Estatuto Orgânico, consagrando a advocacia como um dos três pilares da administração da justiça; e a Lei no 6/94, de 13 de setembro, que cria o Instituto de Patrocínio e Assistência Jurídica (IPAJ), como corolário do princípio constitucional do livre acesso dos cidadãos aos tribunais, do direito de defesa e do direito de assistência e patrocínio judiciário.

O ponto seguinte apresenta algumas considerações sobre a "constitucionalização" do pluralismo jurídico em Moçambique.

\subsection{Tratamento Constitucional do Pluralismo Jurídico em Moçambique}

A revisão constitucional de 2004 veio consagrar diversas alterações no ordenamento jurídico-constitucional, com as quais a Lei de Bases da Organização Judiciária, que agora se propõe, deve conformar-se. Para além do reconhecimento, já referido, do pluralismo jurídico (artigo $4^{\circ}$ ), a Constituição enfatiza, no seu artigo 11ํㅡㄹ alínea g), "a promoção de uma sociedade de pluralismo, tolerância e cultura de paz", e proclama, no artigo 118\%, que "o Estado reconhece e valoriza a autoridade tradicional legitimada pelas populações e segundo o direito consuetudinário" ( $n^{\mathrm{o}}$ 1) e "define o relacionamento da autoridade tradicional com as demais instituições e enquadra a sua

Transformação Social: Uma Paisagem das Justiças em Moçambique. v. I. Porto: Afrontamento, 2003. p. 47-128. 
Pluralismo Jurídico: o Palimpsesto Político e Jurídico em Moçambique...

participação na vida econômica, social e cultural do país, nos termos da lei" (no 2). Consequentemente, a atividade destas autoridades na resolução de litígios não deve ser proibida, antes pelo contrário, deve ser encorajada, sempre que for consentida pelas partes e as suas decisões não violarem os princípios e as normas constitucionais.

Ora, antes de aprofundarmos o tratamento constitucional do pluralismo em Moçambique, necessário torna-se discorrer a respeito do ensinamento de Canotilho, que com a complexidade e heterogeneidade do ordenamento jurídico atual, a necessidade atual do jurista constitucional deve ser a de elaborar novos modelos normativos. Pois, para delinear o quadro moral e racional de sua Constituição, um Estado precisa considerar o pluralismo jurídico, interno e transnacional, na medida em que normas constitucionais atualmente têm por fontes não apenas o estrito positivismo kelseniano, mas incorporam referências da própria realidade à qual elas se destinam. Portanto, o sistema jurídico não se compõe mais apenas de normas puras, devendo incorporar os valores presentes no contexto ao seu redor, que também o integra. Dessa simbiose deriva sua capacidade de autorregenerar-se à medida que a evolução histórico-social se impõe ao direito.

Se considerarmos a norma fundamental como um elemento unificador da realidade, devemos estar abertos às suas transformações, de modo a incluir em seu bojo os novos direitos considerados legítimos pela sociedade, aos quais também se estende a proteção legal em um Estado Democrático de Direito.

Podemos arriscar dizer que foi também com esse espírito que o legislador constituinte moçambicano consagrou no artigo

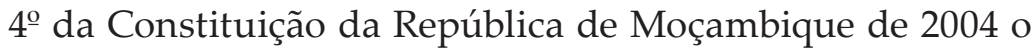
pluralismo jurídico, reconhecendo “[...] a existência dos vários 
sistemas normativos e de resolução de conflitos que coexistem na sociedade moçambicana, na medida em que não contrariam os valores e princípios fundamentais da constituição".

Ora, o legislador constituinte moçambicano, ao referir que só serão reconhecidos sistemas normativos de resolução de conflito que não contrariem os valores e princípios fundamentais, procurou assegurar um pluralismo equilibrado e limitado pela ordem jurídica formal e, ao mesmo tempo, permitiu a existência de um pluralismo compreensivo referente aos elementos autorreguladores da sociedade, com finalidade de assegurar que os diversos sistemas de resolução não positivados que coexistem na sociedade moçambicana tivessem a proteção constitucional. Na verdade o legislador constituinte apenas reconheceu constitucionalmente prática que já era habitual na sociedade moçambicana.

Esse reconhecimento por parte do legislador constituinte moçambicano corresponde a uma necessidade social inelutável “[...] conforme com o princípio da adequação, o qual constitui um corolário da finalidade precípua a que se dirigem as regras jurídicas". Na medida em que estas visam a disciplinar a vida em sociedade segundo certa ordem de valores, importa que estejam em conformidade com o sentimento de justiça dos seus destinatários, sob pena de serem rejeitadas pelo corpo social que visam a conformar o que, em última análise, conduz (como tantas vezes ocorre) à sua ineficácia.

Por outro lado, a Constituição da República de Moçambique, para além de consagrar que os preceitos constitucionais relativos aos direitos fundamentais são interpretados e integrados em harmonia com a Declaração Universal dos Direitos do Homem e a Carta Africana dos Direitos Humanos e dos Povos (art. 43.ํ), também constitucionaliza o direito de ação popular (art. 81ํㅜ), bem como reconhece o papel que as organizações sociais, como 
Pluralismo Jurídico: o Palimpsesto Político e Jurídico em Moçambique...

formas de associação com afinidades e interesses próprios, desempenham na promoção da democracia e na participação dos cidadãos na vida pública.

Assim, a Constituição reconhece que as organizações sociais contribuem para a realização dos direitos e das liberdades dos cidadãos, bem como para a elevação da consciência individual e coletiva no cumprimento dos deveres cívicos (art. 78.ำ), pelo que se torna imperativo que estas organizações possam atuar na promoção e defesa dos direitos dos cidadãos e designadamente tenham um papel ativo no novo sistema de acesso à justiça e ao direito, ao nível da informação, da consulta e do patrocínio jurídico. A Constituição reconhece, ainda, como já é consensual nas sociedades contemporâneas, que os tribunais judiciais há muito deixaram de ter o monopólio da administração da justiça, prevendo, expressamente, a possibilidade de serem criados mais tribunais comunitários.

Entretanto, é importante observar a advertência de Boaventura de Sousa Santos, segundo a qual o pluralismo pode induzir em erro. Apresenta uma conotação normativa, designa algo de bom, porque pluralista. Nesse sentido, prefere a expressão "pluralidade de ordens jurídicas"44. O legislador constituinte moçambicano resguardou-se desse perigo ao referir que normativos e de resolução de conflitos que coexistem na sociedade moçambicana, só serão relevantes na medida em que não contrariem os valores e princípios fundamentais da constituição.

Ademais, o legislador constituinte moçambicano, ao instituir constitucionalmente o pluralismo jurídico, reconhece que

\footnotetext{
${ }^{44}$ SANTOS, Boaventura de Sousa. O Estado heterogéneo e o pluralismo jurídico. In: SANTOS, Boaventura de Sousa; TRINDADE, João Carlos (Org.). Conflito e Transformação Social: Uma Paisagem das Justiças em Moçambique. v. I. Porto: Afrontamento, 2003. p. 52-53.
} 
“[...] o Estado não detém o monopólio de produção de normas, de maneira que o direito não se resume ao direito Estatal, mas envolve também um direito vivo que surge no seio da própria sociedade, apresentando, às vezes, maior legitimidade do que os atos normativos emanados das instituições públicas" ${ }^{45}$.

Na verdade, fora do Estado há Direito Positivo dotado, portanto, de garantia jurídica e não apenas de garantias extrajurídicas, havendo equivalência entre o Direito Positivo estatal e o não estatal.

Portanto, a pluralidade de formas e de sistemas de resolução de conflitos existentes no Estado moçambicano aliados às normas positivas do Estado soberano, impuseram à Constituição o paradoxo da tolerância.

O pluralismo jurídico também encontra amparo constitucional em vários países do mundo, dos quais podemos citar: a Constituição em vigor na República da África do Sul reconhece a instituição, o estatuto e o papel da autoridade tradicional, exercidos de acordo com o direito costumeiro e desde que não a contrariem (art. 211, no 1). Os tribunais devem fazer uso do direito costumeiro, nos casos em que este for aplicável, desde que não violem a Constituição ou a legislação ordinária (art. 211, no 3).

Em 2003 foi aprovada a Traditional Leadership and Governance Framework Bill, que regula o direito costumeiro (de acordo com o estabelecido no art. 211, no 3 da Constituição), lei esta que prevê o funcionamento das autoridades tradicionais como instituições locais, à disposição das comunidades. No

${ }^{45}$ CARVALHO, Lucas Borges de. Caminhos (e descaminhos) do pluralismo jurídico no Brasil. In: WOLKMER, Antonio Carlos; VERNAS NETO, Francisco Q.; LIXA, Ivone M. (Org.). Pluralismo jurídico: os novos caminhos da contemporaneidade. São Paulo: Saraiva, 2010. p. 14. 
Pluralismo Jurídico: o Palimpsesto Político e Jurídico em Moçambique...

seguimento desta decisão, têm vindo a ser criadas houses of traditional leaders e foi instituído o Conselho das Autoridades Tradicionais (nos termos do Council of Traditional Leaders Bill de 1996 e da Council of Traditional Leaders Act de 1997), de modo a garantir o funcionamento do sistema de direito costumeiro, conforme consagrado na actual Constituição - art. 212, no 2 , alíneas a) e b).

O projeto da nova Constituição do Quénia, que se encontra em debate, reconhece o conjunto das civilizações, das pessoas e comunidades baseadas nos valores e princípios constitucionais não escritos, nas tradições, nas lutas do presente e nas aspirações futuras.

Estabelece, ainda, a proteção dos valores culturais e o reconhecimento da cultura como a base do orgulho nacional e da identidade. $\mathrm{O}$ funcionamento dos órgãos do Estado deve pautar-se, assim, pelos princípios da promoção do multiculturalismo, da cooperação, da compreensão, da tolerância e do respeito pelos diferentes costumes, tradições, crenças, línguas, práticas religiosas, sabedorias e filosofias que afirmem o desenvolvimento e respeito pela preservação da dignidade e do bem-estar do povo.

Em Uganda, o Governo defende que os Local Council Courts (LCC) assumam um papel muito importante na administração da justiça. Estes LCC (que não estavam dependentes do sistema judiciário formal) foram criados a partir dos Resistance Committee Courts, tendo sido implantados em regiões onde a justiça formal não estava presente ${ }^{46}$. Os LCC conhecem de delitos de pequena gravidade (de foro cível e criminal), privilegiando na sua atuação a reconciliação, a compensação e o perdão.

${ }^{46}$ UGANDA. Ministry of Local Government of the Republic of Uganda (2003). Local Councils Administration of Justice. Guides for Local Council Courts. Disponível em: <http://www.molg.go.ug/docs/Local CourtsGuide.pdf>. Acesso em: 20 nov. 2013. 
Hoje em dia, esses tribunais encontram-se incorporados na base do sistema judiciário, sendo possível recorrer da sua decisão para um tribunal judicial (magistrate's court). Os Ministérios da Administração Local e da Justiça supervisionam conjuntamente a actuação dos LCC, pois estes, para além das questões jurídicas, intervêm também na administração local.

No entanto, pode ler-se num relatório do Ministério da Administração Local que aqueles tribunais enfrentam um conjunto de dificuldades e de obstáculos que precisam de ser resolvidos, como:

[...] os LCC têm, geralmente, um fraco conhecimento do direito formal vigente; os membros do tribunal não têm acesso a materiais de referência essenciais; com frequência, não conhecem os direitos das crianças; as decisões do LCC são muitas vezes enviesadas em desfavor das mulheres; a documentação sobre os procedimentos do tribunal é escassa (afectando, nomeadamente, a questão dos recursos); os LCC estão ainda a lidar com casos que ultrapassam os limites da sua jurisdição, como por exemplo, violações ${ }^{47}$.

Na Namíbia, os tribunais comunitários resultam de uma reformulação dos antigos tribunais tradicionais. De acordo com a Community Courts Act (Lei no 10, de 2003), as autoridades tradicionais podem requerer ao Ministro responsável pela área da justiça a criação de tribunais comunitários. A jurisdição dos tribunais comunitários circunscreve-se à área territorial de cada "comunidade tradicional". Não constituem uma jurisdição obrigatória, dependendo a sua intervenção do acordo das partes. Têm competência para decidir sobre todas as questões relacionadas com pedidos de compensação e de

\footnotetext{
${ }^{47}$ UGANDA. Ministry of Local Government of the Republic of Uganda (2003). Local Councils Administration of Justice. Guides for Local Council Courts. Disponível em: <http://www.molg.go.ug/docs/Local CourtsGuide.pdf>. Acesso em: 20 nov. 2013.
} 
Pluralismo Jurídico: o Palimpsesto Político e Jurídico em Moçambique...

restituição de bens, desde que tutelada pelo direito costumeiro. Das decisões dos tribunais comunitários, pode haver recurso para a estrutura formal dos tribunais, concretamente para os Magistrate's Courts, desde que o recorrente tenha esgotado todas as possibilidades de recurso existentes na estrutura do tribunal comunitário. Para a decisão do recurso, o juiz presidente do Magistrate's Court pode nomear dois assessores, que conheçam o direito e as normas aplicadas e o funcionamento dos tribunais comunitários.

Em Cabo Verde, encontramos outros exemplos de convivência entre os tribunais judiciais e as instâncias comunitárias de resolução de conflitos, aqueles não detendo o monopólio da resolução dos litígios. Realça-se a existência de estruturas "tradicionais" (Regedores ou Cabos-chefe) no período colonial e, após a independência, a implantação dos "tribunais de zona", constituídos por juízes leigos. É reconhecido que os tribunais de zona, enquanto forma de participação popular na administração da justiça, foram extremamente importantes para "aproximar mais a justiça das populações".

Jorge Fonseca é da opinião de que se devem criar, a título experimental, em comarcas de maior movimento processual, tribunais de pequenas causas cíveis. O funcionamento desses tribunais seria marcado por princípios de simplicidade de procedimentos, informalidade, oralidade e procura de uma justa composição dos litígios por acordo das partes. Teriam competência para apreciar e decidir causas de valor não excedente aos da alçada dos tribunais de 1. ․ instância, com incidência, entre outras a definir por lei, em ações destinadas a efetivar o cumprimento de obrigações que tenham por objeto prestações pecuniárias, ações relativas ao descumprimento contratual, ao arrendamento urbano, à administração e ao uso da propriedade, da superfície, do usufruto e de uso, de habitação, ações possessórias, de usucapião e acessão, de indenização por prática de 
certos crimes de pequena gravidade, designadamente contra a propriedade e a honra, desde que não tenha havido participação criminal ou tenha havido desistência. Funcionariam com juízes licenciados ou bacharéis em direito ou togados ou com juízes leigos de idoneidade comprovada ${ }^{48}$.

As decisões não dependeriam de critérios de estrita legalidade, podendo os juízes decidir segundo a equidade, desde que obtido o acordo das partes ${ }^{49}$.

A Constituição da Colômbia consagra que "[...] as Autoridades dos povos indígenas podem exercer funções jurisdicionais dentro do seu âmbito territorial, e em conformidade com as suas próprias normas e procedimentos, sempre que não sejam contrários à Constituição e às leis da República. A lei estabelecerá as formas de coordenação desta jurisdição especial com o sistema jurídico nacional" (art. 246).

Assim, no seguimento da Constituição de 1991, a Lei no 270, de 1996, Estatutaria de la Administración de Justicia, incorpora os juízes de paz e a jurisdição das comunidades indígenas na estrutura geral da Administração da Justiça, como parte da organização judiciária.

Também em Portugal, o artigo 202, nº 4, da Constituição da República Portuguesa, determina que a "lei poderá institucionalizar instrumentos e formas de composição não jurisdicional de conflitos", sendo de salientar a criação, nos últimos anos, das Comissões de Protecção de Crianças e Jovens, dos Centros de arbitragem institucional (por exemplo, centros de arbitragem de conflitos de consumo, de conflitos desportivos etc.) e dos Julgados de Paz.

\footnotetext{
${ }^{48}$ FONSECA, Jorge Carlos de Almeida (Coord.). Estudo sobre o estado da Justiça em Cabo Verde. Praia: Gabinete do Ministro da Justiça, Governo de Cabo Verde, 2002.

${ }^{49}$ Loc. cit.
} 
Pluralismo Jurídico: o Palimpsesto Político e Jurídico em Moçambique...

Portanto, como se viu, o reconhecimento constitucional de instrumentos e formas de composição não judicial de conflitos não é caso isolado de Moçambique.

O ponto seguinte apresenta alguns dos resultados de um estudo de caso realizado por Sara Araújo no bairro Jorge Dimitrov e procura exemplificar uma das configurações dos vários sistemas normativos de resolução de conflitos que coexistem na sociedade moçambicana.

\subsection{Estudo de Caso: Justiças Cruzadas no Bairro Jorge Dimitrov}

Para melhor elucidarmos os motivos pelos quais Boaventura de Sousa Santos apelidou o pluralismo jurídico em Moçambique de palimpsesto político e jurídico, torna-se imperioso citar como um dos vários exemplos o Estudo de Araújo ${ }^{50}$ sobre justiças cruzadas num dos bairros da capital moçambicana Maputo - Jorge Dimitrov. ${ }^{51}$ Assim, segundo o referido estudo, atualmente não existe no bairro Jorge Dimitrov um tribunal comunitário em funcionamento. Entretanto, nos anos 1980, foi criado um tribunal popular de base que, segundo a lei, deveria ter sido transformado em tribunal comunitário e permanecer em funcionamento nos dias de hoje. Diga-se, no entanto, que esse tribunal deixou de funcionar, e a desempenhar as suas funções encontra-se um gabinete de atendimento da organização

\footnotetext{
${ }^{50}$ Sara Araújo, Licenciada em sociologia pela Universidade de Coimbra e doutoranda do Programa Direito, Justiça e Cidadania no Século XXI da mesma universidade. Investigadora do Centro de Estudos Sociais da Universidade de Coimbra. Foi membro da equipa de investigação binacional para a reforma da organização judiciária moçambicana, uma parceria entre o Centro de Estudos Sociais e o Centro de Formação Jurídica e Judiciária moçambicano.

${ }^{51}$ Jorge Dimitrov é um dos doze bairros que constituem o distrito municipal $n^{0} 5$ da cidade de Maputo.
} 
Mulher Lei e Desenvolvimento (MULEIDE), que funciona na sede do Grupo Dinamizador ${ }^{52}{ }^{53}$

Estabelecida em Moçambique desde 1991, a MULEIDE é uma ONG centrada na defesa dos direitos das mulheres e da igualdade de oportunidades, cuja atuação se estende a diferentes áreas, entre as quais a de apoio na resolução de conflitos, assistência jurídica e patrocínio judiciário. ${ }^{54}$

As sessões de resolução de conflitos são conduzidas no bairro de Jorge Dimitrov pelo chamado Grupo da Educação Legal da MULEIDE, que é composto exclusivamente por membros da comunidade, entre estes encontram-se um Secretário de Bairro Adjunto do Grupo Dinamizador (SBA) e duas ex-juízas do tribunal comunitário que encerrou. Todos/as intitulam-se "conselheiros/as", procurando distanciar-se do formalismo

52 Em Moçambique, chamaram-se Grupos Dinamizadores às organizações de base da sociedade, a seguir à Independência Nacional, em 25 de junho de 1975. Os Grupos Dinamizadores de Local de Trabalho foram formados em todas as empresas, comerciais, industriais ou de serviços e nas repartições públicas, com o objetivo de estimular aumento de produtividade, criticar os trabalhadores faltosos, assistir a direção principalmente nas suas relações com os restantes trabalhadores, evitar os roubos - e, mais importante, orientar Sessões de Esclarecimento semanais (aos sábados). Nessas sessões eram analisados os problemas do local de trabalho e discutidas as novas leis e orientações que iam surgindo. A partir de 1978, esses Grupos Dinamizadores foram substituídos por verdadeiras células da Frelimo nesse momento já transformado em Parido Político, de ideologia marxista - leninista. Mais ou menos pela mesma altura, foram igualmente criados os Grupos de Vigilância, que tinham a função de detectar e denunciar - ou tentar eliminar - tentativas de sabotagem econômica. Já nos anos 80 , surgiram os Comités Sindicais, que continuam até hoje, enquanto que as restantes estruturas praticamente deixaram de existir. Eram comitês compostos por oito a doze pessoas, liderados por um secretário, que passaram a desempenhar um conjunto de tarefas. Para além de funções como a mobilização das populações para a participação político-partidária, a segurança nacional, a organização de processos de produção coletiva e a execução de programas de educação, foram-lhes atribuídas inicialmente funções na área da justiça.

${ }^{53}$ ARAÚJO, Sara. Acesso à justiça e pluralismo jurídico em Moçambique. Resolução de litígios no bairro «Jorge Dimitrov». VI Congresso de Português de Sociologia. Mundos Sociais: Saberes e Práticas. 2008. p. 8. Disponível em: <http://www.aps. pt/vicongresso/pdfs/62.pdf >. Acesso em: 5 mar. 2013.

${ }^{54}$ Loc. cit. 
Pluralismo Jurídico: o Palimpsesto Político e Jurídico em Moçambique...

associado aos juízes. Tal como é frequente acontecer nos tribunais comunitários, o tipo de casos processados depende, em grande medida, da procura. ${ }^{55}$

O volume da procura é baixo. Durante os quinze dias úteis de observação de Sara Araújo, passaram por esta instância dezesseis casos. Assim, 37,5\% dos casos foram conflitos no seio do casal (expulsão da mulher de casa, divisão de bens em casos de divórcio, entre outros); $12,5 \%$ dos casos foram de reconhecimento de paternidade; $18,8 \%$ dos casos foram conflitos entre vizinhos (não devolução de bens, acusação de namorar o marido da vizinha, acusação de arrancar plantas); $18,8 \%$ foram conflitos relacionados com a posse de terrenos; houve um caso de uma mulher viúva, a quem a ex-mulher do marido falecido queria confiscar os bens; um caso em que uma mulher se queixa que o pai da filha deixou de apoiá-la financeiramente etc. Enfim, segundo este estudo, foram vários casos apresentados que careceram de formas de resolução de conflitos distintos do formal. ${ }^{56}$

\section{Pluralismo Jurídico no Brasil}

\subsection{Pluralismo Jurídico e Direito Alternativo no Brasil}

O Direito Alternativo, como teoria, chegou ao Brasil na década de 1980, sendo marcado como um movimento de juízes, tendo tido grande repercussão, sobretudo nos estados do Sul do país (notadamente no Rio Grande do Sul). Esse movimento

\footnotetext{
${ }^{55}$ Loc. cit.

${ }^{56}$ ARAÚJO, Sara. Acesso à justiça e pluralismo jurídico em Moçambique. Resolução de litígios no bairro «Jorge Dimitrov». VI Congresso de Português de Sociologia. Mundos Sociais: Saberes e Práticas. 2008. p. 8-9. Disponível em: $<$ http://www.aps. pt/vicongresso/pdfs/62.pdf $>$. Acesso em: 5 mar. 2013.
} 
foi inspirado nos modelos europeus que o antecederam, de modo particular o modelo italiano iniciado na década de 1970. Consistia, inicialmente, em um grupo de magistrados que se reuniam na forma de um grupo de estudos, na ânsia de democratizar o direito, abandonando uma visão dogmatizada que se tinha do mesmo ${ }^{57}$.

Esse movimento, a partir daí, cresceu e se manifesta por todo o país, com decisões que fogem ao comum do direito e vão além da aplicação seca nos moldes de um positivismo radical. Ainda que a princípio estas não estejam vinculadas diretamente ao movimento do Direito Alternativo, pode-se afirmar que são expressões de um olhar alternativo para o direito ${ }^{58}$.

A corrente do pluralismo jurídico no Brasil caracteriza-se por uma busca das fontes do direito não apenas nos meios convencionais aos quais a cultura jurídica estava acostumada. Trata-se uma visão dos atores sociais como também possíveis produtores de fenômenos jurídicos. Nesse sentido, Wolkmer aduz que:

Trata-se de extrair a constituição da normatividade não apenas mais e apenas das fontes ou canais habituais clássicos representados pelo processo legislativo e jurisdicional do Estado, mas captar o conteúdo e a forma do fenômeno jurídico mediante a informalidade de ações concretas de atores coletivos, consensualizados pela identidade e autonomia dos interesses do todo comunitário, num locus [grifo do autor] político, independente dos rituais formais de institucionalização ${ }^{59}$.

${ }^{57}$ PIRES, Caio José Leitão; GOMES, Raíza Feitosa. O pluralismo jurídico e a real participação da sociedade nas questões jurídicas: uma análise de caso. Âmbito Jurídico, Rio Grande, XIV, n. 91, ago. 2011. Disponível em: <http://www.ambitojuridico. com.br/site/index.php?n_link=revista_artigos_leitura\&artigo_id=9998>. Acesso em: mar. 2013.

${ }^{58}$ Loc. cit.

${ }^{59}$ WOLKMER, Antonio Carlos. Pluralismo Jurídico: fundamentos de uma nova cultura no direito. 3. ed. São Paulo: Alfa Omega, 2001. p. 129. 
Pluralismo Jurídico: o Palimpsesto Político e Jurídico em Moçambique...

Para Wolkmer, o envolvimento e a participação dos grupos sociais se dão principalmente nos "novos movimentos sociais", que adotariam a forma de atores sociais, sendo protagonistas nas formas de criação da sociedade, inclusive do direito. ${ }^{60}$

Deve ser ressaltado que, ao buscar essa proximidade social, o direito encontra grande complexidade, já que os conflitos e as divergências estão postos na sociedade mesmo em grupos que são enxergados superficialmente como homogêneos. Assim é o caso ao qual está ligada a decisão do referido juiz, a prostituição, que tem sido vista de divergentes formas pelos movimentos sociais e em estudos feministas. $\mathrm{O}$ feminismo radical defende a visão das prostitutas como vítimas da opressão masculina, sendo tal atividade a expressão máxima da submissão feminina e, assim, agravante das desigualdades já existentes entre homens e mulheres, devendo ser extirpada ${ }^{61}$.

De outra perspectiva, o chamado feminismo liberal, que foi influenciado pela atuação de movimentos organizados de prostitutas, alega que a prostituição é um ato de autodeterminação sexual, e, portanto, um trabalho como outro qualquer, devendo ser, então, regulamentado. Nesse sentido, o presente trabalho também pretende analisar de que forma essas divergências são contempladas (ou não) pelas visões críticas do dogmatismo jurídico aqui já apresentadas ${ }^{62}$.

\footnotetext{
${ }^{60}$ WOLKMER, Antonio Carlos. Pluralismo Jurídico: fundamentos de uma nova cultura no direito. 3. ed. São Paulo: Alfa Omega, 2001. p. 129.

${ }^{61}$ PIRES, Caio José Leitão; GOMES, Raíza Feitosa. O pluralismo jurídico e a real participação da sociedade nas questões jurídicas: uma análise de caso. Âmbito Jurídico, Rio Grande, XIV, n. 91, ago. 2011. Disponível em: <http://www.ambitojuridico. com.br/site/index.php?n_link=revista_artigos_leitura\&artigo_id=9998>. Acesso em: mar. 2013.

${ }^{62}$ Loc. cit.
} 


\subsection{Direito de Pasárgada}

No livro O Discurso e o Poder, resultado de estudos empíricos, realizados durante os anos 1970, numa comunidade do Rio de Janeiro, Boaventura de Sousa Santos afirma e analisa a existência de um direito, diferente do estatal, que vigora naquela comunidade, fruto da organização social entre os moradores ${ }^{63}$.

Segundo Sousa Santos, o surgimento de Pasárgada na cidade do Rio de Janeiro se dá na década de 1930, quando seus primeiros habitantes instalaram-se em propriedades alheias e do governo. Existia, àquela época, abundante terra disponível, não havendo, portanto, muitos conflitos a ela relacionados ${ }^{64}$.

As lides relacionadas à posse e propriedade das terras em Pasárgada foram aumentando com o passar dos anos e o crescimento populacional da favela. Uma vez que suas "propriedades" eram tidas como ilegais, a população não poderia recorrer à Justiça oficial, fazendo surgir, na comunidade, a associação de moradores, que passa a solucionar os conflitos locais ${ }^{65}$.

Pasárgada originou-se a partir de ocupações em terrenos particulares, razão pela qual é tida, pelo direito oficial estatal, como ilegal, daí, o resultado de ser, praticamente, desconsiderado pelo Estado, conforme constata-se da ausência de políticas públicas e da prestação de serviços públicos, entre eles, os mais básicos de infraestrutura, tais como o fornecimento de água e esgoto ${ }^{66}$.

${ }^{63}$ FELISMINO, Lia Cordeiro. Pluralismo jurídico: um diálogo entre os pensamentos emancipatórios de Boaventura de Sousa Santos e Antônio Carlos Wolkmer. Anais do XIX Encontro Nacional do CONPEDI. Tema: Direitos Fundamentais e Transdisciplinaridade. Fortaleza, 9, 10, 11 e 12 de junho de 2010. p. 8486.

${ }^{64}$ Loc. cit.

${ }^{65}$ BORTOLOZZI JUNIOR, Flávio. Pluralismo jurídico e o paradigma do direito moderno: breves apontamentos. Cadernos da Escola de Direito e Relações Internacionais, n. 12, 2010. p. 27.

${ }^{66}$ FELISMINO, Lia Cordeiro. Pluralismo jurídico: um diálogo entre os pensamentos emancipatórios de Boaventura de Sousa Santos e Antônio Carlos Wolkmer. 
Pluralismo Jurídico: o Palimpsesto Político e Jurídico em Moçambique...

Seus moradores, diante disso, geralmente não eram reconhecidos pelo Estado enquanto sujeito de direitos, mas tão somente como objetos de repressão criminal. Assim, diante da ausência do Estado (e aqui destaca-se, em especial, do direito estatal), os moradores de Pasárgada acabam por se organizar, de forma a melhorar o desenvolvimento da comunidade e garantir a segurança e a ordem nas relações sociais. ${ }^{67}$ Boaventura de Sousa Santos ensina que:

Pasárgada é uma comunidade densamente povoada, no seio da qual se estabeleceu uma teia muito complexa de relações sociais entre os habitantes e entre estes, individualmente, e a comunidade no seu todo, algumas das quais têm origem em contratos (compra e venda, arrendamento, etc.) e outros negócios jurídicos que envolvem a propriedade, a posse e direitos reais vários sobre a terra e as habitações (ou parte delas) individualmente apropriadas. Tais relações têm uma estrutura homológica das relações jurídicas. No entanto, à luz do direito oficial brasileiro, as relações desse tipo estabelecidas no interior das favelas são ilegais ou juridicamente nulas, uma vez que dizem respeito a transações sobre terrenos ilegalmente ocupados e a construções duplamente clandestinas. Dentro da comunidade, contudo, as relações são legais e como tal são vividas pelos que nelas participam; a intervenção dos moradores neste domínio visa constituir como que um Ersatz da proteção jurídica oficial de que carecem $^{68}$.

Aqui, as práticas sociais e jurídicas, tais como compra e venda de imóveis, arrendamento de terrenos etc., eram consideradas ilegais pelo direito estatal, já que não eram originários de títulos "legais" de posse/propriedade. Isso não inibia, contudo, a que, no interior desta comunidade, admitisse-se uma

\footnotetext{
Anais do XIX Encontro Nacional do CONPEDI. Tema: Direitos Fundamentais e Transdisciplinaridade. Fortaleza, 9, 10, 11 e 12 de junho de 2010. p. 8486.

${ }^{67}$ Loc. cit.

${ }^{68}$ SANTOS, Boaventura de Sousa. O discurso e o poder: Ensaios sobre a sociologia retórica jurídica. Porto Alegre: SAFE, 1988. p. 14.
} 
forma de dinâmica social e uma normatividade paralela a do Estado, onde a associação de moradores desempenhava papel de fórum jurídico e desenvolvia práticas e discursos jurídicos ${ }^{69}$.

Por não ser oficial, o Direito de Pasárgada tem a sua validade restrita ao interior da comunidade. É caracterizado por ter um discurso jurídico informal e uma linguagem comum, diferentemente do formalismo jurídico, de linguajar rebuscado, imposto pelo direito positivo estatal ${ }^{70}$.

Nessa comunidade, as decisões, antes de se constituírem na aplicação direta de fatos às normas, eram produtos da aplicação, gradual, provisória, irreversível, cuja carga normativa, cuja fundamentação fática era dominada pela argumentação respaldada em situações concretas, no intuito de se obter uma decisão que fosse aceita pelas partes e pelo auditório em causa (composto, normalmente, por acompanhantes das partes). Além disso, no Direito de Pasárgada, as decisões assumiam, via de regra, formas de mediação ou negociação, diferentemente do que ocorre no domínio do direito estatal, em que há a polarização entre vencedor e vencido ${ }^{71}$.

Outra característica do Direito de Pasárgada trazida por Boaventura reside em que, no Direito de Pasárgada, o discurso jurídico não é legalista, e projetava-se sobre um pensamento essencialmente comum e quotidiano, por meio de uma linguagem também comum ${ }^{72}$.

${ }^{69}$ FELISMINO, Lia Cordeiro. Pluralismo jurídico: um diálogo entre os pensamentos emancipatórios de Boaventura de Sousa Santos e Antônio Carlos Wolkmer. Anais do XIX Encontro Nacional do CONPEDI. Tema: Direitos Fundamentais e Transdisciplinaridade. Fortaleza, 9, 10, 11 e 12 de junho de 2010. p. 8487.

${ }^{70}$ Loc. cit.

${ }^{71}$ Loc. cit.

${ }^{72}$ Loc. cit. 
Pluralismo Jurídico: o Palimpsesto Político e Jurídico em Moçambique...

As distinções entre forma e conteúdo eram pouco rígidas, sendo que os formalismos processuais, em vez de se constituírem como o limite do discurso jurídico, como no caso do direito positivo estatal, eram utilizados como argumentos. O grau de institucionalização era muito pequeno, e não necessitava de especialização profissional ${ }^{73}$.

Em relação ao poder dos instrumentos de coerção ao serviço da produção jurídica, a diferença é enorme. O Direito Estatal dispõe um amplo e poderoso aparato coercitivo, detentor do monopólio da violência legítima, como as forças policiais, paramilitares e mesmo forças armadas ${ }^{74}$.

O Direito de Pasárgada, ao contrário, dispunha de instrumentos de coerção muito incipientes e de fato quase inexistentes. A associação participava na organização de formas coletiva de coerção contra um vizinho transgressor que não se deixava persuadir pela retórica jurídica no sentido da reposição da legalidade. Era notória "[...] uma circulação retórica que tende a subverter qualquer divisão rígida do trabalho jurídico, o que, por esta via, potencia a proximidade entre o agente privilegiado do discurso (o presidente) os demais participantes e o auditório"75.

A característica fundamental do sistema jurídico de Pasárgada é que este se reveste de um discurso tópico-retórico, em oposição ao discurso lógico-sistemático do Direito Estatal ${ }^{76}$.

Segundo a concepção tópico-retórica, o discurso jurídico tem uma natureza argumentativa, visando a uma deliberação

\footnotetext{
${ }^{73}$ Loc. cit.

${ }^{74}$ BORTOLOZZI JUNIOR, Flávio. Pluralismo jurídico e o paradigma do direito moderno: breves apontamentos. Cadernos da Escola de Direito e Relações Internacionais, n. 12, 2010. p. 28.

${ }^{75}$ SANTOS, Boaventura de Sousa. O discurso e o poder: ensaio sobre a sociologia da retórica jurídica. Porto Alegre: Fabris, 1988. p. 46.

${ }^{76}$ BORTOLOZZI JUNIOR, Flávio. Op. cit., p. 27.
} 
dominada pela lógica do razoável em face do circunstancialismo concreto do problema, em caso algum redutível à dedução lógica e necessária a partir de enunciados normativos gerais. ${ }^{77}$

Percebe-se ainda no que refere à diferenciação entre o Direito de Pasárgada e o direito Estatal (denominado, pelos moradores, de direito do asfalto), que o Direito de Pasárgada, quanto aos instrumentos de coerção, somente os possui de maneira escassa, sendo que os principais instrumentos de coerção acabam sendo a ameaça e o discurso da violência, ao contrário do estatal, que dispõe de um amplo e institucionalizado aparato de coerção ${ }^{78}$.

Entretanto, apesar da existência de um direito paralelo ao direito estatal, e das diferenças entre ambos, percebe-se uma constante interação entre esses ordenamentos jurídicos. Frequentemente, o Direito de Pasárgada recorre ao discurso oficial, mesmo que apenas como argumento, seja para legitimar-se, seja para construir um ambiente de maior oficialidade e justificar a imposição de algumas decisões, por meio da ameaça da aplicação do direito estatal, caso haja o descumprimento das regras de conduta estabelecidas pela comunidade ${ }^{79}$.

Portanto, o Direito de Pasárgada é um direito paralelo não oficial, cobrindo uma interação jurídica muito intensa à margem do sistema jurídico estatal (o direito do asfalto, como lhe chamam os moradores das favelas, por ser o direito que vigora apenas nas zonas urbanizadas e, portanto, com pavimentos asfaltados) e tinha como objetivo "[...] maximizar o desenvolvimento interno da comunidade e garantir a segurança e a

\footnotetext{
77 SANTOS, Boaventura de Sousa. Op. cit., p. 7.

${ }^{78}$ FELISMINO, Lia Cordeiro. Pluralismo jurídico: um diálogo entre os pensamentos emancipatórios de Boaventura de Sousa Santos e Antônio Carlos Wolkmer. Anais do XIX Encontro Nacional do CONPEDI. Tema: Direitos Fundamentais e Transdisciplinaridade. Fortaleza, 9, 10, 11 e 12 de junho de 2010. p. 8487-8488.

${ }^{79}$ Ibid., p. 8488.
} 
Pluralismo Jurídico: o Palimpsesto Político e Jurídico em Moçambique...

ordem nas relações sociais entre os habitantes" 180 . Obviamente, o Direito de Pasárgada é apenas válido no seio da comunidade e a sua estrutura normativa assenta na inversão da norma básica (Grundnorm) da propriedade, por meio da qual o estatuto jurídico da terra de Pasárgada é consequentemente invertido ${ }^{81}$ : “a ocupação ilegal (segundo o direito do asfalto) transforma-se em posse e propriedade legais (segundo o Direito de Pasárgada)". 82 Possuindo características informais, os requisitos e formais processuais mantêm caráter exclusivamente instrumental, apenas sendo usados para contribuir à decisão justa da lide.

Conforme Sousa Santos, "Esta falta de uniformidade, que pode surpreender ou mesmo escandalizar quem a veja com os olhos etnocêntricos do direito oficial, não é, no entanto, caótica" $^{\prime 83}$. Aliado à esta característica, a linguagem do discurso pasargadiano é comum e acessível àqueles que utilizam-na.

No que tange à institucionalização e à coerção, pode-se aqui apontar mais diferenças entre o Direito oficial e o sistema jurídico de Pasárgada. O Direito Estatal apresenta alto grau de institucionalização, sendo a função jurídica autônoma às demais funções sociais, bem como possui alto grau de especialização. O Direito de Pasárgada, por sua vez, apresenta um

${ }^{80}$ SANTOS, Boaventura de Sousa. O discurso e o poder: Ensaios sobre a sociologia retórica jurídica. Porto Alegre: SAFE, 1988. p. 11.

${ }^{81}$ Conforme sinaliza Boaventura de Sousa Santos, um parcela importante da intervenção da associação, no microcosmo social constituído pela favela, dá-se no campo da administração das relações entre seus próprios moradores, repartindo-se basicamente em duas áreas: 1) ratificação das relações jurídicas e 2) prevenção e resolução de litígios (Loc. cit.).

${ }^{82}$ Ibid., p. 14.

${ }^{83}$ Ibid., p. 31. Sousa Santos complementa: "A sistematização da atuação derivam não só da lógica normativa constitucional que subjaz à filosofia política do estado liberal como, mais imediatamente, do vasto arsenal do formalismo jurídico em geral e do formalismo processual em especial e ainda da profissionalização do contexto em que estes são accionados". Ibid., p. 52. 
grau de institucionalização baixo; a associação de moradores desempenha diversas outras funções além da jurídica ${ }^{84}$.

\subsection{Do Direito de Pasárgada à Manifestação Legal do Pluralismo no Brasil: o Exemplo dos Juizados Especiais Cíveis}

Dentre as muitas contribuições doutrinárias para a teoria do pluralismo jurídico, encontra-se a proposta de "pluralismo jurídico comunitário-participativo" apresentada por Antonio Carlos Wolkmer. Tal proposta consagra a legitimidade dos sujeitos emergentes na criação e efetivação dos "novos direitos" buscando a instauração de um pluralismo jurídico de cunho integrador, que promova e estimule a participação dos segmentos populares e dos novos sujeitos coletivos, satisfazendo efetivamente suas necessidades ${ }^{86}$.

A proposta de Wolkmer busca também a concretização de um projeto jurídico fruto das "[...] práticas sociais insurgentes, motivada para a satisfação justa de necessidades essenciais

${ }^{84}$ BORTOLOZZI JUNIOR, Flávio. Pluralismo jurídico e o paradigma do direito moderno: breves apontamentos. Cadernos da Escola de Direito e Relações Internacionais, n. 12, 2010. p. 28.

${ }^{85}$ Conforme esclarece o autor: "Ainda que os chamados direitos 'novos' nem sempre sejam inteiramente 'novos' na verdade, por vezes, o 'novo' é o modo de obtenção de direitos que não passam mais pelas vias tradicionais - legislativa e judicial -, mas provêm de um processo de lutas e conquistas das identidades coletivas para o reconhecimento pelo Estado. Assim, a designação de novos direitos refere-se à afirmação e materialização de necessidades individuais (pessoais) ou coletivas (sociais) que emergem informalmente em toda e qualquer organização social, não estando necessariamente previstas ou contidas na legislação estatal positiva" (WOLKMER, Antonio Carlos. Pluralismo Jurídico: fundamentos de uma nova cultura no direito. 3. ed. São Paulo: Alfa Omega, 2001.).

${ }^{86}$ BORTOLOZZI JUNIOR, Flávio. Pluralismo jurídico e o paradigma do direito moderno: breves apontamentos. Cadernos da Escola de Direito e Relações Internacionais, n. 12, 2010. p. 29. 
Pluralismo Jurídico: o Palimpsesto Político e Jurídico em Moçambique...

[...]", bem como "[...] contempla também uma ampla gama de manifestações de normatividade paralela, institucionalizadas ou não, de cunho legislativo ou jurisdicional, 'dentro' e 'fora' do sistema estatal positivo" ${ }^{\prime \prime 7}$.

Nesse contexto, no Brasil, criaram-se os Juizados Especiais de Pequenas Causas, por meio da Lei no 7.244, de 7 de novembro de 1984, que foram precedidos pelos Juizados Informais de Conciliação em diversas cidades do Estado de São Paulo. O êxito da iniciativa fica claramente demonstrado pelo número de juizados criados e instalados em 1999: 759 Juizados em todo o Brasil, onde até essa data desempenhavam funções 1.170 juízes. ${ }^{88}$

Refira-se que a designação de Juizados de Pequenas Causas foi alterada por meio da Lei no 9.099 , de 26 de setembro de 1995, devido ao fato de a Constituição brasileira referir-se a causas cíveis de menor complexidade e não a causas de menor valor econômico, propondo que se designassem antes de Juizado de Causas Cíveis de Menor Complexidade e de Juizado Criminal de Infrações de Menor Potencial Ofensivo. Essa lei criou então os Juizados Especiais Cíveis e Criminais que são "órgão da Justiça Ordinária" a criar "pela União, no Distrito Federal e nos Territórios, e pelos Estados, para conciliação, processo, julgamento e execução, nas causas da sua competência". Embora partisse dos mesmos fundamentos da lei anterior, veio acrescentar algumas novidades, nomeadamente o alargamento do valor das ações para quarenta salários mínimos, a obrigatoriedade da presença de advogado nas causas entre vinte e quarenta salários mínimos, o alargamento das suas

\footnotetext{
${ }^{87}$ WOLKMER, Antonio Carlos. Pluralismo jurídico: novo paradigma de legitimação. Disponível em: <http://www.mundojuridico.adv.br/sis_artigos/artigos. asp?codigo=646>. Acesso em: 25 fev. 2013.

${ }^{88}$ FAISTING, André Luiz. O dilema da dupla institucionalização do poder judiciário: o caso do juizado especial de pequenas causas. In: SADEK, Maria Tereza Aina (Org.). O sistema de justiça. São Paulo: Editora Sumaré, 1999. p. 45.
} 
competências à área criminal e a obrigatoriedade da existência destes órgãos nos Estados.

Conforme referido por Grinover, essa lei produziu uma verdadeira revolução no sistema processual penal brasileiro ao não se limitar a importar soluções de outros sistemas jurídicos, mas instituindo um sistema próprio de justiça penal consensual $^{89}$. De acordo com a lei, os juizados devem pautar a sua atuação pela oralidade, simplicidade, informalidade, economia processual e celeridade, tentando, sempre que possível, a conciliação ou a transação.

Os serviços de cartório podem ser prestados e as audiências realizadas fora da sede da Comarca, em bairros ou em cidades pertencentes à Comarca, ocupando prédios públicos. A descentralização da justiça nos bairros, com a criação de tribunais especiais para o julgamento de causas de diminuta complexidade e com serviços de assistência judiciária, implica que os juizados sejam polos de informação de direitos, pondo cobro à desinformação jurídica e facilitando o acesso de classes menos favorecidas à justiça. O objetivo dos Juizados Especiais é a aproximação da justiça aos cidadãos. Para o efeito, alguns dos Juizados funcionam em centros comerciais e até em autocarros: os Juizados Itinerantes, nos quais funciona uma sala de audiências e duas salas de conciliação. Para Ovídio Batista:

Estas justiças especiais, para as causas de reduzida expressão econômica, foram inspiradas nas experiências de outros povos, particularmente nas Small Claims Courts, existentes nos Estados Unidos da América, foram sugeridas pela Lei Federal, cabendo aos Estados cria-las ou não, segundo seus próprios critérios de conveniência, numa tentativa de introduzir no Brasil uma forma de justiça alternativa, despida do formalismo próprio das cortes de justiça ordinária,

${ }^{89}$ GRINOVER, Ada Pellegrini et al. Juizados Especiais Criminais: Comentários à Lei 9.099 de 26.09.95. São Paulo: Revista dos Tribunais, 1996. p. 2. 
Pluralismo Jurídico: o Palimpsesto Político e Jurídico em Moçambique...

e de índole mais participativa e menos profissionalizada e burocrática, através da convocação de juízes não integrantes dos quadros do Poder Judiciário, e com o nítido sentido de justiça conciliadora, menos técnica e mais democrática. ${ }^{90}$

O legislador brasileiro incentivou a participação popular nos juizados especiais, quer na função de conciliação, quer na de juiz leigo, com competência para dirigir a instrução e o julgamento, sob a supervisão do juiz "togado" (magistrado judicial), e para proferir decisão, posteriormente homologada pelo juiz togado. Os juízes leigos podem, ainda, atuar como árbitros com poderes idênticos aos do juiz togado, podendo decidir por equidade. Tal fundamentação vem da percepção de que o Direito já não é mais decorrente unicamente do Estado, mas também da sociedade, que busca se autorregulamentar, por meio de novos sujeitos emergentes.

\section{Conforme Grossi:}

[...] se assiste a 'atores modificados protagonistas do processo jurídico', a 'diferentes modalidades de produção e de funcionamento das regras jurídicas', a uma crescente privatização da produção jurídica: vitais centros monopoiéticos (ou seja, produtores de regras jurídicas prontamente observadas pelos indivíduos) já estão inseridos em núcleos sociais, econômicos e culturais muito distantes dos Estados ${ }^{91}$.

A concepção do pluralismo jurídico busca aproximar a sociedade do Direito, o direito concreto e efetivo, social, democrático, participativo e, acima de tudo, justo; que respeita as minorias e a multiculturalidade, e não daquele direito-lei, individualista, que é ineficaz e que não propaga a Justiça92.

\footnotetext{
${ }^{90}$ SILVA, Ovídio A. Baptista da. Curso de Processo Civil. v. 1. Processo de Conhecimento. 6. ed. rev. e atual. São Paulo: Revista dos Tribunais, 2002. p. 55-56.

${ }^{91}$ GROSSI, Paolo. Mitologias jurídicas da modernidade. Tradução de Arno Dal Ri Junior. Florianópolis: Fundação Boiteux, 2004. p. 99-100.

${ }^{92}$ Loc. cit.
} 
No entanto, a doutrina pluralista não se pretende absoluta, única e dogmatizada, como o faz o monismo estatal. Sua legitimação é buscada nas expressões da sociedade e apenas por meio da própria sociedade pode se concretizar. Embora não se oponha à figura do Estado, não o concebe como absoluto e incondicional detentor da criação de normas jurídicas. ${ }^{93}$ Menciona-se novamente as palavras de Paolo Grossi:

É claro que o Estado não pode abdicar da fixação de linhas fundamentais, mas também é claro que se impõe uma deslegificação, abandonando a desconfiança iluminista do social e realizando um autêntico pluralismo jurídico, onde os indivíduos sejam os protagonistas ativos da organização jurídica do mesmo modo que acontece nas transformações sociais. Somente dessa forma será possível preencher o fosso que atualmente constatamos com amargura. ${ }^{94}$

Portanto, não se trata, aqui, da falência do Estado, mas sim de uma profunda transformação. Este é necessário para a paz social, no entanto, não pode presumir-se único e onipotente na função de criação de normas jurídicas, mesmo porque está distante das necessidades sociais e de sua dinâmica. A emergência de novos atores no cenário da confecção jurídica já é factual e deve o jurista se desamarrar de antigos dogmas individualistas, que já não mais condizem com a realidade e com a necessidade da sociedade, e buscar a consolidação da Justiça Social como forma de evolução jurídica. ${ }^{95}$

\footnotetext{
${ }^{93}$ BORTOLOZZI JUNIOR, Flávio. Pluralismo jurídico e o paradigma do direito moderno: breves apontamentos. Cadernos da Escola de Direito e Relações Internacionais, n. 12, 2010. p. 30.

${ }^{94}$ GROSSI, Paolo. Op. cit., 145-146.

${ }^{95}$ BORTOLOZZI JUNIOR, Flávio. Pluralismo jurídico e o paradigma do direito moderno: breves apontamentos. Cadernos da Escola de Direito e Relações Internacionais, n. 12, 2010. p. 30.
} 
Pluralismo Jurídico: o Palimpsesto Político e Jurídico em Moçambique...

\section{Considerações Finais}

Como afirmado na introdução, este texto procurou analisar de forma paralela o pluralismo jurídico em Moçambique e no Brasil, fazendo ênfase ao estudo feito por Boaventura de Sousa Santos, que parte de duas concepções por ele apelidadas (palimpsesto ${ }^{96}$ político e jurídico em Moçambique e Direito de Pasárgada no Brasil).

O pluralismo jurídico moçambicano não pode ser analisado apenas a partir do que o colonialismo reconheceu ou do que está previsto na legislação. A realidade é complexa e imprevisível. As práticas são altamente diversificadas e os diferentes direitos tendem a ser usados de forma interligada, de acordo com as estratégias das instâncias que resolvem conflitos e dos próprios litigantes. Ademais, o pluralismo jurídico é a oposição ao formalismo jurídico do positivismo posto pela sociedade burguesa, é contra o monismo jurídico estatal, sendo o surgimento e uso de um direito paralelo ao direito estatal que tem eficácia simultaneamente em uma mesma sociedade, o que faz ocorrer que o uso de um ofusca o outro. O direito é projeção normativa que instrumentaliza os princípios ideológicos, tendo como umas das bases a certeza e a segurança, sendo formas de controle do poder de um determinado grupo social.

Já no Brasil, o Direito de Pasárgada recorre, frequentemente, ao direito oficial, ainda que somente a título argumentativo,

\footnotetext{
${ }^{96}$ Boaventura de Sousa Santos serve-se de uma metáfora para pretender mostrar como as diferentes culturas políticas e jurídicas que perpassaram o Estado moçambicano ao longo da sua história continuam a se cruzar na realidade política e judiciária moçambicana: o palimpsesto de políticas e culturas jurídicas. Um palimpsesto é um pergaminho ou outro material sobre o qual se escreve a segunda vez, mas cuja primeira escrita não desaparece totalmente.
} 
seja para se legitimar, seja para construir um ambiente de maior oficialidade, ou seja, ainda, para impor as suas decisões, por meio da ameaça da aplicação do direito estatal, caso haja o descumprimento das regras de conduta estabelecidas pela comunidade.

Apesar de essa manifestação normativa ser caracterizada por pluralismo jurídico, esse fenômeno vem se reconfigurando em uma nova forma de expressão jurídica, identificada com a mobilização de diversos atores sociais em torno de resistências e de lutas contra as práticas desiguais e excludentes oriundas do neoliberalismo e com a reafirmação dos sistemas jurídicos não estatais. Nesse ponto específico, encontra-se o marco de conexão do presente estudo de caso com o pluralismo jurídico, se não na expressão de novas fontes jurídicas afirmadas, mas sim em uma forma embriônica de busca por justiça alternativa. Um exemplo concreto da busca por uma justiça alternativa é a disseminação dos Juizados Especiais, criados com competência para o processo e julgamento de causas de reduzido valor econômico. Primeiro, com a promulgação da Lei Federal n. 7.244, de 7 de novembro de 1984, que regulamentava a criação e o funcionamento dos Juizados Especiais de Pequenas Causas, depois tal lei foi revogada com a promulgação da Lei 9.099, de 26 de setembro de 1995, que instituiu os Juizados Especiais, tanto no âmbito da jurisdição civil quanto no da jurisdição criminal, com competência para conciliação e julgamento, no campo da jurisdição civil, das causas cujo valor não exceda sessenta vezes o salário mínimo. 
Pluralismo Jurídico: o Palimpsesto Político e Jurídico em Moçambique...

\section{Referências}

ÁFRICA DO SUL. Constituição da República da África do Sul. 1996. Disponível em: <http://www.constitutionalcourt.org.za/site/constitution/english-web/ch2.html>. Acesso em: 20 nov. 2013.

. Council of Traditional Leaders Bill de 1996. Disponível em: $\langle$ www.gov.za/documents/download.php?f=71927>. Acesso em: 20 nov. 2013.

Council of Traditional Leaders Act de 1997. Disponível em:

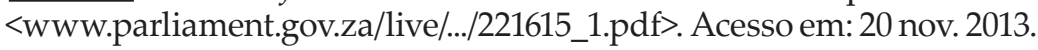

ALMEIDA, Pedro Ramos de. História do Colonialismo Português em África. Cronologia Século XX. Imprensa Universitária. n. 5. Lisboa: Editorial Estampa, 1979.

ARAÚJO, Sara. O Estado moçambicano e as justiças comunitárias: Uma história dinâmica de imposições e respostas locais diferenciadas. 7.․․ Congresso Ibérico de Estudos Africanos, 2010, p. 1-17. Disponível em: <http://www.ces.uc.pt/myces/UserFiles/encontros/1097_CIEA7_29

494 ARA\%DAJO_O\%20Estado\%20mo\%E7ambicano\%20e\%20as\%20 justi\%E7as\%20comunit\%E1rias.pdf >. Acesso em: 5 mar. 2013.

ARAUUJO, Sara; JOSÉ, André. Pluralismo jurídico, legitimidade e acesso à justiça: Instâncias comunitárias de resolução de conflitos no Bairro de Inhagoia «B»-Maputo. Oficina do CES. n. 284. Coimbra: CES, 2007.

ARNAUD, André-Jean; FARINÃS DULCE, Maria José. Introdução à análise sociológica dos sistemas jurídicos. Rio de Janeiro: Renovar, 2000.

BEZERRA, Paulo Cesar Santos. Acesso à justiça: um problema ético-social no plano da realização do direito. Rio de Janeiro: Renovar, 2002.

BORTOLOZZI JUNIOR, Flávio. Pluralismo jurídico e o paradigma do direito moderno: breves apontamentos. Cadernos da Escola de Direito e Relações Internacionais, n. 12, p. 21-31, 2010.

BRASIL. Constituição da República Federativa do Brasil de 1988. São Paulo: Atlas, 2001.

. Lei n. ${ }^{\circ} 7.244$, de 7 de Novembro de 1998, que cria os Juizados Especiais de Pequenas Causas.

CANOTILHO, José Joaquim Gomes. Direito Constitucional e Teoria da Constituição. 6. ed. Coimbra: Almedina, 2002. 
CARVALHO, Lucas Borges de. Caminhos (e descaminhos) do pluralismo jurídico no Brasil. In: WOLKMER, Antonio Carlos; VERNAS NETO, Francisco Q.; LIXA, Ivone M. (Org.). Pluralismo jurídico: os novos caminhos da contemporaneidade. São Paulo: Saraiva, 2010. p. 13-36.

COLÔMBIA. Constituição de 1991. Bogotá: [s. n.], 1991.

. Lei n.․270, de 1996. Bogotá: [s. n.], 1996.

FAISTING, André Luiz. O dilema da dupla institucionalização do poder judiciário: o caso do juizado especial de pequenas causas. In: SADEK, Maria Tereza Aina (Org.). O sistema de justiça. São Paulo: Editora Sumaré, 1999.

FELISMINO, Lia Cordeiro. Pluralismo jurídico: um diálogo entre os pensamentos emancipatórios de Boaventura de Sousa Santos e Antônio Carlos Wolkmer. Anais do XIX Encontro Nacional do CONPEDI. Tema: Direitos Fundamentais e Transdisciplinaridade. Fortaleza, 9, 10, 11 e 12 de junho de 2010. p. 8480-8493.

FONSECA, Jorge Carlos de Almeida (Coord.). Estudo sobre o estado da Justiça em Cabo Verde. Praia: Gabinete do Ministro da Justiça, Governo de Cabo Verde, 2002.

GRIFFITHS, John. What is Legal Pluralism? Journal of Legal Pluralism and Unofficial Law, n. 24, p. 1-55, 1986.

GRINOVER, Ada Pellegrini et al. Juizados Especiais Criminais: Comentários à Lei 9.099 de 26.09.95. São Paulo: Revista dos Tribunais, 1996.

GROSSI, Paolo. Mitologias jurídicas da modernidade. Tradução de Arno Dal Ri Junior. Florianópolis: Fundação Boiteux, 2004.

KELSEN, Hans. Teoria Geral do Direito e do Estado. Trad. Luis Carlos Borges. 3. ed. São Paulo: Martins Fontes, 1998.

MAR, Eli J. E. Exploração Portuguesa em Moçambique 1500-1973: Esboço Histórico. Kastrup: African Studies, 1975. 2 v.

MEDRADO, Luiz Flávio Matos. Do monismo ao pluralismo jurídico. JurisWay. Disponível em: <http://www.jurisway.org.br/v2/dhall. asp?Id_dh=4280>. Acesso em: 5 mar. 2013.

MERRY, Sally Engle. Legal pluralism. Law \& Society Review, v. 22, n. 5, p. 869-896, 1988. 
Pluralismo Jurídico: o Palimpsesto Político e Jurídico em Moçambique...

MOÇAMBIQUE. Constituição da República de Moçambique de 2004. Disponível em: <http://www.mozambique.mz/pdfconstituição2004>. Acesso em: 26 dez. 2012.

NAMÍBIA. Community Courts Act. Lei n.o 10, de 2003. Disponível em: <www.parliament.gov.na/acts/acts.php?list_id=50>. Acesso em: 20 nov. 2013.

NOËL ROTH, André. O Direito em Crise: Fim do Estado Moderno? In: FARIA, José Eduardo (Org.). Direito e Globalização Econômica: Implicações e Perspectiva. São Paulo: Malheiros, 1996.

PIRES, Caio José Leitão; GOMES, Raíza Feitosa. O pluralismo jurídico e a real participação da sociedade nas questões jurídicas: uma análise de caso. Âmbito Jurídico, Rio Grande, XIV, n. 91, ago. 2011. Disponível em: <http://www.ambitojuridico.com.br/site/index.php? n_link=revista_artigos_leitura\&artigo_id=9998>. Acesso em: mar. 2013.

POMBAL, António. O Poder Executivo na Experiência Moçambicana. In: Controle Social do Poder Político em Moçambique: Divisão de Poderes. Nampula: Centro de Pesquisa Konrad Adenauer, 2003.

496 PORTUGAL. Constituição (1976). Constituição da República Portuguesa. Atualizada de acordo com a Lei Constitucional no 1/2004, de 24 de julho de 2004. Coimbra: Almedina, 2004.

RANDEIRA, Shalino. Pluralismo Jurídico, soberania fraturada e direitos de cidadania diferenciados: instituições internacionais, movimentos sociais e Estado pós-colonial na Î́ndia. Trad. de Ana Cláudia Jorge. In: SANTOS, Boaventura de Sousa (Org). Reconhecer para Libertar: os caminhos do cosmopolitismo multicultural. Rio de Janeiro: Civilização Brasileira, 2003.

SANTOS, Boaventura de Sousa. O discurso e o poder: Ensaios sobre a sociologia retórica jurídica. Porto Alegre: SAFE, 1988.

. O Estado heterogéneo e o pluralismo jurídico. In: SANTOS, Boaventura de Sousa; TRINDADE, João Carlos (Org.). Conflito e Transformação Social: Uma Paisagem das Justiças em Moçambique. v. I. Porto: Afrontamento, 2003. p. 47-128.

. Para um novo senso comum: a ciência, o Direito e a política na transição paradigmática. 3. ed. São Paulo: Cortez Editora, 2001. 
. Pela Mão de Alice: O Social e o Político na pós-modernidade.

São Paulo: Ed. Cortez, 1997.

SERRA, Carlos Manuel. Estado, Pluralismo Jurídico e Recursos Naturais. Disponível em: <http://www.cfjj.org.mz/img/pdf/microsoft_word_-trabalho_pluralismo_juridico_1_.pdf $>$. Acesso em: 25 fev. 2013.

SILVA, Cristina Nogueira da. Codificação de Usos e Costumes na Doutrina Colonial. Quaderni Fiorentini per la Storia del Pensiero Giuridico Moderno, n. 33-34, t. II, p. 899-921, 2004-2005.

SILVA, Ovídio Araújo Baptista da. Curso de processo civil: processo de conhecimento. v. 1. 6. ed. rev. e atual. São Paulo: Revista dos Tribunais, 2002.

TAMANAHA, Brian. Understanding Legal Pluralism: Past to Present, Local to Global. Sidney Law Review, v. 30, n. 3, p. 375-411, Sept. 2008.

TRINDADE, João Carlos. Rupturas e continuidades nos processos políticos e jurídicos In: SANTOS, Boaventura de Sousa; TRINDADE, João Carlos (Org.). Conflito e Transformação Social: Uma Paisagem das Justiças em Moçambique. v. I. Porto: Afrontamento, 2003. p. 97-128.

UGANDA. Ministry of Local Government of the Republic of Uganda (2003). Local Councils Administration of Justice. Guides for Local Council Courts. Disponível em: <http://www.molg.go.ug/docs/LocalCourts Guide.pdf>. Acesso em: 20 nov. 2013.

VASCONCELOS, Arnaldo. Teoria da Norma Jurídica. 6. ed. São Paulo: Malheiros, 2006.

WOLKMER, Antonio Carlos. Pluralismo Jurídico: fundamentos de uma nova cultura no direito. 3. ed. São Paulo: Alfa Omega, 2001.

. Pluralismo jurídico: novo paradigma de legitimação. Disponível em: <http://www.mundojuridico.adv.br/sis_artigos/artigos.asp? codigo $=646>$. Acesso em: 25 fev. 2013. 


\section{A Interpretação do Duty to Mitigate the Loss na Convenção das Nações Unidas sobre Contratos de Compra e Venda Internacional de Mercadorias e a sua Recepção pelo Direito Civil Brasileiro}

The Interpretation of the Duty to Mitigate the Loss under the United Nations Convention on Contracts for the International Sale of Goods and its Reception by Brazilian Civil Law

Fernanda Sirotsky Scaletscky*

Resumo: $\mathrm{O}$ depósito do instrumento de adesão do Brasil à Convenção das Nações Unidas sobre Contratos de Compra e Venda Internacional de Mercadorias de 1980 marca uma nova etapa na história dos contratos internacionais no país. A CISG, que passou a valer a partir de abril de 2014 no ordenamento pátrio, trará diversas modificações no que tange à regulamentação dos contratos internacionais de compra e venda de mercadorias, tendo em vista que ela será a legislação padrão brasileira sobre o tema, bem como pelo fato de conter princípios diferentes daqueles que regiam, até o momento, a matéria no Brasil, como o princípio da autonomia da vontade das partes. $\mathrm{O}$ presente trabalho buscará compreender um destes novos institutos que a CISG introduzirá no Direito Brasileiro e cotejá-lo à legislação brasileira já existente, a saber, o art. 77 da CISG, que trata da doutrina do Duty to Mitigate the Loss, traduzida para o português como o dever do credor de mitigar as próprias perdas. Apesar da adoção da CISG

* Universidade de São Paulo. 
pelo Brasil, muitas questões ainda pairam a respeito da interpretação e da aplicação do duty to mitigate no Direito Brasileiro, tendo em vista se tratar de teoria estrangeira que, até pouco tempo atrás, era desconhecida e inaplicada pelos juristas do Brasil. Nesse sentido, o presente trabalho buscará responder à seguinte pergunta: qual seria a forma mais adequada de interpretação do instituto do duty to mitigate no Direito Brasileiro, ou, em outras palavras, qual a forma de interpretação mais consectária com o disposto na CISG?

Palavras-chave: Artigo 77 da CISG. Duty to Mitigate the Loss. Boa-fé Objetiva. Venire Contra Factum Proprium. Encargo de Evitar o Próprio Dano.

Abstract: The deposit of the instrument of accession of Brazil to the United Nations Convention on Contracts for the International Sale of Goods of 1980 marks a new stage in the history of international contracts for the country. The CISG, which will be applicable in Brazil starting April 2014, will bring several modifications regarding the regulation of international contracts for the sale of goods, considering that it will become Brazilian's standard legislation on the topic, as well as by the fact that it contains different principles from those who govern the matter in Brazil today, for example, the principle of the parties' autonomy. The present paper will seek to understand one of these new institutes that the CISG will introduce in Brazilian law and compare it to Brazilian legislation, namely, art. 77 of the CISG, which deals with the doctrine of the Duty to Mitigate the Loss, translated into Portuguese as the creditor's duty to mitigate its own losses. Despite the adoption of the CISG by Brazil, many questions still exist regarding the interpretation and the application of the duty to mitigate in Brazilian law, considering that it is a foreign theory and that, until recently, it was unknown and inapplicable by Brazilian jurists. In this sense, this paper will seek to answer the following question: what would be the most appropriate way to interpret the duty to mitigate in Brazilian law, or, in other words, what form of interpretation would be more adjustable to the provisions of the CISG?

Keywords: Article 77 of the CISG. Duty to Mitigate the Loss. Good Faith. Venire Contra Factum Proprium. Creditor's Duty to Mitigate his Own Losses. 


\section{Introdução}

O depósito do instrumento de adesão do Brasil à Convenção das Nações Unidas sobre Contratos de Compra e Venda Internacional de Mercadorias ("CISG" ou “Convenção"), junto do Secretário Geral da Organização das Nações Unidas (ONU), no dia 4 de março de 2013 (Decreto Legislativo n. 538, publicado em 19 de outubro de 2012), marca uma nova etapa na história dos contratos internacionais no Brasil e um passo a mais na estrada que o país vem trilhando nos últimos anos para se cristalizar como um dos principais players do cenário mundial.

A CISG passou a valer a partir de $1^{\circ}$ de abril de $2014^{1}$ no ordenamento jurídico pátrio e, com a adesão do Brasil, a Convenção passou a contar com setenta e nove Estadosmembros, sendo que nove em cada dez nações preponderantes no cenário do comércio global já eram membros da Convenção, que cobre potencialmente $90 \%$ (noventa por cento) das trocas internacionais. A CISG, sendo uma das mais brilhantes realizações visando à unificação de regras para compra e venda internacional de mercadorias, tem-se mostrado relevante não apenas como standard legislativo internacional, mas também tendo um papel decisivo ao influenciar e modelar as legislações nacionais sobre compra e venda de mercadorias ${ }^{2}$.

\footnotetext{
1 Nesse sentido, está a redação do art. 99, 2 da CISG, na tradução para o português realizada por Eduardo Grebler e Gisely Radael, que explicita que a Convenção entra em vigor no primeiro dia do mês seguinte aos dozes meses subsequentes ao depósito do instrumento de ratificação: "quando um Estado ratificar, aceitar, aceder ou aprovar a presente Convenção, ou a ela aderir, após haver sido depositado o décimo instrumento de ratificação, aceitação, aprovação ou acessão, a Convenção, salvo a Parte excluída, entrará em vigor com relação a esse Estado no primeiro dia do mês seguinte ao término do prazo de doze meses, contado da data em que haja depositado seu instrumento de ratificação, aceitação, aprovação ou acessão, observado o disposto no parágrafo (6) deste artigo". Disponível em: $<$ http://www. cisg-brasil.net/doc/egrebler2.pdf>. Acesso em: 23 abr. 2013.

2 SCHWENZER, Ingeborg. Regional and Global Unification of Sales Law. European Journal of Law Reform, n. 13, 2011. p. 370-379. A autora cita como exemplos da
} 
Nos dias de hoje, a negociação internacional busca, cada vez mais, ter o apoio de regras uniformes e neutras, que contenham verdadeiros padrões de conduta global e que possibilitem transações comerciais estáveis e seguras. É por isso que a adoção da CISG pelo Brasil, entre outros benefícios, irá reduzir os obstáculos para os negociantes internacionais que buscarem contratar a compra e a venda de mercadorias com empresas brasileiras, por meio de regras mais coerentes, simples e padronizadas para o caso de uma eventual disputa futura entre empresas.

A incerteza legal e a relativa falta de incentivos para fazer negócios com o Brasil são alguns dos pontos que chamam a atenção na atual legislação que governa os contratos para compra e venda internacional de mercadorias no país, pois quando são os tribunais brasileiros que possuem jurisdição para julgar casos relativos a contratos dessa natureza, é a Lei de Introdução às Normas do Direito Brasileiro, Lei n ${ }^{\circ}$ 4.657/1942 (LINDB), que irá ser aplicada à questão controversa, sobretudo no que diz respeito à escolha da lei aplicável ao contrato internacional $^{3}$. Nesse sentido, o art. $9^{\circ}$ da LINDB estabelece como regra geral que as obrigações serão regidas pela lei do país em que foram constituídas, ou seja, a jurisdição do local onde as partes constituíram o contrato internacional.

$\mathrm{O}$ art. 9ํำ da LINDB representa uma limitação expressa à autonomia da vontade das partes, ao adotar a lei do local de

influência da CISG em nível nacional o fato de a Finlândia, a Noruega e a Suécia terem aproveitado a entrada em vigor da CISG em seus países, no ano de 1989, para reformar suas legislações nacionais sobre o tema, grandemente influenciadas pelo texto da Convenção, bem como os recentes países do Leste Europeu que, após a ruína da União Soviética, ocorrida com o fim da Guerra Fria, viram na CISG uma inspiração para a formulação de seus novos Códigos Civis.

3 ALMEIDA PRADO, Mauricio; BUENO DE MIRANDA, Sílvia Julio; ALVES, Rafael Francisco; PEARSON, Marcus. Harmonising with CISG. Disponível em: $<$ http://www. latinlawyer.com/news/article/44128/harmonising-cisg/>. Acesso em: 19 abr. 2013. 
constituição da obrigação como lei aplicável para a qualificação e regência das relações obrigacionais, sendo tal norma de ordem pública, ou seja, não admitindo derrogação pela vontade das partes. Tal regra, da forma como foi construída, demonstra a não admissão da autonomia da vontade como regra de conexão em matéria obrigacional no Direito Internacional Privado Brasileiro, o que, apesar de ser uma tendência do Direito dos países sul-americanos, fica muito distante dos padrões adotados pelos países de outras partes do globo, com quem o Brasil tem estreitas relações econômicas ${ }^{4}$. Já a CISG, diferentemente da LINDB, tem como um de seus pilares o respeito à autonomia da vontade das partes, permitindo-lhes não apenas derrogar algumas das disposições da Convenção, mas também excluir totalmente a sua aplicação ${ }^{5}$.

A CISG, por conferir às partes maior certeza quantos aos seus direitos e obrigações e quanto ao que esperar em caso de descumprimento contratual, bem como por possuir um texto neutro, uniforme e padronizado, que inexistia no passado na legislação brasileira, como antes mencionado, aumenta a segurança jurídica dos contratantes e diminui os custos de transação dos negócios internacionais. As vantagens antes mencionadas beneficiarão tanto as empresas brasileiras como as estrangeiras, que obterão o mesmo grau de segurança e previsibilidade jurídica no âmbito dos contratos internacionais já vivenciado em outros países signatários da Convenção.

Como bem coloca Nadia de Araujo, a adesão do Brasil à CISG trará muitas mudanças nos contratos internacionais de

\footnotetext{
4 Para ver mais sobre a questão da regulamentação das relações obrigacionais internacionais pela LINDB, ver a obra de BASSO, Maristela. Curso de direito internacional privado. 2. ed. São Paulo: Atlas, 2011. p. 195-202.

5 ARAUJO, Nadia de; SPITZ, Lidia. O que muda com a Convenção de Viena. Disponível em: <http://www.valor.com.br/brasil/2928448/o-que-muda-com-convencao-de-viena>. Acesso em: 17 abr. 2013.
} 
compra e venda de mercadorias, que passarão a ser regidos pela legislação uniforme, quando ausente acordo sobre a lei aplicável entre as partes, e não mais pela legislação civil brasileira, ou mesmo pela LINDB .

Nesse sentido, e levando-se em conta todas as considerações anteriormente expostas, é mais do que justificável que os estudiosos do Direito Brasileiro debrucem-se, o mais rapidamente possível, sobre o entendimento dos dispositivos da Convenção, tendo em vista que a CISG será a legislação padrão brasileira aplicável aos contratos internacionais de compra e venda de mercadorias. É por isso que o presente trabalho buscará compreender um desses dispositivos e cotejá-lo à legislação brasileira já existente.

Trata-se do art. 77 da CISG, que trata da doutrina do Duty to Mitigate the Loss ("duty to mitigate"), traduzida para o português como o dever do credor de mitigar as próprias perdas. Apesar da adoção da CISG pelo Brasil e, consequentemente, da indubitável incorporação da referida teoria no ordenamento jurídico pátrio a partir de 2014, muitas questões ainda pairam a respeito da interpretação e da aplicação do duty to mitigate no Direito Brasileiro, tendo em vista se tratar de teoria estrangeira que, até pouco tempo atrás, era desconhecida e inaplicada pelos juristas brasileiros.

O presente trabalho buscará nas premissas - sobretudo advindas da doutrina estrangeira e nacional - e, subsidiariamente, na jurisprudência estrangeira e nacional, responder à seguinte pergunta: qual seria a forma mais adequada de interpretação do duty to mitigate no Direito Brasileiro, ou, em outras palavras, qual a forma de interpretação mais consectária com o disposto na CISG?

6 Ibidem. 
Na busca pela resposta a essa pergunta, o presente trabalho será dividido em duas grandes partes: na Parte I, buscar-se-á compreender como o art. 77 da CISG é interpretado pela doutrina internacional, que já utiliza o dispositivo há mais de duas décadas; e, na Parte II, procurar-se-á entender a interpretação e o uso que o Direito Brasileiro tem feito do duty to mitigate, por meio da análise das teorias que foram utilizadas para incorporar essa doutrina no Brasil até o momento.

\section{O Duty to Mitigate the Loss na CISG}

O artigo 77 da CISG, na tradução para o português realizada por Eduardo Grebler e Gisely Radael, dispõe que:

Artigo 77

A parte que invocar o inadimplemento do contrato deverá tomar as medidas que forem razoáveis, de acordo com as circunstâncias, para diminuir os prejuízos resultantes do descumprimento, incluídos os lucros cessantes. Caso não adote estas medidas, a outra parte poderá pedir redução na indenização das perdas e danos, no montante da perda que deveria ter sido mitigada ${ }^{7}$.

Tendo em vista a literalidade do dispositivo acima, num primeiro momento $(A)$, o presente trabalho dedicar-se-á à parte inicial do art. 77 da CISG, ou seja, ao dever imposto ao credor inadimplido de minimizar as próprias perdas, devendo tomar, para tanto, as medidas consideradas razoáveis, segundo as

7 Disponível em: <http://www.cisg-brasil.net/doc/egrebler2.pdf >. Acesso em: 23 abr. 2013. O mesmo dispositivo em inglês, que é uma das línguas oficiais da CISG, tem a seguinte redação: "Article 77: a party who relies on a breach of contract must take such measures as are reasonable in the circumstances to mitigate the loss, including loss of profit, resulting from the breach. If he fails to take such measures, the party in breach may claim a reduction in the damages in the amount by which the loss should have been mitigated". Disponível em: <http://www.uncitral.org/ pdf/english/texts/sales/cisg/CISG.pdf>. Acesso em: 23 abr. 2013. 
circunstâncias do caso concreto. Em um segundo momento (B), cuidar-se-á da segunda parte do art. 77 da CISG, que traz a consequência jurídica imposta pela Convenção à parte que descumprir o dever de mitigar as próprias perdas.

\subsection{A Interpretação da Primeira Parte do Artigo 77 da CISG segundo a Doutrina Internacional}

Antes de iniciarmos propriamente a interpretação do art. 77 da CISG dada pela doutrina internacional, que há anos se debruça sobre o tema, é importante mencionar que um dos pilares da Convenção é o de que, sendo ela um texto de caráter nitidamente internacional, a sua interpretação deve ser feita de maneira autônoma em relação às legislações nacionais dos países que a ratificaram. Nesse sentido, conforme bem colocou Nadia de Araujo, "no tocante às matérias reguladas pela Convenção, as questões devem ser dirimidas de acordo com os princípios que a inspiraram, e não por meio de recurso à lei doméstica"s.

Também é importante mencionar, ainda de forma introdutória, que todos os dispositivos da Convenção devem ser interpretados à luz de suas disposições gerais, constantes, sobretudo, dos artigos $7^{\circ}$ ao $13^{\circ}$ da CISG, que encampam vários dos princípios que embasam o entendimento deste instrumento legislativo9.

\footnotetext{
8 ARAUJO, Nadia de; SPITZ, Lidia. O que muda com a Convenção de Viena. Disponível em: <http://www.valor.com.br/brasil/2928448/o-que-muda-com-convencao-de-viena>. Acesso em: 17 abr. 2013. Como bem colocam as autoras, o uso da jurisprudência já consolidada da CISG é de enorme valia na interpretação da Convenção, embora sua utilização não tenha qualquer efeito vinculante, apenas persuasivo.

9 Dentre eles, o art. 9o da CISG merece uma atenção especial para o trabalho que aqui será desenvolvido, pois trata de uma importante regra para a compreensão dos casos concretos em que se aplica a Convenção, a saber, a importância da conduta
} 
Ademais, deve-se esclarecer de antemão que o art. 77 da CISG aparece em sua Seção II, que trata da indenização (Damages), sendo certo que este artigo será aplicável apenas quando a parte buscar eventual indenização por descumprimento contratual, e não quando o que se busca são outros remédios disponíveis, como o cumprimento específico da obrigação ou a rescisão do contrato, segundo a opinião que prevalece na doutrina internacional ${ }^{10}$.

A regra de que o vendedor ou o comprador podem requerer os danos (ou as perdas e danos, como é a praxe no vocabulário jurídico brasileiro) causados pelo descumprimento contratual da outra parte encontra uma grande exceção na CISG, que limita quantitativamente o montante da indenização devida à vítima de um descumprimento contratual, caso esta não adote as medidas razoáveis para diminuir ou mesmo evitar os danos advindos desse descumprimento.

Sendo assim, a primeira parte do art. 77 da CISG traz a seguinte frase: "a parte que invocar o inadimplemento do contrato deverá tomar as medidas que forem razoáveis, de acordo com as circunstâncias, para diminuir os prejuízos resultantes do descumprimento, incluídos os lucros cessantes".

das partes. Nesse sentido, o art. $9^{\circ}$ da CISG, em sua tradução para o português, tem a seguinte redação: "(1) As partes se vincularão pelos usos e costumes em que tiverem consentido e pelas práticas que tiverem estabelecido entre si. (2) Salvo acordo em contrário, presume-se que as partes consideraram tacitamente aplicáveis ao contrato, ou à sua formação, todo e qualquer uso ou costume geralmente reconhecido e regularmente observado no comércio internacional, em contratos de mesmo tipo no mesmo ramo de comércio, de que tinham ou devessem ter conhecimento".

${ }_{10}$ Entretanto, alguns autores, como o professor John O. Honnold, buscam estender a regra do art. 77 da CISG para outras hipóteses de descumprimento contratual, que não a indenização por perdas e danos. Nesse sentido, ver a obra de HONNOLD, John. Uniform Law for International Sales under the 1980 United Nations Convention. 3. ed. The Hague: Kluwer Law International, 1999. Disponível em: <http://www. cisg.law.pace.edu /cisg/biblio/honnold.html>. Acesso em: 24 abr. 2013. 
A Interpretação do Duty to Mitigate the Loss...

Dois pontos aparecem como essenciais, desde logo, para sua correta compreensão: i) a necessidade de uma ação por parte da vítima de um inadimplemento contratual e ii) que essa ação seja razoável dentro das circunstâncias do caso.

Segundo Bianca e Bonell, o art. 77 traz o que eles denominam de princípio da prevenção (prevention principle), pelo qual uma parte ameaçada por uma perda decorrente de um inadimplemento contratual incorrido pela outra parte não tem a permissão de esperar passivamente pela ocorrência ou aumento do dano, para então ingressar com a ação indenizatória ${ }^{11}$. Em uma interpretação literal do dispositivo, conforme bem coloca Chengwei Liu, uma parte contratante não pode "sentar e esperar" que a outra parte incorra em um descumprimento contratual, devendo agir de forma ativa para minimizar eventual perda dele decorrente ou mesmo visando a evitá-la. Mesmo que a parte não tenha contribuído para o descumprimento do contrato ou para os efeitos que dele advieram, ela não poderá, como mais adiante examinaremos, buscar a indenização pelos danos que poderia ter evitado, caso tivesse tomado as medidas razoáveis no momento devido ${ }^{12}$.

Levando em consideração o anteriormente mencionado sobre o fato de ser a razoabilidade um dos princípios centrais da Convenção, as medidas que são esperadas do credor inadimplido visando a diminuir suas próprias perdas são apenas aquelas consideradas razoáveis, segundo as circunstâncias do caso (measures as are reasonable in the circumstances). Tendo em vista a ausência de uma definição do que seria considerado razoável, ou mesmo de razoabilidade (reasonableness), na CISG,

${ }^{11}$ BIANCA, Cesare Massimo; BONELL, Michael Joachim. Commentary on the International Sales Law: the 1980 Vienna Sales Convention. Milan: Giuffrè, 1987. p. 559-560.

12 CHENGWEI, Liu. Remedies for Non-performance: Perspectives from CISG, UNIDROIT Principles \& PECL. 2003. p. 18-19. Disponível em: <http://www.cisg.law.pace.edu/ cisg/biblio/chengwei-77.html>. Acesso: 24 abr. 2013. 
a avaliação do que seria razoável dependerá de um exame fático do caso concreto. Ou seja, de forma geral, a razoabilidade deve ser interpretada segundo o que pessoas de boa-fé, e em situação similar à das partes do contrato, julgam como sendo razoável ${ }^{13}$.

Conforme bem coloca Ingeborg Schwenzer, o art. 77 da CISG demanda que a parte lesada tome as medidas razoáveis, levando-se em consideração as circunstâncias do caso e o princípio da boa-fé, para mitigar as suas perdas. Na determinação do que seriam consideradas medidas razoáveis, as práticas estabelecidas entre as partes, bem como os usos do comércio internacional, devem ser levados em consideração de forma primordial (art. 9ํ da CISG). Também se deve ter claro que o ponto de referência do julgador deve ser a conduta que uma pessoa razoável, na mesma posição e sob as mesmas circunstâncias da parte lesada, adotaria no caso concreto (art. 8(2) da CISG).

Ademais, se um dos princípios guiadores da CISG é a razoabilidade (reasonableness), o art. 77 da Convenção exige que tanto o credor como o devedor atinja o desafio de ser razoável durante uma situação considerada difícil, a saber, quando ele já está perdendo ou está prestes a perder dinheiro em virtude de um comportamento da parte contrária, em um contrato internacional de compra e venda de mercadorias ${ }^{14}$. Apesar de o preceito contido no art. 77 da CISG impor ao credor inadimplido que ele aja visando a diminuir ou evitar os danos que o descumprimento contratual da outra parte causaria para

${ }^{13}$ CHENGWEI, Liu. Op. cit., p. 19-20. Na decisão do que é razoável, segundo este autor, todos os fatores relevantes da contratação devem ser levados em consideração e atenção deve ser dada, em especial, à natureza e ao propósito do contrato, bem como às circunstâncias, usos e práticas do comércio ou da profissão envolvidos, tendo em vista que estas referências refletem o comportamento de partes consideradas razoáveis.

${ }^{14}$ OPIE, Elizabeth. Commentary on the manner in which the UNIDROIT Principles may be used to interpret or supplement Article 77 of the CISG. 2005. p. 1. Disponivel em: <http://www.cisg.law.pace.edu/cisg/principles/uni77.html>. Acesso em: 23 abr. 2013. 
si mesmo, não se exigem da parte esforços excepcionais, até mesmo porque a parte já é vítima de uma quebra contratual e já suporta as consequências dela decorrentes. Seria desproporcional, juridicamente, exigir do credor inadimplido, que já se encontra em uma situação precária pelo descumprimento da outra parte, a tomada de atitudes ou a despesa de somas exageradas e desproporcionais às suas forças, levando-se em consideração a sua já enfraquecida posição contratual. Por isso é que o art. 77 da Convenção é claro ao estabelecer que as medidas que a parte lesada deve tomar são apenas aquelas consideradas razoáveis nas circunstâncias concretas de cada $\operatorname{caso}^{15}$.

Um último ponto a ser mencionado em relação à primeira parte do dispositivo do art. 77 da CISG diz respeito ao momento de sua aplicação. Alguns autores ${ }^{16}$ alegam que ele seria aplicável tanto no que a doutrina internacional chama de anticipatory breach (quando ocorre a quebra contratual por uma das partes antes mesmo de a sua prestação ser devida no tempo), quanto a uma quebra contratual relativa a uma obrigação cuja execução seja atualmente devida. Ou seja, o dever de mitigar

\footnotetext{
${ }^{15}$ Exemplos de medidas razoáveis seriam, por exemplo, a revenda das mercadorias pelo vendedor, cujo preço o comprador deixou de pagar, ou uma nova compra pelo comprador, caso as mercadorias entregues pelo vendedor fossem defeituosas, ou mesmo a possibilidade de o próprio comprador remediar as mercadorias defeituosas entregues pelo vendedor. DJAKHONGIR, Saidov. Methods of limiting damages under the Vienna Convention on Contracts for the International Sale of Goods. Pace International Law Review, v. 14, issue 2, fall 2002. p. 355. É importante mencionar também que o dinheiro gasto pela parte lesada ao tomar as medidas razoáveis para minimizar os danos será considerado uma perda advinda do inadimplemento contratual, que poderá ser, logo, objeto de compensação, mesmo que as ações da parte para mitigar os danos tenham sido em vão, contanto que tenham sido razoáveis, segundo as circunstâncias do caso. BIANCA, Cesare Massimo; BONELL, Michael Joachim. Commentary on the International Sales Law: the 1980 Vienna Sales Convention. Milan: Giuffrè, 1987. p. 560.

${ }^{16}$ Neste sentido, o posicionamento de Liu Chengwei, John O. Honnold e Saidov Djakhongir.
} 
as próprias perdas seria aplicável quando a parte contrária já inadimpliu sua obrigação contratual, ou mesmo quando a execução da prestação pela outra parte ainda não é devida no tempo, mas o credor já tem fortes motivos para acreditar que haverá uma quebra contratual futura. Tem-se constatado que a aplicação do duty to mitigate a casos de anticipatory breach se baseia no raciocínio de que o objetivo do art. 77 da CISG é a mitigação dos prejuízos. Nesse sentido, medidas visando a mitigar as perdas sofridas pelo credor devem ser tomadas assim que este perceba que a outra parte não executará a sua prestação contratual e lhe causará, logo, prejuízos $^{17}$.

\subsection{A Interpretação da Segunda Parte do Artigo 77 da CISG segundo a Doutrina Internacional}

A segunda parte do art. 77 da CISG traz a consequência da ausência de mitigação das próprias perdas pela parte lesada da relação contratual; a saber, caso não sejam adotadas as medidas razoáveis para mitigar as próprias perdas, a parte causadora da quebra contratual poderá reivindicar a redução na indenização das perdas e danos, no montante da perda que deveria ter sido mitigada pela parte lesada. A ideia por trás dessa consequência é a de que a parte lesada não pode buscar compensação com respeito aos danos que ela poderia ter, razoavelmente, evitado. Ou seja, caso a parte lesada adote uma atitude passiva e não aja face ao descumprimento contratual perpetrado pela outra parte, em uma interpretação literal do

\footnotetext{
${ }_{17}$ Entretanto, como bem coloca Djakhongir Saidov, resta ainda em debate se haveria um requerimento geral de mitigação, por parte do credor, neste estágio anterior do contrato, quando a prestação da outra parte ainda não atingiu a data para poder ser exigida pelo credor. DJAKHONGIR, Saidov. Methods of limiting damages under the Vienna Convention on Contracts for the International Sale of Goods. Pace International Law Review, v. 14, issue 2, fall 2002. p. 356-358.
} 
dispositivo, existe a consequência, à disposição da parte que incorreu na quebra do contrato, de buscar a redução das perdas e danos, que, de outra forma, seriam devidos.

Sendo assim, um pré-requisito para a aplicação da sanção prevista na segunda parte do art. 77 da CISG é a falha, pela parte lesada, de tomar as medidas que são razoáveis e esperadas dela, tendo em vista as circunstâncias do caso, para impedir ou, ao menos, diminuir as perdas advindas de uma quebra contratual, sendo a redução dos danos a única consequência disponível para os casos sujeitos ao art. 77 da CISG. A obrigação contida no art. 77 da CISG, por exemplo, não pode ser diretamente executada e a sua falha não gera a possibilidade de rescisão do contrato ${ }^{18}$.

É importante que se mencione, conforme Jeffrey S. Sutton, que a falha em mitigar as próprias perdas pela parte lesada não elimina o seu direito à indenização pelas perdas e danos - pois, afinal, a outra parte descumpriu o que havia sido pactuado no contrato -, mas apenas acarreta a diminuição no montante, no valor a ser indenizado ${ }^{19}$.

Segundo Ingeborg Schwenzer, o duty to mitigate não é uma obrigação diretamente exequível do contrato, mas sim, um dever que deve ser desempenhado nos próprios interesses da parte lesada. Ou seja, a falha em mitigar os próprios danos não leva o credor inadimplido a vir a ser responsabilizado por perdas e

${ }^{18}$ KNAPP, Victor. Bianca-Bonell Commentary on the International Sales Law. Milan: Giuffrè, 1987. p. 559-567. Disponível em: <http://www.cisg.law.pace.edu/cisg/biblio/ knapp-bb77.html>. Acesso em: 26 abr. 2013.

19 SUTTON, Jeffrey S. Measuring Damages Under the United Nations Convention on the International Sale of Goods. Ohio State Law Journal, v. 50, 1989. p. 737-752. Tal regra se refere a uma concepção fundamental para a visão norte-americana dos danos, a saber, a de que a indenização não deve incluir os danos por perdas que poderiam ter sido evitadas. Essa regra está na Seção 347 do Restatement (Second) of Contracts (legislação civil norte-americana sobre contratos) e na Seção 2-715(2)

(a) do Uniform Commercial Code (Código Comercial Norte-Americano). 
danos, mas impede a recuperação dos danos que poderiam ter sido mitigados, sendo, inclusive, irrelevante se a parte lesada agia com culpa ao deixar de mitigar as próprias perdas ${ }^{20}$.

Por fim, éimportante esclarecer que a parte que descumpriu o contrato tem o dever de provar que a parte lesada falhou em preencher a sua obrigação de mitigar as próprias perdas, como também falhou em provar a razoabilidade, ou não, das despesas incorridas pela última ao buscar mitigar os danos. Isso porque existe uma presunção favorável face à parte lesada, mas que pode ser invertida, caso reste devidamente comprovado que esta não agiu de forma razoável ao buscar minimizar as próprias perdas ${ }^{21}$.

\section{A Recepção do Duty to Mitigate the Loss no Brasil}

Nesta segunda parte do trabalho, procurar-se-á entender a interpretação e o uso que o Direito Brasileiro tem feito do duty to mitigate the loss, por meio da análise das três principais teorias que foram utilizadas pelos aplicadores do direito pátrio para incorporar este instituto no Brasil. Assim, serão estudadas as teorias da 1) boa-fé objetiva, 2) do abuso de direito e do venire contra factum proprium, bem como do 3) encargo

${ }^{20}$ SCHWENZER, Ingeborg. Commentary on the UN Convention on the International Sale of Goods (CISG). 3. ed. New York: Oxford University Press, 2010. p. 1043.

${ }^{21}$ OPIE, Elizabeth. Commentary on the manner in which the UNIDROIT Principles may be used to interpret or supplement Article 77 of the CISG. p. 3-4. 2005. Disponivel em: $<$ http://www.cisg.law.pace.edu/cisg/principles/uni77.html>. Acesso em: 23 abr. 2013. No entanto, a autora Ingeborg Schwenzer discorda em parte deste posicionamento relacionado à prova do duty to mitigate. Apesar de ambas as autoras concordarem que cabe à parte que descumpriu o contrato a prova de que a parte lesada não cumpriu com o duty to mitigate, Schwenzer acredita que caberia à parte lesada a prova das despesas com as medidas tomadas para evitar ou mitigar as próprias perdas, caso esta reclamasse a compensação destas despesas com base no art. 74 da CISG. SCHWENZER, Ingeborg. op. cit., p. 1048. 
de evitar o próprio dano. Ao final, buscar-se-á verificar qual seria o entendimento mais adequado para a recepção do duty to mitigate no Brasil.

Antes de adentrar no estudo proposto para o presente capítulo, é importante que se mencione que o duty to mitigate the loss tem maior amplitude e positivação no âmbito das convenções internacionais, como a Convenção de Haia de 1964 a respeito da Lei Uniforme sobre a Venda Internacional de Mercadorias, os Princípios UNIDROIT para os Contratos Comerciais Internacionais e os Princípios Europeus para o Direito Contratual. Os princípios, regras e deveres advindos da chamada lex mercatoria incorporam, como bem mencionado por Véra Fradera, o dever do credor de mitigar as próprias perdas ${ }^{22}$.

Ademais, conforme exposto por John O. Honnold, o duty to mitigate the loss tem concepções diversas nas várias legislações nacionais:

O princípio de que uma parte deve mitigar as perdas que razoavelmente podem ser evitadas é geralmente reconhecido, mas é expresso de maneiras diferentes e é aplicado com diferentes graus de ênfase. Muitos códigos não falam explicitamente de um "dever" de "mitigar" a perda. Em vez disso, a linguagem legal normalmente utilizada de que uma parte é responsável pelos danos que "provoca" acaba, muitas vezes, por fornecer uma base para a conclusão de que parte dos danos foi causada pelo credor, em vez da parte que causou a quebra contratual. Da mesma forma, alguns

${ }^{22}$ FRADERA, Véra Maria Jacob de. Pode o credor ser instado a diminuir o próprio prejuízo? Revista trimestral de direito civil, Rio de Janeiro: Padma, v. 19, p. 109-119, jul./set. 2004. Berthold Goldman também alude ao fato de o duty to mitigate the loss ser um princípio constante da lex mercatoria, ao alegar que: "[...] existem regras específicas do comércio internacional [...]; um exemplo poderia ser a obrigação do credor de minimizar os prejuízos advindos da inexecução, por parte do devedor, de suas obrigações contratuais". GOLDMAN, Berthold. The applicable law: general principles of law - the lex mercatoria. In: LEW, Julian D. M. (Ed.). Contemporary Problems in International Arbitration. London: Martinus Nijhoff Publishers, 1987. p. 115. 
sistemas legais limitam a recuperação do credor com base em princípios semelhantes ao que outros sistemas jurídicos chamam contributory negligence - ex., a doutrina francesa da faute de la victime (tradução livre) ${ }^{23}$.

Véra Fradera alude que o dever de mitigar tem origem no direito anglo-saxão (mitigate), de onde passou, posteriormente, aos sistemas jurídicos continentais, sendo que o vocábulo mitigate tem raiz no verbo francês mitiger. A recepção deste conceito se deu de maneira desigual e assistemática, tendo em vista que alguns ordenamentos nacionais o utilizam frequentemente como o alemão e o suíço -, enquanto outros usam seu conteúdo sem utilizar a sua denominação, como ocorre na França ${ }^{24}$.

${ }^{23}$ HONNOLD, John. Uniform Law for International Sales under the 1980 United Nations Convention. 3. ed. The Hague: Kluwer Law International, 1999. Disponível em: $<$ http://www.cisg.law.pace.edu /cisg/biblio/honnold.html $>$. Acesso em: 24 abr. 2013. No original em inglês: "the principle that a party must mitigate loss that reasonably can be avoided is generally recognized but is expressed in different ways and is applied with varying degrees of emphasis. Many codes do not explicitly speak of a 'duty' to 'mitigate' loss. Instead, statutory language that a party is responsible for the damage it 'causes' often provides a basis for concluding that some of the damage was caused by the plaintiff rather than the party in breach. Similarly, some systems limit the plaintiff's recovery by principles akin to what other legal systems call contributory negligence-e.g., the French doctrine of faute de la victime".

${ }^{24}$ FRADERA, Véra Maria Jacob de. Op. cit., p. 111-112. Como bem exposto pela autora em comento, na busca da natureza jurídica do duty to mitigate the loss verifica-se que, na Alemanha, este dever recebe o nome de Obligenheit (uma obrigação cuja exigência de cumprimento se reveste de menor intensidade), na Suíça recebe o nome de incombance, enquanto que a jurisprudência francesa, apesar de não utilizar nenhuma das mencionadas terminologias, vem aplicando este conceito com base no princípio da boa-fé objetiva e do abuso de direito. Já no direito da Common Law, o princípio da mitigação dos prejuízos advém do próprio sistema, tendo em vista que aquele que viola um contrato é responsável pelos danos, sem considerações de culpa ou de negligência por parte do infrator. 


\subsection{As Teorias Utilizadas para a Recepção do Duty to Mitigate the Loss no Brasil}

A aplicação e a utilidade do duty to mitigate the loss no Brasil foram pioneiramente pensadas pela doutrinadora Véra Maria Jacob de Fradera, da Universidade Federal do Rio Grande do Sul. Em julho de 2004, Véra Fradera publicou um artigo pioneiro sobre o assunto, intitulado Pode o credor ser instado a diminuir o próprio prejuízo?, ${ }^{25}$ expondo a existência de um dever, sobretudo no âmbito das Convenções Internacionais, por parte do credor, de adotar medidas visando a minimizar ou mesmo evitar as perdas decorrentes de uma quebra contratual, denominado, pela doutrina estrangeira, de duty to mitigate the loss. A pergunta a que a autora visou responder, já no ano de 2004, não é tão distinta da que intentamos responder nesta Parte II do trabalho, a saber, "como poderia ser recepcionado o duty to

516 mitigate the loss no âmbito do Código Civil Brasileiro de 2002"?

Nesse sentido, importantes são as palavras de Daniel Pires Novais Dias, que aponta que a doutrina brasileira tem se manifestado de forma favorável à recepção do duty to mitigate the loss, sendo que as maiores divergências acerca deste tema se referem ao fundamento jurídico de sua recepção ${ }^{26}$.

\subsubsection{Um Dever Anexo Advindo da Boa-Fé Objetiva}

O primeiro fundamento jurídico que trata da recepção do duty to mitigate the loss no âmbito do direito contratual brasileiro

\footnotetext{
${ }^{25}$ FRADERA, Véra Maria Jacob de. Pode o credor ser instado a diminuir o próprio prejuízo? Revista trimestral de direito civil, Rio de Janeiro: Padma, v. 19, p. 109-119, jul./set. 2004.

${ }^{26}$ DIAS, Daniel Pires Novaes. O duty to mitigate the loss no Direito civil brasileiro e o encargo de evitar o próprio dano. p. 4. Disponível em: <http://www.revistas.unifacs. br/index.php/redu/article/download/1894/ 1441>. Acesso em: 3 maio 2013.
} 
percebe o conceito como um dever acessório advindo da boa-fé objetiva, tendo em vista que o legislador civil brasileiro adota uma concepção cooperativa do contrato.

Como bem coloca Flávio Tartuce, a corporificação legislativa de uma atual teoria geral dos contratos, cujo expoente pioneiro é o Código de Defesa do Consumidor Brasileiro, teve uma continuidade com o advento do Código Civil de 2002 (CCB), ambos estando repletos de novos princípios jurídicos contratuais e cláusulas gerais, sendo, logo, verdadeiros representantes legislativos de uma nova concepção do contrato ${ }^{27}$. $\mathrm{O}$ art. 422 do CCB, que incorporou a boa-fé objetiva em nosso sistema civil, tem a seguinte redação: "os contratantes são obrigados a guardar, assim na conclusão do contrato, como em sua execução, os princípios de probidade e boa-fé" 28 .

Ademais, a positivação da boa-fé também trouxe a criação de diversos deveres jurídicos anexos às obrigações contratuais, que, apesar de sempre terem estado presentes no ordenamento jurídico, não haviam recebido a devida atenção até o advento do CCB. Ao criar tais deveres, a boa-fé objetiva atua como verdadeira fonte de integração do conteúdo do contrato, independente do que foi estabelecido segundo a vontade das partes, ou seja, eles possuem uma origem não-voluntarística ${ }^{29}$.

${ }^{27}$ TARTUCE, Flávio. A boa-fé objetiva e a mitigação do prejuízo pelo credor: Esboço do tema e primeira abordagem. 2005. Disponível em: <www.flaviotartuce.adv.br/ secoes/artigos/Tartuce_duty.doc $>$. Acesso em: 3 maio 2013.

${ }^{28}$ Com a boa-fé objetiva, surgiram novos conceitos visando à integração dos contratos e, neste sentido, está o Enunciado no 26 da I Jornada de Direito Civil do Conselho de Justiça Federal: "a cláusula geral contida no art. 422 do novo Código Civil impõe ao juiz interpretar e, quando necessário, suprir e corrigir o contrato segundo a boa-fé objetiva, entendida como a exigência de comportamento leal dos contratantes". Disponível em: <http://www.jf.jus.br/cjf/CEJ-Coedi/jornadas-cej/ enunciados-aprovados-da-i-iii-iv-e-v-jornada-de-direito-civil/compilacaoenunciadosaprovados1-3-4jornadadircivilnum.pdf>. Acesso em: 3 maio 2013.

${ }^{29}$ Segundo Anderson Schreiber, a fonte dos deveres anexos é própria boa-fé objetiva, sendo que a sua criação independe da vontade das partes, podendo surgir mesmo 
A respeito dos deveres anexos, laterais, instrumentais, acessórios de conduta, meramente de conduta, de proteção ou de tutela, como também são denominados, advindos da boa-fé objetiva, Judith Martins-Costa explica que são deveres que "podem situar-se autonomamente em relação à prestação principal", sendo considerados, geralmente, "deveres de cooperação e proteção dos recíprocos interesses e se dirigem a ambos os participantes do vínculo obrigacional, credor e devedor". São deveres que as partes carregam durante toda a vida contratual, da fase pré-contratual à execução, ao se comprometerem a adotar certos comportamentos, tendo em vista o fim do negócio jurídico, os quais são baseados na objetiva confiança depositada mutuamente pelas partes, sendo variáveis conforme as circunstâncias concretas de cada caso ${ }^{30}$.

Entre os deveres com tais características, encontram-se os deveres de colaboração e de cooperação entre as partes contratantes, sendo que o duty to mitigate the loss seria uma concretização destes, tendo em vista impor às partes uma conduta guiada a evitar a oneração da prestação da outra parte,

contra esta vontade. Ver: SCHREIBER, Anderson. A proibição de comportamento contraditório: tutela da confiança e venire contra factum proprium. Rio de Janeiro: Renovar, 2005. p. 82. Ademais dessa função integradora, advinda do art. 422 do Código Civil, a boa-fé ainda possui a função interpretativa (art. 113 do Código Civil), eis que os negócios jurídicos devem ser interpretados conforme a boa-fé e os usos do lugar de sua celebração e a função de controle (art. 187 do Código Civil), uma vez que aquele que contraria a boa-fé objetiva comete abuso de direito. Nesse sentido, ver: TARTUCE, Flávio. Manual de direito civil: volume único. 2. ed. São Paulo: Método, 2012. p. 539.

${ }^{30}$ MARTINS-COSTA, Judith. A Boa-fé no Direito Privado: sistema e tópica no processo obrigacional. 1. ed. São Paulo: Editora Revista dos Tribunais, 2000. p. 438-440. Flávio Tartuce enumera aqueles que são considerados como sendo os deveres anexos, entre outros: "dever de cuidado em relação à outra parte negocial, dever de respeito, dever de informar a outra parte sobre o conteúdo do negócio, dever de agir conforme a confiança depositada, dever de lealdade e probidade, dever de colaboração ou cooperação, dever de agir com honestidade e dever de agir conforme a razoabilidade, a equidade e a boa razão". TARTUCE, Flávio. Manual de direito civil... Op. cit., p. 538. 
tendo como fundamento "o próprio acordo de vontade por elas firmado e por finalidade acautelar e substancializar a prestação contratada, assim o credor que onera ou complica a atuação do devedor está se voltando contra o que foi por ele pactuado, bem como contra o equilíbrio das prestações" ${ }^{\prime 31}$. É por isso que, na III Jornada de Direito Civil do Conselho de Justiça Federal, a doutrinadora Véra Fradera elaborou uma proposta interpretativa do art. 422 do CCB a respeito desse novo dever contratual, que acabou sendo aprovada no Enunciado nº 169, que tem a seguinte redação: "o princípio da boa-fé objetiva deve levar o credor a evitar o agravamento do próprio prejuízo". Dessa forma, o duty to mitigate the loss constituiria um dever de natureza acessória, advindo diretamente do dever de cooperação e lealdade que deve pautar a conduta das partes do contrato, o qual, por sua vez, advém diretamente da boa-fé objetiva ${ }^{32}$.

Véra Fradera, ao comentar as peculiaridades da recepção do duty to mitigate the loss pelos tribunais franceses, aduz que, apesar de reticente quanto à recepção do conceito de boa-fé objetiva, a jurisprudência francesa vem adotando o dever de mitigar com base nele. Ademais da boa-fé, a jurisprudência francesa também tem se utilizado dos conceitos de venire contra factum proprium e de abuso de direito para sancionar o

${ }^{31}$ DIAS, Daniel Pires Novaes. O duty to mitigate the loss no Direito civil brasileiro e o encargo de evitar o próprio dano. p. 28. Disponível em: <http://www.revistas.unifacs. br/index.php/redu/article/download/1894/ 1441>. Acesso em: 3 maio 2013.

${ }^{32}$ Como bem lembrado por Flávio Tartuce, conforme o Enunciado no 24 da I Jornada de Direito Civil do Conselho de Justiça Federal, a quebra dos deveres anexos decorrentes da boa-fé objetiva gera a violação positiva do contrato, hipótese de inadimplemento negocial que independe de culpa, gerando a responsabilidade contratual objetiva, cuja redação é a seguinte: "em virtude do princípio da boa-fé, positivado no art. 422 do novo Código Civil, a violação dos deveres anexos constitui espécie de inadimplemento, independentemente de culpa". TARTUCE, Flávio. A boa-fé objetiva e a mitigação do prejuízo pelo credor: Esboço do tema e primeira abordagem. 2005. p. 2. Disponível em:<www.flaviotartuce.adv.br/secoes/artigos/ Tartuce_duty.doc $>$. Acesso em: 3 maio 2013. 
comportamento do credor que deixar de tomar as medidas razoáveis para mitigar as próprias perdas ${ }^{33}$. Nesse sentido, estabelece a doutrinadora as consequências em caso de descumprimento do duty to mitigate the loss, com base na violação da boa-fé objetiva:

No âmbito do direito brasileiro, existe o recurso à invocação da violação do princípio da boa-fé objetiva, cuja natureza de cláusula geral permite um tratamento individualizado de cada caso, a partir de determinados elementos comuns: a prática de uma negligência, por parte do credor, ensejando um dano patrimonial, um comportamento conduzindo a um aumento do prejuízo, configurando, então, uma culpa, vizinha daquela de natureza delitual. [...] A consideração do dever de mitigar como dever anexo justificaria, quando violado pelo credor, o pagamento de perdas e danos. Como se trata de um dever e não de obrigação, contratualmente estipulada, a sua violação corresponde a uma culpa delitual ${ }^{34}$.

Independentemente de se achar adequada a recepção do duty to mitigate the loss por meio de quebra de um dever anexo advindo da boa-fé objetiva, o fato é que este foi o fundamento

\footnotetext{
${ }^{33}$ Como exemplo desta utilização, a autora cita o caso Bailleux c. Jaretty, que acabou se tornando um clássico sobre o assunto na França e que influenciou grandemente a aplicação do duty to mitigate the loss no Brasil. O caso trata de um locador que permaneceu onze anos sem cobrar os aluguéis e, ao invocar a cláusula resolutória do contrato de locação, acaba sendo privado de exercer o seu direito com fundamento na proibição do venire contra factum proprium. FRADERA, Véra Maria Jacob de. Pode o credor ser instado a diminuir o próprio prejuízo? Revista trimestral de direito civil, Rio de Janeiro: Padma, v. 19, p. 113, jul./set. 2004. Os contratos bancários e os de locação de imóveis são a principal fonte de exemplos deste instituto na doutrina, em geral. Nesse sentido, Flávio Tartuce menciona caso semelhante de um contrato de locação de imóvel urbano em que houve o inadimplemento das prestações devidas pelo locatário e haveria, por parte do locador, o dever de ingressar, tão logo fosse possível, com a competente ação de despejo, para que a dívida não assumisse valores excessivos. TARTUCE, Flávio. Direito civil, v. 3: teoria geral dos contratos e contratos em espécie. 8. ed. São Paulo: Método, 2013. p. 111.

${ }^{34}$ FRADERA, Véra Maria Jacob de. Pode o credor ser instado a diminuir o próprio prejuízo? Revista trimestral de direito civil, Rio de Janeiro: Padma, v. 19, jul./set. 2004. p. 119.
} 
jurídico escolhido pelo Superior Tribunal de Justiça (STJ) para recepcionar o instituto no Brasil no REsp n ${ }^{\circ} 758.518 / \mathrm{PR}^{35}$.

O caso em comento trata de uma ação de resolução contratual, com pedidos de reintegração de posse e de indenização, em que o promissário-comprador, além de deixar de pagar as prestações relativas ao contrato, acaba abandonando o imóvel. Mais de um ano depois do abandono, o promitente-vendedor ajuíza a ação; entretanto, com base na aplicação do duty to mitigate the loss, o STJ entendeu que o promitente-vendedor descuidou-se com o seu dever de mitigar o prejuízo sofrido:

[...] pois o fato de ter deixado o devedor na posse do imóvel por quase 7 (sete) anos, sem que este cumprisse com o seu dever contratual (pagamento das prestações relativas ao contrato de compra e venda), evidencia a ausência de zelo

${ }^{35}$ O referido julgado, datado de junho de 2010, possui a seguinte ementa: “DIREITO CIVIL. CONTRATOS. BOA-FÉ OBJETIVA. STANDARD ÉTICO-JURÍDICO. OBSERVÂNCIA PELAS PARTES CONTRATANTES. DEVERES ANEXOS. DUTY TO MITIGATE THE LOSS. DEVER DE MITIGAR O PRÓPRIO PREJUÍZO. INÉRCIA DO CREDOR. AGRAVAMENTO DO DANO. INADIMPLEMENTO CONTRATUAL. RECURSO IMPROVIDO. 1. Boa-fé objetiva. Standard ético-jurídico. Observância pelos contratantes em todas as fases. Condutas pautadas pela probidade, cooperação e lealdade. 2. Relações obrigacionais. Atuação das partes. Preservação dos direitos dos contratantes na consecução dos fins. Impossibilidade de violação aos preceitos éticos insertos no ordenamento jurídico. 3. Preceito decorrente da boa-fé objetiva. Duty to mitigate the loss: o dever de mitigar o próprio prejuízo. Os contratantes devem tomar as medidas necessárias e possíveis para que o dano não seja agravado. A parte a que a perda aproveita não pode permanecer deliberadamente inerte diante do dano. Agravamento do prejuízo, em razão da inércia do credor. Infringência aos deveres de cooperação e lealdade. 4. Lição da doutrinadora Véra Maria Jacob de Fradera. Descuido com o dever de mitigar o prejuízo sofrido. O fato de ter deixado o devedor na posse do imóvel por quase 7 (sete) anos, sem que este cumprisse com o seu dever contratual (pagamento das prestações relativas ao contrato de compra e venda), evidencia a ausência de zelo com o patrimônio do credor, com o consequente agravamento significativo das perdas, uma vez que a realização mais célere dos atos de defesa possessória diminuiriam a extensão do dano. 5. Violação ao princípio da boa-fé objetiva. Caracterização de inadimplemento contratual a justificar a penalidade imposta pela Corte originária, (exclusão de um ano de ressarcimento). 6. Recurso improvido" (STJ, REsp 758.518/PR, Terceira Turma, Rel. Des. Conv. Vasco dela Giustina, julgado em 17.06.2010, DJE 01.07.2010). 
com o seu patrimônio e o agravamento significativo das perdas, uma vez que a realização mais célere dos atos de defesa possessória diminuiria a extensão do dano. [...] a conduta da ora recorrente, inegavelmente, viola o princípio da boa-fé objetiva, circunstância que caracteriza inadimplemento contratual a justificar a penalidade imposta pela Corte originária (de exclusão da indenização referente a um ano sem a fruição do imóvel - desde o abandono do imóvel pelo promissário-comprador até o ajuizamento da ação) (p. 12 do acórdão, grifo nosso).

Do que se conclui que a verificação do duty to mitigate the loss como um dever anexo advindo da boa-fé objetiva é o principal fundamento de recepção desta teoria pela doutrina e pela jurisprudência brasileiras, tendo em vista a posição já consolidada do STJ.

\subsubsection{Abuso de Direito e o Venire Contra Factum Proprium}

O segundo fundamento jurídico utilizado para a recepção do duty to mitigate the loss no Brasil percebe o conceito como uma consequência do abuso de direito e, segundo alguns autores, mais especificamente, como uma modalidade do princípio do nemo potest venire contra factum proprium.

Atualmente, de todas as teorias que buscam explicar os fundamentos do abuso de direito no Brasil, a principal é a noção de contrariedade ao fundamento axiológico-normativo do direito exercido, ou seja, o abuso de direito se concretiza quando alguém age de forma aparentemente regular, mas em contradição com os valores do ordenamento jurídico pátrio ${ }^{36}$.

\footnotetext{
${ }^{36}$ SCHREIBER, Anderson. A proibição de comportamento contraditório: tutela da confiança e venire contra factum proprium. Rio de Janeiro: Renovar, 2005. p. 109. Como assevera Danielle Leite, o abuso de direito pode ser considerado o "exercício irregular de um direito subjetivo, que, sob o pretexto de realizá-lo com base na lei, dela se afasta por contrariar os princípios e valores que compõem o ordenamento jurídico,
} 
No CCB aparece claramente a figura do abuso de direito, denotando uma evolução da legislação pátria sobre o assunto. Nesse sentido, o art. 187 do CCB tem a seguinte redação: "também comete ato ilícito o titular de um direito que, ao exercê-lo, excede manifestamente os limites impostos pelo seu fim econômico ou social, pela boa-fé ou pelos bons costumes". Dessa forma, conforme a interpretação literal do dispositivo do art. 187 do CCB, resta necessário, para a configuração do abuso de direito, que o seu titular, ao agir, exceda os limites impostos pelo seu fim econômico ou social, pela boa-fé ou pelos bons costumes.

Conforme bem expôs Anderson Schreiber, a boa-fé pode ser considerada como um dos critérios axiológico-materiais para a verificação do abuso de direito, sendo possível concluir que, no direito positivo brasileiro, a "boa-fé objetiva e o abuso de direito são conceitos autônomos, figuras distintas, mas não mutuamente excludentes, círculos secantes que se combinam naquele campo dos comportamentos tornados inadmissíveis (abusivos) por violação ao critério da boa-fé" ${ }^{\prime 37}$. De qualquer forma, conforme menciona Flávio Tartuce, independentemente de se fundamentar a recepção do duty to mitigate the loss em um dever anexo decorrente da boa-fé objetiva ou por meio de outro fundamento jurídico qualquer, a sua consequência, em caso de descumprimento do preceito, seria a responsabilidade objetiva pela presença do abuso de direito ${ }^{38}$.

contendo em seu interior práticas que contrariam o bom senso e a equidade, não estando apto à produção dos efeitos visados por seu agente, além de sujeitar-se às sanções correspondentes". LEITE, Danielle Moraes. Teorias Consectárias do Abuso de Direito. Rio de Janeiro, 2010. p. 5-6. Disponível em: <http://www.emerj.tjrj.jus. br/paginas/trabalhos_conclusao/1semestre2010/trabalhos_12010/danielleleite. pdf $>$. Acesso em: 4 maio 2013.

${ }^{37}$ SCHREIBER, Anderson. A proibição de comportamento contraditório: tutela da confiança e venire contra factum proprium. Rio de Janeiro: Renovar, 2005. p. 113-114.

${ }^{38}$ TARTUCE, Flávio. A boa-fé objetiva e a mitigação do prejuízo pelo credor: Esboço do tema e primeira abordagem. 2005. p. 2. Disponível em: <www.flaviotartuce.adv.br/ 
Nesse contexto, os doutrinadores começaram a identificar alguns padrões de conduta que podem ser vistos como abuso de direito, criando teorias para descrever tais comportamentos, a fim de que possam ser sancionados para garantir a manutenção da boa-fé objetiva e da segurança jurídica nas relações negociais. Ou melhor, o comportamento contraditório poderia ser visto como uma espécie ou uma categoria do gênero abuso de direito, ou seja, um abuso de direito por violação da boa-fé objetiva.

Uma dessas teorias é o venire contra factum proprium, que é uma das condutas mais características do abuso de direito e que se configura pela existência de um comportamento contraditório, ou seja, a contradição entre uma conduta e o exercício de um direito, afrontando uma expectativa criada pelo seu titular de que aquele direito não mais seria exercido. Existiria uma quebra da confiança contratual, tendo em vista que o titular do direito o exerce após ter criado em sua contraparte a legítima expectativa de que não o faria ${ }^{39}$. A doutrina acabou situando na boa-fé objetiva o seu fundamento normativo, tendo em vista que o venire contra factum proprium acabou se tornando um princípio de "proibição à ruptura da confiança". É a tutela da confiança o fundamento atual do instituto e é por isso que foi aprovado o Enunciado no 362 da IV Jornada de Direito Civil: "a vedação do comportamento contraditório (venire contra factum proprium) funda-se na proteção da confiança, tal como se extrai

\footnotetext{
secoes/artigos/Tartuce_duty.doc $>$. Acesso em: 3 maio 2013. Sobre o assunto, também é importante que se mencione o Enunciado no 37 da I Jornada de Direito Civil, que interpreta o artigo em comento e que tem a seguinte redação: "a responsabilidade civil decorrente do abuso do direito independe de culpa e fundamenta-se somente no critério objetivo-finalístico".

39 Para Anderson Schreiber, podem ser apontados quatro pressupostos para a aplicação da proibição do comportamento contraditório: (i) um fato próprio, uma conduta inicial; (ii) a legítima confiança de outrem na conservação do sentido objetivo dessa conduta; (iii) um comportamento contraditório com este sentido objetivo, e, por isso mesmo, violador da confiança depositada e (iv) um dano ou um potencial de dano decorrente da contradição. SCHREIBER, Anderson. Op. cit., p. 124.
} 
dos arts. 187 e 422 do Código Civil". Ou seja, conforme bem esclarece Anderson Schreiber:

\begin{abstract}
Mais que contra a simples coerência, atenta o venire contra factum proprium à confiança despertada na outra parte, ou em terceiros, de que o sentido objetivo daquele comportamento inicial seria mantido, e não contrariado. Ausentes tais expectativas, ausente tal atentado à legítima confiança capaz de gerar prejuízo a outrem, não há razão para que se imponha a quem quer que seja coerência com um comportamento anterior (grifo nosso) $^{40}$.
\end{abstract}

É importante que se mencione que alguns doutrinadores estudam em separado o abuso de direito do venire contra factum proprium, tratando-os como fundamentos jurídicos diversos de recepção do duty to mitigate the loss no Brasil. Nesse sentido, o duty to mitigate, aparentemente, poderia ser considerado como outra modalidade específica de abuso de direito, diversa do venire contra factum proprium, da supressio, surrectio e tu quoque. Este seria o posicionamento, por exemplo, de Cristiano Chaves de Farias, Nelson Rosenvald e Danielle Moraes Leite ${ }^{41}$. Entretanto, no presente trabalho, tanto o abuso de direito como o venire contra factum proprium serão tratados conjuntamente, pois ambos, ao final, dizem respeito ao comportamento abusivo de uma das partes contratantes, em flagrante desrespeito aos princípios basilares do ordenamento jurídico brasileiro, sobretudo a boa-fé objetiva, mesmo que possam se manifestar de diferentes formas.

${ }^{40}$ SCHREIBER, Anderson. A proibição de comportamento contraditório: tutela da confiança e venire contra factum proprium. Rio de Janeiro: Renovar, 2005. p. 90.

${ }^{41}$ Danielle Moraes Leite considera o duty to mitigate the loss como a modalidade de abuso de direito na qual existe um abuso de direito, por parte do credor, que agrava a sua situação e, indiretamente, a do devedor, ao não tomar as medidas para evitar as próprias perdas, havendo uma verdadeira violação à boa-fé objetiva. LEITE, Danielle Moraes. Teorias Consectárias do Abuso de Direito. Rio de Janeiro, 2010. p. 15. Disponível em: <http://www.emerj.tjrj.jus.br/ paginas/trabalhos conclusao/1semestre2010/trabalhos_12010/danielleleite.pdf $>$. Acesso em: 4 maio 2013. 
Todavia, uma severa crítica pode ser formulada contra a viabilidade desse fundamento jurídico de recepção do duty to mitigate the loss no Brasil, pois a conduta do credor inadimplido, ou a ausência desta, não tem o condão de gerar na outra parte a legítima expectativa ou a confiança de que, em momento posterior, ele não virá a pleitear a indenização pela soma total dos danos sofridos em virtude da quebra contratual, elemento este que seria fundamental para a configuração do venire contra factum proprium. Sendo assim, segundo Daniel Pires Novais Dias:

A aplicação do duty to mitigate sob o fundamento do venire contra factum proprium resta inviável: além de questionável a própria existência de contradição entre essas condutas, manifestamente não há como reconhecer na conduta da vítima de não evitar a produção ou o agravamento do próprio prejuízo, principalmente por omissão, a aptidão para gerar no ofensor a confiança de que ela não mais iria pleitear reparação pela integralidade dos danos sofridos ${ }^{42}$.

Nesse sentido, importante que se mencione um caso em que foi aplicada a doutrina do duty to mitigate the loss e que embasa a crítica feita pelo autor acima citado. No caso, decorrente do Tribunal Regional Federal da 5 $5^{\underline{a}}$ Região, a correntista teve dinheiro indevidamente sacado de sua conta, mas não aceitou a proposta de acordo da instituição financeira para a restituição dos valores devidos e, consequentemente, não foi indenizada pelos danos morais que alegou ter sofrido. Neste caso, como bem relatado por Daniel Pires Novais Dias, "não é plausível defender que o fato de ela não ter aceito a proposta de acordo do banco é contraditório com o ajuizamento de ação indenizatória pelos danos sofridos, ou pior ainda, que aquela

${ }^{42}$ DIAS, Daniel Pires Novaes. O duty to mitigate the loss no Direito civil brasileiro e o encargo de evitar o próprio dano. p. 33. Disponível em: <http://www.revistas.unifacs. br/index.php/redu/article/download/ 1894/1441>. Acesso em: 3 maio 2013. 
negativa é apta a gerar no banco a confiança de que sua cliente lesada não mais exerceria o seu direito à indenização" ${ }^{\prime \prime 3}$.

Sendo assim, parece adequada a crítica formulada pelo mencionado autor, tendo em vista que, como já referido, o venire contra factum proprium caracteriza-se justamente pela contradição entre dois atos subsequentes de um agente e pela quebra da confiança e da expectativa que foram depositadas no outro contratante, características estas que não estão presentes na doutrina do duty to mitigate the loss, até mesmo porque não seria correto pensar que uma eventual omissão do credor geraria a legítima expectativa de que este, em momento futuro, não pleitearia a cobrança total das somas, ou a indenização que acredita lhe ser devida.

\subsubsection{O Encargo de Evitar o Próprio Dano}

O último fundamento jurídico que será estudado no presente trabalho e que trata da recepção do duty to mitigate the loss no âmbito do Direito Contratual Brasileiro foi preconizado pelo jurista António Menezes Cordeiro, que o nomeou de encargo ou ônus material do credor de evitar o próprio dano, figura esta já utilizada no Direito Civil Português para incorporar a Obligenheit do Direito Alemão.

A explicação para esse instituto, segundo o mencionado autor, é a de que se trata de um dever de comportamento, ao menos estruturalmente, dirigido também ao interesse de outras pessoas, mas que se diferencia por não poder ser exigido o seu cumprimento. E, face ao seu não cumprimento, o sistema jurídico reage apenas com sanções mais fracas, relacionadas com a diminuição da posição jurídica da própria pessoa ligada

${ }^{43}$ Ibidem, p. 32. O caso em comento é do TRF5. $3^{\mathrm{a}}$ T., AC 358434/PE, Rel. Des. Leonardo Resende Martins, j. 03/09/2009, DJ 18/09/2009. 
ao encargo, ou seja, o cumprimento do encargo serve apenas para a aquisição ou para a conservação de uma determinada vantagem jurídica ${ }^{44}$. Nas palavras do autor português, "o encargo corresponde estruturalmente a um dever; segue, no entanto, um regime particular: é um dever de comportamento que funcionando embora também no interesse de outras pessoas, não possa, por estas, ser exigido no seu cumprimento" ${ }^{\prime \prime 4}$.

Não se está diante de um dever propriamente dito, pois ele não pode ser exigido por terceiros, mas caso o credor não aja com fins a mitigar as próprias perdas, perderá o direito de ser indenizado pelo montante dos danos que poderia ter evitado. Nesse sentido, conforme Daniel Pires Novais Dias:

Como visto, não há que se falar em dever genérico ou mesmo acessório de evitar danos a si porque esta conduta por parte do lesado não é exigivel: primeiro que ela tem por finalidade a proteção principalmente dos seus próprios interesses, e, apenas reflexamente, os do responsável, e, segundo, que a consequência jurídica pela sua não adoção é a perda, total ou parcial, do direito à indenização pelos danos que poderia ter evitado sofrer ${ }^{46}$.

A consequência do descumprimento desse encargo seria justamente a perda, total ou parcial, do direito à indenização pelo dano que poderia ter sido evitado, caso o credor lesado tivesse tomado as medidas razoáveis para tanto, no caso concreto. Entretanto, caso cumprido o encargo, à semelhança do que ocorre na CISG, a parte teria direito a reclamar o reembolso pelos gastos razoáveis despendidos ao buscar mitigar as próprias perdas. Ou seja, a conduta da parte lesada, ao

\footnotetext{
${ }^{44}$ Ibidem, p. 34.

${ }^{45}$ CORDEIRO, António Menezes. Tratado de Direito Civil Português. I - Parte Geral Tomo I. 3. ed. Coimbra: Almedina, 2005. p. 358-360.

${ }^{46}$ DIAS, Daniel Pires Novaes. O duty to mitigate the loss no Direito civil brasileiro e o encargo de evitar o próprio dano. p. 35-36. Disponível em: <http://www.revistas. unifacs.br/index.php/redu/article/download/ 1894/1441>. Acesso em: 3 maio 2013.
} 
buscar cumprir o encargo de evitar ou minimizar os próprios danos, deve se pautar pelo critério da razoabilidade, diante das circunstâncias específicas do caso concreto. Se o credor lesado deve se pautar pela proporção entre as despesas feitas para cumprir o encargo e a utilidade que delas se pretende auferir, seria irrazoável "o gasto que se mostrar superior ao prejuízo que se queira evitar" ${ }^{47 "}$.

Nesse sentido, para Daniel Pires Novais Dias, o encargo de evitar o próprio dano deve ser reconhecido no Direito Civil Brasileiro porque ele é "a figura dogmática mais adequada para suprir a lacuna [...] acerca da ausência de prescrição jurídica titularizada pela vítima em evitar a produção ou agravamento de danos a si". Para o autor, essa figura seria a que "melhor se compatibiliza com a situação jurídica do credor inadimplido ou da vítima de dano extracontratual em face da produção ou agravamento do próprio prejuízo" ${ }^{\prime 48}$.

\subsection{Sugestão para a Interpretação do Dispositivo da CISG no Brasil}

Independentemente da conclusão a que se chegue, pode-se dizer que o Direito Civil Brasileiro vem experimentando um fenômeno de teorização e aplicação judicial do duty to mitigate the loss. Até o momento, como já examinado, muitas teorias foram

\footnotetext{
${ }^{47}$ Ibidem, p. 37. Como exemplo de medida irrazoável, o autor cita a conduta de proprietário de veículo comercial que sofreu acidente e que não aluga outro veículo, sendo este desembolso tolerável, implicando perdas imediatas muito maiores à empresa; e, como razoável, a recusa de uma vítima de lesão corporal a se submeter à cirurgia, ou a qualquer outro tratamento, apto a diminuir a extensão da lesão, desde que tal envolva risco para a sua vida.

${ }^{48}$ DIAS, Daniel Pires Novaes. O duty to mitigate the loss no Direito civil brasileiro e o encargo de evitar o próprio dano. p. 35. Disponível em: $<\mathrm{http}$ ://www.revistas.unifacs. br/index.php/redu/article/download/ 1894/1441>. Acesso em: 3 maio 2013.
} 
desenvolvidas no bojo do direito pátrio para buscar justificar a incorporação desse instituto. Aliás, é de nossa opinião que, muitas vezes, o excesso de fundamentos jurídicos utilizados para a recepção de instituto alienígena acaba por causar mais dúvidas e incertezas do que segurança jurídica entre os advogados, magistrados e aplicadores do direito em geral.

A forma mais adequada de interpretação e de recepção dessa teoria, segundo o entendimento que aqui se segue, seria a de, com base na boa-fé objetiva, entender o dispositivo segundo as premissas que lhe foram delineadas pela doutrina estrangeira que, há anos, estuda o art. 77 da CISG. Isso porque, ademais de o STJ ter um entendimento consolidado a respeito de a boa-fé objetiva ser o fundamento mais adequado para a utilização do duty to mitigate the loss no Brasil, como visto pela análise do REsp n $n^{\circ} 758.518 / \mathrm{PR}$, a boa-fé também é um dos princípios norteadores da CISG, como exposto em seu art. $7^{\circ}{ }^{49}$.

Assim, à luz da boa-fé objetiva, quer em sua função criadora de deveres anexos, quer em sua função interpretativa, o duty to mitigate the loss deve ser interpretado, conforme preconizado pelo art. 77 da CISG, como um encargo, pois dever, ao menos na língua portuguesa e em nosso vocabulário jurídico, significa a possibilidade de sua exigência, o que não ocorre in casu. Ou seja, um encargo que pesa sobre os ombros da parte lesada ou do credor inadimplido de tomar todas as medidas razoáveis, medidas estas que seriam tomadas por pessoas com normal diligência e em situação semelhante à do credor, tendo em vista as circunstâncias do caso concreto para evitar (anticipatory breach) ou mitigar os danos advindos do inadimplemento contratual.

\footnotetext{
${ }^{49}$ Em sua tradução para o português, o referido artigo tem a seguinte redação: "Artigo 7(1): na interpretação desta Convenção ter-se-ão em conta seu caráter internacional e a necessidade de promover a uniformidade de sua aplicação, bem como de assegurar o respeito à boa-fé no comércio internacional" (grifo nosso).
} 
E, no que tange às consequências ou às sanções advindas do incumprimento desse encargo, como bem aludido pela eminente jurista Véra Fradera, duas opções se abrem em face do credor: a) se ele tomou as medidas razoáveis, conforme as circunstâncias do caso, para mitigar as próprias perdas, ele terá direito ao reembolso dessas despesas, independentemente da natureza que se lhe atribui; e b) se ele não tomou as medidas necessárias e razoáveis para minimizar suas perdas, isso geraria o pagamento de perdas e danos ou, ao menos, a redução da indenização para que dela se retire o montante das perdas que o credor poderia, razoavelmente, ter evitado ${ }^{50}$.

\section{Considerações Finais}

O fato de que a CISG passou a valer a partir de abril de 2014 no ordenamento jurídico pátrio e de que, com a sua adesão, ocorrerão diversas modificações no que tange à regulação dos contratos internacionais de compra e venda de mercadorias faz com que se torne urgente a necessidade de os estudiosos do Direito Brasileiro debruçarem-se sobre o entendimento dos dispositivos da Convenção, tendo em vista que a CISG passará a ser a legislação padrão brasileira aplicável aos contratos internacionais de compra e venda de mercadorias.

O presente trabalho buscou compreender um dos dispositivos da Convenção, que traz uma teoria que, até pouco tempo atrás, era desconhecida e inaplicada pelos juristas brasileiros, a saber, o art. 77 da CISG, que trata da doutrina do duty to mitigate the loss, traduzida para o português como o dever do credor de mitigar as próprias perdas.

${ }^{50}$ FRADERA, Véra Maria Jacob de. Pode o credor ser instado a diminuir o próprio prejuízo? Revista trimestral de direito civil, Rio de Janeiro: Padma, v. 19, jul./set. 2004. p. 118-119. 
Na Parte I do presente trabalho, buscou-se compreender como a doutrina estrangeira tem interpretado o dispositivo do art. 77 da CISG. Nesse sentido, verificou-se que uma parte lesada por uma perda decorrente de um inadimplemento contratual, mesmo antes de a prestação da outra parte ser devida no tempo (anticipatory breach), não tem a permissão de esperar passivamente pela ocorrência ou aumento do dano para então ingressar com uma ação indenizatória. É necessário, dessa forma, um comportamento ativo dessa parte, sendo que as medidas que ela deve adotar para evitar as próprias perdas devem seguir o critério da razoabilidade (reasonableness), pois são esperadas do credor inadimplido apenas aquelas medidas consideradas razoáveis, segundo as circunstâncias do caso (measures as are reasonable in the circumstances).

A segunda parte do art. 77 da CISG traz a consequência em caso de ausência de mitigação das próprias perdas pela parte lesada da relação contratual; ou seja, caso não sejam adotadas as medidas razoáveis para mitigar as próprias perdas, a parte causadora da quebra contratual poderá reivindicar a redução na indenização das perdas e danos, no montante da perda que deveria ter sido mitigada pela parte lesada.

Já na Parte II do trabalho, buscou-se responder à seguinte pergunta: qual seria a forma mais adequada de interpretação do duty to mitigate the loss no Direito Brasileiro, ou, em outras palavras, qual a forma de interpretação mais consectária com o disposto na CISG? Para a consecução desse objetivo, analisaram-se as teorias utilizadas, até o momento, para incorporar essa doutrina no Brasil, com destaque para: a) a boa-fé objetiva, b) o abuso de direito e o venire contra factum proprium e c) o encargo de evitar o próprio dano, bem como alguns exemplos do uso dessas teorias pela jurisprudência pátria.

O primeiro fundamento jurídico que trata da recepção do duty to mitigate the loss percebe o conceito como um dever 
acessório, advindo da boa-fé objetiva, tendo em vista que o legislador civil brasileiro adota uma concepção cooperativa do contrato. $\mathrm{O}$ duty to mitigate the loss representaria o dever de colaboração que deve haver entre as partes contratantes, em todas as fases contratuais. Independentemente de se achar adequada a recepção do instituto por meio da quebra de um dever anexo advindo da boa-fé objetiva, o fato é que foi este o fundamento jurídico escolhido pelo STJ para recepcioná-lo no Brasil, do que se conclui que a compreensão do duty to mitigate the loss como um dever anexo advindo da boa-fé objetiva é o principal fundamento de recepção dessa teoria pela doutrina e pela jurisprudência brasileiras até o momento.

O segundo fundamento jurídico a respeito da recepção do duty to mitigate the loss no Brasil percebe o conceito como uma consequência do abuso de direito e, segundo alguns autores, mais especificamente, como uma modalidade do princípio nemo potest venire contra factum proprium, que é uma das condutas mais características do abuso de direito. Ele se configura pela existência de um comportamento contraditório, ou seja, a contradição entre uma conduta e o exercício de um direito, afrontando uma expectativa criada pelo seu titular de que aquele direito não mais seria exercido. Todavia, uma severa crítica pode ser formulada contra a viabilidade desse fundamento jurídico de recepção do duty to mitigate the loss no Brasil, pois a conduta do credor inadimplido, ou a ausência desta, não tem o condão de gerar na outra parte a legítima expectativa de que, em momento posterior, ele não virá a pleitear a indenização pela soma total dos danos sofridos em virtude da quebra contratual, elemento este que seria fundamental para a configuração do venire contra factum proprium.

O último fundamento jurídico de recepção do duty to mitigate the loss estudado no presente trabalho é o chamado encargo ou ônus material do credor de evitar o próprio dano, 
A Interpretação do Duty to Mitigate the Loss...

figura esta utilizada pelo Direito Civil Português, com base na doutrina de António Menezes Cordeiro. A explicação para esse instituto é a de que se trata de um dever de comportamento, dirigido também no interesse de outras pessoas, mas que se diferencia por não poder ser exigido o seu cumprimento por elas. Não se está diante de um dever propriamente dito, pois ele não pode ser exigido por terceiros, mas caso o credor não aja com fins a mitigar as próprias perdas, perderá o direito de ser indenizado pelo montante dos danos que poderia ter evitado.

De todo o dito, segundo a concepção que aqui se adota, a forma mais adequada de interpretação e de recepção do duty to mitigate seria a de, com base na boa-fé objetiva, entender o dispositivo segundo as premissas que lhe foram delineadas pela doutrina estrangeira que, há anos, estuda o art. 77 da CISG. Isso porque, ademais de o STJ ter um entendimento consolidado a respeito de a boa-fé objetiva ser o fundamento mais adequado para a utilização do duty to mitigate the loss no Brasil, a boa-fé também é um dos princípios norteadores da CISG, segundo o seu art. 7º . Assim, à luz da boa-fé objetiva, o duty to mitigate the loss deve ser interpretado, conforme preconizado pelo art. 77 da CISG, como um encargo que pesa sobre os ombros do credor inadimplido de tomar todas as medidas razoáveis, tendo em vista as circunstâncias do caso concreto, para evitar (anticipatory breach) ou mitigar os danos advindos do inadimplemento contratual. E, no que tange às consequências ou às sanções advindas do incumprimento desse encargo, como bem aludido por Véra Fradera, duas opções se abrem em face do credor: a) se ele tomou as medidas razoáveis, conforme as circunstâncias do caso, para mitigar as próprias perdas, ele terá direito ao reembolso dessas despesas, independentemente da natureza que se lhe atribui; e b) se ele não tomou as medidas necessárias e razoáveis para minimizar suas perdas, isso geraria 
o pagamento de perdas e danos ou, ao menos, a redução da indenização para que dela se retire o montante das perdas que o credor poderia, razoavelmente, ter evitado.

\section{Referências}

ALMEIDA PRADO, Mauricio; BUENO DE MIRANDA, Sílvia Julio; ALVES, Rafael Francisco; PEARSON, Marcus. Harmonising with CISG. Disponível em: <http://www.latinlawyer.com/news/article/44128/ harmonising-cisg/>. Acesso em: 19 abr. 2013.

ARAUJO, Nadia de; SPITZ, Lidia. O que muda com a Convenção de Viena. Disponível em: <http://www.valor.com.br/brasil/2928448/ o-que-muda-com-convencao-de-viena>. Acesso em: 17 abr. 2013.

BASSO, Maristela. Curso de direito internacional privado. 2. ed. São Paulo: Atlas, 2011.

BIANCA, Cesare Massimo; BONELL, Michael Joachim. Commentary on the International Sales Law: the 1980 Vienna Sales Convention. Milan: Giuffrè, 1987. Disponível em: <http://www.cisg.law.pace.edu/ cisg/principles/uni77.html>. Acesso em: 23 abr. 2013.

CHENGWEI, Liu. Remedies for Non-performance: Perspectives from CISG, UNIDROIT Principles \& PECL. 2003. Disponível em: <http://www.cisg. law.pace.edu/cisg/biblio/chengwei-77.html>. Acesso em: 24 abr. 2013.

CORDEIRO, António Menezes. Tratado de Direito Civil Português: I - Parte Geral - Tomo I. 3. ed. Coimbra: Almedina, 2005.

DIAS, Daniel Pires Novaes. O duty to mitigate the loss no Direito civil brasileiro e o encargo de evitar o próprio dano. Disponível em: $<\mathrm{http}: /$ www.revistas.unifacs.br/index.php/redu/article/download/1894/1441>. Acesso em: 3 maio 2013.

DJAKHONGIR, Saidov. Methods of limiting damages under the Vienna Convention on Contracts for the International Sale of Goods. Pace International Law Review, v. 14, issue 2, p. 307-377, fall 2002.

FARIAS, Cristiano Chaves de; ROSENVALD, Nelson. Direito civil: teoria geral. Rio de Janeiro: Lumen Juris, 2009. 
A Interpretação do Duty to Mitigate the Loss...

FRADERA, Véra Maria Jacob de. Pode o credor ser instado a diminuir o próprio prejuízo? Revista trimestral de direito civil, Rio de Janeiro: Padma, v. 19, p. 109-119, jul./set. 2004.

GAMA JUNIOR, Lauro. Contratos internacionais à luz dos princípios do UNIDROIT 2004: soft law, arbitragem e jurisdição. Rio de Janeiro: Renovar, 2006.

GOETZ, Charles J.; SCOTT, Robert E. The mitigation principle: toward a general theory of contractual obligation. Virginia Law Review, v. 69, p. 967-1024, Sept. 1983.

GOLDMAN, Berthold. The applicable law: general principles of law the lex mercatoria. In: LEW, Julian D. M. (Ed.). Contemporary Problems in International Arbitration. London: Martinus Nijhoff Publishers, 1987.

GOTANDA, JOHN Y. Awarding damages under the United Nations Convention on the International Sale of Goods: a matter of interpretation. Georgetown Journal of International Law, v. 37, p. 95-140, fall 2005.

HONNOLD, John. Uniform Law for International Sales under the 1980 United Nations Convention. 3. ed. The Hague: Kluwer Law International, 1999. Disponível em: <http://www.cisg.law.pace.edu/cisg/biblio/honnold.html>. Acesso em: 24 abr. 2013.

KNAPP, Victor. Bianca-Bonell Commentary on the International Sales Law. Milan: Giuffrè, 1987. p. 559-567. Disponível em: <http://www.cisg. law.pace.edu/cisg/biblio/knapp-bb77.html>. Acesso em: 26 abr. 2013.

LEITE, Gisele. Roteiro sobre o princípio da boa-fé objetiva. Jus Vigilantibus, Vitória, set. 2006. Disponível em: <http://jusvi.com/artigos/22364>. Acesso em: 3 maio 2013.

LEITE, Danielle Moraes. Teorias Consectárias do Abuso de Direito. Rio de Janeiro, 2010. Disponível em: <http://www.emerj.tjrj.jus.br/paginas/ trabalhos_conclusao/1semestre2010/trabalhos_12010/danielleleite. pdf $>$. Acesso em: 4 maio 2013.

LÔBO, Paulo Luiz Netto. Deveres gerais de conduta nas obrigações civis. Jus Navigandi, Teresina, ano 10, n. 711, 16 jun. 2005. Disponível em: <http://jus.com.br/revista/texto/6903>. Acesso em: 12 maio 2013.

LOOKOFSKY, Joseph. The 1980 United Nations Convention on Contracts for the International Sale of Goods. Disponível em: $<$ http://www.cisg.law. pace.edu/cisg/biblio/loo77.html>. Acesso em: 24 abr. 2013. 
MARTINS-COSTA, Judith. A Boa-fé no Direito Privado: sistema e tópica no processo obrigacional. 1. ed. São Paulo: Editora Revista dos Tribunais, 2000.

. O Direito Privado como um "sistema em construção": as cláusulas gerais no Projeto do Código Civil Brasileiro. Jus Navigandi, Teresina, ano 5, n. 41, 1 maio 2000. Disponível em: <http://jus.com.br/ revista/texto/513>. Acesso em: 12 maio 2013.

OPIE, Elizabeth. Commentary on the manner in which the UNIDROIT Principles may be used to interpret or supplement Article 77 of the CISG. 2005. Disponível em: $<$ http://www.cisg.law.pace.edu/cisg/principles/ uni77.html>. Acesso em: 23 abr. 2013.

PAUTREMAT, Solène Le. Mitigation of Damage: A French Perspective. International \& Comparative Law Quarterly, v. 55, p. 205-217, 2006.

SCHREIBER, Anderson. A proibição de comportamento contraditório: tutela da confiança e venire contra factum proprium. Rio de Janeiro: Renovar, 2005.

SCHWENZER, Ingeborg. Regional and Global Unification of Sales Law. European Journal of Law Reform, n. 13, p. 370-379, 2011.

. Commentary on the UN Convention on the International Sale of Goods (CISG). 3. ed. New York: Oxford University Press, 2010.

. The CISG: Successes and Pitfalls. Disponível em: $<\mathrm{http}: / /$ www.cisg.law.pace.edu/cisg/biblio/schwenzer-hachem.html>. Acesso em: 12 maio 2013.

SUTTON, Jeffrey S. Measuring Damages Under the United Nations Convention on the International Sale of Goods. Ohio State Law Journal, v. 50, p. 737-752, 1989.

TARTUCE, Flávio. A boa-fé objetiva e a mitigação do prejuízo pelo credor: Esboço do tema e primeira abordagem. 2005. Disponível em: $<w w w$. flaviotartuce.adv.br/secoes/artigos/Tartuce_duty.doc $>$. Acesso em: 3 maio 2013.

. Direito civil, v. 3: teoria geral dos contratos e contratos em espécie. 8. ed. São Paulo: Método, 2013.

. Manual de direito civil: volume único. 2. ed. São Paulo: Método, 2012. 
. A boa-fé objetiva e os amendoins: um ensaio sobre a vedação do comportamento contraditório (venire contra factum proprium non potest). Material da $2^{a}$ Aula da Disciplina Direito Civil, Teoria Geral dos Contratos, ministrada no Curso de Pós-Graduação Lato Sensu em Direito Civil, Negocial e Imobiliário - Universidade Anhanguera Uniderp - Rede LFG.

VISCASILLAS, Pilar Perales. IB, 2001. Disponível em: <http://www.cisg. law.pace.edu/cisg/biblio/perales1-77.html>. Acesso em: 26 abr. 2013.

ZIEGEL, Jacob S. The Remedial Provisions in the Vienna Sales Convention: Some Common Law Perspectives. Disponível em: $<$ http://www.cisg. law.pace.edu/cisg/biblio/ziegel6.html>. Acesso em: 12 maio 2013.

Submissão: 29/09/2013

Aceito para Publicação: 24/12/2013 


\section{Notícias}

A presente seção inaugura um novo espaço da revista Cadernos do Programa de Pós-Graduação em Direito PPGDir.l UFRGS, continuando seu processo de expansão de conteúdo. A incorporação é permanente, e continuará a ser elaborada nas próximas edições da revista.

A seção foi criada para apresentar os principais acontecimentos, as homenagens, os prêmios, as notícias e as posições ocupadas pelos integrantes do Programa de Pós-Graduação em Direito. Ela é elaborada com notícias escolhidas pelo Conselho Editorial a partir do recebimento de dados de professores, alunos, acadêmicos ou interessados em colaborar com o espaço. É, portanto, um local aberto a todos, para que possam trazer ao conhecido público as conquistas alcançadas pelo Programa.

Além das notícias relacionadas aos professores, a seção também apresenta fatos de especial relevância para a Universidade, para a faculdade de Direito e para o Programa de Pós-Graduação. Por isso, a atualização do conceito do Programa e a nova avaliação da UFRGS como melhor universidade do Brasil encontram espaço nesta edição. Assim, a estrutura que circunda o Programa e permite seu patamar de excelência será lembrada em seus principais acontecimentos.

O objetivo da seção é demonstrar o impacto do Programa e apresentar à comunidade os principais resultados dos esforços empreendidos. É uma seção ainda em desenvolvimento que, com o tempo, tornar-se-á um veículo de comunicação e arquivo dos eventos ligados aos Programa de Pós-Graduação e seus membros. 


\section{Condecoração Bundesverdienstkreuz, Ordem da Cruz ao Mérito, Concedida à Professora Claudia Lima Marques}

Na noite dessa quarta-feira, 27, houve a solenidade de entrega da condecoração Bundesverdienstkreuz - Ordem da Cruz ao Mérito - à jurista e professora da UFRGS Claudia Lima Marques. A cerimônia ocorreu no Salão Nobre da Faculdade de Direito, com as presenças do reitor Carlos Alexandre Netto, do cônsul-geral da República Federal da Alemanha, Hans-Joseph Over, e do diretor da Faculdade de Direito, Danilo Knijnik.

A medalha, assinada pelo presidente da Alemanha, é concedida a cidadãos do povo, por serviços extraordinários nas áreas da política, da economia, da cultura, da arte ou do trabalho voluntário. Ao escolher a professora Claudia, o governo alemão reconhece seus esforços a favor do diálogo Brasil-Alemanha e da divulgação da ciência alemã no Brasil e na América Latina.

O reitor Carlos Alexandre Netto saudou os presentes, parabenizando a homenageada. "A condecoração da professora Claudia é uma honra para toda a comunidade acadêmica da UFRGS, que mantém mais de vinte acordos de cooperação com instituições alemãs, grandes parceiras acadêmicas da nossa Universidade", salientou Netto.

A condecorada, que recebeu das mãos do cônsul-geral a medalha, agradeceu a todos que cruzaram seu caminho e, de alguma forma, ajudaram-na a alcançar posição de destaque na área do Direito. "É com grande alegria que recebo esta medalha, concebida especialmente para distinguir pessoas do povo por suas contribuições à sociedade. Meu mérito é o 
de tentar utilizar o que aprendi para servir aos outros, com a ciência do direito, e ao meu país", completou.

Ordem da Cruz ao Mérito - A Bundesverdienstkreuz é a única comenda alemã, criada em 1951 pelo Presidente Theodor Heuss e pelo Primeiro-Ministro Konrad Adenauer, e atualmente é dividida em três classes e oito graus. O grau recebido pela jurista é da classe internacional de Cavaleiro ("Ritter").

$<$ http://www.ufrgs.br/ufrgs/noticias/claudia-marques-recebe-condecoracao-ordemda-cruz-ao-merito-1>

\section{Projeto A Proteção Nacional e Internacional dos Consumidores premiado no $1^{\circ}$ Prêmio IBE de Incentivo a Projetos Colaborativos Brasil Europa}

11 de setembro de 2013

Os vencedores do $1^{\circ}$ Prêmio IBE de Incentivo a Projetos Colaborativos Brasil Europa apresentaram seus trabalhos na sexta-feira, 11 de setembro, durante o encerramento do $3^{-}$ Congresso Anual do IBE Inovação, Cultura e Sustentabilidade Desafios para o Brasil e Europa, que ocorreu na Universidade Federal de Santa Catarina (UFSC).

O prêmio, de caráter acadêmico, é destinado ao melhor projeto em andamento que mantenha acordos de cooperação entre universidades brasileiras e europeias. O IBE recebeu 23 inscrições de pesquisadores de diferentes áreas de todo o País. O primeiro lugar, que deu ao vencedor passagem e hospedagem para visitar a instituição parceira na Europa, ficou com o projeto Produção de baixo custo e confiável de compósitos de matriz cerâmica oxida. 
O projeto da área de Engenharia Química é de responsabilidade do pesquisador Dachamir Hotza, da UFSC, em parceria com a Technische Universität Hamburg-Harburg (TUHH), da Alemanha, e tem como objetivo geral a capacitação de recursos humanos, a pesquisa cooperativa e a aplicação dos resultados no setor produtivo na área de materiais compósitos, envolvendo temas relativos ao desenvolvimento de tecnologias inovadoras aplicadas ao processamento cerâmico.

O segundo lugar ficou com o projeto A Proteção Nacional e Internacional dos Consumidores (em especial dos Consumidores dos Serviços Bancários e Financeiros nos Processos de Integração Mercosul e União Europeia), da pesquisadora Claudia Lima Marques (UFRGS) com a Justus-Liebig Universität Gießen, da Alemanha. Na área do Direito, o projeto analisa a proteção internacional e nacional dos consumidores no Brasil e na Alemanha, na União Europeia e no Mercosul, em especial quanto aos serviços bancários e financeiros (mercado de capitais inclusive), de forma a contribuir para o desenvolvimento do Brasil, seu sistema bancário e de bolsa e a melhoria do currículo na UFRGS, que atualmente inclui Direito do Consumidor Nacional e Internacional.

Em terceiro lugar, ficou o projeto Desenvolvimento e Aplicações de Metaheurísticas para Planejamento de Cadeias de Suprimento, dos pesquisadores Guilherme de Alencar Barreto (UFC) e Fernando Buarque de Lima Neto (UPE) com a WestfälischeWilhelms-Universität Münster (WWU), da Alemanha.

\section{Adaptado de:}

$<$ http://www.ibe.usp.br/index.php/pt/noticias/355-vencedores-do-1-premio-ibeapresentam-seus-projetos-no-encerramento-do-3-congresso-anual> 


\section{Prêmio Melhor Livro de Direito na 55. a edição do Prêmio Jabuti para professores Claudia Lima Marques e Bruno Miragem}

17 de outubro de 2013

No dia 17 de outubro, a Câmara Brasileira do Livro divulgou os ganhadores do Prêmio Jabuti, o mais importante Prêmio na área editorial brasileira. Nesta 55. a edição do Prêmio Jabuti, foram feitas 2.107 inscrições, divididas em 27 categorias, e, entre elas, a categoria Melhor Livro de Direito. Segundo o regulamento, em cada categoria são indicadas dez obras como finalistas do Prêmio, dentre as quais três são escolhidas como as premiadas.

Dentre os premiados na categoria Direito, encontram-se os professores da Faculdade de Direito da Universidade Federal do Rio Grande do Sul Claudia Lima Marques e Bruno Miragem, que ficaram em $3^{\circ}$ lugar, com a obra $O$ novo Direito Privado $e$ a proteção dos vulneráveis, publicada pela Editora Thomson Reuters/Revista dos Tribunais, São Paulo.

Um dos editores da Revista dos Tribunais, Henderson Fürst, expressou a alegria e a honra de toda a equipe editorial pelo Prêmio que, uma vez mais, contemplou obras daquela tradicional casa editorial. Henderson ainda relembrou que os originais da obra premiada lhe foram entregues durante a cerimônia que celebrou os cem anos da Editora Revista dos Tribunais, como um presente dos professores da UFRGS à Editora.

Destacou ainda que a professora Claudia Lima Marques conseguiu um feito raro: teve duas obras indicadas na lista dos dez finalistas. Além da obra premiada em coautoria com Bruno Miragem, também a obra Diálogo das fontes, sob sua 
coordenação, com trabalhos dos colegas e alunos do Programa de Pós-Graduação do Direito da UFRGS, foi indicada ao Prêmio de Melhor Livro de Direito 2013.

O Prêmio Jabuti, em seus 55 anos de existência, é o mais tradicional e prestigiado prêmio literário do país e dá aos vencedores o lastro da comunidade intelectual brasileira, além do reconhecimento a todos aqueles que trabalham com o livro. A entrega da premiação ocorreu no dia 13 de novembro, na Sala São Paulo, e os dois professores premiados da UFRGS, Claudia Lima Marques e Bruno Miragem, estiveram presentes.

Adaptado de:

$<$ http://www.ufrgs.br/direito/?p=2246>

\section{Professor José Alcebiades de Oliveira Junior eleito Vice-Presidente Sul do CONPEDI - 2013-2015}

16 de novembro de 2013

Foi realizada a eleição dos novos integrantes da Diretoria e do Conselho Fiscal do Conselho Nacional de Pesquisa e PósGraduação em Direito - CONPEDI para a gestão 2013/2015, em 16 de novembro de 2013, último dia do XXII Congresso Nacional do CONPEDI/UNINOVE, ocorrido no Renaissance São Paulo Hotel. A escolha ocorreu por aclamação durante a Assembleia Geral, conforme prevê o estatuto do Conselho. O representante do Programa de Pós-Graduação em Direito da UFRGS no Conselho foi o professor José Alcebiades de Oliveira Junior, eleito Vice-Presidente Sul. 
Foram eleitos para a Diretoria:

Presidente: Prof. Dr. Raymundo Juliano Feitosa (UFRN)

Secretário executivo: Prof. Dr. Orides Mezzaroba (UFSC)

Secretário adjunto: Prof. Dr. Felipe Chiarello de Souza Pinto (Mackenzie)

Vice-Presidente Sul: Prof. Dr. José Alcebiades de Oliveira Junior (UFRGS)

Vice-Presidente Sudoeste: Prof. Dr. João Marcelo de Lima Assafim (UCAM)

Vice-Presidente Nordeste: Profa. Dra. Gina Marcílio Vidal Pompeu (UNIFOR)

Vice-Presidente Norte/Centro: Profa. Dra. Julia Maurmann Ximenes (IDP)

E, para o Conselho Fiscal:

Prof. Dr. José Querino Tavares Neto (UFG /PUC PR)

Prof. Dr. Roberto Correia da Silva Gomes Caldas (PUC SP)

Profa. Dra. Samyra Haydêe Dal Farra Naspolini Sanches (UNINOVE)

Prof. Dr. Lucas Gonçalves da Silva (UFS) (suplente) Prof. Dr. Paulo Roberto Lyrio Pimenta (UFBA) (suplente)

Adaptado de:

<http://www.conpedi.org.br/noticias.php?id=1212> 


\section{UFRGS avaliada Melhor Faculdade de Direito do Brasil pelo segundo ano consecutivo}

6 de dezembro de 2013

A UFRGS é a melhor universidade do Brasil na avaliação de indicadores de qualidade da Educação Superior, segundo resultado divulgado no dia 6 de dezembro pelo MEC. A Universidade manteve a nota da avaliação anterior, de 4,28 para o Índice Geral de Cursos, que corresponde ao conceito 5, valor máximo do Índice calculado pelo Instituto Nacional de Estudos e Pesquisas Educacionais Anísio Teixeira (Inep/MEC). A classificação envolveu 2.171 instituições de ensino superior entre universidades, faculdades e institutos públicos e privados.

O cálculo do IGC inclui a média ponderada dos Conceitos Preliminares de Curso (CPC) e os conceitos da Coordenação de Aperfeiçoamento de Pessoal de Nível Superior (Capes), responsável por avaliar os programas de pós-graduação das instituições. Já o CPC avalia o rendimento dos alunos no Exame Nacional de Desempenho dos Estudantes - Enade (55\% do total da nota), a infraestrutura (15\%) e o corpo docente $(30 \%)$.

A UFRGS obteve ainda índices de CPC elevados, 4 e 5, nas nove graduações em que foi avaliada em 2012. Cinco cursos da Universidade estão classificados com conceito 5: Administração, Design, Jornalismo, Publicidade e Propaganda e Relações Internacionais. A avaliação mostrou também bons índices alcançados pelos cursos de Ciências Econômicas, Psicologia, Direito e Ciências Contábeis, que atingiram conceito 4 .

O Reitor divide com toda a comunidade acadêmica o mérito de fazer da UFRGS a Universidade de melhor qualidade no Brasil. “É com muita alegria e orgulho que recebemos, pelo segundo ano consecutivo, a maior nota entre as universidades brasileiras em avaliação feita pelo MEC. Esse resultado se 
reflete em todas áreas e só reforça o acerto na condução das políticas acadêmicas e inclusivas até agora implementadas. A comunidade da UFRGS está, novamente, de parabéns."

\section{Programa de Pós-Graduação com Conceito 5 na Avaliação Trienal da CAPES 2013 - Mensagem do Reitor}

Mensagem do Reitor ao Programa de Pós-Graduação em Direito da UFRGS:

Vimos parabenizar a comunidade da Faculdade de Direito pelo ótimo desempenho dos Programas de Pós-Graduação na avaliação trienal 2013, recentemente divulgado pela CAPES.

As conquistas do conceito 5 pelo Programa em Direito expressam o talento acadêmico, a dedicação e o esforço coletivo de professores e estudantes, bem como a competente gestão dos coordenadores e o apoio dos servidores técnico-administrativos. Muito obrigado!

A UFRGS vem avançando significativamente na excelência da pós-graduação e o Programa da Faculdade de Direito é motivo de especial satisfação e orgulho. Contem com o apoio da Administração Central para continuar nesta bela caminhada.

Por favor, transmita à comunidade nossos cumprimentos e agradecimento.

Carlos Alexandre Netto, reitor e Rui Vicente Oppermann, vice-reitor.

Adaptado de:

$<$ http://www.ufrgs.br/ppgd/index/vdest/975/> 


\title{
Defesas de Dissertações e Teses de 2013
}

\author{
Dissertações de Mestrado 2013
}

\section{A Constituição de Cádiz e sua Influência no Brasil}

Wagner Silveira Feloniuk Data de defesa: 01/03/2013

Resumo: Dissertação a respeito da Constituição de Cádiz de 1812 e sua influência sobre o constitucionalismo brasileiro. Contextualiza historicamente o texto gaditano como uma consequência da conjuntura histórica da Espanha na Europa do início do século XVIII, sob o domínio de Napoleão. Após, apresenta as normas principais da Constituição, sua repercussão na sociedade e o estágio de avanço frente aos outros textos liberais da época. Na segunda parte, passa ao estudo da história do Brasil, concentrando-se nos anos de 1820 a 1824, quando a Constituição de Cádiz influiu sobre o início da história constitucional. Além de ser outorgada, ela atuou inspirando as Bases para a Constituição da Monarquia Portuguesa, as primeiras eleições gerais no Brasil, o trabalho dos brasileiros nas cortes Portuguesas e a Constituição de 1824.

Palavras-chave: Constituição. Cádiz. Gaditano. Carta. Texto. Espanha. Brasil. Liberalismo. Nação. Espanhola. 1812. 1822. 1824.

Abstract: Dissertation about Constitution of Cadiz of 1812 and its influence in Brazilian constitutionalism. Gaditan text is contextualized as a Spain historical situation in the early eighteenth Europe under Napoleon rule consequence. After, presents the main constitution's rules, their impact upon society and the advance stage compared to other liberal era's texts. On the second part, is studied the Brazil's history, focusing on the years 1820 to 1824, when the Constitution of Cádiz influenced upon the constitutional history 
beginning. After being ratified, it served as an inspiring for Bases of the Constitution of the Portuguese Monarchy, the first general elections in Brazil, Brazilian's work in the Portuguese Courts and the Constitution of 1824.

Keywords: Constitution. Cádiz. Gaditano. Text. Brazil. Liberalism. Nation. Spanish. 1812. 1822. 1824.

\section{A Hermenêutica do Direito Natural Clássico: a Proposta Metodológica de Leo Strauss}

Bruno Irion Colletto

Data de defesa: 20/11/2013

Resumo: A presente pesquisa tem por objetivo apresentar uma investigação filosófica acerca da idéia de direito natural tendo por base o pensamento de Leo Strauss. Este filósofo alemão, radicado nos Estados Unidos, como um crítico da modernidade e do que chamava de "Crise dos Nossos Tempos", desenvolveu uma proposta metodológica de apropriação e de estudo dos textos clássicos (filosofia política clássica), abordando os ensinamentos dos pré-modernos como passíveis de fornecer respostas verdadeiras às questões políticas da modernidade. A hermenêutica de Leo Strauss acerca da idéia de direito natural e a sua proposta metodológica serão estudados por meio de um panorama geral do seu projeto político-filosófico, bem como por meio do estudo dos seus escritos específicos sobre filosofia política clássica e sobre direito natural clássico, buscando compreender e explicar suas posições. Resgatar o papel da filosofia política era o seu intento principal, o que culminava numa reafirmação não apenas do papel da filosofia, mas também do papel da política: uma solução clássica, não para uma questão contemporânea, mas para uma questão perene da humanidade.

Palavras-chave: Leo Strauss. Filosofia Política Clássica. Direito Natural. 
Abstract: This research aims at presenting a philosophical inquiry to the idea of 'natural right'. It is based on the doctrine of Leo Strauss, a German Philosopher radicated in the United States. The author, a critic of modernity, which he called 'Crisis of Our Times', has proposed a methodological approach to have cognizance and to study classical philosophical literature (classical political philosophy). He believed pre-modern teachings could yield true answers to modern political questions. Leo Strauss' hermeneutics regarding the idea of natural right and his methodological approach will be studied through a general overview of his political and philosophical project and his specific studies regarding classical political philosophy and natural right. The intent is to understand and explain his position. This research concludes that his intention was to rescue the role of political philosophy, not only through the reaffirmation of the role of philosophy, but also the role of politics. He searched for a classical solution not for a contemporary question, but for a perennial human inquiry.

Keywords: Leo Strauss. Classical Political Philosophy. Natural Right.

\section{A Interface entre os Tratados Multilaterais Ambientais e as Regras de Comércio Internacional da Organização Mundial do Comércio}

Luisa Zuardi Niencheski

Data de defesa: 26/11/2013

Resumo: A presente dissertação tem por finalidade analisar a compatibilidade das medidas restritivas comerciais, constantes em diversos tratados multilaterais ambientais, com as normas que compõem um sistema que prevê o multilateralismo, a abertura e a equidade nas relações comerciais. Trata-se de um estudo que, a partir da análise de tratados internacionais, da jurisprudência e da revisão bibliográfica existente na área do comércio e meio ambiente, investiga os aspectos da fragmentação do direito internacional, reconhecendo a necessidade 
de coordenação entre os subsistemas normativos. Para tanto, serão percorridas teorias a respeito da potencialidade de conflito entre diferentes normas e jurisdições competentes, demonstrando que, através de métodos interpretativos e do recurso a princípios gerais do direito internacional, é possível encontrar a forma apropriada para harmonizá-los. Nesse espectro, ganha importância o exame do artigo XX do GATT 1994 e dos casos que ressaltam a aplicação desta norma que fornece exceções ao regime comercial, permitindo a execução de políticas governamentais que atendam à proteção dos recursos naturais. A toda evidência, conclui-se que as disposições dos tratados ambientais e comerciais interagem no cenário jurídico internacional, denunciando que o sistema de livre-comércio inclina-se a adaptar a agenda ambiental entre as suas preocupações, respondendo ao desafio de promover o equilíbrio entre as normas do direito internacional e a coerência entre esses diversos tratados.

Abstract: The following dissertation aims to analyze the compatibility of trade restrictive measures introduced in various multilateral environmental agreements with trade rules, guided by open, non-discriminatory, equitable and predictable multilateral trading relations. This study relies on the agreements examination, case and literature review in the trade and environment area, researching aspects of the fragmentation of international law that recognize the need for coordination between normative self-contained regimes. Likewise, the thesis goes through relevant theories regarding the potential conflict between different norms and competent jurisdictions, demonstrating that it is possible to find the proper way to harmonize them by interpretive methods and general principles of international law. Furthermore, it is required to explore the role introduced under article XX of the GATT 1994 and the jurisprudence that highlight the application of this rule, which provides exceptions to the trade regime, allowing the enforcement of government policies that address the protection of natural resources. Thereby, this study concludes that the provisions of the multilateral environmental and trade treaties interact in the international legal arena, emphasizing that the free trade system is inclined to adapt the environmental agenda among their concerns, responding to the challenge of promoting the balance between the norms of international law and coherence between these various treaties. 


\title{
A Proteção do Meio Ambiente em Período de Conflito Armado
}

Michelle Coelho Muller

Data de defesa: 24/10/2013

\section{A Proteção Internacional do Trabalhador Contratado ou Transferido para o Exterior: as Principais Questões sobre o Foro Competente e a Legislação Aplicável}

\author{
Geovana Geib \\ Data de defesa: 29/05/2013
}

Resumo: Não se pode negar que a globalização influencia, de modo decisivo, todos os aspectos da organização econômica da sociedade contemporânea. Impulsionada, principalmente, pelas inovações da tecnologia e das telecomunicações, nunca se produziu tanto e de forma tão diversificada. No mundo do trabalho, a principal transformação gerada pela globalização é o deslocamento de trabalhadores para postos de trabalho em diferentes países. Por consequência, isto ocasiona um representativo aumento dos conflitos de leis trabalhistas no espaço e a necessidade dos Estados regularem o tema. Assim, o principal desafio do Direito Internacional do Trabalho hoje é garantir respostas eficazes a este aumento de conflitos e assegurar uma efetiva proteção internacional destes trabalhadores contratados ou transferidos para o exterior por seus empregadores. Por esta razão, através de pesquisa doutrinária e jurisprudencial, a presente monografia (que se utiliza da metodologia francesa) demonstrará porque a proteção internacional efetiva dos trabalhadores contratados ou transferidos para laborar no exterior só poderá ser garantida através de regras benéficas quanto à determinação da lei aplicável e do órgão jurisdicional competente para processar e julgar tais demandas.

Palavras-chave: Direito Internacional Privado. Direito do Trabalho. Contrato Individual de Trabalho. Transferência. Jurisdição. Lei Aplicável. 
Abstract: Nobody can deny that globalization influences, in a decisive way, all aspects of economic organization of contemporary society. Mainly, driven by innovations in technology and telecommunications, humanity had never produced so much and in a so diversified way. In the labor world, the main change due to globalization is the displacement of workers to workplaces indifferent countries. Consequently, this causes a representative increase of labor law conflicts in space and a demand for States to regulate this issue. Thus, the main challenge of the International Labor Law today is to ensure an effective response to this mentioned increase of conflicts and guarantee an effective international protection of these workers hired or transferred abroad by their employers. For this reason, through doctrinal and jurisprudential research, this monograph (which uses the French methodology) demonstrates why effective international protection of workers hired or transferred for working abroad can only be guaranteedthrough beneficial rules regarding to the determination of the applicable law and the competent court to adjudicate such claims.

554 Keywords: Private International Law. Labor Law. Individual Labor Contract. Transference. Jurisdiction. Applicable Law.

\section{Ação Rescisória em Matéria Tributária - Aspectos Controvertidos}

\section{Alteração da Demanda: a Flexibilização do Princípio da Estabilidade da Demanda}

Rafael Flach

Data de defesa: 16/08/2013 


\section{Análise de Direito e Economia da Arbitragem nos Contratos por Adesão}

Patrícia Fernandes Fraga

Resumo: Trata-se de dissertação, requisito para obtenção de título de Mestre em Direito, vinculada ao Programa de Pós-Graduação em Direito da Universidade Federal do Rio Grande do Sul. Este trabalho respeita à pesquisa acerca da instauração da arbitragem, designadamente, por meio da cláusula arbitral, no interior dos contratos estandardizados, sob o enfoque da análise econômica do direito. Portanto, a pesquisa concerne à tentativa de união de institutos bastante polêmicos e sinuosos, pois, aparentemente incompatíveis, a arbitragem, de um lado, em virtude de carecer da autonomia da vontade inequívoca para sua validade e os contratos por adesão, do outro lado, por restringir essa mesma autonomia de forma notória, e sobrepairando a ambos a perspectiva, muito mais pragmática, da análise econômica do direito, que instrumentará o exame da eficiência desses institutos, quando atuarem conjuntamente. Além disso, não se prescindirá da devida análise jurídica dos institutos da arbitragem e dos contratos por adesão, vez que se não houver fundamentos jurídicos que legitimem sua utilização de nada serviria o presente exame. Contudo, tentar-se-á verificar, nos limites do ordenamento jurídico nacional brasileiro, se há modificações plausíveis e suscetíveis de melhorias.

Palavras-chave: Direito Civil. Análise Econômica do Direito. Arbitragem. Contrato por Adesão. Cláusula Arbitral.

Abstract: This thesis is a requirement for obtaining a Master Degree in Law at the Graduate Program in Law of Federal University of Rio Grande do Sul. This paper is the research about the establishment of arbitration, namely, through the arbitration clause, within the standardized contracts, from the standpoint of economic analysis of law. Therefore, the research concerns the attempted union of two quite controversial and apparently incompatible institutes: arbitration 
and standard contracts. The first, on the one hand, lacks of freedom in unequivocal choice for its validity; the last, on the other hand, restricts this autonomy noticeably. To both, the perspective, much more pragmatic, on economic analysis of law, will be imposed and will provide the tolls to examine the effectiveness of these institutions, when acting together. Furthermore, it is not possible to exclude the due legal analysis of the institutes of arbitration and standard contracts, once the lack of legal grounds to legitimize their use make the present analysis pointless. However, this paper will try to determine, within the limits of the Brazilian national law, if there are plausible and susceptible modifications for improvement.

Keywords: Civil Law. Economic Analysis of Law. Arbitration. Standard Adhesion Contract. Arbitration Clause.

\section{Análise Jurídica e Econômica do Casamento e de seus Aspectos Patrimoniais}

Cristiana Sanchez Gomes Ferreira

Data de defesa: 14/05/2013

\section{Aspectos Comparativos da Cooperação Internacional no Tráfico de Pessoas para Exploração Sexual - União Europeia e Mercosul}

Daniela Pereira Lucht

Data de defesa: 22/11/2013

Resumo: Este estudo teve como objetivo abordar aspectos comparativos de cooperação internacional focando o tráfico internacional de pessoas para fins de exploração sexual. Inicia-se a abordagem refletindo sobre a dignidade da pessoa humana e as questões socioculturais que permitem que a exploração sexual continue a existir 
e necessite uma investigação e persecução diferenciada de outras modalidades criminosas. A cooperação internacional, entre órgãos governamentais e não governamentais, é discutida em razão da transnacionalidade do crime de tráfico internacional de pessoas e atuação de organizações criminosas. O estudo comparativo de legislações e melhores práticas implementadas pelos Estados é realizado principalmente em relação aos países membros da União Europeia e do MERCOSUL e busca apontar pontos positivos e dificiências a fim de sugerir ações que devem ser implementadas ou melhoradas para que o tráfico internacional de pessoas para exploração sexual possa tornar-se cada vez mais difícil de ser realizado.

Palavras-chave: Cooperação Internacional. Tráfico Internacional de Pessoas. Exploração Sexual. Crimes Transnacionais. Globalização. Organizações Criminosas. União Europeia. MERCOSUL.

Abstract: This work aims to address comparative aspects of international cooperation focusing on international trafficking in persons for sexual exploitation. The approach initiates reflecting on the dignity of the human person and the socio-cultural issues that allow the sexual exploitation to continue to exist and to require an investigation and prosecution that differs from other criminal procedures. International cooperation, between governmental and non-governmental organizations, is discussed because of the transnational nature of the crime of international trafficking in persons and of the activities of criminal organizations. The comparative study of legislation and best practices implemented by the States addresses mainly the European Union and MERCOSUR member States and seeks to identify strnghts and weaknesses in order to suggest actions that should be implemented or improved so that the international trafficking in persons for sexual exploitation may become increasingly difficult to realize.

Keywords: International Cooperation. International Trafficking in Persons. Sexual Exploitation. Transnational Crimes. Globalization. Criminal Organizations. European Union. MERCOSUR. 


\section{As Ideias acerca dos Elementos Constituintes do Estado e sua Recepção por Tratados Luso-Hispânicos do Século XVIII}

Marcos Pascotto Palermo

Data de defesa: 12/12/2013

\section{As Provas Ilícitas e o Processo Civil Brasileiro: Fundamento e Elementos para Aplicação da Regra Constitucional de Exclusão de Provas}

Eduardo Siqueira Néri

Data de defesa: 11/11/2013

Resumo: A prova ilícita é aquela cujas condutas empreendidas para sua obtenção, formação ou utilização violam prescrições de direito material, ou direitos fundamentais materiais. A inadmissibilidade de uma prova relevante, determinada pela aplicação de uma regra de exclusão de finalidade extraprocessual, implica necessária inobservância do direito fundamental à prova da parte que requer sua admissão e possível óbice à averiguação fidedigna dos fatos relevantes para a causa. O Artigo 5º, inciso LVI, da Constituição Federal de 1988, contém uma regra (não um princípio) de inadmissibilidade, no processo, das provas ilícitas, que tem por escopo proteger bens jurídicos e por fundamento a capacidade de coibir a adoção de condutas antijurídicas através de um efeito profilático. Tratando-se de uma regra (e não de um princípio), uma vez que preenchido o suporte fático da norma, ela deve ser aplicada por subsunção (não por ponderação), o que não exclui a possibilidade de, ao momento da sua aplicação, verificar-se uma hipótese de superabilidade. A teoria da ponderação de interesses parte de premissas adequadas à noção de superabilidade, contudo, os interesses (razões) a serem ponderados no caso concreto não podem ser determinados somente pela importância do bem jurídico sobre o qual incidirão os efeitos da sentença e daquele que foi afetado pela prova ilícita, sendo imprescindível considerar o caráter prospectivo e complementar da proteção conferida pela 
regra constitucional de exclusão de provas. Não existem boas razões para restringir a aplicação do Artigo 5º inciso LVI, da Constituição Federal, ao âmbito do processo penal, ou aos casos em que a obtenção, formação ou utilização da prova implica violação de direitos fundamentais; é praticada por um agente estatal; ou é praticada pela própria parte que requer sua admissão. Também não existem bons argumentos para criarem-se requisitos de legitimidade para requerer a exclusão da prova ou aproveitar os efeitos da exclusão. Entretanto, caracterizam hipóteses de superabilidade os casos em que aquele que obtém, forma ou utiliza uma prova ilícita possui motivos razoáveis para acreditar na juridicidade da conduta por ele empreendida; ou sequer planeja obter meios de comprovação através das condutas adotadas, promover a aplicação da regra não representa qualquer benefício, apenas prejuízos, ao mesmo tempo em que excepcioná-la não implica redução da capacidade de coibir do efeito profilático. Por fim, considera-se que a incorporação da teoria dos frutos da árvore venenosa ao direito brasileiro é medida que representa o resguardo da capacidade protetiva da regra constitucional de exclusão de provas, sendo com ela compatível a exceção de fonte independente; passível de compatibilização a exceção de descoberta inevitável; e incompatível a exceção de purgação da mácula.

Palavras-chave: Prova Ilícita. Prova Inadmissível. Processo Civil. Exceção de Boa-Fé. Teoria dos Frutos da Árvore Venenosa.

Abstract: Illegally obtained evidence is so called the one whose conducts employed in order to obtain, form or employ it violate material law or fundamental material rights prescriptions. Inadmissibility of a relevant evidence determined by the application of an exclusionary rule of a non procedural purpose implies mandatory non observance of the fundamental right to evidence of that part who requires its admission, as well as possible hindrance to the faithful verification of relevant facts to the lawsuit. The Article 5, item LVI, of the Brazilian Federal Constitution of 1988 contains a rule (and not a principle) of inadmissibility, in the procedure, of illegally obtained evidences, which aims to protect juridical assets and is based upon the capacity of evading the adoption of antijuridical conducts through a deterrent effect. Considering it a rule (and not 
a principle), once fulfilled its factual support, it must be applied subsumptionally (and not ponderously), what does not exclude the possibility of, at a certain moment of its application, being verified a hypothesis of defeasibility. The interests ponder theory (teoria da ponderação de interesses) starts off from suitable premises to the very notion of defeasibility, however interests (reasons) to be pondered in the actual case may not be determined solely by the relevance of the juridical asset which shall be subjected to the effects of the decision and of the one to be affected by the illegally obtained evidence, being vital to consider both the prospective and complementary characters of the protection given by the constitutional evidence exclusionary rule. There are no good reasons to restrict the application of the Article 5, item LVI, of the Federal Constitution to the criminal procedure ambit, or to the cases where the obtaining, formation or usage of the evidence implies violation of fundamental rights; is carried out by a state agent; or is carried out by the very part who requires its admission. There are neither good arguments in order to create requirements of legitimacy for the evidence exclusion or to relish the effects of its exclusion. Nevertheless, characterize hypotheses of defeasibility those cases in which the one who obtains, forms or employs a illegally obtained evidence possesses reasonable arguments to believe in the rightfulness of the adopted conduct; or does not even plan to obtain means of evidence through the adopted conducts, in such a way that to promote the application of the rule does not represent any benefits for the parts, only disadvantages and, at the same time that except it does not imply the reduction of the deterrence capacity of the deterrent effect. Eventually, it is considered that the incorporation of the fruits of the poisonous tree doctrine to Brazilian law is a measure that represents the beware of the protective capacity of the constitutional exclusionary rule, being compatible to it, the independent source doctrine, possibly suited, the inevitable discovery exception and unsuitable, the purged taint exception.

Keywords: Illegally Obtained Evidence. Inadmissible Evidence. Civil Procedure. Deterrent Effect. Good Faith Exception. Fruits of the Poisonous Tree Doctrine. 


\section{Capacidade Contributiva e Tributação Indireta: Mecanismos de Aplicação da Capacidade Contributiva para além da Eletividade}

Elisângela Simon Caureo

Data de defesa: 30/08/2013

Resumo: O presente estudo é um exercício de argumentação e análise da doutrina acerca da tributação sobre o consumo da população de baixa renda sob a ótica do princípio da capacidade contributiva. O tema é a aplicação do Princípio da capacidade contributiva em relação aos tributos indiretos, também chamados tributos sobre o consumo. A doutrina nacional afirma que a capacidade contributiva, em relação a esses tributos, é promovida unicamente pelo binômio seletividade/essencialidade. Este trabalho busca demonstrar que o principio da capacidade contributiva determina a proteção do mínimo existencial e de acordo com ela deve ser interpretado. Conclui-se que a capacidade contributiva, em relação aos titulares de renda mínima (mínimo existencial), especificamente quanto aos tributos indiretos, deve ser otimizada (comando para ser otimizado), preservando, dessa maneira, os direitos de propriedade e de liberdade do titular do mínimo existencial. Assim, para além da técnica da seletividade e da essencialidade, estão a serviço da capacidade contributiva nesse campo, as técnicas de praticabilidade e de simplificação tributaria.

Palavras-chave: Capacidade Contributiva. Tributação sobre o Consumo. Tributos Indiretos. Mínimo Existencial. Liberdade. Propriedade. Praticabilidade.

Abstract: This study analyses the jurisprudence about taxes over the low-income population's consumption, on the perspective of the ability to pay principle. The subject of the study is the enforcement of the ability to pay regarding the indirect taxes, also called tax over the consumption. The brazilian jurisprudence maintains that the ability to pay principle regarding these taxes is promoted solely by the binomial selectivity/essentiality. This work pursuit to expose that the ability to pay principle determines the protection of the 
minimum existential and, according to this, should be interpreted. The conclusion is that the contributive capacity regarding to the bearer of the minimum income (existential minimum), especially on the indirect tax, should be optimized (command to be optimized), thus preserving the rights to property and the freedom minimum income bearer. So, beyond the selectivity and essentiality technique, are in this field for the service of the Ability to Pay, the techniques of practicability and tax simplification.

Keywords: Contributive Capacity. Ability to Pay. Tax over Consumption. Indirect Tax. Existential Minimum. Freedom. Property. Practicability.

\section{Coisa Julgada e Precedente - Análise das Relações Jurídicas de Trato Continuado}

Paulo Mendes de Oliveira

Data de defesa: 09/07/2013

\section{Concorrência e Consumidor: Dúplice Capitulação da Venda Casada}

Resumo: Apesar dos princípios da livre concorrência e da defesa do consumidor estar lado a lado em sede constitucional e terem uma relação bastante íntima, tendo em vista o objetivo comum que os une, percebe-se, com poucas ressalvas, que a defesa da concorrência e a defesa do consumidor, no Brasil, sempre se mantiveram quase que incomunicáveis. Um exemplo de conduta que realça essa íntima interface entre Defesa do Consumidor e da Concorrência é o abuso de posição dominante, que tem como uma das suas principais manifestações a venda casada (tying ou vente liée). A venda casada, por gerar danos à livre concorrência e constituir-se como uma falha interna na relação de consumo, vem a ser capitulada como prática 
abusiva no Código de Defesa do Consumidor (CDC) e como infração à ordem econômica na Lei de Concorrência. Assim, a prática comercial pode vir a ser reprimida simultaneamente pelas duas esferas, $\mathrm{o}$ que impinge um diálogo entre a tutela da concorrência e a tutela do consumidor. Desta feita, a presente dissertação visou a responder aos seguintes problemas de pesquisa: (I) qual o liame entre defesa do consumidor e da concorrência? (II) Como essas defesas podem ser mais bem coordenadas e harmonizadas? (III) É necessária a dúplice capitulação? (IV) como articular as defesas, a fim de que resultados mais efetivos no que toca ao bem-estar do consumidor possam ser atingidos? A conclusão que se chegou é que a dúplice repressão à venda casada - não só não constitui um bis in idem - como é necessária. Não há que se falar em repressão apenas pela esfera da concorrência ou pela do consumidor, uma vez que, como bem salientado ao longo do presente estudo, em ambas as hipóteses restaria o consumidor desprotegido, sem mecanismos de Dessarte, poderá haver a aplicação simultânea da Lei Antitruste e do Código do Consumidor a uma prática de venda casada, sendo que cada uma irá atuar em um nível diferente de proteção ao consumidor: a primeira de forma macro e a segunda, micro. No entanto, para que essa dupla tutela se torne eficaz, é necessário uma coordenação entre essas duas leis, a fim de que se preserve a coerência do sistema.

Palavras-chave: Livre Concorrência. Consumidor. Venda Casada.

Abstract: Although the principle of free competition and consumer protection are side by side in the constitutional seat and have a very intimate relationshio, in view of the common goal that bind them, it is clear, with few exceptions, that antitrust and consumer protection in Brazil, always remained almost unreachable. An example of conduct that emphasizes this intimate interface between Consumer and Competition is the abuse of a dominant position, which has as one of its main manifestations the tying. The tying, since generates demage to competition and to the consumers, is typified as a violation of the economic order in the Competition Act and as an abusive practice in the Consumer Protection Code. Thus, commercial practice is likely to be suppressed simultaneously by the two spheres, which enforces a dialogue between the protection of the consumer and the protection of competition. Therefore, this thesis aims to answer the 
following research problems: (I) what is the link between consumer protection and competition protection? (II) How these defenses can be better coordinated and harmonized? (III) The dual capitulation is required? (IV) How to articulate the defenses to achieve more effective results, when it comes to the welfare of the consumer? The conclusion reached is that the twofold repression of tying - not only isn't a bis in idem - as it is needed. There is no way to speak of repression only by the sphere of competition or of consumer, since, as stressed throughout this study, in both cases the consumer would be left unprotected, without defense mechanisms. Thus, is possible that in a practice of tying occurs the simultaneous application of the Antitrust Act and the Consumer Protection Code. Each of these laws eill act on a different level of consumer protection: the first, in the macro level and the second, on the micro. However, for this dual control becomes effective, it is necessary coordination between these two laws, in order to preserve the coherence of the system.

Keywords: Free Competition. Consumer. Tying.

\section{Controle de Constitucionalidade e Jurisdição Stricto Sensu}

Romulo Ponticelli Giorgi Junior Data de defesa: 01/03/2013

Resumo: O presente trabalho procura demonstrar a irracionalidade de conferir-se, aos juízes ordinários brasileiros, tanto o controle de constitucionalidade como a possibilidade de julgar casos diretamente a partir de princípios constitucionais, sem a mediação da lei, bem como os prejuízos daí decorrentes para a efetivação dos valores fundamentais da democracia, inscritos na Constituição de 1988. Procura-se demonstrar que os valores fundamentais do Estado Democrático de Direito aplicam-se ao controle de constitucionalidade e que este é um instrumento da democracia que pode, se utilizado incorretamente, gerar sérios problemas. Para tanto, após especificar alguns conceitos para afastar ambiguidades e clarear os pressupostos metodológicos, passa-se à demonstração da incompatibilidade do 
controle cumulado de constitucionalidade com a jurisdição ordinária no sistema Romano-Germânico, especialmente no Brasil, analisando os problemas causados pela cumulação das jurisdições ordinária e constitucional e demonstrando a necessidade de separação entre os níveis fundamental, ordinário e judiciário do ordenamento. Passase, então, à demonstração da necessidade de uma clara delimitação entre a competência dos órgãos jurisdicionais de primeiro grau, de segundo grau, dos tribunais superiores e do Supremo Tribunal Federal. Conclui-se que é viável e necessário vetar o controle de constitucionalidade e o regramento dos casos diretamente a partir de princípios constitucionais pelo julgador ordinário, sugerindo-se a adoção, pelo Supremo Tribunal Federal, de interpretação constitucional que vede este procedimento, pois a Constituição brasileira de 1988 menciona o controle cumulado de constitucionalidade apenas nos seus arts. 97 e 102, III, permitindo a sua limitação, sem a necessidade de emenda constitucional apenas aos tribunais, reduzindo um pouco a irracionalidade gerada pela adoção apressada de institutos típicos do common law. A erradicação completa do problema, eliminando a cumulação de jurisdições em todos os graus, entretanto, dependeria de emenda constitucional e está fora do objeto do presente trabalho.

Palavras-chave: Controle de Constitucionalidade. Controle Cumulado. Juiz Ordinário. Fins do Estado. Níveis do Ordenamento. Democracia Deliberativa. Segurança Jurídica. Limites da Jurisdição. Estado do Bem-Estar Social.

Abstract: The present work aims to demonstrate the irrationality of granting to the Brazilian district judges both the power of judicial review and the direct application of constitutional principles, without statute mediation, as well as the resulting losses to the accomplishment of the fundamental values of democracy, inscribed in the 1988 Brazilian Constitution. The paper seeks to demonstrate that the fundamental values of the democratic state are applicable to the judicial review of legislation and that this is a tool that can, if incorrectly used, generate serious problems. For this, after specifying some concepts to avoid ambiguities and make clear the methodological assumptions, follows the demonstration of the incompatibility of the cumulated constitutional review with the common jurisdiction in the civil law, especially in Brazil, analyzing the problems caused 
by the accumulation of the common and constitutional jurisdictions and demonstrating the need to separate the fundamental, ordinary and judiciary levels of the legal system. Follows the demonstration of the need of a clear delimitation of the competence of the district, appellate, superior and supreme courts. The paper concludes that is feasible and necessary to prohibit to the district judges both the constitutional review and the direct application of constitutional principles, without statute mediation, suggesting the adoption, by the Brazilian Supreme Court, of a constitutional interpretation the prohibits this procedure, because the Brazilian 1988 Constitution mentions the cumulated constitutional review only in its articles 97 e 102, III, allowing the limitation, without the necessity of a constitutional amendment, only to the appellate, superior and supreme courts, reducing the irrationality generated by the hurried adoption of typical common law institutes. The complete eradication of the problem, eliminating the accumulation of the common and constitutional jurisdictions in all courts, however, would need a constitutional amendment and is out of the scope of this paper.

Keywords: Judicial Review. Constitutional Review. Cumulated Control. District Judge. State Ends. Legal System Levels. Deliberative Democracy. Legal Certainty. Limits of Adjudication. Welfare State.

\section{Cooperação Jurídica Internacional em Matéria Penal: uma Análise do Mutual Legal Assistance Treaty Brasil/Estados Unidos}

Helena Vasconcelos

Data de defesa: 02/12/2013

\section{Direito Contratual como Redutor das Falhas de Mercado}

Manoel Gustavo Neubarth Trindade

Data de defesa: 13/05/2013 


\section{Direito Tributário e Livre Concorrência}

Luiz Fernando Barboza dos Santos

Data de defesa: 16/08/2013

Resumo: A tributação possui inegável importância no atual contexto econômico, influenciando diretamente o comportamento dos agentes que atuam no mercado. Em face disso, a relação entre o Direito Tributário e o princípio da livre concorrência apresenta-se cada vez mais solidificada. O reconhecimento dessa relação depende da adoção de uma visão mais ampla do Direito Tributário, o qual deve ser compreendido de forma sistêmica e interdisciplinar. Por outro lado, a aludida relação depende, também, da compreensão da livre concorrência sob um prisma de liberdade e de igualdade. Liberdade no sentido de permitir que os agentes possam ingressar e atuar criativamente no jogo do livre mercado, exercendo sua autonomia privada; igualdade no sentido de que todos os concorrentes possuam as mesmas condições de competitividade, sendo que eventuais diferenças, inerentes ao sistema capitalista, devem decorrer somente da eficiência econômica revelada por cada um dos agentes. Ao Estado compete respeitar o princípio da neutralidade, o qual guarda pertinência com a preservação da livre concorrência. Esse princípio possui dois planos: um primeiro plano referente a um dever negativo ou de omissão, em que o ente público não pode interferir na competitividade por meio da tributação; um segundo plano atinente a um dever positivo ou de ação, que permite ao Estado prevenir ou restaurar a igualdade de condições na concorrência. $\mathrm{O}$ artigo 146-A da Constituição positivou o princípio da neutralidade no ordenamento pátrio. Mas, a par disso, institui também uma regra de competência, permitindo a elaboração de lei complementar que estabeleça critérios especiais de tributação, com o objetivo de prevenir desequilíbrios da concorrência. Com base nesse arsenal legal e teórico, possibilitou-se o enfrentamento dos aspectos práticos dessa relação entre Direito Tributário e livre concorrência, como, por exemplo, os efeitos nocivos que a Guerra Fiscal do ICMS ou a prática de sonegação fiscal causam à competitividade do mercado.

Palavras-chave: Tributação. Livre Concorrência. Neutralidade. Artigo 146-A. Guerra Fiscal. Sonegação Fiscal. 
Abstract: The instrument of taxation features undeniable importance in current economic context, directly influencing market players' behavior. On the face of it, relationship between Tax Law and the principle of free competition has become ever more solidified. Recognition of this relationship depends on adoption of a wider vision of Tax Law, which must be systemically and interdisciplinary understood. Moreover, the aforesaid relationship also depends on understanding free competition in a prism of freedom and equality. Freedom with respect to allow agents to join in and creatively act in the interplay of free market, exerting their private autonomy; equality in the sense that all bidders have the same competitive conditions, and any differences inherent in the capitalist system should take place only economic efficiency revealed by each agent. The State is responsible for respecting the principle of neutrality, which holds relevance to the preservation of free competition. This principle features two levels: the first one regards to a negative duty or omission, in which the public entity cannot interfere in competitiveness through taxation; the second one is concerned to a positive duty or action, which permit the State prevent or restore equal conditions in competition. Article 146-A of Constitution affirmed the principle of neutrality in Brazilian Law. However, in addition, it also established a jurisdiction rule, permitting elaboration of complementary law as to establish special criteria for taxation aiming to prevent imbalances in competition. Based on this legal and theoretical background, it made possible the confrontation of practical aspects of relationship between Tax Law and free competition, such as, for example, the harmful effects of "ICMS Fiscal War" and tax evasion practice cause to market competitiveness.

Keywords: Taxation. Free Competition. Neutrality. Article 146-A. Fiscal War. Tax Evasion. 


\title{
Do Caráter Taxativo das Hipóteses de Indignidade Sucessória no Código Civil Brasileiro: um Problema de Argumentação Jurídica
}

\author{
Bruno Hermes Leal \\ Data de defesa: 23/01/2013
}

Resumo: Esta dissertação tem por objetivo apresentar propostas argumentativas ao tratamento jurisprudencial da indignidade sucessória, no que tange, especialmente, à impossibilidade de estender a sua eficácia excludente (da herança) a hipóteses que não se encontrem contempladas no art. 1.814 do Código Civil brasileiro. A estruturação formal dos capítulos desta dissertação constituem-se em degraus convergentes à demonstração dessa hipótese científica. $\mathrm{O}$ primeiro capítulo desta dissertação dedica-se à narrativa sobre a construção do Direito das Sucessões a partir de seus aspectos eminentemente filosóficos e sociológicos, tendo por objetivo metodológico precípuo demonstrar que o conceito de herança intestada já foi arquitetado ao redor das mais diversas concepções filosóficas e sociológicas. Esse ponto de partida, salientando os diversificados e contraditórios fundamentos que já foram atribuídos ao Direito das Sucessões, é fundamental ao recorte metodológico do segundo capítulo, qual seja a opção por um estudo dogmático-jurídico da indignidade sucessória. O segundo capítulo desta dissertação dedica-se à exposição dos contornos normativos objetivos e subjetivos através dos quais o Direito brasileiro delimita a noção jurídica de indignidade sucessória. O terceiro capítulo desta dissertação será dedicado à escolha de certa Teoria da Argumentação Jurídica que alcance, simultaneamente, a racionalidade dos pronunciamentos jurisdicionais e a permeabilidade do Direito à realidade social. O quarto capítulo, por fim, congrega o dissenso teórico do primeiro capítulo, os contornos normativos expostos no segundo capítulo, bem como o cabedal 
hermenêutico ofertado pela Teoria da Argumentação Jurídica escolhida no terceiro capítulo, para demonstrar que a dogmática atual do Direito brasileiro não possibilita que o Poder Judiciário crie situações de indignidade sucessória além das previstas no art. 1.814 do Código Civil brasileiro.

Palavras-chave: Direito das Sucessões. Indignidade. Argumentação Jurídica. Robert Alexy.

Abstract: This essay aims to present argumentative proposals to jurisprudential treatment of indignity for succession, regarding especially the impossibility to extend its exclusionary effectiveness to hypotheses that are not specifically addressed in art. 1814 of the Brazilian Civil Code. The formal structure of the chapters of this dissertation are converging to the demonstration of this scientific hypothesis. The first chapter of this dissertation is devoted to the narrative of the construction of the Law of Succession from their eminently philosophical and sociological aspects, aiming to demonstrate that the concept of intestate inheritance has been architected around several philosophical and sociological concepts. This starting point, highlighting the diverse and contradictory foundations that have already been assigned to the Law of Succession, is fundamental to the methodological approach of the second chapter, which is the option for a study of the legal-dogmatic indignity for succession. The second chapter of this dissertation is dedicated to the exposure of normative objective and subjective contours through which Brazilian law defines the legal notion of indignity for succession. The third chapter will be devoted to the choice of certain Legal Argumentation Theory to reach both the rationality of judicial pronouncements and the permeability of Law to social reality. The fourth chapter, finally, brings altogether the theoretical dissent from the first chapter, the normative outlines exposed in the second chapter, as well as the hermeneutic tools offered by the Theory of Legal Argumentation chosen in the third chapter, in order to show that the current Brazilian law does not allow judges to create hypotheses of indignity for succession beyond those expressly provided by art. 1814 of the Brazilian Civil Code.

Keywords: Law of Successions. Indignity. Legal Reasoning. Robert Alexy. 


\section{Em Busca da Tradição Ocidental no Século XX: a Filosofia Política Crítica de Gerhart Niemeyer e o Conservadorismo Norte-Americano}

Giancarlo Michel de Almeida

Data de defesa: 18/11/2013

Resumo: Após a primeira metade do séc. XX, tem ocorrido uma revolução na Filosofia Política, Jurídica e Moral. A partir da rejeição do projeto racionalista da modernidade, Filósofos pós Segunda Guerra tentam recuperar o que se havia perdido na modernidade, que são os preceitos da Filosofia Política clássica, da tradição Ocidental, da transcendência judaico-cristã. Destacamos Gerhart Niemeyer para a compreensão do papel do conservadorismo nesse debate. Consideramos que sua Filosofia amadurece até um conservadorismo moderado em três fases: funcionalismo imanentista e crítica à modernidade, anticomunismo e, então, a definição de Filosofia Política conservadora. Sua crítica se desenvolve identificando a raiz moderna das ideologias do séc. XX: na rejeição do divino e da ordem existente, materialismo, a ideia (dialética) de luta de classes, positivismo e jus naturalismo moderno, ativismo revolucionário daí resultante, bem como no historicismo moderno. Seu principal conceito, total critique, denuncia que as ideologias modernas possuem caráter político apenas destrutivo, pois requer a destruição do mundo existente (construído na realidade da experiência humana e baseado no Direito Natural transcendente) para a realização de uma natureza humana idealizada e utópica, ou seja, irrealizável. Assim, após a fragmentação da Tradição Ocidental, para reconstruir uma ordem legítima e fundamentada é necessário atentar para ideias como: a tradição Ocidental e o Direito Natural, a identidade e passado público, mito fundador, realm como unidade política, moral e limites em função do mito, virtudes existenciais da comunidade, consenso de valores (homonoia), bem como a capacidade crítica necessária para manter a continuidade da unidade cultural em uma democracia. Então, destacamos a importância do conservadorismo americano nesse movimento. Observamos que sua experiência acadêmica e política, ao longo da Guerra Fria, estão no contexto do conservadorismo norte-americano. Contudo, seu conservadorismo é diferente, devido a sua crítica ao liberalismo e a Direita, delineando um conservadorismo moderado. 
Palavras-chave: Filosofia do Direito. Filosofia Política. Metodologia. Crítica à Modernidade. Tradição Ocidental. Direito Natural. Conservadorismo Norte-Americano.

Abstract: After the first half of the 20th century there is a revolution in Political, Legal and Moral Philosophy. From the rejection of the rationalist project of modernity, post Second War philosophers try to recover what was lost in modernity, which are the precepts of classical Political Philosophy, on Western tradition, on the JudeoChristian transcendence. Featuring Gerhart Niemeyer on the understanding the role of conservatism on this debate. We consider that his philosophy matures to a moderate conservatism in three phases: immanentist functionalism and critique of modernity, anticommunism, and then the definition of conservative political philosophy. His critique analysis is developed on identifying the modern root of 20th century ideologies: the rejection of the divine and the existing order, the materialism, the (dialectic) idea of class struggle, positivism and modern jusnaturalism, the resulting revolutionary activism, as well as the modern historicism. Its main concept, "total critique" shows off that modern ideologies have only destructive political character, because it requires the destruction of the existing world (founded in the reality of human experience and based on the sound transcendent Natural Law) to conduct an idealized and utopian human nature, which is unrealizable. So, after the fragmentation of Western Tradition, to rebuild a lawful and reasoned order it is necessary to look after ideas such: the public identity and public past, the founding myth, "realm" as political unit, moral and limits concerning the myth, existential virtues of community, common sense values (homonoia), as well as the necessary critic skill to keep the abidance of the cultural unity in a democracy. Then, we point the importance of American conservatism over this postmodern movement. We found that his academic and politics experience, throughout the Cold War, are within the context of American conservatism. However, his conservatism is different for his critique of liberalism, which means a moderate conservativism.

Keywords: Law Philosophy. Political Philosophy. Methodology. Critique of Modernity. Western Tradition. Natural Law. American Conservatism. 


\section{Estudo Comparado da Disciplina da Remuneração dos Administradores de Sociedades por Ações no Brasil e Reino Unido e sua Relação com a Propriedade do Capital}

Bruno Haack Vilar

Data de defesa: 18/06/2013

Resumo: Este trabalho analisa a disciplina da remuneração dos administradores de sociedades por ações no direito brasileiro em cotejo com aquela do Reino Unido, sob a perspectiva da estrutura de propriedade do capital predominante em cada um desses países. Após um escorço histórico que ilustra o papel da sociedade por ações em mobilizar poupança popular, exploram-se os fatores que levaram à fragmentação da propriedade acionária no Reino Unido e analisa-se a ocorrência de tal fatores no Brasil. A seguir destacam-se as relações entre distribuição do capital (se concentrada ou dispersa) e administração societária, com especial ênfase a seus reflexos sobre a remuneração. Por fim investiga-se a disciplina da remuneração dos administradores de companhias no direito britânico e brasileiro, atentando-se para a adequação deste a um cenário em que sociedades de capital disperso passam a disputar espaço no mercado com sociedades de capital concentrado. Conclui-se que as mudanças pelas quais vem passando o mercado de capitais brasileiro nos últimos anos podem vir a exigir alterações no direito.

Abstract: This thesis analyses the discipline of executive remuneration in Brazilian law as compared to that of British law and under the perspective of the prevailing capital ownership structure in each of these countries. After a brief historical illustration of the role of corporations in the mobilisation of public savings, the factors that produced the dispersion of shareholding in the United Kingdom are review and their occurrence in Brazil is analysed. The relationships between share ownership distribution (if concentrated or dispersed) and corporate governance are reviewed, with an emphasis on its effects over remuneration. Finally the discipline of executive remuneration in British and Brazilian law is investigated, considering the adequacy of the latter to a scenario in which 
dispersed capital companies share an space in market with concentrated capital companies. Conclusion is that the changes observed in the brazilian capital market in the last years may come to demand modifications in law.

\section{Interação entre Direito Internacional da Concorrência e Defesa Comercial}

Eduardo Wendling

Data de defesa: 22/08/2013

\section{Interpretação Jurídica e Criação Judicial do Direito. De Savigny a Friedrich Müller}

Resumo: O presente estudo pretende se ocupar de dois temas fundamentalmente: a interpretação jurídica e a criação judicial do Direito, numa perspectiva histórica. Ter-se-á como foco algumas das principais teorias do Direito alemão que se ocuparam destes assuntos e o diálogo entre elas, desde a Escola Histórica do Direito, passando pela Jurisprudência dos Conceitos, pela Jurisprudência dos Interesses, pelo Movimento para o Direito Livre, pela Teoria Pura do Direito e, por derradeiro, culminando na Teoria Estruturante do Direito. Como pressuposto para o estudo da interpretação, procurar-se-á estabelecer pontos de partida conceituais, em especial tendo em mira as concepções de hermenêutica desenvolvidas ao longo da tradição filosófica que se ocupou da matéria. Ou seja, pretende-se estabelecer uma relação entre hermenêutica filosófica e hermenêutica jurídica. A partir daí, serão estudadas as referidas escolas jurídicas, tendo como linhas mestras as suas concepções de interpretação, incluídas aqui as noções de metodologia, de ciência e da função judicial, sempre tendo em conta o contexto no qual foram desenvolvidas e as possibilidades eventuais de aplicá-las ao contexto brasileiro atual. 
Palavras-chave: Hermenêutica Filosófica. Hermenêutica Jurídica. Ciência Jurídica. Criação Judicial do Direito.

Abstract: This study intends to engage in essentially two themes: the legal interpretation and judicial creation of law, in a historical perspective. It will have as its focus some of the main theories of German law that took care of these issues and the dialogue between them, from the Historical School of Law, passing through the Jurisprudence of Concepts, the Jurisprudence of Interests, the Movement for the Right Free, by Pure Theory of Law, and the last, culminating in the Structuring theory of Law. As a prerequisite for the study of interpretation, it will seek to establish conceptual starting points, particularly in the main hermeneutical concepts developed throughout the philosophical tradition that occupied the area. That is, we intend to establish a relationship between philosophical hermeneutics and legal hermeneutics. Thereafter, these schools will be studied, taking into acount their notions of interpretation, including here the notions of methodology, of science inself and of the judicial function, always taking into account the context in which they were developed and the possibilities of any apply of them to the current Brazilian context.

Keywords: Philosophical Hermeneutics. Legal Hermeneutics. Jurisprudence. Judge-made Law.

\section{Investigando a Operatividade das Imunidades Tributárias}

Raquel Xavier Vieira Braga

Data de defesa: 20/05/2013

Resumo: A presente dissertação examina o instituto jurídico da imunidade tributária. Para tanto, dedica-se na primeira parte à sua definição, razão pela qual analisa o uso da palavra imunidade, preparando o trabalho para investigar a espécie normativa na qual a imunidade tributária está inserida. A partir de então, analisa a forma de atuação da norma imunizante. Compreendidos o conteúdo, os fundamentos 
e as características das imunidades, realiza a definição conceitual de imunidade tributária, o que permite partir para segunda parte do trabalho: seu estudo classificatório. Nele, investiga-se a operatividade das imunidades tributárias da seguinte forma: primeiramente, é examinada a forma de direcionamento da norma; em segundo lugar, analisa-se como a norma imunizante se manifesta no texto constitucional; em terceiro lugar, reflete-se sobre a abrangência da norma quanto às espécies tributárias e às situações as quais a norma alcança; num quarto momento, investiga-se a força normativa das imunidades tributárias para, na quinta etapa, debruçar-se sobre a eficácia normativa da imunidade tributária; e, por fim, o trabalho analisa o seu modo de interpretação, examinando os critérios sistemáticos que controlam a interpretação da norma imunizante.

Palavras-chave: Direito Constitucional. Direito Tributário. Imunidade Tributária. Definição. Classificação Operacional.

Abstract: This paper examines the legal institute of tax immunity. In order to do such, it dedicates on the first step to define tax immunity, which reason is to analyse the use of the word immunity to investigate the type of standard which tax immunity is inserted. As a result, it analyses the acting form of the immunizing rule. After understanding the content, the aims and the characteristics of the immunities, this work defines the concept of the tax immunity which leads to its classificatory study, the second step of this paper. This study investigates the operativity of the immunities in this way: first, examines the direction's form of the rule. Second, analyses the rule's manifestation in constitutional terms. In a third moment, reflects about the rule's coverage related to taxes sorts and the situations which the rule achieves. Moreover, investigates the rule's strength of the tax immunity. Furthermore, examines the efficacy of the tax immunity. Finally, the analysis is focused on its interpretation type, that investigates the systematic criteria which controls the interpretation of the immunizing rule.

Keywords: Constitutional Law. Tax Law. Tax Immunity. Definition. Operational Classification. 


\title{
Iura Novit Curia: o Juiz e a Qualificação Jurídica da Demanda no Processo Civil Brasileiro
}

\author{
Otávio Augusto Dal Molin Domit
}

Data de defesa: 04/07/2013

Resumo: $\mathrm{O}$ estudo que segue se propõe a revisitar criticamente a aplicação da máxima iura novit curia no processo civil brasileiro, em especial a questão relativa à existência ou não de vinculação do órgão judicial à qualificação jurídica da demanda. As discussões vão desde o exame dos pressupostos culturais e lógicos do momento de nascimento da máxima, passando pela análise do papel que o fundamento jurídico da causa petendi desempenha na individualização do objeto litigioso do processo, até chegar ao exame dos limites e condições legais e constitucionais postos pelo ordenamento jurídico brasileiro à afirmada livre determinação do juiz na enunciação do direito aplicável ao caso. Esse estudo é feito pela revisitação de posições doutrinárias consolidadas, lançando-se mão de exemplos e casos práticos, de forma a verificar se a tradicional concepção de que se valem doutrina e jurisprudência na aplicação da máxima iura novit curia está conforme às diretrizes básicas do processo civil brasileiro contemporâneo.

Palavras-chave: Iura Novit Curia. Formalismo Processual. Objeto do Processo. Causa Petendi. Fundamento Jurídico. Vinculação do Juiz.

Riassunto: Il saggio che segue si pone lo scopo di riesaminare criticamente l'applicazione della massima iura novit curia nel processo civile brasiliano, in speciale per quanto riguarda alla vinculazione o meno dell'organo giudiziale alla qualificazione giuridica della domanda. Il dibattito prende le mosse dall'analise dei pressuposti culturali e logici presenti all'epoca di nascita dell'aforisma, camina attraverso l'indagine del ruolo del fondamento giuridico della causa petendi nell'identificazione dell'oggetto del processo e finisce con l'esame dei limiti e condizioni legali e costituzionali fissati dall'ordinamento giuridico brasiliano alla detta libera determinazione del giudice nell'enunciazione del diritto applicabile al caso. Lo studio va fatto 
con la rivisita di posizioni dottrinali consolidate, attraverso l'esame di esempi e casi pratici, cercando di verificare se la tradizionale concezione dottrinale e giurisprudenziale sull'applicazione della massima iura novit curia è conforme alle linee fondamentale del contemporaneo processo civile brasileiano.

Parole-chiave: Iura Novit Curia. Formalismo Processuale. Oggetto del Processo. Domanda. Causa Petendi. Fondamento Giuridico. Vinculazione del Giudice.

\section{Novos Deveres das Instituições Financeiras na Prevenção do Superendividamento}

Fabiana Prietos Peres Data de defesa: 29/05/2013

Resumo: A presente dissertação de mestrado serve para refletir acerca das questões concernentes à crise financeira mundial, as modificações legislativas acerca da regulação do crédito ao consumidor e o os novos deveres das instituições financeiras diante de tal cenário. Considerando a necessidade urgente de uma regulação mundial, seja nacional ou em blocos econômicos, acerca do fenômeno do superendividamento, valemo-nos de exemplos de outros países para buscar uma conexão possível, considerando a cultura da sociedade de consumo, leis vigentes e necessidades específicas, entre os deveres dos consumidores e, principalmente, das instituições financeiras. Se o consumidor brasileiro paga atualmente as maiores taxas de juros no mundo, com a justificativa do mercado que tal prática é reflexo de sua inadimplência, deve-se atentar para a razão de tal inadimplência. A inadimplência do consumidor, muitas vezes o levando ao superendividamento, é um reflexo tanto da cultura do imediatismo, fomentada pela publicidade, quanto da ausência de limites e informações adequadas à este consumidor quando da concessão do crédito, o levando a subestimar os riscos da operação. O consumidor não tendo conhecimento necessário para gerir sua vida financeira, ao receber ofertas de crédito com informações deficientes, incompletas, obscuras e até mesmo com ilusões que rodeiam 
apenas seus benefícios e não seus riscos, é um forte candidato ao superendividamento. Muito embora existam muitas ações, tanto no Brasil quanto no mundo, para tratamento do superendividamento, buscando a ressocialização do consumidor na sociedade, devemos preocupar-nos igualmente com a prevenção deste superendividado, que deve ser realizada com a tomada da responsabilidade [neste sentido como um dever, uma postura a ser adotada pela instituição financeira previamente] no sentido de qualificar seus prepostos a igualmente terem condições de informar, clara e adequadamente, o consumidor dos riscos e benefícios do crédito. Para tanto, analisaremos alguns pressupostos que permeiam nossas hipóteses, passando no primeiro capítulo pelos benefícios e riscos do crédito e, no segundo capítulo, abordando os contratos por adesão, os princípios que norteiam tais pactos, especialmente a boa-fé, chegando ao dever geral de informação, o qual abrigaria o dever de informação formal como esclarecimento, o aconselhamento e advertência, passando igualmente pela necessidade de um prazo de reflexão ao consumidor como condutor de tais deveres.

Palavras-chave: Superendividamento. Crédito Responsável ao Consumidor. Deveres das Instituições Financeiras.

Abstract: The present dissertation serves to reflect on the issues that concerned the global financial crisis, the legislative changes regarding the regulation of consumer credit and the new duties of financial institutions faced with this scenario. Considering the urgent need of global regulation, whether national or in economic blocks, around the phenomenon of over-indebtedness, we may use examples from other countries to seek a possible connection, considering the culture of the consumer society, laws and specific needs between the consumers duties and especially, the financial institutions. If the Brazilian consumer currently pays the highest interest rates in the world, with the market justification that such practice is a reflection of its own default, we should look for the reason of such default. The consumer default, often leading him to over-indebtedness, is both a reflection from the culture of immediacy, fostered by advertising, and the absence of limits and suitable information for the consumer when granting credit, leading to underestimate the risks of this operation. When consumers do not have the knowledge to manage their 
financial lives, andreceives credit offers with disabilitiesinformation, incomplete, unclear and even illusions that surround only its benefits and not its risks, became a strong candidate for over-indebtedness. Although there are many actions, both in Brazil and around the world for over-indebtedness treatment, seeking the consumer rehabilitation in the consumer society, we must also concern ourselves about the over-indebtedness prevention, which should be performed with taking responsibility [in this sense as a duty, an attitude to be adopted by the financial institution previously] in order to qualify their agents and also having the conditions to inform clearly and properly, the risks and benefits of consumer credit. To do so, we are going to analyze some assumptions that permeate our chances, passing in the first chapter of the benefits and risks of credit and, in the second chapter, addressing the adhesion contracts, the principles guiding such pacts, especially the good faith, even to the general information duty, which would protect the duty as formal clarification of information, advice and warning, by also passing for the consumer period for reflection as a driver of such duties.

Keywords: Over-indebtedness. Responsible Lending to Consumers. Duties of Financial Institutions.

\section{O Conselho de Estado e a Justiça Administrativa: uma Análise do Contencioso Administrativo no Brasil-Império}

José Correa de Melo

Data de defesa: 26/08/2013

Resumo: O presente trabalho propõe-se a realizar uma análise do contencioso administrativo brasileiro no século XIX, de forma panorâmica, a partir da figura central, estruturante, do Conselho de Estado. Valendo-se das investigações historiográficas mais recentes, amparadas em fontes primárias e fundamentação empírica, busca contribuir com uma tentativa de interpretação sobre o papel desempenhado pelo órgão no contexto da formação e consolidação do Estado brasileiro e no quadro constitucional do período, desde o prisma teórico 
e filosófico de um contributo que se pretendeu colher na tradição clássica. Para tanto, utiliza os conceitos da razão prática (phronesis), bem como a doutrina de justiça em Aristóteles, dentre outros, para percorrer a doutrina da Teoria do Estado e parte da História do Estado Moderno em busca dos modelos e influências que repercutiram na caudal de fatores que forjaram o Estado Nacional no tempo de D. Pedro II e que, em última medida, garantiram a ordem e a unidade do país. Nesse cruzamento de perspectivas, fez-se uma comparação com a França, de cujo modelo, o Brasil se inspirou mais de perto, para a criação do que ficou conhecido como o Terceiro Conselho de Estado. Por outro lado, o estudo do contencioso administrativo imperial é também um resgate dos primórdios do Direito Público em geral e especialmente do Direito Administrativo brasileiros, a merecer novos estudos e desenvolvimentos.

Abstract: This paper proposes to undertake an analysis for Administrative Contentious of Brazil in the nineteenth century, so panoramic, from the central figure, structuring of the Council of State. Utilizing the latest historiographical investigations, supported by primary sources and empirical foundation, seeks to contribute to an attempt at interpretation of the role played by the agency in connection with the formation and consolidation of the Brazilian state and the constitutional framework of the period, from the theoretical perspective and a philosophical contribution was intended spoon in the classic tradition. Therefore, using the concepts of practical reason (phronesis) as well as the doctrine of justice in Aristotle, among others, to traverse the doctrine of the Theory of the State and part of the history of the modern state in search of models and influences that affected the flow factors that forged the nation state in D. Pedro II and that in the final measure, secured order and unity of the country. At this intersection of perspectives, made a comparison with France, whose model, Brazil has inspired more closely to the creation of what became known as the Third Council of State. Moreover, the study of imperial administrative contentious, is also a rescue of early public law in general and especially the Brazilian Administrative Law, deserving further studies and developments.

Keywords: Brazilian Administrative Law. History. Council of State. Administrative Council. 


\section{O Critério de Sustentabilidade para Combustíveis na Europa (Diretivas 2009/28/CE e 2009/30/CE): Incentivo ao Desenvolvimento Sustentável ou Violação aos Acordos da OMC?}

Vinicius Diniz Vizzotto

Data de defesa: 14/08/2013

\section{O Problema da Ação Anulatória conforme o Art. 486 do CPC e o Art. 929 do Projeto de Novo CPC}

Cassio Benvenutti

Data de defesa: 24/06/2013

Resumo: $\mathrm{O}$ ato processual é objeto de intenso debate na doutrina. As diversas correntes que o estudam partem do pressuposto da autonomia científica do processo civil e formulam propostas para a sua definição e classificação. Autonomia científica não deve se equiparar a alheamento metadisciplinar. O problema reside na metodologia utilizada a partir de então. A grande maioria dos estudos reputa o processo como uma relação jurídica, logo, o que pertence ao regime jurídico do direito material não toca o processo e o que pertence ao regime jurídico do processo não toca o direito material. A separação absoluta arrisca paralisar o processo em uma estática jurídica. Um paradigma que acabou deixando o ato processualizado no esquecimento, bem como relegou a um segundo escalão de preocupações o remédio jurisdicional que o impugna: a denominada ação anulatória. $\mathrm{O}$ texto defende uma consciência do processo enquanto uma articulação dinâmica, de maneira a renovar as definições e classificações por intermédio de uma instrumentalidade efetiva que permita, finalmente, identificar o ato processualizado, com a sua finalidade, a sua estrutura e o seu regime jurídico específico. A partir dessa percepção, desenvolve um estudo analítico da ação anulatória para desconstituir o ato processualizado, reportando as suas intempéries na prática do foro e os desencontros teóricos. Uma dissertação que de algum modo confronta as normas que informam e estruturam o processo em seu 
formalismo interno e também indica os reflexos da malha normativa em que o direito processual civil está inserido, em um contexto metaprocessual. O resultado é a ponderação entre a heterocomposição por intermédio da tutela jurisdicional e a autocomposição com a força da autonomia privada. Ao largo do raciocínio se demonstra que o Estado afirma compromissos através do direito, no sentido não apenas de organizar um resultado a ser proporcionado pela Jurisdição, mas de sobremaneira preordenar meios conducentes à tutela dos direitos em um sentido amplo, sempre na virtude do nexo teleológico que verticaliza os valores e os direitos fundamentais constitucionalmente assegurados. A justiça e a pacificação social agradecem.

Palavras-chave: Processo Civil. Ato Processual. Ato no Processo. Ação Anulatória.

Abstract: The procedural act is a matter of intense debate in the doctrine. There are various currents based on the assumption of scientific autonomy of civil procedure and formulate proposals for its definition and classification. Scientific autonomy should not equate to disciplinary alienation. The problem is in the methodology used thereafter. The vast majority of studies consider the process as a legal relationship, so what belongs to the legal right of the material does not touch the process, and what belongs to the legal process does not touch the right material. The absolute separation risks to paralise the process in a static entity. A paradigm that eventually left the act practiced in procedure into oblivion, and relegated to a second tier of concerns that the drug court challenges: the so-called annulment action. The text advocates an awareness of the process as a dynamic articulation in order to renew the definitions and classifications through an effective instrumentality allowing finally to identify the act practiced in the procedure, with its purpose, its structure, and its specific legal system. From this perception, develops an analytical study of the annulment action, its practices of weatherproof venue and theoretical disagreements. A dissertation that somehow confronts the norms that inform and structure the process in its internal formalism, and shows the effects of the regulatory loop in which the civil procedural law is embedded in a disciplinary context. The result is a balance between the judicial protection and protection based in private autonomy. The text demonstrates that the state affirms commitments through 
the law in order not only to organize a result to be provided by the jurisdiction, but greatly to preordain routes leading to the protection of rights in a broad sense, always in view of final nexus that demands values and fundamental rights constitutionally assured. The social justice and peacemaking thank.

Keywords: Civil Procedure. Procedural Act. Act in the Process. Annulment Action.

\section{Os Efeitos da Coisa Julgada Inconstitucional em Matéria Tributária}

Kazan Sidharta Nassif Costa

Data de defesa: 05/06/2013

\section{Precedente e Decisão Judicial: a Teoria do Precedente no Common Law e a Proposição de um Modelo Rescisório para as Cortes Superiores Brasileiras}

Ricardo Stifelman Data de defesa: 06/05/2013

\section{Proteção das Crianças e dos Adolescentes Frente à Alienação Parental: Análise a partir da Ótica da Lei n 12.318 de 26 de Agosto de 2010}

Resumo: A Lei oㅜ 12.318 de 26 de agosto de 2010 trouxe ao ordenamento jurídico brasileiro a discussão ampliada das questões que envolvem a alienação parental, que já estavam sendo objeto de estudo 
por parte da doutrina e da jurisprudência nacional. A alienação parental caracteriza-se quando geralmente um genitor, ou alguém que tenha autoridade sobre a criança e o adolescente a influencia de forma negativa e constante com o intuito de afastá-la de um adulto ou de uma parcela da família. O surgimento da pessoa como sujeito de direitos é uma categoria jurídica recente na história da humanidade, e, ainda mais recente, é o reconhecimento da criança e do adolescente nessa posição e com tutela prioritária. A percepção de grupo familiar se modifica ao ser estudada ao longo do tempo e do espaço em razão de dados culturais que tornam os grupos singulares e merecedores de um olhar específico e atento às suas especificidades. As famílias reconhecidas desde as suas origens como o núcleo básico da sociedade passaram a representar um núcleo fundado não apenas em elementos econômicos e de reprodução mas ancorados na afetividade existente entre seus membros. O cerne é o ser, como indivíduo único e singular de direitos e obrigações. A afetividade foi alçada a objeto de reconhecimento pelo ordenamento jurídico. Antes se falava em pátrio poder, hoje em poder familiar, numa nova perspectiva, de poder-dever, consubstanciado na auctoritas, que quer dizer "fazer crescer" (na expressão latina), e não no sentido vulgar que destaca apenas o lado obscuro da palavra na compreensão de autoritarismo. A pesquisa desenvolvida na presente dissertação tem como objetivo esclarecer quando e como ocorre a alienação parental, e quais são as formas de evitá-la e proteger as crianças e os adolescentes, e todos os que formam as diferentes famílias. Identificar a ocorrência da alienação parental é o primeiro passo na perspectiva teórica, para que ele não ocorra nos casos concretos. Fundado na perspectiva preventiva se pretende traçar a conceituação da família e suas posturas no âmbito do Direito brasileiro, sob o manto da Constituição Federal de 1988 e seus princípios: da dignidade da pessoa humana, do melhor interesse da criança e do adolescente, da convivência familiar e da paternidade responsável; sob a perspectiva do Código Civil de 2002, do Estatuto da Criança e do Adolescente, e da Lei da Alienação Parental.

Palavras-chave: Alienação Parental. Direitos da Criança e do Adolescente. Garantias. 
Abstract: Law n. 12,318 (August 26th, 2010) brought to Brazilian legislation an expanded discussion about issues involving parental alienation, which were. and it is already being, object of study by the doctrine and national jurisprudence. Parental alienation is the negative influence constantly made to a child or adolescent by an adult with the objective to keep them away from another adult, usually a parent or someone who has authority over them. The new position of children and adolescent as subjects of rights, priority protect, is relatively recent in the humanity history. The perception of the family group is modified while it is being studied over time and space, because of cultural data, that makes groups and individuals deserve a special attention. Families recognized from its origins as nucleus of society came to represent a core based not only on economic elements and procreation but anchored in the affection between their members. The core is the human as unique and singular individual with rights and obligations. The affectivity was raised as object of recognition by the legal system. People used to talk in paternal power, today they talk in family power, in a new perspective between power and obligation, embodied in auctoritas, which means "to make grow" (the Latin term), and not in vulgar sense that only highlights the dark side of the word, meaning authoritarianism. The research developed in this dissertation aims to explain when and how parental alienation occurs, and what are the ways to prevent it and protect children and adolescents, and everybody who form the different families. Identify the occurrence of parental alienation is the first step in the theoretical perspective, to avoid it in specific cases. Founded in preventive perspective that is intended to draw the conceptualization of the family and their postures under Brazilian law, under the cloak of 1988 Constitution and its principles: the dignity of the human person, the best interests of the child and adolescent, the family and responsible parenthood; from the perspective of the Civil Code of 2002, the Statute of Children and Adolescents, and the Law of Parental Alienation.

Keywords: Parental Alienation. Rights of Children and Adolescents. Guarantees. 
Razão Prática e Direito: entre Método e Prudência

João Leonardo Marques Roschildt

Data de defesa: 02/07/2013

Regimes Políticos de 1964 a 1988 no Brasil

Mateus de Lima Wesp

Data de defesa: 01/03/2013

Regras de Dedutibilidade no Imposto de Renda:

Conteúdo Normativo e Controle Jurisdicional

Bruno Capelli Fulginiti

Data de defesa: 30/04/2013

Secularização e Direito: os Pressupostos FilosóficosTeológicos do Conceito Jurídico de Dignidade da Pessoa Humana

Draiton Gonzaga de Souza

Data de defesa: 01/07/2013 


\section{Serviço Público: Aproximações entre o Tratamento da Noção no Direito Francês e no Direito da União Europeia}

Ana Maria de Almeida Vieira

Data de defesa: 16/10/2013

Resumo: O presente estudo tem por finalidade analisar as aproximações entre o tratamento conferido à noção de serviço público no direito francês e no direito da União Europeia. Utilizando-se de pesquisa bibliográfica, analisa-se, primeiramente, o desenvolvimento da concepção de serviço público no direito francês, discorrendo sobre a noção clássica e identificando os principais elementos que caracterizam o instituto atualmente. Após, examina-se a evolução da abordagem da questão no direito comunitário, delineando-se as noções forjadas no âmbito da União Europeia. Por fim, do cotejo entre o tratamento do tema no direito francês e no direito comunitário, destacam-se as aproximações encontradas, concluindo-se pela assimilação, por parte das instituições europeias, dos principais aspectos caracterizadores da noção francesa, mediante a consagração de novas expressões passíveis de serem compreendidas por todos os Estados-membros e cujo conteúdo reflete a realização das adequações necessárias à realidade da União Europeia, sobretudo no que diz respeito às atividades de interesse geral dotadas de caráter econômico.

Palavras-chave: Serviços Públicos. Serviços de Interesse Geral. Serviços de Interesse Econômico Geral. União Europeia.

Abstract: This study aims to analyze the treatment given to the notion of public service both in French law and in European Union law. Using bibliographic research, it first analyzes the notion developed in French law, by reviewing the classic notion and identifying the main elements that characterize the institute nowadays. After that, it examines how the subject approach evoluted in the European Union, tracing the notions forged by it. At last, after the comparison between how the subject is treated under the French and the European Union law, the approaches are outlined, concluding that the European Union institutions assimilated the main aspects that characterize 
the French notion, by the consecration of new expressions that can be understood by all member States, and whose content reflects the necessary adjustments to the reality of the European Union, especially with regard to the activities of general interest endowed with economic character.

Keywords: Public Services. Services of General Interest. Services of General Economic Interest. European Union.

Sociedades por Ações e o Conflito de Interesse:

Análise do Interesse Social, Transações entre Partes

Relacionadas e o Exercício do Direito de Voto

em Assembleias Sociais

Marcelo Leão Lucietto

Data de defesa: 27/06/2013

Tributação Progressiva em face do Princípio da Capacidade Contributiva no Sistema Constitucional Tributário Brasileiro

Daniel do Amaral Vieira Data de defesa: 23/10/2013 
Teses de Doutorado 2013

\title{
A Compensação dos Danos Provocados por Atos Lícitos no Direito Civil Brasileiro (a partir da Doutrina Solidarista)
}

\author{
Daniel Ustárroz \\ Data de defesa: 08/05/2013
}

Resumo: O presente texto discute a possibilidade de ser reconhecida, no quadro das fontes de responsabilidade civil previstas no direito privado brasileiro, o dever de indenizar a partir de um ato lícito. Para tanto, apresenta a teoria solidarista de Léon Bourgeois, discutindo a possibilidade de sua recepção em face das premissas do Código Civil de 2002. Após, estabelece critérios que devem guiar o intérprete na identificação do dever de indenizar, a partir de ato lícito, bem como particularidades que regulam as formas de compensação.

Palavras-chave: Direito Privado Brasileiro. Responsabilidade Civil. Fontes do Dever de Indenizar. Ato Lícito Danoso. Indenização Equitativa.

Riassunto: La tese discute la possibilità di essere riconosciuta nel modello di diritto privato brasiliano la responsabilità civile da atti leciti. Presenta la teoria solidarista di Léon Bourgeois, discutendo la sua compatibilità con le premmesse del Codice Civile del 2002. Dopo stabilisce i criteri che devono guidare l'interprete nell'individuare il indennizzo da atto lecito, così come le caratteristiche speciali che regolano forme di compensazione.

Parole-chiave: Diritto Privatto Brasiliano. Responsabilità Civile. Fonti della Responsabilità Civile. Atto Lecito Dannoso. Equo Indennizzo. 


\section{A Consideração dos Ausentes à Deliberação Ambiental: uma Proposta a partir da Ética do Discurso de Jürgen Habermas}

Leonardo da Rocha de Souza

Data de defesa: 17/04/2013

Resumo: A ética do discurso de Jürgen Habermas indica, como requisito para o discurso ideal, que todos os afetados pela norma devem dar seu consentimento sobre o conteúdo da deliberação. Na tentativa de aplicar esse princípio do discurso à matéria ambiental, percebemos que ela atinge um número incontável de pessoas, separadas daqueles que estão deliberando por questões relativas à geografia, ao tempo, à cultura, à classe social e à espécie. O propósito desta tese, ciente da extensão da matéria ambiental, é demonstrar a necessidade de reconhecer os interesses daqueles que estão ausentes à deliberação, identificando quem são e de que forma são atingidos, bem como os motivos que levariam os presentes à deliberação a considerá-los. Veremos que o reconhecimento dos ausentes à deliberação é exigência de uma sociedade complexa, marcada pela diversidade de modos de vida e de pontos de vista. Sem reconhecer todos os atingidos pela norma ambiental, a deliberação ficará desequilibrada. Por isso, as pré-compreensões e os interesses privados dos que estão deliberando devem dar lugar ao entendimento e atendimento dos interesses dos ausentes. Podemos identificar esses ausentes em cinco grupos: as outras culturas, as outras classes sociais, as outras nações, as futuras gerações e a natureza. Ao identificar e atender aos interesses desses grupos chegaremos, em relação ao tratamento da matéria ambiental, a concepções multiculturais, justas, cosmopolitas, de solidariedade intergeracional e policêntricas. Os presentes à deliberação ambiental chegarão a essas concepções, considerando os ausentes, incentivados por um ou mais dos seguintes motivos: o medo das consequências ambientais e das sanções; as vantagens e as desvantagens econômico-financeiras; a pressão exercida por organizações e outros atores 
internacionais; os compromissos firmados em tratados e declarações internacionais; ou por meio da formação de uma nova racionalidade ambiental. O ideal é que essa nova racionalidade ambiental seja formada nos presentes à deliberação de forma que considerem os interesses dos ausentes não por uma influência externa ou egoísta, mas sim por valorizar os ausentes: as outras culturas, classes sociais, nações, futuras gerações e espécies.

Palavras-chave: Deliberação Ambiental. Ética do Discurso. Jürgen Habermas. Consideração dos Ausentes. Reconhecimento.

Abstract: The discourse ethics of Jürgen Habermas suggests, as a requirement for the ideal discourse, that all those affected by the norms should give their consent on the content of the deliberation. In an attempt to apply this principle of discourse to environmental theme, we realized that it reaches countless people, separated from those who are acting for issues relating to geography, time, culture, social class and species. The purpose of this thesis, aware of the extent of environmental theme, is to demonstrate the need to recognize the interests of those who are absent for deliberation, identifying who they are and how they are achieved, and the reasons that lead those that are present on the deliberation to consider them. We will see that the recognition of absentees for deliberation is a requirement of a complex society, marked by the diversity of lifestyles and viewpoints. Without recognizing all those affected by the environmental norms, the decision will be unbalanced. Therefore, the pre-understandings and the private interests of those who are presents must give way to understanding and meeting the interests of absentees. We can identify those absentees in five groups: other cultures, other classes, other nations, future generations and nature. To identify and meet the interests of these groups we arrive, in relation to the treatment of environmental themes, to the multicultural, fair, cosmopolitan, intergenerational solidarity and polycentric conceptions. The present determination to reach these environmental concepts, considering the absentees, aided by one or more of the following reasons: fear of the environmental consequences and penalties; advantages and disadvantages economic-financial, the pressure exerted by international organizations; commitments firmed in international treaties 
and conventions, or through the formation of a new environmental rationality. In an ideal situation, this new environmental rationality would be absorbed by the people who are deliberating in such a way that they consider the interests of absent not by an external influence or selfish, but by recognizing those who are absent: other cultures, social classes, nations, future generation and species.

Keywords: Environmental Deliberation. Discourse Ethics. Jürgen Habermas. Consideration of Absentees. Recognition.

A tese foi publicada, tendo as seguintes informações:

SOUZA, Leonardo da Rocha de. A Consideração dos Ausentes à Deliberação Ambiental: uma Proposta a partir da Ética do Discurso de Jürgen Habermas. Rio de Janeiro: Lumen Juris, 2013.

\section{A Determinação do Objeto da Patente em Direito Brasileiro e Europeu}

\section{La Détermination de l'Objet du Brevet en Droit Brésilien et Européen}

(Titulação simultânea com a Université Robert Schuman, França)

Roner Guerra Fabris

Data de defesa: 29/11/2013

Resumo: O estudo é relativo ao balanço entre a extensão da proteção do objeto da patente e da segurança jurídica. A tese se apoia sobre a legislação e decisões brasileiras e europeias. O estudo aborda num primeiro capítulo a determinação do objeto da patente no momento de sua redação: a descrição é analisada do ponto de vista formal e substantivo. Em seguida a reivindicação é analisada a partir de suas estruturas formais e de direito substantivo. A noção de meios é definida. A função da descrição e da reivindicação na determinação do objeto da patente estando definidas, a segunda parte do estudo é consagrada às regras de interpretação. A análise constitucional brasileira é realizada levando em consideração os limites dados pelo protocolo interpretativo do artigo 69 da Convenção Europeia de Patentes. Em seguida são propostos parâmetros internos e externos 
para guiar a interpretação das reivindicações e determinar o objeto da patente. O processo interpretativo visa assegurar ao titular da patente seu pleno direito e aos terceiros a segurança jurídica.

Palavras-chave: Patente. Objeto. Reivindicação. Determinação. Extensão. Interpretação.

Résumé: L'étude fait un bilan de l'étendue de la protection de l'objet du brevet et de la sécurité juridique. Elle s'appuie sur la législation et les décisions brésiliennes et européennes. L'étude aborde dans un premier temps la détermination de l'objet du brevet lors de sa rédaction: la description est analysée du point de vue de la forme, puis de celui du fond. Ensuite, la revendication est analysée du point de vue de ses structures et de ses conditions de fond. La notion de moyen est définie. Le rôle de la description et de la revendication dans la détermination de l'objet du brevet étant défini, la deuxième partie de l'étude est consacré aux règles d'interprétation. L'analyse constitutionnelle brésilienne est faite en prenant en compte les cadres données par le protocole interprétatif de l'article 69 de la Convention Européen de Brevets. Ensuite, nous proposons des paramètres internes et externes pour guider l'interprétation des revendications et déterminer l'objet du brevet. La démarche vise à assurer au titulaire du brevet le plein droit et aux tiers la sécurité juridique.

\section{A Função Dissuasória da Responsabilidade Civil sob as Lentes da Análise Econômica do Direito: Contributo ao Exame dos seus Limites e Possibilidades de Aplicação na Responsabilidade da Empresa}

Fabiano Koff Coulon

Data de defesa: 03/09/2013

Resumo: A tese tem por objeto a compreensão da função dissuasória da responsabilidade civil a partir de contribuições da análise econômica do direito. Seus objetivos consistem em identificar as variáveis que devem ser consideradas para a atribuição de um quantum 
indenizatório adequado a dar conta dessa função de acordo com a lógica econômica (como os custos de precaução e a probabilidade de ocorrência de eventos danosos), estabelecer a forma pela qual elas se relacionam com o objetivo a ser alcançado, fundamentar a importância da observância destas variáveis, mediante a demonstração de que, caso a indenização não as reflita, devem surgir situações indesejáveis de falta ou excesso de estímulo para a adoção de cuidados por parte dos potenciais causadores de danos, bem como contrapor tais variáveis com alguns dos critérios frequentemente utilizados na fixação do valor indenizatório em nossa jurisprudência. Partindo da contextualização das funções da responsabilidade civil no panorama mais amplo do funcionalismo jurídico, a tese analisa também a aplicação da função dissuasória na responsabilidade da empresa pelos atos de seus empregados, utilizando-se para tanto dos contributos da teoria econômica da agência, mais especificamente dos problemas associados ao risco moral e à ação oculta por parte dos empregados, para que, ao final, possa ser efetivada uma reflexão crítica sobre as possibilidades e limites da aplicação de tal função a este ramo da responsabilidade civil.

Abstract: The thesis aims to understand the deterrence function of tort law through the lens of law and economics. Its objectives are to identify the variables that must be considered to quantify the amount of damages according to economic logic (such as the costs of precaution and the probability of incurring in liability), to set the way they relate to the deterrence goal, to support the observance of these variables by showing that if damages does not reflect them, there must occur situations of underdeterrence or overdeterrence that are not desirable, and to compare this approach with the actual criteria commonly used in determining the amount of damages by judicial courts. Starting from the understanding of functions of tort law in a broader picture of the role of functionalism in private law, the thesis also analyzes the deterrence function in the enterprise's liability for the acts of their employees, using the contributions of agency theory, more specifically the problems associated with moral hazard and hidden action by employees, concluding with a reflection on the possibilities and limits of such a function to this branch of tort law. 


\section{A Norma de Direito Fundamental Associada: Direito, Moral e Razão em Robert Alexy}

Roberto José Ludwig

Data de defesa: 11/06/2013

Resumo: A tese tem por objeto um ente normativo que Robert Alexy denomina "norma de direito fundamental associada", ou seja, uma norma não diretamente estatuída pelo texto de direito fundamental mas que é associada a uma determinação de direito fundamental nele constante. Por esse instrumento, que implica procedimento de interpretação e argumentação, podem ser resolvidos racionalmente casos que envolvem ponderação de princípios colidentes. O conceito, além de conjugar o direito fundamental com a teoria dos princípios e ambos com a argumentação jurídica, apresenta utilidade prática, bem como supera os problemas que se levantam a seu respeito.

Palavras-chave: Direitos Fundamentais. Interpretação. Teoria da Norma. Teoria dos Princípios. Ponderação. Regra.

Abstract: The subject of the thesis is a normative entity that Robert Alexy calls "associated norm of fundamental right", that is, a norm, which is not directly enacted by the text of the Constitution but is associated with a fundamental rights provision by means of a relationship of specification and justification. With the use of this instrument, which implies a procedure of interpretation and argumentation, cases that involve the balancing of colliding principles can be settled rationally via application of the rule that expresses the concrete relation of precedence between those principles. In this way, the concept provides a connection between the theory of fundamental rights and both the theory of principles and the theory of legal argumentation. In addition, it offers practical utility, explanatory power and efficiency in problem-solving.

Keywords: Fundamental Rights. Interpretation. Theory of Norms. Theory of Principles. Balancing. Rule. 


\section{A Proibição da Reformatio in Pejus no Sistema Recursal do Processo Civil}

Ernesto José Toniolo

Data de defesa: 13/12/2013

\section{A Prova do Nexo da Causalidade na Responsabilidade Civil}

Artur Thompsen Carpes

Data de defesa: 13/12/2013

Resumo: Falar em nexo de causalidade supõe reconhecer determinado evento como "causa", outro como "efeito", além da existência de uma relação entre estes. Só é possível qualificar determinado evento como "causa" mediante raciocínio lógico, isto é, através de interpretação acerca da relação que se estabelece entre dois eventos, um anterior e o seu respectivo efeito. Tal relação não é de uma simples associação e não possui, portanto, natureza exclusivamente fática, dependendo sempre de significativo grau de reflexão. A notória complexidade da prova do nexo de causalidade decorre de semelhante constatação: trata-se de fenômeno não absolutamente empírico, do que decorrem dificuldades na sua demonstração em juízo e, por conseguinte, óbices à efetividade da tutela do direito da vítima do dano. A presente tese busca definir os contornos da prova do nexo de causalidade, de sorte a apontar critérios objetivos que proporcionem sua racionalização e facilitação em juízo. Parte-se da premissa de que a verdade a ser buscada no processo civil é aquela que assume caráter de probabilidade preponderante em relação à hipótese contrária. A probabilidade, de sua vez, decorre da valoração das provas produzidas a respeito da causalidade específica, ou seja, a partir do critério da probabilidade baconiana. A teoria da causalidade adequada demanda a utilização do id plerumque accidit ou lei de cobertura para aferir o nexo de causalidade, o que implica, no mais 
das vezes, em prová-lo por presunção através de raciocínio lógico de natureza indutiva. Não é possível confundir o nexo de causalidade com a causalidade geral, medida através de cálculo estatístico, porque tal conceito não se presta a aferir a relação particular existente entre os eventos. Definidas as premissas conceituais em torno do conceito de nexo de causalidade e de verdade, são apontados os critérios a partir dos quais será possível racionalizar a atividade probatória, mediante a correta delimitação da prova do nexo de causalidade, o juízo de sua admissibilidade, a produção da prova, sua valoração e decisão quanto ao juízo de fato no processo civil brasileiro.

Palavras-chave: Direito Processual Civil. Prova. Nexo de Causalidade. Verdade. Probabilidade. Presunção.

Abstract: To address causality, in addition to the relationship between both events, one needs to recognize a determined event as the "cause" and another event as the "effect". It is only possible to define such certain event as the "cause" of another pursuant to logic reasoning; in other words, through the interpretation of the relationship established between succeeding events and the effect between them. Such relationship, however, is not a simple association of such events and does not have, therefore, an exclusively factual nature. It always requires a substantial degree of reflection. The known evidentiary complexity in causality derives from a similar observation: it is not exclusively empirical, for there are competing difficulties to evidence it in court imposing, as a result, obstacles to the effectiveness of the delivery of justice to the claimant. This thesis seeks to define the contours for evidence of causality in a legal proceeding, setting forth objective criteria to provide for its rationalization and facilitation in court. The initial premise is that the truth being searched in civil procedure is one that has predominant probability over the other hypothesis. Probability, in its turn, is the result of valuation of evidence produced regarding the specific causality; in other words, from the perspective of baconian probability. Being the theory of causality adequate to the expression, in law, of the nomologic model of causal explanation, the rationalization of causality in court requires the application of $i d$ plerumque accidit or scientific law, which implies, 
most of the time, in providing evidence based on assumptions through inductive logic reasoning. One should not mistake general causality with legal causality, the former measured by statistical calculation, since such concept is not appropriate for assessing the particular relationship between cause and effect in law. Having established the conceptual premises around the concept of causality and the truth, the criteria for rationalizing the evidence available are established. The thesis examines the issues with the definition of the type of evidence for causality, its admission in court, its production, and its valuation - through an analysis of the evidentiary standards and the rigorous need to observe the inferring structure of evidentiary reasoning - and, at last, the decision regarding the facts surrounding causality.

Keywords: Civil Procedure. Evidence. Causality. Truth. Probability. Presumption.

\section{Aplicação do Princípio da Tutela da Aparência Jurídica ao Terceiro Registral Imobiliário de Boa-Fé: Aspectos Jurídicos e Econômicos}

\section{As Diferentes Lógicas do Direito na Transmissão Patrimonial em uma Sociedade Limitada Intuitus Personae: uma Proposta de Interpretação da Matéria após o Código Civil de 2002}




\title{
Direito e Governança Ambiental Global
}

\author{
Alessandra Lehmen \\ Data de defesa: 20/06/2013
}

Resumo: Este estudo dedica-se a investigar de que formas a governança ambiental global se tem desenvolvido no mundo globalizado e como se articula o influxo recíproco entre esta e o direito internacional ambiental. Tomando por base o fenômeno da globalização, o status de preocupação comum da humanidade que reveste as questões de proteção internacional ao meio ambiente e, ainda, o conceito de desenvolvimento sustentável, verifica-se de que formas a nova governança ambiental global se distingue da governança tradicional, para, em seguida, refletir sobre as implicações deste processo para o direito internacional ambiental. Dá-se especial relevo à crescente participação de atores não estatais, buscando compreender seu papel e a quebra de paradigma consistente na adoção de formas contratuais, voluntárias, para a consecução dos objetivos da proteção internacional ao meio ambiente. Considerando-se que os instrumentos da nova governança são inclusivos, mas, ao mesmo tempo, multifacetados e, por vezes, caóticos, busca-se conciliá-los com os instrumentos da governança tradicional com vistas a garantir que a flexibilidade das soluções construídas de baixo para cima não seja ameaçada e, ao mesmo tempo, que seja conferida coesão ao sistema, evitando que antinomias ponham em risco a efetividade desejada. Para tanto, propõe-se uma nova arquitetura institucional que compreende duas instituições centrais: uma Organização Mundial do Meio Ambiente (OMMA) e uma Corte Internacional de Meio Ambiente (CIMA), constituídas de forma a consagrar expressamente a principal característica da nova governança ambiental global, a saber, a participação de atores não estatais.

Palavras-chave: Governança Ambiental. Direito Internacional. Atores Não Estatais. Organização Mundial do Meio Ambiente. Corte Internacional de Meio Ambiente.

Abstract: This dissertation aims at investigating how global international governance develops in the globalized world, and how the reciprocal influx between the later and international environmental 
law is articulated. Taking into consideration the globalization phenomenon, the status of a common concern of humanity that characterizes the issues of international environmental protection as well as the concept of sustainable development, the study analyzes how the new global environmental governance sets itself apart from traditional governance, while reflecting upon the implications of said process for international environmental law. The increasing level of participation of non-state actors is especially considered in an effort to understand its role and the breaking of a paradigm it entails, consisting in the adoption of voluntary, contractual instruments for achieving the goals of international environmental protection. Bearing in mind that the instruments of the new governance are inclusive but at the same time multifaceted and even chaotic, this study tries to reconcile them with traditional governance instruments so that the flexibility of bottom-up solutions is not threatened and that at the same time the system gains cohesion, thus avoiding contradictions that may jeopardize its desirable effectiveness. In order to reach these goals, a new institutional architecture which encompasses two central institutions is proposed: a World Environmental Organization (WEO) and an International Environmental Court (IEC), constituted so as to expressly recognize the main feature of the new global environmental governance, that is, the participation of non-state actors.

Keywords: Environmental Governance. International Law. NonState Actors. World Environmental Organization. International Environmental Court.

\section{Erro Médico nas Cirurgias Plásticas: Compreensão do Fenômeno da Metamorfose da Pessoa em Paciente para além das Fronteiras Jurídicas}

Gustavo Silveira Borges

Data de defesa: 31/07/2013

Resumo: Esta tese destina-se a ser uma contribuição para o estudo da responsabilidade civil médica, em especial, nas cirurgias plásticas, a partir de um enfoque interdisciplinar, da Sociologia, da Psicanálise, da 
Medicina e da Bioética, para compreensão do processo de percepção corporal da pessoa, sua conversão em paciente até a judicialização nos casos de erro médico. A hipótese da pesquisa parte de uma análise inter-relacional com diferentes ramos do saber, notadamente com a abordagem de elementos da psicanálise como instrumento de (re) leitura das subjetividades na produção da homogeneidade da imagem corporal, objetivando-se a explicação do aumento do número de cirurgias plásticas e, como consequência, do volume de demandas judiciais que tem como pedido a reparação de danos decorrente de erro médico. A pesquisa é conduzida a partir do questionamento sobre o fenômeno da metamorfose da pessoa em paciente e seus reflexos jurídicos. Inicialmente, buscou-se investigar, tomando-se como base as reflexões sobre o mal-estar produzido pelas novas formas de subjetividade na busca pela beleza corporal e da homogeneidade das identidades corporais, como ocorre a transformação da pessoa em paciente, os transtornos mentais com representações corporais e a relação deste processo como fenômeno jurídico. $\mathrm{Na}$ segunda parte da tese, exploraram-se os fundamentos jurídicos da relação médico-paciente, bem como a vinculação jurídico-obrigacional, examinando-se os deveres jurídicos essenciais que devem ser observados na relação cirurgião plástico-paciente. Por fim, a investigação termina com o exame dos fundamentos da responsabilidade civil médica nas cirurgias plásticas e a análise do tratamento jurídico da jurisprudência pátria para esta situação.

Palavras-chave: Responsabilidade Civil Médica. Código Civil. Código de Defesa do Consumidor. Diálogo das Fontes. Cirurgia Plástica. Psicanálise.

Abstract: This thesis is aimed at being a contribution to the study of civil liability in the area medicine, specifically with a focus on plastic surgery. This will involve an interdisciplinary focus in Sociology, in Psychoanalysis, in Medicine and Bioethics, for a better understanding of the process of an individual's corporal perception in his participation as a patient up to the point of judicial intervention via cases of medical malpractice. The hypothesis of this research is part of an interrelated analysis with different sources of knowledge, notably with an approach using psychoanalysis elements as an instrument 
of (re)reading the subjectivities in the creation of homogeneity of the corporal image, with the objective of explaining the increase in the number of plastic surgeries, and the consequent increase in judicial actions pleading damages from a medical error. The study is conducted from the inquisition about the phenomenon of metamorphosis of an individual from patient to legal party. Initially, the study sought to investigate, using the negative effects produced by new forms of subjectivity in the search of physical beauty and homogeneity in physical identity as the base, the transformation of a person as a patient, the mental disturbances with physical manifestations, and the relationship of this process as a judicial phenomenon. The second part of this thesis explores the legal foundations of the doctor-patient relationship, such as a legal-obligatory link, and the essential legal duties that should be observed in the plastic-surgeon patient relationship. Finally, the investigation ends with an examination of the fundamental responsibilities of medical liability in plastic surgeries, and an analysis of the legal treatment in national jurisprudence for this situation.

Keywords: Responsibility. Medical Liability. Civil Code. Code of Consumer Defense. Dialogue of Sources. Plastic Surgery. Psychoanalysis.

\section{Função Social da Processualística - Autoridade da Razão Dogmática na Tutela Jurisdicional}

Gabriel Pintaúde

Data de defesa: 03/09/2013

\section{O Direito de Recomeçar: em Busca de um Modelo para o Tratamento do Superendividamento no Brasil}

Clarissa Costa de Lima

Data de defesa: 30/08/2013 


\title{
O Interesse Local e a Competência Municipal no Constitucionalismo Brasileiro
}

\author{
Marta Marques Avila \\ Data de defesa: 23/05/2013
}

Resumo: A instituição municipal, presença constante no constitucionalismo brasileiro, teve, anteriormente à Constituição de 1988, a expressão 'peculiar interesse' relacionada à sua competência. Com a entrada em vigor do atual texto constitucional, a expressão referida à competência municipal foi alterada para 'interesse local'. Com o fim de identificar a possível majoração das atribuições e do poder decisório municipal, são analisadas as visões de teóricos e práti$\cos$ da atividade municipal. Concluiu-se que, mesmo o Município tendo sido valorizado pelo texto constitucional vigente, o poder decisório da instituição municipal não foi fortalecido, a começar pela própria redação constitucional. Propõe-se a interpretação da repartição de atribuições entre os entes, de forma que a regulamentação e a ação do Poder Público tenham como ponto de partida a instituição municipal.

Palavras-chave: Município. Competência. Interesse Local. Peculiar Interesse. Autonomia. Predominância. Poder de Decisão.

Abstract: Municipality as an ever-present concept in Brazilian constitutions used to be viewed as a competence of 'peculiar interest' prior to the Constitution of 1888 . However, the approval and implementation of the current constitutional text interchanged 'peculiar interest' for 'local interest'. Therefore the goal of the present study is to verify if there has been any increase in municipality attributions as well as in its power of decision. Towards this end, analysis of municipality theoretical framework was carried out to establish that upgrading in the concept of municipality in the current Brazilian Constitution as to its power of decision has not been enhanced due to the very same constitutional text's phrasing. Analysis on how the sharing of attributions occur among the entities involved in municipal Public Power legal regulation and decision making is called for so as the municipality itself become the starting point of any action, as it should. 
Keywords: Municipality. Competence. Local Interest. Peculiar Interest. Autonomy. Predominance. Power of Decision.

\title{
O Reforço do Direito de Arrependimento dos Consumidores nos Contratos a Distância e por Meios Eletrônicos
}

\author{
Antonia Espíndola Longoni Klee \\ Data de defesa: 30/08/2013
}

Resumo: $\mathrm{O}$ presente trabalho analisa a formação do contrato eletrônico e a proteção do consumidor no ordenamento jurídico brasileiro, partindo das características da internet, das peculiaridades do comércio eletrônico, do exame dos planos de existência, de validade e de eficácia dos contratos, bem como das características da formação do contrato no meio eletrônico, em especial aquele celebrado a distância, e pela internet. Para uma melhor compreensão, aborda o conceito e a classificação de contrato eletrônico, a prova do contrato eletrônico, a criptografia e a assinatura digital. Examina o direito de arrependimento do consumidor, analisando a sua natureza jurídica e a sua regulamentação pelo Código de Defesa do Consumidor e pelo Decreto $n^{\circ} 7.962 / 2013$. Expõe que, para o reforço do direito de arrependimento do consumidor nos contratos a distância e por meios eletrônicos, há a necessidade de se adaptar o conceito de estabelecimento empresarial. Para isso aborda a teoria do estabelecimento empresarial, discorrendo sobre os contratos celebrados fora do estabelecimento empresarial, em domicílio e a distância e sobre o estabelecimento empresarial virtual relacionado ao exercício do direito de arrependimento do consumidor. Da mesma forma, estuda a atualização do microssistema do Código de Defesa do Consumidor no que tange ao comércio eletrônico, especificamente com relação ao direito de arrependimento do consumidor, tendo em vista sua vulnerabilidade acentuada pelos meios eletrônicos e pela internet. Conclui que a criação e o desenvolvimento da internet e a disseminação de sua utilização pelas pessoas é um movimento social que necessita de amparo jurídico e legal no Brasil, a fim de garantir uma maior segurança nas relações estabelecidas virtualmente e a distância. 
Apesar de o direito positivo brasileiro regular a maior parte das transações realizadas na internet, a tese demonstra a necessidade de se criar uma legislação específica, baseada na experiência estrangeira, principalmente a legislação europeia, para que se mantenha a ordem e se garanta a segurança das relações jurídicas, buscando um aprofundamento da proteção do consumidor na sociedade de consumo massificada. Sugere alteração do atual artigo 49 do Código de Defesa do Consumidor, com base no Projeto de Lei do Senado ${ }^{\circ}$ 281/2012, no Decreto ${ }^{\circ}$ 7.962/2013 e na Diretiva Europeia 2011/83/UE, propondo uma nova redação ao dispositivo, e a inclusão do artigo 49-A ao Código de Defesa do Consumidor, para regular algumas exceções ao direito de arrependimento do consumidor que contrata a distância e por meios eletrônicos. As proposições realizadas sugerem o reforço do direito de arrependimento do consumidor, para adequar o ordenamento jurídico brasileiro às transformações sofridas pela sociedade da informação. Por último, propõe a priorização da educação para consumo dos usuários dos meios de contratação a distância e eletrônicos, inclusive a internet.

Palavras-chave: Direito do Consumidor. Contrato Eletrônico. Direito de Arrependimento. Relações de Consumo na Internet. Estabelecimento Empresarial Virtual. Proteção do Consumidor.

Abstract: This paper analyzes the configuration of the e-contract, and the consumer's protection in the Brazilian legal system, starting as of the characteristics of the Internet, the peculiarities of the e-commerce, the examination of plans of existence, of the validity and efficacy of contracts, as well as of the features of the contract's formation in the electronic means, mainly those entered remotely, and by the Internet. For a better understanding, it approaches the concept and categorization of e-contract, the proof of the e-contract, the digital cryptography and signature. It examines the consumer's right to cancellation, analyzing its regulation by the Consumer's Defense Code, and Decree no 7.962/2013. It states that, so as to reinforce the consumer's right to cancellation in contracts remote and by electronic means, it is necessary to adapt to the concept of business 
establishment. For such, it approaches the business establishment theory, going over the contracts entered outside the business establishment, in a domicile, and remotely, and the virtual business establishment related to the exercise of the consumer's cancellation right. Likewise, it studies the updating of the Consumer's Defense Code microsystem in connection with the e-commerce, mainly in relation to the consumer's right to cancellation, in view of their vulnerability, accentuated by the electronic means and by the Internet. It concludes that the creation and development of the Internet, and its disseminated utilization by the people is a social movement that needs a juridical and legal support in Brazil, so as to assure a higher security in those virtually and remotely established relations. Although the Brazilian legal system regulates most of the transactions carried out via Internet, the thesis demonstrates the necessity of creating a specific legislation, based on the foreign experience, mainly the European experience, so as to keep the order and assure the security of the legal relations, aiming at a stronger consumer's protection in the massified consumption society. It suggests the amendment of present article 49 of the Consumer's Defense Code, based on Senate's bill no 281/2012, and Decree no 7.962/2013, and European's Direction 2011/83/EU, proposing a new text to the disposition, plus the inclusion of article 49-A of the Consumer's Defense Code, so as to regulate some exceptions to the consumer's right to cancellation, when contracting remotely and by electronic means. The propositions made suggest reinforcing the consumer's right to cancellation, so as to adequate the Brazilian legal system to the transformations undergone by the information society. Finally, it proposes the prioritization of an education for consumption, of users of the means of contracting remotely and by electronic means, including the Internet.

Keywords: Consumer's Right. Electronic Contract. Right to Cancellation. Consumption Relations in the Internet. Virtual Business Establishment. Consumer's Protection. 


\section{Path Dependence: as Assimétricas Trajetórias da Institucionalização da Inovação Tecnológica no Brasil e nos Estados Unidos}

Thami Covatti Piaia

Data de defesa: 29/08/2013

Resumo: O presente trabalho tem como insight fundamental, explicar as assimétricas trajetórias da inovação tecnológica no Brasil e nos Estados Unidos e demonstrar como a Lei da Inovação Brasileira (10.973/04) pode contribuir para a diminuição desta diferença, criando um ambiente favorável para a pesquisa e desenvolvimento de novas tecnologias no Brasil, no âmbito universidade/empresa. Sendo que os dois países foram descobertos na mesma época e passaram por processos de colonização e imigração, então qual seria a razão para tamanha disparidade na questão relacionada à inovação tecnológica. Ao passo que os Estados Unidos ocupam posição de destaque no cenário mundial, o Brasil não aparece no ranking dos países mais inovadores do mundo. A razão estaria na path dependence de ambos os países. As trajetórias dependentes formadoras desses países foram muito distintas, resultando em Matrizes Institucionais completamente diferentes. A Matriz Institucional americana, formada por regras formais, informais e pelo enforcement é muito mais eficaz que a Matriz Institucional brasileira. Na tentativa de mudar a situação, foi criada em 2004, a Lei da Inovação brasileira. A referida lei, veio para regular e institucionalizar a inovação no Brasil. A Lei prevê a propriedade das novas tecnologias produzidas na interação universidade/empresa, diminuindo os custos de transação, reduzindo o ambiente de incerteza e criando uma situação de maior segurança jurídica, levando a uma evolução institucional e gerando um melhor desempenho econômico.

Palavras-chave: Path Dependence. Instituições. Inovação Tecnológica.

Abstract: This work has fundamental insight, explaing the asymmetric trajectories of technological innovation in Brazil and the United States and demonstrates how the Brazilian Innovation Act $(10.973 / 04)$ can contribute to reducing this gap by creating a favorable environment for research and development of new technologies in 
Brazil, within the university/company. Being that the two countries were discovered around the same time and went through processes of colonization and immigration, then what is the reason for such disparity as it relates to technological innovation. While the United States occupy a prominent position on the world stage, Brazil does not appear in the ranking of the most innovative countries in the world. The reason would be the path dependence of both countries. Dependent trajectories forming these countries were very different, resulting in Institutional Matrices completely different. The American Institutional Matrix, formed by formal rules, informal and the enforcement is much more effective than Brazilian Institutional Matrix. In an attempt to change the situation, was established in 2004, the Brazilian Innovation Act. The act came to regulate and institutionalize innovation in Brazil. The act provides for the ownership of new technologies produced in the interaction between university/company, reducing transaction costs, reducing the uncertain environment and creating a situation of greater legal certainty, leading to institutional development and creating a better economic performance.

Keywords: Path Dependence. Institutions. Innovation.

\section{Pronunciar o Direito: Globalização e Direitos Fundamentais na Reconstrução da Racionalidade Jurídica - Estudo a partir do Direito Contratual}

Marcos Cáprio Fonseca Soares

Data de defesa: 15/04/2013

\section{Verdade e Hermenêutica Jurídica em Paul Ricouer - o Fundamento Epistemológico da Aplicação do Direito}

Guilherme Boff

Data de defesa: 08/11/2013 
Nesta obra foram utilizadas as fontes Palatino Linotype e Myriad Pro.

Capa em papel supremo 250g.

Páginas internas em papel offset $75 \mathrm{~g}$.

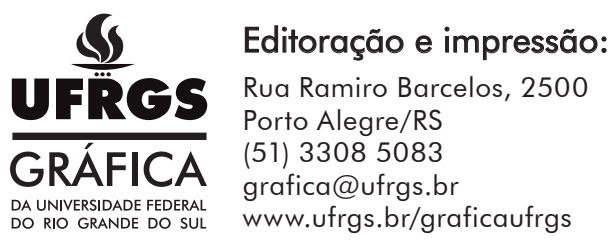

2014 - Realização: Núcleo de Criação, Editoração, Revisão e Web da Gráfica da UFRGS 